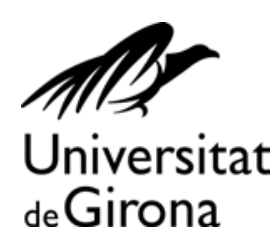

\title{
LAS GARANTÍAS DEL CRÉDITO TRIBUTARIO
}

\author{
Zuley Fernández Caballero
}

\author{
Dipòsit legal: Gi. 4I7-20I4 \\ http://hdl.handle.net/10803/131015
}

\begin{abstract}
ADVERTIMENT. L'accés als continguts d'aquesta tesi doctoral i la seva utilització ha de respectar els drets de la persona autora. Pot ser utilitzada per a consulta o estudi personal, així com en activitats o materials d'investigació i docència en els termes establerts a l'art. 32 del Text Refós de la Llei de Propietat Intel.lectual (RDL 1/1996). Per altres utilitzacions es requereix l'autorització prèvia i expressa de la persona autora. En qualsevol cas, en la utilització dels seus continguts caldrà indicar de forma clara el nom i cognoms de la persona autora i el títol de la tesi doctoral. No s'autoritza la seva reproducció o altres formes d'explotació efectuades amb finalitats de lucre ni la seva comunicació pública des d'un lloc aliè al servei TDX. Tampoc s'autoritza la presentació del seu contingut en una finestra o marc aliè a TDX (framing). Aquesta reserva de drets afecta tant als continguts de la tesi com als seus resums i índexs.
\end{abstract}

ADVERTENCIA. El acceso a los contenidos de esta tesis doctoral y su utilización debe respetar los derechos de la persona autora. Puede ser utilizada para consulta o estudio personal, así como en actividades o materiales de investigación y docencia en los términos establecidos en el art. 32 del Texto Refundido de la Ley de Propiedad Intelectual (RDL 1/1996). Para otros usos se requiere la autorización previa y expresa de la persona autora. En cualquier caso, en la utilización de sus contenidos se deberá indicar de forma clara el nombre y apellidos de la persona autora y el título de la tesis doctoral. No se autoriza su reproducción u otras formas de explotación efectuadas con fines lucrativos ni su comunicación pública desde un sitio ajeno al servicio TDR. Tampoco se autoriza la presentación de su contenido en una ventana o marco ajeno a TDR (framing). Esta reserva de derechos afecta tanto al contenido de la tesis como a sus resúmenes e índices.

WARNING. Access to the contents of this doctoral thesis and its use must respect the rights of the author. It can be used for reference or private study, as well as research and learning activities or materials in the terms established by the 32nd article of the Spanish Consolidated Copyright Act (RDL 1/1996). Express and previous authorization of the author is required for any other uses. In any case, when using its content, full name of the author and title of the thesis must be clearly indicated. Reproduction or other forms of for profit use or public communication from outside TDX service is not allowed. Presentation of its content in a window or frame external to TDX (framing) is not authorized either. These rights affect both the content of the thesis and its abstracts and indexes. 


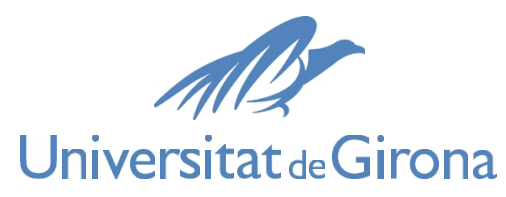

\section{TESIS DOCTORAL}

"Las garantías del crédito tributario"

Autor/a

Sra. Zuley Fernández Caballero

Any

2013

\section{PROGRAMA DE DOCTORAT \\ Dret, Turisme i Empresa}

Dirigida per:

Dra. María Luisa Esteve Pardo

Dr. Esteban Quintana Ferrer 



\section{RESUMEN}

La Hacienda Pública goza de un derecho de crédito frente al obligado tributario. Con el ejercicio de la función recaudatoria se realiza aquel derecho, pero cuando se producen actuaciones evasivas del deudor, la Administración tributaria puede recurrir no sólo a la ejecución forzosa de la deuda, sino también a otros mecanismos que incrementan las posibilidades de hacer efectivo su cobro. Dentro de las medidas que el ordenamiento jurídico configura para asegurar el crédito tributario se encuentran las garantías tributarias. Este trabajo versa sobre las garantías del crédito tributario en sentido estricto, es decir, los derechos o facultades concedidos por el ordenamiento tributario a la Hacienda Pública acreedora en virtud de los cuales, en fase recaudatoria, puede actuar sobre un bien concreto o sobre un patrimonio para aumentar las posibilidades de cobro. Estas garantías tributarias en sentido estricto responden a dos tipologías diferentes: las garantías reales y las garantías personales. De todos los tipos de garantías reales y personales en la tesis sólo se profundiza en aquellos instrumentos cuyo régimen jurídico se localiza en el ordenamiento tributario. Por ello, se ubican en el seno de las garantías reales tributarias a la hipoteca legal tácita, el derecho de afección y la hipoteca legal expresa. Sin embargo, la normativa tributaria vigente mantiene dentro de este grupo otras prerrogativas que aseguran el cobro del crédito pero que no son garantías reales en sentido estricto. Sobre estas otras medidas -derecho de prelación general, derecho de retención y medidas cautelaresse reflexiona también en el trabajo. Por su parte, las garantías personales que contempla el ordenamiento tributario y que se analizan en la tesis son la responsabilidad tributaria y la solidaridad tributaria pasiva. Ésta última se manifiesta tanto a través de la solidaridad de dos o más titulares en la realización del hecho imponible, como de la solidaridad entre responsables del tributo y de la solidaridad en el seno del régimen de tributación conjunta. La responsabilidad tributaria es una garantía personal que ha suscitado y sigue suscitando múltiples críticas porque el legislador se ha decantado por la utilización desmedida de esta institución. Finalmente, se abordan las llamadas garantías "voluntarias" (de elección voluntaria, aunque de presentación obligatoria), cuyo ámbito de actuación se circunscribe a los procedimientos dispuestos para solicitar el aplazamiento o fraccionamiento del pago o la suspensión de la ejecución de actos administrativos en caso de interposición de reclamaciones. No estamos en presencia de garantías dispuestas a favor de la Administración por la normativa tributaria, sino de las garantías generales de Derecho civil que el ordenamiento tributario simplemente obliga a presentar a los obligados tributarios en determinados procedimientos. 


\section{RESUM}

La Hisenda Pública gaudeix d'un dret de crèdit enfront de l'obligat tributari. Amb l'exercici de la funció recaptadora es realitza aquell dret, però quan es produeixen actuacions evasives del deutor, l'Administració tributària pot recórrer no només a l'execució forçosa del deute, sinó també a altres mecanismes que incrementen les possibilitats de fer efectiu el cobrament del deute. Dins les mesures que l'ordenament jurídic preveu per assegurar el crèdit tributari es troben les garanties tributàries. Aquest treball versa sobre les garanties del crèdit tributari en sentit estricte, és a dir, els drets o facultats concedits per l'ordenament tributari a la Hisenda Pública creditora en virtut dels quals, en fase recaptatòria, pot actuar sobre un bé concret o sobre un patrimoni per augmentar les possibilitats de cobrament del deute. Aquestes garanties tributàries, en sentit estricte, responen a dues tipologies diferents: les garanties reals i les garanties personals. De tots els tipus de garanties reals i personals només a aquesta tesi s'aprofundeix només en aquells instruments, el règim jurídic dels quals es localitza en l'ordenament tributari. Per això, se situen en el si de les garanties reals tributàries a la hipoteca legal tàcita, el dret d'afecció i la hipoteca legal expressa. No obstant això, la normativa tributària vigent manté dins d'aquest grup altres prerrogatives que asseguren el cobrament del crèdit, però que no són garanties reals en sentit estricte. Sobre aquestes altres mesures -dret de prelació general, dret de retenció i les mesures cautelars- es reflexiona també a en aquest treball. Per altra banda, les garanties personals que preveu l'ordenament tributari i que s'analitzen en la tesi són la responsabilitat tributària i la solidaritat tributària passiva. Aquesta última es manifesta a través de la solidaritat de dos o més titulars en la realització del fet imposable, i també en els casos de la solidaritat entre responsables del tribut i de la solidaritat en el si del règim de tributació conjunta. La responsabilitat tributària és una garantia personal que ha suscitat i continua suscitant múltiples crítiques, perquè el legislador s'ha decantat per la utilització desmesurada d'aquesta institució. Finalment, s'aborden les anomenades garanties "voluntàries" (d'elecció voluntària, encara que de presentació obligatòria), l'àmbit d'actuació de les quals se circumscriu als procediments disposats per sol-licitar l'ajornament o fraccionament del pagament o la suspensió de l'execució d'actes administratius en cas d'interposició de reclamacions. No estem en presència de garanties disposades a favor de l'Administració per la normativa tributària, sinó de les garanties generals de Dret civil que l'ordenament tributari simplement obliga a presentar als obligats tributaris en determinats procediments. 


\begin{abstract}
Taxpayers must pay their taxes. In case the taxpayer takes evasive actions in order to avoiding this payment, tax authorities may use other mechanisms to enforce the payment of the taxes. Among other measures, governments can issue tax warrants. This thesis deals strictly with tax warrants that allow tax authorities to take steps to collect the taxpayers' debt. There are two different types of tax warrants: personal warrants and warrants on goods. This thesis focuses on the warrants regulated in Spanish statutory tax laws. Other legal measures, which are not tax warrants, but may help to enforce the revenue collection are also analyzed. Personal tax warrants, as regulated in Spanish tax law, are particularly controversial. Many of the cases in which someone has to pay the tax debts when the taxpayer does not do this are wrongly regulated as personal warrants. As it is maintained in this thesis, some of these cases should be rather regulated as legal tax infringements than as personal warrants. Finally, the thesis addresses "voluntary" warrants, which presentation is mandatory but the taxpayer can freely choose among the different types that the law presents. This kind of warrants is this of civil law, this means that are not specifically foreseen for tax purposes.
\end{abstract}





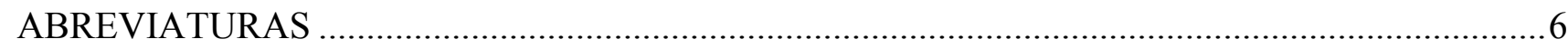

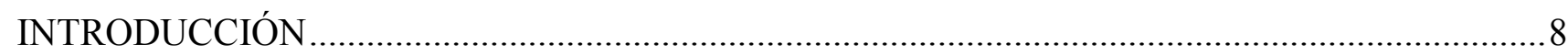

CAPÍTULO PRIMERO

EL CUMPLIMIENTO DE LA OBLIGACIÓN TRIBUTARIA: EL PAGO

1. EL PAGO EN PERÍODO VOLUNTARIO

1.1. EL PAGO COMO MECANISMO ORDINARIO DE CUMPLIMIENTO DE LA

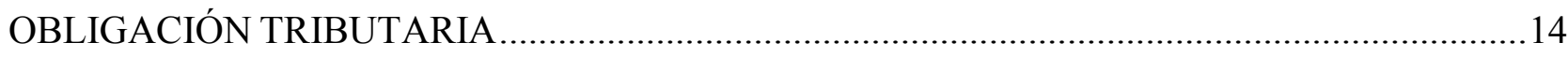

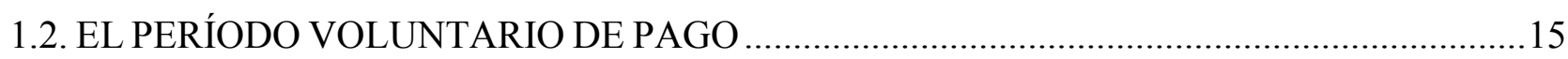

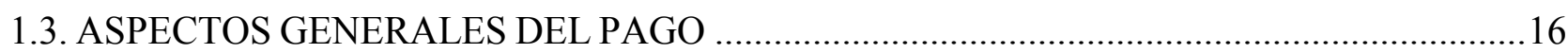

1.3.1. Formas de pago y efecto temporal del mismo...............................................................17

1.3.2. Sujetos legitimados para el pago y para el cobro de la deuda tributaria ..........................29

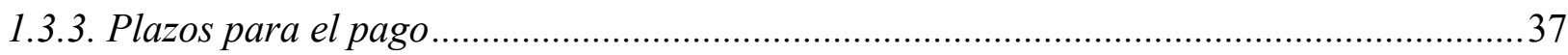

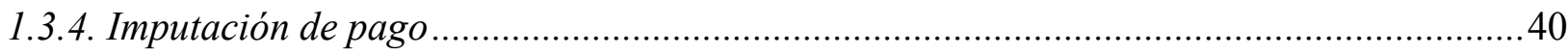

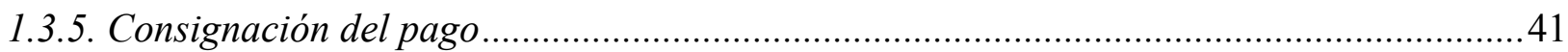

1.4. MEDIDAS CAUTELARES EN EL PERÍODO VOLUNTARIO .............................................42

1.4.1. Potestad de los órganos de recaudación para adoptar medidas cautelares ......................42

1.4.2. El régimen jurídico de las medidas cautelares ...............................................................4

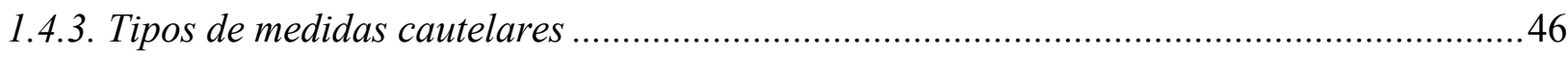

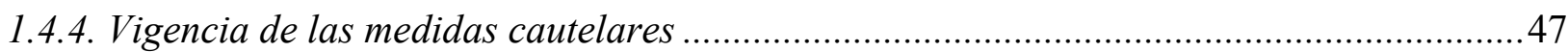

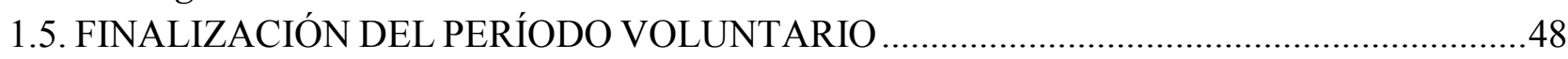

1.6. OBLIGACIONES ACCESORIAS APLICABLES UNA VEZ QUE FINALIZA EL PERÍODO

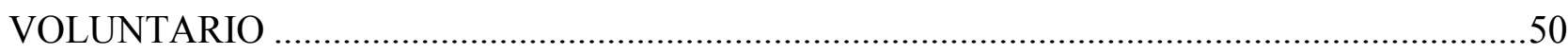

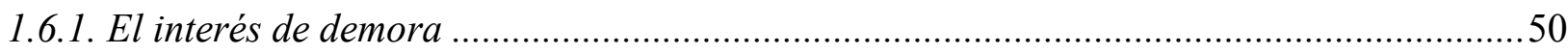

1.6.2. Los recargos por declaración extemporánea ……………………………………........6

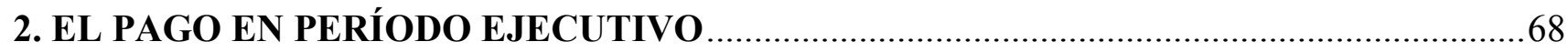

2.1. INICIO DEL PERÍODO EJECUTIVO ……………….................................................68

2.2. OBLIGACIONES ACCESORIAS EN EL PERÍODO EJECUTIVO. LOS RECARGOS DEL

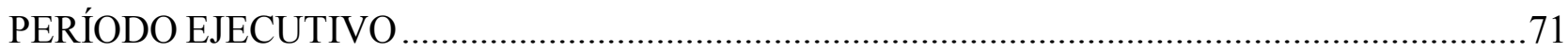

2.2.1. Tipos de recargos y presupuestos para su devengo ....................................................73

2.2.2. Compatibilidad de estos recargos entre sí, con otras obligaciones accesorias y con las

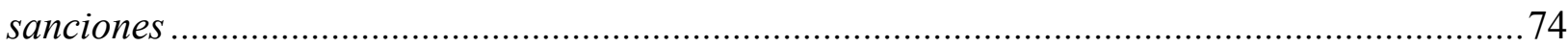

2.3. IMPUTACIÓN DEL PAGO EN EL PERÍODO EJECUTIVO …………………………….......74

2.4. ASPECTOS GENERALES DEL PROCEDIMIENTO EJECUTIVO O DE APREMIO.............76

2.4.1. Características generales........................................................................................76

2.4.2. Concurrencia con otros procesos o procedimientos ejecutivos .........................................77

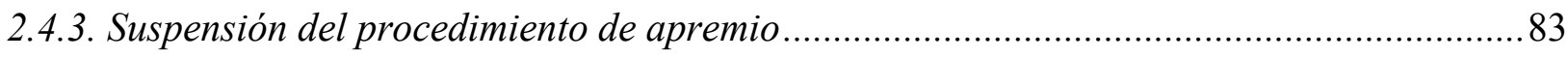

2.5. DESARROLLO DEL PROCEDIMIENTO DE APREMIO .....................................................

2.5.1. Inicio del procedimiento de apremio. La providencia de apremio ....................................91

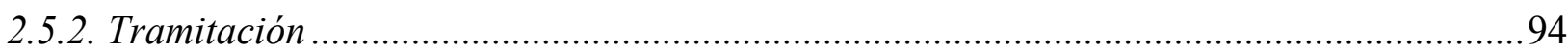

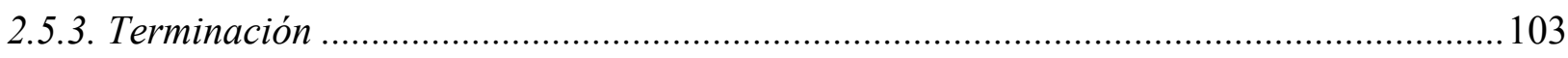




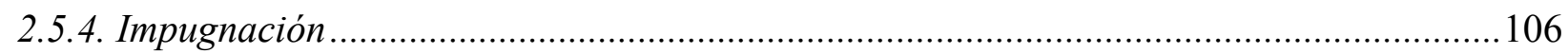

3. EL APLAZAMIENTO O FRACCIONAMIENTO DEL PAGO .........................................110

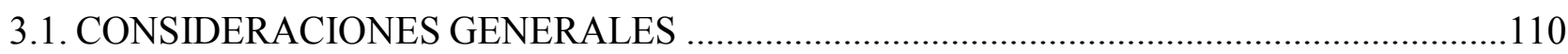

3.1.1. Fuentes normativas del aplazamiento o fraccionamiento ................................................ 111

3.1.2. La discrecionalidad administrativa ........................................................................... 112

3.2. PRESUPUESTOS NECESARIOS PARA EL APLAZAMIENTO O FRACCIONAMIENTO

DEL PAGO DE LA DEUDA TRIBUTARIA …........................................................................... 115

3.2.1. Sujetos legitimados para solicitar el aplazamiento o fraccionamiento ..............................115

3.2.2. La determinación de las deudas aplazables o fraccionables ............................................116

3.2.3. La existencia de dificultades económicas-financieras en el obligado al pago .................119

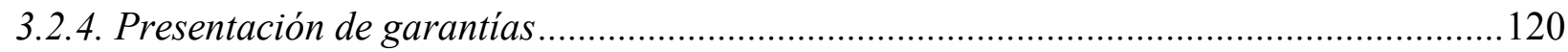

3.3. PROCEDIMIENTO PARA LA CONCESIÓN DE LOS APLAZAMIENTOS O

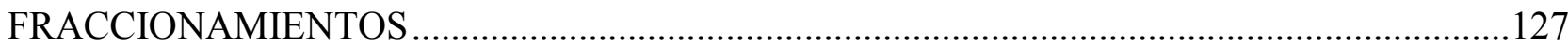

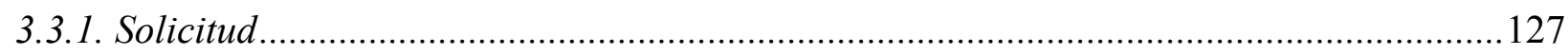

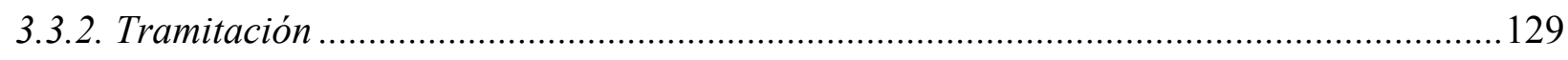

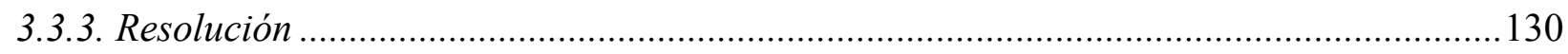

\section{CAPÍTULO SEGUNDO}

\section{LAS GARANTÍAS DEL CRÉDITO TRIBUTARIO}

\section{LA RESPONSABILIDAD PATRIMONIAL UNIVERSAL Y LAS GARANTÍAS DEL}

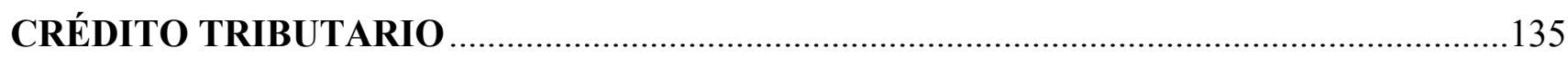

2. CARACTERÍSTICAS GENERALES DE LAS GARANTÍAS TRIBUTARIAS ..................136

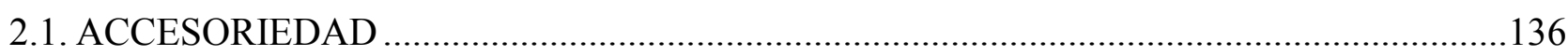

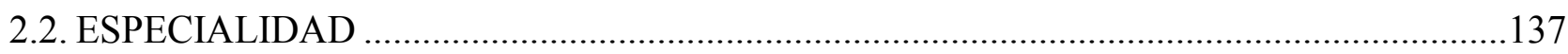

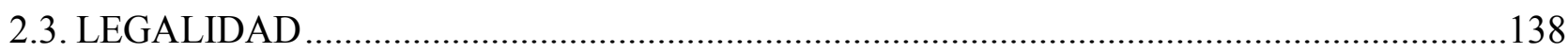

3. CLASES DE GARANTÍAS DEL CRÉDITO TRIBUTARIO ..............................................138

3.1. LAS GARANTÍAS DEL CRÉDITO TRIBUTARIO EN SENTIDO AMPLIO.......................138

3.2. LAS GARANTÍAS DEL CRÉDITO TRIBUTARIO EN SENTIDO ESTRICTO...................139

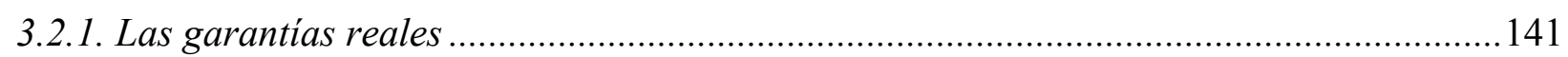

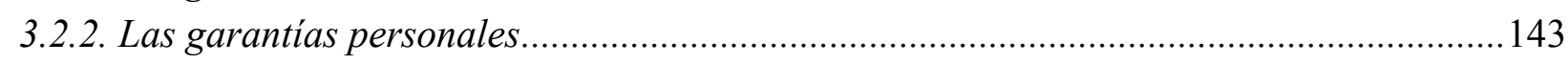

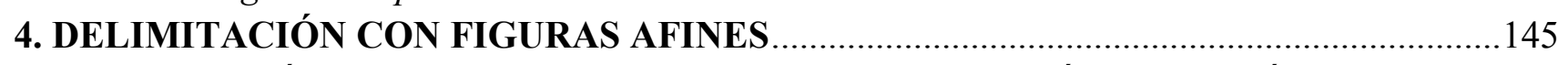

4.1. DISTINCIÓN ENTRE LOS PRIVILEGIOS Y LAS GARANTÍAS DEL CRÉDITO

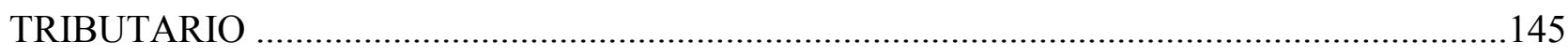

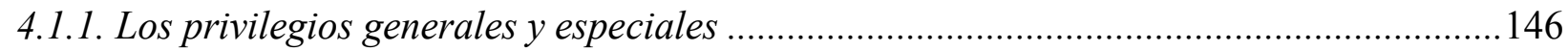

4.1.2. Diferencias entre los privilegios y las garantías del crédito tributario ..............................147

4.2. DISTINCIÓN ENTRE LAS MEDIDAS CAUTELARES Y LAS GARANTÍAS DEL

CRÉDITO TRIBUTARIO .....................................................................................................149

4.2.1. Diferencias entre las medidas cautelares y las garantías del crédito tributario..............149

4.2.2. Las medidas cautelares y las garantías voluntarias del crédito tributario .......................153

5. LAS GARANTÍAS DEL CRÉDITO TRIBUTARIO EN LA NORMATIVA TRIBUTARIA 


\section{CAPÍTULO TERCERO \\ LAS GARANTÍAS REALES TRIBUTARIAS}

\section{LA HIPOTECA LEGAL TÁCITA}

156

1.1. ANTECEDENTES Y VINCULACIÓN CON OTRAS RAMAS DEL DERECHO ................156

1.2. NATURALEZA JURÍDICA DE LA HIPOTECA LEGAL TÁCITA.....................................158

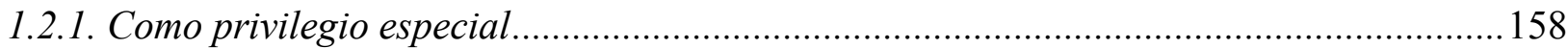

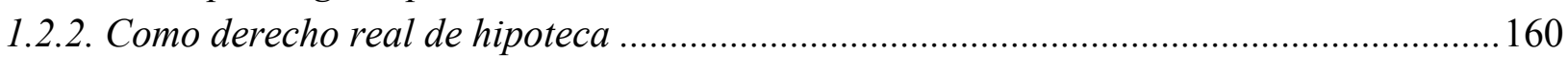

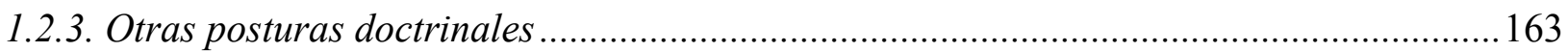

1.3. ÁMBITO DE APLICACIÓN DE LA HIPOTECA LEGAL TÁCITA...................................... 165

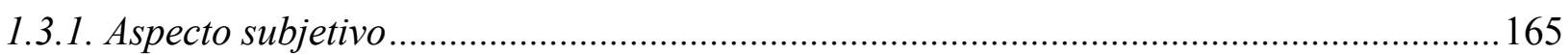

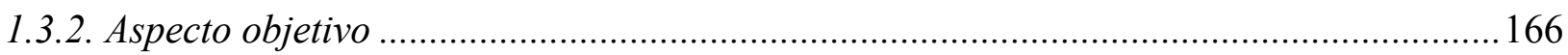

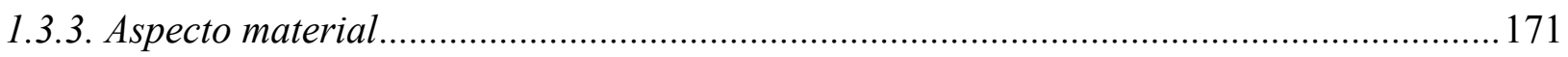

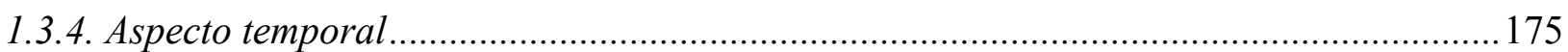

1.4. LA HIPOTECA LEGAL TÁCITA EN VÍA DE APREMIO................................................... 180

1.4.1. Ejecución de la hipoteca legal tácita .................................................................................. 180

1.4.2. Actuación del tercer adquirente o acreedor inscrito ....................................................... 181

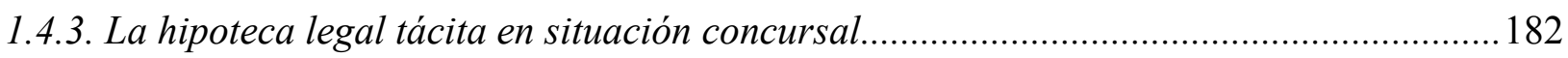

1.5. LA EXTINCIÓN DE LA HIPOTECA LEGAL TÁCITA.........................................................184

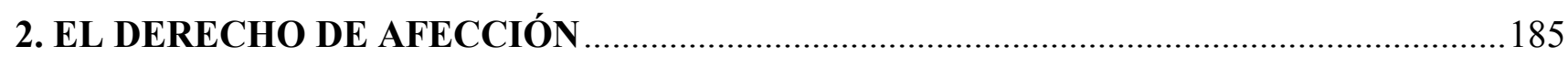

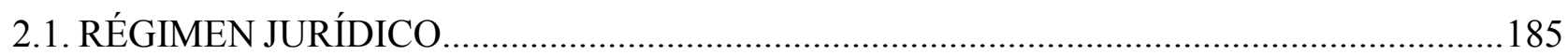

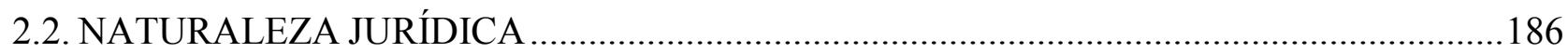

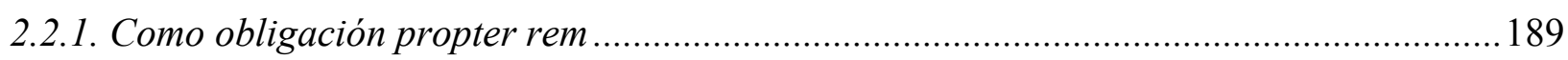

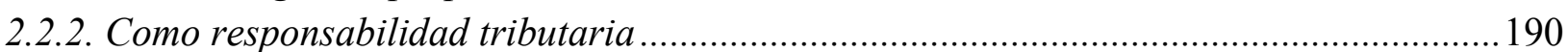

2.3. DISTINCIÓN CON OTRAS FIGURAS AFINES .................................................................. 192

2.3.1. El derecho de afección y la hipoteca ordinaria ................................................................. 192

2.3.2. El derecho de afección y la hipoteca legal tácita .............................................................. 193

2.3.3. El derecho de afección y el derecho de prelación general ............................................. 195

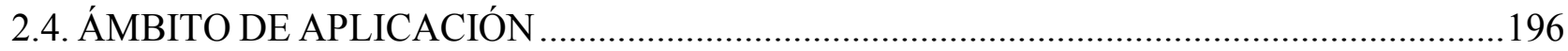

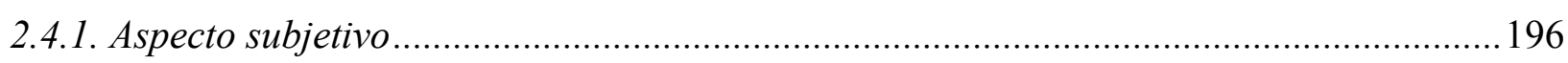

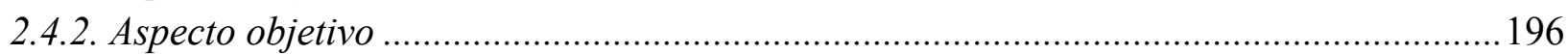

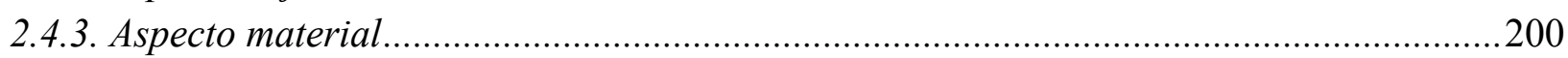

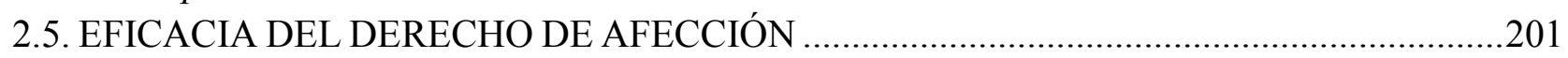

2.6. EJECUCIÓN DEL DERECHO DE AFECCIÓN ....................................................................203

2.7. EXTINCIÓN DE LA GARANTÍA Y PRESCRIPCIÓN …....................................................205

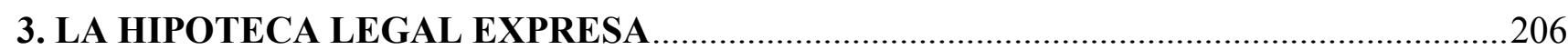

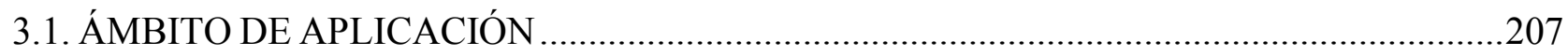

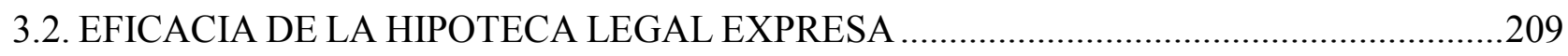

3.3. CONSTITUCIÓN DE LA HIPOTECA LEGAL EXPRESA ................................................210

3.4. RELEVANCIA PRÁCTICA DE LA HIPOTECA LEGAL EXPRESA .................................211

4. SUPUESTOS EXCLUIDOS DE LAS GARANTÍAS REALES DEL CRÉDITO

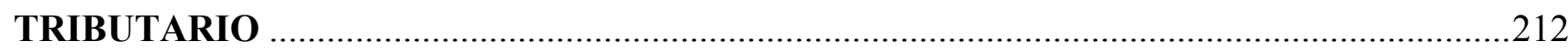

4.1. EL DERECHO DE PRELACIÓN GENERAL ......................................................................213

4.1.1. Régimen jurídico del derecho de prelación ......................................................................213

4.1.2. Naturaleza jurídica del derecho de prelación ....................................................................216 


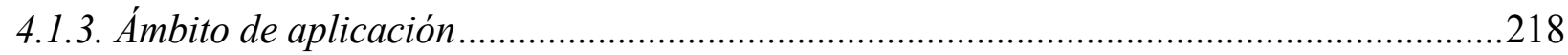

4.1.4. Eficacia del derecho de prelación general.....................................................................222

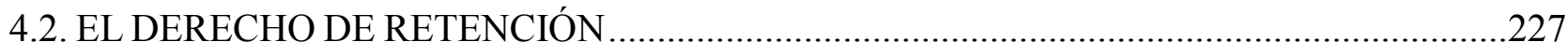

4.2.1. La regulación del derecho de retención en otros ámbitos del derecho .............................227

4.2.2. Regulación en el ámbito tributario ................................................................................228

4.2.3. Concepto y naturaleza jurídica del derecho de retención.................................................229

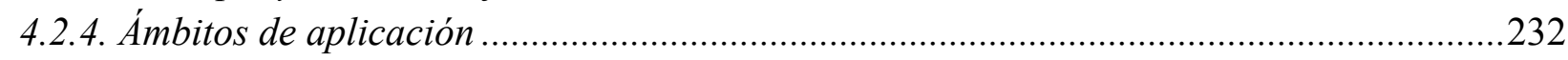

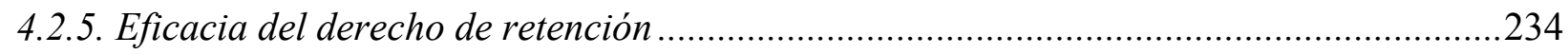

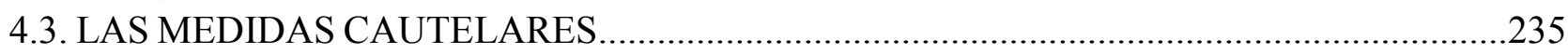

CAPÍTULO CUARTO

\section{LAS GARANTÍAS PERSONALES TRIBUTARIAS}

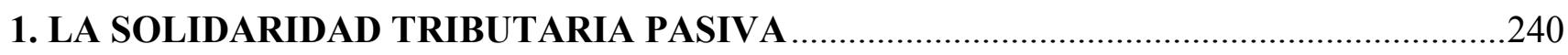

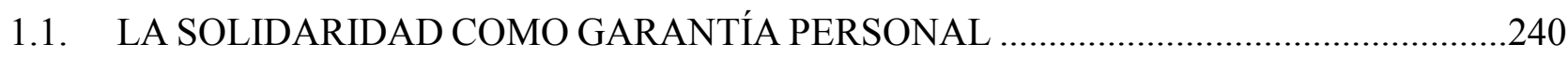

1.2. MODALIDADES DE LA SOLIDARIDAD TRIBUTARIA PASIVA EN EL

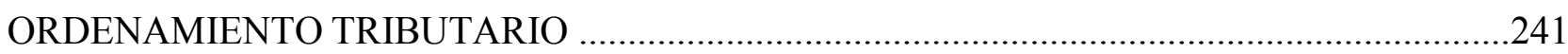

1.2.1. La solidaridad de dos o más titulares en la realización del hecho imponible ...................241

1.2.2. La tributación conjunta en el IRPF como supuesto de solidaridad tributaria ..................242

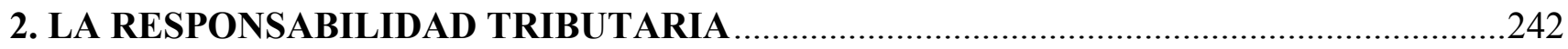

2.1. CONCEPTO Y CARACTERES DE LA RESPONSABILIDAD TRIBUTARIA ...................242

2.1.1. Los responsables en el marco de los obligados tributarios .............................................243

2.1.2. El carácter ex lege de la obligación de responsabilidad ...................................................248

2.1.3. El mantenimiento de la obligación de pago del obligado principal .................................250

2.1.4. La acción de regreso contra el deudor principal ........................................................251

2.1.5. El carácter solidario o subsidiario de la responsabilidad tributaria ...............................252

2.2. NATURALEZA Y FUNDAMENTO DE LA RESPONSABILIDAD TRIBUTARIA.............253

2.3. LA EXTENSIÓN DE LA OBLIGACIÓN DE LA RESPONSABILIDAD TRIBUTARIA ....256

2.3.1. La responsabilidad por la totalidad de la deuda tributaria en periodo voluntario..........257

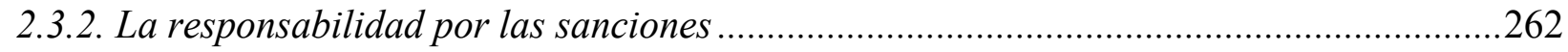

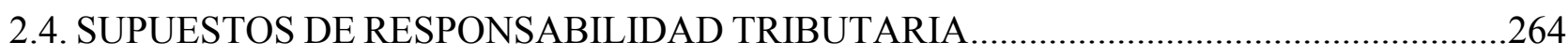

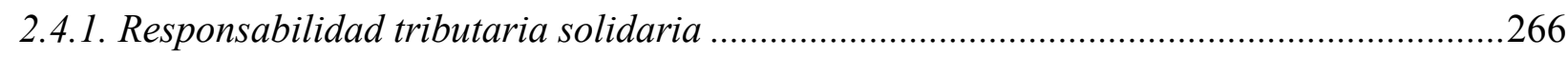

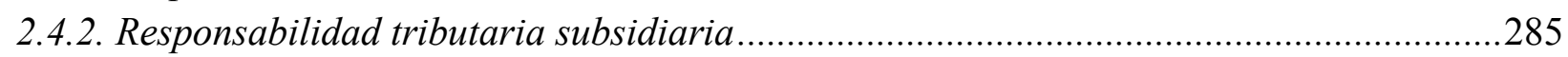

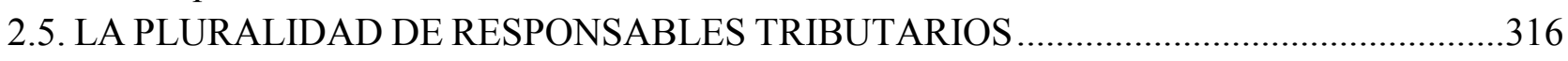

2.5.1. La solidaridad en el ámbito civil y la responsabilidad tributaria solidaria ......................317

2.5.2. Supuestos de solidaridad civil y de mancomunidad en la $L G T$.......................................... 318

2.5.3. El carácter mancomunado o solidario de la obligación de pago en el supuesto de pluralidad de responsables tributarios ............................................................................... 321

\section{EL PROCEDIMIENTO DE DERIVACIÓN DE LA RESPONSABILIDAD TRIBUTARIA}

3.1. NACIMIENTO Y EXIGIBILIDAD DE LA OBLIGACIÓN DEL RESPONSABLE .............322

3.2. RÉGIMEN JURÍDICO DEL PROCEDIMIENTO DE DERIVACIÓN DE

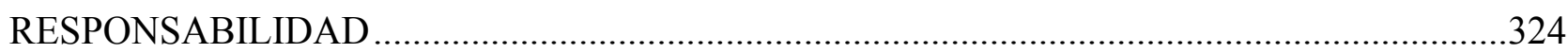

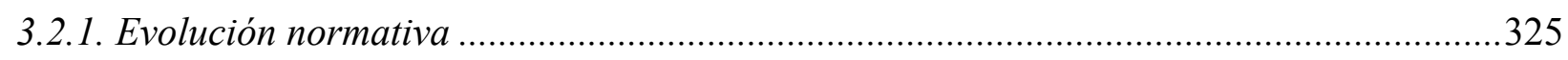

3.2.2. Naturaleza jurídica del procedimiento de derivación de responsabilidad ........................329 
3.3. INICIO DEL PROCEDIMIENTO DE DERIVACIÓN DE RESPONSABILIDAD .................331

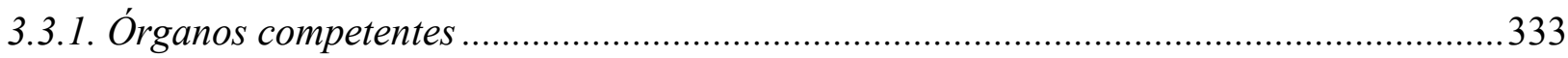

3.3.2. Inicio del procedimiento de derivación de la responsabilidad solidaria...........................334

3.3.3. Inicio del procedimiento de derivación de la responsabilidad subsidiaria ...................... 335

3.4. DESARROLLO DEL PROCEDIMIENTO DE DERIVACIÓN DE RESPONSABILIDAD..336

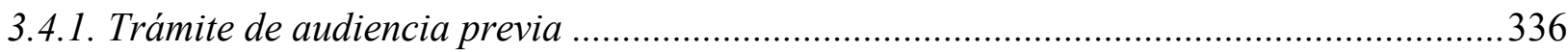

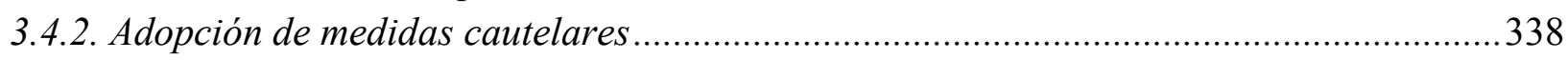

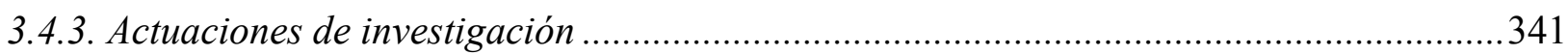

3.5. TERMINACIÓN DEL PROCEDIMIENTO DE DERIVACIÓN DE RESPONSABILIDAD 341

3.5.1. Acto administrativo de declaración de responsabilidad ....................................................... 342

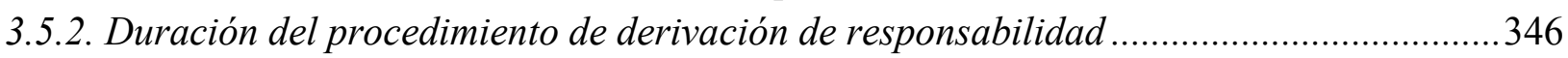

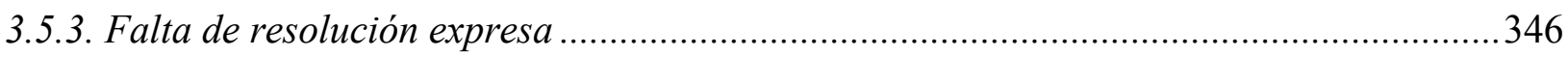

3.6. EXIGIBILIDAD DE LA DEUDA TRIBUTARIA AL RESPONSABLE ...............................348

4. LA EXTINCIÓN DE LA OBLIGACIÓN DEL RESPONSABLE Y SU DERECHO AL

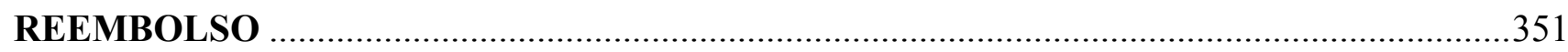

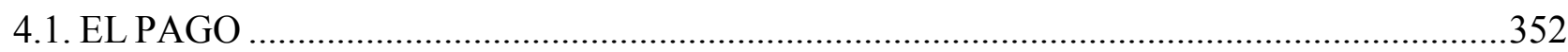

4.2. LA PRESCRIPCIÓN COMO FORMA DE EXTINCIÓN DE LA OBLIGACIÓN

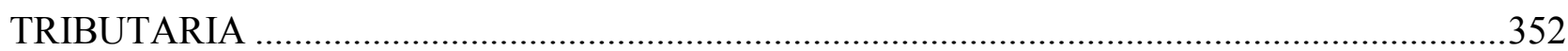

4.2.1. La prescripción de la obligación del responsable tributario.............................................. 353

4.2.2. La interrupción de la prescripción de la obligación del responsable ...............................359

4.3. EL DERECHO DE REEMBOLSO DEL RESPONSABLE TRIBUTARIO.............................361

4.3.1. Fundamento de la acción de regreso que corresponde al responsable tributario ............361

4.3.2. El derecho de reembolso del responsable tributario en la $L G T$.....................................362

4.3.3. Configuración práctica de la acción de regreso del responsable .....................................363

CAPÍTULO QUINTO

LAS GARANTÍAS DEL CRÉDITO TRIBUTARIO EN CASO DE APLAZAMIENTO O FRACCIONAMIENTO DEL PAGO O INTERPOSICIÓN DE UN RECURSO

1. LAS GARANTÍAS EN EL APLAZAMIENTO O FRACCIONAMIENTO DEL PAGO ....366

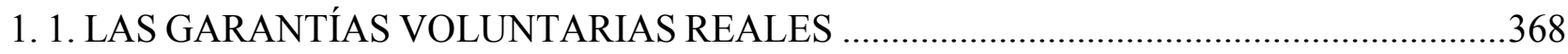

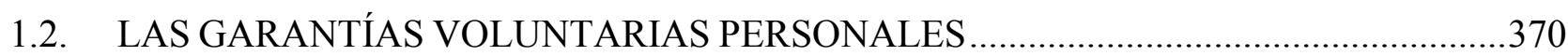

2. LAS GARANTÍAS EN LA SUSPENSIÓN DE LA EJECUCIÓN DE LOS ACTOS POR LA

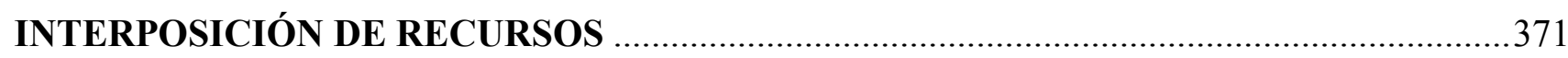

2.1. APTITUD DE LAS GARANTÍAS REALES PARA LA OBTENCIÓN DE LA SUSPENSIÓN

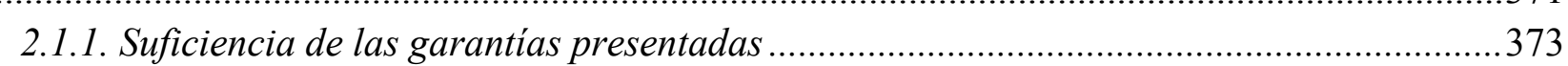

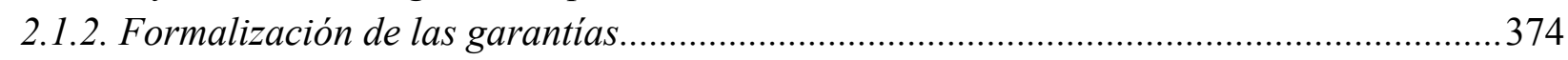

2.1.3. Las garantías reales para la suspensión en los distintos procedimientos impugnatorios 375

2.2. LA FIANZA EN LA SUSPENSIÓN DE LOS ACTOS ADMINISTRATIVOS POR

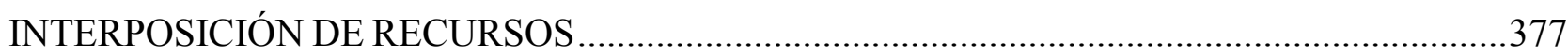

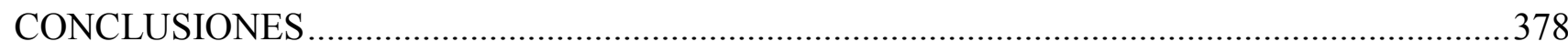

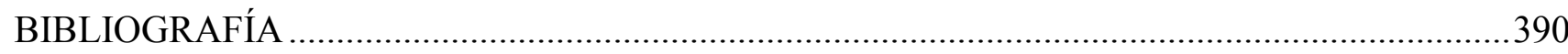




\section{ABREVIATURAS}

$\begin{array}{ll}\text { AEAT } & \text { Agencia Estatal de Administración Tributaria } \\ \text { CE } & \text { Constitución española } \\ \text { ed. } & \text { Edición } \\ \text { IBI } & \text { Impuesto sobre Bienes Inmuebles } \\ \text { IEF } & \text { Instituto de Estudios Fiscales } \\ \text { IGRC } & \text { Instrucción General de Recaudación y Contabilidad } \\ \text { IRPF } & \text { Impuesto sobre la Renta de las Personas Físicas } \\ \text { IS } & \text { Impuesto sobre Sociedades } \\ \text { ISD } & \text { Impuesto sobre Sucesiones y Donaciones } \\ \text { ITPAJD } & \text { Impuesto sobre Transmisiones Patrimoniales y Actos Jurídicos Documentados } \\ \text { IVA } & \text { Impuesto sobre el Valor Añadido } \\ \text { IVTM } & \text { Impuesto sobre Vehículos de Tracción Mecánica } \\ \text { LC } & \text { Ley 22/2003, de } 9 \text { de julio, Concursal } \\ \text { LEC } & \text { Ley } 1 / 2000, \text { de } 7 \text { de enero, de Enjuiciamiento Civil } \\ \text { LGP } & \text { Ley 47/2003, de } 26 \text { de noviembre, General Presupuestaria } \\ \text { LGT } & \text { Ley 58/2003, de } 17 \text { de diciembre, General Tributaria } \\ \text { LIRPF } & \text { Ley } 35 / 2006, \text { de } 28 \text { de noviembre, del Impuesto sobre la Renta de las Personas Físicas y } \\ & \text { de modificación parcial de las leyes de los Impuestos sobre Sociedades, sobre la Renta de } \\ & \text { no Residentes y sobre el Patrimonio }\end{array}$

LJCA Ley 29/1998, de 13 de julio, reguladora de la Jurisdicción Contencioso-Administrativa

LOFCA Ley Orgánica 8/1980, de 22 de septiembre, de Financiación de las Comunidades Autónomas

LPHE Ley 16/1985, de 25 de junio, del Patrimonio Histórico Español

LRHL Real Decreto Legislativo 2/2004, de 5 de marzo, por el que se aprueba el texto refundido de la Ley Reguladora de las Haciendas Locales

LRJ-PAC Ley 30/1992, de 26 de noviembre, de Régimen Jurídico de las Administraciones Públicas y del Procedimiento Administrativo Común

núm. Número

op. cit. Obra citada

pág. $\quad$ Página

RGGI Real Decreto 1065/2007, de 27 de julio, por el que se aprueba el Reglamento General de las actuaciones y los procedimientos de gestión e inspección tributaria y de desarrollo de las normas comunes de los procedimientos de aplicación de los tributos

RGR Real Decreto 939/2005, de 29 de julio, por el que se aprueba el Reglamento General de Recaudación

RISD Real Decreto 1629/1991, de 8 de noviembre, por el que se aprueba el Reglamento del Impuesto sobre Sucesiones y Donaciones

RLPHE Real Decreto 111/1986, de 10 de enero, de desarrollo parcial de la Ley de Patrimonio Histórico Español

RPREA Real Decreto 391/1996, de 1 de marzo, por el que se aprueba el Reglamento de Procedimiento en las Reclamaciones Económico-Administrativas 
RRVA Real Decreto 520/2005, de 13 de mayo, por el que se aprueba el Reglamento general de desarrollo de la Ley 58/2003, de 17 de diciembre, General Tributaria, en materia de revisión en vía administrativa

RTEAC Resolución del Tribunal Económico-Administrativo Central

ss. $\quad$ Siguientes

SAN Sentencia de la Audiencia Nacional

STC Sentencia del Tribunal Constitucional

STS Sentencia del Tribunal Supremo

STSJ Sentencia del Tribunal Superior de Justicia

TEAC Tribunal Económico-Administrativo Central

TRLRHL Real Decreto Legislativo 2/2004, de 5 de marzo, por el que se aprueba el texto refundido de la Ley Reguladora de las Haciendas Locales

vid. véase

vid. infra véase debajo

vid. supra véase arriba

Vol. Volumen 


\section{INTRODUCCIÓN}

No es desatinado pensar que en una relación obligacional es preferible ocupar la parte activa que la pasiva, esto es, ser el acreedor y no el deudor. Sin embargo, no es del todo tranquilizadora la posición que ocupa el acreedor ante la amenaza de incumplimiento de la obligación por parte del deudor. Por esta razón, para atenuar la incertidumbre que afecta al acreedor, se ha instaurado en el ordenamiento jurídico la responsabilidad patrimonial universal, mediante la cual el deudor responde del cumplimiento de sus obligaciones con todos sus bienes presentes y futuros.

En las relaciones obligaciones, pues, se confía en el cumplimiento espontáneo del deudor, pero si no se produce esta circunstancia el acreedor puede dirigirse contra los bienes del deudor para satisfacer su crédito. Puede ocurrir, no obstante, que el patrimonio del deudor no sea suficiente y bajo estas circunstancias el derecho de crédito, reconocido en el Código Civil, resulta insuficiente. Es por ello que el ordenamiento jurídico ha buscado mecanismos de auxilio que concedan al acreedor mayor seguridad para el cobro, entre las que destacan las garantías del crédito. Conviven de esta forma dos instituciones distintas: la responsabilidad patrimonial universal, por un lado, que no es un medio de garantía, es la propia esencia del crédito; y la garantía del crédito, por otro, que no es una figura alejada de la naturaleza del derecho de crédito, sino a un derecho que directa o indirectamente yuxtapone al crédito un instrumento que lo refuerza. Se trata de un accesorio al crédito que fortalece en el acreedor la seguridad de que su derecho de crédito será satisfecho. Los créditos nacen, evidentemente, sin estas garantías, que se adicionan después por pacto o por ley.

La Hacienda Pública goza de un derecho de crédito frente al obligado tributario. De esta forma, la Administración tributaria se configura como un acreedor más y se comporta como tal, necesitando también de instrumentos que consoliden la satisfacción de su derecho. Esta necesidad se hace más patente si se tiene en cuenta la especial naturaleza de la obligación tributaria, el interés jurídico que protege, así como la función que cumple. No debe olvidarse que la financiación de los gastos públicos recae casi en su totalidad en ingresos de naturaleza tributaria. Y la existencia de un adecuado sistema de garantías a favor de la Administración tributaria que le permita reaccionar ante la falta de pago resulta entonces primordial. Por ello debe garantizarse y potenciarse al máximo la seguridad de la recaudación, dentro de los límites constitucionales.

En este trabajo no pretendemos analizar todas y cada una de las prerrogativas que, directa o indirectamente, garantizan y aseguran la recaudación. Ello hubiese supuesto adentrarse en el estudio de casi la totalidad de las instituciones presentes en el Derecho tributario. El trabajo versa sobre las garantías del crédito tributario en sentido estricto, o sea, los derechos o facultades concedidos por el ordenamiento tributario a la Hacienda Pública acreedora en virtud de los cuales, en fase recaudatoria, puede actuar sobre un bien concreto o sobre un patrimonio para aumentar las posibilidades de cobro. De aquí se desprende que estas garantías deben reconducirse al ámbito de la ejecución del crédito. Otras potestades de la Administración tributaria, como el derecho a obtener información de terceros, las potestades en materia de inspección tributaria, o incluso, en la fase ejecutiva, el derecho a obtener información de los bienes que sean de propiedad del deudor, entre otras, quedan fuera de nuestro estudio por no estar comprendidas dentro de las garantías del crédito tributario en sentido estricto. En síntesis, las garantías del crédito tributario a las que nos dedicaremos en las próximas páginas no sólo 
se aplican en la fase recaudatoria, sino que además están directamente encaminadas a su realización sobre determinados bienes o sobre el patrimonio de terceros.

Estas garantías del crédito tributario en sentido estricto responden a dos tipologías diferentes: las garantías reales y las garantías personales. Las primeras son facultades o derechos atribuidos por la ley a la Administración tributaria en virtud de las cuales ésta puede dirigirse sobre bienes concretos para satisfacer su crédito. Por su parte, las garantías personales son derechos o facultades conferidos por la ley a la Administración tributaria conforme a las cuales la masa patrimonial hacia la que puede dirigirse la Administración para satisfacer su crédito viene determinada en función de las cualidades de una persona.

Dentro de las garantías personales del crédito tributario destacan la figura del responsable de la deuda tributaria; la fianza, es decir, el aval bancario; y la fianza personal y solidaria que se exigen para asegurar la deuda en caso de aplazamiento o fraccionamiento del pago o para suspender la ejecución de un acto administrativo cuando se interpone un recurso. Además debemos incluir dentro del grupo de garantías personales al supuesto de solidaridad tributaria pasiva, esto es, la solidaridad de dos o más titulares en la realización del hecho imponible; la solidaridad de los responsables tributarios; y la solidaridad en la tributación conjunta en el IRPF. De todos estos tipos de garantías personales sólo profundizaremos en aquellos instrumentos cuyo régimen jurídico se localiza en el ordenamiento tributario, a saber, la responsabilidad tributaria y la solidaridad tributaria pasiva. De manera menos explícita nos referiremos a la fianza, porque es una institución que procede del ámbito civil y es allí donde se encuentra su régimen jurídico.

Por su parte, en el seno de las garantías reales del crédito tributario debemos situar a la hipoteca legal tácita, el derecho de afección, la hipoteca legal expresa, y las garantías de elección voluntaria que se constituyen para solicitar un aplazamiento o fraccionamiento del pago o la suspensión de una resolución impugnada.

Debemos precisar, sin embargo, que la Ley 58/2003, de 17 de diciembre, General Tributaria (en adelante LGT), reconoce bajo la rúbrica de garantías de la deuda tributaria a otros supuestos que entendemos que son parte de los mecanismos de la Administración tributaria para asegurar su crédito pero que no tienen naturaleza real o personal en sentido estricto, formando así parte de las garantías del crédito tributario en sentido amplio. Nos referimos al derecho de prelación general, el derecho de retención y las medidas cautelares. También en estos casos nos valemos, para el estudio de cada una de estas categorías, de las disposiciones que se encuentran recogidas en el ordenamiento tributario.

En relación con todo este grupo de garantías, el ordenamiento tributario anterior al actualmente vigente ya contemplaba un conjunto de previsiones a favor de la Hacienda Pública que en su mayoría no alcanzaron la eficacia pretendida. El sistema tributario fue ganando en complejidad en la medida en que la sociedad y la economía fueron evolucionando, pero los preceptos reguladores de estas garantías se mantuvieron inmóviles. De nada sirvieron las críticas a las que estuvieron sometidas aquellas previsiones, ni la posibilidad ofrecida por el procedimiento de reforma abierto con la elaboración de la LGT de 2003, para superar la obsolescencia e inadecuación en algunos aspectos de la regulación de las garantías reales y personales del crédito tributario. Casi sin modificaciones, y sí con nuevas incorporaciones, la ley tributaria vigente ha optado por mantener el mismo elenco de 
garantías reales y ampliar los supuestos de responsabilidad tributaria. Con esta línea continuista se veta la posibilidad de superar las deficiencias que fueron detectadas bajo la vigencia de la ley anterior. Situación que también se observa en la normativa reglamentaria actual, donde se aprecia una excesiva reiteración de los mandatos del derogado Reglamento General de Recaudación de 1990.

Ante tal panorama, y a pesar de la evolución del régimen jurídico de estas medidas tutelares, resulta necesario retomar las cuestiones que produjeron controversia bajo la vigencia del régimen anterior y, por tanto, tomar en consideración los criterios que se vertieron en su momento en la doctrina y la jurisprudencia sobre el régimen y aplicación de muchas de estas figuras. Se corrobora con ello, tal como se verá en el transcurso del trabajo, que estamos ante un tema que sigue produciendo polémica y que no se presenta con soluciones pacíficas. Esta circunstancia se aprecia, especialmente, en la existencia de posturas encontradas en cuanto a la concreción de las garantías personales y reales del crédito tributario. Se incluye, por ejemplo, en la normativa actual al tercer adquirente de bienes afectos dentro de los responsables subsidiarios, y ello constituye una previsión equívoca que exige la correcta interpretación de esta garantía con naturaleza real.

Tampoco las garantías reales que exige la Hacienda Pública para otorgar el aplazamiento o fraccionamiento del pago o la suspensión de una resolución impugnada se han visto favorecidas por el legislador, que se ha decantado preferiblemente por otras garantías de más fácil ejecución, como pueden ser los avales.

Por su parte, el Real Decreto 939/2005, de 29 de julio, por el que se aprueba el Reglamento General de Recaudación (en adelante RGR), en línea con lo previsto en la Ley Hipotecaria de 1948, sigue manteniendo la figura de la hipoteca legal expresa, figura de contornos difusos y de muy poca aplicabilidad práctica.

Entre las razones que han influido decisivamente en la elección de la temática desarrollada en este trabajo destaca también el hecho de que, con frecuencia, en el momento en que la Administración tributaria ejecuta su crédito garantizado se produce la concurrencia de los intereses de ésta con los de otros acreedores, con pretensiones sobre el mismo deudor o, incluso, sobre el mismo bien afecto. Esta es una cuestión compleja por la gran cantidad de afecciones y privilegios que son recogidos en normativa dispersa. El ordenamiento tributario presta un especial interés a la posición en que quedarán los créditos de la Hacienda Pública, protegidos por alguna garantía, al concurrir con otros créditos igualmente garantizados o privilegiados. De la misma forma que también resulta muy importante para el crédito tributario la incidencia que pueda tener la apertura de un procedimiento concursal contra el sujeto deudor. Entre las medidas que tradicionalmente favorecen la posición de la Administración tributaria en el concurso, destaca la posibilidad de la ejecución separada de los créditos garantizados con un derecho real de garantía, facultad que, con ciertos matices, ha sido conservada en la Ley 22/2003, de 9 de julio, Concursal (en adelante LC).

Del responsable tributario se ha escrito mucho en los últimos tiempos. Al igual que sucede con el resto de garantías, el legislador ha optado por mantener las mismas disposiciones que en la normativa anterior, en contra de un sector importante de la doctrina, que demandó la supresión de algunos de los supuestos, y por ampliar considerablemente el elenco de responsables, en muchos casos con finalidades distintas a las que definen las garantías personales. Si bien algunos autores consideran 
posible la constitución de la responsabilidad con un fin distinto al estricto aseguramiento del crédito tributario, nosotros partimos de la posición tradicional que defiende la existencia de un elemento común, la función estrictamente garantista, aplicable a todos los supuestos de responsabilidad. Éste no ha sido, sin embargo, el proceder del legislador, que, ante las complicaciones en la recaudación o el interés por castigar conductas perjudiciales para los intereses generales, se ha decantado por configurar supuestos de responsabilidad con una naturaleza distinta como la sancionadora, en el caso, por ejemplo, de la responsabilidad solidaria por la participación en la comisión de una infracción.

La derivación de las sanciones fue y sigue siendo otro de los temas controvertidos en materia de responsabilidad tributaria. La LGT tiene como regla general que las sanciones no alcanzan a la obligación del responsable, salvo las excepciones que esa u otra ley determine. Sin embargo, no queda claro si procede derivar las sanciones en los supuestos de responsabilidad por actos ilícitos, como es el caso del inciso $a$ ) del apartado primero del artículo $42 \mathrm{y}$ el inciso $a$ ) del apartado primero del artículo 43, ambos de la LGT. En estos supuestos, el presunto responsable es un infractor que participa en la comisión de la infracción del deudor principal y, por tanto, debe seguirse contra él un procedimiento tributario sancionador, respetando todos los derechos y garantías reconocidos para este tipo de procedimientos.

Otra de las cuestiones que carece de claridad en la ley tributaria, en relación con los responsables, es el plazo de prescripción de la obligación de pago que incumbe a estos sujetos, ya que la norma sólo contempla la prescripción del derecho a exigir el cumplimiento de esta obligación, sin realizar ninguna distinción entre la fase declarativa de la responsabilidad y la fase recaudatoria. Por otra parte, aunque la LGT prevé la posibilidad de que si se interrumpe el plazo de prescripción para el obligado principal dicho efecto se extienda también a los responsables tributarios, esta disposición es objeto de distintas interpretaciones, a los efectos de no vaciar de contenido el reconocimiento expreso de un plazo de prescripción para los responsables tributarios.

El presente trabajo aparece dividido en cinco capítulos, individualizados, pero interrelacionados entre sí. El primero de ellos, titulado El cumplimiento de la obligación tributaria: el pago, tiene por objeto ofrecer una perspectiva completa del pago como mecanismo ordinario de cumplimiento de la obligación tributaria, para lo cual se examina el procedimiento de recaudación en sus distintas etapas. Se presta especial atención al procedimiento de apremio para el cobro del crédito tributario, en los términos que prevé la normativa tributaria; a la decisiva influencia de otros sectores del ordenamiento jurídico, como el concursal; y a otras cuestiones relacionadas con el régimen interno del pago, como el aplazamiento o fraccionamiento del mismo.

En el segundo capítulo, denominado Las garantías del crédito tributario, se procede a examinar las medidas tutelares que refuerzan el derecho de crédito de que dispone la Administración tributaria y que son necesarias cuando el pago no se ha efectuado. Para desarrollar esta tarea, ha sido necesario subrayar los elementos diferenciales entre la responsabilidad patrimonial universal y las garantías de la obligación y, dentro de éstas últimas, entre las garantías del crédito tributario en sentido amplio y las garantías en sentido estricto. Distinción que nos parece fundamental porque la LGT, al igual que su predecesora de 1963, incluye en el seno de las garantías de la deuda tributaria a instituciones que no poseen las características propias de estas garantías, como es el caso del privilegio general a favor 
de la Hacienda Pública o de las medidas cautelares, aunque en todos los casos lo que se busca es, en sentido amplio, el reforzamiento del crédito tributario.

El tercero de los capítulos, Las garantías reales tributarias, analiza las distintas figuras garantistas que tienen naturaleza real en la LGT: la hipoteca legal tácita, y el derecho de afección. Figuras a las que habría que añadir la hipoteca legal expresa, prevista en el artículo 66 del RGR. El legislador, de manera continuista, ha regulado estas garantías reales de la misma forma que en el régimen anterior, aunque ha reubicado la responsabilidad por sucesión de empresas que se estipulaba en el artículo 73 de la LGT de 1963 dentro de los supuestos de responsabilidad, en la parte subjetiva del tributo. Sin embargo, se mantienen dentro del grupo de las garantías otras prerrogativas que aseguran el cobro del crédito pero que no son garantías en sentido estricto. Sobre estas medidas tutelares reflexionamos también en el tercer capítulo, no sólo porque se encuentran insertadas dentro de las garantías, sino porque su aplicación otorga una mayor efectividad a las verdaderas garantías reales. Nos referimos al derecho de prelación general, al derecho de retención, y a las medidas cautelares.

El capítulo cuarto, que tiene por título Las garantías personales tributarias, se ocupa del examen de la responsabilidad y la solidaridad tributaria como garantías personales del crédito tributario. Dicha labor se lleva a cabo precisando las cuestiones generales que configuran la institución de la solidaridad tributaria, distinguiendo las modalidades de solidaridad e incidiendo en las consecuencias que se derivan de esta distinción. Y en relación con los responsables tributarios, en este capítulo, se estudian los caracteres generales de esta figura y el procedimiento de derivación de la responsabilidad; y se examina, finalmente, el procedimiento de derivación de la responsabilidad; se valora, dentro de las formas de extinción de la obligación del responsable, la incidencia de la prescripción; y se examina el derecho de reembolso que la ley reconoce a los responsables tributarios. Dentro de cada uno de esos temas, se abordan las cuestiones discrepantes que también estuvieron presentes en el régimen de la LGT de 1963, sobre todo las relacionadas con la naturaleza jurídica de la responsabilidad; el alcance de ésta; los supuestos de responsabilidad solidaria y subsidiaria, y más en concreto la deficiente configuración técnica de algunos de ellos o la posibilidad de que queden subsumidos unos por otros; y la concurrencia de varios responsables, entre otros.

Ya por último, en el capítulo quinto (Las garantías del crédito tributario en caso de aplazamiento o fraccionamiento del pago o interposición de un recurso), se abordan las garantías reales y personales que la ley exige que presente el obligado tributario para que pueda aplazar y fraccionar el pago de la deuda o pueda suspender la ejecución de un acto administrativo al interponer un recurso. Separamos estas garantías, de igual naturaleza que las que se estudian en el tercero y cuarto capítulo, porque a diferencia de éstas no son estrictamente tributarias y se contienen no en la LGT, sino en la normativa de Derecho privado. En este capítulo se detallan sucintamente, primero, las garantías reales y personales que debe constituir el obligado tributario si pretende beneficiarse del aplazamiento o fraccionamiento del pago, y se valoran las garantías que exige la ley para que este mismo sujeto suspenda la ejecución del acto administrativo por la presentación de una reclamación. En ambos supuestos observamos como el legislador, de manera general, aboga preferentemente por la presentación de garantías personales de más fácil ejecución. 
Al final de la investigación formulamos un grupo de conclusiones que responden a los distintos objetivos, generales y específicos, propuestos en la tesis. En esta última parte exponemos nuestra posición en relación con muchos de los temas tratados en la investigación, no exentos de polémicas y contradicciones. 


\section{CAPÍTULO PRIMERO \\ EL CUMPLIMIENTO DE LA OBLIGACIÓN TRIBUTARIA: EL PAGO}

El sistema tributario tiene como objetivo la obtención de ingresos que permitan hacer frente a los gastos públicos. A través del procedimiento de recaudación se realizan los créditos tributarios y de Derecho público. A su vez, estos créditos tributarios pueden dotarse de una serie de prerrogativas que incrementan las posibilidades de la Administración tributaria para hacer efectivo su cobro. Precisamente son esos mecanismos que garantizan el crédito tributario los que centran nuestra atención. Sin embargo, antes de adentrarnos en el ámbito de las garantías que aseguran la realización del crédito tributario nos parece oportuno iniciar nuestro trabajo analizando la forma normal a través de la cual se logra la satisfacción de dicho crédito, el pago, ya sea voluntariamente por el deudor o por el ejercicio coactivo de la Administración tributaria. En este primer capítulo pretendemos realizar un estudio pormenorizado del procedimiento de recaudación en sus distintas etapas, a saber, período voluntario y período ejecutivo. Aunque también desarrollaremos otras cuestiones conexas a dicho procedimiento, como las obligaciones tributarias accesorias.

\section{EL PAGO EN PERÍODO VOLUNTARIO}

\subsection{EL PAGO COMO MECANISMO ORDINARIO DE CUMPLIMIENTO DE LA OBLIGACIÓN TRIBUTARIA}

Por medio de la actividad financiera las administraciones buscan obtener recursos que les permitan afrontar las necesidades económicas inherentes a la provisión de los servicios públicos. Con este fin se configuran en el ordenamiento tributario unos hechos imponibles cuya realización por los sujetos pasivos da lugar al nacimiento de la obligación tributaria que deberá satisfacerse por aquellos sujetos.

Se entiende entonces que uno de los aspectos más importantes de los procedimientos tributarios sea el cumplimiento de la obligación tributaria. La LGT identifica, en el primer apartado del artículo 59, como formas de extinción de la obligación tributaria, el pago, la prescripción, la compensación o condonación, y los demás medios previstos en la normativa aduanera y demás leyes.

El apartado 2 del propio artículo determina que el pago, la compensación, la deducción sobre transferencias o la condonación de la deuda tributaria, tienen efectos liberatorios, exclusivamente, si se extingue el crédito, pues de lo contrario sólo se reduce por el importe pagado, compensado, deducido o condonado. De esta forma la ley establece los efectos liberatorios para esas causas de extinción, aunque no concreta este punto respecto de las otras formas de extinción como la prescripción, o las previstas en las leyes aduaneras.

De las causas de extinción de la obligación tributaria descritas sólo nos detendremos en el estudio del pago y sus modalidades, cuya regulación se contiene en los artículos 60 a 65 de la LGT. Con la realización de aquél se logra el fin primordial del procedimiento de recaudación, que es la satisfacción de la deuda tributaria. Por ende, el pago se convierte en la forma deseable de cumplimiento del crédito tributario y extingue la deuda. La compensación y deducción de transferencia no implican ningún ingreso para la Hacienda Pública, pero sí tienen el mismo efecto económico en la medida en que "ahorran" un gasto a la misma por el importe de lo compensado o 
deducido. Las otras formas de extinción, la condonación y la prescripción, siendo, como son, muy relevantes, no forman parte del objeto de la presente tesis.

La legislación tributaria no determina un concepto de pago, por lo que habrá que remitirse a las definiciones que aparecen en la doctrina. GONZÁLEZ MÉNDEZ entendió que el pago es "la entrega por el sujeto pasivo de la obligación tributaria, al acreedor de la misma, de una suma de dinero establecida en la prestación, que produce la extinción de aquella obligación" "Por su parte, FERREIRO LAPATZA escribió que "el pago de la «deuda tributaria» ha de ser definido, así, como la realización del programa diseñado por el legislador al establecer y regular cada una de estas obligaciones; como la realización de la prestación (la entrega de una cantidad de dinero) que constituye el objeto de la obligación",2.

\subsection{EL PERÍODO VOLUNTARIO DE PAGO}

La LGT no reconoce expresamente un procedimiento en sentido estricto para regular el pago en período voluntario, sólo se limita a recoger el contenido de algunos preceptos del antiguo Real Decreto 1684/1990, de 20 de diciembre, que aprueba el Reglamento General de Recaudación, relativo a los plazos o de las formas de pago (artículos 60 a 62 de la LGT). Tampoco la LGT de 1963 dispuso de un procedimiento en sentido estricto para el pago en período voluntario, como puede verse en el Título III "La Gestión Tributaria", Capítulo V "La Recaudación”, que no obstante dedicarse a la función de recaudación sólo se refería al procedimiento de apremio (artículos 126 a 139 de la LGT de 1963). En este sentido, los preceptos que determinaban el pago en período voluntario se encontraban en las normas reglamentarias de aquella época.

En la actualidad la regulación de esta materia está a cargo del RGR. El artículo 68 del RGR establece las normas generales para el inicio y la terminación del procedimiento de recaudación en período voluntario, en términos similares a lo que determinaba el artículo 72 del RGR de 1990. Sin embargo, debemos aclarar, siguiendo los mismos criterios de TEJERIZO LÓPEZ ${ }^{3}$, que la ausencia de un precepto en la ley que se pronuncie sobre el pago en período voluntario no implica que necesariamente debamos remitirnos a las normas del ordenamiento civil, ya que la actuación de la Administración tributaria no es tan pasiva como la que corresponde a un acreedor ordinario y no requiere, en el caso de aquélla, de la realización de determinados actos para que se produzca el pago en el período voluntario.

Para algunos autores no existe realmente un período voluntario, debido al hecho de que el pago produce la extinción de la obligación tributaria y, de no realizarse el ingreso, se produce el inicio del período ejecutivo ${ }^{4}$. En nuestra opinión, el período voluntario de pago es la primera de las dos etapas

\footnotetext{
${ }^{1}$ GONZÁLEZ MÉNDEZ, A., El pago de la obligación tributaria, Ministerio de Economía y Hacienda, Instituto de Estudios Fiscales, Madrid, 1988, pág. 63.

${ }^{2}$ FERREIRO LAPATZA, J. J., La nueva Ley General Tributaria (Ley 58/2003, de 17 de diciembre, Marcial Pons, Madrid, 2004, pág. 166.

${ }^{3}$ TEJERIZO LÓPEZ, J. M., “Capítulo VII. Procedimientos de recaudación”, en la obra La nueva Ley General Tributaria, ThomsonCivitas, Madrid, 2004, pág. 598.

${ }^{4}$ Así lo entienden, entre otros, GALAPERO FLORES, R., El procedimiento de recaudación de los tributos. Estudio de su regulación en la Ley General Tributaria y en el Reglamento General de Recaudación, Universidad de Extremadura, Servicio de Publicaciones, Extremadura, 2008, pág. 57; y TEJERIZO LÓPEZ, J. M., “Capítulo VII. Procedimientos de recaudación”, op. cit., pág. 598.
} 
que conforman el procedimiento de recaudación, pese a que la norma no determina el desarrollo de ningún procedimiento propio de período voluntario. El hecho de que la Administración tributaria no tenga que realizar ninguna actuación para que se efectúe el ingreso en período voluntario no significa que éste no exista.

En la doctrina aparecen otras opiniones que estructuran de manera diferente el procedimiento de recaudación. Algunos autores ubican un período intermedio, de prórroga o extemporáneo, una vez finalizado el período voluntario y antes de que se inicie el período ejecutivo ${ }^{5}$. Como ya hemos mencionado, el procedimiento de recaudación se conforma por dos etapas diferentes: el período voluntario de pago y el período ejecutivo, y dentro de éste último se ubica el procedimiento de apremio, que también se denomina indistintamente período de apremio o procedimiento ejecutivo. De lo anterior se infiere que el período ejecutivo y el procedimiento de apremio no son exactamente lo mismo, aunque en muchas ocasiones coincidan en el tiempo ${ }^{6}$. Bajo esta concepción entendemos que el pago puede hacerse de manera voluntaria en el primero de los períodos; que el obligado puede efectuar su ingreso extemporáneamente en el período ejecutivo, antes de que se inicie el procedimiento de apremio; y que se puede realizar el crédito tributario sobre el patrimonio del deudor en el período ejecutivo a través del procedimiento de apremio.

Ahora bien, para determinar el inicio del período voluntario de pago debemos remitirnos al RGR, que en el apartado primero del artículo 68 relaciona tres supuestos que sirven como indicadores del inicio dicho período. Según el reglamento, el período voluntario de pago se inicia a partir de la fecha de notificación de la liquidación al obligado al pago; o con la apertura del respectivo plazo recaudatorio, cuando se trate de deudas que sean objeto de notificación colectiva y periódica; o bien con la fecha de comienzo del plazo señalado para su presentación, cuando se trate de autoliquidaciones.

\subsection{ASPECTOS GENERALES DEL PAGO}

El artículo 60 de la LGT indica por mandato expreso que el pago de la deuda tributaria se haga en efectivo, convirtiéndose en la forma normal de extinción del crédito tributario. No obstante, la LGT también reconoce otras dos formas de pago, el pago a través de efectos timbrados y el pago en especie, siempre que se admita expresamente por la norma ${ }^{7}$.

\footnotetext{
${ }^{5}$ PÉREZ ROYO es de la opinión que este período intermedio no es más que una fase o plazo dentro del propio período voluntario de pago y justifica la existencia de éste únicamente para contraponerlo al período de ejecución forzosa o de apremio. En definitiva, este autor entendió que, para que una deuda tributaria fuera exigible en el procedimiento ejecutivo, dicha deuda debía haber sido determinada en virtud de un acto administrativo, "por lo que en los procedimientos con autoliquidación la falta de cumplimiento deberá dar lugar a la apertura, no de un procedimiento de ejecución forzosa, sino de un procedimiento que conducirá a una liquidación de deuda en sí que será ya ejecutable en apremio" (PÉREZ ROYO, F., "El pago de la deuda tributaria", Revista Española de Derecho Financiero, núm. 6, 1975, pág. 308). Por su parte, GALAPERO FLORES entiende que el período extemporáneo de pago de la deuda tributaria es aquel plazo que "media entre la finalización del período voluntario, considerado éste como el plazo establecido en las normas para el ingreso de la deuda tributaria, y anterior al inicio de las actuaciones de la Administración para hacer efectiva la deuda tributaria en el período ejecutivo" (GALAPERO FLORES, R., "Recargos por declaración extemporánea sin requerimiento previo", Jurisprudencia Tributaria Aranzadi, Tomo III, 2007, pág. 256). TEJERIZO LÓPEZ afirmó que "es posible observar entre los dos un período de prórroga, tras la finalización del plazo de ingreso voluntario, que resulta aplicable en ciertos supuestos de ingresos a realizar mediante autoliquidación” (TEJERIZO LÓPEZ, J. M., “Capítulo VII. Procedimientos de recaudación”, op. cit., pág. 597).

${ }^{6}$ Para mayor profundización de este aspecto, vid. infra, Capítulo Primero, epígrafe 2.1. "Inicio del período ejecutivo".

${ }^{7}$ GONZÁLEZ SÁNCHEZ, M., "Capítulo VIII. La extinción de la obligación tributaria”, en la obra La Nueva Ley General Tributaria, CALVO ORTEGA R. (director), Thomson-Civitas, Madrid, 2004, pág. 655, considera acertada la postura de la ley al incorporar cuestiones fundamentales reguladas por el RGR, sin llegar a convertirse en reglamentista.
} 
De los mandatos de la LGT y del RGR se deduce, como habíamos indicado, que el pago en efectivo es la forma general de pago de la deuda tributaria, que el pago mediante efectos timbrados se supedita a su previsión previa por disposición reglamentaria, y que el pago en especie queda condicionado a una disposición legal expresa y a la discrecionalidad del acreedor.

\subsubsection{Formas de pago y efecto temporal del mismo}

\subsubsection{El pago en efectivo}

El RGR regula el pago en efectivo en el artículo 34, donde se determinan los medios y el momento de pago. Apenas existen innovaciones a resaltar dentro de este precepto, que reproduce, en su mayor parte, el contenido de los artículos 23 a 25 del RGR de 1990, aunque la regulación que hace de las formas de pago en efectivo es más extensa que la contenida por el artículo 24 del anterior RGR ${ }^{8}$. También destaca VEGA HERRERO, como deficiencia de la norma reglamentaria, la ausencia de regulación de los plazos de pago que el anterior reglamento contemplaba en el artículo 20, pudiendo deberse, según la opinión de esta autora, a que esta cuestión se recoge en el artículo 62 de la LGT 9 .

La regulación reglamentaria de los medios de pago en efectivo parte de la distinción entre deudas tributarias y no tributarias. Para el caso de las primeras, el RGR dispone una relación de medios de pago que se caracteriza por no ser exclusiva y por no tener un orden de preferencia para su utilización. Concretamente el artículo 34 del RGR determina como medios de pago en efectivo: el dinero de curso legal, los cheques, las tarjetas de crédito y débito, las transferencias bancarias, la domiciliación bancaria, y cualesquiera otros autorizados por el Ministerios de Economía y Hacienda. Al dinero de curso legal se le otorga un carácter de medio universal de pago, mientras que los restantes tipos se reservan para determinadas deudas tributarias y bajo las condiciones que prevé el reglamento.

En lo que concierne a las deudas no tributarias, el RGR expresa que el pago en efectivo de las deudas no tributarias debe efectuarse por los medios que autorice su propia normativa y, a falta de una normativa expresa, por los medios establecidos para las deudas tributarias que actúan con carácter supletorio $^{10}$.

\section{A. El dinero de curso legal}

Los artículos 34 a 38 del RGR desarrollan el régimen de este tipo de ingreso. El primero de los preceptos, en su apartado 1, determina que las deudas que se paguen en efectivo deberán hacerse a

\footnotetext{
${ }^{8}$ GALAPERO FLORES, R., El procedimiento de recaudación de los tributos. Estudio de su regulación en la Ley General Tributaria y en el Reglamento General de Recaudación, op. cit., pág. 61.

${ }^{9}$ Esta autora considera que los plazos de pago debieron regularse en el reglamento y no en la LGT por varias razones, "la primera es que aquella se ocupa exclusivamente de los plazos de pago de las deudas tributarias y es posible que las reglas que contiene no sean suficientes para otro tipo de deudas debiendo recordarse a este propósito que el ámbito del RGR es más amplio que el de la LGT; además se trata de una materia típicamente reglamentaria dada su escasa trascendencia para los obligados al pago y, por fin, no tiene demasiado sentido que la LGT aborde esta cuestión para dar una serie de pautas que, en su mayor parte, solo son subsidiarias respecto a lo que establezcan, en cada caso, las normas tributarias específicas" (VEGA HERRERO, M., "Capítulo I. Extinción y garantías de la deuda", en la obra Los Nuevos Reglamentos Tributarios, Thomson-Civitas, Navarra, 2006, pág. 30).

${ }^{10}$ Destaca VEGA HERRERO que los artículos que regulan el pago en efectivo presentan una excesiva pormenorización en gran medida innecesaria, ya que en casi todos ellos se repite el momento en que se entiende hecho el pago, así como una falta de coordinación interna (VEGA HERRERO, M., "Capítulo I. Extinción y garantías de la deuda”, op. cit., pág. 33).
} 
través de dinero de curso legal. La ley, por su parte, no alude al dinero de curso legal, sino que se remite al pago en efectivo. Si bien, ni la ley ni el reglamento definen el dinero de curso de legal como forma de pago en efectivo, éste se desarrolla a través de la Orden del Ministerio de Economía y Hacienda de 15 de octubre de $1992^{11}$.

Las deudas que se paguen por medio de dinero de curso legal se considerarán satisfechas cuando se realice el ingreso de su importe en las cajas de los órganos competentes, entidades colaboradoras, entidades que presten el servicio de cajas o demás personas o entidades autorizadas para recibir el pago, según el apartado 3 del artículo 34 del RGR. También el apartado 4 del mismo precepto dispone que cuando el pago se efectúe a través de entidades de crédito u otras personas autorizadas, la entrega al deudor del justificante de ingreso libera a éste desde la fecha que aparece en el justificante y por el importe que en él figure, quedando obligada la entidad de crédito o persona autorizada frente a la Hacienda Pública desde ese instante y por dicho importe, salvo que pudiera probarse fehacientemente la inexactitud de la fecha o del importe que conste en la validación del justificante.

\section{B. Los cheques}

Los pagos que se hagan en entidades de crédito que presten el servicio de caja también podrán realizarse a través de cheques. La definición de esta forma de pago se puede encontrar en el artículo 534 del Código de Comercio de 1885, modificado por la Ley 19/1985, de 16 de julio, Cambiaria y del Cheque. Dicho precepto dispone que los cheques son un mandato de pago incorporado a un título de crédito formal y completo que permite al librador retirar, en su provecho o en el de un tercero, todos o parte de los fondos que tiene disponibles en poder del librado. Asimismo, éstos se caracterizan por ser una orden de pago: pura y simple que no admite condición; a la vista; sobre fondos previamente disponibles; que no necesita la aceptación del librado y no contrae obligaciones frente al tenedor, sino frente al librador; y con una vida breve ${ }^{12}$.

Ahora bien, la utilización de esta forma de pago en efectivo deberá efectuarse siguiendo las indicaciones de la normativa mercantil y los requisitos que exige el apartado 1 del artículo 35 del RGR, porque nada se indica en la LGT sobre esta materia. Según el artículo mencionado, los cheques deberán ser nominativos a favor del Tesoro público o estar conformados o certificados por la entidad librada en fecha y forma. El deudor queda liberado por el importe satisfecho que se haga efectivo una vez que entregue el cheque en la entidad que en su caso preste el servicio de caja. De la misma forma que sucede para el pago en efectivo a través de dinero de curso legal, el efecto liberatorio del pago

\footnotetext{
${ }^{11}$ Tal como recuerda DAGO ELORZA, el antecedente más próximo a la legislación tributaria se localiza en el artículo 1.170 del Código Civil, cuando señalaba que el pago de las deudas de dinero debía hacerse en la especie pactada y, no siendo posible entregar la especie, en la moneda de plata u oro que tuviera curso legal en España, y que la Ley de 20 de enero de 1939 privó de curso legal, a partir de 20 de febrero de 1939, a la moneda de plata, y la Orden de 29 de octubre de 1941 restringió el curso legal, con efectos de 1 de enero de 1942, a la moneda divisionaria del cobre. A partir de estas fechas, el dinero de curso legal estuvo constituido por los billetes del Banco de España (Ley de 9 de noviembre de 1939) y su moneda fraccionaria. A partir del 1 de enero de 1999, este régimen quedó sustituido por la introducción del euro (Ley 46/1998, de 17 de diciembre, sobre la introducción del euro). El pago deberá hacerse en la moneda de curso legal en España, "y si bien ni la LGT ni el RGR distinguen, la orden de desarrollo sí se refiere a que el pago se haga con moneda de curso legal en España" (DAGO ELORZA, I., "Título II., Capítulo IV. La deuda tributaria”, en la obra Comentarios a la Nueva Ley General Tributaria, HUESCA BOADILLA, R. (coordinador), Thomson-Aranzadi, Navarra, 2004, pág. 401. En esta materia, también puede consultarse ZABALA RODRÍGUEZ-FORNS, A., LLOPIS GINER, F. y DAGO ELORZA, I., Recaudación, aspectos sustantivos y procedimentales, $2^{\mathrm{a}}$ ed., CISS, Valencia, 1993, pág. 214.
}

${ }^{12}$ DAGO ELORZA, I., “Título II., Capítulo IV. La deuda tributaria”, op. cit., pág. 402. 
por medio de cheques se entiende producido desde la fecha de entrega del cheque en la entidad. Ésta última valida el correspondiente justificante de ingreso, que incluye la fecha de entrega y el importe del pago, quedando desde ese momento la entidad obligada ante la Hacienda Pública por la cuantía efectivamente ingresada.

Es claro que la admisión de un cheque impone al acreedor, en este caso la Administración tributaria y sus entes colaboradores, una carga de diligencia, por lo que estos acreedores serán responsables de su presentación al cobro dentro de los plazos previstos legalmente. Por ende, la Hacienda Pública no podrá acudir al apremio por impago si antes no ofrece la posibilidad de un nuevo ingreso al obligado. En este sentido, la tardanza en el cobro del cheque confirmado más allá de los cinco días que establece el Derecho mercantil, no perjudica al deudor que queda liberado ${ }^{13}$. En definitiva, no es correcto pensar que, si transcurre el plazo de pago en período voluntario y no se hace efectivo el cheque en todo o en parte, se expida la providencia de apremio exigiéndose la responsabilidad del deudor o de la entidad que lo conformó o certificó ${ }^{14}$, teniendo en cuenta que la Administración tributaria no actuó diligentemente, como corresponde a cualquier acreedor.

De igual forma, los pagos que se hagan en las cajas de la Dirección General del Tesoro y Política Financiera podrán hacerse a través de cheques, con los requisitos generales que exigen la legislación mercantil y los que regula el apartado 2 del artículo 35 del RGR. Para este tipo de pago, el RGR dispone que los cheques deban ser nominativos a favor del Tesoro público y cruzados al Banco de España. También deberán incluir el nombre y apellidos o razón social o denominación completa del librador. El deudor queda liberado de su obligación de pago, en relación con el importe satisfecho, una vez que se produce la entrega del cheque. En este caso, surtirá efectos desde la fecha en que haya tenido entrada en la caja correspondiente.

\section{Las tarjetas de crédito y de débito}

Con la Orden de 25 de abril de 1997 se incorporan las tarjetas de crédito y de débito como forma de pago en efectivo cuando el pago se realiza ante las entidades de crédito, que en su caso, presten el servicio de caja, siempre que la tarjeta a utilizar se encuentre incluida entre las que, a tal fin, sean aceptadas en cada momento por dichas entidades. Los límites para realizar el pago a través de estas tarjetas los establecen cada entidad emisora individualmente a cada tarjeta, y en ningún caso podrá superar la cantidad que se determina en la Orden del Ministerio de Economía correspondiente por cada documento de ingreso, no pudiendo simultanearse, para un mismo documento de ingreso, con cualquier otro de los medios de pago admitidos. También resulta importante la previsión reglamentaria de que los importes ingresados por los obligados al pago por medio de tarjetas de crédito o de débito no podrán ser minorados como consecuencia de descuentos en la utilización de tales tarjetas o por cualquier otro motivo.

\footnotetext{
${ }^{13}$ Sentencia de la Audiencia Nacional de 25 de enero de 2000.

${ }^{14}$ A tenor de lo que establece el artículo 110 de la Ley Cambiaria, una vez que el banco certifica o conforma el cheque queda acreditada su autenticidad y la existencia de fondos suficientes, con obligación de retener la cuantía necesaria para satisfacerlo a su vencimiento, y siendo la responsabilidad a partir de ese momento de la entidad de crédito.
} 


\section{Las transferencias bancarias}

Otra de las formas en que puede efectuarse el pago en efectivo es a través de transferencias bancarias. El pago se considera realizado en la fecha en que haya tenido entrada el importe correspondiente en la entidad, que en su caso, preste el servicio de caja, quedando liberado desde ese momento el obligado al pago frente a la Hacienda pública por la cantidad ingresada. Cuando exista una orden de transferencia, el pago se entiende realizado en el momento que se produce el ingreso en la cuenta restringida del Tesoro Público y no cuando se dio la orden o cuando la entidad de crédito entregó un justificante del ingreso ${ }^{15}$. También aclara el RGR, en el segundo párrafo del artículo 37, que es la Administración tributaria la que establece las condiciones para que se pueda utilizar esta forma de pago por vía telemática.

\section{E. La domiciliación bancaria}

Cuando se trate del pago mediante domiciliación bancaria, éste deberá ajustarse a los requisitos que determina el apartado $1 \mathrm{del}$ artículo $38 \mathrm{del} \mathrm{RGR.} \mathrm{Según} \mathrm{este} \mathrm{precepto,} \mathrm{se} \mathrm{requiere} \mathrm{que} \mathrm{el} \mathrm{obligado} \mathrm{al}$ pago sea titular de la cuenta en que domicilie el pago y que dicha cuenta se encuentre abierta en una entidad de crédito. Sin embargo, en los términos y condiciones que cada Administración establezca, el pago podrá domiciliarse en una cuenta que no sea de titularidad del obligado, siempre que el titular de dicha cuenta autorice la domiciliación. Además, el reglamento exige, para la utilización de la domiciliación bancaria como forma de pago en efectivo del crédito tributario, que el obligado al pago comunique su orden de domiciliación a los órganos de la Administración tributaria según los procedimientos que se establezcan en cada caso. Este tipo de pago se entiende satisfecho en la fecha de cargo en cuenta de dichas domiciliaciones, considerándose justificante del ingreso el que a tal efecto expida la entidad de crédito donde se encuentre domiciliado el pago, que incorporará como mínimo los datos que se establezcan en la orden ministerial correspondiente.

Más adelante aclara el RGR, en el apartado 3 del artículo 38, que cuando el cargo en cuenta no se realice o se realice fuera de plazo por causa no imputable al obligado al pago no se exigirán a éste los recargos, los intereses de demora, ni las sanciones, sin perjuicio de los intereses de demora que, en su caso, corresponda liquidar y exigir a la entidad responsable por la demora en el ingreso. También se reitera en esta forma de pago que la Administración tributaria establecerá, en su caso, las condiciones para hacerlo efectivo a través de la vía telemática ${ }^{16}$.

\section{F. Efecto temporal del pago}

Con independencia de cuál sea la forma de pago en efectivo que se utilice para satisfacer el crédito tributario, de manera general, son tres las reglas que se utilizan para determinar el momento en que éstas producen sus efectos una vez que se realiza el ingreso. La primera de estas reglas es la del día

\footnotetext{
${ }^{15}$ Estos criterios para determinar el momento en que queda liberado el deudor cuando existe la orden de transferencia se confirman en la Resolución del Tribunal Económico-Administrativo Central (en adelante TEAC) de 1 de diciembre de 1999.

${ }^{16}$ Para algunos autores la utilización de la domiciliación bancaria es un medio de pago residual, "porque la realidad va mucho más rápido y la generalización de los pagos en entidades colaboradoras desvía la atención hacia las relaciones del cliente con la entidad colaboradora" (DAGO ELORZA, I., "Título II. Capítulo IV. La deuda tributaria”, op. cit., pág. 406). Para ZABALA RODRÍGUEZFORNS, LLOPIS GINER, y DAGO ELORZA, se trata de "una institución de escaso uso" (ZABALA RODRÍGUEZ-FORNS, A., LLOPIS GINER, F. y DAGO ELORZA, I., Recaudación, aspectos sustantivos y procedimentales, op. cit., pág. 219).
} 
en que se realiza el ingreso en las cajas de los órganos competentes, oficinas o entidades debidamente autorizadas para su admisión, según consta en el apartado 1 del artículo 61 de la LGT. La segunda, es la realización del pago en una entidad de crédito u otras personas autorizadas para ello, liberando al deudor de su obligación desde la fecha que se consigne en el justificante de ingreso, sin que surtan efecto por sí solas las órdenes de pago dadas por el deudor a las entidades de crédito u otras personas autorizadas para recibir el pago, tal como establecen los apartados 4 y 5 del artículo 34 del RGR. Y en tercer lugar, si se paga mediante cheque queda liberado el obligado desde su entrega si aquél se hace efectivo, y si esto último no se produce se exige en apremio la deuda a la entidad que válidamente lo confirmó o, de no darse esta circunstancia, al propio obligado.

\subsubsection{El pago mediante efectos timbrados}

El ingreso a través de efectos timbrados es otra de las formas de pago admitidas, siempre que así se disponga reglamentariamente. Los efectos timbrados son aquellos documentos que contienen impreso un dibujo, señal o anagrama especial y el valor correspondiente. Junto al pago en efectivo, el pago mediante efectos timbrados es la forma tradicional de realizar el ingreso de la deuda tributaria.

La LGT no regula de manera global y sistemática este medio de pago mediante efectos timbrados y tampoco destina ningún precepto a su aplicación. El primer apartado del artículo 60 de la LGT únicamente alude a esta forma de pago y efectúa una remisión reglamentaria para establecer el régimen de de la misma. El RGR reconoce en su artículo 39 que tienen condición de efectos timbrados el papel timbrado común, el papel timbrado de pagos al Estado, los documentos timbrados especiales, los timbres móviles, y los aprobados por orden del Ministro de Economía y Hacienda. El apartado segundo de ese mismo precepto específica que el empleo, forma, estampación, visado, inutilización, condiciones de canje y demás características se regirán por las normas que regulan los tributos y demás recursos de naturaleza pública que admiten esta forma de pago y por los mandatos del propio reglamento ${ }^{17}$. Entre los tributos que admiten esta forma de pago se encuentran las tasas y los precios públicos (artículo 21 de la Ley 8/1989, de 13 de abril, de Tasas y Precios Públicos; y artículo 27 de la Ley 25/1998, de 13 de julio, de Modificación del Régimen Legal de las Tasas Estatales y de Reordenación de las Prestaciones Patrimoniales de Carácter Público), y el Impuesto sobre Transmisiones Patrimoniales y Actos Jurídicos Documentados (apartado segundo del artículo 12 del Real Decreto Legislativo 1/1993, de 24 de septiembre, por el que se aprueba el Texto Refundido de la Ley de Impuesto sobre Transmisiones Patrimoniales y Actos Jurídicos Documentados, en adelante ITPAJD).

\footnotetext{
${ }^{17}$ Es preciso diferenciar el canje y la devolución de efectos timbrados como consecuencia de la devolución de ingresos indebidos. Se trata de fórmulas distintas que incorporan resultados diferentes y se realizan a través de procedimientos independientes. El canje de los efectos timbrados se regula en el artículo 117 del Real Decreto 828/1995, de 29 de mayo, que aprueba el Reglamento del Impuesto sobre Transmisiones Patrimoniales y Actos Jurídicos Documentados (ITPAJD). Por el contrario, no existe previsión reglamentaria sobre la devolución de efectos timbrados, por lo que habrá que estar a lo dispuesto en la normativa general sobre devolución de ingresos indebidos. En este sentido, el Tribunal Supremo ha despejado toda duda sobre la procedencia o improcedencia de la devolución cuando el pago de la deuda tributaria haya tenido lugar mediante efectos timbrados, afirmando que procede "el canje de los efectos, pero no procede la devolución" (Sentencia de 19 de junio de 1989). ZABALA RODRÍGUEZ-FORNS, LLOPIS GINER, y DAGO ELORZA entienden que, "dado que el adquirente desembolsa una cantidad de dinero en su adquisición para un fin determinado (el pago), la imposibilidad de que este fin se cumpla no puede repercutir negativamente en él, de ahí que se admita el canje de efectos que sufran defectos que imposibiliten la finalidad para la que se adquirieron, siempre y cuando en ellos no exista alguna circunstancia que pueda hacer presumir que ya se han afectado al pago, o sean inutilizables" (ZABALA RODRÍGUEZ-FORNS, A., LLOPIS GINER, F. y DAGO ELORZA, I., Recaudación, aspectos sustantivos y procedimentales, op. cit., pág. 219).
} 
Por último, el pago del crédito tributario a través de los efectos timbrados libera al obligado cuando aquéllos se utilicen en la forma que reglamentariamente se determine, a tenor de lo previsto en el número 2 del artículo 61 de la LGT.

\subsubsection{La dación en pago}

Teniendo en cuenta las características y los objetivos que persigue la obligación tributaria, resulta evidente que la forma ordinaria de la extinción de dicha obligación debe ser mediante el pago en metálico. Sin embargo, en determinados supuestos la ley prevé que el obligado tributario pueda satisfacer su deuda a través de la entrega de bienes distintos del dinero ${ }^{18}$. En todo caso, la obligación tributaria no pierde nunca su carácter dinerario, pues la deuda consiste en una cantidad de dinero ${ }^{19}$, y la entrega de bienes culturales debe considerarse con carácter excepcional porque, en palabras de PEDREIRA MENÉNDEZ, "la Administración deja de percibir ingresos que necesita para poder sufragar los gastos públicos" y "se le genera un nuevo gasto porque debe hacer frente a los deberes de conservación y difusión que tienen esta clase de bienes"20.

El primer ejemplo de dación en pago en nuestro ordenamiento jurídico se encuentra en la Ley de Hidrocarburos de 26 de diciembre de $1958^{21}$, pero hasta la Ley Reguladora del Patrimonio Histórico Español de 1985 (en adelante LPHE) no se constata en la legislación una regulación que confiriera cierta importancia a la dación en pago. El artículo 73 de esa ley autorizó inicialmente el pago de las deudas tributarias del Impuesto sobre Sucesiones y Donaciones (en adelante ISD), el Impuesto sobre el Patrimonio (en adelante, IP) y el Impuesto sobre la Renta de las Personas Físicas (en adelante IRPF), mediante la entrega de bienes que formasen parte del Patrimonio Histórico Español, y esta posibilidad se introdujo más tarde también de forma expresa progresivamente en la normativa reguladora de estos impuestos y del Impuesto sobre Sociedades (en adelante IS), hasta hacerla extensiva finalmente a todas las deudas tributarias y declarar en todo caso exentas las ganancias patrimoniales que pudieran originarse en el IRPF o el IS por la entrega de los bienes.

La LGT de 1963 no contemplaba la dación en pago como forma de extinción de la obligación tributaria, lo que no impidió que se aplicara, como acabamos de indicar, a través de las normas reguladoras de los distintos tributos, en concreto el ISD, el IP y el IRPF. Más tarde, la Disposición Adicional Décima de la Ley 30/1994, de 24 de noviembre, de Fundaciones y de Incentivos Fiscales a la Participación Privada en Actividades de Interés General, extendió la facultad de utilización de este

\footnotetext{
${ }^{18}$ CORTÉS DOMÍNGUEZ entiende que la finalidad económica que tienen los tributos de reunir recursos para el Estado debe tener su reflejo en la forma jurídica de éste. Por ello la obligación tributaria consiste en dar dinero, y aun cuando considera imaginables otras formas de pago distintas de la del dinero, opina este autor que la prestación dineraria es la adecuada, y que sólo a título excepcional se pueden admitir otros medios de pago (CORTÉS DOMÍNGUEZ, M., Ordenamiento Tributario Español, Tecnos, Madrid, 1968, pág. 497 y 498).

${ }^{19}$ Así lo entienden FALCÓN Y TELLA, R., "Problemática del pago en especie, una nota sobre la facultad solutoria de las obligaciones tributarias", Revista Española de Derecho Financiero, núm. 54, 1987, pág. 217 a 221; GONZÁLEZ MÉNDEZ, A. P., El pago de la obligación tributaria, op. cit., pág. 169; PEÑUELAS I REIXACH, LL., El pago de impuestos mediante obras de arte y bienes culturales, la dación de bienes del Patrimonio Histórico Español, Marcial Pons, Madrid, 2001, pág. 85.

${ }^{20}$ PEDREIRA MENÉNDEZ, J., Beneficios e incentivos fiscales del patrimonio cultural, Thomson Aranzadi, Madrid, 2004 , pág. 181.

${ }^{21}$ El artículo 41 de la citada ley de hidrocarburos regulaba la posibilidad de que los concesionarios de las empresas que se dedicaban a la investigación y explotación de hidrocarburos pagasen la cuota mínima del impuesto sobre el producto bruto de las explotaciones de hidrocarburos en efectivo o en especie. En este caso, era el Gobierno y no el contribuyente el que tenía la posibilidad de solicitar que se aplicara esta figura del pago en especie.
} 
medio de pago al IS. Esto obligó a replantear, como dice PEDREIRA MENÉNDEZ, la justificación de la dación en pago. Según este autor, la dación en pago puede ser muy interesante para las sociedades a diferencia de las personas físicas, porque las sociedades en la mayoría de los casos poseen la capacidad económica necesaria "para invertir en un determinada obra de arte, rentabilizar su inversión con los beneficios fiscales (...) y, posteriormente, desprenderse del bien a través de la dación en pago de su IS, obteniendo importantes ventajas fiscales y publicitarias". Por todo ello, este mismo autor se muestra crítico con esta posibilidad, "ya que permite utilizar el PHE para lo que se viene denominando ingeniería financiera, con el objeto de conseguir un ahorro fiscal para las sociedades, no deseable, en nuestra opinión, por la desigualdad que introduce respecto de otros contribuyentes" 22 .

Hasta el año 2002 la normativa estatal sólo reconocía el pago de las deudas tributarias por medio de la dación en pago de bienes del Patrimonio Histórico Español en el ISD, el IP, el IRPF y el IS. En las Leyes de Patrimonio Histórico o Cultural de las Comunidades Autónomas la referencia a la posibilidad de pagar mediante el patrimonio histórico o cultural autonómico se amplió a la totalidad de los tributos propios autonómicos y en algunos casos, incluso, a los tributos de los Entes Locales ubicados dentro de su territorio ${ }^{23}$. En algunas Comunidades, incluso, se aceptó la utilización de esta forma de pago para hacer frente a las sanciones y a deudas no tributarias ${ }^{24}$.

La última de las modificaciones del artículo 73 de la LPHE tuvo lugar por medio la Disposición Adicional Primera de la Ley 24/2001, de 27 de diciembre, de Medidas Fiscales, Administrativas y de Orden Social, que admitió la dación en pago como extinción de todas las deudas tributarias, sin distinción de figuras concretas ${ }^{25}$.

Con la aprobación de la LGT de 2003, se aceptó ya expresamente en la normativa tributaria este sistema de pago, disponiendo el apartado segundo del artículo 60 de dicha ley que

"podrá admitirse el pago en especie de la deuda tributaria en período voluntario o ejecutivo cuando una Ley lo disponga expresamente y en los términos y condiciones que se prevean reglamentariamente".

Se acepta así definitivamente la dación en pago como forma de extinción de las deudas tributarias, pero nada se dice en cuanto al carácter ordinario o extraordinario de la misma. Y es que las leyes

\footnotetext{
${ }^{22}$ PEDREIRA MENÉNDEZ, J., Beneficios e incentivos fiscales del patrimonio cultural, op. cit., pág. 187.

${ }^{23}$ PEDREIRA MENÉNDEZ advierte, en este caso, que "las Comunidades Autónomas carecen de competencias para, a través de una Ley de Patrimonio Cultural, ampliar los medios de pago admisibles en el ámbito de las Haciendas Locales" (PEDREIRA MENÉNDEZ, J., Beneficios e incentivos fiscales del patrimonio cultural, op. cit., pág. 188).

${ }^{24}$ El apartado primero del artículo 96 de la Ley 4/1998, de 11 de junio, del Patrimonio Cultural Valenciano, establece que "las personas, físicas o jurídicas, propietarias de bienes inscritos en el Inventario General del Patrimonio Cultural Valenciano, o respecto de los que se haya iniciado expediente para su inscripción, que fueren deudoras de la Hacienda de la Generalitat por cualquier título, incluido la imposición de las sanciones previstas en esta Ley, podrán hacer pago, total o parcial, de sus deudas mediante la dación de tales bienes".

${ }^{25}$ La redacción que finalmente se dio al artículo 73 de la Ley del Patrimonio Histórico Español fue la siguiente, "el pago de las deudas tributarias podrá efectuarse mediante la entrega de bienes que formen parte del Patrimonio Histórico Español, que estén inscritos en el Registro General de Bienes de Interés Cultural o incluidos en el Inventario General, en los términos y condiciones previstos reglamentariamente. Las ganancias patrimoniales que se pongan de manifiesto con ocasión de la entrega de los anteriores bienes en concepto de pago de cualquiera de los impuestos citados, estarán exentas del Impuesto sobre la Renta de las Personas Físicas o del Impuesto sobre Sociedades".
} 
generales encargadas de la regulación de la dación en pago tributaria admiten su aplicación sin ningún tipo de restricción, determinando únicamente cuáles van a ser los bienes aceptados para el pago. La doctrina en un principio calificó a esta forma de pago como excepcional porque, según FERNÁNDEZ JUNQUERA, esta "forma de pago no venía recogida entre los medios ordinarios de extinción de la deuda tributaria recogidos en la LGT de 1963". Sin embargo, para esta autora el carácter excepcional se deduce porque la dación en pago no se regula entre las "formas ordinarias de pago, precisamente porque con la misma no se atienden directamente los gastos públicos que es a lo que va destinado cada pago. Por ello, porque con la dación en pago no se está cumpliendo directamente con el mandato constitucional de atender al sostenimiento del gasto público, y en esa medida, la dación en pago puede ser entendida como forma extraordinaria de pago" 26 .

Por su parte, el TEAC, a través de su Resolución de 28 de mayo de 1999, expresó que "la LGT establece como principio general el pago en efectivo o con efectos timbrados y que «desde el punto de vista tributario es evidente que cualquier otra forma de pago es excepcional y requiere una norma especial, particularmente para el pago en especie». Hablando con propiedad no puede afirmarse que el habitualmente llamado «pago en especie» sea una forma de pago. Se trata, más bien, de un subrogado del pago, de un medio de extinción de la obligación tributaria que sustituye al verdadero pago o cumplimiento, el cual sólo tiene lugar cuando se entrega la cantidad de dinero en que ha sido cifrada la cuota o la deuda tributaria. En este sentido, la «datio pro soluto» es un medio de extinción tan especial «o extraordinario, según como quiera mirarse» como los demás sistemas de extinción de la obligación previstos por la LGT (prescripción, compensación, condonación)”.

Nuestra opinión respecto a la dación en pago es que se trata de una forma de pago excepcional o extraordinaria debido a la finalidad recaudatoria de los tributos y el carácter dinerario de la obligación tributaria, siendo la finalidad última la obtención de ingresos por parte de las administraciones territoriales con los que hacer frente a las necesidades de la sociedad. Por ende, y a pesar de que la legislación tributaria actual reconozca la dación en pago como una de las formas ordinarias de pago de todas las deudas tributarias, su utilización debe ser cautelosa y para casos justificados en relación con la importancia cultural, artística, e histórica de los bienes que se pretendan entregar y las condiciones reales de precariedad económica del contribuyente que le impida hacer frente a su obligación de pago.

\section{A. Justificación de la dación en pago}

En un inicio, la dación en pago tuvo la intención de facilitar el pago del ISD en determinadas herencias cuyo patrimonio se configuraba fundamentalmente por bienes de interés histórico y artístico. Esta circunstancia implicaba en algunas ocasiones que los herederos tuvieran que hacer

\footnotetext{
${ }^{26}$ FERNÁNDEZ JUNQUERA, M., "La dación en pago", en la obra Estudio de Derecho Financiero y Tributario en Homenaje al profesor Calvo Ortega, Tomo I, Lex Nova, Valladolid, 2005, pág. 596 a 597. Así también lo entienden GALAPERO FLORES, R., El procedimiento de recaudación de los tributos. Estudio de su regulación en la Ley General Tributaria y en el Reglamento General de Recaudación, op. cit., pág. 63, y GONZÁLEZ SÁNCHEZ, M., "Capítulo VIII. La extinción de la obligación tributaria", op. cit., pág. 656. Al respecto, afirmó VEGA HERRERO "que en el contexto de la LGT el pago en especie tiene un carácter excepcional, en cuanto que se condiciona a una previsión legal expresa, de manera que ni la Ley ni el RGR se puede extraer como conclusión que el pago en especie sea una alternativa al pago en efectivo de deudas tributarias ni tampoco que el obligado tributario pueda optar por pagar de una u otra forma" (VEGA HERRERO, M., "Capítulo I. Extinción y garantías de la deuda", op. cit., pág. 39, y de este misma autora, VEGA HERRERO, M. y MUÑOZ DEL CASTILLO, J. L., “Capítulo II. Tributos y obligaciones tributarias”, en la obra La Nueva Ley General Tributaria, CALVO ORTEGA, R. (director), Thomson-Civitas, Madrid, 2004, pág. 80 a 83.
} 
frente a un impuesto de gran cuantía habiendo recibido una herencia sin efectivo o con poco efectivo para satisfacer la deuda tributaria. Para solucionar este problema, estos contribuyentes debían acudir a la venta rápida de los bienes recibidos, lo cual implicaba generalmente una devaluación de aquellos bienes $^{27}$.

Sin embargo, en la actualidad, con la aceptación de la dación en pago como una forma más de extinción de la obligación tributaria, los argumentos para defender esta institución no pueden partir del contenido de los artículos 44 y 46 de la Constitución, que defienden el acceso a la cultura y la protección del patrimonio cultural. Se alude, por el contrario, a una justificación extrafiscal de la dación en pago. Según PEÑUELAS I REIXACH, los "fines extrafiscales se consiguen con el simple mecanismo de permitir que el sacrificio económico que debe realizar el sujeto pasivo se lleva a cabo mediante la entrega de bienes del PHE que tengan el mismo valor económico de la deuda pecuniaria. Las normas que disciplinan la dación de los bienes del PHE y las formas de extinguir las obligaciones tributarias permiten que éstas se extingan mediante la realización de una prestación diferente a la inicialmente prevista como objeto de dichas obligaciones, pero no alteran el valor de la deuda tributaria" $^{28}$.

El problema radica en este tipo de extinción de la obligación tributaria en que la utilización de este medio de pago transforma una serie de tributos, cuya finalidad es la recaudación, en tributos extrafiscales. Se da cumplimiento de esta forma a una finalidad constitucionalmente deseada, pero no se obtienen recursos necesarios para hacer frente al gasto público. Con esta situación las administraciones territoriales aumentan su patrimonio cultural, pero a la vez aumentan sus necesidades de ingresos.

También hay que tener en cuenta que cuando se produce la dación en pago en el IRPF o el IS, puede suceder que determinados bienes salgan del territorio de una Comunidad Autónoma, lo que sería contraproducente por vulnerar las competencias de esta Comunidad en materia de cultura. PEÑUELAS I REIXACH entiende en este caso que, después de un acuerdo mutuo, se debe optar por restar "el valor de los mismos del porcentaje de ingresos a los que tiene derecho la Comunidad Autónoma en función de su participación en la recaudación de estos dos impuestos"29.

\section{B. Procedimiento para la extinción de las deudas tributarias por medio de la dación en pago}

El procedimiento que se sigue cuando se utiliza la dación en pago como forma de extinción de la obligación tributaria se contiene en el artículo 73 de la LPHE, que a su vez remite a los términos y condiciones previstos reglamentariamente. El desarrollo reglamentario se encuentra en el artículo 40 del RGR, en relación con los artículos 73 y 74 de la LPHE y el artículo 65 del Real Decreto

\footnotetext{
${ }^{27}$ FALCÓN Y TELLA, R., "Problemática del pago en especie, una nota sobre la facultad solutoria de las obligaciones tributarias", $o p$. cit., pág. 224. También VARONA ALABERN, J. E., Extinción de la obligación tributaria, novación y confusión, Lex Nova, Valladolid, 1998, pág. 69.

${ }^{28}$ PEÑUELAS I REIXACH, LL., El pago de impuestos mediante obras de arte y bienes culturales, la dación de bienes del Patrimonio Histórico Español, op. cit., pág. 28.

${ }^{29}$ PEÑUELAS I REIXACH, LL., El Pago de impuestos mediante obras de arte y bienes culturales, la dación de bienes del Patrimonio Histórico Español, op. cit., pág. 36.
} 
111/1986, de 10 de enero, de desarrollo parcial de la Ley de Patrimonio Histórico Español (en adelante RPHE).

El anterior RGR de 1990, en el apartado primero del artículo 29, establecía que eran admitidos para el pago de deudas de la Hacienda Pública bienes del Patrimonio Histórico Español en los casos establecidos en las leyes. Esta especificación hacia los bienes integrantes del Patrimonio Histórico Español desaparece con la redacción del artículo 40 del RGR vigente. Por ello, para determinar los bienes que podrán entregarse para efectuar el pago de la deuda tributaria habrá que acogerse al contenido del artículo 73 de la LPHE y del artículo 65 del RPHE. En el caso del primer precepto, sólo admite el pago de la deuda tributaria con bienes que estén incluidos en el Inventario General o inscritos en el Registro General de Bien de Interés Cultural, prescripción que se reitera en el apartado primero del artículo 65 del RPHE.

El obligado al pago que pretenda utilizar la dación en pago como medio para satisfacer deudas a la Administración tributaria deberá solicitarlo al órgano de recaudación que tenga atribuida la competencia en la correspondiente norma de organización específica. La solicitud tendrá que ir acompañada necesariamente del nombre y apellidos o razón social o denominación completa, número de identificación fiscal y domicilio fiscal del obligado al pago y, en su caso, de la persona que lo represente. Además deberá llevar la identificación de la deuda precisando, al menos, su importe, concepto y fecha de finalización del plazo de ingreso en período voluntario. Asimismo, tendrá que señalar el lugar, la fecha y la firma del solicitante.

La solicitud de pago por medio de bienes del Patrimonio Histórico Español podrá presentarse tanto en período voluntario como en período ejecutivo, pero siempre antes de que se notifique al obligado el acuerdo de enajenación de los bienes embargados o sobre los que se hubiese constituido garantía de cualquier naturaleza. Si la solicitud de la dación en pago se hace en período voluntario, se impide el inicio del período ejecutivo, aunque no el devengo de los intereses de demora que correspondan (artículo 40 del RGR). Por el contrario, si la solicitud se presenta en el período ejecutivo esta presentación no tendrá efectos suspensivos. No obstante, el órgano de recaudación podrá suspender motivadamente las actuaciones de enajenación de los bienes embargados hasta que se dicte el acuerdo que ponga fin al procedimiento de este tipo de pago por el órgano competente.

Ahora bien, si la deuda tributaria a que se refiere la solicitud de la dación en pago se ha determinado mediante autoliquidación, se deberá adjuntar el modelo oficial de ésta, debidamente cumplimentado, salvo que el interesado no esté obligado a presentarlo por obrar ya en poder de la Administración tributaria; en tal caso, el contribuyente señalará el día y procedimiento en que lo presentó ${ }^{30}$.

Una vez que el obligado al pago manifiesta su intención de utilizar bienes del Patrimonio Histórico Español para satisfacer su deuda tributaria, se exige que se acompañe la solicitud con la valoración de los bienes y el informe sobre el interés de aceptar esta forma de pago, emitidos ambos por el órgano competente del Ministerio de Cultura o por el órgano competente determinado por la normativa que

\footnotetext{
${ }^{30}$ Se salva de este modo el interrogante que se planteaba con la legislación anterior, en cuanto a si era posible o no utilizar la dación en pago tras una rectificación de la autoliquidación presentada por el contribuyente, ya se hubiera realizado de forma voluntaria o a través de una liquidación provisional de oficio o de una liquidación derivada de un acta de inspección.
} 
autorice la dación en pago. En defecto de los citados informes, deberá acompañarse el justificante de haberlos solicitado ${ }^{31}$.

El artículo 65 del RPHE reitera que es el obligado al pago quien debe pedir la valoración, reseñando el código de identificación del bien a la Junta de Calificación, Valoración y Exportación de Bienes del Patrimonio Español. La solicitud de este código de identificación puede impedir que se utilice la dación en pago de bienes no inscritos en el Inventario o en el Registro General porque estén pendientes de resolución administrativa. Para estos casos, entiende PEDREIRA MENÉNDEZ que "fuera preciso una suspensión del procedimiento de recaudación en tanto no se resuelva la calificación del bien, puesto que durante ese período se encuentra afectado de las mismas limitaciones y derechos que ya estuvieran inscritos en el Registro como BIC o en el oportuno Inventario",32.

El órgano competente para llevar a cabo la valoración de los bienes que se presenten al pago de la deuda tributaria será la Comisión de Valoración, según regula el apartado 4 del artículo 9 del RPHE. Por su parte, el artículo 74 de la LPHE prevé que el interesado no está vinculado por la valoración, de manera que si se muestra inconforme con ella puede optar por el pago en metálico. Por ende, cabe afirmar que la renuncia del solicitante puede hacerse en cualquier momento. No se trata formalmente de un mecanismo para el aplazamiento sin cumplir con los requisitos que al efecto establece la LGT y el RGR, porque mientras los órganos administrativos estén valorando se suspende el procedimiento de recaudación, aunque hemos de reconocer que en la práctica la situación planteada (inconformidad con la valoración y pago en metálico) produce los mismos efectos que un aplazamiento. De hecho, el deudor puede desistir después de haber presentado su solicitud, por lo que entonces deberá pagar su deuda con los correspondientes intereses de demora, operación que en definitiva resulta mucho más económica que presentar una garantía o aval para la concesión del aplazamiento. Además, en todo este proceso el contribuyente está evadiendo el control de oportunidad de la Administración tributaria sobre la concurrencia o no de las condiciones necesarias para conceder el aplazamiento.

Cuando la solicitud no reúna los requisitos que exige el RGR, el órgano competente para la tramitación requerirá al solicitante para que en el plazo de 10 días contados a partir del día siguiente al de la notificación del requerimiento subsane el defecto o aporte los documentos, con indicación de que, si así no lo hiciera, se tendrá por no presentada la solicitud y se archivará sin más trámite. Si esta solicitud de la dación en pago se hubiese presentado en período voluntario de ingreso y el plazo para atender el requerimiento de subsanación finalizase con posterioridad a dicho período, sin haberse procedido a tal subsanación, se iniciará el procedimiento de apremio mediante la notificación de la oportuna providencia de apremio.

Una vez realizada la valoración, el Director del Departamento de Recaudación de la Agencia Estatal de Administración Tributaria (en adelante AEAT) deberá notificar en el plazo de seis meses la

\footnotetext{
${ }^{31}$ Para la fijación del tiempo que se establece para elaborar los informes, debemos acudir al apartado 2 del artículo 83 de la Ley 30/1992, de 26 de noviembre, de Régimen Jurídico de las Administraciones Públicas y del Procedimiento Administrativo Común (en adelante LRJ-PAC), que en principio concede un plazo de diez días, aunque puede extenderse dicho plazo hasta los tres meses. En este sentido, PEÑUELAS I REIXACH, LL., El Pago de impuestos mediante obras de arte y bienes culturales, la dación de bienes del Patrimonio Histórico Español, op. cit., pág. 165 y 166.
}

${ }^{32}$ PEDREIRA MENÉNDEZ, J., Beneficios e incentivos fiscales del patrimonio cultural, op. cit., pág. 200. 
resolución, acordando de forma motivada la aceptación o no de los bienes en pago de la deuda. Transcurrido el plazo sin que se haya notificado la resolución, los interesados podrán considerar desestimada la solicitud a efectos de interponer, frente a la denegación presunta, el correspondiente recurso, o esperar la resolución expresa.

El acuerdo del órgano competente podrá aceptar o denegar la solicitud, y en ambos casos se remitirá copia al Ministerio de Cultura o a quien corresponda en función del tipo del bien, así como a la Dirección General del Patrimonio del Estado. Si se dicta acuerdo de aceptación, su eficacia quedará condicionada a la entrega o puesta a disposición de los bienes ofrecidos. De producirse esta entrega en la forma establecida en el acuerdo de aceptación y en el plazo establecido en el RGR, los efectos extintivos de la deuda se entenderán producidos desde la fecha de la solicitud.

También en el caso de la aceptación de la dación en pago, la deuda devengará interés de demora desde la finalización del plazo de ingreso en período voluntario hasta que los bienes hayan sido entregados o puestos a disposición de la Administración tributaria con conocimiento de ésta, pudiendo afectarse en el acuerdo de aceptación el bien dado en pago a la cancelación de dichos intereses de demora, de ser suficiente el valor del citado bien.

Si por el contrario, la resolución dictada fuese denegatoria y la solicitud se hubiera presentado en período voluntario de pago, con la notificación del acuerdo denegatorio se iniciará el plazo de ingreso regulado en el apartado segundo del artículo 62 de la LGT. De no producirse el ingreso en dicho plazo, se iniciará el período ejecutivo con la providencia de apremio en los términos previstos en el apartado primero del artículo 167 de la LGT. De realizarse el ingreso en dicho plazo, procederá la liquidación de los intereses de demora devengados a partir del día siguiente al del vencimiento del plazo de ingreso en período voluntario hasta la fecha del ingreso realizado durante el plazo abierto con la notificación de la denegación. De no realizarse el ingreso en este último plazo, los intereses se liquidarán hasta la fecha de vencimiento de dicho plazo, sin perjuicio de los que puedan devengarse con posterioridad. Ahora bien, si la solicitud se presentó en período ejecutivo, la consecuencia entonces será la iniciación del procedimiento de apremio, de no haberse producido con anterioridad.

La entrega de los bienes a la Administración tributaria deberá efectuarse en el plazo de 10 días contados a partir del siguiente al de la notificación del acuerdo de aceptación de la dación en pago, salvo que dicha entrega o puesta a disposición se hubiese realizado en un momento anterior. De no producirse la entrega o puesta a disposición de los bienes quedará sin efecto el acuerdo de aceptación. Si la solicitud se presentó en período voluntario de ingreso y éste ya hubiese transcurrido, se iniciará el período ejecutivo al día siguiente de aquel en que finalizó el plazo para la entrega o puesta a disposición de los bienes, exigiéndose el ingreso del principal de la deuda y el recargo del período ejecutivo. En este caso se procederá a la liquidación de los intereses de demora devengados a partir del día siguiente al del vencimiento del plazo de ingreso en período voluntario hasta la fecha de fin del plazo para entregar o poner a disposición los bienes, sin perjuicio de los que se devenguen posteriormente. Si la solicitud se presentó en período ejecutivo de ingreso, deberá continuarse con el procedimiento de apremio. 


\subsubsection{Sujetos legitimados para el pago y para el cobro de la deuda tributaria}

\subsubsection{Sujetos legitimados para el pago}

La LGT no destina ningún artículo para definir los sujetos legitimados para el pago de la deuda tributaria. El RGR, en el primer apartado de su artículo 33, dispone que está legitimada para el pago cualquier persona que tuviera o no interés en el cumplimiento de la obligación, tanto si el obligado al pago conoce y aprueba esta situación, como si este sujeto ignora su existencia. A su vez, el segundo párrafo de dicho precepto advierte que, en caso de producirse el pago por el tercero, éste no estará legitimado para ejercitar frente a la Administración tributaria los derechos que corresponden al obligado tributario.

El RGR de 1990 enumeraba en su artículo 10 los obligados al pago. Este precepto identificaba como obligados al pago a los contribuyentes, a los adquirentes de explotaciones económicas, a los sucesores mortis causa en la deuda tributaria, y a los perceptores de cuotas de liquidación en aquellos supuestos relativos a sociedades o entidades disueltas y liquidadas. Ese mismo reglamento de 1990, en su artículo 18, incorporaba, además de aquéllos obligados, a los terceros que pagaran la deuda tributaria atendiendo a los mismos criterios que actualmente delimita el primer apartado del artículo 33 del RGR.

La LGT actual acomete la regulación de los obligados tributarios en los artículos 35 a 38, hecho que nos parece acertado teniendo en cuenta que estos sujetos constituyen una parte esencial de la obligación tributaria y, por tanto, su determinación se ve afectada por el principio de reserva de ley. Ahora bien, el artículo 35 de la LGT enumera un grupo amplio de sujetos a los que la normativa tributaria impone el cumplimiento de obligaciones tributarias: la obligación tributaria principal, la obligación tributaria de realizar pagos a cuenta, las obligaciones entre particulares resultantes del tributo, las obligaciones tributarias accesorias, y las obligaciones tributarias formales. Sin perjuicio de las críticas que puedan hacerse a la redacción del artículo 35 de la $\mathrm{LGT}^{33}$, tenemos que reconocer que los sujetos que pueden y deben pagar según la ley son los obligados tributarios. Sin embargo, debemos matizar esta afirmación tan rotunda, porque no todos los sujetos que allí se contemplan están obligados a ingresar una cantidad en concepto de deuda tributaria. Por ello, entendemos que los sujetos legitimados para realizar el pago son únicamente aquéllos sobre los que recaiga una obligación de pago, es decir, los contribuyentes, los sustitutos de los contribuyentes, los obligados a realizar pagos fraccionados, los obligados a practicar ingresos a cuenta, los sucesores, los responsables, las herencias yacentes, comunidades de bienes y demás entidades que, carentes de personalidad jurídica, constituyan una unidad económica o un patrimonio separado.

Además de estos sujetos que acabamos de mencionar, debemos tener en cuenta que, tal como ya hemos indicado, puede realizar el pago cualquier persona que tenga o no interés en el cumplimiento de la obligación tributaria. Esta posibilidad, que reconoce el RGR, es la que comúnmente se denomina el pago por tercero. La aplicación mimética de esta figura que proviene del Derecho civil al ámbito tributario presenta, no obstante, algunos inconvenientes. No es acertado aplicar, sin reservas, las reglas del Código Civil al pago del tributo por terceros, y tampoco podemos olvidar que

\footnotetext{
${ }^{33}$ Vid. infra, Capítulo Cuarto, epígrafe 2.1.1. "Los responsables en el marco de los obligados tributarios”.
} 
el tercero no asume, frente a la Administración tributaria, los mismos derechos que corresponden al obligado tributario.

\section{$\underline{\text { A. El pago realizado por un tercero }}$}

El pago de la deuda tributaria por un tercero no se regula expresamente en la LGT, sino en el RGR (apartado 1 del artículo 33). El problema fundamental que plantea esta forma de pago radica en la concreción de los efectos que produce el pago efectuado por un tercero, atendiendo a que dicho pago sea o no conocido, o incluso prohibido, por el deudor ${ }^{34}$.

La doctrina tradicionalmente ha resuelto este problema aceptando la aplicación de los preceptos del Código Civil que regulan la admisibilidad del pago por tercero ${ }^{35}$. También la jurisprudencia asume esta posición a favor del pago del tributo por terceros y la aplicación de las reglas del Código Civil para estos $\operatorname{casos}^{36}$.

No obstante, varios autores se mostraron inicialmente contrarios a este tipo de solución. CORTÉS DOMÍNGUEZ alegó, con anterioridad a la aprobación del RGR de 1968, que la inadmisión del pago por tercero se basa en la influencia que despliega el principio de capacidad económica y también en la prohibición del cambio del lado pasivo de la obligación tributaria, con independencia de cuáles hayan sido los pactos que voluntariamente acuerden las partes ${ }^{37}$. Al referirse a esta doctrina, PÉREZ ROYO sostiene, por el contrario, que el principio de capacidad contributiva, aun siendo la piedra angular del ordenamiento tributario, "no puede ser entendido como una regla de carácter absoluto" y que "en el propio ordenamiento tributario existen en primera línea instituciones como la de la responsabilidad tributaria, que constituye una excepción al principio citado". Y en cuanto al segundo argumento esgrimido por CORTÉS DOMÍNGUEZ, este mismo autor interpreta que en el pago por tercero "no se produce ningún cambio de deudor, puesto que el sujeto pasivo y los restantes obligados tributarios no desaparecen del ámbito de la relación" y "aún después del pago realizado por el tercero, continúan sujetos a las eventuales vicisitudes que posteriormente se presenten o puedan presentarse en el desarrollo de la mencionada función" 38 .

AGULLÓ AGÜERO acepta, no sin reservas, la aplicación de la legislación civil para el pago de la deuda tributaria por un tercero. En este sentido, afirma la autora que la aplicación "exclusiva del artículo 1.158 C.C. limita las posibilidades del pago por el tercero de deudas tributarias", y aclara que ese precepto "permite el pago por tercero únicamente en el caso de que lo conozca y lo apruebe el deudor o en el supuesto de que lo ignore". Según la opinión de esta autora, "habrá que entender que en el caso de las deudas tributarias es válido el pago por el tercero aun cuando exista la negativa $\mathrm{u}$

\footnotetext{
${ }^{34}$ Sobre estas hipótesis de pago por tercero, vid. CRISTÓBAL MONTES, A., El pago o cumplimiento de las obligaciones, op. cit., pág. 53 a 64, y PASCUAL ESTEVILL, L., El pago, op. cit., pág. 237 a 262.

${ }^{35}$ Dentro de los primeros autores que se mostraron partidarios de la aplicación del régimen civil al pago de la deuda tributaria por un tercero, se encuentra DÍEZ PICAZO, L., "La extinción de la deuda tributaria", Revista de Derecho Financiero y Hacienda Pública, núm. 54, 1964, pág. 470 a 471.

${ }^{36}$ Entre otras, Sentencia del Tribunal Supremo de 3 de diciembre de 2009, Sentencia de la Audiencia Nacional de 10 de diciembre de 2003, o Sentencia del Tribunal Superior de Justicia de la Comunidad Valenciana de 11 de diciembre de 2000.

${ }^{37}$ CORTÉS DOMÍNGUEZ, M., Ordenamiento tributario español, op. cit., pág. 530.

${ }^{38}$ PÉREZ ROYO, F., "El pago de la deuda tributaria por un tercero", Revista Española de Derecho Financiero, núm. 2, 1974, pág. 223 a 233 .
} 
oposición del deudor", y afirma que en Derecho tributario el tercero no se subroga en la posición del acreedor, por lo que "sólo al solvens compete en su caso derecho a que le sea repetido el pago" 39 .

Si se examina la institución del pago por un tercero del Código Civil se advierten una serie de situaciones que en algunos casos hacen imposible la pura transposición de esta figura al ámbito tributario. El artículo 1.158 del Código Civil dispone que puede hacer el pago cualquier persona, incluyendo, por tanto, a cualquiera que no esté obligado al pago y que sin embargo decida hacerlo, sin que sea necesario que tenga ningún tipo de relación con el deudor, ni vínculos contractuales. En cambio, el precepto señalado sí requiere que el tercero tenga el animus solvendi o voluntad de pagar en lugar del deudor ${ }^{40}$. No obstante, la admisibilidad del pago por tercero en el Derecho civil produce determinados efectos que son la causa por la cual la doctrina tributarista se cuestiona la aplicación del ordenamiento civil cuando se trata del pago de la deuda tributaria por un tercero no obligado ${ }^{41}$.

Según la doctrina civilista, "la posibilidad que tiene quien ha cumplido, de que la carga final del cumplimiento recaiga, en todo en parte, sobre otra persona, se llama derecho de reembolso" ${ }^{42}$. Dicha doctrina se basa, pues, en que el efecto del pago de tercero, en cuanto a las relaciones entre el deudor y el solvens (tercero), se concreta en el ejercicio de medios tendentes a reintegrar el desembolso que hizo este último sujeto por parte del deudor. Esta reintegración se podrá efectuar a través del derecho de reembolso (de la actio in rem verso) o de la figura de la subrogación del solvens. El derecho de reembolso es el que permite al solvens reclamar del deudor lo que haya pagado, mientras que la figura de la subrogación del solvens supone una subrogación en los derechos de crédito del acreedor satisfecho, con todos sus accesorios y garantías. Evidentemente, en el ámbito tributario esta figura de la subrogación del solvens resulta improcedente, debido a la imposibilidad de que el tercero ocupe el lugar de la Administración tributaria, ostentando todas sus prerrogativas. Será por tanto el derecho de reembolso el medio más apropiado para que el tercero pueda resarcirse del pago de la deuda que hizo en lugar del obligado tributario ${ }^{43}$.

En nuestra opinión, en el ámbito de las relaciones entre la Administración tributaria y los sujetos legitimados para el pago de los tributos, la posibilidad de aplicación del régimen previsto en el Derecho civil se presenta como algo complejo. Y ello porque para el ordenamiento civilista el pago por un tercero puede tener lugar, bien como consecuencia de la novación de la obligación en su lado pasivo, lo que es inadmisible en el ámbito tributario; o bien provocando una cesión del crédito con

\footnotetext{
${ }^{39}$ AGULLÓ AGÜERO, A., "La legitimidad del pago por tercero en la deuda tributaria y régimen jurídico de la devolución de ingresos indebidos”, Crónica Tributaria, núm. 35, 1981, pág. 263 a 271.

${ }^{40}$ Como apunta CRISTÓBAL MONTES, “el tercero, a diferencia de lo que ocurre con el deudor, no está vinculado a la relación obligatoria y, por tanto, si se prescinde de su animus solvendi, se pierde también todo punto de referencia y aun de justificación respecto a su incidencia en el débito ajeno" (CRISTÓBAL MONTES, A., El pago o cumplimiento de las obligaciones, op. cit., pág. 51).

${ }^{41}$ Para analizar los efectos que produce el pago por el tercero debemos recurrir a los artículos 1.158 y 1.159 del Código Civil, en relación con los artículos $1.209,1.210,1.211$, y 1.212 del propio código.

${ }^{42}$ TUR FAÚNDEZ, M. N., El Derecho de reembolso, en el pago por tercero, regímenes económico-matrimoniales, solidaridad, fianza, responsabilidad civil y otros supuestos, régimen jurídico, jurisprudencia, Editorial General de Derecho, Valencia, 1996, pág. 27.

${ }^{43}$ CALVO VÉRGEZ entiende que únicamente podrá resarcirse el tercero de lo pagado a través del ejercicio de una acción de enriquecimiento sin causa contra el verdadero deudor (CALVO VÉRGEZ, J., "Capítulo II. Ámbito de aplicación del reglamento, administraciones, recursos, órganos y entidades de recaudación”, en la obra Los nuevos reglamentos tributarios, CALVO ORTEGA, R. (director), Thomson-Civitas, Navarra, 2006, pág. 80).
} 
subrogación del tercero en lugar del acreedor, con la consiguiente eliminación del acreedor inicial y de la relación de éste con el deudor ${ }^{44}$, igualmente inaplicable en el ordenamiento tributario. La subrogación del tercero en lugar de la Administración tributaria es imposible, porque la posición que ocupa la Administración tributaria frente a los obligados tributarios se somete al Derecho Público, al ser aquélla titular de una función pública que es indisponible. Además la Hacienda Pública tiene el privilegio de poder ejecutar sus propios actos, y éstos gozan de una presunción de legalidad que no puede transmitirse a los solvens. Tampoco las reglas específicas del Derecho tributario relativas a la prescripción del derecho o acción de la Administración tributaria para exigir el pago pueden aplicarse al tercero, cuyo derecho deberá regirse, en cuanto a la prescripción, por las disposiciones del Código Civil.

El pago por un tercero produce, pues, para este sujeto el nacimiento de un derecho de crédito a exigir la repetición contra los obligados al pago de la cantidad satisfecha, sin que se produzca ninguna subrogación con la Administración tributaria. Esta última, con absoluta independencia de la relación que se establece entre el obligado tributario y el tercero, continúa ejerciendo sus funciones frente al primero de ellos, que nunca dejan de ocupar su posición pasiva en la relación jurídica tributaria. Como afirma TEJERIZO LÓPEZ, "es evidente que, frente al obligado tributario, el tercero que ingresó su prestación no podrá ejercer las prerrogativas con que cuenta la Administración, de tal modo que nace a su favor un crédito contra aquél, pero sin que venga rodeado de las garantías y privilegios del crédito tributario" 45 .

Otro problema al que se enfrenta la traslación del régimen civil del pago por tercero al ámbito tributario se deriva del régimen de transmisión de las garantías de que dispone la Administración tributaria para asegurar su crédito, porque según el Código Civil, en su artículo 1.212, la transmisión del crédito lleva aparejada la transmisión de las garantías, mientras que en el ámbito tributario las garantías que regulan la LGT y el RGR difícilmente podrán ser traspasadas a otras personas distintas de la Administración tributaria. En este sentido, las garantías están vinculadas al crédito tributario y nada tienen que ver con el derecho de crédito que nace para el tercero con motivo del pago que efectúa.

Igualmente problemática se presenta esta traslación cuando el tercero paga una deuda tributaria a cuyo cumplimiento se hallan sujetos una pluralidad de obligados tributarios. Si aplicamos el artículo 1.212 del Código Civil al ámbito tributario, puede interpretarse que todos los que aparecen como obligados frente a la Administración tributaria lo están también frente al tercero. La solución se vuelve dudosa en el caso de los responsables tributarios, porque ellos responden de un deber ajeno por mandato de la ley. El responsable no aparece hasta una determinada fase del procedimiento de recaudación, concretamente en el momento en que se produce la derivación de la acción administrativa, por lo que, si el tercero efectuara el pago, con el consiguiente nacimiento de su derecho de repetición, con anterioridad a la declaración de la responsabilidad, no creemos posible

\footnotetext{
${ }^{44}$ Sobre la subrogación y los artículos 1.158 y 1.159 del Código Civil, recomendamos el estudio del profesor HERNÁNDEZ MORENO, A., El pago del tercero, Bosch, Barcelona, 1983, pág. 46 a 69. También PASCUAL ESTEVILL, L., El pago, op. cit., pág. 262 a 275.

45 TEJERIZO LÓPEZ, J. M., “Capítulo VII. Procedimientos de recaudación”, op. cit., pág. 603.
} 
que aquél pueda dirigirse contra el responsable porque, como ya hemos dejado claro, el tercero no puede ocupar el lugar de la Administración tributaria en el procedimiento de recaudación.

Por último, debemos referirnos al supuesto en el que el tercero realiza el pago de una obligación tributaria que ya está satisfecha o que ha prescrito. El artículo 1.895 del Código Civil configura esta situación como un cobro de lo indebido, imponiendo al acreedor la obligación de restituir la cantidad percibida y al deudor el derecho a ejercitar la acción de reembolso. En el ámbito tributario, si aplicamos los mandatos del segundo párrafo del primer apartado del artículo 33 del RGR, el tercero no está legitimado para ejercitar acción alguna en nombre del deudor y tampoco sería procedente que éste fuera el que ejercitara la acción, ya que esto supondría un enriquecimiento injusto por su parte. La solución que proponía el apartado tercero del artículo 18 del RGR de 1990 para resolver esta cuestión fue reconocer que el tercero podía ejercitar los derechos que derivasen a su favor exclusivamente del acto de pago. Sin embargo, esta fórmula desaparece en el RGR vigente, y además el primer apartado del artículo 32 de la LGT no incluye al tercero entre las personas legitimadas para obtener la devolución de ingresos que indebidamente se hubieran realizado en el Tesoro Público con ocasión del cumplimiento de la obligación de pago. En estas circunstancias, la cuestión problemática reside entonces en determinar si existe a favor del deudor principal un derecho a la devolución de las cantidades satisfechas por un tercero a la Hacienda Pública. Sobre esta interrogante, apunta AGULLÓ AGÜERO que "en el Derecho tributario es el deudor el único legitimado para exigir la devolución de ingresos indebidos", de manera que "del pago por tercero únicamente se derivaría la acción de reembolso por parte del tercero que paga" $"$.

\subsubsection{Sujetos legitimados para el cobro}

La Administración tributaria es el sujeto legitimado para el cobro y puede recaudar directamente a través de sus órganos competentes o hacerlo por medio de personas y entidades que aparezcan expresamente autorizadas para ello. Como precisa DAGO ELORZA, "está claro que el Estado y cualquier otro acreedor, en cuanto está legitimado, tiene capacidad suficiente", para exigir el pago, "mientras que respecto de los legitimados para recibir el pago, habrá que estar a la teoría de la competencia (en cuanto a los órganos administrativos), o de la autorización o concesión (respecto de las entidades autorizadas) ${ }^{, 47}$.

\section{A. Órganos Administrativos}

El RGR determina las reglas necesarias para la recaudación de los recursos de naturaleza pública por las distintas Administraciones, manifestando un cambio de estructura respecto al RGR de 1990 al incluir no sólo la regulación de la Hacienda Pública estatal, autonómica y local, sino también la de sus Organismos Autónomos.

De conformidad con lo dispuesto en el artículo 3 del RGR, relativo a la recaudación de la Hacienda Pública estatal y de las entidades de Derecho público estatales, la gestión recaudatoria del Estado y de sus Organismos Autónomos se ha de llevar a cabo, tratándose de los recursos del sistema

\footnotetext{
${ }^{46}$ AGULLÓ AGÜERO, A., "La legitimidad del pago por tercero en la deuda tributaria y régimen jurídico de la devolución de ingresos indebidos", op. cit., pág. 268 y 270.

${ }^{47}$ DAGO ELORZA, I., “Título II., Capítulo IV. La deuda tributaria”, op. cit., pág. 397.
} 
tributario estatal y aduanero, ya sea en período voluntario o en período ejecutivo, por la AEAT. No obstante, en relación con las tasas, la recaudación en período voluntario se realiza por el órgano de la Administración General del Estado u Organismo Autónomo que tenga atribuida su gestión. Respecto al resto de los recursos de naturaleza pública, su gestión recaudatoria en período voluntario debe ser asumida por las Delegaciones de Economía y Hacienda, salvo que las mismas estuviesen atribuidas a otros órganos de la Administración General del Estado o sus Organismos Autónomos. En cambio, durante el período ejecutivo será la AEAT la que, previa remisión, en su caso, de las correspondientes relaciones certificadas de deudas impagadas en período voluntario, realice la gestión recaudatoria. Según reconoce CALVO VÉRGEZ, "se incluye así por vez primera en un RGR la especialidad de la recaudación en período ejecutivo de los Organismos Autónomos del Estado, regulándose tanto el procedimiento como la competencia para dictar los actos" ${ }^{\$ 4}$. Aquellos recursos de naturaleza pública cuya gestión esté atribuida a una entidad de Derecho público distinta de las que hemos señalado serán recaudados en período voluntario por los servicios de dicha entidad, mientras que la recaudación en período ejecutivo corresponderá a la AEAT cuando así lo establezca una ley o cuando así se hubiese establecido en el correspondiente convenio.

Por otro lado, el RGR atribuye legitimación activa a los Departamentos Ministeriales y Organismos Autónomos con competencia sobre aquellas tasas cuya gestión tienen encomendada por las normas que las regulan. Las unidades administrativas de los Departamentos Ministeriales, Organismos Autónomos del Estado y demás Entes públicos gestionan la recaudación en período voluntario de los recursos de Derecho público.

El artículo 4 del RGR precisa dos especialidades que deben ser tenidas en cuenta cuando la gestión de la recaudación la desarrollen los Organismos Autónomos del Estado ${ }^{49}$ : que la declaración de fallido de los obligados tributarios corresponde realizarla a los órganos de recaudación de la AEAT, y que la declaración de crédito incobrable debe efectuarse por los órganos de recaudación del Organismo Autónomo correspondiente, teniendo en cuenta su normativa específica, previa comunicación por la AEAT de la insolvencia del deudor.

Los órganos de recaudación del Estado, Comunidades Autónomas y Entes Locales se relacionan en los artículos 6, 7 y 8 del RGR. En este sentido, el artículo 6 del RGR establece que son órganos de recaudación del Estado las unidades administrativas de la AEAT, centrales o periféricas, a las que las normas de organización específica atribuyan competencias en materia de recaudación; las unidades administrativas de los órganos de la Administración General del Estado, organismos autónomos estatales y entidades de Derecho público estatales que tengan atribuida la gestión recaudatoria de los

\footnotetext{
${ }^{48}$ CALVO VÉRGEZ, J., "Capítulo II. Ámbito de aplicación del reglamento, administraciones, recursos, órganos y entidades de recaudación”, op. cit., pág. 69.

${ }^{49}$ El apartado primero del artículo 4 del RGR precisa que "la gestión recaudatoria en período ejecutivo de los créditos de los organismos autónomos del Estado se rige por lo dispuesto en este reglamento, con las siguientes particularidades (...). Las relaciones certificadas de deudas impagadas en período voluntario serán expedidas por los órganos competentes de los organismos autónomos. Cuando las deudas de un mismo deudor sean inferiores a la cantidad que se fije por resolución del Director del Departamento de Recaudación de la Agencia Estatal de Administración Tributaria como coste mínimo de recaudación estimado, dichas deudas sólo se incluirán en las relaciones mencionadas cuando el importe acumulado, incluidas todas las que estuviesen en gestión de cobro, supere dicho coste mínimo estimado. (...) La providencia de apremio será dictada por los órganos de recaudación de la Agencia Estatal de Administración Tributaria. (...) Las cantidades recaudadas, a excepción de los recargos del periodo ejecutivo y las costas, serán transferidas a las cuentas oficiales del organismo autónomo por la Agencia Estatal de Administración Tributaria”.
} 
correspondientes recursos de Derecho público; la Dirección General del Tesoro y Política Financiera; y las unidades administrativas de las Delegaciones de Economía y Hacienda.

Las deudas tributarias que corresponda gestionar a las Comunidades Autónomas se recaudan según el artículo 7 del RGR directamente por las Comunidades Autónomas y sus organismos autónomos, de acuerdo con lo establecido en sus normas de atribución de competencias, y también por otras entidades de Derecho público con las que se haya formalizado el correspondiente convenio o en las que se haya delegado esta facultad. Además, debe incluirse como sujeto legitimado para el cobro del crédito tributario, en los territorios autónomos, la AEAT cuando así se acuerde mediante la suscripción de un convenio para la recaudación.

Las Entidades Locales y sus organismos autónomos llevan a cabo la recaudación de las deudas cuya gestión tienen atribuidas en los siguientes términos: directamente por aquéllas de acuerdo con lo establecido en sus normas de atribución de competencias; por otros entes territoriales a cuyo ámbito pertenezcan cuando así se haya establecido legalmente, cuando con ellos se haya formalizado el correspondiente convenio o cuando en ellos se haya delegado esta facultad, de acuerdo con la distribución de competencias que en su caso se haya establecido entre la entidad local titular del crédito y el ente territorial que desarrolle la gestión recaudatoria; $\mathrm{y}$, al igual que sucede con las Comunidades Autónomas, por la AEAT cuando se acuerde mediante la suscripción de un convenio para la recaudación.

\section{B. Entidades privadas autorizadas para recaudar}

El apartado 1 del artículo 61 de la LGT reconoce que el ingreso de la deuda tributaria puede efectuarse en las cajas de los órganos competentes, oficinas recaudadoras o entidades autorizadas para su admisión. Asimismo, el RGR, en el artículo 9, reconoce como entidades que prestan servicio de caja y entidades colaboradoras en la gestión recaudatoria a las entidades de crédito con las que cada Administración así lo convenga, con los requisitos a que se refiere el artículo 17 del propio RGR. Dentro de las entidades de crédito que autoriza el RGR que presten el servicio de caja o que actúen como entidades colaboradoras se encuentran los bancos, las cajas de ahorro, y las cooperativas de crédito. En ningún caso la autorización o convenio que se formalice con estas entidades de crédito les atribuirá el carácter de órganos de recaudación, al amparo de lo previsto en los apartados 2 y 3 del artículo 9 del RGR. Por otra parte, la Dirección General del Tesoro y Política Financiera podrá convenir la prestación del servicio de caja o autorizar a una entidad de crédito para actuar como entidad colaboradora en la gestión de aquellos ingresos de la Administración General del Estado no encomendados a la AEAT.

PALAO TABOADA analiza la autorización que confiere el Ministerio de Hacienda a las Entidades de depósito y las que tienen condición de colaboradoras desde una perspectiva civilista, vinculándola concretamente al artículo 1.162 del Código Civil, según el cual,

"el pago deberá hacerse a la persona en cuyo favor estuviese constituida la obligación o a otra autorizada para recibirla en su nombre”. 
Por ello afirma este autor que la autorización es una "relación de cuenta corriente como gestión de negocio ajeno, si bien (...) el servicio de caja que constituye el contenido esencial de aquella relación, se limita al cobro de las deudas tributarias designadas por la Administración y al ingreso periódico en el Tesoro Público de los fondos así obtenidos. Pero esta limitación, que es consecuencia del carácter restringido de la cuenta corriente, no altera esencialmente la naturaleza de la correspondiente relación jurídica. Podemos decir, por lo tanto, que la autorización genera entre el Banco y la Administración una relación básica de cuenta corriente, a la vez indisolublemente ligada a la autorización para el cobro" $"$.

Por su parte, explica DAGO ELORZA el carácter evidentemente reglamentario de los términos de la autorización, "que sitúa a la entidad colaboradora en el ámbito de la supremacía especial de la Administración y en un estado de particular sujeción a sus relaciones con ella. Hay una notable discrecionalidad en el otorgamiento de dicha «autorización» y, una vez concedida, intensas facultades administrativas de fiscalización y control, con potestad para restringir o suspender las actividades, y estrictas obligaciones impuestas a la entidad"51.

De cualquier forma, como advierte CALVO VÉRGEZ, la legitimación activa se atribuye "a estas entidades colaboradoras en la recaudación", y estas entidades "no son sino entidades de depósito expresamente autorizadas por el Ministerio de Economía y Hacienda previa consideración de su solvencia y de su eventual contribución al servicio de la recaudación. No tienen el carácter de órgano de recaudación, ni pueden tomar decisiones en los procedimientos correspondientes. Nos hallamos ante un claro ejercicio privado de funciones públicas (la función recaudatoria como aspecto integrante de la tributaria)" ${ }^{, 52}$.

A estas entidades corresponde verificar las deudas cuyo pago pretenden realizar los obligados tributarios. Su función radica en recibir los ingresos de los deudores, tanto en el plazo del período voluntario como en el período ejecutivo, obligándose a dar traslado del ingreso al Tesoro Público. El control de estas entidades se realiza a través de los órganos competentes de la Agencia Tributaria, que pueden suspender temporalmente o revocar con carácter definitivo la autorización previamente otorgada.

El desarrollo de la actividad recaudatoria por este tipo de entidades colaboradoras suscita dos tipos de cuestiones principales: por un lado, la responsabilidad de las entidades en la admisión del pago, en los términos que acabamos de indicar; y por otro, los efectos jurídicos que puedan derivarse de este tipo de ingreso para los obligados tributarios. En lo que respecta a esta segunda cuestión, el apartado cuarto del artículo 34 del RGR estipula que

"Cuando el pago se realice a través de entidades de crédito u otras personas autorizadas, la entrega al deudor del justificante de ingreso liberará a éste desde la fecha que se consigne en el justificante y por el importe que figure

\footnotetext{
${ }^{50}$ PALAO TABOADA, C., "Los Bancos y Cajas de Ahorro como Entidades colaboradoras en la recaudación tributaria", Crónica Tributaria, núm. 15, 1975, pág. 113 y ss.

${ }^{51}$ DAGO ELORZA, I., “Título II., Capítulo IV. La deuda tributaria”, op. cit., pág. 419.

52 CALVO VÉRGEZ, J., "Capítulo II. Ámbito de aplicación del reglamento, administraciones, recursos, órganos y entidades de recaudación”, op. cit., pág. 76 .
} 
en él, quedando obligada la entidad de crédito o persona autorizada frente a la Hacienda pública desde ese momento y por dicho importe, salvo que pudiera probarse fehacientemente la inexactitud de la fecha o del importe que conste en la validación del justificante" ${ }^{\text {"53. }}$.

\subsubsection{Plazos para el pago}

Los plazos para el pago de la deuda tributaria se prevén en el artículo 62 de la LGT. De esta forma se eleva el tradicional rango reglamentario de esta materia al rango de ley. La anterior LGT de 1963 regulaba este aspecto en el artículo 126, que a su vez remitía al artículo 61. Este último precepto efectuaba una nueva remisión a las disposiciones reglamentarias que eran, en definitiva, las que determinaban los plazos de pago. El Informe de la Comisión para el Estudio del Borrador del Anteproyecto de la nueva Ley General Tributaria, de julio de 2001, (en adelante Informe 2001) sugirió que la nueva ley debería incorporar algunos de los preceptos contenidos en el RGR de 1990. Se argumenta en el Informe 2001 que, "a pesar de la tradición que supone la regulación de la práctica totalidad de los trámites recaudatorios a través de normas reglamentarias, no debe olvidarse que, al menos y por lo que se refiere al procedimiento de apremio, nos encontramos ante una de las manifestaciones más importantes de la autotutela administrativa, en la que la Administración goza de potestades exorbitantes que suponen concretas limitaciones a los derechos de los administrados. Estas consideraciones llevan a la Comisión a entender que, al menos en sus aspectos esenciales, el procedimiento recaudatorio debe estar regulado a través de normas con rango legal, sin perjuicio del necesario desarrollo reglamentario".

Siguiendo las indicaciones del Informe 2001, el artículo 62 de la LGT incorpora los contenidos de los artículos 20 y 108 del RGR de 1990. El primero de los preceptos sirvió como precedente para los apartados 1 a 4 y 7 del artículo 62 de la LGT, ampliando los plazos de pago de las deudas liquidadas por la Administración tributaria. Por el contrario, tratándose de deudas autoliquidadas, de cobro periódico y de aduanas y de comercio exterior, el régimen coincide con el anterior. Por su parte, el apartado 5 del artículo 62 de la LGT recoge los plazos del artículo 108 del RGR de 1990, si bien los incorpora dentro de los plazos de pago en período ejecutivo, inmediatamente a continuación de los plazos de pago en período voluntario. En el caso del apartado 8 del artículo 62 de la LGT carece de antecedente en la ley anterior. Su precedente se puede encontrar en el apartado 6 del artículo 80 de la Ley 40/1998, reguladora del IRPF, en virtud de la adición de dicho apartado por la Ley 24/2001, de 27 de diciembre, de Medidas Fiscales, Administrativas y del Orden Social. Finalmente, se incorpora en la LGT el apartado 9 del artículo 62, que es también un precepto novedoso sin antecedentes homogéneos. Además debemos señalar que el artículo 62 de la LGT presenta una mejor conexión con los artículos 160 y 161 de la LGT, que son los encargados de regular el procedimiento de recaudación.

\footnotetext{
${ }^{53}$ El Tribunal Supremo, en su Sentencia de 17 de abril de 1999, determinó que la relación que existe entre las Administraciones y las entidades colaboradoras es de carácter administrativo, no quedando sujetas al principio de reserva de ley. Respecto a los efectos liberatorios que produce el ingreso efectuado por los deudores en las entidades colaboradoras vid. las Sentencias del Tribunal Supremo de 28 de abril de 1988 y de 15 de abril de 1992; las Sentencias de los Tribunales Superiores de Justicia de Andalucía y de Murcia de 21 de febrero de 2002 y de 8 de abril de 1999, respectivamente; y las Sentencias del Tribunal Superior de Justicia de Cataluña de 8 de febrero de 1999 y de 21 de noviembre de 2000.
} 
De la interpretación conjunta de los artículos 62 de la LGT y 68 del RGR se deduce que es posible diferenciar dos plazos distintos de pago: los plazos de pago en período voluntario y los plazos de pago en período ejecutivo. En el presente apartado del trabajo, sólo nos referiremos al primero de estos plazos, los que determina la ley para el período voluntario ${ }^{54}$. Los apartados 1 y 2 del artículo 62 de la LGT distinguen, dentro del período voluntario, los tributos que precisa la presentación de autoliquidaciones por parte de los obligados tributarios, cuyos plazos de pago serán los que señalen la propia normativa de cada tributo, de otros tributos cuyas deudas son liquidadas por la Administración tributaria. Para éstos últimos tributos, la ley también prevé plazos de pago en el período voluntario, pudiéndose distinguir dos grandes supuestos: las deudas liquidadas por la Administración después de un procedimiento administrativo de comprobación o investigación, en muchos casos precedido por una autoliquidación presentada por el deudor; y las deudas liquidadas por la Administración a través de un procedimiento administrativo de liquidación, previa declaración del deudor, o comprobación de valores de la Administración. El procedimiento y determinación de los plazos de pago para ambos supuestos es común, y la ley ha ampliado sustancialmente los plazos legales concediendo quince días más para atender el pago de la deuda tributaria ${ }^{55}$. En efecto, el plazo de pago, que se iniciará a partir de la fecha de notificación de la liquidación, se extiende, según se haya notificado en la primera o segunda quincena del mes, hasta el día 20 del mes siguiente o hasta el día 5 del segundo mes posterior, respectivamente.

Ahora bien, cuando se trate de tributos de notificación colectiva y periódica, la LGT establece en el apartado 3 del artículo 62 un plazo general entre el día 1 de septiembre y el 20 de noviembre, o el inmediato día hábil siguiente. Aquí es importante recordar que el plazo es supletorio y sólo aplicable cuando la Administración tributaria competente no haya determinado uno específico. Por otra parte, si el pago se efectúa a través de efectos timbrados, este pago debe hacerse en el momento de la realización del hecho imponible si no se dispone de otro plazo en la normativa específica. Cuando se trate de liquidaciones de tributos aduaneros, el plazo de pago voluntario se fija en la propia norma aduanera, según lo dispuesto en el apartado 7 del artículo 61 de la LGT. En este sentido, el Reglamento (CE) No 450/2008, del Parlamento Europeo y del Consejo, de 23 de abril de 2008, por el que se establece el Código Aduanero Comunitario, determina en su artículo 72 que el plazo de pago no podrá sobrepasar los diez días siguientes a contar desde la notificación al deudor de la deuda aduanera. En caso de globalización de contrataciones, el plazo de ingreso de la deuda aduanera será fijado de manera que no permita al deudor disponer de un plazo de pago más largo que si se le

\footnotetext{
${ }^{54}$ Los plazos de pago que establece el apartado 5 del artículo 62 de la LGT para el período ejecutivo los analizamos en este Capítulo Primero, vid. infra, epígrafe 2.5.1. "Inicio del procedimiento de apremio. La providencia de apremio".

${ }^{55}$ La LGT de 1963 no determinaba expresamente los plazos de pago en período voluntario. El apartado primero del artículo 61 de dicha ley disponía que "el pago deberá hacerse dentro de los plazos que determine la normativa reguladora del tributo o, en su defecto, la normativa recaudatoria". Por lo que había que remitirse, no sólo a los plazos de pago del período voluntario que establecían la normativa de cada tributo, sino también al artículo 20 del RGR de 1990. Este reglamento indicaba que las deudas tributarias resultantes de liquidaciones practicadas por la Administración debían pagarse de la siguiente manera, "las notificadas entre los días 1 y 15 de cada mes, desde la fecha de notificación hasta el día 5 del mes siguiente o el inmediato hábil posterior"; y "las notificadas entre los días 16 y último de cada mes, desde la fecha de notificación hasta el día 20 del mes siguiente o el inmediato hábil posterior". Por contemplar un plazo más reducido, estos preceptos son menos beneficiosos para el contribuyente que los que regula la ley actual (MARTíN QUERALT, J., "Novedades en el procedimiento de recaudación”, en la obra La reforma de la Ley General Tributaria, Estudios de Derecho Judicial, Madrid, 2005, pág. 287). Además, la “ampliación de los plazos en período voluntario para la deudas liquidadas por la Administración obedece a la necesaria coordinación de los mismos con la modificación de los plazos para interponer recurso de reposición o reclamación económico-administrativa que también se han pasado a ser de 15 días a un mes" (CERVANTES SÁNCHEZRODRIGO y OTROS., Guía de la Ley General Tributaria, CISS, Valencia, 2004, pág. 148).
} 
hubiera concedido un pago aplazado, y las autoridades aduaneras también podrán conceder una prórroga de ese plazo a solicitud del deudor cuando el importe de los derechos de importación o exportación exigibles haya sido determinado durante el control posterior al levante, aunque dicha prórroga no puede sobrepasar el tiempo necesario para que el deudor tome las medidas apropiadas para ultimar su obligación.

Finalmente, en los dos últimos números del artículo 62 de la LGT se regula la posibilidad de la suspensión del ingreso de la deuda por motivo de su compensación con un crédito. Según el apartado octavo de dicho precepto, cuando la normativa de cada tributo lo establezca, el ingreso de la deuda de un obligado tributario podrá suspenderse total o parcialmente, sin aportación de garantía y a solicitud de éste, si otro obligado presenta una declaración o autoliquidación de la que resulte una cantidad a devolver o una comunicación de datos, con indicación de que el importe de la devolución que pueda ser reconocido se destine a la cancelación de la deuda cuya suspensión se pretende. En este caso, el importe de la deuda suspendida no podrá ser superior a la devolución solicitada, y la deuda suspendida quedará total o parcialmente extinguida en el importe que proceda de la devolución reconocida, sin que sean exigibles intereses de demora sobre la deuda cancelada con cargo a la devolución. "A diferencia del régimen general de la compensación, que sería en cierta medida asimilable, en este caso la nota que lo caracteriza es la ausencia de reconocimiento del crédito a favor del declarante-cedente. No obstante lo anterior, temporalmente se suspende la obligación de ingreso del sujeto pasivo, a expensas de que se produzca el reconocimiento del crédito a favor del cedente, y dejando al margen, evidentemente, las relaciones que entre cedente y deudor cedido existan, que son ajenas completamente a la Administración"56.

Para MONEDERO MONTERO DE ESPINOSA “no se trata, estrictamente, de un supuesto de cesión de crédito, dado que, ni el acreedor de la devolución frente a la Hacienda Pública asume la posición de cedente, ni la Hacienda Pública tampoco es cesionaria del crédito, esto es, ningún intercambio de prestaciones se produce entre el cedente y cesionario, propio del contrato de cesión de crédito configurado como una modalidad de la compra-venta; en realidad, la comunicación que realiza el acreedor de la devolución a la Administración de que se destine su importe al pago de la deuda cuya suspensión se pretende, ha de ser calificado como un caso de promesa unilateral del pago de deuda realizado por tercero -acreedor de la futura devolución-, en definitiva, el verdadero negocio causal se encuentra en las relaciones entre el deudor y acreedor de la Administración. Esta previsión normativa, introduce un precepto general que contempla mecanismos de extinción como el que rige para la compensación de deudas entre cónyuges en el Impuesto sobre la Renta de las Personas Físicas"57.

De modo similar, el número 9 del artículo 62 de la LGT dispone que el ingreso de la deuda de un obligado tributario se suspenderá total o parcialmente, sin aportación de garantías, cuando se compruebe que por la misma operación se ha satisfecho a la misma u otra Administración una deuda tributaria o se ha soportado la repercusión de otro impuesto, siempre que el pago realizado o la

\footnotetext{
${ }^{56}$ DAGO ELORZA, I., “Título II., Capítulo IV. La deuda tributaria”, op. cit., pág. 437.

${ }^{57}$ MONEDERO MONTERO DE ESPINOSA, J. I., "La extinción de la deuda tributaria, Análisis especial de la compensación”, en la obra Estudios sobre la nueva Ley General Tributaria (Ley 58/2003, de 17 de diciembre). Homenaje a D. Pedro Luis Serrera Contreras, MARTÍNEZ LAFUENTE, A. (director), Instituto de Estudios Fiscales, Madrid, 2004, pág. 437.
} 
repercusión soportada sea incompatible con la deuda exigida y además, en este último caso, el sujeto pasivo no tenga derecho a la completa deducción del importe soportado indebidamente. La problemática se planteaba, normalmente, entre tributos correspondientes a distintas Administraciones Públicas, respecto del pago del impuesto ingresado, puesto que esta situación implicaba una enorme actividad por parte del sujeto pasivo, que debía solicitar, cautelarmente, la devolución del ingreso satisfecho, y por otro lado impugnar la liquidación practicada. A esto habría que añadir que el sujeto debía acumular las dos actuaciones o peticiones en un mismo procedimiento para evitar descoordinaciones, que sólo podía ser judicial, porque estas acumulaciones no se pueden efectuar en sede administrativa. El legislador prestó atención a este problema, según DAGO ELORZA fortaleciendo la posición del Estado, "en su acepción anfibológica, pues en modo alguno se puede trasladar al ciudadano las ineficiencias del Estado, que dispone, o debe disponer, de los instrumentos adecuados para resolver estas situaciones" 58 .

\subsubsection{Imputación de pago}

La imputación de pagos es un incidente que se produce cuando convergen varias deudas de un mismo deudor con un mismo acreedor y el pago no alcanza a cubrirlas todas, de manera que se hace necesario decidir a cuál o cuáles de ellas se imputa el pago.

La LGT aborda la imputación de pagos en el artículo 63. El precedente inmediato de dicho precepto lo encontramos en el artículo 62 de la LGT de 1963 y en el artículo 45 del RGR de 1990. El mandato actual introduce pequeñas modificaciones respeto a sus antecesores, y en el primero de sus números dispone que las deudas tributarias son autónomas. Como señala GONZÁLEZ SÁNCHEZ, "con ello lo que se pretende es evitar el pago parcial, a prorrata o no, de todas las deudas acumuladas y para esto se trata de precisar la preferencia para el pago de unas respecto de otras" ${ }^{259}$.

Tal como estipula el primer apartado del artículo 63 de la LGT, el obligado al pago de varias deudas podrá imputar cada pago a la deuda que libremente determine. Así sucede también en el ámbito del Derecho privado, cuando el primer párrafo del artículo 1.172 del Código Civil indica que el que tuviese varias deudas de una misma especie a favor de un solo acreedor, podrá declarar, al tiempo de hacer el pago, a cuál de ellas debe aplicarse. De lo contrario, de no existir declaración de imputación, prevé el segundo párrafo del artículo 1.172 del Código Civil que

Si el deudor "aceptare del acreedor un recibo en que se hiciese la aplicación del pago, no podrá reclamar contra ésta, a menos que hubiera mediado causa que invalide el contrato".

Por otro lado, el número 2 del artículo 63 de la LGT establece que

"El cobro de un débito de vencimiento posterior no extingue el derecho de la Administración tributaria a percibir los anteriores en descubierto".

\footnotetext{
${ }^{58}$ DAGO ELORZA, I., “Título II., Capítulo IV. La deuda tributaria”, op. cit., pág. 440.

${ }^{59}$ GONZÁLEZ SÁNCHEZ, M., “Capítulo VIII.-La extinción de la obligación tributaria”, op. cit., pág. 660.
} 
Este segundo apartado adquiere relevancia sobre todo en los tributos periódicos, pues en ellos el hecho de que un mismo sujeto deba diferentes anualidades no significa que todas ellas queden reunidas en una sola deuda, existiendo una por cada período devengado.

Una tercera característica destacable en la estructura del artículo 63 de la LGT es la distinción que se hace en él entre la imputación de pago en período voluntario y en período ejecutivo. El tercero y cuarto apartados determinan unas reglas imperativas de imputación o aplicación de pago para deudas que se encuentren en el procedimiento ejecutivo. Por ello, cuando el número 1 del artículo 63 de la LGT dispone que el propio obligado puede elegir a qué deuda desea aplicar la cantidad que ingrese, entendemos que se está refiriendo a las deudas del período voluntario. En caso contrario, si se tratase de deudas del período ejecutivo, habrá que proceder según el mandato de los apartados 3 y 4 del artículo 63 de la $\mathrm{LGT}^{60}$.

\subsubsection{Consignación del pago}

La consignación del pago se regula en el artículo 64 de la LGT y en el artículo 43 del RGR. En éste último se prevé la consignación como forma de pago, reconociendo sus efectos liberatorios cuando el órgano competente no admita el pago, indebidamente o por causa de fuerza mayor, efectos que se producen desde la fecha en que se realiza la consignación.

Por su parte, el artículo 64 de la LGT dispone que los obligados tributarios pueden consignar el importe de la deuda tributaria y, en su caso, de las costas reglamentariamente devengadas, en la Caja General de Depósitos u órgano equivalente de las restantes Administraciones públicas o en alguna de sus sucursales, con los efectos liberatorios o suspensivos que las disposiciones reglamentarias determinen. Este precepto introduce algunos cambios significativos en relación con su homólogo anterior, el artículo 63 de la LGT de $1963^{61}$. Por un lado, en el aspecto subjetivo, amplía la referencia de los sujetos pasivos, al utilizar un concepto más general como el de obligados tributarios, y por otro, extiende el lugar de realización del depósito no sólo a la Caja General de Depósito y a sus sucursales, sino también a sus órganos equivalentes. El artículo 64 de la LGT, sin embargo, sigue sin abordar todos los aspectos de la consignación y se limita a indicar la existencia de esta modalidad de pago de la deuda tributaria, con la determinación de quién puede realizarla y ante quién puede efectuarse, y a reconocer sus efectos suspensivos o liberatorios, haciendo un reenvío a las normas reglamentarias. Por lo demás, la consignación no puede sustituir el pago normal por una simple decisión del deudor o por una mera elección del ente acreedor o recaudador, sino que tiene que ser justificada.

En el Derecho civil la consignación cumple con relación al pago ordinario una función de subrogado en aquellos casos en que el acreedor rehúsa sin razón aceptar el ofrecimiento de pago del deudor o, en todo caso, cuando este pago se hace imposible. Según el artículo 1.176 del Código Civil, si el

\footnotetext{
${ }^{60}$ Vid. infra, Capítulo Primero, epígrafe 2.3. "Imputación del pago en el período ejecutivo".

${ }^{61}$ Determinaba el artículo 63 de la LGT de 1963 que "los sujetos pasivos podrán consignar el importe de la deuda tributaria, y, en su caso, las costas reglamentariamente devengadas en la Central de la Caja General de Depósitos o en alguna de sus sucursales, con los efectos liberatorios o suspensivos que las disposiciones reglamentarias determinen".
} 
acreedor a quien se hiciere el ofrecimiento de pago se negare sin razón a admitirlo, el deudor quedará libre de responsabilidad mediante la consignación de la cosa debida. La consignación por sí sola producirá el mismo efecto cuando se haga estando el acreedor ausente o cuando esté incapacitado para recibir el pago en el momento en que deba hacerse y cuando varias personas pretendan tener derecho a cobrar o se haya extraviado el título de la obligación. Por su parte, el artículo 1.178 del mismo código prevé que la consignación se haga depositando las cosas debidas a disposición de la Autoridad judicial, ante quien se acredita el ofrecimiento, en su caso, y el anuncio de la consignación en los demás. Más adelante, el artículo 1.180 del Código Civil precisa que hecha debidamente la consignación, podrá el deudor pedir al Juez que mande cancelar la obligación.

Como puede comprobarse, existen muchas similitudes en el régimen del pago por consignación en el Derecho civil y en el Derecho tributario, aunque también se aprecian algunas diferencias. En el ámbito tributario, la consignación no se realiza frente a ningún órgano judicial, sino ante un órgano administrativo, que puede ser la Caja General de Depósito o cualquiera de los órganos equivalentes o sus sucursales; y, por otro lado, la consignación tributaria puede hacerse con la finalidad de extinguir la obligación o con el objetivo de suspender la ejecutoriedad del acto impugnado. El primero de los supuestos (la extinción de la obligación) se produce cuando el órgano encargado de admitir el pago no lo hace sin causa aparente o por causa de fuerza mayor. Para este caso, la consignación tendrá efectos liberatorios del pago desde la fecha en que haya sido efectuada, siempre que se consigne la totalidad de la deuda y se comunique tal hecho al órgano recaudador, siendo la liberación sólo parcial si lo que se consigna es sólo una parte de la deuda. La consignación con finalidad de suspensión de la ejecutoriedad del acto impugnado tiene lugar en los casos de interposición de reclamaciones o recursos, y en estos supuestos la suspensión se producirá desde la fecha en que haya sido efectuada la consignación, siempre que se realice de acuerdo con las normas que regulan los recursos y reclamaciones.

Finalmente, la consignación no es más que un simple medio para asegurar el pago, porque cuando se aplica adecuadamente lo consignado se extingue la obligación ${ }^{62}$. Su aplicación al pago es de oficio y produce los efectos desde la correcta consignación, impidiendo desde ese momento la generación de intereses de demora, recargos y sanciones relacionados con el pago.

\subsection{MEDIDAS CAUTELARES EN EL PERÍODO VOLUNTARIO}

\subsubsection{Potestad de los órganos de recaudación para adoptar medidas cautelares}

Dentro de las facultades de los órganos de recaudación se encuentra la posibilidad de adoptar medidas cautelares. Esta potestad se reconoce en la LGT en el apartado 1 del artículo 162 y en el primer número del artículo 10 del RGR. La ley determina que en el ejercicio de sus funciones los órganos de recaudación están facultados para asegurar o efectuar el cobro de la deuda tributaria. En este sentido, los funcionarios que desarrollan las actividades de recaudación pueden comprobar e investigar la existencia y situación de los bienes o derechos de los obligados tributarios. Además

\footnotetext{
${ }^{62}$ ZABALA RODRÍGUEZ-FORNS, A., LLOPIS GINER, F. y DAGO ELORZA, I., afirman que "técnicamente no puede hablarse de la consignación como una causa de extinción de las obligaciones, salvo que se conciba como medio de pago, lo cual no es del todo correcto" (ZABALA RODRÍGUEZ-FORNS, A., LLOPIS GINER, F. y DAGO ELORZA, I., Recaudación, aspectos sustantivos y procedimentales, op. cit., pág. 257; DAGO ELORZA, I., "Título II., Capítulo IV. La deuda tributaria”, op. cit., pág. 443).
} 
estos funcionarios gozan de las facultades que se reconocen a la Administración tributaria en el artículo 142 de la LGT, donde se relacionan las facultades de los órganos de inspección de los tributos, y pueden adoptar medidas cautelares en los términos previstos en el artículo 146 de la LGT.

Según DAGO ELORZA, esta última remisión que hace el artículo 162 de la LGT al artículo 146 de la misma ley puede plantear dudas interpretativas, porque "las medidas cautelares que pueden y usualmente deben adoptarse en el curso del procedimiento de recaudación no tienen por qué coincidir con las medidas adoptadas en el curso del procedimiento de inspección. Típicamente, en el procedimiento recaudatorio, las medidas cautelares son las retenciones y el embargo preventivo"63.

Así pues, en el ejercicio de sus funciones se produce una equiparación de las competencias de los órganos administrativos en ambos tipos de actuaciones, inspectoras y recaudadoras. De esta forma, se validan los criterios de algunos autores que entienden que la adopción de medidas cautelares corresponde a una pluralidad de órganos de la Administración tributaria, "pues tanto la finalidad genérica de las mismas, como sus características de temporalidad e instrumentalidad, configuran una técnica a utilizar por aquellos órganos que tengan constancia del periculum in mora, que podrán ser los de gestión o inspección en el desarrollo de la actividad normal de liquidación de los tributos, pero sobre todo por las actuaciones de comprobación e investigación, y también los órganos de recaudación, en período voluntario o en la vía de apremio"64.

Por su parte, el RGR se encarga de desarrollar las facultades de los órganos de recaudación a través del artículo 10, siguiendo la misma línea que la LGT. El precepto, en sus dos primeros apartados, prevé que los funcionarios que desempeñen funciones de recaudación sean considerados agentes de la autoridad y dispongan de las facultades reconocidas en el artículo 142 de la LGT. Asimismo, el RGR permite que estos funcionarios puedan adoptar las medidas cautelares recogidas en el artículo 146 de la LGT, previstas para el procedimiento de inspección, lo que implica, según el RGR, que los órganos de recaudación están legitimados para adoptar medidas cautelares en el marco de su actuación, bajo las mismas condiciones que los procedimientos de inspección ${ }^{65}$.

\footnotetext{
${ }^{63}$ DAGO ELORZA, I., "Título III., Capítulo V. Actuaciones y procedimientos de recaudación", en la obra Comentarios a la Nueva Ley General Tributaria, HUESCA BOADILLA, R. (coordinador), Thomson Aranzadi, Navarra, 2004, pág. 1051.

${ }^{64}$ CORCUERA TORRES, A., Las medidas cautelares que aseguran el cobro de la deuda tributaria, Marcial Pons, Madrid, 1998, pág. 72; PEÑA ALONSO, J. L. y CORCUERA TORRES, A., La reforma de la Ley General Tributaria, McGraw-Hill, Madrid, 1995, pág. 181. Sobre la posibilidad de que las medidas cautelares sean adoptadas por órganos de gestión, inspección o recaudación, vid. LAMELA FERNÁNDEZ, M., “Aproximación a la reforma de la Ley General Tributaria”, Crónica Tributaria, núm. 75, 1995, pág. 128; PÉREZ ROYO, F. y AGUALlO AVILÉS, A., Comentarios a la reforma de la Ley General Tributaria, Aranzadi, Pamplona, 1996, pág. 516; RUIZ HIDALGO, C., La responsabilidad tributaria en el alzamiento de bienes en la nueva Ley General Tributaria, Marcial Pons, Madrid, 2009, pág. 43 y 44.

${ }^{65}$ Este fue el mismo criterio seguido por la Presidencia de la AEAT que, mediante Resolución de 27 de julio de 2004, determinó que son órganos competentes para adoptar medidas cautelares los Delegados Especiales de la AEAT en cuyo ámbito radique la Dependencia Regional de Recaudación a la que estuviera atribuida la gestión recaudatoria de las deudas de los obligados tributarios. En el caso de que la gestión recaudatoria estuviera atribuida a la Oficina Nacional de Recaudación, será competente el Subdirector General de Procedimientos Especiales del Departamento de Recaudación de la AEAT. Los órganos competentes para ratificar las medidas cautelares adoptadas en el procedimiento inspector, según esta Resolución, serán los Jefes de Dependencia de Recaudación, y cuando se trate de deudores adscritos a la Oficina Nacional de Recaudación, el Jefe de la Oficina Nacional de Recaudación.
} 


\subsubsection{El régimen jurídico de las medidas cautelares}

Si buscamos los antecedentes del régimen jurídico de las medidas cautelares constataremos que durante algún tiempo éstas sólo existieron para cuestiones aisladas en el ámbito tributario. En efecto, el apartado 2 del artículo 74 de la LGT de 1963 establecía una liquidación cautelar anotable en los Registros públicos para garantizar el cumplimiento de los requisitos de una exención o bonificación. También el número tercero del artículo 142 de la misma ley permitía la adopción de medidas cautelares para la conservación y custodia de los documentos que estuvieran siendo objeto de investigación por parte de los órganos de inspección. Y el artículo 128 de la LGT de 1963 recogía, finalmente, los dos únicos casos de medidas cautelares que aseguraban el cobro de deuda: el embargo preventivo de dinero y de mercancías en cuantía suficiente para asegurar el pago de la deuda tributaria que correspondiera exigir por actividades lucrativas ejercidas sin establecimiento y que no hubieran sido declaradas, y la intervención de los ingresos de los espectáculos públicos que no hubieran sido previamente descubiertos a la Administración tributaria.

En la actualidad el régimen general de las medidas cautelares se contempla en el artículo 81 de la LGT. Para TEJERIZO LÓPEZ, a nivel general, este régimen jurídico de las medidas cautelares es criticable por tres motivos: porque para incluir las medidas cautelares dentro de las garantías de la deuda tributaria habría que aceptar un concepto genérico de garantías; porque siguen regulándose algunos tipos de medidas cautelares a través de preceptos concretos, como si no se tratara de la misma categoría; y por último, porque no es posible distinguir dentro de las normas de la LGT los aspectos procedimentales de esa figura ${ }^{66}$.

Del régimen jurídico de las medidas cautelares pueden extraerse algunos elementos importantes de la configuración de esta institución. Nos referimos, entre otras, a la posibilidad que tiene la Administración tributaria de adoptar medidas cautelares de carácter provisional cuando aparezcan indicios racionales de que, en el caso de no tomarse las mismas, el cobro de la deuda tributaria se viera frustrado o gravemente dificultado ${ }^{67}$.

La existencia de indicios racionales de que el cobro se verá frustrado o gravemente dificultado es uno de los elementos básicos del régimen jurídico de las medidas cautelares. Los indicios racionales que el órgano competente debe valorar para adoptar las medidas cautelares se concretan, según SOPENA GIL, en "una serie de circunstancias ciertas de las que se puede obtener, por inducción lógica, una conclusión sobre el hecho desconocido, cuyo establecimiento se intenta. Son hechos separados entre sí, que convergen hacia un hecho concreto, que el cobro de la deuda tributaria se vea frustrado o gravemente dificultado",68. En palabras de CORCUERA TORRES, "se tratará del acontecimiento de

\footnotetext{
${ }^{66}$ TEJERIZO LÓPEZ, J.M., “Capítulo VII. Procedimientos de recaudación”, op. cit., pág. 594.

${ }^{67}$ GARCÍA PALACIOS, J., "El nuevo régimen de las medidas cautelares”, en la obra Estudios sobre la nueva Ley General Tributaria (Ley 58/2003, de 17 de diciembre), Homenaje a Pedro Luis Serrera Contreras, Instituto de Estudios Fiscales, Madrid, 2004, pág. 677, entiende que los indicios que especifica la ley deben ser "probados y conducir racionalmente a la conclusión que de ello se obtiene, constituyendo la apreciación de los mismos el núcleo fundamental de la motivación de acuerdo por el que se adopten las medidas cautelares, sujeto en este punto a fiscalización, en su caso, por parte de los órganos jurisdiccionales". Por su parte, TEJERIZO LÓPEZ, J.M., "Capítulo VII. Procedimientos de recaudación", op. cit., pág. 595, define estos indicios racionales como "cualquier acto o negocio jurídico, delictivo o no, que posibilite la disminución del patrimonio del deudor, minorado su crédito o aumentando su pasivo, defraudando con ello el débito con la Hacienda Pública".

${ }^{68}$ SOPENA GIL, J., El embargo de dinero por deudas tributarias, Marcial Pons, Madrid, 1993, pág. 326.
} 
una serie de hechos, llevados a cabo voluntariamente por parte de los sujetos obligados al pago de los tributos, a partir de los cuales el órgano competente tenga la certeza de que se realizan con la finalidad de alcanzar la situación de insolvencia, para burlar de esta manera sus obligaciones con el Fisco, con el menoscabo que ello supone para el crédito tributario"69.

Otro de los elementos a resaltar del régimen jurídico de las medidas cautelares se contiene el apartado primero del artículo 81 de la LGT, según el cual las medidas deben estar motivadas y debidamente notificadas, con los efectos que se recogen en el apartado 2 del artículo 57 de la LRJPAC. Sobre la necesidad de la motivación del acto administrativo por medio del cual se adopten las medidas cautelares, se han manifestado un número importantes de autores. GARCÍA LUIS ${ }^{70}$ admite que la motivación adquiere importancia como instrumento de control de actuaciones arbitrarias, dado el carácter cautelar de la medida y la indeterminación de los indicios racionales que permiten recurrir a ellas. CORCUERA TORRES incide también en esta idea, cuando expresa que "no existen dudas de que este requisito no es sólo imprescindible, sino que se configura en la práctica como el verdadero criterio por el cual se van a tener que guiar los sujetos pasivos, la Administración tributaria y los Tribunales a la hora de plantearse autorizar o resolver acerca de la legalidad de una garantía"71. La jurisprudencia se ha manifestado en el mismo sentido que la doctrina y conecta la inexistencia de la motivación a una posible indefensión y a la vulneración de algunos derechos constitucionales ${ }^{72}$.

También la LGT destaca cuatro requisitos que deben reunir las medidas cautelares para que puedan ser aplicadas: deben ser proporcionales al daño que se pretenda evitar; deben establecerse por una cuantía estrictamente necesaria para asegurar el cobro de la deuda tributaria; no pueden producir un daño de difícil o imposible reparación; y, por último, no deben prejuzgar el fondo de la cuestión o implicar violación alguna de los derechos amparados en las leyes ${ }^{73}$.

Otro de los aspectos importantes dentro del régimen general de las medidas cautelares se desprende del apartado quinto del artículo 81 de la LGT, que autoriza la adopción de las mismas sobre deudas incluso no liquidadas. La norma, a raíz de su reciente modificación ${ }^{74}$, posibilita la adopción de medidas cautelares, en los mismos términos y condiciones señalados, durante cualquier momento de la tramitación de los procedimientos de aplicación de los tributos, cuando la Administración tributaria actuante pueda acreditar de forma motivada y suficiente la concurrencia de indicios racionales de que el pago se verá frustrado o gravemente dificultado. Además, se observa una relajación a la hora de determinar el órgano competente para adoptar una medida cautelar antes de

\footnotetext{
${ }^{69}$ CORCUERA TORRES, A., Las medidas cautelares que aseguran el cobro de la deuda tributaria, op. cit., pág. 83.

${ }^{70}$ GARCÍA LUIS, T., "El procedimiento de apremio", en la obra La reforma de la Ley General Tributaria, Lex Nova, Valladolid, 1996, pág. 509 y 510.

${ }^{71}$ CORCUERA TORRES, A., Las medidas cautelares que aseguran el cobro de la deuda tributaria, op. cit., pág. 122; PÉREZ ROYO, F y AGUALlO AVILÉS, A., Comentarios a la Reforma de la Ley General Tributaria, op. cit., pág. 523.

${ }^{72}$ Sentencias del Tribunal Supremo de 1 de abril y de 11 de noviembre de 1985, de 9 de febrero de 1988, o de 18 de octubre de 1994.

${ }^{73}$ Este último criterio no se encuentra en LGT pero es uno de los pronunciamientos que aparece en la doctrina. Vid. TEJERIZO LÓPEZ, J.M., "Capítulo VII. Procedimientos de recaudación”, op. cit., pág. 595, y CORCUERA TORRES, A., Las medidas cautelares que aseguran el cobro de la deuda tributaria, op. cit., pág. 128 a 138. También el apartado 3 del artículo 72 de la LRJ-PAC hace mención a esta limitación.

${ }^{74}$ Que introdujo la Ley 7/2012, de 29 de octubre, de modificación de la normativa tributaria y presupuestaria y de adecuación de la normativa financiera para la intensificación de las actuaciones en la prevención y lucha contra el fraude.
} 
que exista una deuda tributaria liquidada, puesto que ya no es imprescindible la autorización judicial. Con la reforma de 1995 de la LGT de 1963, la autorización se modificó por una atribución de competencia, en principio exclusiva, de los Delegados Especiales de la AEAT. La LGT actual nada dice en relación con este aspecto, lo que podría indicar que las medidas cautelares se adopten por el órgano competente en ese momento en el procedimiento de que se trate. De todas formas, cuando se trate de deudas no liquidadas deberá existir "un grado de cuantificación de la deuda, sin circunscribir la adopción de cautelas a una determinada área funcional de la gestión tributaria (...), pues, lógicamente, sus presupuestos de aplicación pueden darse de las diversas fases o momentos de ésta gestión, comprobación, inspección o recaudación-"75.

Por otra parte, el artículo 81 de la LGT prevé diversos supuestos especiales de adopción de medidas cautelares, en el apartado 7, donde se lee

"Se podrá acordar el embargo preventivo de dinero y mercancías en cuantía suficiente para asegurar el pago de la deuda tributaria que proceda exigir por actividades lucrativas ejercidas sin establecimiento y que no hubieran sido declaradas. Asimismo, podrá acordarse el embargo preventivo de los ingresos de los espectáculos públicos que no hayan sido previamente declarados a la Administración tributaria”.

A estos dos supuestos especiales ya tradicionales de nuestro ordenamiento tributario, con la modificación que introduce la Ley 7/2012, de 29 de octubre, en el apartado 8 de este precepto se añade uno nuevo, cuando se permite la adopción de medidas cautelares por el órgano competente de la Administración tributaria en el caso de que, con motivo de un procedimiento de comprobación e investigación inspectora, se haya formalizado denuncia o querella por delito contra la Hacienda Pública o se haya dirigido proceso judicial por dicho delito.

Finalmente, en relación con todas las modalidades de medidas cautelares, hay que destacar que los efectos de las mismas cesan en el plazo de seis meses desde su adopción, salvo que se conviertan en embargos en el procedimiento de apremio o en medidas cautelares judiciales, cuyos efectos surten desde la fecha de adopción de la medida cautelar; que desaparezcan las circunstancias que motivaron su adopción; que en la solicitud del interesado se acordase su sustitución por otra garantía que se estime suficiente; o que se amplíe dicho plazo hasta seis meses más mediante acuerdo motivado. En todos los supuestos anteriores, la extensión del plazo dentro del que producen sus efectos las medidas cautelares no podrá exceder de seis meses.

\subsubsection{Tipos de medidas cautelares}

Las medidas cautelares que se pueden adoptar son muy variadas. El apartado 4 del artículo 81 de la LGT contempla una lista de medidas que puede considerarse abierta, porque permite en su letra $e$ ) la adopción de cualquier otra medida cautelar que prevea la legislación. Dicho esto, puede pensarse que toda medida cautelar debe estar prevista por la ley. Sin embargo, y en esto coincidimos con

${ }^{75}$ DAGO ELORZA, I., Título II., Capítulo IV. La deuda tributaria”, op. cit., pág. 560. 
TEJERIZO LÓPEZ ${ }^{76}$ y GALAPERO FLORES ${ }^{77}$, no será necesario una norma con rango de ley para la aplicación de medidas cautelares, siempre que no se lesione la libertad o los derechos esenciales de los ciudadanos y se cumpla con los requisitos que se regulan en los números 1 y 3 del artículo 81 de la LGT, en los términos que hemos subrayado en el apartado anterior. En relación con el primero de los límites, el que las medidas cautelares que se adopten no deben violar los derechos amparados por las leyes, debemos decir que es una previsión que aparece estipulada en el apartado tercero del artículo 72 de la LRJ-PAC, cuya interpretación según REBOLLO PUIG, citando a GONZÁLEZ PÉREZ, no puede ser maximalista, ya que haría virtualmente inaplicable la restricción del precepto, porque toda medida restrictiva supone, en principio, la violación de algún derecho del afectado ${ }^{78}$. Como bien apunta CORCUERA TORRES, "los derechos que no se pueden ver afectados por las cautelas, según el límite que se está estudiando, deben ser distintos de los que son objeto directo de las mismas"79.

Por lo que respecta a los tipos de medidas cautelares, la LGT relaciona algunas modalidades, entre las que destaca la retención del pago de devoluciones tributarias o de otros pagos que deba realizar la Administración tributaria. En este caso se hace referencia a dos tipos de medidas: las que se vinculan con la retención de las devoluciones de ingresos y las procedentes de ingresos realizados acorde con las normas jurídicas aplicables (en el caso de la retención cautelar de la devolución, que puede ser total o parcial, tendrá que ser notificada al afectado junto con el acuerdo de devolución); y las medidas que incluyen los pagos distintos de las devoluciones tributarias ${ }^{80}$.

El resto de medidas cautelares que recoge la LGT son el embargo preventivo de bienes y derechos, del que se practicará, en su caso, anotación preventiva; la prohibición de enajenar, gravar o disponer de bienes o derechos; la retención de un porcentaje de los pagos que las empresas que contraten o subcontraten la ejecución de obras o prestación de servicios correspondientes a su actividad principal realicen a los contratistas o subcontratistas, en garantía de las obligaciones tributarias relativas a tributos que deban repercutirse o cantidades que deban retenerse a trabajadores, profesionales $u$ otros empresarios, en la parte que corresponda a las obras o servicios objeto de la contratación o subcontratación; y cualquier otra legalmente prevista ${ }^{81}$.

\subsubsection{Vigencia de las medidas cautelares}

Cuando hemos analizado el régimen jurídico de las medidas cautelares adelantamos que éstas producen efectos durante el plazo de seis meses desde su adopción, según lo dispuesto en el apartado

\footnotetext{
${ }^{76}$ TEJERIZO LÓPEZ, J.M., “Capítulo VII. Procedimientos de recaudación”, op. cit., pág. 596.

${ }^{77}$ GALAPERO FLORES, R., El procedimiento de recaudación de los tributos. Estudio de su regulación en la Ley General Tributaria y en el Reglamento General de Recaudación, op. cit., pág. 54.

${ }^{78}$ REBOLLO PUIG, M., "Medidas provisionales en el procedimiento administrativo", en la obra La protección jurídica del ciudadano. Estudios de Homenaje al Profesor Jesús González Pérez, Tomo I, Civitas, Madrid, 1993, pág. 675.

${ }^{79}$ CORCUERA TORRES, A., Las medidas cautelares que aseguran el cobro de la deuda tributaria, op. cit., pág. 139.

${ }^{80}$ GARCÍA PALACIOS, J., "El nuevo régimen de las medidas cautelares”, op. cit., pág. 684, al referirse al precepto entiende que se trata de cualquier pago distinto de las devoluciones tributarias que corresponde realizar a la Administración gestora, estatal, autonómica o local, respectivamente, aunque para los supuestos de otras obligaciones del Estado u otros entes públicos que haya que satisfacerse con cargo al Tesoro, habría que recurrir al embargo preventivo de créditos.

${ }^{81}$ Sobre esta materia, vid. DAGO ELORZA, I., “Título II., Capítulo IV. La deuda tributaria”, op. cit., pág. 562 a 564; CORCUERA TORRES, A., Las medidas cautelares que aseguran el cobro de la deuda tributaria, op. cit., pág. 140 a 189.
} 
6 del artículo 81 de la LGT. Sin embargo, la propia ley determina algunas excepciones a esa regla general y permite variar el término de los seis meses cuando las medias cautelares

\begin{abstract}
"se conviertan en embargos en el procedimiento de apremio o en medidas cautelares judiciales, que tendrán efectos desde la fecha de adopción de la medida cautelar"

Cuando "desaparezcan las circunstancias que motivaron su adopción”

Y cuando "a solicitud del interesado, se acordase su sustitución por otra garantía que se estime suficiente".
\end{abstract}

La novedad de este apartado consiste en establecer la continuidad de los efectos de la medida no sólo para los embargos en el procedimiento de apremio, sino también de las medidas cautelares judiciales. Aunque como señala DAGO ELORZA "la medida cautelar judicial en que se transforma la administrativa ha de requerir decisión judicial al respecto, sin perjuicio de que, recaída ésta, se mantenga la sucesividad de efectos de la medida administrativa" ${ }^{~}{ }^{2}$. Respecto a la segunda excepción, que desaparezcan las circunstancias que motivaron su adopción, implica que puede tomarse la decisión de que se sustituya la medida por una garantía que se estime suficiente, siempre que el interesado así lo solicite. En este sentido, precisa la ley que en el caso de que el obligado tributario presente aval solidario de entidad de crédito o sociedad de garantía recíproca o certificado de seguro de caución que garantice el cobro de la cuantía de la medida, esta última debe ser levantada. Ahora bien, si el obligado hace efectivo el pago en el período voluntario de la obligación tributaria cuyo cumplimiento asegura la medida cautelar, sin mediar suspensión de ingreso, la Administración tributaria deberá abonar los gastos del aval aportado.

Finalmente, debemos recordar que a pesar de que la norma determina que el plazo de la medida cautelar es de seis meses, la letra $d$ ) del apartado 6 del artículo 81 de la LGT permite ampliar ese término por otros seis meses, mediante acuerdo normativo. No obstante, el tiempo máximo de duración que corresponda a las medidas cautelares no puede ser en ningún caso superior a los doce meses desde su adopción.

\title{
1.5. FINALIZACIÓN DEL PERÍODO VOLUNTARIO
}

El período voluntario de pago finaliza el día que vencen los correspondientes plazos de ingreso. Esta es la regla general que contempla el apartado 2 del artículo 68 del RGR, que también determina que en el caso de deudas a ingresar mediante autoliquidación presentadas fuera de plazo sin realizar el ingreso o sin presentar solicitud de aplazamiento, fraccionamiento o compensación, el plazo concluirá el mismo día de la presentación de la autoliquidación.

De manera general, podemos decir que las posibilidades para hacer efectivo el pago de la deuda tributaria durante el período voluntario son dos básicamente.

\footnotetext{
${ }^{82}$ DAGO ELORZA, I., “Título II., Capítulo IV. La deuda tributaria”, op. cit., pág. 561.
} 
Por un lado, puede extinguirse la obligación tributaria en período voluntario de pago a través del ingreso de la deuda tributaria en los plazos previstos para su satisfacción dentro de ese período. Esta posibilidad se manifiesta de distinta manera dependiendo del tipo de deuda de que se trate. Si son deudas tributarias resultantes de liquidaciones practicadas por la Administración tributaria (liquidación administrativa derivada de una previa declaración del obligado tributario o de una actuación de comprobación o investigación por los órganos de gestión o inspección tributaria), el pago en período voluntario deberá hacerse en los plazos previstos en el segundo apartado del artículo 62 de la $\mathrm{LGT}^{83}$. En cambio, si las deudas tributarias tienen su origen en una autoliquidación, el pago en período voluntario deberá hacerse en los plazos que establezca cada tributo, tal como lo dispone el apartado 1 del artículo 62 de la LGT. En este sentido, el pago de la deuda tributaria en ambas situaciones ocasiona, como hemos dicho, la extinción de la obligación y la finalización del período voluntario. Por el contrario, si no se satisface la deuda tributaria en los plazos descritos, habiéndose presentado la autoliquidación o la declaración por el obligado tributario, los efectos que sobrevienen son otros, tanto para las deudas liquidadas por la Administración tributaria como para las deudas autoliquidadas. En los dos casos si no hay ingreso en los plazos previstos, ya sea por la LGT o por la normativa de cada tributo, se produce el fin del período voluntario y el nacimiento del período ejecutivo al día siguiente.

La segunda de las posibilidades a la que hacíamos referencia se produce cuando el pago voluntario se realiza fuera de los plazos de ingreso voluntario pero antes de que se inicie el período ejecutivo. En el caso de las autoliquidaciones pueden producirse tres situaciones diferentes. La primera, cuando se presenta una autoliquidación extemporánea, fuera del plazo de ingreso dispuesto por la normativa de cada tributo, sin requerimiento previo de la Administración tributaria, y se realiza el pago en el mismo día de la presentación ${ }^{84}$. En este supuesto se produce la terminación del período voluntario el mismo día de la presentación y del ingreso simultáneos y la deuda se ve incrementada con los recargos del artículo 27 de la LGT, con exclusión de las sanciones ${ }^{85}$. En otro caso, si se presenta la autoliquidación extemporánea sin requerimiento previo de la Administración tributaria, pero sin efectuar el ingreso el obligado tributario en ese mismo momento, entonces se produce la finalización del período voluntario el día de la presentación extemporánea sin ingreso (apartado segundo del artículo 68 del RGR), y al día siguiente se inicia ya el período ejecutivo, debiendo satisfacer entonces el obligado tributario no sólo los recargos por declaración extemporánea, sino también los recargos del período ejecutivo del artículo 28 de la LGT, con exclusión de las sanciones.

Ahora bien, cuando se trate de las declaraciones que aportan los obligados a las Administraciones tributarias para comunicar los datos necesarios para la liquidación del tributo, puede darse el caso que el obligado tributario presente su declaración fuera del plazo previsto para hacerlo. Esta presentación

\footnotetext{
${ }^{83}$ Es decir, "si la notificación de la liquidación se realiza entre los días uno y 15 de cada mes, desde la fecha de recepción de la notificación hasta el día 20 del mes posterior o, si éste no fuera hábil, hasta el inmediato hábil siguiente (...). Si la notificación de la liquidación se realiza entre los días 16 y último de cada mes, desde la fecha de recepción de la notificación hasta el día cinco del segundo mes posterior o, si éste no fuera hábil, hasta el inmediato hábil siguiente”.

${ }^{84}$ El período voluntario de pago se extiende en este caso más allá del plazo concedido por cada tributo, ya que el período ejecutivo no se inicia hasta el día siguiente de la presentación extemporánea de la autoliquidación (GALAPERO FLORES, R., El procedimiento de recaudación de los tributos. Estudio de su regulación en la Ley General Tributaria y en el Reglamento General de Recaudación, op. cit., pág. 117).

${ }^{85}$ Vid. infra, Capítulo Primero, epígrafe 1.6.2. "Los recargos por declaración extemporánea".
} 
de la declaración extemporánea y espontánea conlleva la liquidación de la deuda por parte de la Administración tributaria y la exigencia de los recargos del artículo 27 de la LGT, con exclusión de las sanciones. En este caso se inicia un nuevo período voluntario de pago una vez notificada la liquidación administrativa, que finaliza en el momento del ingreso por parte de deudor o el último día del plazo que, en aplicación del segundo apartado del artículo 61 de la LGT, se concede a este tipo de deudas.

\subsection{OBLIGACIONES ACCESORIAS APLICABLES UNA VEZ QUE FINALIZA EL PERÍODO VOLUNTARIO}

La LGT identifica un conjunto de obligaciones tanto para la Administración tributaria como para los administrados. Los apartados 2 y 3 del artículo 17 de la LGT dividen a estas últimas en obligaciones materiales y obligaciones formales, además de determinar la imposición de sanciones tributarias por el incumplimiento de ambas. La LGT reconoce en sus artículos 19 a 28 como obligaciones materiales la obligación de carácter principal, y otras como la obligación de realizar pagos a cuenta, las obligaciones establecidas entre particulares resultantes del tributo y las obligaciones accesorias. Estas últimas son las obligaciones de satisfacer el interés de demora, los recargos por declaración extemporánea y los recargos del período ejecutivo (recargo ejecutivo, recargo de apremio reducido y recargo de apremio ordinario). Por su parte, las obligaciones formales se regulan en el artículo 29 de la LGT, no tienen un carácter pecuniario, y son impuestas a los obligados tributarios deudores o no del tributo, condicionándose su cumplimiento al desarrollo de actuaciones o procedimientos tributarios o aduaneros.

De los preceptos que acabamos de reseñar puede deducirse que las obligaciones tributarias accesorias tienen carácter pecuniario, pero se diferencian de las demás obligaciones tributarias de igual contenido, como la obligación tributaria principal, las obligaciones tributarias de realizar pagos a cuenta y las obligaciones tributarias entre particulares derivadas del tributo, con todas las cuales son compatibles. SOLER ROCH las define como "aquéllas en las que el presupuesto de hecho, aun siendo en sí mismo autónomo, guarda relación directa con una obligación ya realizada sin cuya existencia sería imposible el nacimiento mismo de la obligación accesoria" ${ }^{\text {" }}$.

\subsubsection{El interés de demora}

El interés de demora es uno de los componentes de la deuda tributaria que se exige a los obligados tributarios y los infractores por realizar el ingreso una vez que vence el período voluntario para hacer el pago. Esta institución tiene su origen en el Derecho privado, pero a lo largo de los años se configuró también como una figura propia del Derecho tributario ${ }^{87}$. Al referirse a esta obligación

\footnotetext{
${ }^{86}$ SOLER ROCH, M. T., "La estructura jurídica del tributo y las distintas obligaciones tributarias, especial referencia a intereses de demora y recargos", en la obra La Reforma de la Ley General Tributaria, ZORNOZA PÉREZ, J. (director), Consejo General del Poder Judicial, Madrid, 2005, pág. 90. Por su parte, el primer párrafo del número 1 del artículo 25 de la LGT define a las obligaciones accesorias como aquellas "prestaciones pecuniarias que se deben satisfacer a la Administración tributaria y cuya exigencia se impone en relación con otra obligación tributaria".

${ }^{87}$ En palabras de RODRÍGUEZ MÁRQUEZ, J. S., "El interés de demora exigible por la Administración en el Proyecto de Ley General Tributaria, luces y sombras", Quincena Fiscal, núm. 15, 2003, pág. 12 y 13, "la evolución legislativa del interés nos muestra cómo se ha pasado de una regulación muy apegada a la concepción iusprivatista de esta prestación a una configuración de la misma como institución propia del ámbito tributario. La ruptura entre ambos esquemas se produjo por la Ley 10/1985, de 26 de abril, de Reforma Parcial de la Ley General Tributaria. Dicha norma introdujo importantes modificaciones en esta prestación. Así, parte de la idea de
} 
accesoria, la Comisión para el estudio del borrador del Anteproyecto de la nueva Ley General Tributaria expresó en su Informe 2001 que no era posible estructurar un interés de demora de forma que respondiera a los esquemas propios del Derecho privado ${ }^{88}$. Además definió los intereses de demora como las prestaciones dinerarias exigibles cuando se produce el incumplimiento de una obligación tributaria, o en su caso, el cumplimiento de dicha obligación en una fecha posterior a su vencimiento en los supuestos previstos por la LGT. En relación con el régimen jurídico de los intereses de demora, dicho Informe 2001 sugirió que se precisaran las circunstancias de su devengo; la cuantía o valor de referencia; y la regla de su cómputo anual. También formuló la posibilidad de introducir la culpabilidad estimable en el retraso del deudor como aspecto determinante de la exigibilidad del interés de demora, a la vez que propuso la inexigibilidad de los intereses cuando la Administración tributaria incumpliera los plazos para resolver. De estas dos últimas propuestas sólo la segunda se incorporó a la regulación de la LGT actual.

En la actualidad es el artículo 26 de la LGT el que regula los intereses de demora, de forma más completa que la de su antecesor, el apartado tercero del artículo 61 de la LGT de 1963. Según la legislación vigente, el interés de demora es una prestación accesoria que se exige a los obligados tributarios y a los sujetos infractores como consecuencia de la realización de un pago fuera de plazo o de la presentación de una autoliquidación o declaración de la que resulte una cantidad a ingresar una vez finalizado el plazo establecido al efecto en la normativa tributaria, de cobro de una devolución improcedente o en el resto de casos previstos en la norma tributaria ${ }^{89}$.

neutralización financiera, como función que está llamada a cumplir el interés de demora. Ello implica, a su vez, la construcción de un interés de demora automático, que no requiere la intimación del acreedor; objetivo, desvinculado de la existencia o no de un retraso culpable; y generalizado a la práctica totalidad de los supuestos de retraso en el pago de las deudas tributarias. Además, elevó la cuantía del interés de demora tributario respecto del que se exige ante el retraso en el pago de deudas no tributarias e introdujo una discriminación en el tipo aplicable según que el acreedor fuese la Hacienda o el particular. Sin embargo, la Ley 10/1985 no llegó a establecer una regla general de abono de intereses de demora en el ámbito tributario, aplicable a todos los supuestos de pago extemporáneo. Por el contrario, optó por seguir exigiendo dicha prestación supuesto a supuesto. La introducción de la regla general en el art. 61.2 de la LGT fue obra de la Ley 25/1995, de 20 de julio, de Modificación Parcial de la Ley General Tributaria. El último hito en esta evolución se produjo con la entrada en vigor de la Ley 1/1998, de 26 de febrero, de Derechos y garantías de los Contribuyentes, que terminó con uno de los aspectos de la regulación del interés que mayor polémica había suscitado, la diferencia entre los tipos aplicables según que el acreedor fuera la Administración -el interés de demora- o el particular (el interés legal)". Vid. También, de este mismo autor, El interés de demora en la Ley General Tributaria, Instituto de Estudios Fiscales, Marcial Pons, Barcelona, 1999, pág. 33 a 51. Según GARCÍA NOVOA, la Ley 10/1985, de 26 de abril, introdujo importantes modificaciones en el interés de demora, incluyendo la función de compensación financiera y la consiguiente construcción de un interés de demora automático, que no requiere intimación del acreedor, desvinculado de la existencia o no del actuar culpable del obligado y generalizado a la práctica totalidad de los supuestos de retraso en el pago de la deuda tributaria (GARCÍA NOVOA, C., "Capítulo IV. Elementos de cuantificación de la obligación tributaria", en la obra La nueva Ley General Tributaria, CALVO ORTEGA, R. (director), Thomson-Civitas, Madrid, 2004, pág. 284). Por su parte, CARBAJO VASCO manifestó que la Ley 10/1985 supuso un retroceso en el planteamiento del interés de demora en el caso de la Hacienda Pública como deudora, al ser aplicable sólo al supuesto de devoluciones de ingresos indebidos (CARBAJO VASCO, D., "Interés legal del dinero e intereses de demora”, Crónicas Tributaria, núm. 53, 1985, pág. 54). MARTÍN FERNÁNDEZ, por último, expresó que dicha norma optó, incorrectamente, por exigir intereses de demora supuesto a supuesto, sin una formulación general (MARTÍN FERNÁNDEZ, F. J., "Intereses de demora y expedientes de rectificación en la reciente jurisprudencia”, Revista Española de Derecho Financiero, núm. 73, 1992, pág. 154).

${ }^{88}$ Informe para la Reforma de la Ley General Tributaria, Comisión para el Estudio y Propuesta de Medidas para la Reforma de la Ley General Tributaria, Ministerio de Hacienda, Secretaría de Estado de Hacienda, julio 2001, pág. 64 a 65. CALVO ORTEGA se mostró contrario a la postura que se asume en el Informe, y entendió que "debería haberse introducido en la reforma los mismos supuestos de exoneración que se admiten en el caso de las infracciones tributarias" (CALVO ORTEGA, R., "El proyecto de Ley General Tributaria, aportaciones y aspectos críticos", Nueva Fiscalidad, núm. 8, 2003, pág. 34).

${ }^{89}$ HERRERO DE GAÑA ESPINOSA DE LOS MONTEROS es del criterio que la técnica utilizada por la LGT actual para concretar los intereses de demora es muy cuestionable porque "trata de definir los intereses de demora mediante la enumeración de algunas situaciones en la que se devengan. Este recurso mediocre se hace tanto más incomprensible desde el momento en el que la figura que se trata -como aquí ocurre con los intereses- es conocida desde tiempo inmemorial y ha sido definida con acierto por otras leyes y por la jurisprudencia como la compensación debida al acreedor por falta de disposición tempestiva de la cantidad de dinero que se adeudaba" 
En la doctrina y la jurisprudencia pueden encontrarse otros conceptos, como la acepción que propone GONZÁLEZ SÁNCHEZ, al decir que se trata de una "cantidad que se determina mediante la aplicación de un porcentaje expresamente previsto, y que se debe en concepto de daños y perjuicios por el retraso en el cumplimiento de una obligación"90. LÓPEZ MARTÍNEZ definió los intereses de demora como el "expediente técnico frente al incumplimiento tempestivo del deudor de su obligación de pago, que constituye una obligación patrimonial de carácter público, accesoria y dependiente de la obligación tributaria principal, aunque con regulación jurídica autónoma, cuya prestación, devengada por la realización del presupuesto de hecho contenido en una norma de carácter legal, consistente en la entrega de una cantidad de dinero, calculada por un módulo objetivo de carácter compensador por la pérdida patrimonial ocasionada al acreedor por el retraso en el cumplimiento de la obligación debida, y fundamentado en el principio de equidad que debe regir las relaciones entre la Administración tributaria y los Administrados" ". Para MORILLO MÉNDEZ, el interés de demora es una "indemnización necesaria y automática que compense el retraso producido en el cumplimiento de las obligaciones tributarias" $"$. Mientras que CARRASCO PARRILLA caracterizó a los intereses de demora como "aquella prestación accesoria a la obligación de pago de la deuda tributaria, que procede como contribución remuneratoria o indemnización que en concepto de daños y perjuicios corresponde abonar al obligado tributario como consecuencia del retraso en el pago de la deuda tributaria"93.

Por su parte, la jurisprudencia se ha referido a los intereses de demora como "un simple incremento de la deuda tributaria, motivado por el impago del crédito principal" "94, o como la "figura jurídica que como variedad de la acción de resarcimiento trata de compensar como arreglo al módulo objetivo del coste financiero el perjuicio consistente en la indisponibilidad de cantidades dinerarias que fueran legalmente debidas"

De todos estos conceptos pueden extraerse algunos de los elementos caracterizadores de esta institución. Podemos decir que los intereses de demora representan una obligación accesoria a la obligación tributaria principal, cuyo presupuesto de hecho viene marcado por el retraso en el pago de la deuda tributaria, que encarna una indemnización por daños y perjuicios que se hayan podido producir con el retraso en el pago ${ }^{96}$.

(HERRERO DE GAÑA ESPINOSA DE LOS MONTEROS, J.M., "Título II. Los tributos”, en la obra Comentarios a la Nueva Ley General Tributaria, HUESCA BOADILLA, R. (coordinador), Thomson-Aranzadi, Navarra, 2004, pág. 211).

${ }^{90}$ GONZÁLEZ SÁNCHEZ, M., “El interés de demora en materia tributaria”, Crónica Tributaria, núm. 55, 1985, pág. 114.

91 LÓPEZ MARTÍNEZ, J., Régimen jurídico de los llamados "intereses moratorios” en materia tributaria. Un análisis de su ubicación en el seno de la deuda tributaria, Civitas, Estudio de Derecho Financiero y Tributarios, Madrid, 1994, pág. 241.

${ }^{92}$ MORILLO MÉNDEZ, A., "La morosidad en el cumplimiento de las obligaciones tributarias y la Ley 10/1985, de modificación parcial de la LGT”, Impuestos, núm. 11, 1985.

${ }^{93}$ CARRASCO PARRILlA, P.J., Consecuencias del retraso en el pago de las deudas tributarias, Ediciones de la Universidad de Castilla-La Mancha, Cuenca, 2000, pág. 109.

${ }^{94}$ Sentencia del Tribunal Constitucional 14/1986, de 31 de enero.

${ }^{95}$ Sentencia del Tribunal Supremo de 24 de enero de 1995.

${ }^{96}$ Esta misma consideración se observa, entre otros, en el Tribunal Constitucional, en su Sentencia 76/1990, de 26 de abril, o en el Tribunal Supremo, en las Sentencias de 5 de septiembre de 1991, de 29 de enero de 1994 y de 7 de marzo de 1995. 
Por otra parte, en el ámbito tributario no es posible encontrar ningún requisito para la exigibilidad de los intereses de demora salvo el relativo al vencimiento del plazo establecido para el pago de la deuda tributaria. En consecuencia, si acudimos al Derecho común de obligaciones llegaremos a la conclusión de que la exigencia de intereses de demora precisa el incumplimiento de una obligación positiva cuya prestación sea exigible y líquida, y de que es necesaria la presencia de culpabilidad en el retraso del cumplimiento de la obligación, así como la interpelación del acreedor al deudor para el pago de la obligación, a no ser que la ley disponga otra cosa. En este sentido, la doctrina y la jurisprudencia coinciden en que en las obligaciones tributarias pecuniarias el retraso culpable es irrelevante, porque en el ámbito tributario mora y retraso son términos que se equiparan ${ }^{97}$. Asimismo la deuda tributaria representa una obligación con plazo determinado y, por ello, una vez llegado dicho plazo, si la obligación no ha sido satisfecha estaremos en presencia de una mora automática que invalida el requisito de la intimación.

\subsubsection{La naturaleza jurídica del interés de demora}

Para determinar la naturaleza jurídica del interés de demora debe tenerse en cuenta las modificaciones legislativas que ha sufrido esta figura durante los últimos años. Hasta la promulgación de la Ley 10/1985, de 26 de abril, de modificación parcial de la LGT, se asumía sin grandes reparos el carácter indemnizatorio o compensatorio de los intereses de demora, tanto en la doctrina (CALVO ORTEGA ${ }^{98}$, SOLER ROCH ${ }^{99}$, MANTERO SÁEZ ${ }^{100}$, FERNÁNDEZ LÓPEZ ${ }^{101}$, GONZÁLEZ SÁNCHEZ ${ }^{102}$, ÁLVAREZ MORALES ${ }^{103}$, FALCÓN Y TELLA ${ }^{104}$, o PÉREZ $\mathrm{ROYO}^{105}$, entre otros), como en la jurisprudencia ${ }^{106}$.

\footnotetext{
${ }^{97}$ SIMÓN ACOSTA, E., "Los intereses de demora en Derecho Tributario", Actualidad Jurídica Aranzadi, núm. 612, 2004, pág. 3. CARRASCO PARRILLA, P. J., Consecuencias del retraso en el pago de las deudas tributarias, op. cit., pág. 23 a 50. Por el contrario, otros autores se oponen a la idea de que los intereses de demora operen al margen de la culpabilidad, al afirmar que si no hay culpabilidad no hay intereses de demora. Entre otros, MARTÍNEZ LAFUENTE, A., "La extinción de las sanciones tributarias", Crónica Tributaria, núm. 53, 1985, pág. 110 y 111; CARBAJO VASCO, D., "Interés legal del dinero e intereses de demora", op. cit., pág. 39 a 54; MARTÍN FERNÁNDEZ, F. J., "Intereses de demora y expedientes de rectificación en la reciente jurisprudencia”, op. cit., pág. 152.

98 CALVO ORTEGA, R., "La responsabilidad tributaria solidaria por actos ilícitos”, Hacienda Pública Española, núm. 5, 1970, pág. 58.

${ }^{99}$ SOLER ROCH, M. T., Los recargos de prórroga y apremio en los tributos de la Hacienda Pública, Estudios de Hacienda Pública, Institutos de Estudios Fiscales, Madrid, 1974, pág. 147.

${ }^{100}$ MANTERO SÁEZ, A., "Rectificación de liquidaciones, graduación de sanciones e intereses de demora", Crónica Tributaria, núm. 21, 1977, pág. 66 .

${ }^{101}$ FERNÁNDEZ LÓPEZ, E., “Los intereses de demora en los expedientes de inspección”, Crónica Tributaria, núm. 10, 1974, pág. 39.

102 GONZÁLEZ SÁNCHEZ, M., “Art. 58”, en la obra Comentarios a las Leyes Tributarias y Financieras, Tomo I, Edersa, Madrid, 1982, pág. 490.

${ }^{103}$ ÁLVAREZ MORALES, C. J., "Consideraciones jurídico-financieras sobre la modificación del interés legal del dinero”, Revista Jurídica Española, La Ley, Vol. 2, 1985, pág. 1184.

${ }^{104}$ FALCÓN Y TELLA, R., "El interés de demora”, en la obra Cuestiones Tributarias Prácticas, 2 ed., La Ley, Madrid, 1990, pág. 545.

${ }^{105}$ PÉREZ ROYO, F., Infracciones y sanciones tributarias, Instituto de Estudios Fiscales, Madrid, 1972, pág. 29.

${ }^{106}$ Sentencia del Tribunal Supremo de 27 de diciembre de 1982.
} 
Con la aprobación de la Ley 10/1985, se produjo una discriminación en cuanto al tipo de interés a aplicar en función del sujeto que ocupara la posición acreedora, ya fuera la Administración tributaria o el obligado tributario. Esta ley modificó el artículo 58 de la LGT de 1963, según el cual

"el interés de demora será el interés legal del dinero vigente el día que comience el devengo de aquél, incrementado en un 25 por 100, salvo que la ley de presupuestos generales del Estado establezca uno diferente".

También sufrió una modificación el artículo 155 de la LGT de 1963, que aplicaba el interés legal en las relaciones deudoras de la Administración tributaria. De esta forma se establecía una diferencia de trato entre los intereses que debía percibir de los deudores tributarios la Hacienda Pública cuando era acreedora y los intereses que debía pagar cuando era deudora.

Algunos autores consideraron que la diferencia de 25 puntos porcentuales entre el interés de demora y el interés legal otorgaba al primero un carácter sancionador ${ }^{107}$, o al menos disuasorio o cuasi sancionador ${ }^{108}$, aunque también una doctrina minoritaria defendía la naturaleza exclusivamente indemnizatoria del interés de demora a pesar del incremento ${ }^{109}$.

La discriminación que producía la diferencia entre ambos tipos de interés fue considerada por el Tribunal Supremo, mediante Auto de 20 de septiembre de 1988, para plantear una cuestión de inconstitucionalidad, por entender que se vulneraban los artículos 14, 31 y 25 de la Constitución Española (en adelante CE), y que se escondía una verdadera sanción detrás de esa diferencia de trato. El Tribunal Supremo afirmó que la prestación de intereses de demora es, "por su propia esencia, una reparación de los perjuicios ocasionados por la morosidad en el cumplimiento de la obligación tributaria, y su finalidad es únicamente resarcir ese perjuicio patrimonial. Pero la naturaleza esencial de los intereses de demora se «adultera» cuando se utiliza con un fin distinto, como en la presente regulación ocurre, puesto que el fin disuasorio que supone el incremento del interés legal en un 25 por 100 transforma el interés de demora en una sanción".

El Tribunal Constitucional desestimó la cuestión de inconstitucionalidad y un recurso de inconstitucionalidad presentado por cincuenta senadores sobre el mismo asunto, en la Sentencia 76/1990, de 26 de abril, sobre la base de dos razonamientos: la posible vulneración del principio de igualdad y la posible vulneración del apartado primero del artículo 25 de la CE. Sobre la primera cuestión entendió el Tribunal Constitucional, en el Fundamento Jurídico Noveno, que "no cabe, en efecto, sostener que la Administración tributaria y el contribuyente se encuentren en la misma situación como si de una relación jurídico-privada se tratara. Como antes se vio, esa pretendida

\footnotetext{
${ }^{107}$ COLLADO YURRITA, M. A., "Los intereses de demora en la Ley General Tributaria”, Revista Española de Derecho Financiero, núm. 56, 1987, pág. 505; LOZANO CUTANDA, B., "El artículo 61.2 de la LGT., La exención de penalidad de los ingresos tardíos sin requerimiento previo", Revista Española de Derecho Financiero, núm. 63, 1989, pág. 374.

${ }^{108}$ CARBAJO VASCO, D., "Interés legal del dinero e intereses de demora", op. cit., pág. 42; LÓPEZ DÍAZ, A., "Cuota y deuda tributaria", en la obra Comentarios a la Ley General Tributaria y lineas para su reforma. Libro homenaje a F. Sáinz de Bujanda, Vol. I, Instituto de Estudios Fiscales, Madrid, 1991, pág. 943.

${ }^{109}$ ALBIÑANA GARCÍA-QUINTANA, C., "El interés de demora en espera de una regulación coherente", Tapia, núm. 52, 1990, pág. 6; GONZÁLEZ SÁNCHEZ, M., "El interés de demora en materia tributaria", op. cit., pág. 114 y 116; MORILLO MÉNDEZ, A., "La morosidad en el cumplimiento de las obligaciones tributarias y la Ley 10/1985, de modificación parcial de la LGT", op. cit., pág. 31; FALCÓN Y TELLA, R., "El interés de demora”, op. cit., pág. 545 y 549.
} 
igualdad resulta desmentida por el art. 31.1 de la Constitución que, al configurar el deber tributario como deber constitucional, está autorizando al legislador para que, dentro de un sistema tributario justo, adopte las medidas que sean eficaces y atribuya a la Administración las potestades que sean necesarias para exigir y lograr el exacto cumplimiento de sus obligaciones fiscales por parte de los contribuyentes, potestades que por esencia sitúan a la Administración como potentior persona en una situación de superioridad sobre los contribuyentes".

La clave del incremento del 25 por 100 sobre el interés legal se encuentra, según el Tribunal Constitucional, "en evitar el grave perjuicio que para la Hacienda supondría que grupos enteros de contribuyentes dejaran en masa de pagar tempestivamente sus cuotas tributarias porque el coste del retraso le supusiera, de todos modos, un ahorro respecto del interés de mercado del dinero. Evitar este riesgo configura el fin que el legislador trata de lograr. Y no parece que se pueda dudar del carácter objetivo y de la razonabilidad de preservar aquel interés público. El que, en cambio, cuando es el contribuyente el acreedor frente a la Hacienda, el interés sea el legal, -sin incremento del 25 por 100tiene otra justificación: tratar de compensar el perjuicio que para dicho contribuyente, a título individual, le ha causado la no disposición de una cantidad de dinero realmente no debida a la Administración. Un supuesto este que, por muy frecuente que pueda ser, nunca lo será en la magnitud numérica y cuantitativa del anterior. En este segundo caso, el legislador trata sólo de compensar o reparar, a través de la determinación de un módulo objetivo, la producción de un perjuicio sufrido en la esfera patrimonial de un particular, perjuicio cuya producción no puede decirse que haya sido deliberadamente buscada por la Administración. En el primer caso, por el contrario, el legislador trata de compensar o resarcir el erario público por el perjuicio que le supone la no disposición tempestiva de los fondos necesarios para atender a los gastos públicos, a la vez que de salir preventivamente al paso de una posible actitud dilatoria en el pago de sus deudas tributarias por los contribuyentes, y ante el riesgo de que dicha actitud pudiera generalizarse". Considera, por tanto, este tribunal, constitucionalmente legítimo que el legislador pueda establecer un incremento del 25 por 100 sobre el interés legal para cuantificar el interés de demora, pues así "que persigue un progresivo acercamiento a dicha realidad financiera, sin que ello suponga un sacrificio excesivo al contribuyente moroso, ya que en definitiva el tipo de interés que viene obligado a pagar no supera los habitualmente aplicables en las relaciones entre particulares".

Respecto a la vulneración del primer apartado del artículo 25 de la CE, el Tribunal Constitucional determinó que "la norma cuestionada no trata de sancionar una conducta ilícita, pues su sola finalidad consiste en disuadir a los contribuyentes de su morosidad en el pago de las deudas tributarias y compensar al erario público por el perjuicio que a éste supone la no disposición tempestiva de todos los fondos necesarios para atender a los gastos públicos. Los intereses de demora no tienen naturaleza sancionadora, sino exclusivamente compensatoria o reparadora del perjuicio causado por el retraso en el pago de la deuda tributaria. (...) Más que una penalización en sentido estricto, son una especie de compensación específica, con arreglo a un módulo objetivo, del coste financiero que para la Administración tributaria supone dejar de disponer a tiempo cantidades dinerarias que le son legalmente debidas. En suma, no hay aquí sanción alguna en sentido técnico-jurídico, y ello excluye sin más cualquier transgresión del art. 25.1 de la Constitución”.

A pesar de que el Tribunal Constitucional dejó solventada la naturaleza indemnizatoria de los intereses de demora, se produjeron algunas opiniones contrarias a los razonamientos esgrimidos por 
el Alto Tribunal. CARRASCO PARRILLA afirmó que "el TC fue víctima de sus propios argumentos, ya que si pretende justificar el incremento del $25 \%$ en la culpabilidad del retraso, mal se puede argüir que no se trate de sancionar con este incremento puesto que la culpabilidad únicamente es tenida en cuenta en Derecho tributario a la hora de proceder a la imposición de sanciones. Nos llama poderosamente la atención cómo a pesar de establecerse la naturaleza indemnizatoria, se concreta unas líneas más arriba la distinta finalidad que los intereses tienen dependiendo de la persona que ocupe el lugar de acreedor; ya que si éste se ocupa por la potentior persona su finalidad consistirá en disuadir y compensar, mientras que si lo ocupan los contribuyentes sólo será compensatoria" ". RAMALLO MASSANET observó que "la prestación tributaria es la misma, es el objeto de una misma relación obligacional, la tenga que cumplir el deudor contribuyente o no la tenga que cumplir y, consecuentemente, se le deba devolver. Luego vendrán, en su caso, los recargos, las sanciones, etc.; en definitiva, otras reacciones del ordenamiento jurídico ante los incumplimientos o desajustes del plan de prestación y cada uno de ellos con su propio presupuesto de hecho. Dar dos justificaciones diferentes a los intereses activos y pasivos establecidos en los mencionados artículos de la Ley General Tributaria es estar rompiendo la construcción dogmática de la relación obligacional tributaria (...). Si el acreedor es un potentior persona y sólo en virtud de hecho se le debe pagar un interés inverso por la misma deuda, dejamos de estar ante una relación crediticia, ante una relación entre acreedor y deudor. Pienso que sería preferible -constitucional y dogmáticamenteseguir manteniendo esa relación jurídica en términos de igualdad y si se coloca a la «Administración como potentior persona a una situación de superioridad sobre los contribuyentes» -que, en efecto a mi entender, debe colocarse- no debe hacerse en el seno de la obligación, sino en el resto de relaciones jurídicas en donde se encarnan las otras reacciones del ordenamiento jurídico ante el no cumplimiento de la obligación" $" 111$.

La Ley 25/1995 modificó el inciso c) del apartado segundo del artículo 58 de la LGT de 1963, aunque sin modificar la cuantificación del interés de demora, con la siguiente redacción

"El interés de demora que será el interés legal del dinero vigente a lo largo del período en el que aquél se devengue, incrementado en un 25 por 100, salvo que la Ley de Presupuestos Generales del Estado establezca otro diferente".

En la actualidad, el apartado 6 del artículo 26 de la LGT incorpora los mismos mandatos que el inciso c) del segundo apartado del artículo 58 de la LGT de 1963. Por ende, pueden aplicarse a la ley vigente las mismas observaciones que hicimos en relación con las anteriores disposiciones. Esencialmente, que a los intereses de demora se les debe atribuir una naturaleza indemnizatoria ${ }^{112}$, pues con su aplicación lo que se pretende es reparar el daño económico que se causa a la Hacienda

\footnotetext{
${ }^{110}$ CARRASCO PARRILla, P. J., Consecuencias del retraso en el pago de las deudas tributarias, op. cit., pág. 119.

111 RAMALlo MASSANET, J., Prólogo a la obra de LÓPEZ MARTíneZ, J., Régimen jurídico de los llamados "intereses moratorios" en materia tributaria. Un análisis de su ubicación en el seno de la deuda tributaria, Civitas, Estudio de Derecho Financiero y Tributarios, Madrid, 1994, pág. 16.

112 Así también los entiende VEGA HERRERO, M. y MUÑOZ DEL CASTILLO, J. L., "Capítulo II. Tributos y obligaciones tributarias", op. cit., pág. 114; GALAPERO FLORES, R., El procedimiento de recaudación de los tributos. Estudio de su regulación en la Ley General Tributaria y en el Reglamento General de Recaudación, op. cit., pág. 186 y 187; MARTÍN FERNÁNDEZ, F. J., "Intereses de demora y expedientes de rectificación en la reciente jurisprudencia", op. cit., pág. 147; LÓPEZ MARTÍNEZ, J., Régimen jurídico de los llamados "intereses moratorios" en materia tributaria. Un análisis de su ubicación en el seno de la deuda tributaria, op. cit., 183 y 184.
} 
Pública por el cumplimiento tardío en el pago de la deuda tributaria. Sin embargo, coincidimos con GONZÁLEZ GARCÍA ${ }^{113}$, ALFONSO GALÁN ${ }^{114}$, y LÓPEZ MARTÍNEZ ${ }^{115}$, entre otros, en que resulta muy difícil mantener únicamente el carácter indemnizatorio de los intereses de demora cuando éstos exceden el interés legal del dinero.

\subsubsection{Régimen jurídico de los intereses de demora}

El apartado 1 del artículo 26 de la LGT determina que el interés de demora no requiere la previa intimación de la Administración tributaria, ni la concurrencia del retraso culpable del obligado. A su vez, el número 2 del precepto prevé cuáles son los supuestos en los que se debe exigir el interés de demora $^{116}$ : cuando finalice el plazo establecido para el pago en período voluntario de una deuda resultante de una liquidación practicada por la Administración tributaria o del importe de una sanción, sin que el ingreso se hubiera efectuado; cuando finalice el plazo establecido para la presentación de una autoliquidación o declaración sin que éstas hubieran sido presentada o se presentaron incorrectamente, salvo que se trate de declaraciones extemporáneas sin requerimiento previo a las que puedan aplicarse el apartado 2 del artículo 27 de la LGT $^{117}$; cuando se suspenda la ejecución del acto, con la excepción del supuesto de recursos y reclamaciones contra sanciones ${ }^{118}$, durante el tiempo que transcurra hasta la finalización del plazo de pago en período voluntario abierto por la notificación de la resolución que ponga fin a la vía administrativa ${ }^{119}$; cuando se inicie el

\footnotetext{
${ }^{113}$ GONZÁLEZ GARCÍA, A., "Los intereses moratorios a favor de la Hacienda”, Cuadernos de Jurisprudencia Tributaria, Aranzadi, 1998, pág. 34.

${ }^{114}$ ALFONSO GALÁN, R. M., Los intereses por retaso o demora a favor de la Hacienda Pública, Dykinson, Madrid, 1998, pág. 107
} a 115 .

115 LÓPEZ MARTÍNEZ, J., Régimen jurídico de los llamados “intereses moratorios” en materia tributaria. Un análisis de su ubicación en el seno de la deuda tributaria, op. cit., 187.

${ }^{116}$ Según SOLER ROCH se trata de una lista abierta e indicativa que lo que hace es reiterar lo que anteriormente regulaba el apartado primero del artículo 26 de la LGT (SOLER ROCH, M. T., "La estructura jurídica del tributo y las distintas obligaciones tributarias, especial referencia a intereses de demora y recargos", op. cit., pág. 109). Por su parte, RODRÍGUEZ MÁRQUEZ expresa que el interés de demora debe excluirse cuando el retraso se deba al comportamiento de la Administración tributaria. En este sentido, identifica cuatro grupos de supuestos a los cuales debe limitarse el devengo de intereses de demora: cuando el contribuyente solicita un aplazamiento o fraccionamiento o el pago mediante compensación, y la Administración deja transcurrir el plazo establecido sin pronunciarse acerca de dicha petición; cuando el obligado tributario interpone recurso, solicita y obtiene la suspensión de la ejecución del acto impugnado y el órgano encargado de resolver demora su resolución por un período superior al establecido legalmente; cuando la Administración se retrasa en dictar el acto de liquidación, incumpliendo el plazo determinado por la normativa aplicable; y cuando la Administración liquida de forma incorrecta, de manera que el acto de liquidación resulta anulado, debiendo sustituirse por uno nuevo (RODRÍGUEZ MÁRQUEZ, J. S., El interés de demora en la Ley General Tributaria, op. cit., pág. 326 y 327).

${ }^{117}$ Los intereses de demora son incompatibles en este caso con los recargos por declaración extemporánea del 5, 10 y el 15 por 100 , es decir, los recargos por autoliquidaciones o declaraciones extemporáneas realizadas con un año de retraso como máximo. Por el contrario, los intereses de demora son compatibles con el recargo del 20 por 100, aplicable a las presentaciones extemporáneas con un retraso superior a un año, aunque en este supuesto la LGT ha establecido aquel año de retraso como período de carencia en relación con el devengo de dichos intereses (segundo párrafo del apartado 2 del artículo 27 de la LGT).

${ }^{118}$ La excepción que reconoce esta regla fue reconocida por la jurisprudencia del Tribunal Supremo en la Sentencia de 18 de septiembre de 2001, al determinar que "es una consecuencia lógica de la suspensión automática y sin garantías de la ejecución en estos casos (art. 212.3. ${ }^{\circ}$ de la Ley), criterio cuya eficacia se vería seriamente comprometida si se computaran aquellos intereses”. Así también lo entiende SOLER ROCH, M. T., "La estructura jurídica del tributo y las distintas obligaciones tributarias: especial referencia a intereses de demora y recargos", op. cit., pág. 110. Por otro lado, varios autores se muestran contrarios a que se devenguen intereses durante el tiempo que dure la suspensión si al final se admite la tercería: entre otros, RODRÍGUEZ MÁRQUEZ, J. S., El interés de demora en la Ley General Tributaria, op. cit., pág. 290; SARTORIO ALBALAT, S., Ley General Tributaria e interés de demora, Marcial Pons, Madrid, 1999, pág. 437; MARTÍN FERNÁNDEZ, F. J., La suspensión de la ejecución de los actos tributarios en vía de recurso, Marcial Pons, Madrid, 1999, pág. 189; DE MIGUEL ARIAS, S., La práctica del embargo para el cobro de la deuda tributaria, Thomson Reuters-Aranzadi, Pamplona, 2011, pág. 410.

${ }^{119}$ La ley no se pronuncia en relación al cómputo de los intereses suspensivos en vía procesal. A juicio de RODRÍGUEZ MÁRQUEZ, esta es una situación comprensible, ya que la LGT no trata cuestiones relacionadas con el recurso contencioso-administrativo, aunque 
período ejecutivo, siempre que no sea aplicable el recargo ejecutivo o el recargo de apremio reducido previstos en el apartado 5 del artículo 28 de la LGT; y dos nuevos supuestos que no aparecían en la LGT de 1963: cuando el obligado tributario haya obtenido una devolución improcedente y cuando este mismo sujeto reciba una petición de cobro de deudas de titularidad de otros Estados o de entidades internacionales o supranacionales conforme a la normativa sobre asistencia mutua, siempre que dicha normativa no disponga otra cosa.

Uno de los aspectos importantes de los intereses de demora es el cálculo de su cuantía. Según dispone el apartado 3 del artículo 26 de la LGT,

"el interés de demora se calculará sobre el importe no ingresado en plazo o sobre la cuantía de la devolución cobrada improcedentemente, y resultará exigible durante el tiempo al que se extienda el retraso del obligado" ${ }^{20}$.

Aquí debe tenerse en cuenta que, en los demás casos, donde el devengo de intereses se refiere a otro tipo de situaciones que también implican un diferimiento en el cumplimiento de la obligación tributaria, dicho importe será el de la deuda liquidada ${ }^{121}$ o el de la deuda objeto de suspensión, aplazamiento o fraccionamiento o compensación.

También precisa este precepto que si el retraso comprende varios ejercicios, el interés de demora se calcule aplicando el correspondiente a cada uno y en proporción al tiempo transcurrido.

Una de las novedades que introduce la ley en esta materia se observa en el apartado 4 del artículo 26 de la LGT, y consiste en la no exigencia del interés de demora a los obligados tributarios para aquellos casos en los que la Hacienda Pública incumpla con los plazos máximos que la ley le concede para dictar resoluciones. No obstante, el incumpliendo al que hace referencia este apartado no se aplica incomprensiblemente a los plazos para resolver solicitudes de aplazamiento o fraccionamiento del pago ${ }^{122}$, ni a la resolución de recursos administrativos cuando se haya acordado la suspensión del acto recurrido.

La LGT prevé, finalmente, otro supuesto donde no es exigible el interés de demora: el supuesto en que se produce la inexigibilidad de los intereses de demora correspondientes al tiempo transcurrido

no deja de ser un "pecado de omisión" (RODRÍGUEZ MÁRQUEZ, J. S., "El interés de demora exigible por la Administración en el Proyecto de Ley General Tributaria: luces y sombras", op. cit., pág. 21).

${ }^{120}$ Lo que supone según GARCÍA NOVOA que se "vincula la exigencia de los intereses a que exista un plazo para el cumplimiento de la obligación y que dicho plazo haya sido incumplido. Por tanto, la inclusión o no de los recargos de apremio o recargos del período ejecutivo previstos en el art. 28 en la base del interés dependerá de que éstos deban ingresarse en determinado plazo". GARCÍA NOVOA, C., "Capítulo IV. Elementos de cuantificación de la deuda tributaria", op. cit., pág. 287.

${ }^{121}$ Es el caso de los expedientes relacionados con la aplicación de técnicas antiabuso, tales como la liquidación de deudas resultantes del procedimiento para declarar el conflicto en la aplicación de la norma tributaria o la regularización que proceda como consecuencia de la existencia de simulación.

${ }^{122}$ Al parecer de SOLER ROCH, "esta excepción es criticable, por introducir una desigualdad injustificada (se discrimina en función del objeto del procedimiento) e inconsecuente con el fundamento de la norma (enervar la exigibilidad de los intereses cuando la demora sea imputable a la Administración)" (SOLER ROCH, M. T., "La estructura jurídica del tributo y las distintas obligaciones tributarias, especial referencia a intereses de demora y recargos”, op. cit., pág. 114 y 115). Del mismo modo, RODRÍGUEZ MÁRQUEZ interpreta que el retraso de la Hacienda Pública en resolver la solicitud de aplazamiento excluye el retraso del deudor y, por tanto, carece de sentido el cómputo de los intereses de demora. (RODRÍGUEZ MÁRQUEZ, J. S., "El interés de demora exigible por la Administración en el Proyecto de Ley General Tributaria, luces y sombras", op. cit., pág. 17). 
entre la presentación de la declaración extemporánea y el pago voluntario de la deuda derivada de la liquidación (apartado 2 del artículo 27 de la LGT). Se trata de una solución lógica, porque el retraso no se debe aquí al deudor, sino al desarrollo del procedimiento de liquidación, y porque, una vez que se dicta el acto administrativo es cuando comienza a cursar el plazo para el pago voluntario, durante el cual no cabe el devengo de intereses ${ }^{123}$.

Cuando resulte necesaria la práctica de una nueva liquidación como consecuencia de haber sido anulada otra liquidación por una resolución administrativa o judicial, se conservarán íntegramente los actos y trámites no afectados por la causa de anulación, con mantenimiento íntegro de su contenido y exigencia del interés de demora sobre el importe de la nueva liquidación. En estos casos, la fecha de inicio del cómputo del interés de demora será la misma que, de acuerdo con lo establecido en el apartado 2 del artículo 26 de la LGT, hubiera correspondido a la liquidación anulada, y el interés se devengará hasta el momento en que se haya dictado la nueva liquidación, sin que el final del cómputo pueda ser posterior al plazo máximo para ejecutar la resolución ${ }^{124}$.

En relación con el tipo de interés aplicable, el apartado 6 determina que la cuantía del interés de demora será el interés legal del dinero vigente a lo largo del período en el que aquél resulte exigible, incrementado en un 25 por 100, salvo que la Ley de Presupuestos Generales del Estado establezca otra $\operatorname{cosa}^{125}$. El antecedente legislativo de este precepto se encuentra en el apartado 2 del artículo 58 de la LGT de 1963, que se expresaba con idénticos criterios, tanto en el caso de obligaciones tributarias como de obligaciones de devolución y reembolso. No obstante, la ley introduce una novedad para los supuestos de aplazamiento, fraccionamiento o suspensión de deudas garantizadas en su totalidad mediante aval solidario de entidad de crédito o sociedad de garantía recíproca o mediante

\footnotetext{
${ }^{123}$ Un antecedente de esta regla podemos encontrarlo en el Real Decreto 939/1986, de 26 de abril, que aprobó el Reglamento General de Inspección, cuyo artículo 69 en su apartado tercero determinaba, en relación con las liquidaciones derivadas de actas de disconformidad, que los intereses de demora se computarían hasta la práctica de la liquidación por el Inspector Jefe o, si no se ha practicado la misma, hasta el plazo previsto para ello.

${ }^{124}$ La solución adoptada por la LGT en el apartado 5 del artículo 26 responde a la doctrina del Tribunal Supremo que, en la Sentencia de 28 de noviembre de 1997, distinguió entre los intereses suspensivos y los intereses de demora no aplicables en estos supuestos y los intereses de demora que sí procede exigir sobre la nueva liquidación. Esta posición de la ley y la jurisprudencia encuentra dentro de la doctrina detractores y seguidores. Éstos últimos consideran razonable que se exijan intereses de demora sobre la nueva liquidación en los casos de estimación parcial del acto de liquidación anterior, "pero no cuando se produce la anulación total de dicho acto (...) aunque ello no impida dictar una nueva liquidación ya que, en dicho supuesto, aunque es evidente que el ingreso resultante se produce con retraso, no es menos cierto que dicho retraso es imputable a una previa actuación irregular de la Administración" (SOLER ROCH, M. T., "La estructura jurídica del tributo y las distintas obligaciones tributarias: especial referencia a intereses de demora y recargos", op. cit., pág. 115). Entre los que mantienen una postura contraria a la que se acaba de señalar, vid. RODRÍGUEZ MÁRQUEZ, J. S., "El interés de demora exigible por la Administración en el Proyecto de Ley General Tributaria: luces y sombras", op. cit., pág. 19 y 30.

${ }^{125}$ Sobre la diferencia a la hora de fijar los tipos de interés (legal y de demora) en el caso de retraso en el cumplimiento de las obligaciones tributarias, apunta SABINIANO MEDRANO que "la discriminación de los tipos según los casos es incompatible con la naturaleza indemnizatoria de la obligación de pagar intereses, pues el perjuicio que hay que indemnizar es idéntico en todos ellos. En particular, dentro de los supuestos de aplicación del tipo reducido, si el aplazamiento, fraccionamiento o suspensión de la deuda han sido acordados o son procedentes en Derecho, no está justificado reducir el tipo sólo cuando la caución es más sólida y no en otros casos, por el mismo motivo general ya enunciado, porque nada tiene que ver la seguridad del cobro con el tipo de interés de demora y porque conduce al absurdo de endurecer el tratamiento a los obligados con mayores dificultades económicas" (SABINIANO MEDRANO I., "Las obligaciones tributarias accesorias: el interés del demora y los recargos", en la obra Estudios sobre la nueva Ley General Tributaria (Ley 58/2003, de 17 de diciembre) en homenaje a D. Pedro Luis Serrera Contreras, MARTÍNEZ LAFUENTE, A. (director), Instituto de Estudios Fiscales, Madrid, 2004, pág. 170).
} 
certificado de seguro de caución, en cuyo caso el interés de demora exigible coincidirá con el interés legal ${ }^{126}$.

Esta distinción en la cuantía de los intereses de demora se considera aceptable por el Consejo de Estado, siguiendo la doctrina del Tribunal Constitucional, en su Sentencia 76/1990. El Dictamen del Consejo de Estado sobre el Anteproyecto de LGT, de 22 de mayo de 2003, concluye que "la introducción de esta medida diferenciadora está suficientemente justificada, pues se trata de incentivar la utilización de las garantías antes referidas, utilización que resulta favorable para los intereses públicos" $" 127$. CALVO ORTEGA, por su parte, entiende que la diferencia en la cuantía del interés se produce en este supuesto porque se considera que se produce una mora no culposa, ya que el acreedor tiene conocimiento del retraso del pago por parte del deudor ${ }^{128}$.

\subsubsection{Los recargos por declaración extemporánea}

A pesar de que el procedimiento de recaudación se compone fundamentalmente de dos períodos, el período voluntario de pago y el período ejecutivo, el pago de la deuda tributaria puede efectuarse una vez que finaliza el período voluntario pero antes de que se inicien las actuaciones de la Administración tributaria para hacerlo efectivo sobre el patrimonio del deudor. Ese lapso de tiempo es el que algunos autores denominan período de prórroga, intermedio o extemporáneo entre el período voluntario y el período ejecutivo. Precisamente es en este momento cuando se devengan los recargos por declaración extemporánea sin requerimiento previo, una vez finalizado el período voluntario de pago sin haberse producido ninguna actuación administrativa con conocimiento formal del obligado tributario, conducente al reconocimiento, regularización, comprobación, inspección, aseguramiento o liquidación de la deuda tributaria ${ }^{129}$.

\footnotetext{
${ }^{126}$ Siguiendo a la doctrina mayoritaria, entendemos el incremento del 25 por 100 supone una penalización, sobre todo para aquellos casos donde no exista la culpabilidad del obligado tributario, equiparándose de esta forma al contribuyente que actúa con culpabilidad con el que lo hace sin ella. SOLER ROCH apunta que en líneas generales la norma responde a un planteamiento acertado, pero tiene algunos aspectos discutibles: "el primero de ellos es no haber incluido en este grupo de supuestos las deudas objeto de compensación a instancia del deudor; el segundo, el condicionar la aplicación del interés legal al tipo de garantía sobre la deuda objeto de aplazamiento, fraccionamiento o suspensión" (SOLER ROCH, M. T., "La estructura jurídica del tributo y las distintas obligaciones tributarias: especial referencia a intereses de demora y recargos", op. cit., pág. 113). GARCÍA NOVOA afirma que se trata de una penalización, especialmente criticada en supuestos en que el cobro de intereses no responde a un comportamiento culpable, "lo que aleja al interés de su función de compensación financiera (...). Sin embargo esa ausencia de culpabilidad se da en todos los casos de aplazamientos y fraccionamientos y no sólo en los garantizados con aval solidario o seguro de caución, lo que hace incomprensible la precesión del art. 26.6 de la Ley 58/2003" (GARCÍA NOVOA, C., "Capítulo IV. Elementos de cuantificación de la deuda tributaria", op. cit., pág. 286). En el mismo sentido, GALAPERO FLORES, R., El procedimiento de recaudación de los tributos. Estudio de su regulación en la Ley General Tributaria y en el Reglamento General de Recaudación, op. cit., pág. 192.

${ }^{127}$ Dictamen del Consejo de Estado sobre el Anteproyecto de LGT, de 22 de mayo de 2003, pág. 27.

${ }^{128}$ CALVO ORTEGA, R., "El proyecto de Ley General Tributaria: aportaciones y aspectos críticos”, op. cit., pág. 34.

${ }^{129}$ Esta definición de "requerimiento previo" es una de las novedades que introduce el artículo 27 de la LGT y, según GARCÍA NOVOA, en lo sustancial, coincide con la descripción de actuaciones administrativas aptas para interrumpir la prescripción que recogía el inciso a) apartado primero del artículo 66 de la LGT de 1963, y que ahora reproduce el inciso a) del primer apartado del artículo 68 de la LGT. Asimismo, este autor afirma que es una aclaración necesaria, "porque no cualquier comunicación informal, como venía señalando la jurisprudencia y la doctrina del TEAC, sería un «requerimiento» y determinaría la aplicación de sanciones" (GARCÍA NOVOA, C., "Capítulo IV. Elementos de cuantificación de la deuda tributaria", op. cit., pág. 288). Como bien reconoce este mismo autor, la Resolución del TEAC de 19 de mayo de 2002 dispuso que procedía la aplicación de los recargos por declaración extemporánea y no una sanción ante un escrito meramente informativo, remitido por la Hacienda Pública, donde se recordaba al deudor la obligación de satisfacer sus obligaciones fiscales. Una posición similar a la de esta doctrina es la mantenida por MARTÍN FERNÁNDEZ, F. J., "Una visión general del Anteproyecto de Nueva Ley General Tributaria", Asociación Española de Asesores Fiscales, mayo, 2003, pág. 28. Por su parte, al referirse a la definición que brinda la ley sobre el requerimiento previo, VEGA HERRERO, M. y MUÑOZ DEL CASTILLO, J. L., "Capítulo II. Tributos y obligaciones tributarias", op. cit., pág. 117 a 118 ,
} 
Los recargos por declaración extemporánea son las prestaciones pecuniarias que se originan en las deudas tributarias que se ingresan a través de autoliquidaciones o declaraciones-liquidaciones, cuya presentación se realiza fuera del plazo del período voluntario y antes de que exista alguna intervención por parte de la Administración tributaria. Tienen como finalidad facilitar la recaudación de este tipo de deudas. De esta forma se permite que el deudor cumpla con su obligación de manera voluntaria, aunque fuera de tiempo, bajo un régimen más benévolo que el que exige el cumplimiento de la obligación por parte de la Hacienda Pública.

Esta es una institución que ha sufrido constantes modificaciones legislativas ${ }^{130}$. Actualmente, la LGT regula este tipo de recargos en el artículo 27 de manera muy similar a su antecesor, el apartado tercero del artículo 61 de la LGT de 1963. El precepto vigente define los recargos por declaración extemporánea sin requerimiento previo como aquellas prestaciones pecuniarias a las que tendrá que hacer frente el obligado tributario como consecuencia de la presentación de autoliquidaciones o declaraciones fuera del plazo sin requerimiento previo por parte de la Administración tributaria. No obstante, y a pesar de las pocas diferencias que se observan en el tratamiento legislativo de los recargos extemporáneos en la LGT de 1963 y la ley actual, esta última norma introduce tres aspectos novedosos. Por un lado, identifica qué se entiende por requerimiento previo. Por otro lado, aclara que, si junto con la presentación de la autoliquidación no se efectúa el ingreso y no se solicita el aplazamiento, fraccionamiento o compensación, la liquidación administrativa que proceda por recargos e intereses de demora derivada de la presentación extemporánea no impedirá la exigencia de los recargos e intereses del período ejecutivo que correspondan sobre el importe de la

consideraron que se trataba de una "definición excesivamente amplia y ambigua que reproduce, prácticamente de forma literal, la primera de las causas interruptivas de la prescripción del derecho de la Administración para determinar la deuda tributaria [art. 68.1 . a)]. Parece desde el punto de vista lógico y teleológico que el concepto de requerimiento previo debería circunscribirse a las actuaciones de la Administración tributaria, notificadas al obligado tributario, con el fin de presentarse la correspondiente autoliquidación o declaración".

${ }^{130}$ Siguiendo en este punto a BALLARÍN ESPUÑA, el artículo 92 del RGR de 1968 regulaba un período de prórroga entre la finalización del período voluntario y el inicio del procedimiento de apremio de veinte días, durante el que se podía ingresar la deuda con un recargo del 5 por 100. Este recargo se aplicó hasta la entrada en vigor del Real Decreto 338/1985, de 15 de marzo, por el que se dictan Normas de Gestión Tributaria, Recaudatoria y Contable, que modificó el artículo 92 del RGR de 1968, configurando un plazo de prórroga indeterminado para los supuestos de autoliquidaciones y elevando el recargo de prórroga a un 10 por 100 . Poco tiempo después, la Ley 10/1985, de 26 de abril, de Modificación Parcial de la Ley General Tributaria, introdujo cambios en el apartado 2 del artículo 61 de la LGT de 1963. En concreto esta ley previó que a los ingresos extemporáneos sin requerimiento se les aplicaría un interés de demora mínimo del 10 por 100 de la prestación, además de las sanciones oportunas. En ese mismo año, la Ley 46/1985, de 27 de diciembre, Presupuestos Generales del Estado para el 1986, modificó el mismo precepto, con el fin de excluir las sanciones. Con la aprobación del RGR de 1990, se eliminan las referencias al período de prórroga y los intereses de demora. Por su parte, el segundo apartado de la Disposición Adicional Decimocuarta de la Ley 18/1991, de 6 de junio, del IRPF, también modificó la redacción del apartado 2 del artículo 61 de la LGT de 1963, con el fin de determinar que cuando se tratara de ingresos procedentes de autoliquidación realizados fuera del plazo voluntario y sin mediar requerimiento administrativo se exigiría un recargo del 50 por 100 , sin intereses de demora, ni sanciones; y de especificar que si el ingreso era en los tres meses tras la finalización de dicho plazo, el recargo llegaba sólo hasta el 10 por 100, y que si se presentaba la declaración-liquidación sin el ingreso, se exigiría este último a través del procedimiento de apremio con un recargo único del 100 por 100. La Ley 25/1995, 20 de julio, Modificación Parcial de la Ley General Tributaria, introdujo cambios importantes que se incluyeron en el apartado tercero del artículo 61 de la LGT de 1963. Entre ello, la determinación de que los ingresos correspondientes a declaraciones-liquidaciones o autoliquidaciones presentadas fuera de plazo sin requerimiento previo, así como las liquidaciones derivadas de declaraciones presentadas fuera de plazo sin requerimiento previo, sufrirían un recargo del 20 por 100 con exclusión de las sanciones que, en otro caso, hubieran podido exigirse, pero no de los intereses de demora. No obstante, si el ingreso o la presentación de la declaración se efectuaba dentro de los tres, seis o doce meses siguientes al término del plazo voluntario de presentación e ingreso, se aplicaría un recargo único del 5, 10 o 15 por 100, respectivamente, con exclusión del interés de demora y de las sanciones que, en otro caso, hubieran podido exigirse. Estos recargos eran compatibles, cuando los obligados tributarios no efectuaran el ingreso al tiempo de la presentación de la declaración-liquidación o autoliquidación extemporánea, con el recargo de apremio que preveía el artículo 127 de la LGT de 1963 (BALLARÍN ESPUÑA, M., Los ingresos tributarios fuera de plazo sin requerimiento previo, Marcial Pons, Madrid, 1997, pág. 49 a 89). 
autoliquidación. Por último, se exige que las autoliquidaciones extemporáneas deban identificar expresamente el período impositivo de liquidación y contener únicamente los datos de ese período ${ }^{131}$.

\subsubsection{Naturaleza jurídica de los recargos por declaración extemporánea}

La naturaleza indemnizatoria o sancionadora de los recargos por declaración extemporánea fue y sigue siendo objeto de discusión doctrinal. A la hora de determinar la naturaleza de esta institución creemos oportuno referirnos en primer lugar a los recargos que antecedieron al actual recargo por declaración extemporánea del artículo 27 de la LGT. Concretamente, debemos analizar el recargo único del 50 por 100 o del 10 por 100 del apartado segundo del artículo 61 de la LGT de 1963 en la redacción dada por el segundo apartado de la Disposición Adicional Decimocuarta de la Ley 18/1991, de 6 de junio, del IRPF y los recargos por ingreso extemporáneo previstos en el tercer apartado del artículo 61 de la LGT de 1963 tras la modificación que introdujo la Ley 25/1995, 20 de julio, de modificación parcial de la LGT.

En cuanto al recargo único que preveía el segundo apartado del artículo 61 de la LGT de 1963, el Tribunal Constitucional reconoció que el mínimo del 10 por 100 no era un interés de demora sino un recargo, que cumplía una función disuasoria tendente a evitar el impago dentro del plazo. Por tanto, su naturaleza no era represiva "en sentido propio, pues no supone un castigo por la realización de una conducta ilícita administrativamente, sino un estímulo para el cumplimiento de las obligaciones tributarias o, lo que es lo mismo una disuasión para el incumplimiento", tal como expresan la Sentencia 164/1995, de 13 de noviembre, y otras posteriores (171/1995, 198/1995, 44/1996, 276/2000, 291/2000, 93/2001) ${ }^{132}$. Además el Tribunal Constitucional ha manifestado que sólo si la cuantía del recargo alcanzase o se aproximase al importe de las sanciones tributarias podría concluirse que estamos ante una sanción ${ }^{133}$.

BALLARÍN ESPUÑA expresa su disentimiento con el último argumento de la jurisprudencia del Tribunal Constitucional. Según esta autora, "a nadie se le puede ocultar la excesiva incerteza que significa excluir de la calificación de sanciones a los recargos por el mero hecho de que su cuantía no alcance a la de las reacciones que se imponen frente a conductas formalmente tipificadas como infracciones tributarias. A nuestro juicio, dicha fórmula implica dotar a la interpretación de grandes dosis de inseguridad jurídica, toda vez que un mismo recargo por ingreso extemporáneo hoy puede

\footnotetext{
${ }^{131}$ La intención que se persigue con la introducción de este requisito formal es evitar, según JUNOY PINTOS, que "en declaraciones posteriores se regularice ocultando a la Administración la información necesaria para que pueda comprobar y liquidar los recargos que procedan. En el caso de incumplir estos requisitos no se aplicarán los recargos y dicha conducta será constitutiva de infracción tributaria leve, de acuerdo con lo establecido en el artículo 187 de la LGT" (JUNOY PINTOS, R., La Nueva Ley General Tributaria comentada, GÓMEZ-MOURELO (director), La Ley, Madrid, 2004, pág. 135). En un sentido similar, la Comisión para el estudio del borrador del Anteproyecto de la nueva Ley General Tributaria en su Informe 2001, pág. 19, afirmó que "de esta forma, se pretende evitar que los sujetos realicen regularizaciones encubiertas beneficiándose de la aplicación del régimen de recargos. Así puede suceder, por ejemplo, en el Impuesto sobre el Valor Añadido, mediante la declaración de cuotas repercutidas en períodos posteriores al de su devengo".

${ }^{132}$ Para GARCÍA NOVOA, el Tribunal Constitucional lo que hizo "fue excluir que estos recargos pudiesen tener la consideración de sanciones, otorgándoles la confusa condición de una «penalización económica en caso de retraso en el pago para tratar de conseguir que éste se produzca dentro del plazo», equiparándolas a las «cláusulas penales que pueden concebir las partes, que, sin embargo, sólo funcionan en el Derecho Privado a partir de lo establecido en los arts. 1.152 y ss. Del Código Civil»" (GARCÍA NOVOA, C., "Capítulo IV. Elementos de cuantificación de la deuda tributaria", op. cit., pág. 289).

${ }^{133}$ Una postura similar se observa en los pronunciamientos del Tribunal Supremo, en las Sentencias de 22 de septiembre de 2002 , de 9 de julio de 2003 y de 31 de mayo de 2005, del Tribunal Superior de Justicia de Baleares, en la Sentencia de 30 de mayo de 1995, o de la Audiencia Nacional, en las Sentencias de 23 de julio de 2002 y de 7 de noviembre de 2003.
} 
ser una sanción (por poseer idéntico montante al de la multa por infracción grave) y mañana puede convertirse en una medida meramente «disuasoria» si el legislador decide incrementar la cuantía de dicha multa. Y aun manteniéndose invariable el otro término de comparación (la cuantía de la multa), de una aplicación literal de la doctrina del TC manifestada en la Sentencia 164/1995, bastaría con mantener a un recargo un punto porcentual por debajo de la multa para calificar a dicho recargo como meramente disuasorio -y no como represivo-, lo cual no deja de resultar repudiable a cualquier sensibilidad jurídica. (...) Como consecuencia de lo expuesto, no podemos convenir con el Alto Tribunal que los recargos por ingreso tardío, en cuanto exceden del interés legal del dinero y no alcancen la cuantía de la multa por infracción grave, posean una función disuasoria y no represiva. (...) La función exclusivamente indemnizatoria se cumple por el interés legal del dinero (no por el interés de demora tributario)", de manera que "el matiz sancionador ya resulta perceptible a partir de que la cuantía de cualquier recargo sobre pase la del interés legal"134.

De manera muy parecida, FALCÓN Y TELLA afirma que "la distinción entre sanciones pecuniarias y las cantidades exigidas coactivamente por otros conceptos no puede ser cuantitativa, sino que necesariamente ha de basarse (...) en criterios cualitativos. Pues en otro caso bastaría con elevar la cuantía de las sanciones para abrir la puerta a «cláusulas penales» más reducidas y escapar así a las exigencias propias del Derecho sancionador"135. RAMALLO MASSANET también entendió que "ciertamente -en el plano de la legalidad ordinaria por lo menos- es problemático admitir que las instituciones jurídicas se diferencian por sus cuantías y no por sus respectivos presupuestos de hecho y su régimen jurídico" 136 .

La jurisprudencia que se pronunció sobre el recargo del 50 por 100, también previsto en el apartado segundo del artículo 61 de la LGT de 1963, consideró casi por unanimidad que el mencionado recargo tenía una clara naturaleza sancionadora. En la Sentencia del Tribunal Constitucional 276/2000, 16 de noviembre, se indica claramente que, "en definitiva, el recargo del 50 por 100 de la deuda tributaria establecido en el art. 61.2 LGT, en su redacción dada por la Ley 18/1991, en tanto que supone una medida restrictiva de derechos que se aplica en supuestos en los que ha existido una infracción de la Ley y desempeña una función de castigo, no puede justificarse constitucionalmente más que como sanción". Posición que se mantuvo invariable en sentencias posteriores, como la Sentencia 26/2001, de 29 de enero, la Sentencia 93/2001, de 2 de abril, la Sentencia 108/2001, de 8 de mayo, o la Sentencia 127/2002, de 23 de mayo ${ }^{137}$.

Sobre este recargo del 50 por 100, apuntó BALLARÍN ESPUÑA que "la naturaleza sancionadora del recargo único no se derivaba tan sólo de que coincidiera el presupuesto generador de la infracción

\footnotetext{
${ }^{134}$ BALLARÍN ESPUÑA, M., Los ingresos tributarios fuera de plazo sin requerimiento previo, op. cit., pág. 259, 260 y 261.

${ }^{135}$ FALCÓN Y TELLA, R., Editorial de Quincena Fiscal, núm. 21, 1995, pág. 6.

${ }^{136}$ RAMALLO MASSANET, J., "Los nuevos recargos en la Ley General Tributaria”, Tribuna Fiscal, núm. 65, marzo de 1996, pág. 69. CARRASCO PARRILlA, P. J., Consecuencias del retraso en el pago de las deudas tributarias, op. cit., pág. 138 y 143 ; SABINIANO MEDRANO I., "Las obligaciones tributarias accesorias: el interés del demora y los recargos", op. cit., pág. 188 y 189.

${ }^{137}$ El Tribunal Superior de Justicia de Madrid, en Sentencia de 12 de enero de 1998, al referirse a ese recargo del 50 por 100 , expresó que "lo que sucede es que la sanción a que nos venimos refiriendo ha sido impuesta de plano, sin sujetarse al procedimiento sancionador establecido al efecto $\mathrm{y}$, muy especialmente, sin el preceptivo trámite de audiencia previa al interesado, lo que nos coloca ante un supuesto de nulidad de pleno derecho". Esta misma postura ya había sido defendida por este mismo tribunal en la Sentencia de 20 de diciembre de 1997, y también fue asumida por el Tribunal Superior de Justicia de la Comunidad Valenciana en la Sentencia de 11 de octubre de 1997.
} 
grave tipificada en el derogado art. 79. a) de la LGT y el de la obligación de pago del recargo único, sino que al equiparse también la cuantía de la multa proporcional ligada a la infracción y la del recargo, forzosamente había que entenderse que éste participaba de idéntica naturaleza que la sanción, o de lo contrario debería haberse negado asimismo el carácter intimidatorio-represivo de esta última. (...) Desde nuestra perspectiva, dado que todo lo que no es indemnización es susceptible de generar un efecto intimidatorio-represivo (pudiendo, por tanto, ser calificado de sanción), entendemos que en la cuantía que excedía del interés legal del dinero, constituía desde el punto de vista material una sanción"

El recargo que regulaba el apartado tercero del artículo 61 de la LGT de 1963, en cambio, establecía una cuantía menor que la del recargo único del 50 por 100 o del 10 por 100 y ligaba su aplicación a una conducta no tipificada como infracción grave ${ }^{139}$. CARRASCO PARRILLA entiende que no tiene ningún sentido afirmar que dichos recargos se establecen para fomentar el pago voluntario, porque "se exigen por la simple presentación extemporánea de declaraciones, declaraciones-liquidaciones o autoliquidaciones, a las que no se acompañe del correspondiente ingreso, puesto que de tal hipótesis no se deriva un pago voluntario, únicamente se lleva a cabo una presentación extemporánea de la correspondiente declaración". Según este autor, para determinar si existe un carácter sancionador en estos recargos lo primero que habría que hacer es relacionar la regulación de esta figura con la "configuración de las infracciones tributarias graves y determinar la ilicitud o no de la conducta consistente en presentar fuera de plazo las declaraciones, declaraciones-liquidaciones $o$ autoliquidación que conllevan haber dejado de ingresar la totalidad o parte de la deuda tributaria"140.

La naturaleza de estos recargos del apartado tercero del artículo 61 de la LGT de 1963 sólo puede abordarse distinguiendo, de una parte, los recargos del 5, 10 y 15 por $100 \mathrm{y}$, de otra, el recargo del 20 por 100. De los primeros se podría deducir que tenían una naturaleza indemnizatoria, toda vez que excluían los intereses de demora. Por otra parte, según lo que se desprende de la jurisprudencia del Tribunal Constitucional, no era posible que pudieran llegar a alcanzar la calificación de sanción, ya que el recargo incorporaba los intereses de demora y su cuantía se encontraba por debajo de la multa que era aplicable a las infracciones graves. "Más lo anterior no significa”, al parecer de BALLARÍN

\footnotetext{
${ }^{138}$ BALLARÍN ESPUÑA, M., Los ingresos tributarios fuera de plazo sin requerimiento previo, op. cit., pág. 262 y 263 . También destacan la identidad de la cuantía del recargo con la sanción por infracción tributaria grave, entre otros, GARCÍA PRATS, F. J., “Acerca del art. 61.2 de la LGT y su posible inconstitucionalidad”, Tribuna Fiscal, núm. 15, enero, 1992, pág. 41 y 42; ESEVERRI MARTÍNEZ, E., "El ingreso extemporáneo de las deudas autoliquidadas", Crónica Tributaria, núm. 61, 1992, pág. 19; LORENZO GIL, L., "El recargo único del art. 61.2 de la Ley General Tributaria”, Impuestos, Tomo I, 1994, pág. 903.

139 Este precepto indicaba literalmente que "los ingresos correspondientes a declaraciones-liquidaciones o autoliquidaciones presentadas fuera de plazo sin requerimiento previo, así como las liquidaciones derivadas de declaraciones presentadas fuera de plazo sin requerimiento previo, sufrirán un recargo del $20 \%$ con exclusión de las sanciones que, en otro caso, hubieran podido exigirse pero no de los intereses de demora. No obstante, si el ingreso o la presentación de la declaración se efectúa dentro de los tres, seis o doce meses siguientes al término del plazo voluntario de presentación e ingreso, se aplicará un recargo único del 5, 10 o $15 \%$ respectivamente con exclusión del interés de demora y de las sanciones que, en otro caso, hubieran podido exigirse".

${ }^{140}$ CARRASCO PARRILlA, P. J., Consecuencias del retraso en el pago de las deudas tributarias, op. cit., pág. 192 y 193. A favor de esta postura, vid. entre otros, PÉREZ ROYO, F y AGUALLO AVILÉS, A., Comentarios a la Reforma de la Ley General Tributaria, op. cit., pág. 247 y 248; ARAGONÉS BELTRÁN, E., "Comentarios al artículo 79 de la LGT", en la obra La Reforma de la Ley General Tributaria. Análisis de la Ley 25/1995, de 20 de julio, Cedecs, Madrid, 1995, pág. 152; MERINO JARA, I., "Infracciones y sanciones", La reforma de la Ley General Tributaria, Lex Nova, Valladolid, 1996, pág. 372; MARTÍN FERNÁNDEZ, F. J., GALÁN SÁNCHEZ, R. M., y RODRÍGUEZ MÁRQUEZ, J. S., "Los recargos por declaración extemporánea en la Ley General Tributaria", Revista de Estudios Financieros, núm. 161-162, 1995, pág. 41 a 44; PONT MESTRES, M. y PONT CLEMENTE, J. F., Análisis de la Ley 25/1995 de modificación de la Ley General Tributaria (Estudio detallado de cada artículo), Civitas, Madrid, 1995, pág. 66 a 67; FALCÓN TELLA, R., “Los ingresos fuera de plazo, ¿cláusulas penales o sancionadoras?”, Quincena Fiscal, núm. 21, 1995 , pág. 7.
} 
ESPUÑA, "que desde un punto de vista lógico-jurídico no se dirija, además de compeler al pago puntual, a castigar a los que efectúan el ingreso tardíamente, en tanto que la finalidad disuasoria se halla indefectiblemente unida, (...) con la finalidad represiva"141.

Por lo que respecta al recargo del 20 por 100 por retrasos superiores a doce meses, a diferencia de los anteriores, es compatible con los intereses de demora y carece, por tanto, de una simple naturaleza indemnizatoria, si tenemos en consideración que los intereses de demora son la figura a través de la cual se pretende lograr el objetivo de resarcimiento del acreedor. "La exigencia en todo caso del interés de demora representa claramente una medida disuasoria de la opción por demoras superiores a los dos años, por razón de ventajas financieras posibles" ${ }^{142}$. Por tanto, el recargo del 20 por 100 carece de cualquier matiz indemnizatorio, al devengarse éste junto con los intereses de demora ${ }^{143}$. Como consecuencia de lo expuesto, entiende BALLARÍN ESPUÑA que tras el art. 61.3 de la LGT de 1963 "no subyacen meros ilícitos civiles, sino que posiblemente se tipifican auténticos ilícitos penales, conceptuados, respectivamente, por el exceso sobre el interés legal del dinero de los recargos del 5, 10 y 20 por $100 \mathrm{y}$, en todo caso, por el recargo del 20 por 100; aunque es preciso reconocer que, de acuerdo con los criterios del TC en materia de recargos, el carácter de ilícito penal debería resultar excluido para los retrasos inferiores a un año e, hipotéticamente, incluso para los retrasos superiores a dicho plazo. Sin embargo, (...) el recargo del 20 por 100, (...) es, muy probablemente, una sanción tributaria y, por tanto, conceptúa asimismo un ilícito de carácter penal"144.

Finalmente, la LGT actual introduce en el artículo 27 el régimen de los recargos por declaración extemporánea sin requerimiento previo en los mismos términos que el apartado tercero del artículo 61 de la LGT de 1963. LÓPEZ MARTÍNEZ se decanta por dotar de una naturaleza indemnizatoria a estos recargos extemporáneos porque "la obligación viene configurada como aquel vínculo jurídico de carácter patrimonial que nace de la relación jurídica en la que la parte activa ostenta un derecho público subjetivo frente al sujeto obligado, ante cuyo incumplimiento la reacción del ordenamiento jurídico es de tipo indemnizatorio" ${ }^{145}$. También CARRASCO PARRILLA interpreta que se trata de una medida indemnizatoria a tanto alzado que cumple así mismo la finalidad de disuadir del

\footnotetext{
${ }^{141}$ BALLARÍN ESPUÑA, M., Los ingresos tributarios fuera de plazo sin requerimiento previo, op. cit., pág. 265.

${ }^{142}$ LÓPEZ GETA, J. M., "La Ley 25/1995, de 20 de julio, de modificación parcial de la Ley General Tributaria”, Impuesto, núm. 17, 1995, pág. 106; PÉREZ HERRERO, L., "El cumplimiento extemporáneo de las obligaciones tributarias”, Actualidad Financiera, núm. 1, 1996, pág. 50.

${ }^{143}$ MORILLO MÉNDEZ, A., "Los recargos en la Ley General Tributaria: tipología, naturaleza y compatibilidades”, Impuestos, núm. 23, 1995, pág. 14; HINOJOSA TORRALVO, J. J., "Los aspectos temporales del pago de la deuda tributaria en la Ley 25/1995", Impuestos, núm. 18, 1995, pág. 20; GARCÍA NOVOA, C., "Las consecuencias del impago del tributo tras la reforma de la Ley General Tributaria", Impuestos, núm. 19, 1996, pág. 29 a 31 y 36; ARIAS VELASCO, J. y SARTORIO ALBALAT, S., Procedimientos Tributarios, 6 a ed., Marcial Pons, Madrid, 1996, pág. 80; PÉREZ HERRERO, L., "El cumplimiento extemporáneo de las obligaciones tributarias", op. cit., pág. 49; GARCÍA GÓMEZ, A. J., "La falta de ingreso en plazo de las deudas tributarias. Los instrumentos de respuesta en manos de la Administración al hilo de la Ley 25/1995, de modificación parcial de la LGT, con especial referencia a los regímenes de recargos", Revista Española de Derecho Financiero, núm. 91, 1996, pág. 487; ALBIÑANA GARCÍAQUINTANA, C., "El ajetreado artículo 61 de la Ley General Tributaria”, Tapia, núm. 86, 1996, pág. 10; BALLARÍN ESPUÑA, M., Los ingresos tributarios fuera de plazo sin requerimiento previo, op. cit., pág. 265 y 266; VEGA HERRERO, M. y MUNOZ DEL CASTILLO, J. L., "Capítulo II. Tributos y obligaciones tributarias”, op. cit., pág. 118.

${ }^{144}$ BALLARÍN ESPUÑA, M., Los ingresos tributarios fuera de plazo sin requerimiento previo, op. cit., pág. 266.

145 LÓPEZ MARTÍNEZ, J., Régimen jurídico de los llamados “intereses moratorios” en materia tributaria. Un análisis de su ubicación en el seno de la deuda tributaria, op. cit., pág. 180.
} 
incumplimiento así como estimular positivamente el pago, una vez que aquél se ha producido ${ }^{146}$. GALAPERO FLORES, por el contrario, asume la misma posición del profesor PÉREZ ROYO, al afirmar que los recargos extemporáneos son sencillamente la imposición de una sanción en su grado mínimo cuando la infracción se traduce en un retraso en el pago superior a tres meses ${ }^{147}$. CALERO GARCÍA mantiene una posición mixta, cuando afirma "que podría considerarse un híbrido entre una indemnización, al excluir los intereses de demora, y una sanción. Ahora bien, el exceso en la imposición de este recargo no responde a una mayor actividad, empleo de medios, o un mayor coste para la Administración, fundamento del recargo de apremio; por consiguiente, puede afirmarse que en lo que exceda de la mera finalidad indemnizatoria es una sanción administrativa"148. Otros autores, finalmente, como MORENO FERNÁNDEZ ${ }^{149}$ o ALFONSO GALÁN ${ }^{150}$, aprecian el carácter sancionador de los recargos extemporáneos en la medida que excedan sobre la cantidad que hubiese correspondido de haberse exigido el interés de demora.

Partiendo de las opiniones vertidas por la doctrina, entendemos que el arrepentimiento espontáneo de los sujetos que cumplen tardíamente pero de manera voluntaria debería constituir un criterio atenuante para la graduación de la sanción que correspondería a una infracción grave por dejar de ingresar. Esto implicaría articular los supuestos de presentación extemporánea de autoliquidaciones o declaraciones de manera voluntaria como una sanción, asegurando de esta manera la aplicación de los principios y garantías del procedimiento sancionador ${ }^{151}$.

\subsubsection{Régimen jurídico de los recargos por declaración extemporánea}

El artículo 27 de la LGT dispone la cuantía del recargo extemporáneo mediante la aplicación de un porcentaje variable en función de la extensión temporal del retraso del obligado en la presentación de la declaración o autoliquidación. La ley regula dos supuestos diferentes, en función del tiempo que transcurra desde el momento en que se debió presentar la autoliquidación o declaración hasta la fecha en que ésta se hizo efectiva. El apartado segundo del artículo 27 de la LGT distingue que

"Si la presentación de la autoliquidación o declaración se efectúa dentro de los 3, 6 o 12 meses siguientes al término del plazo establecido para la

\footnotetext{
${ }^{146}$ CARRASCO PARRILlA, P. J., Consecuencias del retraso en el pago de las deudas tributarias, op. cit., pág. 196 y 197. En el mismo sentido, FALCÓN Y TELLA, R., "La doctrina constitucional en materia de recargos por ingreso extemporáneo", Quincena Fiscal, núm. 8, 2001, pág. 7 y 8; MORILLO MÉNDEZ, A., "Los recargos en la Ley General Tributaria, tipología, naturaleza y compatibilidades", op. cit., pág. 14; PÉREZ HERRERO, L., "El cumplimiento extemporáneo de las obligaciones tributarias", op. cit., pág. 43.

${ }^{147}$ GALAPERO FLORES, R., El procedimiento de recaudación de los tributos. Estudio de su regulación en la Ley General Tributaria y en el Reglamento General de Recaudación, op. cit., pág. 197, y 199 a 200. De esta misma autora, "Recargos por declaración extemporánea sin requerimiento previo", op. cit., pág. 253 a 264.

${ }^{148}$ CALERO GARCÍA, M. L., "La nueva regulación del recargo único. El art. 61.3 de la LGT”, Impuesto, núm. 18, 1995 , pág. 61 y 65.

149 MORENO FERNÁNDEZ, J. I., "Los recargos por pagos extemporáneos con o sin requerimiento previo de la Administración; análisis de los artículos 61.3 y 127.1 de la LGT”, en la obra La reforma de la Ley General Tributaria, Lex Nova, Valladolid, 1996, pág. 203 y 204.

150 ALFONSO GALÁN, R. M., "La naturaleza jurídica del recargo único del artículo 61.2 de la Ley General Tributaria", Jurisprudencia Tributaria, núm. 73, 1996, pág. 21.

${ }^{151}$ En este sentido, BALLARÍN ESPUÑA, M., Los ingresos tributarios fuera de plazo sin requerimiento previo, op. cit., pág. 277, y ESEVERRI MARTÍNEZ, E., "Comentario al artículo 61 de la LGT", en la obra La reforma de la Ley General Tributaria. Análisis de la Ley 25/1995, de 20 de julio, Cedecs, Madrid, 1995, pág. 96.
} 
presentación e ingreso, el recargo será del 5, 10 o $15 \%$, respectivamente. Dicho recargo se calculará sobre el importe a ingresar resultante de las autoliquidaciones o sobre el importe de la liquidación derivado de las declaraciones extemporáneas y excluirá las sanciones que hubieran podido exigirse y los intereses de demora devengados hasta la presentación de la autoliquidación o declaración".

Y más adelante precisa este mismo apartado que si la presentación de la autoliquidación o declaración se efectúa una vez transcurridos 12 meses desde el término del plazo para la presentación, el recargo será del 20 por 100 y excluirá las sanciones que pudieran exigirse, pero no los intereses de demora por el período transcurrido desde el día siguiente al término de los 12 meses posteriores a la finalización del plazo establecido para la presentación hasta el momento en que la autoliquidación o declaración se haya presentado.

Del contenido de este precepto se deduce que estos recargos son incompatibles con las sanciones en todos los casos. No obstante, la exclusión de las sanciones en estos casos no se produce por el sólo hecho de presentar extemporáneamente, aunque fuera de plazo, la autoliquidación o declaración, sino que es necesario que una y otra se hagan completa y correctamente.

La relación de compatibilidad entre los recargos y el interés de demora, en cambio, presenta más complejidad. En primer lugar, no se aplicarán los intereses de demora para el caso de que la declaración o autoliquidación se presenten dentro de los 12 meses siguientes al último día establecido para efectuar la liquidación, siendo aplicable entonces únicamente los recargos del 5, 10 o 15 por 100. Por el contrario, la incompatibilidad de los intereses de demora no es absoluta cuando la presentación se realiza en un plazo superior a los 12 meses, pues en este caso son exigibles, junto al recargo del 20 por 100, los intereses de demora que se devenguen una vez transcurridos esos 12 primeros meses. $\mathrm{Y}$ en tercer lugar, los recargos por declaración extemporánea y espontánea son compatibles con los intereses de demora tanto cuando la presentación espontánea pero tardía de la autoliquidación no va acompañada del ingreso simultáneamente, en todo o en parte, de la deuda autoliquidada, puesto que aquí se inicia el período ejecutivo al día posterior a esta presentación, como cuando se acompaña a la presentación una solicitud de aplazamiento, fraccionamiento o compensación.

Por último, los recargos extemporáneos son también compatibles en todos los casos con los recargos del período ejecutivo, siempre que se produzcan simultáneamente los presupuestos de ambos tipos de recargos.

En relación con los aspectos más formales del régimen jurídico de los recargos por declaración extemporánea, el número 4 del artículo 27 de la LGT exige que el obligado tributario identifique expresamente dentro de la autoliquidación extemporánea el período impositivo de liquidación y que aquélla contenga únicamente los datos relativos a dicho período. Este precepto se relaciona directamente con el apartado 6 del artículo 191 de la LGT, que califica de infracción leve la falta de ingreso en plazo de tributos o pagos a cuenta que hubieran sido incluidos o regularizados por el mismo obligado tributario en una autoliquidación presentada con posterioridad sin cumplir los requisitos establecidos en el apartado 4 del artículo 27 de la LGT. 
Finalmente, todos los recargos por declaración extemporánea previstos en el apartado 2 del artículo 27 de la LGT se reducen en un 25 por 100 siempre que se realice el ingreso total del importe restante del recargo en el plazo del apartado 2 del artículo 62 de la LGT abierto con la notifícación de la liquidación de dicho recargo y siempre que se realice el ingreso total del importe de la deuda resultante de la autoliquidación extemporánea o de la liquidación practicada por la Administración derivada de la declaración extemporánea, al tiempo de su presentación o en el plazo del apartado 2 del artículo 62 de la LGT, respectivamente, o siempre que se realice el ingreso en el plazo o plazos fijados en el acuerdo de aplazamiento o fraccionamiento de dicha deuda que la Administración tributaria hubiera concedido con garantía de aval o certificado de seguro de caución y que el obligado al pago hubiera solicitado al tiempo de presentar la autoliquidación extemporánea o con anterioridad a la finalización del plazo del apartado 2 del artículo 62 de la LGT abierto con la notificación de la liquidación derivada de la declaración extemporánea. Esta reducción se practica sin más requisito que la notificación al interesado, cuando no se haya realizado los ingresos señalados en los plazos previstos incluidos los correspondientes al acuerdo de aplazamiento o fraccionamiento.

\section{EL PAGO EN PERÍODO EJECUTIVO}

\subsection{INICIO DEL PERÍODO EJECUTIVO}

El período ejecutivo es la fase que se abre una vez que vence el período voluntario de pago sin que se haya satisfecho la deuda tributaria. Debe tratarse, además, de una deuda fijada por la Administración tributaria a través de un acto de liquidación o reconocida por el propio contribuyente u obligado tributario mediante una autoliquidación no acompañada de ingreso. La simple falta de la presentación de la autoliquidación en el término previsto, sin embargo, no da inicio al período ejecutivo. En este último supuesto lo que procederá será la comprobación o inspección por parte de la Hacienda Pública con la consiguiente liquidación de la deuda tributaria no ingresada, o la presentación extemporánea por el contribuyente de la declaración o autoliquidación sin el requerimiento de la Administración tributaria, en los términos que hemos señalado en el apartado anterior.

Durante el período ejecutivo podrá procederse a la realización de la deuda tributaria mediante apremio. Lo que se inicia una vez que finaliza el período voluntario de pago es el período ejecutivo, pero el procedimiento de apremio requiere de la intervención de la Administración tributaria por medio de un acto expreso de ésta, a través de la providencia de apremio.

No todos los ingresos que se realizan fuera del período voluntario son producto de un procedimiento de apremio porque el obligado tributario puede realizar el pago fuera del período voluntario pero antes de que se inicie la vía de apremio ${ }^{152}$. Como señala LÓPEZ DÍAZ, "el procedimiento ejecutivo

\footnotetext{
${ }^{152}$ Como bien expresa LÓPEZ DÍAZ, "no debe confundirse el procedimiento ejecutivo con el período ejecutivo, ya que no todos los ingresos que se realicen una vez finalizado el período voluntario son el resultado de un procedimiento ejecutivo, sino que el obligado al pago puede efectuar el pago fuera de plazo, pero antes de que se inicie el correspondiente procedimiento. En estos casos, no se puede sostener que la deuda se esté pagando en período voluntario, pero tampoco que dicho pago es el resultado de un procedimiento ejecutivo" (LÓPEZ DÍAZ, A., Periodo Ejecutivo. Procedimiento de Apremio y Recargo, Aranzadi, Navarra, 2001, pág. 22 y 26, y, del mismo autor, La recaudación de deudas tributarias en vía de apremio, Marcial Pons, Madrid, 1992, pág. 75 y ss.). En este mismos sentido, entre otros, PÉREZ DE VEGA, L. M., La iniciación del procedimiento de apremio de las deudas tributarias, Lex Nova, Valladolid, 1998, pág. 95 a 122; CAYÓN GALIARDO, A. M., "El inicio del procedimiento de apremio: presupuestos materiales y formales", en la obra Recaudación ejecutiva y Hacienda Local, SERRANO ANTÓN, F. (director), Thomson-Civitas, Navarra, 2008, pág. 59.
} 
requiere que la deuda esté incursa en apremio para que pueda llevarse a cabo, pero, además necesita de unas actuaciones preparatorias para su iniciación y, como todo procedimiento, precisa de un acto iniciador que es la providencia de apremio. Ello determina la no coincidencia temporal del inicio del período o fase ejecutiva con el procedimiento" 153 .

Asumiendo la doctrina del profesor PÉREZ ROYO, el período ejecutivo "sí se inicia con el vencimiento del período voluntario de pago, pero el segundo no se puede iniciar mientras no se expida el título ejecutivo. No podemos pensar en la existencia de un procedimiento administrativo de apremio iniciado ope legis, sin ningún tipo de actuación administrativa. Habrá siempre, por ello, un lapso de tiempo, mayor o menor según la diligencia de los órganos competentes de recaudación, entre el inicio del período ejecutivo -o, si se prefiere, la finalización del período voluntario de pago- y la efectiva iniciación del procedimiento administrativo de apremio"154.

El primer apartado del artículo 161 de la LGT regula el inicio del período ejecutivo. Según este precepto, el inicio del período ejecutivo se determina en función del tipo de deuda, ya sea por deudas resultantes de liquidaciones practicadas por la Administración tributaria o por deudas autoliquidadas por los obligados. Cuando se trata de deudas liquidadas por la Administración tributaria el período ejecutivo se inicia al día siguiente del vencimiento del plazo de pago en período voluntario que otorga la LGT en el artículo 62 a este tipo de deudas. Asimismo, cuando sean deudas a ingresar mediante autoliquidaciones presentadas sin realizar el pago, el período ejecutivo se inicia al día siguiente del vencimiento del plazo de pago en período voluntario que determinan las leyes de cada tributo, tal y como lo expresa el apartado primero del artículo 62 de la LGT. Por otra parte, es posible que el deudor presente la autoliquidación extemporáneamente sin requerimiento por parte de la Administración tributaria, pero sin efectuar el pago, y en este caso el período ejecutivo comenzaría al día siguiente de la presentación de la autoliquidación.

En el número 2 del artículo 161 de la LGT se prevén una serie de circunstancias que imposibilitan el inicio del período ejecutivo. En concreto, se retrasa el inicio del período ejecutivo mientras dura la tramitación del expediente por aplazamiento, fraccionamiento o compensación que solicitó el obligado en el período voluntario. Por el contrario, la presentación de una solicitud de este tipo dentro del procedimiento ejecutivo no paraliza el mismo ${ }^{155}$.

\footnotetext{
${ }^{153}$ LÓPEZ DÍAZ, A., Periodo Ejecutivo. Procedimiento de Apremio y Recargo, op. cit., pág. 26.

${ }^{154}$ PÉREZ ROYO, I., "El tiempo en el pago de la prestación tributaria”, en la obra Comentarios a la Ley General Tributaria y líneas para su reforma, libro-homenaje al profesor Dr. D. Fernando Sainz de Bujanda, Vol. II, Ministerio de Economía y Hacienda, Instituto de Estudios Fiscales, Madrid, 1991, pág. 988. En este mismo sentido, DE MIGUEL ARIAS, S., La práctica del embargo para el cobro de la deuda tributaria, op. cit., pág. 77 a 79. Indica HINOJOSA TORRALVO que la diferencia entre el período ejecutivo y el procedimiento de apremio resulta útil "para establecer una necesaria distinción entre los aspectos estrictamente temporales (el tiempo para el desarrollo de la recaudación ejecutiva), y sus aspectos procedimentales (los actos tendentes a hacer efectiva la recaudación coercitiva" (HINOJOSA TORRALVO, J. J., "Los aspectos temporales del pago de la deuda tributaria en la Ley 25/1995”, op. cit., pág. 5 y ss.)

${ }^{155}$ En este caso, advierte LÓPEZ DÍAZ, que la "administración podría continuar con el procedimiento ejecutivo hasta llegar a la fase de la enajenación de los bienes, la cual, sí debería paralizarse hasta que recayese pronunciamiento sobre la solicitud del aplazamiento. Una vez concedido el aplazamiento, sí deben paralizarse las actuaciones de ejecución" (LÓPEZ DÍAZ, A., Período Ejecutivo. Procedimiento de Apremio y Recargo, op. cit., pág. 45).
} 
Tampoco se produce el inicio del período ejecutivo cuando se presenta la declaración sin ingreso fuera del plazo voluntario que va acompañada de una solicitud expresa de aplazamiento o fraccionamiento de la deuda.

Por último, la interposición de un recurso o reclamación en tiempo y forma contra una sanción también impide el inicio del período ejecutivo hasta que la sanción sea firme en vía administrativa y haya finalizado el plazo para el ingreso voluntario del pago ${ }^{156}$.

Cuando se inicia el período ejecutivo, la Administración tributaria recaudará las deudas liquidadas o autoliquidadas a las que se refiere el apartado 1 del artículo 161 de la LGT por el procedimiento de apremio sobre el patrimonio del deudor, teniendo siempre en cuenta, según dispone el apartado 4 del precepto, que el inicio del período ejecutivo determina la exigencia de los intereses de demora y de los recargos del período ejecutivo y, en su caso, de las costas del procedimiento de apremio.

En todo caso, cuando se trate de una deuda autoliquidable y el obligado a presentar la autoliquidación no cumpla con esta obligación, la Administración tributaria puede valerse de algún procedimiento de comprobación o inspección para liquidar la deuda de oficio, concediéndole al obligado tributario un nuevo plazo voluntario de pago, por lo que el período ejecutivo se iniciaría de acuerdo con lo dispuesto para las deudas que son liquidadas por la Hacienda Pública.

Finalmente, nos gustaría destacar que la LGT regula en la Disposición Adicional Décima dos supuestos que pueden entenderse como formas de ejecutar el cumplimiento de pago sin que se otorgue al deudor la posibilidad de ingreso en período voluntario. El apartado primero de dicha Disposición establece que en los procedimientos por delito fiscal la responsabilidad civil comprenderá la totalidad de la deuda tributaria no ingresada, incluidos sus intereses de demora, y que se exigirá por la vía de apremio. Todo indica que para estos casos se permite la exigencia coactiva sin darle previamente al deudor la posibilidad del pago en período voluntario. De la misma forma, el apartado 3 de la Disposición Adicional Décima dispone que cuando se hubiera acordado el fraccionamiento de pago de la responsabilidad civil conforme al artículo 125 del Código Penal, el juez o tribunal lo comunicará a la Administración tributaria, y en este caso el procedimiento de apremio se iniciará si el responsable civil del delito incumpliera los términos del fraccionamiento.

Como hemos visto, el artículo 161 de la LGT precisa el momento en que se inicia el período ejecutivo y los efectos que produce, así como los actos que impiden el nacimiento del mismo. De aquí deducimos que los presupuestos que dan inicio al período ejecutivo son tres: el vencimiento del plazo voluntario de pago sin que se haya ingresado la deuda tributaria; la existencia de una deuda liquidada; y la no presentación de una solicitud de aplazamiento, fraccionamiento o compensación en período voluntario $^{157}$.

\footnotetext{
${ }^{156}$ Esta disposición es coherente con el inciso a) del apartado 3 del artículo 212 de la LGT, que determina que "no se exigirán intereses de demora por el tiempo que transcurra hasta la finalización del plazo de pago en período voluntario abierto por la notificación de la resolución que ponga fin a la vía administrativa".

${ }^{157}$ Según DE MIGUEL ARIAS, en los supuestos de tributos autoliquidados "se precisa, además, la presentación de la respectiva autoliquidación" (DE MIGUEL ARIAS, S., La práctica del embargo para el cobro de la deuda tributaria, op. cit., pág. 79). Vid. también ALONSO MURILLO, F. y PÉREZ DE VEGA, L. M., “Actuaciones y procedimientos de recaudación”, en la obra Estudios de la Ley General Tributaria, Lex Nova-Landewell, Valladolid, 2006, pág. 679 y 680.
} 


\subsection{OBLIGACIONES ACCESORIAS EN EL PERÍODO EJECUTIVO. LOS RECARGOS DEL PERÍODO EJECUTIVO}

El inicio del período ejecutivo produce efectos jurídicos importantes, ya que determina la exigencia de los intereses de demora, los recargos del período ejecutivo y también, en su caso, de las costas del procedimiento de apremio $^{158}$.

El recargo ejecutivo es una de las obligaciones accesorias de la obligación tributaria principal y se regula en el artículo 28 de la LGT. Estos recargos sustituyen los recargos de apremio a los que hacía mención el inciso d) del apartado 2 del artículo 58 de la LGT de 1963, cuya evolución normativa pasa por tres momentos fundamentales, como destaca la Sentencia de 10 mayo 2007 del Tribunal Supremo: "en la primera, anterior al 1 de enero de 1987, el artículo 128.1 de la LGT decía que «el procedimiento de apremio se iniciará cuando, vencido el plazo de ingreso voluntario, no se hubiera satisfecho la deuda tributaria», y resultaba, por tanto, de aplicación la doctrina jurisprudencial de que «no cabe el apremio una vez que la deuda tributaria ha sido pagada». En la segunda, la Ley 33/1987 añadió al anterior precepto un segundo párrafo, según el cual «el vencimiento del plazo de ingreso en período voluntario determinará la exigibilidad del recargo de apremio establecido reglamentariamente... », creándose, así, según el Tribunal Supremo, «un recargo de apremio sin apremio». En la tercera, la Ley 25/1995 distingue un recargo del 10\% desde que se inicia el período ejecutivo (el día siguiente al vencimiento del plazo de ingreso voluntario) hasta que se dicte la providencia de apremio, y un recargo del $20 \%$ desde que tal providencia se adopta".

Dentro de la Comisión para el estudio y propuesta de medidas para la Reforma de la LGT se debatió la cuestión de si se mantenían o no los recargos de apremio. Dentro de la Comisión se asumieron posiciones divergentes: una postura mayoritaria defendía el criterio de que los recargos de apremio carecían de fundamento y tenían un carácter sancionador, y por ello abogaba por su supresión y sustitución por un interés de demora incrementado; la segunda posición, minoritaria, proponía que estos recargos pasaran a denominarse recargos del período ejecutivo, con el argumento de que su devengo se conecta con el inicio de dicho período, y tuvieran una nueva configuración más acorde con la función que tienen encomendada, que es la de compensar los gastos generales que conlleva la iniciación y desarrollo del procedimiento de apremio. Esta última postura fue la que prevaleció, al introducirse los recargos del período ejecutivo en el artículo 28 de la LGT.

En la actualidad existe un sector doctrinal que afirma que los recargos del período ejecutivo carecen de fundamento. Para CALVO ORTEGA, "cada uno de los conceptos dinerarios que se exigen al deudor tiene su justificación: la cuota, en el hecho imponible; los intereses de demora, en la compensación por el retraso en la percepción de la prestación pecuniaria; el recargo por declaración extemporánea, en el retraso en presentarla; la sanción, en la comisión de un ilícito; y las costas, en los

\footnotetext{
${ }^{158}$ El apartado 1 del artículo 113 del RGR define a las costas como los gastos que se originan durante el desarrollo del procedimiento de apremio que son exigidas al obligado al pago. Por su parte, el apartado 2 considera como tales gastos los honorarios de empresas o profesionales ajenos a la Administración tributaria que intervengan en valoraciones, deslindes y enajenación de los bienes embargados; los honorarios de los registradores y demás gastos que deban abonarse por las actuaciones en los registros públicos; los que deban abonarse por depósito y administración de los bienes embargados; los pagos realizados a acreedores, según se dispone en el apartado 2 del artículo 77 del RGR; los importes que el órgano de recaudación competente haya satisfecho como alquiler de negocio, en aquellos casos en que el derecho de cesión del contrato de arrendamiento del local de negocio haya sido embargado; y los demás gastos que exija y requiera la propia ejecución.
} 
gastos originados a la Administración por el procedimiento de ejecución", pero en cambio "los recargos de ejecución no tienen un fundamento ni una apoyatura jurídico-obligacional"159.

Otro grupo de autores consideran que el recargo tiene un carácter resarcitorio por los gastos ordinarios del procedimiento de apremio, ya que los gastos extraordinarios se sufragan con las costas. CARRASCO PARRILLA opina que la naturaleza del recargo de apremio es la de "una prestación accesoria que tiene como finalidad sufragar los gastos ordinarios originados a la Administración como consecuencia de la apertura del procedimiento de apremio, y consiguientemente puestas en marcha de la maquinaria administrativa tendente a la ejecución del patrimonio del deudor que se ve materializada con la emisión de la providencia de apremio" ${ }^{\text {"160 }}$.

Varios autores coinciden en que los recargos del período ejecutivo tienen un carácter sancionador. GALAPERO FLORES considera "que si bien se pretende fundamentar la existencia del recargo en el hecho de sufragar los costes en que incurre la Administración, lo que verdaderamente subyace es el carácter sancionador de los recargos. Además el contribuyente sufre un doble castigo, el interés de demora, que se fundamenta en una situación y el recargo que se fundamenta en otro hecho, pero que en definitiva se trata de un incremento desmesurado de la cuota, más aun en los supuestos en que no ha habido intencionalidad por parte del contribuyente" $" 161$.

También SABINIANO MEDRANO afirma que el recargo ejecutivo opera como una verdadera sanción por el incumplimiento de la obligación de efectuar el pago dentro del período voluntario. Aunque este autor más adelante matiza su postura, cuando dice que "se trata de una manifestación encubierta de la potestad sancionadora, con la correspondiente secuela de inconstitucionalidad. (...) No es una verdadera indemnización -pues no es correlativa a un perjuicio- sino, en todo caso, un resarcimiento de costes y gastos en los que no hay más remedio que incurrir para desarrollar un servicio o actividad en el régimen de derecho público que no es de solicitud o recepción voluntaria para el obligado tributario. Por tanto, la correlativa obligación de pago se corresponde nítidamente con el concepto de tasa, (...) de modo que debería regularse y establecerse como tal"162.

A nuestro juicio, en realidad lo que persigue el legislador con estos recargos del período ejecutivo es una penalización del deudor tributario por incumplir su obligación de pago en el plazo voluntario, ya que difícilmente podrá sustentarse la justificación de que tiene una finalidad resarcitoria por los

\footnotetext{
${ }^{159}$ CALVO ORTEGA, R., "El proyecto de Ley General Tributaria: aportaciones y aspectos críticos”, op. cit., pág. 35.

${ }^{160}$ CARRASCO PARRILlA, P. J., Consecuencias del retraso en el pago de las deudas tributarias, op. cit., pág. 212. Los defensores de esta tesis coinciden en que los recargos del período ejecutivo cumplen una función compensatoria en relación con la Administración tributaria por los gastos en los que incurre por la apertura de un nuevo procedimiento para el cobro de la deuda y también consideran que se penaliza la actitud del deudor por su incumplimiento del pago. Entre otros, PÉREZ ROYO, F., "El tiempo en el pago de la prestación tributaria: consecuencias del ingreso extemporáneo", Revista Alcabala, núm. 2, 1992, pág. 988 y 989; FERREIRO LAPATZA, J. J., La nueva Ley General Tributaria (Ley 58/2003, de 17 de diciembre), op. cit., pág. 157; y PÉREZ ROYO, F y AGUALlO AVILÉS, A., Comentarios a la Reforma de la Ley General Tributaria, op. cit., pág. 179.

${ }^{161}$ GALAPERO FLORES, R., El procedimiento de recaudación de los tributos. Estudio de su regulación en la Ley General Tributaria y en el Reglamento General de Recaudación, op. cit., pág. 207. Comparten esta posición, entre otros, LÓPEZ MARTÍNEZ, J., Régimen jurídico de los llamados "intereses moratorios" en materia tributaria. Un análisis de su ubicación en el seno de la deuda tributaria, op. cit., pág. 208 y 209; PALAO TABOADA, C., "Notas a la Ley 25/1995, de 20 de julio, de modificación parcial de la Ley general Tributaria”, Centro de Estudios Financieros, núm. 158, 1996, pág. 78; MARTíN QUERALT, J., "Novedades en el procedimiento de recaudación", op. cit., pág. 281.

162 SABINIANO MEDRANO, I., "Las obligaciones tributarias accesorias: el interés del demora y los recargos", op. cit., pág. 196 y 197.
} 
gastos en que incurre la Administración tributaria al tener que hacer frente a un nuevo procedimiento para satisfacer su crédito a través del apremio, sobre todo si se trata del recargo ejecutivo que la ley exige de manera automática, como simple consecuencia del inicio del período ejecutivo. Y más aún si tenemos en cuenta que el propio apartado cuarto del artículo 161 de la LGT determina la exigencia, junto con estos recargos, entre otros, de las costas del procedimiento de apremio, que ya cumplen la función resarcitoria.

\subsubsection{Tipos de recargos y presupuestos para su devengo}

De las normas reguladoras de los recargos del período ejecutivo se extraen dos notas características de esta figura: la primera es que su devengo se produce con el inicio del período ejecutivo, según establece el artículo 161 de la LGT; y la segunda es que los recargos del período ejecutivo se dividen en tres tipos: el recargo ejecutivo, el recargo de apremio reducido y el recargo de apremio $\operatorname{ordinario}^{163}$.

Respecto a la cuantía de estos recargos, el recargo ejecutivo será del 5 por 100 cuando se satisfaga la totalidad de la deuda no ingresada en período voluntario antes de la notificación de la providencia de apremio. La ley actual es más favorable que su antecesora, el apartado primero del artículo 127 de la LGT de 1963, que aplicaba un recargo del 10 por 100 sobre los ingresos fuera de plazo efectuados antes de la notificación de la providencia de apremio. Aunque debemos tener presente, como ya señalamos anteriormente, que el apartado segundo del artículo 161 de la LGT prevé una serie de circunstancias que impiden el inicio del período ejecutivo: la presentación de una solicitud de aplazamiento, fraccionamiento o compensación en período voluntario, y la interposición de un recurso o reclamación en tiempo y forma contra una sanción.

El segundo tipo de recargo del período ejecutivo es el recargo de apremio reducido del 10 por 100, que se aplicará cuando se satisfaga la totalidad de la deuda no ingresada en período voluntario y el propio recargo antes de la finalización del plazo previsto para las deudas apremiadas.

Por su parte, el recargo de apremio ordinario tendrá una cuantía del 20 por 100 y entrará en juego cuando se trate de deudas apremiadas y no satisfechas una vez finalizado el plazo previsto para hacer efectivas estas deudas. Este tipo de recargo corresponde con el tradicional recargo de apremio de la ley anterior y los presupuestos de su devengo son los mismos.

Las novedades que introduce la ley actual en relación con estas obligaciones accesorias del período ejecutivo las encontramos en la reducción del 10 al 5 por 100 del recargo exigible cuando se efectúa el pago antes que se notifique al obligado la providencia de apremio; así como la distinción que se hace entre los dos últimos recargos, en función de que, una vez notificada dicha providencia, el sujeto pague o no la totalidad de la deuda más el recargo de apremio reducido en el período que determine

\footnotetext{
${ }^{163}$ El artículo 28 de la LGT divide en tres tipos los recargos del período ejecutivo. Este hecho, según VEGA HERRERO y MUÑOZ DEL CASTILLO, no reviste gran importancia, porque en la normativa anterior ya existían dos recargos de apremio, el reducido y el ordinario, y "lo que ha hecho la nueva Ley es desglosar este último en los dos denominados reducido y ordinario" (VEGA HERRERO, M. y MUÑOZ DEL CASTILLO, J. L., "Capítulo II. Tributos y obligaciones tributarias", op. cit., pág. 120). Esta clasificación del recargo del período ejecutivo en tres tipos es entendida por GALAPERO FLORES como una posibilidad que se brinda al contribuyente para minorar la cuantía del recargo en función del momento en que se realice el ingreso de la deuda tributaria (GALAPERO FLORES, R., El procedimiento de recaudación de los tributos. Estudio de su regulación en la Ley General Tributaria y en el Reglamento General de Recaudación, op. cit., pág. 206).
} 
la providencia de apremio. Anteriormente, pagara o no en ese plazo, el recargo del 20 por 100 se había consumado con tan sólo la notificación de la providencia de apremio.

\subsubsection{Compatibilidad de estos recargos entre sí, con otras obligaciones accesorias y con las} sanciones

De manera sucinta podemos decir que los recargos del período ejecutivo son completamente incompatibles entre sí, a tenor de lo dispuesto en el tercer párrafo del apartado primero del artículo 28 de la LGT, puesto que el devengo de cada uno de ellos tiene lugar por la realización de presupuestos que, de por sí, impiden que ocurran a la vez los presupuestos de más de un recargo.

Por el contrario, los recargos del período ejecutivo son compatibles con los recargos por declaración extemporánea, previstos en el artículo 27 de la LGT. Ambos tipos de recargos se aplicarán simultáneamente cuando se exija un recargo por declaración extemporánea y la deuda liquidada por la Administración tributaria, sobre la base de aquella declaración, no se ingrese en el período voluntario; o cuando se aplique un recargo por autoliquidación extemporánea y se haya presentado ésta sin efectuar el ingreso al mismo tiempo, tal como estipula expresamente el apartado tercero del artículo 27 de la LGT. Para estos casos el cálculo de los recargos del período ejecutivo se hará sobre una base que comprenderá, entre otros conceptos, el recargo por declaración extemporánea.

En tercer lugar, el recargo de apremio ordinario es compatible con los intereses de demora, salvo en el caso de que resulten exigibles el recargo ejecutivo o el recargo de apremio reducido.

Finalmente, el apartado 5 del artículo 180 de la LGT permite la exigencia de los intereses de demora y de los recargos del período ejecutivo junto con las sanciones que, en su caso, corresponda imponer por una actuación ilícita del obligado tributario. De hecho las sanciones pueden ser objeto del procedimiento de apremio y su importe se integra en la base del cálculo de los recargos del período ejecutivo.

\subsection{IMPUTACIÓN DEL PAGO EN EL PERÍODO EJECUTIVO}

Cuando analizábamos en la primera parte del capítulo la imputación del pago que la ley regula en el artículo 63 de la LGT, veíamos que este incidente se produce cuando convergen varias deudas de un mismo deudor y el pago no alcanza a cubrirlas todas, de manera que se hace necesario determinar a cuál o cuáles de ellas se imputa el pago.

Dijimos en ese momento que cuando las deudas tributarias se encuentren en período voluntario el obligado puede elegir libremente la imputación. También advertimos que cuando se trate de deudas tributarias inmersas en el procedimiento ejecutivo, la LGT establece algunas limitaciones a la libre imputación del pago que puede hacer el deudor, de acuerdo con los mandatos contenidos en los apartados 3 y 4 del artículo 63 de la LGT $^{164}$.

\footnotetext{
${ }^{164}$ Vid. supra, Capítulo Primero, epígrafe 1.3.4. "Imputación de pago".
} 
En relación con este segundo supuesto, para que se produzca la imputación es necesario que el procedimiento de recaudación se encuentre en su etapa ejecutiva, se hayan acumulado varias deudas tributarias del mismo obligado tributario y la cantidad obtenida de la ejecución sea insuficiente para extinguirlas totalmente. Bajo esas condiciones, determina el apartado 3 del artículo 63 de la LGT que la Administración tributaria aplicará el pago a la deuda más antigua y que la antigüedad se determinará de acuerdo con la fecha en que cada una fue exigible.

Por su parte, el apartado 4 del propio artículo 63 de la LGT se refiere a la preferencia también en los casos de acumulación de tipo subjetivo por parte del sujeto acreedor, disponiendo que

"Cuando se hubieran acumulado varias deudas tributarias a favor de una Administración y de otras entidades de derecho público dependientes de la misma, tendrán preferencia para su cobro las primeras".

La preferencia de acumulación, pues, presenta dos modalidades, la temporal y la subjetiva. La primera requiere la concurrencia de las siguientes circunstancias: que exista una acumulación de varias deudas; que pertenezcan al mismo obligado tributario; que se encuentre la deuda inmersa en el período ejecutivo; que no sea posible extinguir totalmente todas las deudas; que se trate de una misma Administración tributaria; y que no exista preferencia a favor de Entidades de Derecho Público dependientes de aquélla. Ante la confluencia de todas estas circunstancias se aplicará el pago a la deuda tributaria más antigua, precisando su antigüedad por la fecha en que pudiera ser exigida.

En cualquier caso, debemos efectuar algunas observaciones sobre estas reglas de imputación. Primero, que si se trata de una sola deuda tributaria se imputará a ella el pago, sin tener en cuenta que este pago sea total o parcial. Segundo, que no debe descartarse la posibilidad de que puedan darse también otras formas de extinción de la deuda tributaria distintas al pago, por lo que si se determina la antigüedad en función de la exigibilidad puede suceder que deudas devengadas con anterioridad pierdan prioridad. Y tercero, que a pesar de que ordinalmente las reglas de imputación por antigüedad del apartado 3 del art. 63 serían de aplicación preferente respecto de las reglas de imputación subjetiva previstas en el apartado 4 del mismo precepto, en realidad ello no es así, porque este mismo apartado 3 recoge unos criterios de imputación por antigüedad aplicables "salvo lo dispuesto en el apartado siguiente" ${ }^{\prime 165}$.

En síntesis, la imputación del pago en procedimiento ejecutivo se produce en el supuesto que lo obtenido en la enajenación de los bienes y derechos embargados no alcance para cubrir todas las deudas. Cabría hablar en este caso, sino de imputación del pago por el deudor, por lo menos de la existencia reglas imperativas para la aplicación de ésta. La primera de estas reglas establece que lo obtenido se aplicará prioritariamente a las costas. La segunda, si son varios los débitos, y una vez cubiertas las costas, que se aplicará la preferencia sobre la suma restante obtenida a aquellos créditos que se encuentren asegurados con una garantía real, y que el sobrante se destinará a los demás créditos por orden de antigüedad, teniendo en cuenta la fecha de vencimiento del período voluntario de cada uno de ellos.

\footnotetext{
${ }^{165}$ La propuesta que hace GONZÁLEZ SÁNCHEZ es "tener en cuenta en primer lugar la preferencia subjetiva, la existencia o no de garantías de las deudas y después guiarse por la antigüedad y el alcance del importe disponible u otras formas de extinción" (GONZÁLEZ SÁNCHEZ, M., “Capítulo VIII.-La extinción de la obligación tributaria”, op. cit., pág. 663).
} 


\subsection{ASPECTOS GENERALES DEL PROCEDIMIENTO EJECUTIVO O DE APREMIO}

\subsubsection{Características generales}

El procedimiento de apremio constituye una de las manifestaciones más sobresalientes del privilegio de autotutela de que goza la Administración tributaria ${ }^{166}$, de acuerdo con el cual ésta se encuentra facultada para ejecutar directamente sus propias decisiones o actos. Como dijera DAGO ELORZA, "difiere de los procedimientos ordinarios o judiciales de ejecución por el hecho fundamental de que concurren en el ente u órgano ejecutante las condiciones del titular de la potestad de ejecución y la del titular del crédito lesionado -en definitiva las de juez y parte-, con las lógicas matizaciones, que no viene ahora al caso detallar, de la titularidad del crédito de la Hacienda Pública y del órgano competente para la exacción, la Agencia Estatal de Administración Tributaria, que es un mero órgano instrumental"167.

Las características principales del procedimiento de apremio pueden encontrarse en la LGT en el artículo 163 y en el artículo 93 del RGR. Anteriormente se regulaban en la LGT de 1963 en el artículo 129, que sufrió modificaciones en 1995. De la norma se deduce que es un procedimiento estrictamente administrativo ${ }^{168}$, al concebirse como una función exclusiva y excluyente de la Administración tributaria, específicamente de las Dependencias de Recaudación. Sin embargo, debe recordarse que la LRJ-PAC regula en su artículo 96 el apremio sobre el patrimonio del deudor como procedimiento común que se sigue para la ejecución forzosa de los actos administrativos, junto con la multa coercitiva, la ejecución subsidiaria y la compulsión sobre las personas. Ahora bien, dentro de los medios de ejecución forzosa previstos en la normativa antes enunciada, el apremio sobre el patrimonio es el que resulta aplicable a las prestaciones pecuniarias, "con fundamento en la consideración de que todos los actos administrativos son válidos y ejecutivos desde el instante en que se dictan" $"$. No obstante, la propia LRJ-PAC reconoce que la regulación detallada de este medio de ejecución forzosa se encuentra recogida en el ámbito del Derecho tributario. Según el apartado primero del artículo 97 de la LRJ-PAC,

\footnotetext{
${ }^{166}$ TEJERIZO LÓPEZ, J. M., “Capítulo VII. Procedimientos de recaudación”, op. cit., pág. 610.

${ }^{167}$ DAGO ELORZA, I., “Título III. Capítulo V. Actuaciones y procedimientos de recaudación”, op. cit., pág. 1057.

${ }^{168}$ Explica BEGOÑA DE LA MANO que la norma configura al procedimiento de apremio como un procedimiento exclusivamente administrativo porque "es más restrictivo, porque sólo se refiere a créditos tributarios". Tampoco, según esta doctrina, es acumulable este procedimiento a otros procedimientos de ejecución o judiciales, lo cual implica que el inicio de estos últimos no suspende el inicio o tramitación del apremio, salvo "cuando proceda de acuerdo con lo establecido en la Ley 2/1987, de 18 de mayo, de Conflictos Jurisdiccionales". Además, "sólo la normativa tributaria determinará los casos en la forma en que se suspenderá el procedimiento de apremio tributario. Estos casos serán, en primer lugar los recogidos en el artículo 165 LGT, que justamente lleva por título Suspensión del procedimiento de apremio, si bien no serán exclusivamente éstos los supuestos, puesto que el propio artículo 165 LGT, reconoce la existencia de otros casos" (BEGOÑA DE LA MANO, B., "Sección 4a .- Otras formas de extinción de la deuda tributaria. Capítulo IVLa deuda tributaria. Título II- Los tributos", en la obra La Nueva Ley General Tributaria Comentada, La Ley, Madrid, 2004, pág. 622). Advierte DE MIGUEL ARIAS que, "dado que la posibilidad de instar el procedimiento de apremio deriva, en definitiva, del privilegio de autotutela, es lógico que aquél aparezca concebido como de competencia excluyente y exclusiva de la Administración pública, aunque, en algún supuesto concreto, se requiera la colaboración del Juez durante su desarrollo, (...) razón por la cual le resultan aplicables, si bien con carácter supletorio, las normas generales del Derecho" administrativo (DE MIGUEL ARIAS, S., La práctica del embargo para el cobro de la deuda tributaria, op. cit., pág. 45). Sobre la exclusividad administrativa del procedimiento de apremio, recomendamos el trabajo de DAGO ELORZA, I., "Título III. Capítulo V. Actuaciones y procedimientos de recaudación", op. cit., pág. 1037 y GONZÁLEZ SÁNCHEZ, M., "Procedimiento de apremio y sus consecuencias (artículo 128)", en la obra Comentarios a la Ley General Tributaria y lineas para su reforma, libro-homenaje al profesor Dr. D. Fernando Sainz de Bujanda, Vol. II, Ministerio de Economía y Hacienda, Instituto de Estudios Fiscales, Madrid, 1991, pág. 1591 a 1596.

${ }^{169}$ DE MIGUEL ARIAS, S., La práctica del embargo para el cobro de la deuda tributaria, op. cit., pág. 41, y DAGO ELORZA, I., “Título III., Capítulo V. Actuaciones y procedimientos de recaudación”, op. cit., pág. 1013.
} 
"Si en virtud de acto administrativo hubiera de satisfacerse cantidad líquida se seguirá el procedimiento previsto en las normas reguladoras del procedimiento recaudatorio en vía ejecutiva".

La LGT no proporciona un concepto del procedimiento de apremio. PÉREZ DE VEGA entiende que este procedimiento es "el cauce formal mediante el cual la Administración ha de lograr la efectividad de la función recaudatoria, para la satisfacción del interés general consistente en el exacto cumplimiento de la prestación tributaria, actuando coercitivamente si es preciso contra el patrimonio del deudor, en el sentido de ordenar la ejecución de sus bienes"170. En términos similares, CASCAJERO SÁNCHEZ, señala que el procedimiento de apremio es "aquel procedimiento de ejecución forzosa a través del cual, una entidad pública, con apoyo del título ejecutivo dictado por ella misma, procede a la realización efectiva de su crédito de Derecho público, mediante la ejecución individualizada sobre el patrimonio del deudor, quedando reforzado el crédito con las prerrogativas que lo garantizan en virtud de la ley"171.

Se trata de un procedimiento estrictamente administrativo, autónomo y ejecutivo, no cognitivo y unilateral, cuyo inicio se hace de oficio en todas sus etapas. Si en el transcurso del procedimiento se produce la nulidad de algunas de sus actuaciones, advierte el artículo 166 de la LGT que se dispondrá la conservación de las no afectadas por las causas de nulidad. En esta fase de la exigencia de los tributos no es posible discutir la existencia o cuantía de la deuda, ni las condiciones de la cantidad tributaria no ingresada, sino sólo la procedencia del procedimiento y los vicios o defectos en que se hubiera podido incurrir en su desarrollo. Además es un procedimiento autónomo y separado, no acumulable a los judiciales ni a otros procedimientos de ejecución, ni sometido a suspensión por la iniciación de estos últimos, salvo que se produzca la excepción que establece la Ley Orgánica 2/1987, de 18 de mayo, de Conflictos Jurisdiccionales, o que así lo determinen otras normas sobre concurrencia de procedimientos, a las que ahora haremos referencia.

\subsubsection{Concurrencia con otros procesos o procedimientos ejecutivos}

A pesar de que la LGT reconoce en su artículo 163 como regla general que el procedimiento de apremio no es acumulable a otros procedimientos o procesos de ejecución y que el procedimiento de apremio no se suspenderá por el inicio de esos otros, salvo cuando proceda de acuerdo con lo establecido en la Ley Orgánica 2/1987, puede suceder que el procedimiento de apremio concurra con otros procedimientos de ejecución.

Aquí se presentan dos problemas fundamentalmente: por un lado, el problema sustantivo del orden de prelación de los créditos ${ }^{172} \mathrm{y}$, por el otro, la cuestión procedimental sobre el expediente que tiene preferencia. Por ello, es importante ofrecer reglas de coordinación, como se constata en el apartado 1 del artículo 164 de la LGT y el artículo 123 del RGR. El primero de los preceptos prevé diferentes disposiciones para los procesos o procedimientos ejecutivos singulares y para los que tienen una

\footnotetext{
${ }^{170}$ PÉREZ DE VEGA, L. M., La iniciación del procedimiento de apremio de las deudas tributarias, op. cit., pág. 29.

${ }^{171}$ CASCAJERO SÁNCHEZ, A., “Actuaciones y procedimientos de recaudación”, en la obra Ley General Tributaria. Comentarios y casos prácticos, Centro de Estudios Financieros, Madrid, 2004, pág. 691 y 692.

${ }^{172}$ Vid. infra, Capítulo Tercero, epígrafe 4.1.4.2. "El derecho de prelación en las situaciones de concurso".
} 
naturaleza universal. En este capítulo nos centraremos en la segunda de las problemáticas relacionada con la cuestión procedimental, puesto que el orden de prelación de los créditos será objeto de estudio en el tercer capítulo en el epígrafe destinado al derecho de prelación general de que es titular la Hacienda Pública.

\subsubsection{La concurrencia con otros procesos o procedimientos singulares de ejecución}

De conformidad con lo previsto en la letra a) del apartado primero del artículo 164 de la LGT, el procedimiento de apremio tributario puede concurrir con otros procesos o procedimientos ejecutivos, y esta circunstancia conlleva la existencia de reglas que han de aplicarse en el caso de que se produzca dicha situación, que en síntesis son tres: el procedimiento de apremio no es acumulable a otros procedimientos o procesos de ejecución (apartado 2 del artículo 163 de la LGT); tampoco se suspende por el inicio de otros procedimientos de ejecución (apartado 2 del artículo 163 de la LGT); y se sitúa prioritariamente en el orden de prelación en atención a su naturaleza (artículo 77 de la LGT, en relación con las reglas que establece el apartado 1 del artículo 164 de la LGT), de manera que cuando concurra con otros procesos o procedimientos singulares de ejecución será preferente si el embargo efectuado en el curso del procedimiento es el más antiguo teniendo en cuenta la fecha de la diligencia de embargo del bien o derecho.

Como puede verse, la preferencia de la tramitación solamente se produce respecto de los bienes o derechos que se hayan embargado y no se extiende a otros bienes o derechos del deudor distintos de aquéllos. Dado que la preferencia se cierne sobre bienes y derechos concretos del obligado tributario, no existe ningún obstáculo para que se sigan procesos o procedimientos ejecutivos concurrentes en relación con el resto de los bienes y derechos del deudor. Tal como apunta DE MIGUEL ARIAS, "cuando nos encontremos en procedimientos singulares, la preferencia se establece sólo respecto de los bienes o derechos que hubieran sido objeto del embargo, de forma que aquélla no alcanzará a los elementos no embargados -sobre los cuales tendrá plena eficacia el proceso o procedimiento que primero proceda a su traba-, permitiéndose, de este modo, la tramitación paralela de distintas ejecuciones sobre el patrimonio del deudor. En consecuencia, en estas situaciones la Administración tributaria podrá, pese a la existencia de otras ejecuciones singulares, iniciar el procedimiento de apremio y tramitar el mismo sin obstáculos en relación con aquellos bienes o derechos que no hubieran sido objeto de un embargo previo para otra ejecución" ${ }^{\text {173. }}$.

Por lo tanto, la preferencia procedimental para la ejecución se rige por la regla general de primero en tiempo, primero en derecho. Lo que cambia es el modo de empleo de la regla, el elemento que se toma como preferencia para establecer la prioridad en cada caso. Cuando se trata de la concurrencia entre el apremio y otros expedientes de ejecución singular sobre los mismos bienes o derechos del deudor, la letra a) del apartado 1 del artículo 164 de la LGT determina la preferencia del proceso o procedimiento donde antes se hubiera procedido al embargo, teniendo en consideración la fecha en que se emitió la diligencia para hacerlo efectivo ${ }^{174}$. Cuando no coincidan los bienes o derechos

\footnotetext{
${ }^{173}$ DE MIGUEL ARIAS, S., La práctica del embargo para el cobro de la deuda tributaria, op. cit., pág. 102 y 103.

${ }^{174}$ De esta forma, al concretarse la diligencia de embargo como la fecha del embargo, entiende GÓMEZ CABRERA que queda zanjada cualquier problemática que surja en relación a si debe considerarse como fecha del embargo el de la notificación al deudor o el de la anotación en el registro, cuando proceda ésta (GÓMEZ CABRERA, C., La concurrencia del crédito tributario: aspectos sustantivos y procedimentales: prelación, garantías, tercerías, ejecuciones preferentes, suspensiones de pagos y quiebras, Aranzadi,
} 
trabados, cada procedimiento de ejecución singular seguirá de manera autónoma porque, como ya dijimos, la necesidad de decidir sobre la ejecución sólo se presenta en el caso de que un mismo bien o derecho haya quedado sujeto a más de una traba, para lo que se atenderá al embargo más antiguo, es decir, al procedimiento donde primero se emitió la diligencia de embargo.

\subsubsection{La concurrencia con otros procesos o procedimiento concursales o universales de ejecución}

Si la concurrencia del procedimiento de apremio se manifiesta con otros procesos o procedimientos concursales o universales de ejecución, el procedimiento de apremio será preferente para la ejecución de los bienes o derechos embargados siempre que la providencia de apremio se hubiera dictado con anterioridad a la fecha de declaración del concurso, según el inciso b) del apartado primero del artículo 164 de la LGT.

Aquí también se aplica la regla general de la preferencia de tramitación en relación con el proceso o procedimiento más antiguo. Sin embargo, la aplicación de esta regla arroja numerosos problemas. Uno de los más destacados es la determinación de cuál de aquellos procesos o procedimientos se inició primero y, por tanto, tenía preferencia sobre los demás para exigir la deuda coactivamente. La doctrina que defendió el Tribunal Supremo fue la de declarar que los procesos o procedimientos concursales tenían preferencia sobre el apremio si la solicitud de quiebra o suspensión de pagos tenía una fecha anterior a la providencia de apremio ${ }^{175}$. De la misma forma, la Ley 22/2003, de 9 de julio, Concursal (en adelante LC) regula, en el apartado 1 del artículo 55, que declarado el concurso no podrán iniciarse ejecuciones singulares, judiciales o extrajudiciales, ni seguirse apremios administrativos o tributarios contra el patrimonio del deudor.

En la concurrencia entre el apremio y el concurso no cabe hablar de embargos, pues no se produce la traba de elementos singulares, sino que confluye todo el patrimonio del concursado, que queda bajo intervención de la administración del concurso. En este supuesto se plantea la cuestión de deslinde entre procedimientos, que deberá hacerse teniendo en cuenta lo dispuesto en los preceptos que acabamos de señalar (concretamente la letra $b$ ) del primer apartado del artículo 164 de la LGT y el primer apartado del artículo 55 de la LC). De la interpretación conjunta de esas normas se desprende que la declaración del concurso impide iniciar ejecuciones singulares, incluidas las seguidas en apremios administrativos o tributarios ${ }^{176}$. De esta forma, si la diligencia de apremio no fue dictada en fecha anterior a la declaración del concurso, no podrá iniciarse el apremio, y el crédito tributario se integra a la masa del concurso ${ }^{177}$. Y a la inversa, si la providencia de apremio se dicta antes de que se

\footnotetext{
Pamplona, 2000, pág. 122. En palabras de DAGO ELORZA, "la solución no es sino corolario de la consideración de que el conflicto surge cuando se produce la concurrencia de procedimientos sobre un mismo bien o derecho, y ésta se produce no cuando tiene conocimiento el deudor o terceros, sino cuando la actuación administrativa o judicial se ha dirigido contra un bien o derecho en particular, independientemente del conocimiento público de esta actuación" (DAGO ELORZA, I., "Título III. Capítulo V. Actuaciones y procedimientos de recaudación", op. cit., pág. 1071). Asimismo, la naturaleza singular del proceso o procedimiento concurrente avala que la preferencia de tramitación surja de la prioridad en el embargo, y no de la prioridad de la disposición judicial, porque según TEJERIZO LÓPEZ, "éste es un mandato genérico que se dirige contra todo el patrimonio del deudor, en virtud de la responsabilidad universal que rige nuestro Derecho (artículo 1.924)" (TEJERIZO LÓPEZ, J. M., "Capítulo VII. Procedimientos de recaudación”, op. cit., pág. 612).

${ }^{175}$ Sentencia de 20 de diciembre de 1993 y Sentencia de 21 de marzo de 1994.

${ }^{176}$ Así también se corrobora en la Sentencia del Tribunal Supremo de 30 de abril de 2007.

177 PÉREZ-CRESPO PAYÁ, F., "La Hacienda Pública y las situaciones concursales”, en la obra Estudios sobre la Nueva Ley General Tributaria(Ley 53/2003, de 17 de diciembre) Homenaje a D. Pedro Luis Serrera Contreras, Instituto de Estudios Fiscales, Madrid, 2004, pág. 737, 738 y 739; PÉREZ DE VEGA, L. M., "Algunas consideraciones sobre la concurrencia del procedimiento de apremio
} 
declare el concurso, la Administración tributaria podrá continuar con el procedimiento de apremio y embargar los bienes del concursado, si bien con una limitación importante, dado que no podrán embargarse bienes que resulten necesarios para la continuidad de la actividad profesional o empresarial de aquél (apartado primero del artículo 55 de la LC) ${ }^{178}$, necesidad cuya confluencia incumbe apreciar al Juez del concurso ${ }^{179}$. Sin embargo, varios son los autores que se muestran a favor de que este tipo de limitación no sea aplicable en aquellos casos donde se constate que la actividad del concursado no va a continuar, permitiéndose la traba de aquéllos bienes ${ }^{180}$.

Una vez que se verifica la preferencia del procedimiento de apremio, si no se aprecia la existencia de la limitación a la que hacíamos referencia anteriormente, aquél podrá desarrollarse hasta su terminación, con la posibilidad de embargar y ejecutar los bienes y derechos del deudor. Advierte DE MIGUEL ARIAS que la "preferencia afecta a todo el patrimonio del concursado, puesto que la providencia de apremio no conlleva la traba de un determinado bien o derecho para el pago de la deuda, sino que se limita a prevenir dicha actuación para el caso de que no se efectúe el ingreso en el plazo establecido a tal efecto" 181 .

Por su parte, el apartado segundo del artículo 164 de la LGT permite que la Administración tributaria dicte la providencia de apremio, una vez declarado el concurso, y se devenguen los recargos ejecutivos si se dieran las condiciones para ello con anterioridad a la fecha de declaración del concurso. Esta situación implica que la deuda pueda hacerse efectiva en el seno de un proceso concursal y, a pesar de ello, iniciarse el procedimiento ejecutivo tributario a través de la providencia de apremio, con los correspondientes recargos ejecutivos ${ }^{182}$. Es esta una de las previsiones de la ley que ha sido criticada por la doctrina por la clara contradicción que manifiesta respecto a los mandatos

con otros procedimientos de ejecución”, Carta Tributaria, núm. 13, 2005, pág. 11; DE MIGUEL ARIAS, S., La práctica del embargo para el cobro de la deuda tributaria, op. cit., pág. 105.

178 Según DE MIGUEL ARIAS, la norma induce a la confusión porque aunque el momento para determinar la preferencia de los procedimientos (apremio y concurso) es la fecha de la providencia de apremio, acto seguido, el apartado primero del artículo 55 de la LC se refiere a los bienes objeto de embargo. "De este modo, y dado que la providencia de apremio no conlleva la afección de bienes concretos, será preciso esperar al instante en que proceda a dictarse la correspondiente diligencia de embargo para determinar si resultará aplicable la limitación, (...) y, por tanto, si el procedimiento administrativo puede o no continuar" (DE MIGUEL ARIAS, S., La práctica del embargo para el cobro de la deuda tributaria, op. cit., pág. 106). Igual preocupación manifestó RUBIO SOLER, C. L., "La recaudación en la nueva LGT", en la obra Estudios sobre la nueva Ley General Tributaria (Ley 58/2003, de 17 de diciembre). Homenaje a D. Pedro Luis Serrera Contreras, MARTÍNEZ LAFUENTE, A. (director), Instituto de Estudios Fiscales, Madrid, 2004, pág. 650 y 651 .

${ }^{179}$ PÉREZ DE VEGA, L. M., “Algunas consideraciones sobre la concurrencia del procedimiento de apremio con otros procedimientos de ejecución”, op., cit., pág. 10; RODRÍGUEZ MÁRQUEZ, J. S., La Hacienda Pública y los procesos concursales, Aranzadi, Navarra, 2006, pág. 44; LÓPEZ DÍAZ, A., "Sobre la necesidad de pronunciamiento del juez del concurso para la prosecución de los apremios preferentes”, Quincena Fiscal, núm. 13, 2010, pág. 82; DE MIGUEL ARIAS, S., La práctica del embargo para el cobro de la deuda tributaria, op. cit., pág. 106. Sobre las competencias del Juez del concurso en materia tributaria, recomendamos el exhaustivo trabajo de AGUILAR RUBIO, M., Crédito tributario y concurso de acreedores, La Ley, Madrid, 2009, pág. 214 a 237.

${ }^{180}$ VALERO LOZANO, N., "La Ley General Tributaria y la normativa concursal”, en la obra La aplicación de los tributos en la nueva Ley General Tributaria. XLIX Semana de Estudios de Derecho Financiero, Instituto de Estudios Fiscales-Ministerio de Economía y Hacienda, Madrid, 2005, pág. 183; HERNÁNDEZ VERGARA, A., HERRERO DE EGAÑA y ESPINOSA DE LOS MONTEROS, J. M., "Artículos 160 a 177 de la LGT", en la obra Comentarios a la Ley General Tributaria, HERRERO DE EGAÑA y ESPINOSA DE LOS MONTEROS, J. M. (coordinador), Thomson-Aranzadi, Navarra, 2008, pág. 1076.

${ }^{181}$ DE MIGUEL ARIAS, S., La práctica del embargo para el cobro de la deuda tributaria, op. cit., pág. 107.

${ }^{182}$ A favor de esta postura de considerar correcta la actuación de la Administración tributaria a pesar de haberse iniciado el proceso concursal, vid. la Sentencia del Tribunal Supremo de 10 de noviembre de 1999 y la Resolución del TEAC de 13 de septiembre de 2006. En contra, vid. la Sentencia de la Audiencia Nacional de 27 de abril de 1999 y, en la doctrina, TEJERIZO LÓPEZ, J. M., "Capítulo VII. Procedimientos de recaudación”, op. cit., pág. 617. 
que se prevén en el apartado primero del artículo 55 de la LC, que prohíbe taxativamente el inicio o prosecución de cualquier procedimiento ejecutivo una vez que se ha declarado el concurso ${ }^{183}$. Aunque no creemos que en este caso con la emisión de la providencia de apremio pueda la Administración tributaria trabar alguno de los bienes de concursado ${ }^{184}$, y entendemos que ante este supuesto las posibles soluciones que se pueden adoptar son las tres siguientes: que la Administración tributaria llegue acuerdos singulares con el deudor; que se compensen las deudas del obligado con créditos que tenga frente a la Hacienda Pública; o que la Administración coloque al obligado en la misma posición del deudor que paga fuera del plazo antes de que se le notifique la providencia de apremio, por lo que sólo se le exigirá el recargo ejecutivo, sin necesidad de llegar a dictar la providencia de apremio.

Por último, el apartado cuarto del artículo 164 de la LGT expresa el carácter privilegiado del crédito tributario, lo que permite disponer a la Administración tributaria del derecho de abstención en los procesos concursales. El contenido de este precepto se relaciona con el mandato del artículo 77 de la misma ley, donde se reconoce el derecho de prelación general del crédito tributario ${ }^{185}$. En estos casos, la Hacienda Pública tiene la posibilidad de firmar acuerdos o convenios recogidos en la legislación concursal, pues determina literalmente que la Administración tributaria

"podrá suscribir en el curso de estos procesos los acuerdos o convenios previstos en la legislación concursal, así como acordar, de conformidad con el deudor y con las garantías que se estimen oportunas, unas condiciones singulares de pago, que no pueden ser más favorables para el deudor que las recogidas en el convenio o acuerdo que ponga fin al proceso judicial".

En relación con estos acuerdos o convenios, la Disposición Final Décima de la LC, por la que se modifica el artículo 39 de la Ley 47/2003, de 26 de noviembre, General Presupuestaria (en adelante LGP), establece que el órgano competente para suscribir los acuerdos o contratos será la AEAT cuando se trate de créditos cuya gestión recaudatoria le corresponda de acuerdo con la ley, o en función del contenido del convenio. Asimismo, la competencia será del Fondo de Garantía Salarial cuando se trate de créditos correspondientes al mismo, y dentro de ese órgano, según su normativa reguladora. Por último, el Ministerio de Economía y Hacienda será competente para los restantes créditos de la Hacienda Pública Estatal, pudiendo delegar en los órganos de la AEAT.

\footnotetext{
183 TEJERIZO LÓPEZ, J. M., "Capítulo VII. Procedimientos de recaudación”, op. cit., pág. 615 a 617, y, de este mismo autor, "Capítulo III., Procedimiento de Apremio", en la obra Los nuevos Reglamentos Tributarios, CALVO ORTEGA, R. (director), Thomson-Civitas, Madrid, 2006, pág. 156 a 158.

${ }^{184}$ En este mismo sentido, DE MIGUEL ARIAS, S., La práctica del embargo para el cobro de la deuda tributaria, op. cit., pág. 108 y la Resolución del TEAC de 10 de septiembre de 2008.

${ }^{185}$ En palabras de PÉREZ-CRESPO PAYÁ, el derecho de abstención "es una cualidad inherente al crédito que determina la posibilidad de su realización antes del resto de los titulares de créditos ordinarios o comunes, en los procesos concursales, liquidatarios o no, que se manifiesta como derecho de abstención con un doble significado, procesal y sustantivo. Procesalmente, el derecho de abstención significa que el crédito no se ve afectado por el convenio al que se pueda llegar en la situación concursal, quedando su disposición en manos exclusivamente de su titular, que puede renunciar al mismo con el fin de participar voluntariamente en el convenio, aunque con distintos efectos en la quiebra y en la suspensión de pagos. Desde un punto de vista sustantivo, el derecho de abstención implica una preferencia para el cobro respecto a los concordatarios con relación a un bien concreto, cuando el privilegio es singular, o respecto al conjunto del patrimonio del deudor es general" (PÉREZ-CRESPO PAYÁ, F., "La Hacienda Pública y las situaciones concursales", op. cit., pág. 733).
} 
Es importante destacar, llegados a este punto, que la participación de la Hacienda Pública a través de convenios concursales después de la entrada en vigor de la LC se convirtió en un imperativo. Así se confirma con la lectura del segundo apartado del artículo 77 de la LGT, que dispone que, en caso de convenio concursal, los créditos a los que afecte el convenio, incluidos los derivados de la obligación de realizar pagos a cuenta, queden sujetos a la LC. Esta última norma determina en el apartado 4 del artículo 103 que para los acreedores públicos la participación en un convenio puede hacerse por dos vías: mediante la adhesión al convenio, antes de la celebración de la junta, y a través de la asistencia y posterior votación en la Junta.

A su vez, aclara el apartado segundo del artículo 134 de la LC que la vinculación a un convenio concursal de créditos privilegiados puede tener lugar no sólo por votación favorable o por adhesión a la propuesta computada como voto favorable, sino también por adhesión a un convenio ya aceptado por los acreedores o aprobado por el juez, y también por adhesión prestada en forma antes de la declaración judicial de su cumplimiento, en cuyo caso quedarán afectados por el convenio.

Aprobado el convenio, éste vinculará tanto a los deudores como a los acreedores ordinarios y subordinados respecto a los créditos anteriores a la declaración del concurso, aunque por cualquier causa no hubiesen sido reconocidos (apartado 1 del artículo 134 de la LC). Los acreedores de créditos privilegiados quedarán vinculados al contenido del convenio por medio de un acto expreso de aceptación. Estos créditos se extinguirán, según el artículo 136 de la LC, en la parte que alcance la quita, aplazados en su exigibilidad por el tiempo de espera y, en general, afectados por el contenido del convenio.

La segunda posibilidad de participación de la Administración tributaria en convenios concursales se articula a través de la celebración de acuerdos singulares al margen del convenio. Esta alternativa se establece en el apartado 4 del artículo 164 de la LGT, en el apartado 2 del artículo 39 de la LGP y en el apartado 1 del artículo 10 también de la LGP, y según PÉREZ-CRESPO PAYÁ, "se desenvuelve al margen estrictamente del proceso concursal por lo que en el esquema de la LC solo puede tener por objeto a la parte de los créditos públicos que gocen de privilegio general o especial. Los créditos ordinarios o subordinados, por tanto, han de quedar al margen de los acuerdos singulares quedando afectados directamente por el contenido del posible convenio" $" 186$.

Por último, la Administración tributaria podrá acordar condiciones singulares de pago de acuerdo con el deudor y con las garantías que se estimen oportunas. Según consta en el apartado 4 del artículo 164 de la LGT, estas condiciones no pueden ser más favorables para el deudor que las recogidas en el convenio o acuerdo que ponga fin al proceso judicial. Este privilegio podrá ejercerse en los términos previstos en la legislación concursal y también será posible compensar los créditos en los términos previstos en la normativa tributaria.

${ }^{186}$ PÉREZ-CRESPO PAYÁ, F., “La Hacienda Pública y las situaciones concursales”, op. cit., pág. 764. 


\subsubsection{Suspensión del procedimiento de apremio}

El procedimiento de apremio, una vez iniciado, continuará hasta su terminación. No obstante, la LGT en su artículo 165 prevé diversas causas de suspensión ${ }^{187}$. La suspensión según DE MIGUEL ARIAS "constituye una medida que trata de evitar la ejecución de un acto en los casos en que se plantee la oposición al mismo"188. Para MARTÍN QUERALT estamos ante una "paralización del procedimiento recaudatorio ya iniciado, motivado por causas que aconsejan una detención momentánea del citado procedimiento, en tanto se resuelven cuestiones merecedoras de pronunciamiento por parte de los órganos que actúan en la función jurisdiccional en materia tributaria, y siempre que se constituya por parte del recurrente la oportuna garantía, con el fin de salvaguardar los intereses del ente público" ${ }^{\text {189 }}$.

Las causas de suspensión del procedimiento de apremio previstas en el artículo 165 de la LGT pueden resumirse en tres supuestos concretos: la suspensión acordada en vía de recurso; la suspensión por vicios en la constitución del procedimiento; y la suspensión por presentación de tercerías. Algunos autores denuncian la falta de claridad de este precepto cuando hace alusión a las distintas posibilidades de oposición con las que cuenta tanto el deudor tributario como terceros, debido a que desarrolla sólo de forma parcial esta última cuestión ${ }^{190}$.

\subsubsection{La suspensión acordada en vía de recurso}

La suspensión del procedimiento de apremio por la interposición de recursos está prevista en la normativa destinada a la revisión tributaria y por lo general implica la prestación de garantías ${ }^{191}$. El régimen jurídico de la suspensión por interposición de recurso se regula en la LGT en el artículo 165, que trae causa en los artículos 135 y 136 de la LGT de 1963. También se encuentra el régimen de suspensión en vía de recurso en los artículos 224 y 233 de la LGT y en los artículos 39 a 47 del Real Decreto 520/2005, de 13 de mayo, por el que se aprueba el Reglamento General de Desarrollo de la Ley 58/2003, de 17 de diciembre, General Tributaria, en materia de revisión en vía administrativa (en adelante RRVA).

Dispone el apartado 1 del artículo 165 de la LGT que

"El procedimiento de apremio se suspenderá en la forma y con los requisitos

previstos en las disposiciones reguladoras de los recursos y reclamaciones

\footnotetext{
${ }^{187}$ Se acepta tanto en la doctrina como en la jurisprudencia la opinión que la suspensión de los actos administrativos es una excepción. Entre otros, BARRIOS FLORES, L. F., "Ejecución de actos y resoluciones administrativas: caracteres generales", en la obra $E l$ procedimiento administrativo común (Comentarios, jurisprudencia, Formularios), Tomo II, GARBERÍ LLOBREGAT, J. (director), Tirant lo Blanch, Valencia, 2007, pág. 1672, y Sentencia del Tribunal Supremo de 6 de octubre de 1999.

${ }^{188}$ DE MIGUEL ARIAS, S., La práctica del embargo para el cobro de la deuda tributaria, op. cit., pág. 95.

${ }^{189}$ MARTÍN QUERALT, J., “La suspensión de los procedimientos recaudatorios”, Revista Española de Derecho Financiero, núm. 7 , 1976, pág. 503.

${ }^{190}$ Entre otros, ALONSO MURILLO, F. y PÉREZ DE VEGA, L. M., “Actuaciones y procedimientos de recaudación”, op. cit., pág. 754 y 755; GARCÍA-OVIES SARANDESES, I., "La suspensión de la ejecución de actos en materia tributaria: presupuestos y formas de obtención", en la obra Tratado sobre la Ley General Tributaria. Homenaje a Álvaro Rodríguez Bereijo, Tomo II, Thomson-ReutersAranzadi, Navarra, 2010, pág. 663; DE MIGUEL ARIAS, S., La práctica del embargo para el cobro de la deuda tributaria, op. cit., pág. 95.

${ }^{191}$ Vid. infra, Capítulo Quinto, epígrafe 2. "Las garantías en la suspensión de la ejecución de los actos por la interposición de recursos”.
} 
económico-administrativas, y en los restantes supuestos previstos en la normativa tributaria”.

Esta remisión nos conduce al artículo 233 de la LGT, en sede de reclamaciones económicoadministrativas, en cuyo apartado primero se dispone que se producirá la suspensión automática de la ejecución del acto impugnado a instancia del interesado si se garantiza el importe del acto, los intereses de demora que genere la suspensión y los recargos que procederían en caso de ejecución de la garantía. Se excluye de esta regla general la suspensión de las sanciones, que es automática, sin necesidad de aportar garantías, de acuerdo con lo dispuesto en el apartado 3 del artículo 212 de la LGT. Por tanto, para que la impugnación del acto tributario provoque la suspensión del procedimiento de apremio se requiere la presentación de la solicitud del interesado y, a su vez, que éste preste las garantías necesarias a tal fin (apartado primero del artículo 224 de la LGT, apartado primero del artículo 233 de la LGT y artículo 39 del Real Decreto 520/2005) ${ }^{192}$.

El apartado 2 del artículo 233 de la LGT enumera las garantías que debe presentar el obligado para que se produzca la suspensión del procedimiento: el depósito de dinero o valores públicos; el aval o fianza de carácter solidario de entidad de crédito o sociedad de garantía recíproca o certificado de seguro de caución; y la fianza personal y solidaria de otros contribuyentes de reconocida solvencia para los supuestos que se establezcan en la normativa tributaria. No obstante, si el interesado no pudiera aportar estas garantías, procederá también la suspensión siempre que se aporten otras garantías que se estimen suficientes ${ }^{193}$.

En todo caso, el apartado 4 dispone que el tribunal puede suspender la ejecución del acto con dispensa total o parcial de garantías cuando dicha ejecución pudiera causar perjuicios de difícil o imposible reparación ${ }^{194}$. A su vez, este mismo tribunal podrá modificar la resolución sobre la suspensión cuando aprecie que no se mantienen las condiciones que motivaron la misma; cuando las garantías aportadas hubieran perdido valor o efectividad; o cuando conozca de la existencia de otros bienes o derechos susceptibles de ser entregados en garantía que no hubieran sido conocidos en el momento de dictarse la resolución sobre la suspensión.

Evidentemente, si la reclamación no afecta a la totalidad de la deuda tributaria, la suspensión se referirá a la parte reclamada y quedará obligado el reclamante a ingresar la cantidad restante.

En relación con la duración de la suspensión de la ejecución del acto, aclaran los apartados 7 y 8 del artículo 233 de la LGT que se mantendrá durante la tramitación del procedimiento económicoadministrativo en todas sus instancias. Y la suspensión producida en el recurso de reposición se podrá mantener en la vía económico-administrativa en las condiciones que se determinen

\footnotetext{
${ }^{192}$ Según la Sentencia de la Audiencia Nacional de 1 de julio de 2005 y la Sentencia del Tribunal Superior de Justicia de Andalucía de 3 de octubre de 2006, en aquellos casos en que las garantías que se presenten no resulten suficientes o idóneas no se procederá a la suspensión del procedimiento de apremio.

${ }^{193}$ Entiende GALAPERO FLORES que en este caso se debe acreditar que no es posible aportar las garantías que exige el apartado 2 del artículo 233 de la LGT y que la concesión de la suspensión tendrá menos automatismo (GALAPERO FLORES, R., El procedimiento de recaudación de los tributos. Estudio de su regulación en la Ley General Tributaria y en el Reglamento General de Recaudación, op. cit., pág. 132).

${ }^{194}$ En este supuesto los tribunales exigen que los daños de difícil o imposible reparación se encuentren debidamente acreditados por el solicitante (Sentencia del Tribunal Superior de Justicia de Madrid de 9 de febrero de 2006).
} 
reglamentariamente. Asimismo, se continuará con la suspensión producida en vía administrativa cuando el interesado comunique a la Administración tributaria en el plazo de interposición del recurso contencioso-administrativo que ha interpuesto dicho recurso y ha solicitado la suspensión en el mismo. Dicha suspensión se mantendrá siempre que la garantía que se hubiese aportado en vía administrativa conserve su vigencia y eficacia, hasta que el órgano judicial adopte la decisión que corresponda en relación con la suspensión solicitada. De igual forma sucederá cuando se trate de las sanciones, continuando la suspensión, sin necesidad de prestar garantía, hasta que se adopte la decisión judicial.

El apartado 9 del artículo 233 de la LGT regula, por otro lado, el interés de demora que deberá satisfacer el obligado tributario por el tiempo que dure el período de suspensión cuando, como consecuencia de la resolución de la reclamación, deba ingresar total o parcialmente el importe derivado del acto impugnado, salvo por el período en que se hubiera producido retraso en la terminación del procedimiento superando el plazo legal para dictar resolución.

En sede normativa del procedimiento de apremio, los apartados 10, 11 y 12 del artículo 233 de la LGT establecen las causas de suspensión del procedimiento de apremio. El primero de los preceptos dispone que cuando se trate de actos que no tengan por objeto una deuda tributaria o cantidad líquida, el tribunal podrá suspender su ejecución cuando así lo solicite el interesado y justifique que su ejecución pudiera causar perjuicios de imposible o difícil reparación ${ }^{195}$. Además, matiza el número 11 del precepto señalado que la ejecución del acto o resolución impugnada mediante un recurso extraordinario de revisión no podrá suspenderse en ningún caso. Y finalmente, el apartado 12 remite a las normas reglamentarias que serán las encargadas de regular los requisitos, los órganos competentes y el procedimiento para la tramitación y resolución de las solicitudes de suspensión.

Debemos referirnos, por último, a la parte final del apartado primero del artículo 165 de la LGT que prevé la suspensión del procedimiento de apremio en los restantes supuestos previstos en la normativa tributaria. Esta previsión es entendida por ALONSO MURILLO y PÉREZ DE VEGA como una reiteración, ya que aparece recogida en el apartado tercero del artículo 163 de la LGT, que es incorrecta porque no expresa de manera concreta las causas de suspensión del procedimiento de apremio previstas en otros preceptos de la LGT, y además incompleta, porque no incluye las causas de suspensión del procedimiento de apremio que se derivan de normas de carácter no tributario ${ }^{196}$.

\subsubsection{La suspensión por vicios en la constitución del procedimiento}

Los órganos de recaudación pueden suspender de forma automática el procedimiento de apremio cuando el interesado pruebe que se han realizado algunos de los hechos que aparecen recogidos en el apartado 2 del artículo 165 de la LGT y el apartado 2 del artículo 73 del RGR, no siendo necesaria la prestación de garantías. Esto es, que se haya producido un error material, aritmético o de hecho; que la liquidación hubiera sido ingresada, compensada, aplazada o suspendida; o que hubiera prescrito el

\footnotetext{
${ }^{195}$ PÉREZ TORRES alerta que "no debe confundirse el perjuicio derivado de la ejecución con la carga de cumplimentar el contenido del acto con las consecuencias que impone la presunción de legalidad. La suspensión afecta a la eficacia del acto, no a su virtualidad declarativa" (PÉREZ TORRES, E., "Título V. Revisión en vía administrativa", en la obra Comentarios a la Nueva Ley General Tributaria, HUESCA BOADILLA, R. (coordinador), Thomson Aranzadi, Navarra, 2004, pág. 1572 y 1573).

${ }^{196}$ ALONSO MURILLO, F. y PÉREZ DE VEGA, L. M., “Actuaciones y procedimientos de recaudación”, op. cit., pág. 755 y 756.
} 
derecho a exigir el pago. Estas causas podrán ser alegadas en cualquier momento, y como apunta TEJERIZO LÓPEZ, afectan al procedimiento de apremio en cualquiera de sus fases ${ }^{197}$. Estos supuestos generan lo que el RGR denomina "paralización de las actuaciones".

Si la suspensión se produce porque la liquidación hubiera sido ingresada, compensada, aplazada o suspendida, o porque hubiera prescrito el derecho a exigir el pago, el apremio carecerá de sustento y así debe ser declarado. Por el contrario, si la liquidación presentara un error material, aritmético o de hecho, corresponde rectificar la liquidación por parte del órgano competente, si en efecto existe tal error, o, de lo contrario, el procedimiento debe continuar ${ }^{198}$. En este sentido, alega DE MIGUEL ARIAS que "han de distinguirse aquellas situaciones en las que la deuda existe -aunque se encuentre suspendida-, de aquellas otras en que la misma se ha extinguido -por haber sido pagada, compensada, condonada o por haber prescrito el derecho de la Administración a exigir su cobro-, dado que en los últimos supuestos citados no cabrá desarrollar el procedimiento de apremio ante la ausencia de su presupuesto material. Así, cuando haya prescrito el derecho de la Administración a exigir el pago tendrá que anularse la providencia de apremio, debiendo darse por finalizado el respectivo procedimiento, conclusión ésta a la que también ha de llegarse en los casos en que la deuda hubiera sido ingresada, compensada u objeto de condonación"199.

\subsubsection{La suspensión por presentación de tercerías}

La suspensión del procedimiento de apremio también puede producirse por la oposición de terceros, que instan su oposición frente al embargo, tal como se prevé en los tres últimos apartados del artículo 165 de la LGT, mediante las denominadas tercerías.

La suspensión por tercería se lleva a término cuando sobre los bienes o elementos patrimoniales embargados en el apremio existe una pretensión de un tercero, en principio ajeno al procedimiento ejecutivo, que se ve afectado por las trabas practicadas. Sobre la presentación de tercerías durante el procedimiento de apremio se manifiestan los apartados 3, 4 y 5 del artículo 165 de la LGT, mientras que los artículos 117 a 121 del RGR desarrollan los aspectos relativos a las reclamaciones administrativas previas a la interposición de la tercería. Debemos advertir previamente, siguiendo la doctrina de DAGO ELORZA, "que la materia sobre la que ha de versar las tercerías es de carácter civil o jurídico privado. Las cuestiones de derecho administrativo, referidas a estos actos o vicios del procedimiento, deberán ser planteadas por vía de los recursos y reclamaciones de dicha índole -con ulterior revisión por la jurisdicción contencioso administrativa- y no por vía de tercería, sin que siquiera sea posible, dadas las diferencias de naturaleza y régimen jurídico, su acumulación" 200 .

\footnotetext{
${ }^{197}$ TEJERIZO LÓPEZ, J. M., “Capítulo VII. Procedimientos de recaudación”, op. cit., pág. 618.

198 PÉREZ TORRES interpreta que "si el órgano recaudador aprecia la posible concurrencia del tal error en el título ejecutivo lo razonable es detener la ejecución a su cargo hasta tanto se depure, lo cual puede exceder de su competencia. Sin embargo, la cuestión es diferente en un procedimiento de recurso, porque el Tribunal no actúa como sujeto activo de la relación tributaria, sino como órgano encargado de la resolución de un recurso, por lo que, una vez apreciado el error, lo procedente sería la anulación del acto" (PÉREZ TORRES, E., “Título V. Revisión en vía administrativa”, op. cit., pág. 1573).

${ }^{199}$ DE MIGUEL ARIAS, S., La práctica del embargo para el cobro de la deuda tributaria, op. cit., pág. 97 y 98 . En este mismo sentido, CAYÓN GALIARDO, A. M., "El inicio del procedimiento de apremio: presupuestos materiales y formales", op. cit., pág. 70; TEJERIZO LÓPEZ, J. M., "Capítulo III., Procedimiento de Apremio", en la obra Los nuevos Reglamentos Tributarios, CALVO ORTEGA, R. (director), Thomson-Civitas, Madrid, 2006, pág. 152 y 153.

${ }^{200}$ DAGO ELORZA, I., “Título III., Capítulo V. Actuaciones y procedimientos de recaudación”, op. cit., pág. 1104.
} 
Es importante distinguir entre la tercería de dominio y la tercería de mejor derecho, puesto que los efectos y finalidades de una y otra son diferentes. Se produce una tercería de dominio cuando el tercero considera que el bien embargado es de su propiedad ${ }^{201}$, mientras que en el caso de la tercería de mejor derecho el tercero entiende que su crédito tiene preferencia respecto del de la Administración tributaria, haciendo "valer la prioridad de un crédito perteneciente a un tercero frente al de la Hacienda Pública"202. Es por este motivo que la doctrina ha venido entendiendo en la tercería de mejor derecho, y a diferencia de lo que sucede con la tercería de domino, que con la reclamación no se persigue el levantamiento del embargo y no se considere aquélla como una oposición al procedimiento de apremio $^{203}$.

En definitiva, como expresa DE MIGUEL ARIAS, la tercería de domino "determina el levantamiento de la traba sobre el bien cuya titularidad es objeto de controversia, mientras que, por el contrario, la tercería de mejor derecho únicamente pretende que el embargo practicado beneficie a un determinado sujeto poseedor de un crédito preferente al de la Administración"204.

\section{$\underline{\text { A. Sujeto legitimado }}$}

Por lo que respecta a los sujetos que pueden ejercitar la tercería, debe tratarse de un tercero ajeno al procedimiento ejecutivo desarrollado por los órganos de recaudación y que haya visto afectados sus derechos o intereses por motivo de aquel procedimiento. Según señala DAGO ELORZA, a partir de la interpretación que hace de la jurisprudencia, "no es tercero el deudor, que deberá hacer valer su derecho mediante los recursos pertinentes, ni quien haya sido obligado por cualquier concepto al pago de una deuda, sea como responsable tributario, que se refiere a la responsabilidad ya declarada o como sucesor o continuador de la sociedad deudora, y carece de legitimación de tercerista, por su carácter de parte procesal por sustitución, la Sindicatura de la quiebra" ${ }^{205}$. No procede tampoco la tercería de dominio por parte del copropietario de una propiedad indivisa perteneciente a una sociedad de gananciales, pues como bien advierte DE MIGUEL ARIAS, "no procederá entablar una tercería si el embargo ha sido sobre este tipo de bienes, debiendo articularse en estos casos la eventual oposición del cónyuge no deudor a través de derecho a disolver la sociedad de gananciales", aunque "dicho cónyuge sí podrá interponer la referida tercería cuando el elemento embargado fuera

\footnotetext{
${ }^{201}$ Para FERNÁNDEZ LÓPEZ la tercería de dominio es aquélla en la que el tercero persigue que "se alce la traba recaída sobre un determinado bien porque él y no el ejecutado es su propietario" (FERNÁNDEZ LÓPEZ, M. A., Derecho Procesal Civil III. La ejecución forzosa. Las medidas cautelares, $4^{\mathrm{a}}$ ed., Centro de Estudios Ramón Areces, Madrid, 1996, pág. 375). También VEGA TORRES definió la tercería de domino como "la acción que puede ejercitar el verdadero titular de los bienes embargados para solicitar y obtener el alzamiento de la traba, cuando el embargo se haya efectuado sobre la base de una falsa apariencia de pertenencia de los bienes en cuestión al ejecutado" (VEGA TORRES, J., "El embargo de bienes (I, II, III)", en la obra Derecho Procesal Civil. Ejecución forzosa. Procesos Especiales. Conforme a la Ley 1/2000, de 7 de enero, de Enjuiciamiento Civil, Centro de Estudios Ramón Areces, Madrid, 2000, pág. 153).

${ }^{202}$ DE MIGUEL ARIAS, S., La práctica del embargo para el cobro de la deuda tributaria, op. cit., pág. 401.

${ }^{203}$ PÉREZ ROYO, F y AGUALLO AVILÉS, A., Comentarios a la Reforma de la Ley General Tributaria, op. cit., pág. 595; FRANCO ARIAS, J., El procedimiento de apremio, Bosch, Barcelona. 1987, pág. 371.

${ }^{204}$ DE MIGUEL ARIAS, S., La práctica del embargo para el cobro de la deuda tributaria, op. cit., pág. 401 a 402.

${ }^{205}$ DAGO ELORZA, I., “Título III., Capítulo V. Actuaciones y procedimientos de recaudación”, op. cit., pág. 1105.
} 
de naturaleza privativa, así como también cuando, en el instante del nacimiento de la deuda, la sociedad conyugal estuviera ya disuelta y liquidada" ${ }^{, 206}$.

\section{B. Procedimiento y efectos}

El procedimiento de tercería se desarrolla a través de dos vías: administrativa y judicial. La vía administrativa es previa e inexcusable para poder acceder a la vía judicial ante los juzgados y tribunales civiles. GARCÍA SINDE define este procedimiento como un "procedimiento de carácter previo a la vía judicial, instado por un tercero ante la Administración embargante, tendente a levantar el embargo cautelar trabado o a evitar la ejecución forzosa de bienes que embargados por deudas no están afectos al pago de las mismas por pertenecer en el momento del embargo a tercera o terceras personas distintas del deudor o responsable tributario"207. Es importante recordar que el enjuiciamiento de la tercería corresponde a los Tribunales civiles, la Administración tributaria no prejuzga el fondo del asunto, y que ante la desestimación de la reclamación administrativa el tercero podrá acceder al proceso judicial ${ }^{208}$. En este apartado sólo nos referiremos al primero de los dos procesos (reclamación administrativa) y a los efectos que produce dependiendo de cuál sea el tipo de tercería interpuesta.

El procedimiento que se utiliza para sustanciar una tercería en la vía administrativa se encuentra regulado en los artículos 117 a 121 del RGR, sin perjuicio de la aplicación supletoria de los preceptos de la Ley 1/2000, de 7 de enero, de Enjuiciamiento Civil (en adelante LEC) y las demás normas del ámbito civil.

Independientemente de cuál sea la tercería que pretenda interponer el tercero, éste deberá presentar reclamación de tercería en el procedimiento de apremio, ante el órgano administrativo correspondiente, una vez que se ha dictado la diligencia de apremio. En caso de que se trate de una tercería de dominio, la reclamación tendrá que hacerse antes de que se produzca la transmisión del bien o derecho trabado a un tercero o a la Administración tributaria ${ }^{209}$, y no podrá interponerse la reclamación, si es una tercería de mejor derecho, cuando la Hacienda Pública haya percibido el precio de la venta de los bienes o derechos controvertidos o adquirido la titularidad de aquéllos ${ }^{210}$.

\footnotetext{
${ }^{206}$ DE MIGUEL ARIAS, S., La práctica del embargo para el cobro de la deuda tributaria, op. cit., pág. 413. En este mismo sentido, PÉREZ ROYO, F y AGUALlO AVILÉS, A., Comentarios a la Reforma de la Ley General Tributaria, op. cit., pág. 594. Son numerosas las Sentencias que han negado la condición de tercero al cónyuge no deudor en tanto no se disuelva la sociedad de gananciales. Entre otras, las Sentencias del Tribunal Supremo de 26 de enero de 1985, de 13 de julio de 1988, de 19 de junio de 1989 , de 6 y 12 de junio de 1990, de 29 de abril de 1994, y 25 de febrero de 1997.

${ }^{207}$ GARCÍA SINDE, I., El Embargo de bienes, la reclamación administrativa previa a la tercería judicial de dominio y la enajenación forzosa de bienes en el reglamento general de recaudación, Comares, Granada, 2000, pág. 33. ZABALA RODRÍGUEZ-FORNS, A., LLOPIS GINER, F. y DAGO ELORZA, I., Recaudación, aspectos sustantivos y procedimentales, op. cit., pág. 439; ALONSO MURILLO, F. y PÉREZ DE VEGA, L. M., "Actuaciones y procedimientos de recaudación”, op. cit., pág. 750; MALVÁREZ PASCUAL, L. A. y LEANDRO SERRANO, M., El procedimiento de recaudación tributaria: estudio de la práctica administrativa mediante casos comentados, Centro de Estudios Financieros, Madrid, 2010, pág. 736.

${ }^{208}$ LÓPEZ DÍAZ, A., La recaudación de deudas tributarias en vía de apremio, op. cit., pág. 432.

${ }^{209}$ HERNÁNDEZ VERGARA, A., HERRERO DE EGAÑA y ESPINOSA DE LOS MONTEROS, J. M., “Artículos 160 a 177 de la LGT", op. cit., pág. 1089.

${ }^{210}$ TEJERIZO LÓPEZ, J. M., “Capítulo III., Procedimiento de Apremio”, op. cit., pág. 211.
} 
Si se trata de una tercería de dominio, con la reclamación del tercero se suspende el procedimiento en relación con los elementos controvertidos en el mismo momento en que se produzca la interposición de la tercería de domino, sin tener en cuenta la fase en la que aquél se encuentre y sólo respecto de aquellos bienes o derechos objeto de la controversia. Si los bienes fueran inscribibles, la tercería sólo se admitirá si viene acompañada de una certificación registral que acredite la existencia de la inscripción del título y que ésta es anterior a la anotación de la Hacienda Pública ${ }^{211}$.

Para las tercerías de mejor derecho, no se requerirá la suspensión del procedimiento, que concluirá con la realización de los bienes y la consignación en depósito del producto que se obtenga con dicha realización a resueltas de la resolución de tercería. Los requisitos de esta tercería son, según DAGO ELORZA, la existencia un crédito que debe justificar el tercerista por cualquier medio de prueba; de un deudor común, que lo sea tanto del tercero como de la Hacienda Pública y que no mantenga vínculos con el acreedor tercerista que afecten la posición autónoma e independiente del crédito de éste; y de una preferencia del derecho crédito del tercerista frente al acreedor ejecutante (la Administración tributaria), que no vulnere el régimen de las preferencias y garantías de los créditos jurídicos públicos ${ }^{212}$.

El artículo 117 del RGR dispone que la reclamación en vía administrativa es el requisito previo para el ejercicio de la tercería ante los juzgados y tribunales civiles, que en esta vía civil podrá reclamarse contra la resolución expresa o tácita que resuelva la reclamación de tercería interpuesta por el tercero en la vía administrativa, y que esta reclamación sólo puede fundamentarse en el dominio de los bienes embargados al obligado al pago o en el derecho del tercerista a ser reintegrado de su crédito con preferencia al que es objeto del expediente de apremio.

El artículo 118 del RGR prevé la competencia en materia de tercerías, tanto la competencia para la tramitación de la tercería como la competencia para su resolución, que corresponderá a los órganos que se determinen en la norma de organización específica. En el ámbito de la AEAT son competentes para resolver las tercerías en la vía administrativa los titulares de las Delegaciones Especiales y los titulares de las Delegaciones ${ }^{213}$.

Por su parte, el artículo 119 del RGR regula la forma, los plazos y los efectos de la interposición de la tercería. La tercería se inicia con la presentación de la reclamación por escrito por el interesado ante el órgano que está tramitando el procedimiento de apremio, que lo remite al órgano competente para la tramitación de la tercería. Si el escrito de reclamación no reúne los requisitos exigibles a las solicitudes que se dirigen a la Administración tributaria o el tercerista no acompaña junto con el escrito de reclamación los documentos originales en los que fundamenta su derecho, el órgano competente para la tramitación le requerirá para que subsane su falta en un plazo de 10 días contados a partir del día siguiente al de la notificación del requerimiento, con la advertencia expresa de que, de

\footnotetext{
${ }^{211}$ VEGA TORRES, J., “El embargo de bienes (I, II, III)”, op. cit., pág. 162.

${ }^{212}$ DAGO ELORZA, I., “Título III. Capítulo V. Actuaciones y procedimientos de recaudación”, op. cit., pág. 1110. En este mismo sentido, DE MIGUEL ARIAS, S., La práctica del embargo para el cobro de la deuda tributaria, op. cit., pág. 407; HERNÁNDEZ VERGARA, A., HERRERO DE EGAÑA y ESPINOSA DE LOS MONTEROS, J. M., "Artículos 160 a 177 de la LGT”, op. cit., pág. 1087.

${ }^{213}$ Resolución de 26 de diciembre de 2005, de la Presidencia de la AEAT, sobre organización y atribución de competencias en el área de la recaudación.
} 
no hacerlo así, se procederá al archivo de la reclamación. Un vez que se reciba la documentación, o en su caso, subsanados los defectos observados en aquélla, se dicta, si procede, acuerdo de admisión a trámite que se notifica al tercerista y al obligado al pago. Dicho acuerdo deberá ser emitido en el plazo de 15 días desde que se reciba la reclamación o se entiendan subsanados los defectos.

Si la tercería fuera de dominio, una vez admitida a trámite, se adoptan las medidas de aseguramiento que se requiera según la naturaleza de los bienes. Entre otras, puede practicarse anotación de embargo en los registros correspondientes o realizarse el depósito de los bienes. Una vez adoptadas estas medidas, se suspende el procedimiento de apremio respecto de los bienes o derechos objeto de la tercería. Si los bienes consisten en dinero, en efectivo o en cuentas, se consigna su importe en la Caja General de Depósitos o se ordena su retención en cuentas a disposición del órgano de recaudación competente, según decisión de este último. Si los bienes o derechos no pueden conservarse sin sufrir deterioro o quebranto sustancial en su valor en caso de demora, el órgano de recaudación competente puede acordar su enajenación y se consigna, en este caso, el importe obtenido a los efectos de la posterior resolución de la reclamación de tercería. En estos casos, el procedimiento continúa respecto a los demás bienes y derechos del obligado al pago que no hayan sido objeto de la tercería hasta quedar satisfecha la deuda. Se deja de esta forma sin efecto el embargo sobre los bienes y derechos controvertidos, sin que ello suponga reconocimiento alguno de la titularidad del reclamante, y se procede al archivo de la reclamación de tercería planteada en vía administrativa a los efectos que se resuelva la tercería en la jurisdicción civil.

Si la tercería fuera de mejor derecho, en cambio, una vez admitida a trámite se prosigue con el procedimiento de apremio hasta la realización de los bienes o derechos y se consigna el importe obtenido a la espera del resultado de la reclamación judicial de tercería. Únicamente puede suspenderse la ejecución de estos bienes o derechos si el tercerista consigna el importe de la deuda no ingresada, los intereses que se hayan devengado o se devenguen hasta la fecha del ingreso en el Tesoro, los recargos del período ejecutivo y las costas del procedimiento de apremio, o bien el valor del bien a que se refiere la tercería si este último fuese inferior a la suma de las anteriores cantidades.

La tramitación y resolución de la tercería, ya sea de dominio o de mejor derecho, se regula en el artículo 120 del $\mathrm{RGR}^{214}$, y en el artículo 121 del mismo reglamento se prevén los efectos de la estimación de la reclamación de tercería. Si la tercería es de dominio, la estimación de la reclamación determina el levantamiento del embargo acordado sobre los bienes o derechos objeto de la reclamación, salvo en el supuesto de que se hubiera determinado previamente su enajenación por no haber podido conservarse sin sufrir deterioro o quebranto sustancial en su valor en caso de demora. En este caso, se entrega al reclamante el producto obtenido con la oportuna liquidación del interés legal a su favor sobre la cantidad percibida calculado desde la fecha de consignación del depósito y hasta la ordenación del pago. Si, por el contrario, se trata de una tercería de mejor derecho, la estimación de la reclamación determina la entrega al reclamante del producto obtenido en la

\footnotetext{
${ }^{214}$ Sorprende en este ámbito la ausencia de un trámite de audiencia a favor del obligado tributario, aunque GARCÍA SINDE opina que el deudor puede siempre personarse en el expediente instado por el tercero en el ejercicio de los derechos que le asisten (GARCÍA SINDE, I., El Embargo de bienes, la reclamación administrativa previa a la tercería judicial de dominio y la enajenación forzosa de bienes en el reglamento general de recaudación, op. cit., pág. 70).
} 
ejecución, una vez deducidos los costes necesarios para su realización en el procedimiento de $\operatorname{apremio}^{215}$.

Por último, la Administración tributaria puede plantear tercerías cuando en el momento de embargar bienes o derechos en el seno de un procedimiento de apremio aprecie que los mismos ya han sido embargados por otro acreedor. A esta situación se refiere sucintamente el artículo 122 del RGR, cuando establece que, si al efectuarse el embargo de bienes resulta que éstos ya fueron embargados a resultas de otro procedimiento judicial o administrativo, se dé cuenta al órgano competente con el detalle necesario para que éste lo comunique al servicio jurídico a fin de que, si se estima procedente, se ejerciten las acciones pertinentes en defensa del mejor derecho de la Hacienda Pública. La acción pertinente a que hace referencia el mandato es precisamente la tercería de mejor derecho ante la jurisdicción civil.

\subsection{DESARROLLO DEL PROCEDIMIENTO DE APREMIO}

A lo largo del procedimiento de apremio es posible distinguir varias fases o actuaciones que se suceden en el tiempo con el objetivo de satisfacer la deuda junto con los recargos, intereses y costas que corresponda exigir por parte de la Administración tributaria.

Al igual que sucede con todos los procedimientos administrativos, el procedimiento de apremio se divide en tres fases: inicio (producido con la notificación de la providencia de apremio), desarrollo y terminación. En la fase de desarrollo se producen algunas de las actuaciones más importantes dentro del procedimiento ejecutivo, como la ejecución de las garantías, el embargo de bienes o la enajenación de éstos. A estas fases o etapas del procedimiento nos referimos a continuación.

\subsubsection{Inicio del procedimiento de apremio. La providencia de apremio}

Para que se inicie el procedimiento de apremio es necesario que la deuda tributaria no haya sido pagada de forma espontánea en el período voluntario y se requiere inexcusablemente que exista un crédito a ejecutar que determine la cuantía de la recaudación ${ }^{216}$. El apartado primero del artículo 93 de la LRJ-PAC dispone que las Administraciones públicas no realizarán ninguna actuación material de ejecución de resoluciones que limite derechos de los particulares sin que previamente no haya sido adoptada la resolución que le sirva de fundamento jurídico. En consecuencia, para proceder a la ejecución forzosa del patrimonio del obligado tributario en caso de impago será necesario un acto administrativo previo. Como indica DE MIGUEL ARIAS, este acto administrativo objeto de la ejecución "deberá contener una obligación concreta y posible, fijar la persona obligada a realizar la prestación y no encontrarse suspendido; además (...) habrá tenido que ser objeto de notificación al obligado, concediéndosele a este último un plazo para su cumplimiento"217. Para que la deuda pueda ser apremiada será necesario que esté liquidada, se encuentre vencida, sea exigible y no haya sido

\footnotetext{
${ }^{215}$ LÓPEZ DÍAZ, A., La recaudación de deudas tributarias en vía de apremio, op. cit., pág. 441.

${ }^{216}$ SANZ LARRUGA, F. J., El procedimiento administrativo de apremio, La Ley, Madrid, 1991, pág. 176. Así también lo ha reconocido el Tribunal Supremo en las Sentencias de 17 de junio de 1987 y de 13 de febrero de 1988.

${ }^{217}$ DE MIGUEL ARIAS, S., La práctica del embargo para el cobro de la deuda tributaria, op. cit., pág. 80. En el mismo sentido, SANZ LARRUGA, F. J., El procedimiento administrativo de apremio, op. cit., pág. 174.
} 
pagada $^{218}$, lo cual implica que no podrá estar fraccionada, aplazada o suspendida, ni tampoco prescrita, anulada, condonada o compensada.

A los presupuestos materiales anteriores se añade un presupuesto formal necesario para dar inicio al procedimiento de recaudación, esto es, la notificación al deudor de la providencia de apremio, con identificación de la deuda pendiente, liquidación de los recargos del período ejecutivo y requerimiento de realización del pago. De esta forma, la providencia de apremio adquiere una doble condición: título que despacha la ejecución y título ejecutivo ${ }^{219}$. Así se reconoce en el apartado segundo del artículo 167 de la LGT, donde se determina que la providencia de apremio tiene la misma fuerza ejecutiva que una sentencia judicial para proceder contra los bienes y derechos de los obligados al pago.

El apartado 1 del artículo 70 del RGR desarrolla estos mandatos y define la providencia de apremio como el acto de la Administración que ordena la ejecución contra el patrimonio del obligado al pago $^{220}$. Con la providencia de apremio dictada por los Jefes de la Dependencia de Recaudación se obtiene el derecho a que se realice la ejecución sobre el patrimonio del deudor, sin que éste pueda oponerse a la misma, y se advierte a este sujeto que de no efectuar el pago en el tiempo que se concede en la providencia de apremio se procederá a la ejecución sobre su patrimonio.

Para que surta sus efectos, la providencia debe ser notificada al obligado tributario. La falta de notificación, que en un principio fue una de las causas de nulidad absoluta del procedimiento de apremio, tal como señaló el Tribunal Supremo, por ejemplo, en la Sentencia de 25 de abril 1987, ahora es un requisito subsanable. De hecho, la falta de notificación de la providencia de apremio no se relaciona como uno de los motivos de oposición contra ella en la lista de causas prevista en el apartado 3 del artículo 167 de la LGT. La falta de notificación de la providencia de apremio al deudor se aprecia como un simple defecto subsanable, tal como reconoce expresamente el Tribunal Supremo en su Sentencia de 19 de mayo de 2000, y se califica como una tacha de simple ineficacia. A favor de esta doctrina se manifiesta TEJERIZO LÓPEZ, para quien "resulta razonable que la falta de la notificación de un acto, por más que sea el que inicia el procedimiento, no deba provocar como reacción del ordenamiento la nulidad radical (es decir, sin posibilidad de subsanación) de todo él. Los

\footnotetext{
${ }^{218}$ Tal como señala TEJERIZO LÓPEZ, "el requisito o presupuesto material del procedimiento de apremio es el impago de la deuda tributaria en el período establecido para hacerlo de forma espontánea” (TEJERIZO LÓPEZ, J. M., Capítulo III., Procedimiento de Apremio", op. cit., pág. 172).

219 En esta línea, ALONSO MURILLO y PÉREZ DE VEGA sostienen que "en la providencia de apremio convergen las dos manifestaciones más significativas de la autotutela administrativa: la declarativa y la ejecutiva" y que dicha providencia "se fundamenta en la existencia de una previa decisión administrativa de contenido obligacional que goza de la presunción iuris tantum de legalidad, y cuando resulta incumplida por el obligado, también cumple la nota de ejecutoriedad administrativa, presupuestos previstos para su posterior ejecución forzosa" (ALONSO MURILLO, F. y PÉREZ DE VEGA, L. M., "Actuaciones y procedimientos de recaudación", op. cit., pág. 715 y 716). En este mismo sentido, DELGADO PACHECO, A., "Artículos 160 a 173 de la LGT", en la obra Ley General Tributaria. Antecedentes y Comentarios, MANTERO SÁENZ, A., y GIMÉNEZ-REYNA RODRÍGUEZ, E. (coordinadores), Asociación de Abogados Especializados en Derecho Tributario-Asociación Española de Asesores Fiscales, Madrid, 2005, pág. 751; LÓPEZ DÍAZ, A., Periodo Ejecutivo. Procedimiento de Apremio y Recargo, op. cit., pág. 105; DAGO ELORZA, I., “Título III., Capítulo V. Actuaciones y procedimientos de recaudación”, op. cit., pág. 1117.

${ }^{220}$ En opinión de SÁNCHEZ ONDAL en la actualidad el concepto de providencia de apremio se ha desnaturalizado, ya que la misma asume funciones diversas y advierte de las consecuencias del inicio del procedimiento ejecutivo (SÁNCHEZ ONDAL, J. J., "Presupuestos materiales y formales del procedimiento de apremio", en la obra Recaudación ejecutiva y Hacienda Local, SERRANO ANTÓN, F. (director), Thomson-Civitas, Navarra, 2008, pág. 103).
} 
intereses públicos y las garantías individuales se satisfacen correctamente ordenando simplemente que se retrotraiga al momento de la notificación de la providencia"221.

En cuanto al contenido de la providencia de apremio, ésta debe contener todos los extremos que menciona el artículo 71 del RGR: la identificación del lugar de ingreso de la deuda y del recargo; la repercusión de costas del procedimiento; la posibilidad de solicitar aplazamiento o fraccionamiento de pago; la indicación expresa de que la suspensión del procedimiento se producirá en los casos y condiciones previstos en la normativa vigente; y por último, los recursos que se pueden presentar contra la providencia de apremio y, en relación con los mismos, los órganos y los plazos de interposición $^{222}$.

Asimismo, la providencia de apremio deberá contener los elementos que recoge el apartado 2 del artículo 70 del RGR: el nombre y los apellidos o razón social o denominación completa, número de identificación fiscal y domicilio del obligado al pago; el concepto, importe de la deuda y período al que corresponde; la indicación expresa de que la deuda no ha sido satisfecha tras haber finalizado el correspondiente plazo de ingreso en período voluntario y el comienzo del devengo de los intereses de demora; la liquidación del recargo del período ejecutivo; el requerimiento expreso para que efectúe el pago de la deuda, incluido el recargo de apremio reducido, en el plazo al que se refiere el apartado 5 del artículo 62 de la LGT; la advertencia de que, en caso de no efectuar el ingreso del importe total de la deuda pendiente en dicho plazo, incluido el recargo de apremio reducido del 10 por 100 , se procederá al embargo de sus bienes o a la ejecución de las garantías existentes para el cobro de la deuda con inclusión del recargo de apremio del 20 por 100 y de los intereses de demora que se devenguen hasta la fecha de cancelación de la deuda; y, finalmente, la fecha de su emisión. En cualquier caso, hay que tener en cuenta que si el obligado paga su deuda en el tiempo que establece la providencia de apremio este recargo del 20 por 100 se reduce a la mitad.

En cuanto a los requisitos temporales, el plazo que se concede para el pago de la deuda apremiada será el dispuesto en el apartado 5 del artículo 62 de la LGT: si la notificación de la providencia se realiza entre los días uno y 15 de cada mes, el plazo del pago se extenderá desde la fecha de recepción de la notificación hasta el día 20 de dicho mes o, si éste no fuera hábil, hasta el inmediato hábil siguiente; y si la notificación de la providencia se realiza entre los días 16 y último de cada mes, el plazo para que el obligado tributario realice su ingreso se inicia en la fecha de recepción de la notificación y se prolonga hasta el día cinco del mes siguiente o, si éste no fuera hábil, hasta el inmediato hábil siguiente.

El apartado 3 del artículo 70 del RGR dispone que los órganos competentes para dictar la providencia de apremio son los que establece la norma de organización específica. El apartado 4 del mismo artículo prevé que en el caso de deudas a favor de la Hacienda Pública Estatal que deban satisfacer las Comunidades Autónomas, Entidades Locales, organismos autónomos y otras entidades de Derecho público, y sin perjuicio de la posibilidad de proceder al embargo de sus bienes, en los

\footnotetext{
${ }^{221}$ TEJERIZO LÓPEZ, J. M., “Capítulo VII. Procedimientos de recaudación”, op. cit., pág. 620, y, de este mismo autor, "Capítulo III., Procedimiento de Apremio”, op. cit., pág. 177.

${ }^{222}$ Así se señala, por ejemplo, en la Sentencia del Tribunal Superior de Justicia de Cataluña de 4 de enero de 2000.
} 
supuestos no excluidos por disposición legal, podrá acudirse a los procedimientos de compensación de oficio y deducción sobre transferencias.

\subsubsection{Tramitación}

El procedimiento ejecutivo finaliza, en su caso, con el pago que realiza el deudor del crédito de la Administración tributaria dentro del término que fija la providencia de apremio y que acabamos de señalar. Por el contrario, si se no se cumple con lo que establece la providencia de apremio y no se ingresa la deuda en el plazo previsto, el procedimiento de apremio continuará como se indica en el número 4 del artículo 167 de la LGT.

\subsubsection{Ejecución de las garantías}

El artículo 168 de la LGT regula la ejecución de garantías en caso de impago para aquellas deudas que estuvieran garantizadas. Las garantías serán las correspondientes a los derechos reales que acompañan algunas deudas (hipoteca legal tácita, derecho de afección) u otros derechos o garantías reales o personales que se constituyeran durante el procedimiento. También el precepto reconoce que la Administración tributaria puede enajenar o embargar otros bienes o derechos con anterioridad a la ejecución de las garantías, cuando éstas no sean proporcionales a la deuda garantizada, o cuando el deudor lo solicite, señalando los bienes suficientes al efecto. Para estos casos, la garantía prestada quedará sin efecto en la parte que se asegure por los embargos.

TEJERIZO LÓPEZ se muestra crítico con la ejecución de las garantías a través del procedimiento de apremio cuando la garantía se ha prestado en período voluntario de pago, porque en este caso la ejecución "desconoce el significado jurídico de la solidaridad de deudores, hace incurrir a los obligados tributarios en gasto inútiles por cuanto la garantía no les libera del apremio y, lo que es el colmo de la incongruencia, resulta perjudicial para los intereses de la Hacienda Pública porque la garantía no alcanza el recargo de apremio, con lo cual tiene que seguir el procedimiento ejecutivo sólo para cobrarlo. Nada impide", para este autor, "la existencia de una norma que prorrogue el período de pago voluntario a los solos efectos de hacer efectiva una garantía en dicho período"223.

Lo que pretende la ley es que se ejecuten, con anterioridad al embargo de los bienes del obligado tributario, las garantías que hayan podido establecerse, tanto en el período voluntario de pago como en el ejecutivo, siendo entonces innecesario llegar hasta el embargo si una vez que se realicen las garantías se obtiene suficiente líquido para cubrir la totalidad de la deuda insatisfecha. Ello implica, tal como indica DAGO ELORZA ${ }^{224}$, que nos encontramos ante una cuestión ajena al orden que debe seguirse en el embargo, ya que la previa ejecución de las garantías conlleva a una traba o afección específica que sólo en caso de resultar insuficiente provoca la necesidad de recurrir al embargo, en el que sí opera el orden establecido.

\footnotetext{
${ }^{223}$ TEJERIZO LÓPEZ, J. M., “Capítulo III., Procedimiento de Apremio”, op. cit., pág. 181.

${ }^{224}$ DAGO ELORZA, I., “Título III., Capítulo V. Actuaciones y procedimientos de recaudación”, op. cit., pág. 1122.
} 
El desarrollo del procedimiento de ejecución de las garantías se encuentra en el artículo 74 del $\mathrm{RGR}^{225}$. Cuando se trate de una deuda garantizada y resulte impagada la deuda en el plazo a que se refiere el apartado 5 del artículo 62 de la LGT, este precepto permite ejecutar las garantías, pero se puede evitar la enajenación de las garantías y proceder directamente al embargo de otros bienes si la garantía no es proporcional a la deuda o si el interesado solicita que se proceda al embargo directamente. En la primera situación, será la Administración quien valorará la suficiencia de la garantía respecto de la deuda, y cuando aquélla no sea proporcional a ésta última, el órgano de recaudación podrá embargar otros bienes de valor inferior ${ }^{226}$. En el segundo supuesto, es el propio deudor el que puede evitar la ejecución de la garantía presentando otros bienes suficientes para asegurar el cobro de la deuda. Aunque resulta posible "que la Administración rechace, de forma motivada, dicho ofrecimiento en caso de que viera peligrar el pago de aquélla", de manera que "la decisión sobre esta alternativa dependerá, en último extremo, del órgano de recaudación, quién valorará la conveniencia o no de la propuesta del obligado tributario",227.

En el supuesto de que la garantía consista en aval, fianza, certificado de seguro de caución u otra garantía personal, se requerirá al garante el ingreso de la deuda, incluidos los recargos e intereses que, en su caso, correspondan hasta el límite del importe garantizado, en el plazo establecido en el apartado 5 del artículo 62 de la LGT. De no hacerlo, se procederá contra sus bienes en virtud de la providencia de apremio que se notificó al obligado al pago sin necesidad de nueva notificación al garante $^{228}$.

Por el contrario, si la garantía consiste en hipoteca, prenda u otra de carácter real constituida por o sobre bienes o derechos del obligado al pago susceptibles de enajenación forzosa, se procederá a su realización siguiendo el procedimiento que al respecto establece el RGR para la enajenación de bienes embargados de naturaleza igual o similar.

En todo caso, cuando la garantía se constituya por o sobre bienes o derechos de persona o entidad distinta del obligado al pago, se comunicará a dicha persona o entidad el impago del importe garantizado, requiriéndole para que, en el plazo establecido en el número 5 del artículo 62 de la LGT, ponga dichos bienes o derechos a disposición del órgano de recaudación competente, salvo que pague la cuantía debida. Transcurrido dicho plazo sin que se haya producido el pago o la entrega de los bienes o derechos, se procederá a la enajenación de los mismos.

\footnotetext{
${ }^{225}$ El precepto, según MONTERO DOMÍNGUEZ, asume de forma continuista la especificación del procedimiento de ejecución en función del tipo de garantías de que se trate y de la naturaleza del bien, sin tener en consideración la titularidad del bien (MONTERO DOMÍNGUEZ, A., El Nuevo Reglamento General de Recaudación comentado, La Ley, Madrid, 2006, pág. 281).

${ }^{226}$ HERNÁNDEZ VERGARA, A., HERRERO DE EGAÑA y ESPINOSA DE LOS MONTEROS, J. M., “Artículos 160 a 177 de la LGT”, op. cit., pág. 1103 y 1104.

${ }^{227}$ DE MIGUEL ARIAS, S., La práctica del embargo para el cobro de la deuda tributaria, op. cit., pág. 93. En el mismo sentido, SERRANO ANTÓN, F., "Capítulo 11. Recaudación tributaria", en la obra Comentario sistémico a la nueva Ley General Tributaria, PALAO TABOADA, C. (coordinador), Centro de Estudios Financieros, 2004, pág. 502; MONTERO DOMÍNGUEZ, A., El Nuevo Reglamento General de Recaudación comentado, op. cit., pág. 281.

${ }^{228}$ En esta línea se han pronunciado HERNÁNDEZ VERGARA, A., HERRERO DE EGAÑA y ESPINOSA DE LOS MONTEROS, J. M., "Artículos 160 a 177 de la LGT", op. cit., pág. 1105, y la Sentencia del Tribunal Supremo de 14 de marzo de 2007. En contra de estas posturas doctrinales puede verse la Sentencia del Tribunal Superior de Justicia de Canarias de 25 de julio de 2001, en la que el Tribunal exigió que se pusiera en conocimiento del garante la información necesaria para proteger sus intereses.
} 
Si la garantía consiste en depósito en efectivo, finalmente, se requerirá al depositario el ingreso de la deuda, incluidos los recargos e intereses que, en su caso, correspondan hasta el límite del depósito constituido, en el plazo que establece el quinto apartado del artículo 62 de la LGT, advirtiéndole que en caso de incumplimiento se procederá al embargo de sus bienes y derechos sin más trámites, en virtud de la misma providencia de apremio que se dictó contra el obligado al pago. Si el depositario es la propia Administración tributaria, se aplicará el depósito a cancelar dichas cantidades.

Por lo que respecta al procedimiento de ejecución de las garantías, hay que observar que la ejecución de las hipotecas y otros derechos reales constituidos en garantía de los créditos de la Hacienda Pública se realizará por los órganos de recaudación competentes a través del procedimiento de apremio. Cuando se inicie la ejecución administrativa, el órgano de recaudación competente comunicará la orden de ejecución al Registrador de la Propiedad mediante mandamiento por duplicado, para que éste libre y remita la correspondiente certificación de dominio y cargas con el contenido y efectos establecidos en el artículo 688 de la LEC. Además, el órgano de recaudación competente notificará el inicio del procedimiento de ejecución a la persona a cuyo favor resulte practicada la última inscripción de dominio, si no ha sido requerida para el pago, y a los titulares de cargas o derechos reales constituidos con posterioridad a la hipoteca que aparezcan en la certificación.

Por último, se podrá continuar el procedimiento de apremio cuando la garantía haya devenido manifiestamente insuficiente, jurídica o económicamente, desde la fecha de su constitución, sin necesidad de esperar a su ejecución, mediante acuerdo motivado que deberá constar en el expediente.

\subsubsection{Embargo de los bienes y derechos del deudor}

El embargo de los bienes y derechos del deudor, que aparece regulado en los artículos 169 a 171 de la LGT, constituye la base del procedimiento ejecutivo y tiene por objeto el cobro de la prestación con la cantidad adquirida de la realización de los bienes embargados. Una vez que trascurre el período que se concede al deudor a través de la providencia de apremio para que satisfaga su deuda, desentendiéndose éste de dicho acto administrativo, se pasa al embargo de sus bienes, salvo de que se trate de una deuda garantizada, en cuyo caso se procede primero a la ejecución de las garantías en los términos que hemos señalado en el apartado anterior.

Antes de la entrada en vigor de la LGT de 2003, el artículo 110 del RGR de 1990 establecía que para embargar los bienes del deudor debía emitirse primero la providencia de apremio, que se notificaba a la persona, deudor o tercero, en cuyo poder se encontraban los bienes o derechos a trabar. No obstante, esta obligación de emitir la providencia de apremio desapareció con la promulgación de la LGT actual $^{229}$, y la ley sólo determina que una vez transcurrido el período concedido por la

\footnotetext{
${ }^{229}$ El Proyecto de Reforma de la LGT sí contenía esta exigencia, pero fue retirada durante la tramitación en el Senado, mediante la enmienda 340 del Grupo Popular. En esta enmienda, al referirse al apartado 4 del artículo 167 de la LGT, se señaló que se eliminaba la exigencia de la providencia de apremio para dar inicio al embargo de los bienes del deudor porque tras la aprobación de la LC era innecesario hacer referencia a este acto interno por el que se ordenaba realizar actuaciones necesarias para cobrar la deuda. Estas razones de supresión de la providencia de apremio no fueron aceptadas por TEJERIZO LÓPEZ, por entender que los casos más frecuentes en los que la vía ejecutiva se sigue afectan a deudores que no están inmersos en un proceso concursal y porque se comete el error de considerar a la providencia de apremio como un acto interno de la Administración, cuando en realidad se trata de una resolución del órgano administrativo competente que siempre contiene una manifestación de voluntad y que para su plena efectividad debe ser notificada a los interesados. A su vez, apunta este autor que la falta de emisión de la providencia de apremio obliga a
} 
providencia de apremio sin que se realice el ingreso de la deuda tributaria se proceda a embargar los bienes o derechos del obligado en cantidad suficiente para hacer frente a la misma, según consta en el apartado 4 del artículo 167 de la LGT.

Por su parte, el artículo 170 de la LGT dispone que cada actuación de embargo se documente en una diligencia, que debe notificarse a la persona con la que se entienda la actuación, pudiendo acumularse en una misma diligencia las deudas de un mismo obligado al pago. De igual forma, la diligencia de embargo puede ser impugnada por cualquiera de los motivos que aparecen expuestos en el apartado tercero del artículo 170 de la LGT y, si los bienes a embargar son inscribibles en un registro público, la Administración tributaria tiene derecho a que se practique anotación preventiva de embargo en el registro correspondiente.

La práctica del embargo de bienes o derechos del deudor se somete a las reglas que determina el artículo 169 de la LGT. La primera de éstas consiste en que los bienes que son embargados han de ser suficientes y que no debe haber desproporción entre lo que se recauda a través de la ejecución de los bienes y la deuda tributaria insatisfecha. Como expresa GALAPERO FLORES, la proporcionalidad actúa "como límite de las actuaciones de la Administración a la hora de proceder a la traba de bienes",230.

La segunda de las reglas se recoge en el propio apartado primero del artículo 169 de la LGT y alude al montante de la deuda pendiente para cuya cobertura se procede al embargo de los bienes. Dice el precepto que la deuda para cuya satisfacción se embargan los bienes se compone de las siguientes partidas: el importe de la deuda no ingresada, los intereses que se hayan devengado o se devenguen hasta la fecha del ingreso en el Tesoro, los recargos del período ejecutivo, y las costas del procedimiento de apremio. De esta relación que establece el artículo se desprende literalmente que la ley deja fuera los otros componentes de la deuda tributara que regula el artículo 58 de la LGT, específicamente los recargos por declaración extemporánea y los recargos exigibles legalmente sobre las bases o las cuotas, a favor del Tesoro o de otros entes públicos, aunque hay que interpretar en todo caso que el embargo debe ser suficiente para cubrir todos los elementos que aparecen en el apartado 2 del artículo 58 de la LGT, siempre que se encuentren liquidados.

Respecto al orden del embargo de bienes, la LGT mantiene los mismos criterios que su antecesora ${ }^{231}$. En primer lugar, se impone el acuerdo entre la Administración tributaria y el deudor ${ }^{232}$. En caso de no

fundamentar suficientemente las diligencias del embargo y produce la indefensión del obligado, ya que la providencia puede ser impugnada y, en caso de desaparecer ésta, sería necesario admitir la posibilidad de impugnar la diligencia de embargo, lo cual no deja de ser una cuestión discutible desde un punto de vista de técnica jurídica (TEJERIZO LÓPEZ, J. M., "Capítulo VII. Procedimientos de recaudación", op. cit., pág. 626 a 627$)$.

${ }^{230}$ GALAPERO FLORES, R., El procedimiento de recaudación de los tributos. Estudio de su regulación en la Ley General Tributaria y en el Reglamento General de Recaudación, op. cit., pág. 147.

${ }^{231}$ Para TEJERIZO LÓPEZ no estamos ante una ordenación rígida de los bienes y derechos a embargar (TEJERIZO LÓPEZ, J. M., "Capítulo III., Procedimiento de Apremio", op. cit., pág. 185).

232 PEÑA ALONSO y CORCUERA TORRES han indicado que se trata de una manifestación del principio de proporcionalidad, “al pretender causar el menor perjuicio al deudor, que podrá optar por ceder para la ejecución aquellos bienes que le reporten un menor beneficio o utilidad en su esfera personal, empresarial, profesional, etc., siempre que cumplan los requisitos legales" (PEÑA ALONSO, J. L. y CORCUERA TORRES, A., La reforma de la Ley General Tributaria, op. cit., pág. 196 y 197). Por su parte, SERRANO ANTÓN advierte que dicha previsión constituye una manifestación de terminación convencional en el procedimiento de recaudación (SERRANO ANTÓN, F., La terminación convencional de procedimientos tributarios y otras técnicas transaccionales, Asociación Española de Asesores Fiscales, Madrid, 1996, pág. 102). 
existir este acuerdo, la ley determina que se procederá a embargar los bienes teniendo en cuenta la mayor facilidad de su enajenación y la menor onerosidad de ésta para el obligado ${ }^{233}$. Y si fuera imposible o muy difícil aplicar alguno de los dos criterios anteriores, la ley dispone que se aplique el orden que aparece en el apartado 2 del artículo 169 de la LGT, recogido también en el ordenamiento civil y en la LEC. Según este precepto, se embargarán los bienes o derechos del deudor en el siguiente orden: el dinero efectivo o en cuentas abiertas en entidades de crédito; los créditos, efectos, valores y derechos realizables en el acto o a corto plazo; los sueldos, salarios y pensiones; los bienes inmuebles; los intereses, rentas y frutos de toda especie; los establecimientos mercantiles o industriales; los metales preciosos, piedras finas, joyería, orfebrería y antigüedades; los bienes muebles y semovientes; y por último, los créditos, efectos, valores y derechos realizables a largo plazo $^{234}$.

Siguiendo el orden indicado, se embargarán sucesivamente los bienes o derechos conocidos en ese momento por la Administración tributaria hasta que se presuma cubierta la deuda. En todo caso, se embargarán en último lugar aquéllos para cuya traba sea necesaria la entrada en el domicilio del obligado tributario $^{235}$. Sea como fuere, siempre hay que tener presente que, a solicitud del obligado tributario se podrá alterar el orden de embargo si los bienes que señalen garantizan el cobro de la deuda con la misma eficacia y prontitud que los que preferentemente deban ser trabados y no se cause con ello perjuicio a terceros.

La lista se completa, por último, con los bienes que en ningún caso pueden ser embargados. La LGT sólo prevé en el apartado 5 del artículo 169 la imposibilidad de embargar los bienes o derechos que no puedan serlo por ley, lo que remite al contenido de los artículos 605 a 618 de la LEC. No se embargarán, en definitiva, los bienes o derechos declarados inembargables por las leyes, ni aquellos otros respecto de los que se presuma que el coste de su realización pudiera exceder del importe que normalmente podría obtenerse en su enajenación ${ }^{236}$.

\footnotetext{
${ }^{233}$ Sobre esta materia, vid. DE MIGUEL ARIAS, S., La práctica del embargo para el cobro de la deuda tributaria, op. cit., pág. 255 a 257.

${ }^{234}$ Este orden de embargo previsto en el apartado segundo del artículo 169 de la LGT constituye un privilegio para la Hacienda Pública, si se tiene en cuenta que dentro de los primeros puestos se ubican los bienes o derechos de mayor liquidez y sobre los cuales la Administración tributaria tiene más conocimiento. Según subrayan HERNÁNDEZ VERGARA y HERRERO DE EGAÑA y ESPINOSA DE LOS MONTEROS, la prelación que determina la ley resulta más acorde con la economía familiar, la que está integrada por el efectivo en cuenta, el salario que perciba el obligado y los inmuebles (HERNÁNDEZ VERGARA, A., HERRERO DE EGAÑA y ESPINOSA DE LOS MONTEROS, J. M., “Artículos 160 a 177 de la LGT”, op. cit., pág. 1115). Sobre el privilegio que representa este orden para la Hacienda Pública, vid. LÓPEZ DÍAZ, A., La recaudación de deudas tributarias en vía de apremio, op. cit., pág. 309; ALONSO MURILLO, F. y PÉREZ DE VEGA, L. M., "Actuaciones y procedimientos de recaudación”, op. cit., pág. 726; PEÑA ALONSO, J. L. y CORCUERA TORRES, A., La reforma de la Ley General Tributaria, op. cit., pág. 195; GARCÍA LUIS, T., "El procedimiento de apremio", op. cit., pág. 523; SANZ LARRUGA, F. J., "Reforma de la recaudación ejecutiva de los derechos económicos de la Hacienda Pública", Impuestos, Vol. II, 1988, pág. 151 y 152; ALTAVA LAVALL, M. G., "El orden de prelación civil y tributario en el embargo de bienes. Especial referencia al embargo de dinero", en la obra Historia y Derecho. Estudios jurídicos en Homenaje al Profesor Arcadio García Sanz, Tirant lo Blanch, Valencia, 1995, pág. 55 y 56; y PÉREZ DE VEGA, L. M., "El embargo por deudas tributarias en la LGT y en las normas de desarrollo", en la obra Tratado sobre la Ley General Tributaria. Homenaje a Álvaro Rodríguez Bereijo, Tomo I, Thomson-Reuters-Aranzadi, Navarra, 2010, pág. 695;

${ }^{235}$ Sobre el embargo de bienes para cuya traba sea necesaria la entrada en el domicilio del obligado, vid. DE MIGUEL ARIAS, S., La práctica del embargo para el cobro de la deuda tributaria, op. cit., pág. 259 a 262.

${ }^{236}$ En este sentido, vid. BEGOÑA DE LA MANO, B., "Sección 4 a - Otras formas de extinción de la deuda tributaria. Capítulo IV- La deuda tributaria. Título II- Los tributos", op. cit., pág. 646 a 647.
} 
Para finalizar con este apartado, es preciso hacer tres observaciones relevantes sobre el embargo de los bienes o derechos del deudor.

La primera guarda relación con la forma en que debe realizarse el embargo. Éste se hará nominalmente mediante una diligencia de embargo, que debe notificarse a la persona con la que se entienda la actuación, a tenor de lo dispuesto en el segundo párrafo del apartado 1 del artículo 170 de la $\mathrm{LGT}^{237}$. El RGR dedica varios preceptos a regular este proceso (artículos 76, 79, 80, 82, 84 a 87, 89 y 90). Ahora bien, si el depositario o poseedor de los bienes o derechos, una vez que conozca el embargo por cualquiera de las vías, colabora o consiente en el levantamiento de los bienes o derechos, se convertirá en responsable solidario de la deuda tributaria hasta el límite levantado.

La segunda de las anotaciones es que hay que tener en cuenta el bien o derecho que se traba, porque si los bienes embargados fueran inscribibles en el Registro Público la Administración tributaria tendrá derecho a que se anote preventivamente el embargo. A tal efecto, el órgano competente expedirá mandamiento, con el mismo valor que uno expedido por los jueces, y solicitará que se emita certificación de las cargas que figuren en el registro. El registrador, por su parte, hará constar por nota al margen de la anotación de embargo la expedición de esta certificación, expresando su fecha y el procedimiento al que se refiera. El embargo se notificará por último a los acreedores afectados. En todo caso, la anotación preventiva que se practique no alterará la prelación que para el cobro de los créditos tributarios establece el artículo 77 de la LGT, a menos que se ejercite la tercería de mejor derecho, prevaleciendo el orden registral de las anotaciones de embargo.

La tercera y última consideración tiene que ver con aquellos bienes embargados que están depositados en locales de la Administración o de otros entes públicos, de entidades dedicadas a ello, o, en su defecto, de otras personas que ofrezcan garantías suficientes, e incluso del propio deudor. En este supuesto, corresponden al depositario las obligaciones de custodia y conservación convenientes, así como el derecho a la retribución convenida y al reembolso de los gastos que soporte, incurriendo en responsabilidad civil o penal, e incluso, solidaria en relación con la deuda hasta el importe de lo levantado cuando colabore o consienta el levantamiento.

\subsubsection{Valoración de los bienes embargados}

La valoración de los bienes y derechos embargados, que se realiza antes de la enajenación de los mismos y que debe notificarse al obligado tributario, corresponde a los órganos de recaudación o peritos designados por ellos, que tomarán en cuenta el valor del mercado. En caso de que el obligado al pago no esté de acuerdo con la valoración notificada, podrá proponer una valoración contradictoria en el término de 15 días, y si entre ambas valoraciones no hay una diferencia mayor del 20 por 100, prevalecerá la más alta. En caso contrario, cuando la diferencia entre la suma de valores asignado a los bienes por ambas partes exceda del 20 por 100, GONZÁLEZ-CUÉLLAR SERRANO recuerda que "se convocará al deudor para dirimir sus diferencias de valoración y, si se logra el acuerdo, hacer

\footnotetext{
${ }^{237}$ Expresa literalmente este precepto que, una vez "efectuado el embargo de los bienes o derechos, la diligencia se notificará al obligado tributario y, en su caso, al tercero titular, poseedor o depositario de los bienes si no se hubiesen llevado a cabo con ellos las actuaciones, así como al cónyuge del obligado tributario cuando los bienes embargados sean gananciales y a los condueños o cotitulares de los mismos".
} 
una sola"238. De lo contrario, sino se logra el acuerdo, el RGR en el apartado 4 del artículo 97 determina que el órgano de recaudación competente debe solicitar una nueva valoración pericial en plazo no superior a 15 días. A efectos de la designación del perito, se estará a lo establecido en los párrafos primero y segundo del tercer apartado del artículo 135 de la LGT, que regula la tasación pericial contradictoria. Esta valoración pericial habrá de estar comprendida entre los límites de las efectuadas anteriormente y será la definitivamente aplicable.

La valoración que resulte al final servirá de tipo en la subasta o concurso, previa consideración de las cargas o gravámenes u obligaciones que puedan recaer sobre los bienes embargados. Cuando se trate de bienes muebles podrán formarse lotes, sean o no de análoga naturaleza, para facilitar la licitación.

\subsubsection{Enajenación de los bienes embargados}

Una vez embargados los bienes o derechos del deudor se procede a la realización de los mismos. A estos efectos, los órganos de recaudación deben enajenar los bienes embargados para después aplicar el contenido a la deuda insatisfecha. Sin embargo, existen dos situaciones en las que no se pueden enajenar los bienes embargados. La primera se produce cuando el deudor paga la deuda junto con las costas del procedimiento de apremio, extinguiéndose de esta forma la deuda que tenía frente a la Administración tributaria, tal como indica el apartado 4 del artículo 172 de la LGT. La segunda excepción se contiene en el apartado 3 del artículo 172 de la LGT, y se trata, fundamentalmente, de una suspensión transitoria. Por mandato de este precepto, la Hacienda Pública no podrá proceder a la enajenación de los bienes y derechos embargados en el curso del procedimiento de apremio hasta que el acto de liquidación de la deuda tributaria ejecutada sea firme, es decir, hasta que se hayan agotado los recursos administrativos contra él, aunque esta última regla, a su vez, tiene varias excepciones: cuando tenga lugar un supuesto de fuerza mayor; cuando se hayan embargado bienes perecederos; cuando exista un riesgo de pérdida inminente de valor de los bienes o derechos embargados; y cuando el contribuyente solicite de forma expresa la enajenación.

El procedimiento a seguir para la enajenación de los bienes, siguiendo el orden establecido para el embargo, tal como establece el apartado cuarto del artículo 99 del RGR, es el dispuesto en el artículo 172 de la LGT, esto es, la subasta, el concurso, y la adjudicación directa en los casos y condiciones que se fijen reglamentariamente.

Del mismo modo dispone el citado precepto que el acuerdo de enajenación únicamente podrá impugnarse si las diligencias de embargo se han tenido por notificadas de acuerdo con lo dispuesto en el apartado 3 del artículo 112 de la LGT. En ese caso, contra el acuerdo de enajenación sólo serán admisibles los motivos de impugnación contra las diligencias de embargo a los que se refiere el apartado 3 del artículo 170 de la LGT.

El RGR desarrolla los procedimientos de enajenación de los bienes embargados en los artículos 97 a 107. El presupuesto necesario para que se realicen los bienes embargados es que el acto administrativo de liquidación de la deuda ejecutada haya adquirido firmeza, pues en caso contrario la enajenación se paraliza hasta que se produzca esta circunstancia.

${ }^{238}$ GONZÁLEZ CUÉLLAR-SERRANO, M. L., Los procedimientos tributarios: su terminación transaccional, Colex, Madrid, 1998, pág. 411. 


\section{A. La subasta pública}

El apartado 2 del artículo 100 del RGR prevé que

“el procedimiento ordinario de adjudicación de bienes embargados será la subasta pública, que procederá siempre que no sea expresamente aplicable otra forma de enajenación".

Se trata del medio más típico de enajenación de los bienes embargados. Los interesados podrán participar en los procedimientos de enajenación de los bienes embargados a través de los medios electrónicos, informáticos y telemáticos que se aprueben por el órgano competente.

El procedimiento a seguir para realizar la subasta se describe en el artículo 101 del RGR. En primer lugar, será el órgano de recaudación competente el que acordará la enajenación mediante subasta de los bienes embargados que estime bastantes para cubrir suficientemente el débito perseguido y las costas del procedimiento y evitará, en lo posible, la venta de los de valor notoriamente superior al de los débitos, sin perjuicio de que posteriormente autorice la enajenación de los que sean precisos.

El acuerdo de enajenación deberá contener los datos identificativos del deudor y de los bienes a subastar, el día, hora y lugar en que se celebrará la subasta, y la posibilidad de participar en la subasta por vía telemática. Si se trata de bienes inmuebles para los que el tipo de subasta exceda de la cifra que se determine por la Administración tributaria, en el acuerdo de enajenación deberá constar si aquellos adjudicatarios que ejerciten la opción prevista en el artículo 111 del RGR pueden obtener autorización para efectuar el pago del precio de remate el mismo día en que se produzca el otorgamiento de la escritura pública de venta. De ser así, se hará constar que quien resulte adjudicatario tiene que comunicar de forma expresa que desea acogerse a esta forma de pago en el mismo momento en que solicita el otorgamiento de la escritura pública de venta. Asimismo, se indicará si la autorización puede estar condicionada por decisión de la Mesa de subasta a que quien resulte adjudicatario deba constituir en el plazo improrrogable de los 10 días siguientes a la adjudicación un depósito adicional. Las decisiones que se adopten en relación con esta autorización se considerarán actos de trámite y no serán susceptibles de reclamación o recurso alguno.

El acuerdo de enajenación será notificado al obligado al pago; a su cónyuge si se trata de bienes gananciales o si se trata de la vivienda habitual; a los acreedores hipotecarios, pignoraticios y, en general, a los titulares de derechos inscritos en el correspondiente Registro Público con posterioridad al derecho de la Hacienda Pública que figuren en la certificación de cargas emitidas al efecto; al depositario, si es ajeno a la Administración tributaria; y en caso de existir, a los copropietarios y terceros poseedores de los bienes a subastar. En el supuesto de subastas de derechos de cesión del contrato de arrendamiento de locales de negocio se notificará también al arrendador o administrador de la finca, con los efectos y requisitos establecidos en la Ley 24/1994, de 24 de noviembre, de Arrendamientos Urbanos.

En la notificación se hará constar que en cualquier momento anterior al de la adjudicación de los bienes podrán liberarse los bienes embargados mediante el pago de las cantidades establecidas en el apartado 1 del artículo 169 de la LGT. 
El anuncio de la subasta es obligatorio y se realizará en las oficinas del órgano de recaudación al que esté adscrito el obligado al pago. Cuando el valor de los bienes supere la cuantía que se fije por orden del Ministro de Economía y Hacienda, se anunciará en el boletín oficial correspondiente a la demarcación territorial del órgano de recaudación al que esté adscrito el obligado al pago y, en su caso, en el Boletín Oficial del Estado. El órgano de recaudación competente podrá también acordar la publicación en los ayuntamientos de los lugares donde estén situados los bienes, en medios de comunicación de gran difusión, en publicaciones especializadas y en cualquier otro medio adecuado al efecto y, si se trata de bienes inmuebles, en el boletín oficial correspondiente al lugar donde estén situados.

El adjudicatario tiene la obligación de entregar en el acto de la adjudicación o dentro de los 15 días siguientes la diferencia entre el depósito constituido y el precio de adjudicación. En su caso, se advertirá de la posibilidad de que el pago de la cantidad señalada podrá efectuarse el mismo día en que se produzca el otorgamiento de la escritura pública de venta, así como de la posibilidad de que tal autorización esté condicionada a que se constituya un depósito adicional, si así lo acuerda la Mesa de subasta.

Finalmente, cuando la subasta se realice a través de empresas o profesionales especializados, se hará constar esta circunstancia y las especialidades de la subasta. Asimismo, se precisará cualquier otra circunstancia, cláusula o condición que deba aplicarse en la subasta, así como todas aquellas condiciones relevantes que pudieran establecerse para el trámite de adjudicación directa.

\section{B. El concurso}

El concurso es el segundo de los procedimientos que la ley reconoce para la realización de los bienes embargados. Este procedimiento sólo se admite por interés público o para evitar posibles perturbaciones en el mercado, según estipula el artículo 106 del RGR, y constituye un medio especial de enajenación de bienes muebles, que no puede aplicarse en ningún caso a los inmuebles.

La convocatoria del concurso se publicará en el Boletín Oficial del Estado y en el boletín oficial correspondiente a la demarcación territorial del órgano de recaudación al que esté adscrito el obligado al pago. En la convocatoria se hará constar los bienes objeto de enajenación; el plazo y las condiciones para concurrir; la forma de pago; el depósito a realizar; y se señalarán, si las hubiese, las condiciones especiales del concurso, referidas tanto a los requisitos de los concursantes como a la retirada y utilización de los bienes enajenados. En todo caso, la normativa aplicable a la subasta funciona con carácter subsidiario para los supuestos de enajenación mediante concurso.

Por último, terminado el plazo de admisión de ofertas, el órgano competente decidirá adjudicar el concurso o declararlo desierto en un plazo de cinco días. La adjudicación se hará a la oferta más ventajosa, teniendo en cuenta no sólo el aspecto económico, sino también el cumplimiento de todas las condiciones incluidas en la convocatoria. En caso de que el concurso se declare desierto podrá procederse posteriormente a la adjudicación directa. 


\section{$\underline{\text { C. La adjudicación directa }}$}

La adjudicación directa, como tercer procedimiento de enajenación de bienes embargados, sólo se aplica cuando queden bienes o derechos sin adjudicar después de haber realizado la subasta o el concurso, cuando se trate de productos perecederos o cuando existan otras razones de urgencia, justificadas en el expediente, y en otros casos en que no sea posible o no convenga promover la concurrencia, por razones justificadas en el expediente (artículo 107 del RGR).

Dentro de las reglas que sustentan el régimen de la adjudicación directa se determina que, si se trata de bienes perecederos, en el acuerdo de enajenación el órgano competente podrá establecer los límites y condiciones de la adjudicación directa y se podrá, en este caso, prescindir de la propuesta de adjudicación a que se refiere el apartado 5 del artículo 107 del RGR.

El órgano de recaudación competente procederá en el plazo de seis meses a realizar las gestiones conducentes a la adjudicación directa de los bienes en las mejores condiciones económicas, para lo que utilizará los medios que considere más ágiles y efectivos, y podrá exigir a los interesados un depósito en la cuantía que estime adecuada.

El precio mínimo de adjudicación será el tipo del concurso o la subasta para los casos donde existan bienes que hayan sido objeto de concurso o de subasta con una sola licitación, pero cuando los bienes hayan sido objeto de subasta con dos licitaciones no existirá precio mínimo. Finalmente, cuando los bienes no hayan sido objeto de concurso o subasta, éstos se valorarán con referencia a los precios de mercado y se tratará de obtener, al menos, tres ofertas por ellos, de manera que si las ofertas no alcanzan el valor señalado podrán adjudicarse sin precio mínimo.

En función de las ofertas presentadas se formulará, en su caso, propuesta de adjudicación por el órgano de recaudación competente. Transcurrido el plazo a que se refiere el apartado 3 del artículo 107 del RGR sin haberse dictado acuerdo de adjudicación, se dará por concluido dicho trámite. La adjudicación se formalizará mediante acta en el caso del inciso a) apartado 1 del artículo 107 del RGR, por tratarse de bienes o derechos que quedaron sin adjudicar, y por resolución del órgano de recaudación competente en los demás casos, y en ambos casos los bienes serán entregados al adjudicatario una vez que haya sido hecho efectivo el importe procedente. De la misma manera que sucede en el concurso, aquellos aspectos que no estén previstos expresamente se someterán a las reglas establecidas para la enajenación por subasta que resulten aplicables.

Hay que tener en cuenta, finalmente, que transcurrido el trámite de adjudicación directa se adjudicará el bien o derecho a cualquier interesado que satisfaga el importe del tipo de la última subasta celebrada antes de que se acuerde la adjudicación de los bienes o derechos a la Hacienda Pública.

\subsubsection{Terminación}

La LGT regula uno de los aspectos más importantes para cualquier procedimiento, en este caso, la terminación del procedimiento de apremio. La diferencia con la ley anterior radica en que ésta no preveía la terminación del procedimiento de apremio en un sólo artículo, sino que podía extraerse del contenido de varios de sus preceptos. Según la ley actual, el procedimiento de apremio terminará por cualquiera de las tres formas que reconoce el artículo 173 de la LGT, es decir, con el pago de la 
cantidad debida a que se refiere el apartado 1 del artículo 169 de la LGT; con el acuerdo que declare el crédito total o parcialmente incobrable, una vez declarados fallidos todos los obligados al pago; o por medio del acuerdo de haber quedado extinguida la deuda por cualquier otra causa.

\subsubsection{Terminación del procedimiento de apremio por el pago de la cantidad debida}

El cobro de las cantidades adeudadas es el fin que se persigue con el procedimiento de apremio, y por ello el pago de la cantidad debida es la primera de las formas de terminación que aparecen recogidas en el artículo 173 de la LGT, que a su vez remite al apartado primero del artículo 169 de la LGT. Si se produce esta circunstancia, deberán liquidarse los intereses y los gastos, destinar lo obtenido de los bienes o derechos embargados al pago de la deuda tributaria, levantarse el embargo de los bienes y derechos que no hubieran sido enajenados y devolver al obligado tanto los bienes no adjudicados que tuviera la Administración tributaria como el remanente que hubiera quedado.

Sin embargo, en la práctica es frecuente que el procedimiento de apremio no sirva para obtener fondos suficientes y pagar toda la deuda. En este caso, TEJERIZO LÓPEZ distingue dos supuestos diferentes: "que el procedimiento hubiera servido para exigir varias deudas; y otro, que la cantidad obtenida no hubiera sido bastante para satisfacer todos los componentes de una sola deuda. Ambos casos, (...) aunque presentan una problemática distinta, tienen en común que el importe obtenido en el procedimiento de apremio se aplicará en primer lugar a las costas"239.

En el supuesto de que existan varias deudas y el pago sea insuficiente, debemos recordar las reglas de imputación de pago que analizamos anteriormente ${ }^{240}$. En síntesis, después de satisfacer las costas del procedimiento, en primer lugar, se aplicarán las cantidades obtenidas que están afectadas singularmente al pago de determinadas deudas (garantizadas). Una vez aplicadas éstas, se tendrán en cuenta las referencias genéricas previstas en beneficio de determinados créditos. Y finalmente, sólo si queda sobrante después de haber realizado las operaciones anteriores, este remanente se aplicará a cubrir los créditos siguiendo el orden de antigüedad de los mismos determinados según su fecha de exigibilidad.

Por el contrario, cuando lo obtenido del procedimiento de apremio resulte insuficiente para satisfacer todos los componentes de una sola deuda, se aplicará primero a las costas, y el resto sirve "para satisfacer, en primer término, la cuota tributara, y después las prestaciones pecuniarias accesorias, ya que de otro modo puede darse la paradoja de que la deuda tributaria no se extinga nunca"241.

\footnotetext{
239 TEJERIZO LÓPEZ, J. M., “Capítulo III., Procedimiento de Apremio”, op. cit., pág. 197.

${ }^{240}$ Vid. supra, Capítulo Primero, epígrafe 2.3. "Imputación del pago en el período ejecutivo".

${ }^{241}$ TEJERIZO LÓPEZ, J. M., “Capítulo III., Procedimiento de Apremio”, op. cit., pág. 198. Esta postura doctrinal, con la que coincidimos, es opuesta a la práctica que sigue la Administración tributaria, que aplica, una vez satisfechas las costas, el ingreso sobrante a los intereses y después a la cuota principal, siguiendo el mandato del artículo 1.173 del Código Civil. También los tribunales en alguna ocasión han encontrado acertado este proceder, como puede verse en la Sentencia del Tribunal Superior de Justicia de Extremadura de 20 de marzo de 2003 y la Sentencia de la Audiencia Nacional de 17 de noviembre de 2004.
} 
2.5.3.2. Terminación del procedimiento de apremio por acuerdo del órgano competente que declare el crédito total o parcialmente incobrable

Dentro de las causas de finalización del procedimiento de apremio, el acuerdo del órgano competente que declare el crédito total o parcialmente incobrable es una de las que mayor interés despierta, una vez declarados fallidos todos los obligados al pago. BEGOÑA DE LA MANO entiende que no estamos en este caso ante la figura de la insolvencia del deudor, porque ésta tiene un carácter subjetivo y sólo afecta a este sujeto, sin tener en cuenta que "existen otros obligados tributarios que responden solidariamente o subsidiariamente con el principal, de modo que la Administración deberá ejercitar las acciones correspondientes ante los mismos y solamente en cuanto tampoco de éstos se pueda obtener el cobro, procederá la declaración del crédito incobrable. Además la prueba de la concurrencia de estas circunstancias se exige solamente de una manera formal, respecto de los datos que consten en la Administración, puesto que una prueba absoluta perjudicaría los intereses públicos que verían retardada su posibilidad de actuar frente a otros responsables"242.

La declaración de fallido del deudor principal, ya fuera por desconocerse su paradero, o por no poseer bienes embargables, o si los tiene, por no ser éstos suficientes para cancelar totalmente la deuda, se derivará la actuación contra los responsables. Sólo si no existieran responsables se declarará el crédito incobrable, se dará baja en cuentas al deudor, y se notificará al Registro Mercantil si el obligado estuviera inscrito en éste. En este mismo caso, si se ha declarado fallido el deudor, se consideran vencidos los créditos de posterior vencimiento y se dan de baja por referencia a aquella declaración, siempre que no hubiera otros obligados respecto al mismo, según el artículo 62 del RGR.

Por último, en los supuestos donde se haya declarado el crédito incobrable, si dentro del plazo de prescripción se tiene conocimiento de la solvencia sobrevenida de algún obligado al pago, la Dependencia de Recaudación reanudará el procedimiento de apremio, comunicándolo nuevamente al gestor para que proceda a efectuar un nueva liquidación de los créditos dados de baja y emitiéndose los correspondientes títulos ejecutivos de acuerdo con la situación que tenían aquellos cuando se declaró fallido el deudor principal (artículos 173 de la LGT y 63 del RGR).

2.5.3.3. Terminación del procedimiento de apremio por las causas generales de terminación de los procedimientos tributarios

La tercera de las posibilidades de terminación del procedimiento de apremio, que puede incluirse dentro de la letra c) del primer apartado del artículo 173 de la LGT, viene dada por los supuestos que prevé el artículo 100 de la LGT que regula la terminación de los procedimientos tributarios, en cuyo seno se inserta el procedimiento tributario de recaudación en cualquiera de sus dos períodos.

El apartado primero del artículo 100 de la LGT determina como formas de terminación de los procedimientos tributarios, en general: la resolución; el desistimiento; la renuncia al derecho en que se fundamente la solicitud; la imposibilidad material de continuar el procedimiento por causas sobrevenidas; la caducidad; el cumplimiento de la obligación que hubiera sido objeto de

\footnotetext{
${ }^{242}$ BEGOÑA DE LA MANO, B., "Sección 4 $4^{\text {a }}$ - Otras formas de extinción de la deuda tributaria. Capítulo IV- La deuda tributaria. Título II- Los tributos”, op. cit., pág. 665.
} 
requerimiento; y cualquier otra causa prevista en el ordenamiento tributario. De las causas que se relacionan en este apartado, el desistimiento del obligado tributario y la renuncia al derecho del crédito de la Administración tributaria son causas incompatibles con la finalidad del procedimiento de recaudación y, por lo tanto, entendemos que no podrán configurarse como causas de terminación del procedimiento de recaudación.

Como puede verse, las causas que establece la LGT para la terminación de los procedimientos tributarios tienen un carácter extensivo, y su composición y contenido se adaptan a los mandatos que se recogen para los procedimientos administrativos en el artículo 87 de la LRJ-PAC. En cualquier caso, el número 2 del artículo 100 de la LGT, que concibe la resolución como la contestación efectuada de forma automatizada por la Administración tributaria en aquellos procedimientos en que esté prevista esta forma de terminación, no puede constituir una causa de finalización aplicable al procedimiento de recaudación en la vía de apremio $^{243}$.

\subsubsection{Impugnación}

Al ser el procedimiento de apremio un procedimiento ejecutivo se derivan importantes limitaciones a la hora de contemplar la suspensión del mismo. Como afirma DE MIGUEL ARIAS, "a pesar de existir diversos mecanismos en orden a impugnar los embargos practicados, las especialidades del procedimiento de apremio -caracterizado por su carácter ejecutivo- determinan importantes limitaciones en este ámbito; así en la esfera de la ejecución forzosa, la impugnación presenta un carácter tasado, no resultando posible (...) discutir cuestiones relativas al nacimiento o contenido del débito tributario perseguido una vez iniciada la vía de apremio"244. En este sentido, para discrepar sobre el apremio es necesario, siguiendo la distinción tradicionalmente asumida por la doctrina ${ }^{245}$, realizar una distinción entre las controversias que puedan plantearse sobre su pertinencia y las que se fundamenten en la concreción de cada una de las fases y actuaciones del procedimiento.

La primera de la vías mencionadas constituye un medio de reacción frente al procedimiento de apremio que puede ejercitarse cuando existen motivos que lo hacen improcedente, con el objetivo de que la ejecución forzosa no se realice sobre todos o algunos bienes del obligado tributario ${ }^{246}$. Por el contrario, la segunda de las vías se presenta como la impugnación de los "actos irregulares que el ejecutor puede llevar a cabo, en perjuicio del deudor o del tercero", es decir, de las actuaciones que

\footnotetext{
${ }^{243}$ GALAPERO FLORES, R., El procedimiento de recaudación de los tributos. Estudio de su regulación en la Ley General Tributaria y en el Reglamento General de Recaudación, op. cit., pág. 181.

${ }^{244}$ DE MIGUEL ARIAS, S., La práctica del embargo para el cobro de la deuda tributaria, op. cit., pág. 377 y 378 . En este mismo sentido, MARTÍN QUERALT, J., "La suspensión de los procedimientos recaudatorios", op. cit., pág. 85; SANZ LARRUGA, F. J., El procedimiento administrativo de apremio, op. cit., pág. 342; PÉREZ ROYO, F y AGUALLO AVILÉS, A., Comentarios a la Reforma de la Ley General Tributaria, op. cit., pág. 605; ALONSO MURILLO, F. y PÉREZ DE VEGA, L. M., “Actuaciones y procedimientos de recaudación", op. cit., pág. 741.

${ }^{245}$ Entre otros, SANZ LARRUGA, F. J., El procedimiento administrativo de apremio, op. cit., pág. 342; LÓPEZ DÍAZ, A., La recaudación de deudas tributarias en vía de apremio, op. cit., pág. 410 y ss.; SERRANO ANTÓN, F., "Capítulo 11. Recaudación tributaria", op. cit., pág. 501; MARTÍN CANO, R. A., "Motivos de oposición a la providencia de apremio", Nueva Fiscalidad, núm. 5, 2007, pág. 100; TEJERIZO LÓPEZ, J. M., “Capítulo III., Procedimiento de Apremio”, op. cit., pág. 207.

${ }^{246}$ SANZ LARRUGA, F. J., El procedimiento administrativo de apremio, op. cit., pág. 343.
} 
forman parte del procedimiento de ejecución realizadas "con infracción de las normas del

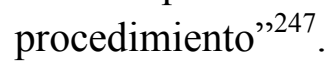

Teniendo en cuenta lo que determina la LGT y las características que acompañan al procedimiento de apremio, podemos afirmar que la oposición a ese procedimiento puede plantearse en dos momentos procedimentales diferentes, frente a la providencia de apremio o contra la diligencia de embargo, aunque el acuerdo de enajenación de los bienes embargados también puede impugnarse cuando el embargo se entienda notificado por no haber comparecido el obligado tributario o su representante, tal como se indica en el segundo de los párrafos del apartado primero del artículo 172 de la LGT. En efecto, según este último precepto, el acuerdo de enajenación de los bienes o derechos embargados sólo podrá ser impugnado si las diligencias del embargo se han tenido por notificadas de acuerdo con lo dispuesto en el número 3 del artículo 112 de la LGT. Este último precepto determina las reglas a aplicar cuando un acto deba entenderse notificado por incomparecencia de los interesados, y dispone que por no haber comparecido el obligado tributario o su representante se tendrá por notificado al primero de estos sujetos de las sucesivas actuaciones y diligencias del procedimiento o cualquiera de sus trámites, manteniéndose el derecho que asiste al obligado a comparecer en cualquier momento del mismo ${ }^{248}$.

\subsubsection{Sujetos legitimados para impugnar el procedimiento de apremio}

La LGT no determina expresamente los sujetos que están legitimados para oponerse al procedimiento de apremio. Es el RGR el que prevé en el apartado 5 del artículo 76 que

"El embargo deberá ejecutarse en sus estrictos términos, sin perjuicio de que el obligado al pago pueda interponer recurso o reclamación económicoadministrativa si considera que se incurre en alguna de las causas del artículo 170.3 de la Ley 58/2003, de 17 de diciembre, General Tributaria".

De estos postulados se infiere que sólo el deudor está facultado para oponerse al procedimiento de apremio. Sin embargo, asumimos la posición DE MIGUEL ARIAS, que entiende que la definición de los sujetos legitimados para impugnar el procedimiento ejecutivo debe dilucidarse de las reglas generales atinentes a los recursos ${ }^{249}$. En este sentido, el apartado primero del artículo 232 de la LGT dispone que están legitimados para promover reclamaciones económico-administrativas los obligados tributarios y los sujetos infractores y cualquier otra persona cuyos intereses legítimos resulten afectados por el acto o la actuación tributaria. Junto a este precepto, y con carácter general, debe interpretarse también el apartado primero del artículo 31 de la LRJ-PAC, que considera interesados en el procedimiento administrativo a quienes lo promuevan como titulares de derechos o intereses legítimos individuales y colectivos.

\footnotetext{
${ }^{247}$ FENECH, M., Principios del Derecho Procesal Tributario, Vol. III, Bosch, Barcelona, 1951, pág. 45.

${ }^{248}$ TEJERIZO LÓPEZ se muestra crítico con este precepto por dos motivos: por considerarlo una contradicción flagrante con lo que prevé el apartado 3 del artículo 112 de la LGT, al que expresamente se remite, y que exige "que el acuerdo de enajenación de los bienes sea notificado, aunque los trámites previos se hubieran llevado a cabo en ausencia del interesado", y por limitarse "a reproducir los motivos de impugnación de la diligencia de embargo, que es también inútil" (TEJERIZO LÓPEZ, J. M., "Capítulo VII. Procedimientos de recaudación", op. cit., pág. 649).

${ }^{249}$ DE MIGUEL ARIAS, S., La práctica del embargo para el cobro de la deuda tributaria, op. cit., pág. 382.
} 
La mayoría de la doctrina aboga por que la legitimación para impugnar el procedimiento ejecutivo favorezca no sólo al deudor tributario, sino también a otras personas implicadas en dicho procedimiento exclusivamente contra aquellos actos que les resulten gravosos ${ }^{250}$. Sin embargo, DE MIGUEL ARIAS alerta sobre la posibilidad de reconocer el derecho a la impugnación a quien no es el deudor tributario, "dado que, en la inmensa mayoría de los casos, dicho sujeto no tiene por qué conocer las vicisitudes relativas al procedimiento de apremio que podría comportar la incorrección de la traba efectuada" 251 .

En definitiva, al procedimiento de apremio podrá oponerse no sólo el deudor tributario, sino también cualquier tercero que se encuentre afectado por alguna o algunas de las actuaciones que se desarrollen dentro del procedimiento ejecutivo. En este último caso, la impugnación sólo puede recaer sobre la diligencia de embargo y manifestarse a través de la interposición de una tercería de dominio o de mejor derecho.

\subsubsection{Impugnación de la providencia de apremio}

El artículo 167 de la LGT contiene una enumeración tasada de los motivos de oposición a la providencia de apremio. Según el apartado tercero de este precepto, constituyen motivos para impugnar la providencia de apremio: la extinción total de la deuda o la prescripción del derecho a exigir el pago; la solicitud de aplazamiento, fraccionamiento o compensación en período voluntario y otras causas de suspensión del procedimiento de recaudación; la falta de notificación de la liquidación; la anulación de la liquidación; y el error u omisión en el contenido de la providencia de apremio que impida la identificación del deudor o de la deuda apremiada.

Tal como se aprecia, en esta fase del procedimiento de recaudación no es posible, en principio, plantear discusión alguna sobre aspectos materiales de la liquidación, principalmente sobre su procedencia y corrección. Sin embargo, la jurisprudencia se ha mostrado vacilante a la hora de enjuiciar los límites de los motivos de impugnación de la providencia de apremio. En este sentido, se observan dos posturas jurisprudenciales que valoran de manera diferente los límites que presentan los motivos de impugnación de la providencia de apremio: por una parte, está la postura que considera los motivos legales como una lista cerrada, destacando el carácter ejecutivo y no declarativo que caracteriza al procedimiento de apremio, postura que sigue presente en el espíritu de la LGT y se encuentra en numerosas Sentencias del Tribunal Supremo ${ }^{252}$.

Frente a esta postura se encuentra otra que es más respetuosa con los derechos de los interesados y que aboga por una apertura de los motivos de oposición al apremio, sobre todo cuando el proceso está viciado con una nulidad radical o cuando se ha realizado de una forma que podría causar indefensión. LÓPEZ DÍAZ señala que, sin encajar estos motivos en la letra de la norma (se refiere al

\footnotetext{
${ }^{250}$ LÓPEZ DÍAZ, A., La recaudación de deudas tributarias en vía de apremio, op. cit., pág. 429; MARTÍN CANO, R. A., "Motivos de oposición a la providencia de apremio", op. cit., pág. 123.

${ }^{251}$ DE MIGUEL ARIAS, S., La práctica del embargo para el cobro de la deuda tributaria, op. cit., pág. 382.

${ }^{252}$ Por todas, vid. las más recientes Sentencias del Tribunal Supremo de 22 de julio de 2005 y de 28 de octubre de 2005. Asumen esta misma doctrina varias Sentencias de los Tribunales Superiores de Justicia, entre otras muchas, la Sentencia del Tribunal Superior de Justicia de Andalucía, Sevilla, de 18 de enero de 2002.
} 
anterior artículo 138 de la LGT de 1963), "responden a los mismos fundamentos de las allí existentes, o bien se derivan de la propia naturaleza del procedimiento ejecutivo" ${ }^{253}$.

\subsubsection{Impugnación de la diligencia de embargo}

En relación con la impugnación de los actos que acompañan al procedimiento ejecutivo, no debería existir ninguna especificidad sobre el régimen general de impugnación de los actos de gestión tributaria. Sin embargo, la LGT, en el apartado 3 del artículo 170, incluye una serie de limitaciones para impugnar la diligencia de embargo, solamente admisible cuando se extinga la deuda o prescriba el derecho a exigir el pago; cuando falte la notificación de la providencia de apremio; cuando se produzca el incumplimiento de las normas reguladoras del embargo contenidas en la LGT; y cuando se produzca la suspensión del procedimiento de recaudación.

Del precepto al que hacemos referencia se pueden extraer algunas consideraciones generales. La primera es la posibilidad de distinguir en él motivos materiales y formales de oposición, tal como señala la doctrina ${ }^{254}$. La segunda, la similitud entre los motivos de impugnación del embargo y las causas de suspensión del procedimiento de apremio que aparecen en el segundo apartado del artículo 165 de la LGT, aunque es posible determinar diferencias entre ambos preceptos, si se tiene en cuenta que la impugnación se sustenta en la falta de algunos de aquellos requisitos, mientras que la suspensión tiene como fin, según LUCHENA MOZO, “evitar un perjuicio a los intereses de los particulares mientras se sustancia el objeto de un recurso o reclamación y hacer con ello efectivo el principio de tutela judicial efectiva" ${ }^{255}$. En tercer lugar, la similitud entre los motivos que se indican en el apartado 3 del artículo 170 de la LGT para la impugnación de la diligencia de embargo y los motivos que establece el apartado 3 del artículo 167 de la LGT para oponerse a la providencia de apremio, reiteración que encuentra acertada DE MIGUEL ARIAS, ya "que es posible que las circunstancias determinantes de la oposición acontezcan en un instante intermedio entre el inicio del apremio y la práctica del embargo. No obstante lo anterior", añade el mismo autor, "no todos los motivos de impugnación esgrimibles frente a la referida providencia pueden ser alegados contra los actos ejecutivos posteriores, siendo necesario advertir, a estos efectos, que la impugnación de la diligencia de embargo no tiene por qué comportar una oposición al procedimiento de ejecución en su conjunto, el cual podrá ser aceptado o rechazado por el obligado tributario"256. Y, finalmente, la

\footnotetext{
${ }^{253}$ LÓPEZ DÍAZ, A., Período Ejecutivo. Procedimiento de Apremio y Recargo, op. cit., pág. 113. Otros autores han expresado este mismo parecer; MARTÍN QUERALT, J., "Comentario a los artículos 136 a 139 de la LGT", en la obra Comentarios a las leyes tributarias y financieras, AMORÓS RICA, N. (director), Tomo II, Edersa, Madrid, 1983, pág. 376 a 380; ARIAS VELASCO, J., Procedimientos tributarios, Marcial Pons, Madrid, 1990, pág. 294 y 295; PEÑA ALONSO, J. L. y CORCUERA TORRES, A., La reforma de la Ley General Tributaria, op. cit., pág. 228.

${ }^{254}$ La distinción entre la oposición material y formal al embargo es puesta de manifiesto por MARTÍN QUERALT, J., "La suspensión de los procedimientos recaudatorios", op. cit., pág. 90 y 91, y "Comentario a los artículos 136 a 139 de la LGT", en la obra Comentarios a las leyes tributarias y financieras, AMORÓS RICA, N. (director), Tomo II, Edersa, Madrid, 1983, pág. 375 y ss.; SANZ LARRUGA, F. J., El procedimiento administrativo de apremio, op. cit., pág. 345 y ss.; LÓPEZ DÍAZ, A., La recaudación de deudas tributarias en vía de apremio, op. cit., pág. 412; SERRANO ANTÓN, F., "Algunas reflexiones sobre la oposición del deudor a la vía de apremio", Tribuna Fiscal, núm. 80, 1997, pág. 72 y ss.; ACEBES FERNÁNDEZ, M., Impugnación de la providencia de apremio, Bayer Hermanos S.A., Barcelona, 2000, pág. 35 y ss.; HURTADO GONZÁLEZ, J. F., "Los motivos de oposición del deudor a la providencia de apremio", Revista de Derecho Financiero y Hacienda Pública, núm. 260, 2001, pág. 455.

${ }^{255}$ LUCHENA MOZO, G. M., “La suspensión del procedimiento de apremio (I)”, Crónica Tributaria, núm. 87, 1998, pág. 110.

${ }^{256}$ DE MIGUEL ARIAS, S., La práctica del embargo para el cobro de la deuda tributaria, op. cit., pág. 386. En este mismo sentido, DAGO ELORZA, I., "Título III., Capítulo V. Actuaciones y procedimientos de recaudación”, op. cit., pág. 1170; MARTÍN CANO, R. A., "Motivos de oposición a la providencia de apremio", op. cit., pág. 121.
} 
posibilidad de aceptar otras causas de oposición que no estén previstas en sede normativa. Desde la anterior LGT de 1963 este fue uno de los debates que aparecían tanto en la doctrina como en la jurisprudencia. En esta cuestión, nosotros somos del criterio, al igual que algunos autores, de que los motivos tasados que hoy en día regula la LGT han de ser entendidos de una forma amplia, y que deberán ser consideradas otras causas de impugnación distintas a las legalmente establecidas cuando su falta de reconocimiento pudiera determinar la indefensión de los particulares ${ }^{257}$. De esta forma, el obligado tributario podrá alegar otras causas de oposición a las previstas en el apartado tercero del artículo 170 de la LGT, sin perjuicio de que además tiene siempre abierta la posibilidad de utilizar las vías impugnatorias de los procedimientos ordinarios y especiales de revisión ${ }^{258}$.

\section{EL APLAZAMIENTO O FRACCIONAMIENTO DEL PAGO}

La conveniencia de contemplar en un apartado independiente la posibilidad de que se aplace o fraccione el pago de la deuda tributaria viene determinada por su importancia, pues con ella pueden llegar a alterase los plazos de ingreso en cualquiera de los dos períodos, voluntario y ejecutivo, del procedimiento de recaudación, siempre con el objetivo último de asegurar el pago. Esta última parte del capítulo la dedicaremos al estudio de ambos mecanismos, el aplazamiento y el fraccionamiento del pago, teniendo en cuenta el período en que fueron solicitados. Serán objeto de nuestra atención las fuentes normativas del aplazamiento o fraccionamiento, los presupuestos que son necesarios para su concesión, el procedimiento que se sigue para ello, y los efectos que produce su concesión.

\subsection{CONSIDERACIONES GENERALES}

Tanto en el aplazamiento como en el fraccionamiento del pago se busca dilatar el plazo en el cual debía hacerse efectiva la deuda tributaria. Según CALVO ORTEGA "son mecanismos de ajuste y como tal tienen en cuenta (...) circunstancias concretas del deudor en un momento dado, siempre posterior a aquel en que se manifestó la capacidad económica (cierre de ejercicio, percepción de una renta, realización de una adquisición, etc.) o en el que surgió la obligación del colaborador de realizar el ingreso, 259 .

Cuando se habla de fraccionamiento se hace referencia a un pago dividido en el tiempo que se determine y a una obligación del deudor de entregar las partes en que se fragmenta la deuda total. En cambio, el aplazamiento implica un pago total en un plazo mayor. Para MORENO FERNÁNDEZ, el aplazamiento consiste en "la concesión al deudor de una obligación tributaria de un nuevo y único plazo para que haga efectivo el cumplimiento de la misma en un momento posterior al que debía

\footnotetext{
${ }^{257}$ ALLER RODRÍGUEZ, C., "Una interpretación sobre los motivos de oposición a la providencia de apremio", Crónica Tributaria, núm. 42, 1982, pág. 323 y ss.; MARTÍN QUERALT, J., "Comentario a los artículos 136 a 139 de la LGT”, op. cit., pág. 376 a 380 ; ARIAS VELASCO, J., Procedimientos tributarios, op. cit., pág. 294 y 295; CASADO OLLERO, G., FALCÓN Y TELLA, R., LOZANO SERRANO, C., y SIMÓN ACOSTA, E., "La vía de apremio", en la obra Cuestiones tributarias prácticas, 2a ed., La Ley, Madrid, 1990, pág. 606; ACEBES FERNÁNDEZ, M., Impugnación de la providencia de apremio, op. cit., pág. 95 y ss.; ALONSO MURILLO, F. y PÉREZ DE VEGA, L. M., “Actuaciones y procedimientos de recaudación”, op. cit., pág. 746; DE MIGUEL ARIAS, S., La práctica del embargo para el cobro de la deuda tributaria, op. cit., pág. 386. En la jurisprudencia, vid., entre otras; las Sentencias del Tribunal Supremo de 20 de junio de 1995 y las Sentencias de los Tribunales Superiores de Justicia de Madrid de 7 de julio de 1994 y de la Comunidad Valenciana de 27 de diciembre de 1993.

${ }^{258}$ RUBIO SOLER, C. L., "La recaudación en la nueva LGT”, op. cit., pág. 662.

${ }^{259}$ CALVO ORTEGA, R., “Capítulo VI. Aplazamiento y fraccionamiento del pago”, en la obra Los nuevos Reglamentos Tributarios, CALVO ORTEGA, R. (director), Thomson-Civitas, Navarra, 2006, pág. 240.
} 
haberlo efectuado, mientras que en el fraccionamiento, se autoriza para que cumpla su obligación por partes, otorgándole tantos nuevos plazos de pago como partes en las que se fraccione su deuda"260.

El aplazamiento y el fraccionamiento se otorgan por la Administración tributaria siempre y cuando se cumplan con los requisitos y condiciones que determine la normativa tributaria. El primer apartado del artículo 65 de la LGT y el primer apartado del artículo 44 del RGR disponen que se puede aplazar o fraccionar el pago de la deuda a solicitud del obligado tributario cuando la situación económicofinanciera de este sujeto le impida, de forma transitoria, efectuar el pago en los plazos establecidos. El precedente directo de esta regulación se encuentra en el apartado cuarto del artículo 61 de la LGT de 1963, tras la reforma operada por la Ley 25/1995, y los artículos 48 a 58 del RGR de 1990, también modificados en 1995. Como veremos más adelante, las modificaciones que ha tenido el régimen del aplazamiento y del fraccionamiento han afectado a la propia configuración de la potestad administrativa, que ha pasado de configurarse como una potestad reglada y no discrecional.

En la LGT se configuran los aspectos esenciales del aplazamiento y fraccionamiento de pago, mientras que en el desarrollo normativo reglamentario se detalla el régimen jurídico de los mismos. A partir de estas disposiciones, podemos apreciar que para la obtención del aplazamiento o fraccionamiento es necesario el cumplimiento de un requisito de doble condición. Por un lado, la condición material que se presenta ante las dificultades económicas-financieras del obligado que le impiden, de forma transitoria, efectuar el pago en los términos que se establecen para ello; y por el otro, la condición formal, que es la solicitud expresa del obligado al pago.

\subsubsection{Fuentes normativas del aplazamiento o fraccionamiento}

El régimen jurídico general del aplazamiento y fraccionamiento de la deuda tributaria se encuentra actualmente en el artículo 65 de la LGT, se desarrolla en el RGR en los artículos 44 a 54, y se completa con el artículo 13 de la LGP. Esta regulación dista de la que contenía la LGT de 1963 en el momento de su promulgación, sobre todo porque esta última norma se refería a dichas instituciones pero no preveía unas bases mínimas para llevarlas a cabo ni los supuestos que las originaban ${ }^{261}$. Es por ello que LOZANO SERRANO afirmó que se trataba de "un instrumento abandonado en manos del poder ejecutivo y de la Administración misma" ${ }^{262}$.

Existen, además, determinados supuestos de aplazamiento o fraccionamiento que se someten a una regulación específica, sin perjuicio de la aplicación supletoria de las disposiciones generales ${ }^{263}$. Así, por ejemplo, se produce un fraccionamiento automático, sin intereses, en dos partes de la deuda en el IRPF, en los términos dispuestos en el artículo 97 de la Ley 35/2006, de 28 de noviembre, del Impuesto sobre la Renta de las Personas Físicas y de modificación parcial de las leyes de los Impuestos sobre Sociedades, sobre la Renta de no Residentes y sobre el Patrimonio (en adelante

\footnotetext{
${ }^{260}$ MORENO FERNÁNDEZ, J. I., El aplazamiento en el pago de los tributos, Lex Nova, Valladolid, 1996, pág. 22.

${ }^{261}$ Sobre la evolución histórica de la normativa tributaria de esta institución, vid. LOZANO SERRANO, C., Aplazamiento y fraccionamiento de los ingresos tributarios, Cuadernos de Jurisprudencia Tributaria, Aranzadi, núm. 3, 1997, pág. 11 a 26; y MORENO FERNÁNDEZ, J. I., El aplazamiento en el pago de los tributos, op. cit., pág. 24 a 30.

${ }^{262}$ LOZANO SERRANO, C., Aplazamiento y fraccionamiento de los ingresos tributarios, op. cit., pág. 17.

${ }^{263}$ Sobre este tema, vid. RODRÍGUEZ MÁRQUEZ, J. S., El interés de demora en la Ley General Tributaria, op. cit., pág. 142 a 151; MORENO FERNÁNDEZ, J. I., El aplazamiento en el pago de los tributos, op. cit., pág. 237 a 302.
} 
LIRPF) y el artículo 62.2 del Real Decreto 439/2007, de 30 de marzo, que aprueba el reglamento de este impuesto (en adelante RIRPF), o se dispone en el propio artículo 97.5 de la LIRPF que los sucesores del causante puedan solicitar a la Administración tributaria el fraccionamiento de la parte de deuda tributaria correspondiente a las rentas que aquél tuviera pendientes de imputación.

También la normativa del ISD prevé la aplicación del procedimiento general de aplazamiento y fraccionamiento que regula el RGR para el pago del mismo, a tenor de lo que regula el artículo 37 de la Ley 29/1987, de 18 de diciembre, del ISD, sin perjuicio de lo que específicamente disponen los artículos 38 y 39 de esta ley y los artículos 79 a 85 del Real Decreto 1629/1991, de 8 de noviembre, por el que se aprueba el Reglamento del Impuesto sobre Sucesiones y Donaciones (en adelante RISD).

Por último, las Haciendas Forales tienen sus propias disposiciones para regular los aplazamientos o fraccionamientos del pago, a través de sus reglamentos de recaudación ${ }^{264}$. A su vez, las Haciendas Autonómicas son competentes para la recaudación de sus propios tributos y de los cedidos por el Estado, y algunas de estas comunidades han dictado normas que regulan el procedimiento de recaudación de manera general y el procedimiento de concesión de los aplazamientos o fraccionamientos de manera particular ${ }^{265}$.

En definitiva, podemos afirmar que el aplazamiento y fraccionamiento de las deudas tributarias gozan de un régimen jurídico general ubicado en la LGT, el RGR y la LGP, y un régimen jurídico específico previsto en la normativa de algunos impuestos, de algunas Haciendas Autonómicas, Forales y Locales, de aplicación preferente, y respecto del cual el régimen general actúa con carácter supletorio.

\subsubsection{La discrecionalidad administrativa}

La discrecionalidad administrativa en materia tributaria se encuentra en cuestiones muy concretas, como es el caso, por ejemplo, de la concesión del aplazamiento o fraccionamiento del pago de la deuda, la condonación de ésta y la aplicación del régimen sancionador. No obstante, la discrecionalidad no está presente en la totalidad del acto administrativo, aparece siempre en alguno o algunos de sus elementos, y esta situación también se manifiesta en materia de aplazamiento o fraccionamiento, donde se insertan determinados elementos reglados con otros que son discrecionales ${ }^{266}$.

\footnotetext{
${ }^{264}$ Decreto Foral 177/2001, de 2 de julio, por el que se aprueba el Reglamento de Recaudación de la Comunidad Foral de Navarra; Decreto Foral 38/2006, de 2 de agosto, por el que se aprueba el Reglamento de Recaudación del Territorio Histórico de Gipuzkoa; Decreto Foral 17/2009, del Consejo de Diputados de 17 de febrero, de modificación del Decreto Foral 48/1994, de 10 de mayo, por el que se aprueba el Reglamento General de Recaudación del Territorio Histórico de Álava; y Decreto Foral 215/2005, de 27 de diciembre, por el que se aprueba el Reglamento de Recaudación del Territorio Histórico de Bizkaia.

${ }^{265}$ A modo de ejemplo, podemos mencionar el Decreto 9/2012, de 17 de enero, por el que se determinan los órganos competentes de la Agencia Tributaria de Andalucía para el aplazamiento y fraccionamiento de deudas de derecho público de naturaleza no tributaria en período voluntario.

${ }^{266}$ Así lo entiende MORENO FERNÁNDEZ, cuando advierte que la actuación de la Administración desemboca en un único -aunque complejo- acto administrativo, en el que concurren "unas partes regladas y otras discrecionales que conviven en coexistencia pacífica las unas con las otras, pero de forma completamente dependiente" (MORENO FERNÁNDEZ, I., El aplazamiento en el pago de los tributos, op. cit., pág. 62).
} 
Durante mucho tiempo, la discrecionalidad de la Administración tributaria en materia de aplazamiento y fraccionamiento fue incuestionable y las propias leyes tributarias insistían en el carácter discrecional y graciable de la potestad administrativa en esta materia. El RGR de 1968 estipulaba en el apartado 1 del artículo 52 que

"la Administración podrá, graciable y discrecionalmente aplazar o fraccionar el pago" de la deuda "previa petición de los obligados".

La jurisprudencia fue tajante a la hora de reconocer la discrecionalidad administrativa en el ámbito del aplazamiento y el fraccionamiento del pago. Se entendía que la potestad discrecional y la graciable no sólo operaban para otorgar los aplazamientos o fraccionamientos, sino también en la apreciación de la situación de tesorería del sujeto, la estimación de la suficiencia de las garantías aportadas, y la concesión de la dispensa de éstas. No quedaba entonces mucho margen para un eventual control judicial de las actuaciones de la Administración tributaria en materia de aplazamiento y fraccionamientos, pues la única vía que podía anular una decisión en este terreno era una desviación de poder, "de perfiles bien difusos dada la amplitud de la discrecionalidad que se predica y, a mayor abundamiento, de difícil prueba por parte del interesado"267.

Ya en la década de los noventa comienza a observarse un recorte en la discrecionalidad de la Hacienda Pública. El RGR de 1990 dejó de referirse al carácter graciable de la potestad de aplazar y fraccionar el pago, para indicar en el apartado 1 del artículo 48 que podrían aplazarse o fraccionarse el pago de la deuda, tanto en el período voluntario como en el período ejecutivo, previa solicitud de los obligados, cuando su situación económico-financiera, discrecionalmente apreciada por la Administración tributaria, les impidiera transitoriamente efectuar el pago de sus débitos. También se reconoció en la LGT de 1963, tras su modificación por la Ley 25/1995, que la Administración tributaria podría aplazar o fraccionar el pago de las deudas tributarias, siempre que la situación económico-financiera del deudor le impidiera, transitoriamente, hacer frente a su pago en tiempo. De forma muy parecida se reguló esta materia en el Real Decreto Legislativo 1091/1988, de 23 de septiembre, por el que se aprueba el Texto Refundido de la LGP, en cuyo apartado 4 del artículo 34 se disponía que

"Podrán aplazarse o fraccionarse las cantidades adeudadas a la Hacienda Pública en los casos y por el procedimiento establecido en el Reglamento General de Recaudación. Dichas cantidades devengarán interés de demora”.

En las dos leyes generales financieras (la LGT y la LGP) y en el RGR vigentes en aquél momento, pues, se utilizaba un verbo (podrá) que atribuía una potestad de elección a la Administración tributaria, que para algunos autores, sin embargo, ya no era discrecional sino reglada. Al referirse al contenido de los artículos mencionados, MORENO FERNÁNDEZ escribió que, aunque las leyes del aplazamiento se referían expresamente a la adjudicación de un poder, ese poder no puede ser visto como una facultad de la Administración para actuar discrecionalmente, porque cada vez que

\footnotetext{
${ }^{267}$ LOZANO SERRANO C., Aplazamiento y fraccionamiento de los ingresos tributarios, op. cit., pág. 30.
} 
concurran las circunstancias que prevé la normativa tributaria para su concesión tendría que conceder el fraccionamiento o aplazamiento ${ }^{268}$.

PÉREZ ROYO defendió también la ausencia de potestad discrecional de la Administración tributaria en la concesión de los aplazamientos y fraccionamientos. Este autor indica que la actuación administrativa en la materia que nos ocupa no es una decisión, sino que más bien se trata "de una manifestación de voluntad por parte de la Administración, sino de una mera comprobación de un determinado hecho: comprobación que podrá exceder de la mera constatación, requiriendo una apreciación por parte del sujeto que la realiza, pero que, de ninguna manera, es libre ni depende de la potestad discrecional de la Administración"269. Asimismo, Ignacio PÉREZ ROYO mantuvo igualmente que se trataba de una potestad reglada "en cuyo ejercicio ocupa un lugar central la aplicación de un concepto jurídico indeterminado, como es la dificultad de tesorería del sujeto pasivo" 270 .

La Administración tributaria, al observar si se produce o no una dificultad transitoria de tesorería, apuntó PONT I CLEMENTE, "no ejerce una opción entre diversas posibilidades (lo que caracteriza la discrecionalidad), sino que realiza un juicio sobre si una situación de la vida real (la planteada por el solicitante del aplazamiento) es o no subsumible en una categoría legal (las dificultades de tesorería)"271. De forma similar, LOZANO SERRANO, abogó por que la potestad del aplazamiento y fraccionamiento se encauce fuera "del proceloso e incontrolable mundo de la discrecionalidad administrativa"272. Y LÓPEZ DÍAZ afirmó, teniendo en cuenta la legislación anterior, que "aun cuando la concesión o denegación del aplazamiento supone una facultad discrecional de la Administración, la existencia de un presupuesto fáctico de la misma, ajeno a la discrecionalidad, así como la propia finalidad del instituto, reducen enormemente el papel a desempeñar por el elemento subjetivo en tal decisión y permiten un control jurisdiccional amplio de dicha resolución. (...) Las dificultades de Tesorería se convierten en la única causa determinante del aplazamiento o fraccionamiento -excluyendo cualquier circunstancia-, pasando así a jugar el papel preponderante que todo presupuesto de hecho tiene asignado en la fiscalización del acto administrativo, con la consiguiente limitación de la facultad discrecional de la Administración"273.

En la actualidad, la redacción del apartado 1 del artículo 65 de la LGT y el apartado primero del artículo 44 del RGR es muy similar al de sus homólogos anteriores, aunque existen ciertas diferencias. El RGR ya no utiliza los términos "discrecionalmente apreciado por la Administración", aunque sí mantiene en su redacción el término "podrá". Al referirse a las disposiciones actuales CALVO ORTEGA afirma, al igual que la doctrina que anteriormente mencionábamos, que no existe tal discrecionalidad. "Más concretamente, la apreciación por la Administración de la situación de hecho que permite el aplazamiento (situación económica-financiera que impida, de forma transitoria,

\footnotetext{
${ }^{268}$ MORENO FERNÁNDEZ, I., El aplazamiento en el pago de los tributos, op. cit., pág. 73.

${ }^{269}$ PÉREZ ROYO, F., “El pago de la deuda tributaria”, op. cit., pág. 313.

${ }^{270}$ PÉREZ ROYO, I., “El tiempo en el pago de la prestación tributaria”, op. cit., pág. 1004.

${ }^{271}$ PONT I CLEMENTE, J. F., El pago fraccionado de los tributos, Marcial Pons, Madrid, 1993, pág. 139 y 140.

${ }^{272}$ LOZANO SERRANO C., Aplazamiento y fraccionamiento de los ingresos tributarios, op. cit., pág. 36.

${ }^{273}$ LÓPEZ DÍAZ, A., "Algunas cuestiones en relación al aplazamiento y fraccionamiento del pago en el nuevo RGR”, Impuestos, 1992, Tomo I, pág. 91 y 92.
} 
efectuar el pago en los plazos establecidos) vincula a la Administración. Siempre, obviamente, que además se presten las garantías adecuadas. Tampoco es discrecional el juicio de adecuación de las garantías presentadas. Sí lo es en los aspectos temporales: determinación de los plazos y ampliación del plazo para la presentación de garantías. Igualmente el calendario de pagos, que pueden establecerse en la propuesta de resolución, y probablemente, la modificación de algunas condiciones" ${ }^{, 74}$.

Se desprende, en definitiva, de todo lo que se acaba de decir, que la concesión del aplazamiento y fraccionamiento por la Administración tributaria se articula como una potestad reglada, susceptible de control jurisdiccional. Se trata de un acto administrativo que manifiesta elementos de discrecionalidad, como pueden ser la determinación de los plazos y las condiciones del aplazamiento, o de las cuantías cuando se refiera al fraccionamiento, pero siempre que el obligado tributario cumpla con los requisitos que determinan las normas aplicables la Administración deberá aplazar o fraccionar el pago de la deuda de este sujeto. Evidentemente, aun cuando no estamos ante una potestad discrecional de la Administración tributaria, sí es cierto que ésta deberá verificar la situación económica-financiera que motiva la solicitud del interesado para aplazar o fraccionar el pago de deuda.

\subsection{PRESUPUESTOS NECESARIOS PARA EL APLAZAMIENTO O FRACCIONAMIENTO DEL PAGO DE LA DEUDA TRIBUTARIA}

\subsubsection{Sujetos legitimados para solicitar el aplazamiento o fraccionamiento}

El aplazamiento y el fraccionamiento de pago de la deuda tributaria tienen un carácter rogado, según el apartado 1 del artículo 65 de la LGT. LÓPEZ DÍAZ afirma que "como regla general, podemos señalar que cualquier obligado al pago puede solicitar el aplazamiento o fraccionamiento, siempre que resulte directamente responsable de la obligación, por serle exigible la misma. Por su parte, en los supuestos de deudas incursas en apremio podrán solicitar aplazamiento o fraccionamiento aquellos sujetos contra los cuales se haya iniciado o pueda iniciarse el procedimiento"275.

Algunos autores no admiten la legitimación para solicitar el aplazamiento o fraccionamiento en el caso de los responsables ${ }^{276}$. Nosotros discrepamos con esta postura, pues entendemos que nada impide que, una vez que se declara la responsabilidad, si el responsable tiene dificultades de tesorería y presenta garantía suficiente, en su caso, pueda solicitar un aplazamiento en cumplimiento de esa obligación ${ }^{277}$. Este razonamiento también puede fundarse en la propia redacción del número segundo del artículo 124 del RGR, según el cual

"Las solicitudes de aplazamiento o fraccionamiento de deudas o las solicitudes de suspensión del procedimiento de recaudación efectuadas por un responsable

\footnotetext{
${ }^{274}$ CALVO ORTEGA, R., “Capítulo VI. Aplazamiento y fraccionamiento del pago”, op. cit., pág. 241.

${ }^{275}$ LÓPEZ DÍAZ, A., “Algunas cuestiones en relación al aplazamiento y fraccionamiento del pago en el nuevo RGR”, op. cit., pág. 98.

${ }^{276}$ Entre otros, PONT I CLEMENTE, J. F., El pago fraccionado de los tributos, op. cit., pág. 156, y PÉREZ ROYO, F., "El pago de la deuda tributaria", op. cit., pág. 311.

${ }^{277}$ En este sentido, LÓPEZ DÍAZ, A., “Algunas cuestiones en relación al aplazamiento y fraccionamiento del pago en el nuevo RGR”, op. cit., pág. 98, y MORENO FERNÁNDEZ, J. I., El aplazamiento en el pago de los tributos, op. cit., pág. 90.
} 
no afectarán al procedimiento de recaudación iniciado frente a los demás responsables de las deudas a las que se refieran dichas solicitudes".

La LGT sí excluye expresamente de la legitimación para solicitar el aplazamiento o fraccionamiento al retenedor y al obligado a realizar ingresos a cuenta, a tenor de lo que prevé el apartado 2 del artículo 65 de la LGT, salvo que el obligado al pago carezca de bienes suficientes para garantizar la deuda y la ejecución de su patrimonio pudiera afectar sustancialmente al mantenimiento de la capacidad productiva y del nivel de empleo de la actividad económica respectiva, o pudiera producir graves quebrantos para los intereses de la Hacienda Pública, en la forma prevista reglamentariamente.

La explicación que encuentra LOZANO SERRANO a la exclusión del retenedor es que se trata de "un tercero, que viene obligado a efectuar la retención con carácter previo al de su ingreso a la Hacienda Pública", por lo que "los fondos con que hace frente a este último no son propios, sino detraídos de los perceptores de renta. De ahí que la situación económica del retenedor no sea, en principio, relevante para impedirle el ingreso en el Tesoro, pues las cantidades a ingresar ya las habrá obtenido previamente de los sujetos pasivos de los impuestos sobre la renta a los que haya satisfecho percepciones sujetas a retención" ${ }^{278}$. A lo que apunta GONZÁLEZ SÁNCHEZ que debería entenderse con un carácter muy limitado la solicitud del aplazamiento o fraccionamiento del retenedor o del obligado a realizar el ingreso a cuenta, "pues difícilmente habría razón en el caso de tales obligados", y este mismo fundamento sirve a este autor para extender la prohibición expresa del aplazamiento y del fraccionamiento a quien deba ingresar cantidades repercutidas por obligación $\operatorname{legal}^{279}$.

Una postura diferente es la que defiende CALVO ORTEGA. Para este autor "por alto que sea el volumen de retención parece difícil que la no concesión del aplazamiento produzca unos efectos tan importantes. En mi opinión, el retenedor tiene también derecho a un aplazamiento. Hay que tener en cuenta que, (...) es un colaborador forzoso de la Administración lo que debe llevar, en principio, a una consideración equitativa de su situación" 280 .

Finalmente, también deben quedar excluidos de la legitimación para solicitar el aplazamiento o fraccionamiento del pago de la deuda los terceros ajenos a la relación jurídica tributaria, aunque tengan interés por efectuar el pago ${ }^{281}$.

\subsubsection{La determinación de las deudas aplazables o fraccionables}

De forma genérica, la LGT regula en el apartado 1 del artículo 65 que las deudas tributarias que se encuentren en período voluntario o ejecutivo podrán aplazarse o fraccionarse previa solicitud del obligado tributario. El contenido de este precepto se retoma en la normativa reglamentaria y se amplía, al disponer el apartado 2 del artículo 44 del RGR que

\footnotetext{
${ }^{278}$ LOZANO SERRANO C., Aplazamiento y fraccionamiento de los ingresos tributarios, op. cit., pág. 56.

${ }^{279}$ GONZÁLEZ SÁNCHEZ, M., “Capítulo VIII.-La extinción de la obligación tributaria”, op. cit., pág. 666.

${ }^{280}$ CALVO ORTEGA, R., “Capítulo VI. Aplazamiento y fraccionamiento del pago”, op. cit., pág. 245 y 246.

${ }^{281}$ MORENO FERNÁNDEZ, I., El aplazamiento en el pago de los tributos, op. cit., pág. 90.
} 
"Serán aplazables o fraccionables todas las deudas tributarias y demás de naturaleza pública cuya titularidad corresponda a la Hacienda pública, salvo las excepciones previstas en las leyes".

De ambos artículos se desprenden varias consideraciones. La primera es la posibilidad de solicitar el aplazamiento y fraccionamiento de cualquier tipo de deuda cuya titularidad corresponda a la Hacienda Pública. El RGR expresa claramente que se trata de todas las deudas tributarias y demás de naturaleza pública, lo que significa que podrán aplazarse tanto las deudas tributarias como aquellas que no lo $\operatorname{sean}^{282}$, a pesar de que la LGT se refiere solamente a las deudas tributarias, excluyendo por tanto las sanciones, que no forman parte de la deuda tributaria tal y como se establece en el artículo 58 de la LGT. Para el caso de las sanciones en concreto entendemos que el aplazamiento es plausible, no sólo porque el RGR otorgue esta posibilidad a todas las deudas de naturaleza pública, sino porque el propio apartado 2 del artículo 190 de la LGT determina que será aplicable a las sanciones tributarias lo dispuesto en el Capítulo IV del Título II de la LGT, a efectos del pago en general y del aplazamiento o fraccionamiento en particular.

La segunda cuestión importante a destacar es que la solicitud del aplazamiento o fraccionamiento puede hacerse tanto en período voluntario de pago como en el período ejecutivo. La presentación de dicha solicitud durante el período voluntario impedirá el inicio del período ejecutivo, pero no el devengo del interés de demora. Por su parte, las solicitudes durante el período ejecutivo podrán presentarse hasta el momento en que se notifique al obligado el acuerdo de enajenación de los bienes embargados. De presentarse la solicitud de aplazamiento o fraccionamiento en el período ejecutivo, la Administración tributaria podrá continuar el procedimiento de apremio mientras dure la tramitación del aplazamiento o fraccionamiento, pero deberán suspenderse las actuaciones de enajenación de los bienes embargados hasta la notificación de la resolución denegatoria del aplazamiento o fraccionamiento. En este caso, la deuda incluirá el recargo de apremio devengado en los términos del artículo 28 de la LGT.

Si nos centramos en las cuestiones procedimentales, es el RGR el que determina los plazos para la presentación de las solicitudes de aplazamiento o fraccionamiento. Según el inciso a) del apartado 1 del artículo 46 del RGR, las solicitudes de aplazamiento o fraccionamiento para deudas que se encuentren en período voluntario de ingreso o de presentación de la correspondiente autoliquidación se presentarán en los plazos que fijan los apartados 1, 2 y 3 del artículo 62 de la LGT, lo cual implica para las deudas tributarias resultantes de una autoliquidación que el plazo para presentar la solicitud de aplazamiento o fraccionamiento será el plazo que establezca la normativa de cada tributo ${ }^{283}$. En el

\footnotetext{
${ }^{282}$ MORENO FERNÁNDEZ se manifiesta de esta misma manera al decir que "la posibilidad de solicitar el aplazamiento existe, entonces, para cualquier clase de deudas, con independencia de que sean tributarias o no. Sin embargo, es importante tener presente que la competencia para conocer las solicitudes de aplazamiento varía, según se trate de deudas con la Administración del Estado, con la de las Comunidades Autónomas o con la de las Corporaciones Locales" (MORENO FERNÁNDEZ, I., El aplazamiento en el pago de los tributos, op. cit., pág. 96).

${ }^{283}$ Durante la vigencia de la normativa anterior, un grupo de autores defendía el criterio de que para conceder el aplazamiento en el caso de deudas autoliquidables era necesario que la Administración tributaria, previamente, dictara un acto administrativo de liquidación. En este sentido, PÉREZ ROYO, F., "El pago de la deuda tributaria", op. cit., pág. 212; LÓPEZ DÍAZ, A., "Algunas cuestiones en relación al aplazamiento y fraccionamiento del pago en el nuevo RGR”, op. cit., pág. 95 y 96; ESEVERRI MARTíNEZ, E., "Sobre la naturaleza jurídica de las autoliquidaciones tributarias", Revista Española de Derecho Financiero, núm. 37, 1983, pág. 100; CHECA GONZÁLEZ, C., La revisión de los actos tributarios en vía administrativa, Lex Nova, Valladolid, 1988, pág. 157 y ss. Por el contrario, otro sector de la doctrina entendió que a la presentación de una autoliquidación podía acompañarse la solicitud del aplazamiento, sin necesidad de esperar para su concesión a la liquidación de la deuda por la Hacienda Pública. Entre otros,
} 
caso de deudas tributarias resultantes de liquidaciones practicadas por la Administración tributaria, si la notificación de la liquidación se realiza entre los días uno y 15 de cada mes, la solicitud deberá presentarse desde la fecha de recepción de la notificación hasta el día 20 del mes posterior; mientras que si la notificación de la liquidación se realiza entre los días 16 y último de cada mes, la solicitud deberá presentarse desde la fecha de recepción de la notificación hasta el día cinco del segundo mes posterior. Finalmente, cuando se trate de deudas de notificación colectiva y periódica que no tengan establecido otro plazo en sus normas reguladoras deberá solicitarse el aplazamiento o fraccionamiento en el período comprendido entre el día uno de septiembre y el 20 de noviembre, aunque la Administración tributaria competente podrá modificar el plazo previsto anteriormente siempre que éste no sea inferior a los dos meses.

El RGR también se refiere en distintos artículos a las deudas que se liquiden mediante autoliquidación extemporáneamente. En este sentido, el inciso a) del apartado 1 del artículo 46 del RGR establece que

"en el caso de deudas resultantes de autoliquidaciones presentadas fuera de plazo, sólo se entenderá que la solicitud se presenta en período voluntario cuando la solicitud de aplazamiento o fraccionamiento se presente junto con la autoliquidación extemporánea".

Y más adelante, el RGR, en el inciso a) del primer apartado del artículo 47, dispone que no se admitirán las solicitudes de aplazamiento o fraccionamiento cuando se trate de deudas autoliquidables si con anterioridad a esta solicitud no se presentó la autoliquidación o no se hizo junto con aquélla. En definitiva, de la aplicación conjunta de ambos preceptos se deduce que cuando se trate de deudas tributarias cuya liquidación se realice por autoliquidación extemporánea, para que sea admitida la solicitud del aplazamiento o fraccionamiento el obligado deberá presentar simultáneamente la autoliquidación.

Por el contrario, si las deudas se encuentran en período ejecutivo, la solicitud se presentará, según el inciso b) del apartado 1 del artículo 46 del RGR, en cualquier momento anterior a la notificación del acuerdo de enajenación de los bienes.

La tercera cuestión a la que queremos referirnos son los supuestos en que excepcionalmente no es posible solicitar el aplazamiento o fraccionamiento de la deuda tributaria. A pesar de que la LGT de manera general reconoce que podrá aplazarse o fraccionarse cualquier tipo de deuda, el apartado 2 del artículo 65 de la LGT determina la imposibilidad de aplazar o fraccionar las deudas tributarias cuya exacción se realice por medio de efectos timbrados y las deudas correspondientes a obligaciones tributarias que deban cumplir el retenedor o el obligado a realizar ingresos a cuenta, salvo en los casos y condiciones previstos en la normativa tributaria.

MORENO FERNÁNDEZ explica que resulta imposible aplazar o fraccionar las deudas tributarias cuya exacción se realice por medio de efectos timbrados porque "tanto la excepcionalidad de la

MARTÍNEZ LAFUENTE, A., "El enjuiciamiento de los actos y de las normas emanadas de la Hacienda Pública a la luz de la Constitución", en la obra Hacienda y Constitución, Instituto de Estudios Fiscales, Madrid, 1979, pág. 519 y 520; MORENO FERNÁNDEZ, I., El aplazamiento en el pago de los tributos, op. cit., pág. 97 y 98. 
forma de recaudación de estas deudas en las que puede no existir un período de pago, como la pequeña cuantía que las mismas suelen representar para un obligado al pago, hace inadmisible el justificar problemas de tesorería" ${ }^{284}$. En cambio sí es posible aplazar o fraccionar, en determinados casos, los ingresos anticipados como los ingresos a cuenta y los pagos fraccionados. En el caso de los pagos fraccionados son los propios deudores del tributo los que deben realizarlos, por lo que pueden verse afectados por una dificultad transitoria de su situación financiera, capaz de afectar tanto al pago fraccionado como a la cuota principal del tributo. Las deudas correspondientes a retenedores y obligados a realizar ingresos a cuenta también podrán ser aplazadas o fraccionadas sólo si se produce algunas de las condiciones que señala el inciso $b$ ) del apartado 2 del artículo 82 de la LGT. Sobre este particular, la doctrina entendió que "con independencia de las razones de fondo que justifican esta norma, se debe favorecer en la medida de lo posible a quienes cumplen de forma voluntaria sus obligaciones tributarias, facilitándoles el pago en caso de que se encuentren en situaciones de iliquidez transitoria, por lo que juzgaríamos de forma positiva que la regulación reglamentaria permitiese los aplazamientos en estos casos con menores requisitos que en la actualidad"285, opinión que más tarde ha visto su reflejo en el contenido del apartado 3 del artículo 44 del RGR vigente.

Con la entrada en vigor de la Ley 7/2012 se modificó el apartado segundo del artículo 65 de la LGT, incorporando otra excepción a las antes expuestas. Nos referimos a la prohibición de aplazar o fraccionar las deudas tributarias que, de acuerdo con la LC, tengan la consideración de créditos contra la masa, en el caso de que el obligado tributario se encuentre en concurso.

\subsubsection{La existencia de dificultades económicas-financieras en el obligado al pago}

El motivo fundamental por el que se permite al obligado solicitar el aplazamiento o fraccionamiento del pago de la deuda tributaria es la existencia de dificultades económicas-financieras que, de forma transitoria, le impidan cumplir con aquella obligación. A este sujeto solicitante corresponde la prueba de que se produce esta circunstancia, y para ello deberá aportar toda la documentación que avale su situación y permita a la Administración tributaria apreciar la existencia o no de tales dificultades.

La LGT parte de la premisa de que la imposibilidad de realizar el ingreso se presenta únicamente en el plazo de ingreso que determina la normativa tributaria o la providencia de apremio, y de que el pago podrá efectuarse en un momento posterior a estos plazos, porque de no ser así no tendría sentido que se otorgase un aplazamiento o fraccionamiento. En caso contrario, lo más beneficioso para lograr la satisfacción del crédito tributario sería la adopción de medidas cautelares para evitar que se produzca la ocultación de los bienes por el deudor o la aparición de nuevos acreedores con derechos de cobro preferentes en relación con el de la Administración tributaria y continuar con el procedimiento de recaudación hasta la terminación del período ejecutivo, salvo que la Administración tributaria conceda el aplazamiento o fraccionamiento del pago condicionado a la presentación de garantías suficientes que aseguren la efectividad de su crédito. En este último supuesto, se posibilita que, una vez que finalice el plazo que se otorga por medio del aplazamiento o fraccionamiento sin que se satisfaga la deuda tributaria, la Hacienda Pública pueda ejecutar las garantías sin tener que llegar a la búsqueda y realización de los bienes del deudor. Creemos, en

\footnotetext{
${ }^{284}$ MORENO FERNÁNDEZ, I., El aplazamiento en el pago de los tributos, op. cit., pág. 100.

${ }^{285}$ SERRANO ANTÓN, F., “Capítulo 11. Recaudación tributaria”, op. cit., pág. 245.
} 
definitiva, que la actuación más apropiada de la Administración tributaria sería la concesión del aplazamiento con la presentación de garantías, porque en caso de producirse el impago de la deuda aplazada o fraccionada, siempre será posible recurrir al procedimiento de apremio sin necesidad de llegar a la enajenación de los bienes ${ }^{286}$.

Ahora bien, esta propuesta de conceder siempre el aplazamiento o fraccionamiento con independencia de que las dificultades económicas-financieras del deudor sean o no transitorias, siempre que se preste garantía, presenta problemas en dos casos.

En primer lugar, cuando se concede al deudor el aplazamiento o fraccionamiento que solicita y éste no formaliza las garantías en el plazo previsto para ello o éstas son insuficientes para satisfacer la deuda tributaria. Ante la primera situación (que no se formalicen las garantías en tiempo), la Administración tributaria podrá iniciar o continuar con el procedimiento de apremio en caso de que se incumpla con la obligación de pago. En cambio, si el problema es la insuficiencia de la garantía presentada para hacer frente a la deuda tributaria lo recomendable sería, a nuestro entender, denegar el aplazamiento o fraccionamiento y continuar con el procedimiento ejecutivo.

La segunda situación problemática se produce cuando se solicita el aplazamiento o fraccionamiento junto con la dispensa de la presentación de garantías. En este caso, lo más oportuno sería denegar la solicitud, para evitar la demora en la ejecución sobre el patrimonio del deudor. También asumimos la misma postura si el deudor manifiesta dificultades económicas-financieras estructurales que le impiden efectuar el pago en el plazo que corresponde. Lo más conveniente para la Administración tributaria sería, en este caso, no conceder el aplazamiento o fraccionamiento y continuar con el procedimiento de recaudación.

La generalización del aplazamiento del pago de las deudas que estamos defendiendo, existan dificultades económicas-financieras transitorias o no por parte del obligado tributario, también se sustenta en un argumento práctico. El obligado tributario podrá siempre presentar la solicitud de aplazamiento junto con las garantías $\mathrm{y}$, por no padecer las mencionadas dificultades, esperar la denegación del aplazamiento o fraccionamiento. A continuación, este sujeto podrá recurrir esta decisión y solicitar la suspensión de la ejecución del acto administrativo, para lo cual se garantizará la deuda en el modo previsto en la normativa revisora. De esta forma, el deudor habrá conseguido materialmente un "aplazamiento" cuya duración dependerá de él mismo, pues podrá desistir de su recurso cuando más le convenga, y sólo tendrá que satisfacer entonces los intereses de demora.

\subsubsection{Presentación de garantías}

La presentación de las garantías es un requisito básico para que se conceda el aplazamiento o fraccionamiento del pago. La dispensa de aquéllas tiene un carácter muy restrictivo, y se limita a supuestos en que las deudas son de pequeña cuantía o en que el deudor carece de bienes suficientes para presentar garantías o para obtener garantías de un tercero.

\footnotetext{
${ }^{286}$ MORENO FERNÁNDEZ, I., El aplazamiento en el pago de los tributos, op. cit., pág. 111 a 112.
} 
El artículo 82 de la LGT, que regula el aplazamiento y fraccionamiento del pago, prevé que para garantizar los aplazamientos o fraccionamientos de la deuda tributaria la Administración tributaria podrá exigir que se constituyan a su favor aval solidario de entidad de crédito o sociedad de garantía recíproca o certificado de seguro de caución.

También se desprende de la interpretación del artículo 82 de la LGT que la norma determina dos tipos de garantías: las preferentes, a las que ya hicimos mención (aval solidario de entidad de crédito o sociedad de garantía recíproca o certificado de seguro de caución) y las subsidiarias (hipoteca, prenda, fianza personal y solidaria $u$ otra que se estime suficiente). Respecto a las garantías preferentes, CALVO ORTEGA opina que su "ejecución no ofrece problemas" y que "al mismo tiempo su prestación, cuando pueda obtenerse, es relativamente fácil comparada con las garantías reales" ${ }^{287}$. En esta misma línea se expresa DAGO ELORZA, cuando afirma que "la LGT demuestra una preferencia por estas modalidades de garantías que son más fácilmente realizables y evitan al acreedor, en nuestro caso la Hacienda Pública, tener que acudir a procedimientos complejos y farragosos, y por tanto ineficientes" 288 .

El elemento que presenta mayor complejidad en este tipo de garantías preferentes es que el deudor pueda demostrar que no ha podido conseguirlas. El RGR en la letra a) del número 4 del artículo 46, establece que cuando se solicite la admisión de garantía que no consista en aval de entidad de crédito o sociedad de garantía recíproca o certificado de seguro de caución, se aportará, junto a la solicitud de aplazamiento o fraccionamiento y a los documentos a que se refieren las letras b), c) y $d$ ) del apartado 3 del propio artículo 46 del RGR, la

"declaración responsable y justificación documental de la imposibilidad de obtener dicho aval o certificado de seguro de caución, en la que consten las gestiones efectuadas para su obtención".

Las garantías subsidiarias para solicitar el aplazamiento o fraccionamiento del pago se estudian más adelante en el quinto capítulo ${ }^{289}$. Para algunos autores estas garantías ofrecen muy poca operatividad y proponen otras alternativas, como el sueldo o pensión, los seguros de vida, las rentas vitalicias o temporales, los frutos, las opciones contractuales, las mercancías o el derecho de traspaso ${ }^{290}$. CALVO ORTEGA $^{291}$ es de la opinión que las figuras más operativas en estos casos serían la inscripción de garantías en el Registro de anotaciones en cuenta a favor de la Administración tributaria, la anotación preventiva de embargo y la afección de depósitos bancarios. Y a juicio de LÓPEZ DÍAZ, se deberían admitir "los bienes embargados como garantía de la deuda, con independencia de que dicho embargo

\footnotetext{
${ }^{287}$ CALVO ORTEGA, R., “Capítulo VI. Aplazamiento y fraccionamiento del pago”, op. cit., pág. 249.

${ }^{288}$ DAGO ELORZA, I., “Título II., Capítulo IV. La deuda tributaria”, op. cit., pág. 461.

${ }^{289}$ Vid. infra., Capítulo Quinto, epígrafe 1. "Las garantías en el aplazamiento o fraccionamiento del pago".

${ }^{290}$ MORENO FERNÁNDEZ, I., El aplazamiento en el pago de los tributos, op. cit., pág. 133.

${ }^{291}$ CALVO ORTEGA, R., “Capítulo VI. Aplazamiento y fraccionamiento del pago”, op. cit., pág. 250 y 251.
} 
resulte o no inscribible en el registro público correspondiente, siempre que el valor del bien resulte suficiente para cubrir la cuantía de la deuda" ${ }^{, 292}$.

En las líneas que siguen abordamos cuestiones básicas que afectan de manera general a cualquiera de las garantías que se presentan para solicitar el aplazamiento o fraccionamiento del pago. Nos centramos para ello en el régimen jurídico de estas garantías, su alcance, su vigencia y los efectos que produce su no formalización por el obligado tributario, así como en la posibilidad de dispensar total o parcialmente su constitución.

\subsubsection{Régimen general de las garantías}

El apartado tercero del artículo 65 de la LGT establece el deber de garantizar las deudas tributarias que vayan a ser objeto de aplazamiento o fraccionamiento. Este precepto remite al artículo 82 de la LGT, que regula el régimen general de las garantías de las deudas para las que se solicita el aplazamiento o fraccionamiento. El RGR, en el inciso e) del apartado 2 del artículo 46, determina que la solicitud de aplazamiento o fraccionamiento contendrá necesariamente la garantía que se ofrece, conforme a lo dispuesto en el artículo 82 de la LGT, y más adelante reitera el mismo contenido de ese mandato al disponer el inciso a) del tercer apartado del propio artículo 46 del RGR que la solicitud de aplazamiento o fraccionamiento se deberá acompañar del compromiso de aval solidario de entidad de crédito o sociedad de garantía recíproca o de certificado de seguro de caución, que son las garantías que se prevén en el apartado 1 del artículo 82 de la LGT.

Ahora bien, el propio artículo 82 de la LGT establece dos excepciones al régimen general de las garantías que pueden presentarse para aplazar o fraccionar el pago. En primer lugar, cuando se justifique que no es posible obtener dicho aval o certificado o que su aportación compromete gravemente la viabilidad de la actividad económica, el obligado podrá aportar como garantías aquellas que consistan en hipoteca, prenda, fianza personal y solidaria u otra que se estime suficiente, en la forma que se determina reglamentariamente; pero también, y esta sería la segunda excepción, el obligado en los términos que se determinan reglamentariamente puede solicitar a la Administración tributaria que adopte medidas cautelares en sustitución de las garantías, no siendo de aplicación, en estos supuestos, lo que dispone el apartado 5 del artículo 81 de la LGT sobre el plazo en que surten efectos las medidas cautelares.

\subsubsection{Alcance de las garantías}

Según el apartado 2 del artículo 48 del RGR, la garantía cubrirá el importe de la deuda en período voluntario, los intereses de demora que genere el aplazamiento y un 25 por 100 de la suma de ambas partidas $^{293}$. Sin embargo, cuando se trate de aplazamientos o fraccionamientos del pago de una deuda

\footnotetext{
${ }^{292}$ LÓPEZ DÍAZ, A., “Algunas cuestiones en relación al aplazamiento y fraccionamiento del pago en el nuevo RGR”, op. cit., pág. 101.

${ }^{293}$ La doctrina se ha mostrado bastante crítica con la exigencia de la garantía de los intereses de demora en el caso de los aplazamientos o fraccionamientos. El profesor FALCÓN Y TELLA afirma que "cuando no existe un retraso culpable resulta desproporcionada la exigencia de un interés superior al legal, ya que mal puede decirse que con esta medida pretenda evitarse un retraso masivo en el pago de los tributos" (FALCÓN Y TELLA, R., "Comentario General de Jurisprudencia”, Revista Española de Derecho Financiero, núm. 68, 1990, pág. 304), y más teniendo en cuenta, como subraya GONZÁLEZ SÁNCHEZ, que en estos casos "el pago se hace fuera del plazo o período normal, pero por concesión discrecional o graciable de la Administración y no por falta de pago intencional del sujeto obligado al mismo" (GONZÁLEZ SÁNCHEZ, M., “Art. 58”, op. cit., pág. 73). PONT I CLEMENTE fundamenta sus críticas sobre la misma materia también partiendo del carácter no moroso que presentan los supuestos de aplazamiento y fraccionamiento (PONT I
} 
que se garantiza en su totalidad mediante aval solidario de entidad de crédito o sociedad de garantía recíproca o mediante certificado de seguro de caución, el interés de demora exigible será el interés legal (segundo párrafo del apartado 6 del artículo 26 de la LGT), en un intento de favorecer la constitución de garantías de fácil ejecución en el supuesto de producirse el impago.

Cuando la solicitud sea de fraccionamiento podrá constituirse una única garantía para la totalidad de las fracciones que puedan acordarse o bien garantías parciales e independientes para una o varias fracciones. Lo importante es que la garantía cubra el importe de las fracciones a que se refiera, incluyendo el importe principal e intereses de demora, y que se incorpore a las fracciones el 25 por 100 de la suma de ambas partidas.

El apartado 4 del artículo 48 del RGR faculta al órgano competente para la tramitación del aplazamiento o fraccionamiento para que aprecie la suficiencia económica y jurídica de las garantías $^{294}$, y para que, cuando dicha apreciación presente especial complejidad, pueda solicitar informe de otros servicios técnicos de la Administración o contratar servicios externos. Asimismo, el órgano competente para tramitar el aplazamiento o fraccionamiento podrá solicitar informe al órgano con funciones de asesoramiento jurídico correspondiente sobre la suficiencia jurídica de la garantía ofrecida.

Si la valoración del bien ofrecido en garantía resultara insuficiente para garantizar el aplazamiento o fraccionamiento en los términos previstos en el RGR, deducidas las cargas en su caso existentes, y no se tratase de un supuesto de dispensa total o parcial de garantías del artículo 50 del RGR, se requerirá al solicitante para que en el plazo de 10 días contados a partir del día siguiente al de la notificación del requerimiento aporte garantías complementarias o bien acredite la imposibilidad de aportarlas, conforme a lo que disponen los apartados 4 y 5 del artículo 46 del RGR.

Por su parte, si el requerimiento no es atendido o, siéndolo, no se entiende complementada la garantía o suficientemente justificada la imposibilidad de complementarla, procederá la denegación de la solicitud.

Una vez que se aprecia la suficiencia económica y jurídica de las garantías, es el propio órgano competente para la tramitación del aplazamiento o fraccionamiento el que deberá aceptar la solicitud

CLEMENTE, J. F., El pago fraccionado de los tributos, op. cit., pág. 172). En cualquier caso, RODRÍGUEZ MÁRQUEZ nos recuerda que "no estamos ante la desincentivación de conductas no deseadas por el legislador. Por el contrario, éste es consciente de que resulta útil, desde un punto de vista de política recaudatoria, la concesión de facilidades de pago de las deudas tributarias. En consecuencia, prevé la posibilidad legal de obtener aplazamientos o fraccionamientos. Ahora bien, de modo paralelo, se preocupa por establecer una compensación a favor del acreedor que proteja la integridad de la deuda, así como la devolución de sus frutos. Es decir, se trata de que el obligado restituya, a la finalización del aplazamiento, una cantidad equivalente, en términos reales y no meramente nominales, a la debida al vencimiento del período voluntario, más su frutos" (RODRÍGUEZ MÁRQUEZ, J. S., El interés de demora en la Ley General Tributaria, op. cit., pág. 120).

${ }^{294}$ Entiende MORENO FERNÁNDEZ que la suficiencia económica "hace referencia al aseguramiento de una cuantía suficiente que garantice, en caso de impago y, por tanto, de una ejecución sobre el deudor, la satisfacción de todos y cada uno de los elementos integrantes de demora, en el caso de haberse solicitado el aplazamiento en período de ingreso voluntario, y del principal, el recargo de apremio e intereses de demora, en el supuesto de haberse solicitado en procedimiento de apremio". En cuanto a la suficiencia jurídica, afirma este autor, que "a la Administración solo se le exige que despliegue sus conocimientos técnicos en la materia objeto de análisis (valoración jurídica de la ejecutoriedad de la garantía), pero sin margen de libertad alguno. La suficiencia jurídica es un concepto jurídico indeterminado donde la Administración goza de un cierto margen de apreciación en orden a determinar la dicha suficiencia" (MORENO FERNÁNDEZ, I., El aplazamiento en el pago de los tributos, op. cit., pág. 136). 
mediante documento administrativo que, en su caso, será remitido a los registros públicos correspondientes para que quede constancia de su contenido.

\subsubsection{Vigencia de las garantías y efectos que produce su no formalización por el obligado tributario}

La vigencia de las garantías que se presentan para solicitar el aplazamiento o fraccionamiento de pago está condicionada al plazo o los plazos que se aseguran a través de ellas sólo cuando la garantía se constituye mediante aval o certificado de seguro de caución, y se extiende al menos en seis meses al vencimiento de dichos plazos garantizados. Ahora bien, estas garantías deberán formalizarse en el plazo de dos meses contados a partir del día siguiente al de la notificación del acuerdo de concesión del aplazamiento o fraccionamiento, cuya eficacia quedará condicionada a dicha formalización. Si transcurre el plazo anterior y el obligado tributario no formaliza las garantías, las consecuencias serán diferentes dependiendo del momento en que se solicitó el aplazamiento o fraccionamiento del pago, ya fuera en el período voluntario de pago o durante el período ejecutivo del mismo.

Si la solicitud se presentó en el período voluntario, se iniciará el período ejecutivo al día siguiente de aquél en que finaliza el plazo para la formalización de las garantías, por lo que se dará curso al procedimiento de apremio, con la exigencia del pago de la cuota principal de la deuda tributaria y el recargo del período ejecutivo. También se procederá a la liquidación de los intereses de demora devengados a partir del día siguiente al del vencimiento del plazo de ingreso en período voluntario hasta la fecha de fin del plazo para la formalización de las garantías, sin perjuicio de los que se devenguen posteriormente en virtud de lo dispuesto en el artículo 26 de la LGT. Este último artículo prevé en el segundo párrafo del apartado cuarto una excepción a la regla general que aparece en el primer párrafo del mismo apartado (que determina la no exigencia del interés de demora desde la fecha que se produzca el incumplimiento, por causas imputables a la Administración tributaria, de alguno de los plazos establecidos en la ley para que ésta dicte resolución) y se devengará el interés de demora, a pesar de que transcurra el plazo máximo para resolver las solicitudes de aplazamiento o fraccionamiento, hasta el momento en que se haga efectivo el pago de la deuda tributaria.

En cambio, si la solicitud se presenta en período ejecutivo de ingreso, y no se formalizan las garantías en el plazo de dos meses desde que se notifica el acuerdo de concesión del aplazamiento o fraccionamiento del pago, se continuará con el procedimiento de apremio.

\subsubsection{Dispensa total o parcial de la constitución de las garantías}

La dispensa total o parcial de la constitución de las garantías para la solicitud del aplazamiento o fraccionamiento del pago se regula en el apartado 2 del artículo 82 de la LGT, y beneficia a las deudas tributarias cuya cuantía sea inferior a la que se fije en la normativa tributaria; al obligado al pago que carezca de bienes suficientes para garantizar la deuda y para quien la ejecución de su patrimonio pudiera afectar sustancialmente al mantenimiento de la capacidad productiva y del nivel de empleo de la actividad económica respectiva; a los supuestos que pudieran producir graves quebrantos para los intereses de la Hacienda Pública; o a los demás casos que establezca la normativa tributaria. Esta última excepción nos remite a la dispensa total que regula el apartado primero del artículo 48 del RGR, que permite que no se exijan garantías cuando la solicitud de aplazamiento o fraccionamiento sea presentada por una Administración pública. 
En todos estos casos la exoneración de la presentación de garantías se encuentra sujeta a la apreciación de conceptos jurídicos indeterminados ${ }^{295}$, y en palabras de LÓPEZ DÍAZ exige "en comprobar que se dan las circunstancias previstas en la ley para no exigir la garantía. Concurriendo tales circunstancias, los órganos de recaudación deben abstenerse de exigir la garantía. De ahí que no se pueda hablar propiamente de dispensa, sino de una exclusión legal y con carácter general del deber de garantizar la deuda, cuando concurran las circunstancias previstas en la ley". Por ello afirma este autor que desaparece "toda discrecionalidad de la Administración a la hora de conceder o denegar la dispensa. Ni siquiera existe discrecionalidad en la valoración de los supuestos, (...) por lo que sólo existirá una solución justa, según concurran o no las circunstancias previstas en la norma"296.

Para CALVO ORTEGA, el criterio que se sigue para la adopción de la decisión de dispensar total o parcialmente la presentación de garantías en el aplazamiento o fraccionamiento no es el de la cuantía, "ya que si esto hubiese sido lo considerado por el legislador se hubiera objetivado, es decir, cuantificado". En su opinión, "se atenderá a la situación económica-financiera del deudor y en la medida en que ésta sea más desfavorable la exoneración será mayor"297.

El procedimiento que se utiliza para solventar las solicitudes de aplazamiento o fraccionamiento con dispensa total o parcial de garantías se establece en el artículo 50 del RGR. Este artículo determina, entre otras cosas, que cuando se solicite un aplazamiento o fraccionamiento con dispensa total o parcial de garantías de acuerdo con lo dispuesto en el inciso b) del apartado 2 del artículo 82 de la LGT, el órgano competente investigará la existencia de bienes o derechos susceptibles de ser aportados en garantía del aplazamiento o fraccionamiento solicitado. Si se comprueba la existencia de dichos bienes y derechos, se efectuará requerimiento al solicitante para que complemente su solicitud con la aportación de aquéllos como garantía y se le advertirá de las consecuencias para el caso de inatención o de atención insuficiente a dicho requerimiento.

Cuando se conceda el aplazamiento o fraccionamiento con dispensa total o parcial de garantías, el solicitante queda obligado durante el período a que aquél se extiende a comunicar al órgano competente para la recaudación de las deudas aplazadas o fraccionadas cualquier variación económica o patrimonial que permita garantizar la deuda. Si cambiara la situación económica o patrimonial del deudor, durante el transcurso del plazo o los plazos por los que se concedieron el aplazamiento o fraccionamiento del pago, aquél deberá formalizar en el término de dos meses las garantías suficientes que permitan asegurar su deuda tributaria. En cambio, si es la Administración tributaria quien conoce de oficio la modificación de dichas circunstancias, notificará al interesado el cambio en su situación económica o patrimonial, concediéndole un plazo de 15 días contados a partir del día siguiente al de la notificación para que alegue lo que estime conveniente. Transcurrido el plazo de alegaciones, la Hacienda Pública requerirá, en su caso, al interesado para la formalización de la garantía o para la modificación de la garantía preexistente, indicándole los bienes sobre los que debe constituirse ésta y el plazo para su formalización.

\footnotetext{
${ }^{295}$ DAGO ELORZA, I., “Título II., Capítulo IV. La deuda tributaria”, op. cit., pág. 567.

${ }^{296}$ LÓPEZ DÍAZ, A., “Algunas cuestiones en relación al aplazamiento y fraccionamiento del pago en el nuevo RGR”, op. cit., pág. 100.

${ }^{297}$ CALVO ORTEGA, R., "Capítulo VI. Aplazamiento y fraccionamiento del pago”, op. cit., pág. 251.
} 
En los supuestos de fraccionamiento en los que se solicite la concesión con dispensa parcial de garantías, de concederse la solicitud, dicha garantía parcial quedará afecta a la totalidad de las fracciones incorporadas al acuerdo y será de aplicación, en caso de incumplimiento de pago, lo dispuesto en el apartado 2 del artículo 54 del RGR. Según este artículo, si la fracción incumplida incluye deudas en período ejecutivo en el momento de presentarse la solicitud, deberá continuarse el procedimiento ejecutivo para la totalidad de las deudas incluidas en el acuerdo de fraccionamiento que se encontrasen en período ejecutivo en el momento de presentarse la solicitud, mientras que en relación con la totalidad de las deudas incluidas en el acuerdo de fraccionamiento que se encontrasen en período voluntario en el momento de presentarse la solicitud se iniciará el período ejecutivo al día siguiente del vencimiento de la fracción incumplida. Además, en todos los casos se exigirán los intereses de demora devengados a partir del día siguiente al del vencimiento del plazo de ingreso en período voluntario hasta la fecha del vencimiento de pago de la fracción incumplida.

Por el contrario, si la fracción incumplida incluye deudas en período voluntario en el momento de presentarse la solicitud, procederá respecto de dicha fracción incumplida a iniciar el procedimiento de apremio. También se exigirá el importe de dicha fracción, los intereses de demora devengados a partir del día siguiente al del vencimiento del plazo de ingreso en período voluntario hasta la fecha del vencimiento del plazo concedido y el recargo del período ejecutivo sobre la suma de ambos conceptos. De no producirse el ingreso de aquéllas cantidades se considerarán vencidas las fracciones pendientes, debiendo iniciarse el procedimiento de apremio respecto de toda la deuda. De la misma forma, también aquí se exigirán los intereses de demora devengados a partir del día siguiente al del vencimiento del plazo de ingreso en período voluntario hasta la fecha del vencimiento de pago de la fracción incumplida.

\subsubsection{Medidas cautelares en el ámbito de los aplazamientos o fraccionamientos}

Sin ánimo de exhaustividad, creemos que resulta necesario precisar algunas cuestiones particulares que manifiestan las medidas cautelares cuando se solicita que se adopten las mismas en sustitución de las garantías necesarias para conceder el aplazamiento o fraccionamiento del pago de la deuda tributaria. Cuando analizamos en el apartado anterior las garantías que exige la Administración tributaria para conceder el aplazamiento o fraccionamiento advertimos que excepcionalmente la ley permite al obligado tributario solicitar a la Hacienda Pública la adopción de medidas cautelares en lugar de aquéllas, a tenor de lo que dispone el tercer párrafo del primer apartado del artículo 82 de la LGT.

El RGR precisa que el obligado al pago puede solicitar a la Administración tributaria que adopte medidas cautelares en sustitución de las garantías si la constitución de éstas resulta excesivamente onerosa en relación con la cuantía y plazo de la deuda tributaria; si el obligado tiene solicitadas devoluciones tributarias u otros pagos a su favor; o si el obligado es titular de bienes o derechos que son susceptibles de embargo preventivo. En este último caso, si dichos bienes o derechos son susceptibles de inscripción en un Registro público, la concesión estará supeditada a la inscripción previa en el correspondiente registro.

Además indica la norma reglamentaria que la Administración tributaria debe conceder o denegar la solicitud de la sustitución de las garantías por medidas cautelares, de forma motivada, en el propio 
acuerdo que resuelve la solicitud de aplazamiento o fraccionamiento, atendiendo, entre otras circunstancias, a la situación económico-financiera del deudor o a la naturaleza del bien o derecho sobre el que se debiera adoptar la medida cautelar.

A su vez, si se produce el incumplimiento del aplazamiento o fraccionamiento se aplicará lo dispuesto con carácter general para los supuestos de falta de pago, y con carácter previo a la ejecución de la garantía, la medida cautelar que se adopte deberá ser convertida en definitiva en el procedimiento de apremio.

Finalmente, si durante el período voluntario existen indicios racionales de que, en otro caso, el cobro de la deuda tributaria se vería frustrado o gravemente dificultado y se solicita un aplazamiento o fraccionamiento con la adopción de medidas cautelares en lugar de las garantías, la Administración tributaria podrá adoptar medidas cautelares de carácter provisional para asegurar el cobro de la deuda, sin perjuicio de la resolución que pueda recaer en relación con aquélla y en tanto ésta se tramita.

\subsection{PROCEDIMIENTO PARA LA CONCESIÓN DE LOS APLAZAMIENTOS O FRACCIONAMIENTOS}

El procedimiento para la concesión de los aplazamientos o fraccionamientos se regula en los artículos 45 a 47 y 51 a 54 del RGR, y se divide en tres etapas; la solicitud del obligado tributario como requisito previo para que se inicie el procedimiento; la tramitación de dicha petición por los órganos de recaudación competentes; y la resolución de concesión o denegación del aplazamiento o fraccionamiento del pago al deudor. A cada uno de estos momentos procedimentales nos referimos seguidamente.

\subsubsection{Solicitud}

El procedimiento de aplazamiento o fraccionamiento se inicia a petición del interesado, ya sea en período voluntario de ingreso o en período ejecutivo ${ }^{298}$. En el primer caso, la solicitud se puede presentar en cualquier momento antes de que finalice el período voluntario, aunque si trata de deudas derivadas de autoliquidaciones fuera de plazo sólo se entenderá que la solicitud se ha realizado dentro del plazo voluntario cuando se presente de forma simultánea a la declaración. Si la deuda se encuentra en vía de apremio, la solicitud puede presentarse en cualquier momento anterior a la enajenación de los bienes embargados.

La solicitud del obligado deberá contener el nombre y apellidos o razón social o denominación completa del solicitante; el número de identificación fiscal y el domicilio fiscal del obligado al pago $\mathrm{y}$, en su caso, de la persona que lo represente; la identificación de la deuda cuyo aplazamiento o fraccionamiento se solicita, indicando al menos su importe, concepto y fecha de finalización del plazo de ingreso en período voluntario; las causas que motivan la solicitud de aplazamiento o

\footnotetext{
${ }^{298}$ Sobre el trámite de solicitud de aplazamiento o fraccionamiento del pago de la deuda y sus efectos vid., entre otros, CALVO ORTEGA, R., "Capítulo VI. Aplazamiento y fraccionamiento del pago", op. cit., pág. 252 a 254; LÓPEZ DÍAZ, A., "Algunas cuestiones en relación al aplazamiento y fraccionamiento del pago en el nuevo RGR”, op. cit., pág. 102 y 103; MORENO FERNÁNDEZ, I., El aplazamiento en el pago de los tributos, op. cit., pág. 165 a 169.
} 
fraccionamiento; los plazos y demás condiciones del aplazamiento o fraccionamiento que se solicita; la garantía que se ofrece; la orden de domiciliación bancaria, indicando el número de código cuenta cliente y los datos identificativos de la entidad de crédito que deba efectuar el cargo en cuenta, cuando la Administración competente para resolver haya establecido esta forma de pago obligatoriamente; y el lugar, fecha y firma del solicitante.

Además los interesados deberán entregar, junto con la solicitud, el compromiso de aval solidario de entidad de crédito o sociedad de garantía recíproca o de certificado de seguro de caución; los documentos que acrediten la representación y el lugar señalado por el obligado a efectos de notificación; y los demás documentos o justificantes que estime oportunos. En particular, deberá justificarse la existencia de dificultades económico-financieras que impidan de forma transitoria efectuar el pago en el plazo establecido. Si la deuda tributaria cuyo aplazamiento o fraccionamiento se solicita ha sido determinada mediante autoliquidación, el interesado deberá presentar el modelo oficial de ésta, debidamente cumplimentado, salvo que no esté obligado a presentarlo por obrar ya en poder de la Administración tributaria, en cuyo caso deberá señalar el día y procedimiento en que lo presentó. También tendrá que entregar la solicitud de compensación durante la vigencia del aplazamiento o fraccionamiento con los créditos que puedan reconocerse a su favor durante el mismo período de tiempo.

Cuando en la solicitud se pida la admisión de garantías que no consistan en aval de entidad de crédito o sociedad de garantía recíproca o certificado de seguro de caución, el obligado deberá aportar los documentos que acrediten la representación y el lugar señalado a efectos de notificación; los documentos que justifiquen la existencia de dificultades económico-financieras que le impiden de forma transitoria efectuar el pago en el plazo establecido; el modelo de autoliquidación, así como la declaración responsable y justificación documental de la imposibilidad de obtener dicho aval o certificado de seguro de caución, en la que consten las gestiones efectuadas para su obtención; la valoración de los bienes ofrecidos en garantía efectuada por empresas o profesionales especializados e independientes; y el balance y cuenta de resultados del último ejercicio cerrado, e informe de auditoría, si existe, en caso de empresarios o profesionales obligados por ley a llevar contabilidad (apartado 4 del artículo 46 del RGR).

Si por el contrario, lo que se solicita además es la dispensa total o parcial de garantía, el interesado deberá presentar junto a la solicitud, los mismos documentos a los que hacíamos mención en el párrafo precedente y la declaración responsable y justificación documental manifestando carecer de bienes o no poseer otros que los ofrecidos en garantía; la justificación documental de la imposibilidad de obtener aval de entidad de crédito o sociedad de garantía recíproca o certificado de seguro de caución, en la que consten las gestiones efectuadas para su obtención; el balance y cuenta de resultados de los tres últimos años, e informe de auditoría, si existe, en caso de empresarios o profesionales obligados por ley a llevar contabilidad; el plan de viabilidad; y cualquier otra información que justifique la posibilidad de cumplir el aplazamiento o fraccionamiento solicitado.

Cuando la solicitud no reúna estos requisitos o no se acompañe los documentos citados en los apartados 4 y 5 del artículo 46 del RGR, el órgano competente para la tramitación del aplazamiento o fraccionamiento requerirá al solicitante para que, en un plazo de 10 días contados a partir del siguiente al de la notificación del requerimiento, subsane el defecto o aporte los documentos con 
indicación de que, de no atender el requerimiento en el plazo señalado, se tendrá por no presentada la solicitud y se archivará sin más trámite.

Ahora bien, si la solicitud de aplazamiento o fraccionamiento se presenta en período voluntario de pago y el plazo para atender el requerimiento de subsanación finaliza con posterioridad al plazo de ingreso de dicho período, no siendo atendido, se iniciará el procedimiento de apremio mediante la notificación de la oportuna providencia de apremio. Y la Administración tributaria denegará la solicitud del aplazamiento o fraccionamiento cuando, a pesar de que el requerimiento de subsanación fue objeto de contestación en plazo por el interesado, éste no subsana los defectos o también cuando la garantía aportada por el solicitante hubiese sido rechazada anteriormente por la Administración tributaria por falta de suficiencia jurídica o económica o por falta de idoneidad.

Por otro lado, no serán admitidas las solicitudes de aplazamiento y fraccionamiento cuando la deuda deba ser declarada mediante autoliquidación y esta última no haya sido objeto de presentación con anterioridad o conjuntamente con la solicitud de aplazamiento o fraccionamiento; cuando la autoliquidación sea presentada habiéndose iniciado con anterioridad un procedimiento de comprobación o investigación que hubiera quedado suspendido por haber pasado el tanto de culpa a la jurisdicción competente o por haber sido remitido el expediente al Ministerio Fiscal, al concurrir alguno de los supuestos regulados en el artículo 305 del Código Penal, siempre que la solicitud de aplazamiento o fraccionamiento se refiera a conceptos y períodos objeto de dicho procedimiento de comprobación o investigación. En este último supuesto, si ya se inició la tramitación de la solicitud, ésta quedará sin efecto de forma automática, debiendo comunicarse al Ministerio Fiscal o al órgano jurisdiccional su presentación.

A su vez, las solicitudes de aplazamiento o fraccionamiento reiterativas de otras anteriores que hayan sido objeto de denegación previa serán inadmitidas cuando no contengan una modificación sustancial de la solicitud previamente denegada y, en particular, cuando dicha reiteración tenga por finalidad dilatar, dificultar o impedir el desarrollo de la gestión recaudatoria.

Por último, debemos subrayar que la inadmisión implica que la solicitud de aplazamiento o fraccionamiento se tenga por no presentada a todos los efectos, y contra el acuerdo de inadmisión de la solicitud el obligado tributario podrá interponer recurso o reclamación económica-administrativa.

\subsubsection{Tramitación}

Antes de continuar con los trámites posteriores a la admisión de la solicitud de aplazamiento o fraccionamiento previstos en el artículo 51 del RGR, debemos precisar cuáles van a ser los órganos competentes para resolver. En este sentido, el artículo 45 del RGR dispone que las solicitudes de aplazamiento o fraccionamiento de las deudas cuya recaudación se lleve a cabo por la AEAT se tramitarán y resolverán por esa agencia, que será el órgano competente en el caso de solicitudes de aplazamiento o fraccionamiento que se presenten en período voluntario. Las demás solicitudes de aplazamiento o fraccionamiento se tramitarán y resolverán por la Dirección General del Tesoro y Política Financiera o por las Delegaciones de Economía y Hacienda, salvo que la gestión de dichos recursos se atribuya a órganos de la Administración General del Estado, organismos autónomos u otra entidad de Derecho público. 
El apartado 1 del artículo 51 del RGR determina que el órgano competente para la tramitación examinará y evaluará la falta de liquidez y la capacidad para generar recursos ${ }^{299}$, y valorará la suficiencia e idoneidad de las garantías, o, en caso de solicitud de dispensa de garantía, verificará la concurrencia de las condiciones precisas para obtenerla. En todo caso, si durante el desarrollo del procedimiento del aplazamiento o fraccionamiento el interesado efectúa el pago de la deuda, la Administración liquidará intereses de demora por el período transcurrido desde el día siguiente al del vencimiento del plazo de ingreso en período voluntario hasta la fecha del ingreso.

En el supuesto de fijación de un calendario provisional por la Administración o de propuesta por el interesado de plazos o fracciones, cada uno de los pagos realizados en virtud de cualquiera de los dos calendarios se imputará a la cancelación del principal de la deuda a que se refiere la solicitud de fraccionamiento. Si el fraccionamiento resulta finalmente concedido, se liquidarán los intereses devengados sobre cada uno los pagos que se realicen en virtud de dicho calendario o propuesta desde el día siguiente al del vencimiento del plazo de ingreso en período voluntario hasta la fecha del pago respectivo, notificándose dicha liquidación al interesado junto con el acuerdo de fraccionamiento y otorgándose los plazos de ingreso que se señalan en el apartado 2 del artículo 62 de la LGT.

Finalmente, queremos destacar que el RGR no reconoce expresamente el trámite de audiencia al solicitante, aunque éste está presente implícitamente en todo el articulado. Además la letra $l$ ) del apartado primero del artículo 34 de la LGT atribuye a los obligados tributarios el derecho a

“formular alegaciones y a aportar documentos que serán tenidos en cuenta por los órganos competentes al redactar la correspondiente propuesta de resolución".

\subsubsection{Resolución}

El procedimiento para la concesión o no del aplazamiento o fraccionamiento del pago finaliza normalmente a través de una resolución expresa que debe adoptar el órgano correspondiente. El tiempo de que dispone la Administración tributaria para dictar la resolución, según el apartado 6 del artículo 52 del RGR, es de seis meses, un término inferior al de siete meses que otorgaba el RGR de 1990 en el apartado 5 del artículo 55, y dicho plazo empieza a contar a partir del día en que la solicitud de aplazamiento entró en el registro del órgano administrativo competente para su tramitación.

En todo caso, el agotamiento del término de seis meses que establece la norma actual permite al obligado acogerse al silencio desestimatorio para poder interponer recurso contra la denegación implícita de su solicitud por parte de la Administración tributaria, que es en definitiva una opción aunque no la única, porque también podrá esperar la resolución expresa, que es inexcusable $\mathrm{e}^{300}$.

\footnotetext{
${ }^{299}$ Según CALVO ORTEGA "las dificultades económico-financieras no son un fenómeno estático y requieren una consideración dinámica". Lo que conlleva, tal como expresa este autor, a que la Administración tributaria considere conjuntamente aquéllas dificultades, las causas que motivan la solicitud y el plan de viabilidad (CALVO ORTEGA, R., "Capítulo VI. Aplazamiento y fraccionamiento del pago", op. cit., pág. 255).

${ }^{300}$ Apunta LOZANO SERRANO que aunque el sujeto pueda entender producida la resolución por el silencio, "no puede hacer otro tanto la Administración, ni podrá, en consecuencia, requerir el pago. Lo que confirma que la solicitud de aplazamiento, en período
} 
Los requisitos que debe cumplir la resolución que ponga fin al procedimiento de aplazamiento o fraccionamiento se encuentran en el artículo 52 del RGR. Este precepto dispone de manera general que la resolución debe ser motivada, especificar el número de código cuenta cliente, en su caso, y los datos identificativos de la entidad de crédito que haya de efectuar el cargo en cuenta. También deberá referirse a los plazos aplicables, que pueden coincidir o no con los solicitados por el interesado y, en todo caso, el vencimiento de los plazos deberá coincidir con los días 5 o 20 del mes. Cuando el acuerdo incluya varias deudas, se señalarán de forma independiente los plazos y cuantías que afecten a cada una. Por último, la resolución podrá establecer las condiciones que estime oportunas para asegurar el pago efectivo y para asegurar la preferencia de la deuda aplazada o fraccionada.

Cuando la resolución de fraccionamiento incluya deudas que se encuentren en período voluntario y en período ejecutivo en el momento de presentarse la solicitud, el acuerdo de concesión no podrá acumular en la misma fracción deudas que se encontraran en distintos períodos de ingreso y, en todo caso, habrá que satisfacer en primer lugar aquellas fracciones que incluyan las deudas que se encontrasen en período ejecutivo en el momento que se efectuó la solicitud.

\subsubsection{Efectos de la concesión}

Si se concede el aplazamiento de la deuda, ésta deberá ingresarse en los nuevos plazos señalados en la resolución ${ }^{301}$, devengándose los intereses de demora por el tiempo que medie entre el período voluntario de pago y el vencimiento del plazo concedido. Si lo que se concede es el fraccionamiento del pago de la deuda, se calculan los intereses de demora de cada fracción desde la finalización del período de voluntario hasta el vencimiento del plazo de cada una, exigiéndose su ingreso con la fracción correspondiente. Por otra parte, la concesión del aplazamiento o fraccionamiento durante el desarrollo del procedimiento de apremio supondrá la suspensión de la ejecución contra los bienes del deudor hasta el momento en que venza el nuevo plazo.

En la doctrina encontramos posiciones divergentes en relación con la paralización del procedimiento ejecutivo una vez que se concede el aplazamiento o fraccionamiento. LÓPEZ DÍAZ sostiene que dicha paralización debe ser solicitada por el interesado, que debe demostrar la concesión del aplazamiento, y que "sería conveniente que en las notificaciones de los acuerdos de concesión de aplazamiento de deudas incursas en apremio se hiciese advertencia al interesado de que las actuaciones no se paralizarán de presentar la correspondiente solicitud ante los órganos de recaudación con el fin de evitar los perjuicios que para aquél puedan derivarse de la errónea creencia de que tal paralización se produce sin más" ${ }^{\text {302 }}$. Por el contrario, MORENO FERNÁNDEZ opina que la "suspensión de la iniciación de procedimiento ejecutivo o la paralización del procedimiento

\footnotetext{
voluntario o en período ejecutivo, tiene siempre la virtualidad de impedir el requerimiento administrativo para efectuar el ingreso, excluyendo, en su caso, la providencia de apremio, debiendo ser resuelta para que pueda realizarse la oportuna gestión de cobro" (LOZANO SERRANO C., Aplazamiento y fraccionamiento de los ingresos tributario, op. cit., pág. 70 a 71).

${ }^{301}$ En palabra de LÓPEZ DÍAZ, ello "supone una ampliación del período voluntario de ingreso por el tiempo que dure el plazo o plazos concedidos. De tal forma que la deuda no se entenderá vencida en tanto no finalice el nuevo plazo" (LÓPEZ DÍAZ, A., “Algunas cuestiones en relación al aplazamiento y fraccionamiento del pago en el nuevo RGR”, op. cit., pág. 105).

${ }^{302}$ LÓPEZ DÍAZ, A., “Algunas cuestiones en relación al aplazamiento y fraccionamiento del pago en el nuevo RGR”, op. cit., pág. 103 y 104.
} 
iniciado (según se trate de deudas en período voluntario de pago o en ejecutiva) se producirá automáticamente, sin necesidad de solicitud por el deudor" ${ }^{303}$.

Si una vez concedido el aplazamiento o fraccionamiento el deudor solicita una modificación en sus condiciones, esta petición no tendrá, en ningún caso, efectos suspensivos, y se tramitará y resolverá de acuerdo con las mismas normas que las establecidas para las solicitudes de aplazamiento o fraccionamiento con carácter general.

\section{$\underline{\text { A. Efectos del pago de las cantidades aplazadas o fraccionadas }}$}

Concedido el aplazamiento del pago de la deuda tributaria, su ingreso en tiempo produce dos efectos fundamentalmente: la extinción de la obligación de pago del solicitante y la liberación de las garantías, para lo cual se comprobará el pago total de la deuda garantizada incluidos los intereses de demora que se devenguen. Si se trata de una deuda fraccionada, en cambio, los efectos del pago de cada fracción serán la extinción del débito de cada fracción que se pague, pero la liberación de la garantía presentada sólo se produce con el pago de todas y cada una de las fracciones, salvo que se hayan presentado garantías parciales para cada fracción, en cuyo caso la liberación de cada una de ellas tendrá lugar a medida que se produzca el pago de cada fracción.

En el supuesto de que el deudor satisfaga su deuda antes de que venza el plazo de aplazamiento o fraccionamiento, los efectos serían los mismos a los que acabamos de hacer referencia, con la excepción de los intereses de demora que deberá pagar el obligado, que no serán los que se devenguen entre el último día del plazo de ingreso voluntario y el del vencimiento del plazo o los plazos concedidos, sino los que corresponden en el trascurso del tiempo entre la finalización del plazo de ingreso voluntario y el día en que efectuó el ingreso. Mientras que si se efectúa el pago de la deuda aplazada o fraccionada en un momento posterior al día de vencimiento, pero antes de que la Administración tributaria se pronuncie, los efectos serán diferentes según se trate de deudas en período voluntario o en ejecutiva, ya que el pago podrá hacerse en cualquier momento anterior a la ejecución de los bienes embargados y los intereses de demora serán aquellos que se devenguen desde el vencimiento del período voluntario hasta la fecha de su ingreso. Si se solicitó el aplazamiento de una deuda que estaba en período voluntario, la falta de pago al vencimiento del plazo concedido supone la apertura de la vía de apremio, para lo cual la Administración deberá emitir y notificar la correspondiente providencia de apremio. Por el contario, si el pago se produce cuando ha finalizado el período voluntario sin haberse iniciado aún el procedimiento de apremio, tendrán aplicación en este supuesto los recargos ejecutivos del apartado 2 del artículo 28 de la LGT.

\section{B. Efectos de la falta de pago de las cantidades aplazadas o fraccionadas}

La falta de pago al vencimiento de las cantidades aplazadas determinará, si el aplazamiento se solicitó en período voluntario, su inmediata exigibilidad a través del procedimiento de apremio, para lo que se expedirá la providencia de apremio con la deuda aplazada, los intereses devengados antes del inicio del período ejecutivo y los recargos ejecutivos. De no efectuarse el pago, se ejecutarán las garantías para satisfacer la deuda, y en caso de que éstas no existan o sean insuficientes, se continuará

\footnotetext{
${ }^{303}$ MORENO FERNÁNDEZ, I., El aplazamiento en el pago de los tributos, op. cit., pág. 187.
} 
con el procedimiento de apremio. En cambio, si el aplazamiento se solicita en período ejecutivo sin efectuar el ingreso, se podrá ejecutar la garantía, y en el caso de inexistencia o insuficiencia de ésta, se proseguirá con la vía de apremio.

En el caso de una deuda fraccionada, cuando el fraccionamiento se solicita en período voluntario y no se efectúa el pago en el plazo estipulado, serán exigidas en vía de apremio las cantidades vencidas, es decir, las fracciones no pagadas, con sus intereses devengados y el recargo ejecutivo, siendo preciso expedir la providencia de apremio para la ejecución de la deuda en la vía de apremio. Y de no pagarse la deuda en los plazos previstos para su ingreso en el período ejecutivo, se considerarán vencidas las fracciones pendientes, que se exigirán por el procedimiento de apremio, con la ejecución de las garantías y los demás medios de ejecución forzosa.

Si el fraccionamiento se solicita en período ejecutivo, continuará el procedimiento de apremio para el cobro de la totalidad de la deuda fraccionada pendiente de pago, de tal modo que si existiesen garantías, se procederá en primer lugar a su ejecución. Los intereses de dichas fracciones, previamente calculados sobre los plazos concedidos serán anulados y se liquidarán según lo establecido en las normas reglamentarias.

Ahora bien, cuando se hayan constituido garantías parciales e independientes para cada uno de los plazos o fracciones, o la garantía presentada sea un aval, se procederá de la siguiente manera: cuando el fraccionamiento se solicitó en período voluntario, el incumplimiento de pago de una fracción determinará la exigencia por la vía de apremio exclusivamente de esa fracción con sus intereses de demora y el recargo ejecutivo, a través de la ejecución de la correspondiente garantía cuando no se satisfaga la fracción una vez requerido para que realizara el pago en la vía de apremio. Si el fraccionamiento se solicitó en el período ejecutivo, se procederá inmediatamente a la ejecución de la garantía que corresponda a dicha fracción, más los intereses de demora y los recargos que corresponda. No se exige, en este segundo supuesto, al deudor el pago en la vía de apremio, porque cuando solicitó el fraccionamiento ya se encontraba en el procedimiento ejecutivo y, en consecuencia, el impago dentro del plazo concedido es causa suficiente para ejecutar las garantías formalizadas, sin necesidad de instar de nuevo al procedimiento ejecutivo para que ingrese lo debido.

En ambos casos, el resto de la fracción subsistirá en los términos que se concedió. No puede producirse un vencimiento anticipado de las demás fracciones, porque esta situación sólo se prevé cuando se produce el impago de la fracción que es objeto de requerimiento de apremio, lo que no puede suceder, según MORENO FERNÁNDEZ, "al procederse por la Administración a la ejecución de la garantía de la fracción impagada y, por tanto, a la extinción del débito correspondiente a esa fracción",304.

\subsubsection{Efectos de la denegación}

Si se deniega el aplazamiento o fraccionamiento y la solicitud se presentó en período voluntario de ingreso, con la notificación del acuerdo denegatorio se iniciará el plazo de ingreso que regula el apartado 2 del artículo 62 de la LGT. De no producirse el ingreso en dicho plazo, comenzará el

\footnotetext{
${ }^{304}$ MORENO FERNÁNDEZ, I., El aplazamiento en el pago de los tributos, op. cit., pág. 236.
} 
período ejecutivo y deberá iniciarse el procedimiento de apremio. Si se produce el pago durante el plazo que se inicia con la notificación de la resolución de denegación del aplazamiento o fraccionamiento, se procederá a la liquidación de los intereses de demora devengados a partir del día siguiente al del vencimiento del plazo de ingreso en período voluntario hasta la fecha del ingreso que se realice durante el plazo abierto con la notificación de la denegación. De no realizarse el ingreso los intereses se liquidarán hasta la fecha de vencimiento de dicho plazo, sin perjuicio de los que puedan devengarse con posterioridad (inciso $a$ ) del apartado cuarto del artículo 52 del RGR). Si la solicitud fue presentada en período ejecutivo de ingreso, deberá iniciarse el procedimiento de apremio de no haberse iniciado con anterioridad.

Contra la denegación de las solicitudes de aplazamiento o fraccionamiento sólo cabrá la presentación del correspondiente recurso de reposición o reclamación económico-administrativa en los términos y con los efectos establecidos en la normativa aplicable a estos procedimientos de revisión.

\subsubsection{Desistimiento}

La normativa reglamentaria prevé el desistimiento del solicitante como forma de finalización del procedimiento de aplazamiento o fraccionamiento del pago de la deuda, en el apartado 6 del artículo 48 del RGR, al contemplar la posibilidad de que el solicitante no subsane el defecto o no aporte los documentos omitidos en la solicitud en el plazo de 10 días contados a partir del siguiente al de la notificación del requerimiento. El desistimiento de la solicitud por los interesados se establece legalmente con carácter general en el apartado 1 del artículo 90 de la LRJ-PAC. Por tanto, la Administración aceptará de plano el desistimiento o la renuncia, y declarará concluso el procedimiento, de acuerdo con el apartado 2 del artículo 92 de la misma ley. 


\section{CAPÍTULO SEGUNDO \\ LAS GARANTÍAS DEL CRÉDITO TRIBUTARIO}

Con el ejercicio de la función recaudatoria se realizan los créditos tributarios, pero cuando se producen actuaciones evasivas del deudor la Administración tributaria puede recurrir no sólo a la ejecución forzosa de la deuda, sino también a otros mecanismos que incrementan las posibilidades de hacer efectivo el cobro de la deuda, como las distintas formas de atribución de responsabilidad tributaria a sujetos diferentes de los sujetos pasivos, el establecimiento de garantías reales como la hipoteca legal o el derecho de afección, el deber de recabar información que afecta a los obligados tributarios y a terceros, la tipificación de conductas infractoras y la aplicación de las correspondientes sanciones, o la articulación de mecanismos como los pagos a cuenta o la repercusión, entre otras. Dentro de esta amplia gama de medidas que el ordenamiento jurídico configura para asegurar el crédito tributario se encuentran las garantías tributarias. En este segundo capítulo nos referiremos, primordialmente, a las garantías de pago del crédito tributario en sentido estricto, y para ello partiremos de una triple distinción entre la responsabilidad patrimonial universal y los derechos de garantía; dentro de estos últimos, entre las garantías en sentido amplio y las garantías en sentido estricto; y en el seno de las garantías en sentido estricto, entre las garantías reales y las garantías personales. Cerraremos el capítulo aludiendo a otras figuras que también tienen por finalidad el fortalecimiento del crédito tributario pero que no reúnen las características principales de las garantías tributarias en sentido estricto, como los privilegios y las medidas cautelares.

\section{LA RESPONSABILIDAD PATRIMONIAL UNIVERSAL Y LAS GARANTÍAS DEL CRÉDITO TRIBUTARIO}

El Código Civil prevé en su artículo 1.911 que el deudor responde de sus obligaciones con todos sus bienes presentes y futuros, instaurando, con el fin de aliviar la incertidumbre del acreedor, la responsabilidad patrimonial universal. En principio se confía en la honradez y capacidad del deudor para asumir sus obligaciones, pero en el supuesto de que no se produzca el cumplimiento espontáneo del deudor se ofrece la posibilidad al acreedor de dirigirse contra los bienes de aquél para satisfacer su crédito. Puede suceder, no obstante, que el patrimonio del deudor no sea suficiente y que entonces la protección que confiere el artículo 1.911 del Código Civil se vuelva ineficaz. Esta situación ha desembocado en la búsqueda de medios que den una mayor firmeza a la cobranza del crédito. Algunos de estos medios han nacido de la autonomía de la voluntad de las partes, avalada por el artículo 1.255 del Código Civil, y otros, en cambio, han sido el fruto de disposiciones normativas concretas encaminadas a estimular al deudor al cumplimiento íntegro de sus compromisos. Todas estas medidas son denominadas por la doctrina como garantías del crédito ${ }^{305}$.

La responsabilidad patrimonial universal es una institución diferente de la categoría que engloba a las garantías del crédito porque es parte esencial del derecho de crédito, mientras que las garantías se

\footnotetext{
${ }^{305}$ GUERRA REGUERA, M., Garantías personales del crédito tributario. Algunas cuestiones, Comares, Granada, 1997, pág. 3.
} 
yuxtaponen al mismo, son un instrumento que lo refuerzan. La responsabilidad patrimonial universal no añade nada al crédito y no constituye ninguna forma particular de aseguramiento, sino que es algo inherente a éste. "No es otra cosa que la esencia misma del derecho de crédito, aquello que en el crédito (y la correspondiente obligación) consiste: el poder de actuación de una persona, el acreedor, sobre el patrimonio de otro, el deudor, cuyo patrimonio, no la persona misma, queda sujeto a ese poder jurídico que el Ordenamiento reconoce y atribuye" ${ }^{, 306}$. Por su parte, las garantías son un derecho o facultad ajenos al derecho de crédito y es frecuente que el acreedor, ante las limitaciones de la responsabilidad patrimonial universal, es decir, las limitaciones del propio derecho de crédito, busque garantías, instrumentos externos, que le permitan reforzar su cobro.

Asumimos, consiguientemente, la posición de la doctrina civil que considera que la facultad que tiene el acreedor de ejecutar sobre los bienes del deudor su derecho de crédito no puede considerarse como una garantía propiamente dicha, porque no constituye ninguna forma especial de refuerzo y es algo inherente al crédito ${ }^{307}$.

En el ámbito tributario, la Administración tributaria es la parte activa de la relación jurídica, ocupando la posición acreedora de la obligación tributaria. La Hacienda Pública es un acreedor más y se comporta como tal, y es por ello que el ordenamiento tributario ha constituido una amplia gama de instrumentos jurídicos cuya finalidad es el reforzamiento del crédito tributario ante la posible insolvencia o incumplimiento del deudor tributario.

\section{CARACTERÍSTICAS GENERALES DE LAS GARANTÍAS TRIBUTARIAS}

Hemos indicado al inicio del capítulo que las garantías del crédito tributario son instrumentos que se adicional al crédito y lo refuerzan. Sin embargo, el carácter accesorio no es el único elemento que define a esta figura, porque como veremos a continuación la doctrina también destaca como características fundamentales de las garantías del crédito, además de la accesoriedad, la especialidad y la legalidad.

\subsection{ACCESORIEDAD}

Las garantías tributarias son mecanismos de protección ajenos al crédito. Se constituyen como un derecho subjetivo o una facultad adicional que se yuxtapone al derecho del crédito, existiendo una relación de subordinación entre ambos. Estamos ante un derecho principal, el derecho de crédito, y un derecho accesorio, el derecho de garantía ${ }^{308}$.

\footnotetext{
${ }^{306}$ RODRÍGUEZ BEREIJO, A., "Las garantías del crédito tributario”, Revista Española de Derecho Financiero, núm. 30, 1981, pág. 183.

${ }^{307}$ Para DÍEZ PICAZO la responsabilidad patrimonial del deudor o el poder de los acreedores para ejecutar sobre los bienes del deudor su derecho de crédito no podía verse como una garantía en sentido propio. Por ende, la responsabilidad del deudor no constituye ningún contenido especial del crédito, ni tampoco ninguna forma especial de refuerzo, "sino que es algo inherente al crédito mismo, al que nada añade". La responsabilidad patrimonial del deudor o el poder que tienen los acreedores para ejecutar sobre los bienes del deudor su derecho de crédito no constituyen garantías del crédito propiamente dicho. A su vez, la garantía es un refuerzo a la posición jurídica del acreedor, que se consigue con la ampliación del ámbito del poder jurídico de aquél. "Toda garantía consiste por ello en un nuevo derecho subjetivo o en una nueva facultad que se yuxtapone al derecho de crédito" que se quiere satisfacer. DÍEZ PICAZO, L., Fundamentos del Derecho Civil Patrimonial II. Las relaciones obligatorias, Civitas, Madrid, 1993, pág. 396 a 397.

${ }^{308}$ La idea que las garantías son accesorias al crédito se infiere del articulado del Código Civil, de los artículos 1.212 ("la subrogación transfiere al subrogado el crédito con los derechos a él anexos, ya contra el deudor, ya contra los terceros, sean fiadores o poseedores
} 
El carácter accesorio de las garantías del crédito tributario impide caracterizar a esta figura admitiendo la existencia de una nueva relación jurídica obligatoria o real diferenciada de aquella que trata de asegurar, porque en la naturaleza de la garantía tan importante como la accesoriedad es la subordinación que tiene la misma respecto al crédito que pretende asegurar. La accesoriedad significa, en definitiva, que el derecho subordinado depende en cuanto a su existencia y subsistencia al derecho principal y, por ello, la extinción del crédito significa la extinción de la garantía ${ }^{309}$, sin perjuicio de que la garantía sea autónoma en cuanto a su constitución y existencia, puesto que en estos aspectos se rige por su propia normativa específica.

\subsection{ESPECIALIDAD}

Las garantías se constituyen como mecanismos jurídicos de protección directa y efectiva que recaen sobre el objeto de la obligación jurídica. Según ARRANZ DE ANDRÉS ${ }^{310}$, la especialidad como rasgo distintivo de las garantías, se caracteriza por producir la afección de un bien concreto al cumplimiento de una obligación determinada. Y en este sentido, las garantías tributarias presentan una doble finalidad: preventiva mientras la obligación no sea exigible y ejecutiva cuando se incumple la obligación de pago por parte del deudor. Con independencia del carácter preventivo o ejecutivo de estas garantías, se necesita que se produzca el impago de la obligación principal para su realización, ya sea en el período voluntario o en el procedimiento de apremio.

El Tribunal Constitucional se ha pronunciado sobre la adopción de medidas de aseguramiento antes de que venzan las obligaciones tributarias por las que se aplicaron en la Sentencia 14/1986, de 31 de enero, indicando en el Fundamento Jurídico 14 que "el ordenamiento vigente, generoso en cuanto a garantizar el cumplimiento de las obligaciones tributarias, parte a la hora de la adopción de alguna medida concreta de aseguramiento, que venga a limitar de algún modo la libre disponibilidad patrimonial del sujeto pasivo o del obligado al pago, de la realidad del vencimiento de la obligación, sin que a ello obste que alguna de tales cautelas puedan ser efectivas con anterioridad a tal momento, pues tal únicamente sucede cuando un mandato legal, conocido por supuesto por interesados y por terceros, gravita sobre la situación tributaria desde el inicio de su constitución, y advierte, a todos de sus posibilidades y alcances, cual sucede por ejemplo con la hipoteca legal tácita; mas en caso alguno es permitido adoptar medidas de aseguramiento concretas y específicas, individualmente determinadas, ante obligaciones no vencidas, que es tanto como decir ante deudas tributarias no devengadas. Exigencia por lo demás coincidente con lo establecido para los aseguramientos de obligaciones de índole privada".

\footnotetext{
de las hipotecas") y 1.528 ("la venta o cesión de un crédito comprende la de todos los derechos accesorios, como la fianza, hipoteca, prenda o privilegio"). GÓMEZ CABRERA señala el carácter accesorio de las garantías, como instituciones alejadas del crédito pero subordinadas a él por tener como finalidad asegurar su satisfacción (GÓMEZ CABRERA C., La concurrencia del crédito tributario: Aspectos sustantivos y procedimentales. Prelación, garantías, tercerías, ejecuciones preferentes, suspensiones de pago y quiebras, op. cit., pág. 30).

${ }^{309}$ MUÑOZ MERINO, A., Privilegios del crédito tributario: el derecho de prelación general, Aranzadi, Pamplona, 1996, pág. 37.

${ }^{310}$ ARRANZ DE ANDRÉS, C., Las garantías reales del crédito tributario: aspectos sustantivos y procedimentales, Aranzadi, Pamplona, 2006, pág. 44; ÁLVAREZ CAPEROCHIPI, J. A., Cursos de Derechos Reales, Tomo II, Los derechos Reales Limitados, Civitas, Madrid, 1987, pág. 118 y 119.
} 


\subsection{LEGALIDAD}

La última de las características que acompañan a las garantías del crédito tributario es su sometimiento al principio de legalidad, pues sólo mediante la ley podrán establecerse mecanismos que aseguren la satisfacción del crédito tributario ${ }^{311}$. Utilizando las palabras de GÓMEZ CABRERA, "ya sea en virtud del principio de reserva de ley, que exige que todos los elementos esenciales de la relación tributaria vengan establecidos en la ley o, simplemente, porque el privilegio excepciona la responsabilidad universal y la «par conditio», que constituyen el derecho común legalmente establecido, las garantías han de venir establecidas en la ley" ${ }^{\text {"312. }}$

\section{CLASES DE GARANTÍAS DEL CRÉDITO TRIBUTARIO}

\subsection{LAS GARANTÍAS DEL CRÉDITO TRIBUTARIO EN SENTIDO AMPLIO}

Como hemos señalado, las garantías son un refuerzo del derecho de crédito que tiene el acreedor y que consiste en un derecho subjetivo o en una nueva facultad que se yuxtapone al derecho de crédito cuya satisfacción se quiere asegurar ${ }^{313}$.

Podemos afirmar desde esta perspectiva que una garantía es cualquier medida para asegurar la efectividad de un crédito. En realidad, con esta aseveración estamos aludiendo a los derechos de garantía en sentido amplio, en los términos propuestos por RODRÍGUEZ BEREIJO, como "cualquier forma o medio especial de asegurar la efectividad de un crédito"314. Se trata de una norma de derecho o un precepto de autonomía privada que añade al crédito algo que el crédito por sí mismo no tiene, y de aquí que con esta incorporación se acrecienta la seguridad del acreedor de que su crédito será satisfecho ${ }^{315}$. Por tanto, las garantías en sentido amplio pueden entenderse como todas

\footnotetext{
${ }^{311}$ En este mismo sentido, RODRÍGUEZ BEREIJO, A., "Las garantías del crédito tributario", op. cit., pág. 184; FALCÓN Y TELLA, R., "Las decisiones de la Comisión relativas al gravamen CECA., ejecución judicial versus ejecución administrativa", Impuestos, núm. 4, 1992, pág. 1115 a 1120; ZABALA RODRÍGUEZ-FORNOS, A., "La intervención de la Hacienda Pública en los procesos concursales", Tribuna Fiscal, núm. 20, 1992, pág. 42; MUÑOZ MERINO, A., Privilegios del crédito tributario: el derecho de prelación general, op. cit., pág. 39; ARRANZ DE ANDRÉS, C., Las garantías reales del crédito tributario: aspectos sustantivos y procedimentales, op. cit., pág. 44. Esta última autora clasifica la legalidad como tipicidad y además adiciona otra característica que entendemos se relaciona estrechamente con aquéllas, la publicidad o posibilidad de conocimiento general de la existencia del derecho de garantía.

312 GÓMEZ CABRERA C., La concurrencia del crédito tributario: Aspectos sustantivos y procedimentales. Prelación, garantías, tercerías, ejecuciones preferentes, suspensiones de pago y quiebras, op. cit., pág. 30.

313 DÍEZ PICAZO, L., Fundamentos del Derecho Civil Patrimonial II. Las relaciones obligatorias, op. cit., pág. 395 a 396.

${ }^{314}$ RODRÍGUEZ BEREIJO, A., "Las garantías del crédito tributario", op. cit., pág. 183. La doctrina siguió esta misma postura como puede verse, por ejemplo, en SIMÓN ACOSTA, E., "La hipoteca legal tácita en garantía de deudas tributarias", en la obra Comentarios a la Ley General Tributaria y lineas para su reforma, libro-homenaje al profesor Dr. D. Fernando Sainz de Bujanda, Vol. II, Ministerio de Economía y Hacienda, Instituto de Estudios Fiscales, Madrid, 1991, pág. 1079. También hacen alusión a las garantías en sentido amplio, MUÑOZ MERINO, A., Privilegios del crédito tributario: el derecho de prelación general, op. cit., pág. 35; GUERRA REGUERA, M., Garantías personales del crédito tributario. Algunas cuestiones, op. cit., pág. 35; GÓMEZ CABRERA C., La concurrencia del crédito tributario: Aspectos sustantivos y procedimentales. Prelación, garantías, tercerías, ejecuciones preferentes, suspensiones de pago y quiebras, op. cit., pág. 29; GONZÁLEZ-CARBALLO ALMODÓVAR, A., "Las garantías del crédito tributario", en la obra Estudios sobre la Nueva Ley General Tributaria (Ley 58/2003, de 17 de diciembre) en homenaje a Serrera Contreras, P. L, Instituto de Estudios Fiscales, Madrid, 2004, pág. 449; GUERVÓS MAÍlLO, M. A., y LAGO MONTERO, J. M., "Las garantías del crédito tributario (Comentario a los artículos 71, 72, 73, 75, 75 y 76 L.G.T.)", Revista de Hacienda Local, Vol. 30 , núm. 88, 2000, pág. 131 .
}

${ }^{315}$ DÍEZ PICAZO, L., Fundamentos del Derecho Civil Patrimonial II. Las relaciones obligatorias, op. cit., pág. 395 a 396. 
aquellas medidas, potestades, facultades que, sin ser esenciales al crédito, son otorgadas por la ley a la Administración tributaria, con el fin de garantizar y asegurar la satisfacción del crédito tributario.

Debemos recordar que el ordenamiento tributario está plagado de instituciones que de una forma $u$ otra podrían considerarse como garantías del crédito tributario desde una perspectiva amplia: las prerrogativas de comprobación e investigación inherentes a los procedimientos de gestión, inspección y recaudación tributaria y los mecanismos sancionadores por el incumpliendo de obligaciones tributarias; la ampliación legal de los sujetos obligados al pago con la incorporación de figuras como el sustituto, el responsable, el pagador a cuenta, o la solidaridad tributaria pasiva, así como la introducción del mecanismo de la repercusión en algunas figuras tributarias o de la actuación mediante representante; los deberes de información tributaria que recaen sobre terceros y los deberes de información y asistencia al obligado tributario que incumben a la Administración tributaria; o las disposiciones que, en los términos que hemos analizado en el primer capítulo, presiden el régimen del pago como forma ordinaria de cumplimiento de las obligaciones tributarias (previsión de distintas formas y sujetos del pago, normas de imputación y consignación del pago, medidas cautelares en el período voluntario, incentivos del pago extemporáneo y espontáneo con la exclusión de sanciones, ejecución forzosa en el seno del procedimiento ejecutivo de apremio, y posibilidad de solicitar el aplazamiento o fraccionamiento del pago).

\subsection{LAS GARANTÍAS DEL CRÉDITO TRIBUTARIO EN SENTIDO ESTRICTO}

Dentro de los medios de tutela del crédito tributario que constituyen las garantías en sentido amplio debemos identificar, por ser el objeto de estudio de este trabajo, las garantías en sentido estricto, cuya definición tiene su origen en la doctrina de DÍEZ PICAZO ${ }^{316}$. Los postulados de este autor fueron acogidos por la doctrina tributaria, que entendió que las garantías del crédito tributario en sentido estricto son únicamente los derechos, facultades o potestades que el legislador adjudica a la Administración tributaria con la finalidad de satisfacer su crédito mediante la realización sobre determinados bienes o sobre el patrimonio de terceros ${ }^{317}$. Como manifiesta GUERRA REGUERA, estamos ante "los derechos o facultades concedidos, directa e indirectamente, por Ley a la Hacienda Pública acreedora y anexionados a su crédito, en virtud de los cuales, en fase recaudatoria, puede actuar sobre un bien concreto o sobre un patrimonio para aumentar las posibilidades de cobro"318.

De los razonamientos anteriores se desprende que las garantías en sentido estricto deben ser orientadas conceptualmente al ámbito de la ejecución del crédito, quedando fuera de esta manera todas aquellas facultades especiales de la Administración tributarias dirigidas a la determinación y liquidación de su derecho de crédito. Lo que significa que las garantías del crédito tributario en

\footnotetext{
${ }^{316}$ DÍEZ PICAZO, L., Fundamentos del Derecho Civil Patrimonial II. Las relaciones obligatorias, op. cit., pág. 396 a 397.

${ }^{317}$ Para definir las garantías del crédito tributario en sentido estricto utilizamos los elementos principales de los conceptos que elaboraron varios autores: RODRÍGUEZ BEREIJO, A., "Las garantías del crédito tributario", op. cit., pág. 184; SIMÓN ACOSTA, E., "La hipoteca legal tácita en garantía de deudas tributarias", op. cit., pág. 1079; MUÑOZ MERINO, A., Privilegios del crédito tributario: el derecho de prelación general, op. cit., pág. 36; GÓMEZ CABRERA C., La concurrencia del crédito tributario: Aspectos sustantivos y procedimentales. Prelación, garantías, tercerías, ejecuciones preferentes, suspensiones de pago y quiebras, op. cit., pág. 29; GARCÍA NOVOA, C., "La necesaria modificación de las garantías del crédito tributario en una nueva futura Ley General Tributaria”, Crónica Tributaria, núm. 107, 2003, pág. 63; GONZẢLEZ-CARBALLO ALMODÓVAR, A., "Las garantías del crédito tributario", op. cit., pág. 449.

${ }^{318}$ GUERRA REGUERA, M., Garantías personales del crédito tributario. Algunas cuestiones, op. cit., pág. 35.
} 
sentido estricto son todas aquellas medidas que añaden al crédito tributario algo que per se no tiene, un extra de seguridad para el acreedor. Se crea así una nueva relación jurídica subordinada, accesoria, autónoma de la relación jurídica principal, cuya finalidad inmediata es la satisfacción del crédito mediante su realización sobre determinados bienes o derechos o sobre el patrimonio de terceros.

En consecuencia, no pueden ser consideradas como garantías del crédito tributario en sentido estricto las potestades de la Hacienda Pública durante la fase declarativa del procedimiento tributario (comprobación e investigación y liquidación por los órganos de gestión, inspección y recaudación); la facultad de determinar unilateralmente la deuda; el derecho a exigir información a terceros; las advertencias que están obligados a hacer ciertos funcionarios a los contribuyentes; las presunciones que se establecen en beneficio del crédito, entre otros. Pero incluso, dentro de la fase ejecutiva o recaudatoria, existen potestades que van más allá del sentido estricto de las garantías del crédito, como por ejemplo, la facultad de crear el título para despachar la ejecución, el privilegio de la autotutela, o el derecho a obtener información sobre los bienes de propiedad del deudor.

Nos centramos así en el estudio de las garantías del crédito tributario en sentido estricto, o sea, de aquellas facultades, potestades o derechos que el legislador concede a la Hacienda Pública para que pueda incidir directa o indirectamente en la ejecución del crédito tributario.

Acotando aún más el objeto de nuestro estudio, las garantías en sentido estricto del crédito tributario tradicionalmente se dividen en garantías reales y garantías personales. Esta distinción entre garantías personales y garantías reales es la que normalmente acepta la doctrina, sobre todo a partir del estudio de RODRÍGUEZ BEREIJO ${ }^{319}$. Aunque algunos autores, como MUÑOZ MERINO incorporan un tercer grupo de garantías, integrado por las denominadas garantías procedimentales ${ }^{320}$.

El elemento distintivo entre un tipo y otro de garantías, reales y personales, se produce porque en el primero de los casos al acreedor se concede un poder jurídico sobre cosas concretas y determinadas, mientras que en el segundo un derecho o una facultad que se dirige hacia la persona del deudor o hacia una tercera persona ajena. En una garantía real se otorga al titular de la misma facultades de reipersecutoriedad y oponibilidad erga omnes, confiriéndose un derecho para ejecutar el bien aun cuando éste haya pasado al poder de una tercera persona. Mientras que los derechos personales de garantías otorgan al acreedor un derecho de naturaleza personal o una facultad que no recae sobre una cosa concreta o determinada, sino sobre una tercera persona que debe responder de la deuda. Como ha puesto de manifiesto ARRANZ DE ANDRÉS, el aseguramiento de un crédito "mediante garantía personal resulta sólo posible si lo efectúa un tercero, mientras que, el establecimiento de una

\footnotetext{
${ }^{319}$ RODRÍGUEZ BEREIJO, A., "Las garantías del crédito tributario", op. cit., pág. 181. Son partidarios de esta división, entre otros, FALCÓN Y TELLA, R., "Las garantías del crédito tributario: perspectivas de reforma", Revista de Derecho Financiero y de Hacienda Pública, núm. 215, septiembre-octubre 1991, pág. 915 a 933; GUERRA REGUERA, M., Garantías personales del crédito tributario. Algunas cuestiones, op. cit., pág. 36 a 42; GÓMEZ CABRERA C., La concurrencia del crédito tributario: Aspectos sustantivos y procedimentales. Prelación, garantías, tercerías, ejecuciones preferentes, suspensiones de pago y quiebras, op. cit., pág. 30 a 32; GARCÍA NOVOA, C., "La necesaria modificación de las garantías del crédito tributario en una nueva futura Ley General Tributaria", op. cit., pág. 63 y ss.; GONZÁLEZ-CARBALLO ALMODÓVAR, A., "Las garantías del crédito tributario", op. cit., pág. 450.

${ }^{320}$ Concretamente la autora se refiere a la prelación general del crédito tributario que regulaba la LGT de 1963 en su artículo 71 , y su criterio parte de la base de que es un instituto para garantizar el crédito tributario impuesto por la ley que añade una cualidad específica al crédito y que por tanto es ajeno a él. Aunque cumple con todos los requisitos para ser una garantía en sentido estricto, añade la misma autora, no puede definirse ni como garantía real ni como garantía personal. Sobre esta materia vid. MUÑOZ MERINO, A., Privilegios del crédito tributario: el derecho de prelación general, op. cit., pág. 57 a 63.
} 
garantía real podrá llevarla a cabo tanto el mismo deudor como una tercera persona ajena a la relación crediticia"321.

\subsubsection{Las garantías reales}

La doctrina tributarista y el Derecho positivo suelen considerar como garantías en sentido estricto a los supuestos que encajan en la categoría de las garantías reales. Para algunos autores, las únicas garantías existentes en sentido estricto son las garantías reales, porque con ellas "la posición acreedora de la Hacienda Pública se ve reforzada por la sujeción de un bien o conjunto de bienes del deudor al cumplimiento de su obligación del pago del tributo"322, y porque "el fundamento del reforzamiento de la efectividad de los derechos de crédito de la Hacienda Pública, su carácter subordinado y accesorio respecto del derecho principal" aparecen, "en el caso de los derechos reales de garantía, de una manera más nítida, ${ }^{, 323}$.

El Derecho privado definió las garantías reales como aquel poder jurídico que se concede al acreedor sobre cosas concretas o determinadas. Normalmente, según este sector del ordenamiento, se atribuye al acreedor un derecho de carácter real que puede ejercitarse erga omnes y un derecho de realización del valor de los bienes, de sus frutos o productos o ambas cosas. En este ámbito, las garantías reales en sentido estricto comprenden, entre otros, los derechos de prenda y de hipoteca, y los casos en que al acreedor se atribuye la propiedad de una cosa determinada o la titularidad de un derecho (transmisión fiduciaria) o se reserva la propiedad de la cosa que se transmite hasta el completo cumplimiento de la obligación asegurada (pacto de reserva de dominio en venta a plazo). También reconoce el Derecho civil que puede hablarse de una garantía real en sentido estricto cuando se confiere al acreedor facultades posesorias o de prolongación o continuación de una situación posesoria sobre un bien determinado o sobre una suma de dinero ${ }^{324}$.

Por su parte, la doctrina tributaria se nutre de esta posición civilista y entiende que las garantías reales se configuran "directamente por la norma tributaria como garantía específica en el ámbito fiscal. Su razón de ser no es otra que el interés público de reforzar las expectativas de cobro del tributo, y ese interés público es el que justifica la atribución de potestades funcionales a favor de la Administración para sujetar ciertos bienes o conjunto de bienes a la satisfacción de las deudas tributarias ${ }^{325}$. En sentido general, podemos afirmar que el establecimiento de las garantías reales en sentido estricto permiten asegurar y reforzar la deuda, pues otorgan a su titular la facultad de reipersecutoriedad, la preferencia y la oponibilidad erga omnes $^{326}$.

\footnotetext{
${ }^{321}$ ARRANZ DE ANDRÉS, C., Las garantías reales del crédito tributario: aspectos sustantivos y procedimentales, op. cit., pág. 40 a 41.

322 GARCÍA NOVOA, C., "La necesaria modificación de las garantías del crédito tributario en una nueva futura Ley General Tributaria”, op. cit., pág. 64.

${ }^{323}$ RODRÍGUEZ BEREIJO, A., “Las garantías del crédito tributario”, op. cit., pág. 194.

${ }^{324}$ DÍEZ PICAZO, L., Fundamentos del Derecho Civil Patrimonial II. Las relaciones obligatorias, op. cit., pág. 397 y ss.

${ }^{325}$ GARCÍA NOVOA, C., "La necesaria modificación de las garantías del crédito tributario en una nueva futura Ley General Tributaria”, op. cit., pág. 64.

${ }^{326}$ Seguimos los criterios de ARRANZ DE ANDRÉS. Para esta autora, este tipo de derecho presenta una nota de inmediación patentizada, que se manifiesta sobre todo en la posibilidad de conservar su valor y enajenarla para satisfacerse con el precio obtenido. ARRANZ DE ANDRÉS, C., Las garantías reales del crédito tributario: aspectos sustantivos y procedimentales, op. cit., pág. 43. En
} 
En resumen, el derecho real de garantía es un derecho accesorio respecto a una relación obligacional, que se rige por una normativa específica que determina su constitución y existencia, y que se caracteriza por producir afección en una cosa concreta para el cumplimiento de una obligación determinada. O, dicho de otra manera, se trata de potestades o facultades que permiten sujetar un bien o conjunto de bienes en el marco de actuación de la Administración tributaria destinada a satisfacer las deudas tributarias.

Sin embargo, éstos no han sido los criterios seguidos por la LGT en la Sección Quinta del Capítulo IV del Título II, dedicada a las garantías de la deuda tributaria. Si bien se trata de un conjunto de instituciones que tienen como finalidad asegurar el cobro de la Hacienda Pública, sólo con algunas de ellas se logra la ejecución inmediata del crédito tributario. De las figuras que regula la Sección Quinta de la LGT, sólo la hipoteca legal tácita que aparece en el artículo 78 de la LGT y el derecho de afección del artículo 79 de la LGT conceden a la Hacienda Pública la facultad de reipersecutoriedad, la preferencia y la oponibilidad erga omnes, al igual que la hipoteca legal expresa del artículo 66 del RGR. En todos estos casos la normativa tributaria configura garantías específicas a favor de la Administración tributaria. Las garantías reales se estudian en el tercer capítulo junto con otras tres medidas tutelares que no pueden ser entendidas como garantías en sentido estricto, porque carecen de los requisitos necesarios para ser concebidas como tal, ya sea porque sólo otorgan una preferencia para el cobro, o porque no permiten la ejecución inmediata del bien, o por su carácter provisional. Se trata del derecho de prelación general del artículo 77, el derecho de retención del artículo 80 y las medidas cautelares del artículo 81, todos de la LGT. Aunque estas prerrogativas no pueden incorporarse al grupo de garantías en sentido estricto, su utilización junto con algunas de las garantías reales fortalece la eficacia de éstas últimas, lográndose así una mayor seguridad en la satisfacción del crédito tributario.

Ahora bien, la ley permite que el obligado tributario pueda solicitar el aplazamiento o fraccionamiento del pago o la suspensión del acto administrativo por la interposición de recursos. En estos casos, el interesado deberá presentar algunas de las garantías que aparecen reguladas en el artículo 82 y en el artículo 233, ambos de la LGT. Estos preceptos exigen la constitución de garantías personales o reales por parte del obligado tributario, cuyo régimen jurídico se encuentra en el Derecho privado. En el quinto capítulo se analizan las garantías reales o personales que deberán presentar los interesados cuando soliciten el aplazamiento o fraccionamiento del pago o la suspensión del ingreso por interposición de recursos. Tradicionalmente, estas garantías para aplazar, fraccionar o suspender, se denominan garantías voluntarias, porque es el obligado tributario el que determina el objeto de la garantía, pudiendo, en cierta medida, elegir la garantía entre varias opciones.

En definitiva, las garantías reales que el ordenamiento tributario establece y regula específicamente a favor de la Administración tributaria son: la hipoteca legal tácita del artículo 78, y el derecho de afección del artículo 79, ambos de la LGT. Junto a estas figuras debemos situar también a la hipoteca legal expresa del artículo 66 del RGR. Otras garantías de carácter real no tributarias, como la hipoteca y la prenda, cuyo régimen se contiene en la normativa civil, son acogidas por el derecho tributario no como garantías atribuibles a la Administración tributaria, sino únicamente para exigir su

este mismo sentido, FERRANDIS VILELLA, J., "Introducción al estudio de los derechos reales de garantías", Anuario de Derecho Civil, Tomo XIII-I, 1960, pág. 45 a 52. 
presentación al obligado tributario en caso de que éste solicite el aplazamiento o fraccionamiento del pago o la suspensión del acto administrativo por la interposición de recursos.

\subsubsection{Las garantías personales}

En el ámbito civil se considera que las garantías son de carácter personal en aquellos casos en que se concede al acreedor un derecho de naturaleza personal o una facultad que no se dirige hacia una cosa determinada, sino hacia la misma persona del deudor o hacia un tercero. Desde la perspectiva civilista, se reconocen dos modos básicos de garantías personales: la atribución de un derecho de crédito contra un tercero que asume la deuda junto con el deudor o en sustitución de éste (fianza, aval, o solidaridad en función de la garantía); o la concesión al acreedor de una facultad subsidiaria contra el mismo deudor y la imposición a éste de una prestación adicional (pena convencional) ${ }^{327}$.

Los conceptos que aparecen en la doctrina tributaria no se diferencian mucho de lo que hemos visto hasta ahora. La mayoría de los autores coincide en que las garantías personales del crédito tributario son derechos o facultades que la ley confiere al acreedor para que pueda satisfacer su crédito sobre la masa patrimonial del deudor o de un tercero en atención a una serie de cualidades personales de estos titulares del patrimonio, determinadas en la ley ${ }^{328}$.

La doctrina incluye, dentro de las medidas garantistas que confieren al acreedor tributario un derecho de naturaleza personal, la responsabilidad tributaria, la solidaridad tributaria pasiva y la fianza. Dentro de este grupo hemos incluido el supuesto típico de garantía personal, la fianza, que se manifiesta a través del aval bancario y la fianza personal y solidaria, y que se exige como garantía para aplazar o fraccionar el pago de la deuda tributaria ${ }^{329}$, o para suspender la ejecución de un acto administrativo cuando se interpone un recurso ${ }^{330}$. El régimen jurídico de la fianza se contiene en el Código Civil y nosotros analizamos su régimen jurídico someramente en el capítulo quinto a los efectos señalados. Al igual que sucede con las garantías reales, también aquí las garantías personales del Derecho civil (la fianza y el aval) que la LGT recoge no constituyen garantías personales tributarias previstas a favor de la Administración tributaria, sino garantías personas civiles que la normativa tributaria únicamente adopta para que los obligados tributarios puedan solicitar el aplazamiento o fraccionamiento del pago o la suspensión del mismo por la presentación de reclamaciones.

La normativa tributaria, en cambio, es la que regula las dos primeras modalidades de garantías personales señaladas, la responsabilidad solidaria y subsidiaria y la solidaridad tributaria pasiva. Esta

\footnotetext{
${ }^{327}$ DÍEZ PICAZO, L., Fundamentos del Derecho Civil Patrimonial II. Las relaciones obligatorias, op. cit., pág. 582.

${ }^{328}$ GUERRA REGUERA, M., Garantías personales del crédito tributario. Algunas cuestiones, op. cit., pág. 36. Define este autor las garantías personales como los "derechos o facultades conferidos directa o indirectamente por Ley al acreedor -esto es, la Administración tributaria- y adicionados a su derecho de créditos, conforme a los cuales, la masa patrimonial hacia la que puede dirigirse para satisfacer su crédito viene determinada en atención a las cualidades de una persona". Por su parte, GARCÍA NOVOA, C., "La necesaria modificación de las garantías del crédito tributario en una nueva futura Ley General Tributaria", op. cit., pág. 63, entiende que con las garantías personales se "confiere al acreedor un derecho de naturaleza personal, normalmente bajo la forma de un crédito a favor de un tercero, que asume la deuda junto con el deudor o en sustitución de éste".

${ }^{329}$ Las garantías que deben presentarse para solicitar el aplazamiento o fraccionamiento del pago de la deuda tributaria fueron objeto de estudio en el Capítulo Primero, vid. supra. epígrafe 3.2.4. "Presentación de Garantías".

${ }^{330}$ Incisos b) y c) del apartado segundo del artículo 233 de la LGT.
} 
segunda precisa la coexistencia de varios titulares del hecho imponible o varios responsables, y se extiende también a la solidaridad de la tributación conjunta en el IRPF ${ }^{331}$. En todos estos casos no sólo se garantiza la satisfacción del crédito tributario, sino que se incorpora a nuevos sujetos en el cumplimiento de la obligación tributaria, lo que justifica para algunos autores la necesidad de su tratamiento en el ámbito de la subjetividad tributaria ${ }^{332}$.

A pesar de que estas dos últimas instituciones (la responsabilidad y la solidaridad tributaria) se abordan en profundidad en el capítulo cuarto, debemos preguntarnos en este momento si la figura del responsable puede encuadrarse dentro del campo de los derechos de garantía, porque no todas las opiniones que aparecen en la doctrina responden afirmativamente a esta cuestión, ya sea por la ubicación sistemática de este sujeto dentro de la LGT, como un obligado al pago; por la dificultad que implica asimilar al responsable tributario con la fianza que se regula en el Código Civil ${ }^{333}$; o por la colocación del responsable junto al obligado principal, que es lo que confiere a este sujeto el carácter de deudor, siendo entonces ésta su condición jurídica y no la de garantía ${ }^{334}$.

A nuestro juicio debemos partir del hecho de que la responsabilidad tributaria tiene por finalidad garantizar el pago de la deuda tributaria, otorgando a la Administración tributaria un derecho subjetivo sobre el patrimonio del responsable. Derecho subjetivo que se regula en la ley y es accesorio al derecho subjetivo o la facultad que se deriva como consecuencia de la realización del hecho imponible. Los autores que están a favor de la inclusión del responsable dentro de las garantías personales del crédito tributario fundamentan, además, su posición en que se trata de una obligación impuesta por la ley a un tercero que no participa de la realización del hecho imponible, pero que responde junto al deudor principal del cumplimiento de la obligación tributaria ${ }^{335}$.

Retomando las palabras del profesor SÁNCHEZ GALIANA, es indudable que "la principal finalidad del responsable es la de asegurar el cumplimiento de la obligación tributaria (...). La finalidad garantista, o si se quiere el fundamento no jurídico de la responsabilidad, presente en todos los supuestos, llevará a que sean dos los patrimonios sujetos al pago de la deuda tributaria, el del sujeto

\footnotetext{
${ }^{331}$ En su momento RODRÍGUEZ BEREIJO apuntó que la solidaridad de varios titulares del hecho imponible y la solidaridad de los responsables, tienen la misma función de conseguir un refuerzo de la posición jurídica del acreedor, cuyo derecho se garantiza en la medida que todos los deudores asumen la totalidad del cumplimiento del deber de cada uno de ellos. Sin embargo, aclara que no estamos en presencia de figuras idénticas, puesto que la solidaridad de dos o más titulares en la realización del hecho imponible afecta únicamente al ámbito de la obligación tributaria, de la que constituye un verdadero reforzamiento. En cambio, la solidaridad de los responsables "más que un reforzamiento o garantía de la obligación tributaria, constituye un reforzamiento de la relación jurídico tributaria, por cuanto junto a la obligación tributaria principal, que incumbe al sujeto pasivo contribuyente, viene a establecerse otra obligación accesoria, dependiente de la primera, pero constituida en condiciones de paridad jurídica: es decir, situadas ambas en un mismo plano". RODRÍGUEZ BEREIJO, A., "Las garantías del crédito tributario", op. cit., pág. 191.

332 GARCÍA NOVOA, C., "La necesaria modificación de las garantías del crédito tributario en una nueva futura Ley General Tributaria", op. cit., pág. 64.

333 PÉREZ ROYO, F., "La sucesión en la deuda por el Impuesto de Sociedades ante el artículo 72 de la Ley General Tributaria", Crónica Tributaria, núm. 3, 1972, pág. 159.

${ }^{334}$ Sobre la naturaleza jurídica de la responsabilidad tributaria vid. infra, Capítulo Cuarto, epígrafe 2.2. "Naturaleza y fundamento de la responsabilidad tributaria".

${ }^{335}$ Tal como interpreta CALVO ORTEGA, R., "La responsabilidad tributaria solidaria por actos ilícitos”, op. cit., pág. 38 a 39 , "si por garantía se entiende cualquier figura jurídica que tiende a aumentar la seguridad del cumplimiento de una obligación o el disfrute de un derecho, es claro, a nuestro juicio, que el legislador tributario ha pretendido con el establecimiento de la responsabilidad aumentar la seguridad del pago de la deuda tributaria. Para ello ha buscado un efecto jurídico concreto: junto a la sujeción el patrimonio del contribuyente se declara por una norma jurídica, no importa ahora en qué plano, la sujeción del patrimonio del responsable". En este mismo sentido, RODRÍGUEZ BEREIJO, A., "Las garantías del crédito tributario", op. cit., pág. 187.
} 
pasivo como obligado principal, y el del responsable en una posición de accesoriedad, tras el cumplimiento de los pertinentes requisitos legales (...). No cabe duda de la consideración de la obligación del responsable como una obligación accesoria, en el sentido, claro está, de dependiente de la principal, o bien que se haría efectiva si el sujeto pasivo no hace frente a la obligación tributaria",336.

Además, entendemos que la figura del responsable tributario constituye una garantía personal del crédito tributario en sentido estricto, no sólo porque tiene por finalidad garantizar el pago de la deuda tributaria, sino porque aunque se asemeje mucho a la fianza no es posible aplicar a ambas instituciones el mismo régimen jurídico.

\section{DELIMITACIÓN CON FIGURAS AFINES}

Junto a la garantías tributarias en sentido estricto (reales y personales), existen otras categorías que presentan semejanzas y que al igual que la primeras tienen como finalidad reforzar y asegurar el crédito y conceden al acreedor tributario la facultad de cobrar con preferencia frente a los otros acreedores concurrentes. Se trata, no obstante, de instituciones distintas que no poseen el poder de persecución y ejecución que acompaña a las garantías tributarias, por lo que habrá que establecer los criterios de delimitación entre los derechos reales y personales de garantía y estas otras categorías. Nos referimos concretamente a los privilegios que acompañan al crédito tributario y a las medidas cautelares que puede adoptar la Administración tributaria cuando vea comprometida la satisfacción de su crédito.

\subsection{DISTINCIÓN ENTRE LOS PRIVILEGIOS Y LAS GARANTÍAS DEL CRÉDITO TRIBUTARIO}

Un crédito tributario privilegiado "no tiene acción frente a un tercero distinto del deudor para reclamarle la satisfacción de su crédito; en consecuencia, no se trata de una garantía personal. Pero es que tampoco tiene poder alguno sobre bienes determinados que pueda ser ejercitado «erga omnes»; por tanto, tampoco nos encontramos ante una garantía real"337. Hemos querido comenzar con las palabras de GÓMEZ CABRERA porque este autor en pocas líneas presenta una de las cuestiones que demanda especial atención por la similitud de instituciones que aparecen reflejadas (los privilegios y las garantías), pero que requieren de un tratamiento diferente, sobre todo desde el punto de vista legislativo.

\footnotetext{
${ }^{336}$ SÁNCHEZ GALIANA, J. A., "El responsable", en la obra Comentarios a la Ley General tributaria y lineas para su reforma. Homenaje a F. Sáinz de Bujanda, Vol. I, Instituto de Estudios Fiscales, Madrid, 1991, pág. 636 a 637. Este autor entiende que para considerar la obligación del responsable como una obligación de garantía sería necesario una "construcción jurídico-tributaria nueva, que supondría completar los actuales preceptos tributarios con algunos trasladables del Derecho civil relativos a la fianza, cambiar la actual sistematización de la LGT y modificar la formulación legal de otros preceptos afectados. En tanto no se produzca esta nueva, aunque quizás más adecuada configuración jurídica del responsable tributario, debemos mantener su carácter de auténtico deudor, obligado al pago, aunque situado en una posición de accesoriedad respecto a la obligación tributaria, no teniendo jurídicamente la consideración de sujeto pasivo, y estimando, eso sí, su finalidad esencialmente garantista del cumplimiento de la prestación tributaria". Veremos más adelante como todavía mantienen su vigencia estos postulados de SÁNCHEZ GALIANA y que, a pesar de que el reclamo que realizaba este autor se dirigía a una disminución de los supuestos de los tipos de responsabilidad y a su correcta configuración, el legislador se decantó por ampliar los supuestos de responsabilidad tributaria, algunos de los cuales presentan un marcado carácter sancionador.

337 GÓMEZ CABRERA C., La concurrencia del crédito tributario: Aspectos sustantivos y procedimentales. Prelación, garantías, tercerías, ejecuciones preferentes, suspensiones de pago y quiebras, op. cit., pág. 32.
} 
En ocasiones los conceptos de prioridad, preferencia o prelación aparecen entrelazados, y con ellos se identifica también la idea de privilegio ${ }^{338}$. Al abordar este tema utilizaremos indistintamente estos términos, asumiendo que etimológicamente significan exactamente lo mismo, porque lo que buscamos en sentido general es delimitar la institución de las garantías con el privilegio, y en particular, las garantías del crédito tributario con los privilegios que suelen acompañar a aquéllos.

\subsubsection{Los privilegios generales y especiales}

El carácter privilegiado de un crédito consiste en una ruptura o una excepción del principio de igualdad de trato de los acreedores que se produce cuando la ley concede a uno de ellos la facultad de cobrar con preferencia a los demás, al que se denomina por ello acreedor ordinario, sobre el producto obtenido por la realización de los bienes del deudor o de otras personas.

Los privilegios son siempre facultades concedidas al acreedor que acompañan a su derecho de crédito, que pueden considerarse como accesorios del crédito mismo, y que no se pueden negociar ni es posible disponer sobre ellos con separación del crédito, del que son accesorios.

Para determinar la naturaleza jurídica de los privilegios, lo primero que debe precisarse es si los privilegios constituyen o no verdaderos derechos reales. La repuesta sería afirmativa si los privilegios recayesen sobre bienes determinados y fueran oponibles frente a terceros y en particular frente a los terceros posibles adquirentes de los bienes.

Según DÍEZ PICAZO, la normativa que establece los privilegios "no concede al acreedor ningún derecho subjetivo autónomo. Por el contrario, el privilegio es una simple cualidad del crédito y, por consiguiente, una simple facultad atribuida, que forma parte del contenido general de un derecho más amplio. Por ello, se hace preciso distinguir aquellos privilegios que van unidos a un derecho especial de garantía (por ejemplo, prenda, hipoteca) y aquellos que se conceden a un acreedor que carece de una garantía especial. En el primer caso existe efectivamente un derecho real, pero el carácter real no es una consecuencia específica del privilegio, sino del carácter que tiene la garantía de que el privilegio es consecuencia. En el segundo caso no se puede hablar de derecho real ni de reipersecutoriedad. El privilegio es una simple facultad del acreedor para reclamar el cobro preferente frente a otros acreedores",339.

Los privilegios pueden clasificarse en generales y especiales. Los privilegios generales son aquellos que recaen sobre la totalidad del patrimonio del deudor. El acreedor de un privilegio general tiene frente a los acreedores comunes y ordinarios el derecho a ser reintegrado preferentemente cualesquiera que sean los bienes realizados o vendidos. Los privilegios especiales, por el contrario, son aquellos que recaen sobre bienes determinados y concretos. Según la naturaleza de los bienes sobre los que recaen pueden ser privilegios inmobiliarios y privilegios mobiliarios. Los privilegios inmobiliarios son aquellos que conceden un derecho al acreedor para cobrar con preferencia a los demás con el producto de la venta de determinados bienes inmuebles pertenecientes al deudor, según establece el artículo 1.923 del Código Civil. Nos referimos a ellos concretamente porque por lo

\footnotetext{
${ }^{338}$ Según este GULLÓN BALLESTEROS, la prelación tiene un sentido más amplio que el privilegio, puesto que el primero puede existir sin el segundo (GULLÓN BALLESTEROS, A., La prelación de créditos en el Código Civil, Bosch, Barcelona, 1962, pág. 15).

${ }^{339}$ DÍEZ PICAZO, L., Fundamentos del Derecho Civil Patrimonial II. Las relaciones obligatorias, op. cit., pág. 753.
} 
general se trata de formas especiales de derechos reales de garantía, en particular de casos de aplicación del derecho real de hipoteca ${ }^{340}$.

Finalmente, el Estado dispone de preferencia sobre los bienes inmuebles de los contribuyentes para percibir impuestos que gravitan sobre dichos bienes. De acuerdo con la técnica ius privatista se trata de un derecho de hipoteca legal, cuyo fundamento puede encontrarse en una potestad de la Hacienda Pública y en el interés o destino a la realización de los fines públicos que la carga impositiva lleva siempre consigo, tal como refleja el propio artículo 1.923 del Código Civil.

\subsubsection{Diferencias entre los privilegios y las garantías del crédito tributario}

Acabamos de indicar que las garantías reales recaen directamente sobre un bien o conjunto de bienes, otorgando a su titular facultades de reipersecutoriedad, eficacia erga omnes y preferencia para el cobro. Por su parte, el crédito privilegiado opera en situaciones de concurrencia de créditos como derecho a cobrar antes que otros acreedores. Es aquí donde se centra nuestro análisis, en el efecto que producen las garantías o los privilegios sobre los bienes gravados, porque es precisamente eso lo que nos permite afirmar que el privilegio no es una garantía real o personal en sentido estricto.

Nuestro criterio se sustenta en el hecho de que el titular de un derecho real o personal de garantía tiene la facultad de perseguir un bien determinado e instar su ejecución para satisfacer su crédito, ostentando acción contra su deudor y también frente a un tercero. Mientras que el acreedor privilegiado sólo podrá ir contra su propio deudor, sin que tenga ningún derecho subjetivo autónomo. El acreedor privilegiado sólo tiene un derecho a cobrar antes que el resto de los acreedores sin que ello suponga ningún otro derecho sobre el bien.

El privilegio general sólo tiene operatividad en el marco de varios acreedores en el ámbito procesal, "pues sólo entrará en juego bien cuando el acreedor privilegiado, que ve lesionado su derecho, se opone, a través de la correspondiente tercería, a la pretensión de otro no preferente de anticiparse en el cobro, bien en las situaciones de concurso cuando el patrimonio del deudor no basta para satisfacer a todos los acreedores" ${ }^{341}$. Esto significa que el derecho de perseguir y ejecutar la cosa no se deriva del privilegio: de él sólo se desprende el derecho de anteponerse al resto de los acreedores concurrentes.

Por ello, debemos reiterar que el privilegio "no es un derecho autónomo sino una cualidad o propiedad de un derecho que puede acompañar tanto a un derecho real como a un derecho de crédito, sea éste simple o garantizado" ${ }^{342}$. En este sentido, señala RODRÍGUEZ BEREIJO que la preferencia general de la Hacienda Pública se manifiesta, cuando previo embargo y enajenación de los bienes, se

\footnotetext{
${ }^{340}$ Entiende RODRÍGUEZ BEREIJO que "los privilegios son considerados como garantías especiales que derogan la garantía común que todos los acreedores, incluso los privilegiados e hipotecarios, encuentran igualmente en el patrimonio del deudor. La razón del privilegio de los créditos tributarios establecida por la ley descansa en la importancia de los ingresos públicos para la existencia y funcionamiento del Estado y demás entes públicos lo que lleva a la necesidad y utilidad de otorgarles privilegios crediticios para la recaudación de los medios pecuniarios que le son necesarios para el cumplimiento de sus fines". RODRÍGUEZ BEREIJO, A., "Las garantías del crédito tributario", op. cit., pág. 194.

${ }^{341}$ GÓMEZ CABRERA C., La concurrencia del crédito tributario: Aspectos sustantivos y procedimentales. Prelación, garantías, tercerías, ejecuciones preferentes, suspensiones de pago y quiebras, op. cit., pág. 33.

${ }^{342}$ ARRANZ DE ANDRÉS, C., Las garantías reales del crédito tributario: aspectos sustantivos y procedimentales, op. cit., pág. 50.
} 
procede a repartir el valor obtenido de la venta de los mismos, y es precisamente en ese momento cuando lo que era simplemente una cualidad del crédito se convierte en un derecho real sobre el producto de la realización forzosa de los bienes ${ }^{343}$.

La dificultad mayor en este tema la encontramos en los llamados privilegios especiales, que algunos autores equiparan a las garantías reales ${ }^{344}$. Y es que si se asume como privilegio especial el derecho de preferencia o prelación que un acreedor despliega frente a los otros acreedores sobre el producto que se obtenga de la venta de determinado bien o bienes, entonces el derecho de preferencia o prelación se asemejará mucho a un derecho real de garantía, porque no sólo se otorga al acreedor privilegiado una preferencia sino que se le concede un derecho de persecución ${ }^{345}$.

Para CARRAMOLINO los privilegios no tienen naturaleza real. En ocasiones el privilegio se concede sobre un bien concreto y determinado (privilegio especial), pero esto no es razón suficiente para calificar al privilegio como real. Pues, según este mismo autor, el privilegio supone una excepción al principio de la par conditio creditorum y sólo podrá hacerse valer en tanto los bienes sobre los que recae se hallen en patrimonio del deudor. En cambio, la garantía puede aplicarse sobre bienes anteriores del deudor en función de la afección que conlleva. El privilegio, por actuar exclusivamente en el ámbito de la responsabilidad del deudor, puede constituirse únicamente sobre los bienes presentes y futuros, y sólo cuando el privilegio derive en una garantía de naturaleza real podrá hacerse valer sobre los bienes que anteriormente fueron del deudor, aunque ello no es un privilegio en sí, sino una función de afección implícita en la garantía ${ }^{346}$.

Esta opinión doctrinal es mayoritaria y la siguen autores como ARRANZ DE ANDRÉS, GÓMEZ CABRERA o GULLÓN BALLESTEROS ${ }^{347}$. Entendemos también nosotros que el acreedor privilegiado no tiene una facultad para dirigirse directamente contra los bienes del deudor y mucho menos contra los de un tercero como si se tratara, por ejemplo, del titular de una hipoteca, porque sólo posee una preferencia o prelación para cobrar el producto de la realización de determinados bienes en relación con el resto de los acreedores ordinarios. Por ende, cuando otro acreedor no preferente pretenda cobrar antes que un acreedor privilegiado, dañará el derecho de crédito de que

\footnotetext{
${ }^{343}$ RODRÍGUEZ BEREIJO, A., "Las garantías del crédito tributario”, op. cit., pág. 195. Para este autor, ésta es una de las causas que produce confusiones en la doctrina al referirse a la naturaleza real de los privilegios, con la que no se muestra de acuerdo.

${ }^{344}$ Tal es el caso de GARCÍA NOVOA, que afirma que las garantías reales "pueden configurarse como privilegios especiales del crédito dotados de las características de oponibilidad erga onmes y reipersecutoriedad" (GARCÍA NOVOA, C., "La necesaria modificación de las garantías del crédito tributario en una nueva futura Ley General Tributaria”, op. cit., pág. 65). En el mismo sentido, GUERRA REGUERA, M., Garantías personales del crédito tributario. Algunas cuestiones, op. cit., pág. 191.

${ }^{345}$ Así lo considera GULLÓN BALLESTEROS, A., "El crédito privilegiado en el Código civil”, Anuario de Derecho Civil, Tomo XIII, 1958, pág. 450, a partir de la interpretación que hace del apartado 7 del artículo 1. 922 del Código Civil, que establece la preferencia para el cobro sobre los bienes muebles del arrendatario existentes en la finca arrendada y sobre los frutos de la misma, extendiéndose incluso a los casos en que los bienes muebles hubieran sido sustraídos, por lo que el acreedor podría reclamarlos de quien los tuviese dentro del término de treinta días contados desde que ocurrió la sustracción.

346 CARRAMOLINO, C., "La hipoteca legal tácita y crédito singularmente privilegiado (una breve reflexión a propósito de la resolución de 3 de abril de 1998)", Revista General de Derecho, año LIV, núm. 649-650, 1998, pág. 12732.

${ }^{347}$ ARRANZ DE ANDRÉS, C., Las garantías reales del crédito tributario: aspectos sustantivos y procedimentales, op. cit., pág. 51; GÓMEZ CABRERA C., La concurrencia del crédito tributario: Aspectos sustantivos y procedimentales. Prelación, garantías, tercerías, ejecuciones preferentes, suspensiones de pago y quiebras, op. cit., pág. 34; GULLÓN BALLESTEROS, A., "El crédito privilegiado en el Código civil”, op. cit., pág. 447 a 451.
} 
dispone éste último, que podrá oponerse a través de una tercería de mejor derecho. Por el contrario, cuando se trata de un crédito que se asegura con una garantía en sentido estricto, el acreedor tiene una facultad, potestad o derecho distinto del que obtiene con su derecho de crédito, aunque accesorio, que podrá ejercitar contra terceros o directamente contra un bien independientemente de quién sea su titular o poseedor.

A modo de resumen podemos decir que el privilegio ordena el cobro entre los distintos créditos concurrentes contra un mismo deudor, señalando cuál de éstos tendrá preferencia sobre los demás, ya sea sobre todo el patrimonio del deudor o sobre el producto de la realización de determinados bienes. Mientras que el crédito asegurado por una garantía real otorga un poder al acreedor para retener o ejecutar directamente determinados bienes para destinarlos al pago y no necesita la existencia de la concurrencia de créditos, como sí pasa con los créditos privilegiados. Por último, el acreedor privilegiado sólo podrá pretender la realización forzosa de los bienes que pertenezcan al deudor en el momento de la ejecución. En cambio, el acreedor garantizado podrá dirigirse contra los bienes gravados, aun cuando éstos hayan pasado a un tercero. Finalmente, es importante recordar que puede darse al crédito garantizado un privilegio especial sobre el producto de la realización de un determinado bien gravado. En efecto, el acreedor asegurado no sólo podrá efectuar la realización forzosa del bien gravado para cubrir el pago, sino que gozará de un privilegio que le permitirá aplicar la preferencia sobre el producto de la realización del bien determinado antes que el resto de los acreedores.

\subsection{DISTINCIÓN ENTRE LAS MEDIDAS CAUTELARES Y LAS GARANTÍAS DEL CRÉDITO TRIBUTARIO}

Otra de las categorías que se asemejan a las garantías en sentido estricto son las medidas cautelares. Cuando las estudiamos en el primer capítulo, al cual nos remitimos, observamos que junto con la retención del pago de devoluciones tributarias o de otros pagos que deba realizar la Administración tributaria, el embargo preventivo constituye uno de los supuestos más típicos de medida cautelar que la Hacienda Pública puede utilizar como garantía de la deuda tributaria. Sin embargo, estas medidas cautelares, y sobre todo la figura del embargo preventivo, no constituyen garantías del crédito tributario en sentido estricto.

\subsubsection{Diferencias entre las medidas cautelares y las garantías del crédito tributario}

En el ámbito tributario la distinción entre las medidas cautelares en general y las garantías del crédito tributario se centra en tres aspectos fundamentales: la finalidad y operatividad; la provisionalidad y la configuración legal.

\section{A. Finalidad y operatividad}

CORCUERA TORRES ${ }^{348}$ entiende que con las garantías lo que la ley pretende es otorgar una serie de privilegios a la Hacienda Pública para hacer prevalecer el interés público tributario frente a las intenciones de terceros acreedores. Mientras que con las medidas cautelares lo que se busca es asegurar el cobro de la deuda tributaria ante la posibilidad de que se produzca el incumplimiento por

\footnotetext{
${ }^{348}$ CORCUERA TORRES, A., Las medidas cautelares que aseguran el cobro de la deuda tributaria, op. cit., pág. 61 a 63.
} 
parte del obligado. De esta forma también se logran efectos disuasorios sobre el deudor sin que se vean implicados intereses ajenos a los de los protagonistas de la situación inicial.

ARRANZ DE ANDRÉS corrobora estos postulados e incluye otros elementos que considera necesarios para establecer las diferencias entre las medidas cautelares y los derechos reales de garantía. La autora apunta "que si bien las medidas cautelares se establecen para asegurar el cumplimiento de la obligación tributaria, la misma atribución puede atribuirse a las garantías, cuya finalidad no es otra que la de forzar la satisfacción del crédito tributario, dando así seguridad a su cumplimiento final"349. Asimismo, entiende que las medidas cautelares conceden a la Hacienda Pública una cierta prioridad frente a otros acreedores, pues "habiendo practicado y anotado, por ejemplo, un embargo preventivo, adquirirá para la satisfacción de su crédito un derecho de ejecución preferente sobre ese bien frente a otros posibles acreedores que puedan concurrir por deudas contra el mismo deudor". Además, en el caso de que se trate de un bien embargado que se enajenó, el adquirente del bien, que se encontraba ajeno en un primer momento, deberá respetar el derecho que se pretendía garantizar a través de dicho embargo. Esta autora alega que en el caso de las garantías reales la eficacia del derecho va más allá del derecho preferente del cobro, debido a que actúa como una carga sobre la cosa, que podrá ejecutarse en caso de impago con independencia de que existan o no otros acreedores concurrentes.

\section{B. Provisionalidad}

Las garantías se aplican de forma definitiva para asegurar la satisfacción del crédito tributario y sus efectos se producen en el proceso de ejecución forzosa del crédito y frente a terceros acreedores que aleguen una preferencia de cobro ante la Hacienda Pública. Las medidas cautelares tienen un carácter esencialmente provisional, pudiéndose aplicar, incluso, antes de que la deuda se encuentre liquidada. La provisionalidad de las medidas cautelares frente al carácter definitivo o ejecutorio de las garantías es uno de los aspectos fundamentales para diferenciar ambas instituciones. Las medidas cautelares se adoptan cuando se percibe un posible incumplimiento, en ocasiones antes de que finalice el período voluntario $^{350}$, cesando en su eficacia si desaparece el periculum in mora o si se convierten en definitivas una vez que se inicia la vía de apremio y se necesita ejecutar los bienes del deudor. Por el contrario, las garantías existirán como relación accesoria al crédito que garantizan, desde el instante en que nace éste, con independencia de que exista o no un peligro de impago, no siendo efectivas hasta que el crédito se encuentre en la fase ejecutiva de cobro.

\section{Configuración legal}

Las diferencias en este caso se encuentran, según CORCUERA TORRES ${ }^{351}$, en que las normas que regulan las medidas cautelares disponen que, en cuanto se cumpla el presupuesto de hecho que da

\footnotetext{
${ }^{349}$ ARRANZ DE ANDRÉS, C., Las garantías reales del crédito tributario: aspectos sustantivos y procedimentales, op. cit., pág. 58.

${ }^{350}$ ORTELLS RAMOS es del criterio que no es necesario que la deuda se encuentre líquida para que pueda adoptarse un embargo preventivo, porque entiende que el embargo preventivo no es una afección de bienes para destinarlos inmediatamente a la realización forzosa al pago de la deuda, sino con el propósito de asegurar la eventual condena. Además, apunta este autor, que "la iliquidez de la obligación no impide el ejercicio de la acción de condena, ni una sentencia de esa naturaleza". ORTELLS RAMOS, M., El embargo preventivo, Bosch, Barcelona, 1984, pág. 82 a 84.
}

${ }^{351}$ CORCUERA TORRES, A., Las medidas cautelares que aseguran el cobro de la deuda tributaria, op. cit., pág. 50 y ss. 
origen a las mismas, la Administración tributaria puede decidir la medida cautelar que más le convenga. De esta forma el mandato se resume en conceder la posibilidad de manifestar una declaración de voluntad, que se encuentra en un acto administrativo expreso. En cambio, los preceptos que regulan las garantías, sobre todo el derecho de afección, determinan expresamente los efectos del mismo, en el caso que suceda el supuesto fáctico, esto es, que se incumpla con la obligación de pago. A estos postulados del autor adiciona ARRANZ DE ANDRÉS ${ }^{352}$ que también las garantías reales que se hubieran establecido por ley requieren de un acto administrativo para su efectiva puesta en práctica.

\subsubsection{El embargo preventivo y los derechos reales de garantía}

El embargo supone, al igual que los derechos reales, la afección de bienes concretos para ser realizados en una determinada fase del procedimiento de apremio. No obstante, esto no implica que se puedan equiparar ambas figuras, por la propia finalidad que persiguen, pues en un caso (el embargo) se pretende hacer efectiva la ejecución y en el otro (garantías) asegurar una ejecución futura. Además, el embargo ejecutivo se practica por un órgano jurisdiccional dentro de un proceso ejecutivo pendiente, una vez que se produce el incumplimiento y se ha despachado la ejecución. Por su parte, las garantías reales del crédito sólo necesitan para su nacimiento que se constituya la obligación que tratan de asegurar ${ }^{353} \mathrm{y}$, por tanto, su origen se encuentra fuera del procedimiento de ejecución.

Según su finalidad puede hablarse de dos tipos de embargo: el embargo preventivo y el embargo ejecutivo. El primero tiene por objeto sujetar los bienes del deudor al proceso de ejecución que se desarrolla para realizar los bienes embargados, hasta cubrir el monto de la deuda tributaria. El segundo se practica para prevenir los resultados de un juicio. El embargo preventivo tiene un carácter instrumental y su función principal es la de asegurar la efectividad de un hipotético derecho. Lo que permite suponer a ARRANZ DE ANDRÉS que "los derechos reales de garantía y los embargos preventivos tienen el mismo significado y la misma finalidad, esto es, procuran a su titular la facultad de cobrar una deuda mediante la realización de un bien previamente sujeto a ejecución, con preferencia al resto de acreedores y con independencia de los derechos adquiridos con posterioridad por terceros" 354 .

Esta similitud entre ambas figuras no es suficiente para equipararlas. No es posible que pueda identificarse plenamente el embargo preventivo con una garantía del crédito tributario. El embargo preventivo se utiliza cuando existen indicios racionales de que se verá frustrada o gravemente dificultada la ejecución de un derecho que se pretende, en el caso de que no llegue aplicarse. Por el contrario, las garantías reales se establecen en el mismo momento en que nace la obligación que se asegura, y no necesitan que se produzca un riesgo de incumplimiento o insatisfacción de la misma ${ }^{355}$.

\footnotetext{
${ }^{352}$ ARRANZ DE ANDRÉS, C., Las garantías reales del crédito tributario: aspectos sustantivos y procedimentales, op. cit., pág. 56.

${ }^{353}$ ORTELLS RAMOS, M., Las medidas cautelares, La Ley, Madrid, 2000, pág. 47 a 51.

${ }^{354}$ ARRANZ DE ANDRÉS, C., Las garantías reales del crédito tributario: aspectos sustantivos y procedimentales, op. cit., pág. 53 a 54.

${ }^{355}$ Es ésta la postura que finalmente asume ARRANZ DE ANDRÉS, C., Las garantías reales del crédito tributario: aspectos sustantivos y procedimentales, op. cit., pág. 54. También ROCA SASTRE hace la misma afirmación, cuando opina que no existe
} 
Otra de las diferencias entre las dos instituciones son los efectos que produce su inscripción registral, sobre la base de las distintas formas que tienen de acceder al Registro las garantías reales y los embargos preventivos. La inscripción en el registro de una garantía real, una hipoteca, por ejemplo, es constitutiva y otorga al titular de la inscripción preferencia ante cualquier otro derecho no inscrito hasta ese momento. Mientras que en la anotación del embargo, la preferencia será solamente efectiva frente a derechos que no hubieran surgido antes de realizarse la anotación ${ }^{356}$.

Ésta es la misma posición que asume el Tribunal Supremo, cuando afirma que el embargo como acto procesal y la anotación, que es su proyección registral, nada prejuzgan sobre la verdadera identidad, situación y eficacia de los créditos, ni altera la naturaleza de la obligación ${ }^{357}$. Como afirma el Tribunal Supremo en su Sentencia de 25 de septiembre de 1985, "es indudable que concurren en la repetida anotación los caracteres de individualidad y absolutidad propios de los derechos reales sobre bienes inmuebles, aunque sus efectos no se asimilen totalmente a los del típico derecho real de garantía, es decir, a la hipoteca, pues así como respecto de ésta y por aplicación de los principios hipotecarios y más concretamente, del principio de fe pública registral, el contenido del Registro al tiempo de la inscripción se considera exacto e íntegro, prevaleciendo, en consecuencia, sobre los actos dispositivos o de gravamen que no consisten en sus asientos, aunque sean anteriores, sin embargo, las referidas anotaciones preventivas no modifican la situación jurídica preexistente a su acceso al Registro, de forma que los créditos contraídos o los actos dispositivos otorgados con anterioridad no resultan afectados por la anotación, regulándose la respectiva preferencia por lo dispuesto en el artículo 1.923 y concordantes del Código civil al que remite el artículo 44 de la Ley Hipotecaria, según los cuales gozan de preferencia los créditos previamente anotados en el Registro en virtud de mandamiento judicial por embargo, sobre los bienes anotados y sólo en cuanto a créditos posteriores a la anotación".

En definitiva, podemos concluir que la anotación del embargo otorga cierto efecto real, que puede, incluso, fundar una garantía real, pero esto no significa que lo sea, sino que es "un medio de publicidad de un privilegio o una vinculación inmobiliaria" ${ }^{\text {"358 }}$. El embargo es pues, un acto procesal que produce la afección de un bien con vistas a la obtención de un resultado concreto, y no concede a su titular las facultades de preferencia, reipersecutoriedad y oponibilidad erga omnes de la misma manera que lo hace una garantía real.

paridad entre la hipoteca y el embargo preventivo, que esta paridad se produce entre la hipoteca y la anotación preventiva del embargo, pero con la diferencia de que ésta última se constituye como una hipoteca de embargo, "con las características de implicar en el fondo una hipoteca de seguridad en la que no está protegido su titular por la fe pública registral” (ROCA SASTRE, R. y ROCA SASTRE, L., Derecho Hipotecario, Tomo IV $-1^{\circ}, 7^{\mathrm{a}}$ ed., Bosch, Barcelona, 1979, pág. 245).

${ }^{356}$ RODRÍGUEZ BEREIJO se refirió a la función de garantía de la anotación registral, "al objeto de asegurar la efectividad del derecho de crédito tributario dotándole de una eficacia real, erga omnes, mediante la afección de un bien a un proceso de ejecución y la atribución al órgano competente de potestad para realizar el valor de aquél en función de la satisfacción del crédito del ejecutante; cuyos efectos son: de una parte, enervar la eficacia de las enajenaciones realizadas después de dicha anotación, en cuanto perjudiquen los derechos del anotante (derecho de reipersecución); y de otra parte, otorgar al acreedor anotante y respecto del inmueble anotado, la preferencia para el cobro establecida en el artículo 1.923, 4, CC, es decir, sólo en cuanto a los créditos posteriores a la anotación, y en cuanto a los créditos anteriores sólo sobre aquellos que no tengan una razón especial de prelación sobre lo anotado (derecho de preferencia)" (RODRÍGUEZ BEREIJO, A., "Las garantías del crédito tributario", op. cit., pág. 213).

${ }^{357}$ Pueden citarse las Sentencias del Tribunal Supremo de 27 de enero de 1990, de 24 de febrero de 1995, de 15 de julio de 1998 , de 6 de mayo de 2003, y de 31 de diciembre de 2004.

${ }^{358}$ ARRANZ DE ANDRÉS, C., Las garantías reales del crédito tributario: aspectos sustantivos y procedimentales, op. cit., pág. 56. 


\subsubsection{Las medidas cautelares y las garantías voluntarias del crédito tributario}

Resulta necesario exponer brevemente las diferencias y similitudes que muestran las medidas cautelares y las llamadas garantías voluntarias, es decir, las garantías que se presentan para solicitar un aplazamiento o fraccionamiento de pago o para la suspensión de la ejecución del acto impugnado. Estas garantías tienen como objetivo inmediato asegurar la efectividad del crédito tributario. Por ello, su finalidad más cercana es conceder a la Administración tributaria un medio de defensa frente al aplazamiento concedido o frente a la suspensión acordada por vía de recurso. La finalidad que manifiestan estas garantías es, pues, muy similar a la de las medidas cautelares. Ello explica que en el segundo párrafo del apartado 1 del artículo 82 de la LGT se disponga que podrá solicitar el obligado a la Administración tributaria la sustitución de algunas de las garantías que se exigen para otorgar el aplazamiento o fraccionamiento por medidas cautelares. Asimismo, el inciso c) del apartado 5 del artículo 81 de la LGT, también prevé, a solicitud del obligado, la sustitución de medidas cautelares por alguna garantía que estime suficiente la Hacienda Pública.

A pesar de la similitud y la posibilidad de intercambiar ambas figuras, existen diferencias entre las garantías voluntarias y las medidas cautelares, sobre todo en lo que se refiere a su nota de provisionalidad. En aquellos supuestos en que se adopten medidas cautelares en lugar de las garantías para aplazar o fraccionar el pago, el apartado 1 del artículo 82 de la LGT establece que no se aplicará lo dispuesto en el artículo 81 de la misma ley, en cuanto a la limitación temporal de la eficacia de las medidas cautelares. En este mismo sentido, el artículo 44 del RGR determina que, siendo necesaria la ejecución de la medida cautelar prevista en sustitución de la garantía, deberá ser dicha medida convertida previamente en definitiva.

\section{LAS GARANTÍAS DEL CRÉDITO TRIBUTARIO EN LA NORMATIVA TRIBUTARIA}

Con el título de "Garantías de la deuda tributaria”, agrupa la LGT, en la Sección Quinta del Capítulo IV del Título II, un conjunto de supuestos que tienen como finalidad común asegurar el cumplimiento de la obligación tributaria, pero que en esencia no tienen la misma naturaleza jurídica. Algunos de ellos, incluso, no pueden considerarse como garantías del crédito tributario en sentido estricto. También llama la atención que la LGT se refiera a las "garantías de la deuda tributaria" en lugar de las "garantías del crédito tributario", que tradicionalmente se usa para denominar a estas instituciones. Y ello, dice GARCÍA NOVOA, porque "aunque crédito y deuda son el anverso y el reverso de la misma moneda, lo cierto es que la garantía se establece en beneficio del acreedor, por lo que resulta más adecuado considerar al crédito y no a la deuda como objeto de dicha garantía"359.

Es precisamente éste uno de los desaciertos de la LGT, el no perfilar acertadamente el concepto de garantía del crédito tributario. No se produce en dicha ley una adecuada depuración conceptual que permita separar las categorías que reúnen la condición de garantía de las que no lo son. Tampoco lo hizo su antecesora, la LGT de 1963. De hecho, el tratamiento legislativo de las garantías tributarias es prácticamente el mismo en ambas leyes, ha permanecido intacto, continuo, salvo muy puntuales

\footnotetext{
${ }^{359}$ GARCÍA NOVOA, C., "Garantías de la deuda tributaria”, en la obra La nueva Ley General Tributaria, Thomson-Civitas, Madrid, 2004, pág. 322.
} 
modificaciones a las que haremos mención en las próximas páginas. Esto supone en la actualidad el mantenimiento de las problemáticas y de las confusiones predicables de la LGT de 1963.

Partiendo del criterio de que las garantías que se regulan en la LGT son las garantías del crédito tributario, debemos recordar que resulta admisible la separación de las garantías en personales y reales, división que no se encuentra ni en la LGT de 1963, ni en la LGT actual. En este sentido, los supuestos de garantías personales establecidos en la normativa tributaria se reconducen a la responsabilidad tributaria, y por tanto, se encuentran en el ámbito de la subjetividad del tributo y no en sede de las garantías, en la Sección Tercera, del Capítulo II “Obligados Tributarios”, del Título II "Los Tributos". En este aspecto debemos reconocer a la legislación actual el haber excluido del ámbito de las garantías a la llamada "sucesión de empresa" del artículo 72 de la LGT de 1963, que ciertamente es un supuesto de responsabilidad, como bien identificaron la doctrina y la jurisprudencia $^{360}$. La opción que asumió el legislador ante dicha situación fue incluir la regulación de aquélla figura dentro de la Sección Tercera del Capítulo II del Título II de la LGT, dedicado a los responsables tributarios (inciso $c$ ) del apartado primero del artículo 42 y apartado 2 del artículo 175 de la LGT, además del artículo 124 y siguientes del RGR).

Otra de las deficiencias de la LGT de 1963 es la ausencia de referencia alguna a las Comunidades Autónomas, aunque es evidente que el cuadro de garantías se aplica igualmente a los débitos de la Hacienda autonómica y local. CAMY ESCOBAR señala además que en caso de concurrencia de créditos tributarios a favor de diversas entidades, la LGT de 1963 se limitaba a reconocer la preferencia del Estado ${ }^{361}$.

Las garantías que regulaban los artículos 71 y siguientes de la LGT 1963 eran en principio aplicables a las Haciendas Territoriales, incluso en los supuestos en que la ley no decía nada. Respecto a la concurrencia de débitos en favor de la Hacienda Pública con deudas tributarias de otras entidades, si de la ejecución forzosa no resultaba cantidad líquida suficiente para pagar todas las deudas, el apartado 3 del artículo 63 de la LGT de 1963 y su concordante el apartado 4 del artículo 49 del RGR de 1968, obligaban a que se hiciese imputación del pago, en primer lugar, a las preferencias frente a las demás entidades. Sin embargo, existían excepciones que se recogían en los artículos 71, 73 y 76

\footnotetext{
${ }^{360}$ RODRÍGUEZ BEREIJO, A., "Las garantías del crédito tributario", op. cit., pág. 187 a 188, calificó al artículo 72 de la LGT de 1963 como un "precepto confuso y falto de rigor técnico-jurídico porque partiendo de los actos de transmisión o sucesión de los particulares, sea por acto mortis causa o por acto inter vivos, en relaciones de derecho privado (cesión o sucesión en la empresa comercial o industrial), no se distingue, si no que confunde los distintos efectos que de una u otra hipótesis de la sucesión se derivan respecto de las obligaciones tributarias".

Por otra parte, son muchos los autores que manifiestan que el artículo 72 de la LGT de 1963 recogía un supuesto más de responsabilidad tributaria, como es el caso de GARCÍA NOVOA, C., "La necesaria modificación de las garantías del crédito tributario en una nueva futura Ley General Tributaria", op. cit., pág. 67; LOZANO SERRANO, C., La responsabilidad del adquirente de empresas por deudas tributarias anterior a la transmisión, Aranzadi, Pamplona, 1998, pág. 23; MUÑOZ MERINO, A Privilegios del crédito tributario: el derecho de prelación general, op. cit., pág. 46 a 48; FALCÓN Y TELLA, R., "Las garantías del crédito tributario: perspectivas de reforma", op. cit., pág. 923 a 927; BARBERENA BELZUNCE, I., "Las responsabilidad tributaria del adquirente de explotaciones económicas y el nuevo Reglamento General de Recaudación”, Impuestos, núm. 23, 1991, pág. 10; ARIAS ABELLÁN, M. D., "El estatuto jurídico del responsable del tributo en el derecho español", Revista Española de Derecho Financiero, núm. 42, 1984, pág. 181 y 182. En la jurisprudencia, en el mismo sentido, se pronuncian, entre otras, la Sentencia de 26 de enero de 1994 , la Sentencia de la Audiencia Nacional de 11 de enero de 2002 y la Sentencia del Tribunal Superior de Justicia de Cataluña de 12 de mayo de 2003.

En relación con su naturaleza de la "sucesión de empresa", es un tema que desarrollamos en vid. infra, Capítulo Cuarto, epígrafe 2.4.1.3. "Sucesión de empresas".

${ }^{361}$ CAMY ESCOBAR, J., "Las garantías de la deuda tributaria y su ejecución", en la obra Propiedad y Derecho Fiscal, Colegio de Registradores de la Propiedad y Mercantiles de España, Madrid, 2005, pág. 99.
} 
de la LGT de 1963 y que otorgaban preferencia a la Hacienda estatal salvo que existieran acreedores que lo fueran de dominio, prenda, hipoteca o de un derecho real debidamente inscrito con anterioridad, o cuando otras entidades fueran titulares de un crédito garantizado por hipoteca legal tácita, o cuando hubieran concedido un aplazamiento o fraccionamiento del pago debidamente garantizado. Si el sobrante, una vez satisfechos los créditos de la Hacienda Pública y los créditos garantizados, no alcanzaba a cubrir las deudas tributarias a favor de las demás entidades, el pago se aplicaría en función de la antigüedad de cada crédito, de acuerdo con la fecha en que fue exigible.

Si partimos de criterio emitido por SIMÓN ACOSTA de que por garantías solamente se debe entender "los derechos, facultades o potestades administrativas, que tienen como finalidad inmediata la satisfacción del crédito mediante su realización sobre determinados bienes o sobre el patrimonio de terceros" ${ }^{\text {362 }}$, podemos concluir que no todas las garantías que preveía la LGT de 1963 en sus artículos 71 a 76 eran verdaderas garantías del crédito tributario, como es el caso del derecho de retención sobre mercancías del artículo 75. Tampoco todas las garantías estaban contempladas en aquellos preceptos. Quedaban fuera de esos artículos las garantías personales que se constituyen por la extensión a terceros de la responsabilidad del pago de la obligación tributaria, que se ubicaban en las normas reguladoras de las situaciones jurídico-subjetivas pasivas. Las verdaderas garantías reales se encontraban, en cambio, en los artículos 73 y 74 de la LGT de 1963.

Debemos reiterar que el régimen de las garantías del crédito tributario que se ha mantenido invariable en el tiempo, observándose idénticas deficiencias tanto en la LGT de 1963 como en la LGT de 2003, sobre todo por la incorporación dentro de las garantías del crédito tributario de otras categorías que no pueden calificarse como tales. En este punto, entendemos, al igual que varios autores ${ }^{363}$, que deben ser consideradas como garantías en sentido estricto del crédito tributario sólo aquéllas figuras cuya naturaleza jurídica sea de derecho real o personal, aunque no nos parece desacertada la ubicación de las garantías personales, concretamente de los responsables, en el ámbito de la subjetividad del tributo.

Finalmente, queremos subrayar que el objeto de estudio del tercer capítulo de este trabajo son todos los supuestos que regula la LGT como "garantías de la deuda tributaria", en sus artículos 77 a 82, que se complementan con los artículos 64 a 67 del RGR vigente. A pesar de que debemos reconocer que no todas las instituciones que aparecen en la ley tienen carácter de derecho real de garantía, hemos decidido estudiarlas porque, aun cuando no cumplan todos los requisitos para ser consideradas como garantías en sentido estricto, complementan a los verdaderos derechos reales, ya que aseguran su aplicación, logrando de esta forma una mayor seguridad y efectividad para el crédito tributario. Las garantías personales del crédito tributario se abordan en el cuarto capítulo, donde se analiza la figura del responsable tributario prevista en los artículos 41 a 43 y 174 a 176 de la LGT y en los artículos 124 a 126 del RGR.

\footnotetext{
${ }^{362}$ SIMÓN ACOSTA, E., "La hipoteca legal tácita en garantía de deudas tributarias”, op. cit., pág. 1080.

${ }^{363}$ Entre otros, GUERRA REGUERA, M., Garantías personales del crédito tributario, op. cit., pág. 36 a 41; ARRANZ DE ANDRÉS, C., Las garantías reales del crédito tributario, op. cit., pág. 40 a 45; GARCÍA NOVOA, C., "La necesaria modificación de las garantías del crédito tributario en una futura ley general tributaria", op. cit., pág. 63; RODRÍGUEZ BEREIJO, A., "Las garantías del crédito tributario", op. cit., pág. 184 y 185.
} 


\section{CAPÍTULO TERCERO \\ LAS GARANTÍAS REALES TRIBUTARIAS}

El presente capítulo está dedicado al estudio de las garantías reales y las demás prerrogativas que la LGT confiere al crédito tributario bajo la rúbrica de "garantías de la deuda tributaria". Para este fin es determinante identificar las figuras que, dentro de los mecanismos establecidos para el aseguramiento del crédito tributario, merecen ser consideradas como garantías reales en sentido estricto, en los términos que hemos señalado en el capítulo anterior. Centraremos nuestra atención en la hipoteca legal tácita del artículo 78 de la LGT, la hipoteca legal expresa del artículo 66 del RGR, y el derecho de afección del artículo 79 de la LGT. También haremos alusión a otras instituciones que la ley ubica dentro de las garantías del crédito tributario y que, a pesar de no cumplir con todas las características propias de las garantías reales en sentido estricto, permiten de igual manera asegurar el cobro del crédito por parte de la Administración tributaria, como son el derecho de prelación general, el derecho de retención y las medidas cautelares.

A diferencia de las garantías reales tributarias que la LGT establece y regula a favor de la Administración tributaria y que se examinan en este tercer capítulo, en el capítulo quinto se incluye el estudio de las garantías reales civiles que la normativa tributaria recoge no para que sean ejercitables directamente por la Administración, sino como exigencia a los obligados tributarios cuando pretendan no pagar, sea como consecuencia de una solicitud de aplazamiento o fraccionamiento del pago o como resultado de una solicitud de suspensión de ingreso por presentación de reclamaciones.

\section{LA HIPOTECA LEGAL TÁCITA}

\subsection{ANTECEDENTES Y VINCULACIÓN CON OTRAS RAMAS DEL DERECHO}

Dentro de las garantías del crédito tributario reconocidas en el ámbito tributario destaca la hipoteca legal tácita, incluida en el artículo 73 de la LGT de 1963. En la actualidad esta institución aparece en el artículo 1.923 del Código Civil, que regula los privilegios a favor de los créditos tributarios, y el artículo 1.924 del mismo Código, que establece un derecho general de prelación. El apartado primero del artículo 1.923 del Código Civil recoge un derecho especial de prelación sobre los bienes inmuebles y derechos reales para el cobro de los créditos en beneficio del Estado por el importe de la última anualidad vencida y no pagada de los impuestos que graviten sobre ellos. También el apartado 6 del artículo 168 de la LH de 1946 contempla la hipoteca legal sobre los bienes de los contribuyentes a favor del Estado en los casos establecidos en la propia ley, además de las preferencias que se reconocen en el artículo 194 de la LH. Acorde con ello, el Decreto de 14 de febrero de 1947, por el que se aprueba el Reglamento Hipotecario, establece en su artículo 271 que

"cada finca responderá por hipoteca legal, en los términos prescritos por el artículo 194 de la Ley, de las contribuciones e impuestos que directa e individualmente recaigan sobre el inmueble, y el Estado y las provincias o los pueblos tendrán, para su cobro, prelación sobre cualquier otro acreedor y sobre el tercer adquirente, aunque hayan inscrito su derecho en el Registro". 
No existe, pues, uniformidad entre el Código Civil y la LH a la hora de precisar la naturaleza de la figura que nos ocupa. El primero se refiere a un derecho especial de prelación, mientras que la LH alude a una hipoteca legal. Tampoco en el ámbito tributario el artículo 73 de la LGT de 1963 estableció una definición expresa de esta institución, que se ubicó dentro de las garantías de la deuda tributaria $^{364}$. Dicho precepto disponía que

"en los tributos que graven periódicamente los bienes o derechos inscribibles en un registro público o sus productos directos, ciertos o presuntos, el Estado, las Provincias y los Municipios tendrán preferencia sobre cualquier otro acreedor o adquirente, aunque éstos hayan inscrito sus derechos para el cobro de las deudas no satisfechas correspondientes al año natural en que se ejercite la acción administrativa de cobro y al inmediato anterior".

Al ser la LGT de 1963 posterior a la LH y al Código Civil, es posible afirmar que las garantías establecidas en la norma tributaria son de igual o mayor amplitud que las previstas en la legislación civil, cuyo contenido quedaría absorbido o subsumido por la normativa fiscal. SIMÓN ACOSTA entendió que no debía "dudarse de la eficacia derogatoria de la Ley General Tributaria, pues resulta clara la intención de la L.G.T. de regular de forma completa esta garantía real, por lo que, además de ley especial, es ley posterior que sustituye y deroga el régimen precedente" 365 .

En el panorama tributario vigente, se emplea expresamente el término de hipoteca legal tácita para denominar la figura que regula el artículo 78 de la LGT, sucesor del artículo 73 de la LGT de 1963. El precepto actual presenta muy pocas diferencias respecto de su antecesor. De hecho puede decirse que la naturaleza y eficacia de ambos son idénticas. El artículo 78 de la LGT prevé que

"en los tributos que graven periódicamente los bienes o derechos inscribibles en un registro público o sus productos directos, ciertos o presuntos, el Estado, las comunidades autónomas y las entidades locales tendrán preferencia sobre cualquier otro acreedor o adquirente, aunque éstos hayan inscrito sus derechos, para el cobro de las deudas devengadas y no satisfechas correspondientes al año natural en que se exija el pago y al inmediato anterior".

No obstante, el artículo 78 de la LGT introduce dos pequeñas modificaciones que pretenden clarificar quiénes son los titulares de la garantía del crédito tributario y cuál va a ser el alcance temporal de la misma. Desde un punto de vista subjetivo, las referencias al "Estado, las Provincias y Municipios" que se hacía en el artículo 73 de la LGT de 1963 se ha sustituido por el "Estado, las comunidades autónomas y las entidades locales". La segunda de las variaciones afecta al objeto, las "deudas no satisfechas que correspondan al año natural en que se ejercita la acción administrativa de cobro y al

\footnotetext{
${ }^{364}$ Aunque el artículo 37 del RGR de 1969 utilizó la expresión "hipoteca legal tácita".

${ }^{365}$ SIMÓN ACOSTA, E., “La hipoteca legal tácita en garantía de deudas tributarias”, op. cit., pág. 1082 a 1083.
} 
inmediato anterior", que actualmente se ha sustituido por "las deudas devengadas y no satisfechas correspondientes al año natural en que se exija el pago y al inmediato anterior" ${ }^{366}$.

El precepto configura la hipoteca legal tácita como una garantía del crédito tributario, que no necesita de inscripción ni de pacto entre los interesados porque opera por la propia disposición de la ley y que se perfecciona y se constituye una vez que se produce el hecho que está previsto en la norma que la crea. Para algunos autores, sin embargo, no es más que un privilegio especial, diferente del privilegio general del artículo 77 de la LGT, obsoleto y de limitada aplicación práctica, que debería desaparecer de la ley o ser reconducido al ámbito de los privilegios especiales ${ }^{367}$.

La hipoteca legal tácita, en suma, es un derecho real de garantía que puede exigirse con preferencia erga omnes frente al resto de los acreedores concurrentes y, a pesar de que su ámbito de aplicación se encuentra actualmente muy restringido, constituye un instrumento muy válido a disposición de la Hacienda Pública para hacer efectivo el cobro de su crédito tributario, más potente incluso que el derecho de prelación general del artículo 77 de la LGT, y muy similar al derecho de afección del artículo 79 de la LGT, con el que comparte la misma naturaleza jurídica y del que se distingue por los efectos que produce.

\subsection{NATURALEZA JURÍDICA DE LA HIPOTECA LEGAL TÁCITA}

La figura que se recoge en el artículo 78 de la LGT es singular. En relación con la naturaleza jurídica de la hipoteca legal tácita, la principal problemática se presenta a la hora de determinar si es una mera preferencia para el cobro o puede operar como una garantía real, pues de configurarse como un derecho real tendría facultades accesorias, reipersecutoriedad y oponibilidad erga omnes y gozaría de preferencia frente a los titulares de otros derechos reales inscritos con anterioridad.

Ya dijimos en el capítulo anterior que en ocasiones puede darse al crédito garantizado un privilegio especial sobre el producto de la realización de un determinado bien. El acreedor que se encuentra asegurado con la garantía real no sólo podrá efectuar la realización forzosa del bien gravado para cubrir el pago, sino que dispondrá de un privilegio que le otorga preferencia sobre el producto de la realización de dicho bien antes que el resto de los acreedores ${ }^{368}$. Entendemos que la figura que contiene el artículo 78 de la LGT reúne estos elementos, aunque existen otras tesis que interpretan de manera diferente la naturaleza jurídica de la hipoteca legal tácita.

\subsubsection{Como privilegio especial}

Un sector de la doctrina sostiene que el derecho que reconoce el artículo 78 de la LGT es un derecho de prelación especial o limitado o un privilegio especial, por recaer sobre un bien concreto del deudor, diferente al derecho de prelación general que reconoce el artículo 77 de la LGT $^{369}$. Debemos

\footnotetext{
${ }^{366}$ Sobre estas cuestiones nos referiremos más adelante al desarrollar los ámbitos subjetivo y objetivo de la hipoteca legal tácita. Vid., infra. Capítulo Tercero, epígrafe 1.3. "Ámbito de aplicación de la hipoteca legal tácita".

${ }^{367}$ Por todos,GARCÍA NOVOA, C., "Capítulo IV. Elementos de cuantificación de la obligación tributaria”, op. cit., pág. 346.

${ }^{368}$ Vid. supra., Capítulo Segundo, epígrafe 4.1.2. "Diferencias entre los privilegios y las garantías del crédito tributario".

369 Entre otros, RODRÍGUEZ BEREIJO, A., "Las garantías del crédito tributario”, op. cit., pág. 199; FALCÓN Y TELLA, R., "Hipoteca Legal Tácita”, Enciclopedia Jurídica Básica, Vol. II. Civitas, Madrid, 1995, pág. 3317; MARTÍNEZ LAFUENTE, A., "La prelación del artículo 73 de la Ley General Tributaria en relación con el Impuesto sobre las Transmisiones Patrimoniales y Actos
} 
recordar que los derechos de prelación especial se diferencian de los derechos reales de garantía en que éstos últimos, además de tener preferencia para el cobro, otorgan a su titular la posibilidad de perseguir y ejecutar el bien sobre el que se hubieran constituido, sin importar que dicho bien se encuentre en manos de terceros ajenos a la relación que garantizan esos derechos reales.

CAMY ESCOBAR entiende que el artículo 1.875 del Código Civil reconoce a la Hacienda Pública algo más que un derecho a pedir que se constituya una hipoteca especial por los trámites ordinarios, y que el artículo 194 de la LH y el artículo 271 de su Reglamento conceden al Estado, las Provincias y los Pueblos una preferencia sobre cualquier otro acreedor y sobre el tercer adquirente, aunque hayan inscrito en el registro sus derechos, para el cobro de la anualidad corriente y de la última vencida y no satisfecha de las contribuciones e impuestos que graven los bienes inmuebles. En este sentido, apunta el autor, "nos encontramos ante un derecho de preferencia especial de determinados créditos tributarios, dotados de unos efectos extraordinarios, que pueden ser ejercitados ante cualquier adquirente o acreedor con derecho inscrito en caso de concurrencia y que no necesita constancia registral para surtir los efectos que le son propios, a diferencia de las verdaderas hipotecas legales" ${ }^{\text {,70 }}$.

Para GARCÍA NOVOA el privilegio especial hace referencia a un crédito que se satisface de forma prioritaria, incluso frente a los que ya se encuentran privilegiados. Tal preferencia de retribuir el crédito descansa sobre una cualificación que del mismo hace la ley y que consiste frecuentemente en habilitar la posibilidad de sujeción o afección de un bien al cumplimiento del crédito especialmente protegido. Su condición privilegiada gravita entorno al hecho de que el crédito afecta a bienes y derechos específicos para su realización. "La prioridad para su pago se hará efectiva a través de una ejecución separada, y por tanto previa al pago de los créditos con privilegio general, como se deduce de la lectura conjunta de los artículos 155 y 156 de la LC „371. Por tanto, según esta doctrina, el privilegio especial se centra en dos ideas fundamentales: la preferencia para su satisfacción frente incluso a los propios créditos privilegiados y la preferencia basada en la afección de ciertos bienes y derechos.

También en la jurisprudencia se utiliza el argumento de que, cuando existe concurrencia de créditos, el crédito tributario del artículo 73 de la LGT de 1963 tiene preferencia frente a los otros créditos del mismo deudor sin necesidad de inscribir aquel derecho en el Registro, de forma que la Hacienda Pública no entra como acreedora de un bien determinado, sino del total del patrimonio del sujeto, y es superior esta garantía a la hipoteca de un bien determinado o cualquier otro derecho real que recaiga sobre cierto bien del deudor ${ }^{372}$. Se entiende por ello que no es exacto rebajar la preferencia del artículo 73 de la LGT de 1963 al nivel de una hipoteca legal ${ }^{373}$.

Jurídicos Documentados", Crónica Tributaria, núm. 24, 1978, pág. 273; MANTERO SÁEZ, A., "La hipoteca legal tácita”, Crónica Tributaria, núm. 35, 1981, pág. 188.

${ }^{370}$ CAMY ESCOBAR, J., "Las garantías de la deuda tributaria y su ejecución”, op. cit., pág. 124 a 125. En el mismo sentido, CASANA MERINO, F., "Las garantías del crédito y los tributos locales", Revista de Hacienda Local, núm. 75, septiembre/diciembre, 1995, pág. 510.

${ }^{371}$ GARCÍA NOVOA, C., “Capítulo IV. Elementos de cuantificación de la obligación tributaria”, op. cit., pág. 346.

${ }^{372}$ Sentencia del Tribunal Superior de Justicia de la Comunidad Valenciana de 4 de julio de 1998.

${ }^{373}$ Las Sentencias de los Tribunales Superiores de Justicia avalan el criterio de que se trata de una preferencia en el cobro que se proyecta frente a cualquier acreedor, incluso frente a los que el artículo 71 de la LGT de 1963 califica como acreedores de dominio, prenda, hipoteca, lo que es lo mismo, acreedores cuyo derecho de crédito está reforzado con un derecho real de garantía. Entre otras, 
Optando por una posición integradora, GUERRA REGUERA consideró que el artículo 73 de la LGT de 1963 regulaba un derecho de preferencia con ciertos rasgos de garantía real, con el argumento de que los créditos hipotecarios gozan de un derecho de preferencia que surge de la constitución de un derecho real de garantía, mientras que en el artículo 73 de la LGT de 1963 la garantía real es consecuencia del alcance del privilegio que se ha reconocido al crédito, del cual se desprenden los efectos reales sin necesidad de inscripción registral ${ }^{374}$.

Las críticas que hace ARRANZ DE ANDRÉS a esta tesis, que reconoce un derecho de prelación especial o limitado o un privilegio especial en el artículo 78 de la LGT, las fundamenta sobre la base de que el derecho de prelación no es un derecho autónomo, sino una cualidad o propiedad de un derecho que puede acompañar tanto a un derecho real como a un derecho de crédito. Como dice esta autora, "a la garantía que nos ocupa la ley la ha cualificado con un privilegio frente a cualquier otro acreedor o adquirente aunque fueran anteriores y hubieran inscrito su derecho, con lo que, insistimos, lo que el legislador contempla no es sino un derecho real al que se le ha cualificado otorgándole un especial derecho de prelación o preferencia" y que no necesita inscripción, no "porque los efectos reales traigan causa de su condición de derecho privilegiado, sino porque su previsión legal le otorga directamente la publicidad necesaria, sin perjuicio de que en el momento en que vaya a ejecutarse pueda dejarse constancia en el Registro a fin de facilitar el conocimiento a terceros interesados de que dicho bien se encuentra sujeto a un procedimiento ejecutivo de la Hacienda"375.

Nosotros no somos partidarios de la tesis que defiende que la naturaleza de la figura del artículo 78 de la LGT es la de un privilegio especial, por estos argumentos que se acaban de reseñar y porque el acreedor privilegiado no tiene la facultad de ejecutar directamente los bienes del deudor y mucho menos los de un tercero, poseyendo sólo una preferencia o prelación para cobrar el producto de la realización de determinados bienes en relación con el resto de los acreedores ordinarios.

\subsubsection{Como derecho real de hipoteca}

Con bastante frecuencia la doctrina ha utilizado la expresión "hipoteca legal tácita" para referirse a la institución que recogía el artículo 73 de la LGT de $1963^{376}$, expresión asumida más tarde por el

Sentencia del Tribunal Superior de Justicia de La Rioja de 7 de octubre de 1996; Sentencia del Tribunal Superior de Justicia de las Islas Baleares de 10 de diciembre de 1996; Sentencia del Tribunal Superior de Justicia de Cataluña de 10 de julio de 1997; Sentencia del Tribunal Superior de Justicia de Cantabria de 25 de noviembre de 1997; Sentencia del Tribunal Superior de Justicia de Castilla-La Mancha de 18 de diciembre de 2000; Sentencia del Tribunal Superior de Justicia de Castilla y León de 15 de enero de 2001; o Sentencia del Tribunal Superior de Justicia de Galicia de 16 de febrero de 2001

${ }^{374}$ GUERRA REGUERA, M., Garantías personales del crédito tributario. Algunas cuestiones, op. cit., pág. 191. En sentido similar, MOYA-ANGELER SÁNCHEZ, J., "Las obligaciones y los responsables tributarios en sus distintas formas y modalidades, hipoteca legal tácita, afección de bienes y derecho de prelación de la Hacienda”, Revista de Hacienda Autonómica y local, Vol. XXI, núm. 61, 1994, pág. 132.

${ }^{375}$ ARRANZ DE ANDRÉS, C., Las garantías reales del crédito tributario: aspectos sustantivos y procedimentales, op. cit., pág. 107.

${ }^{376}$ SERRERA CONTRERAS, L., "La anualidad corriente en la hipoteca legal tácita por contribuciones", Revista Crítica de Derecho Inmobiliario, núm. 524, 1978, pág. 9 y ss.; MARTÍNEZ LAFUENTE, A., "La prelación del artículo 73 de la Ley General Tributaria en relación con el Impuesto sobre las Transmisiones Patrimoniales y Actos Jurídicos Documentados”, op. cit., pág. 273; ARIAS VELASCO, J., Procedimientos tributarios, Ministerio de Economía y Hacienda, Madrid, 1984, pág. 461; FALCÓN Y TELLA, R., "Las garantías del crédito tributario", Cuestiones Tributarias Prácticas, 2a ed., La Ley, Madrid, 1990, pág. 606 a 613 , y, del mismo autor, "Las Garantías del crédito tributario: perspectivas de reforma", Revista de Derecho Financiero y de Hacienda Pública, núm. 215, septiembre-octubre 1991, pág. 920, e "Hipoteca Legal Tácita”, op. cit., pág. 3317; SIMÓN ACOSTA, E., "La hipoteca legal tácita en garantía de deudas tributarias", op. cit., pág. 1079 a 1090; RODRÍGUEZ BEREIJO, A., "Las garantías del crédito tributario", op. cit., pág. 199; DAMAS SERRANO, A. J., "Afección de bienes y derechos", en la obra Comentarios a la Ley General Tributaria y 
legislador tributario actual en el artículo 78 de la LGT. Sin embargo, en la discusión de la naturaleza jurídica de esta figura, una de las cuestiones que más se debate es si se trata en realidad de un derecho real de hipoteca ${ }^{377}$.

Los autores que consideran que no se justifica la existencia de una hipoteca manifiestan que el artículo 78 de la LGT, frente a un titular que ha inscrito su derecho, antepone otro que no ha inscrito el suyo o que lo ha hecho después, lo que es contrario a los principios hipotecarios de prioridad y de fe pública registral ${ }^{378}$. En esta línea, algunos pronunciamientos doctrinales y jurisprudenciales descartan la presencia de una hipoteca legal tácita en el precepto indicado porque la preferencia que establece el mismo queda fuera de todo convenio, de todo mecanismo de publicidad ${ }^{379}$

DURÁN-SINDREU BUXADE afirma en la misma línea que el privilegio que establece el precepto no se resume a la afección de ningún bien concreto al pago del tributo, pues de lo contrario carecería de sentido que, si la garantía del artículo 73 de la LGT de 1963 termina de resolverse en el artículo 74 de la LGT de 1963, se regulara la afección de bienes en artículos diferentes y consecutivos y se estableciesen en ellos distintos tipos de tributos. Además, añade este autor, la ley no otorga "derecho real alguno sobre el bien gravado por el mero hecho de constituir un tributo sobre el mismo" ${ }^{380}$.

Por el contrario, SERRERA CONTRERA, a favor de la tesis que avala la existencia de una hipoteca legal tácita, de pleno derecho y por disposición de la norma, opina que sólo con la publicidad de la ley es suficiente para entender que nadie puede ignorarla. Todos los propietarios, añade este autor, deben conocer el pago de la contribución a las que las fincas están sujetas, pues tendría un costo grandísimo inscribir esta hipoteca que grava todos los bienes inmuebles del país, siendo su esencia la de proteger el crédito tributario cuando la finca pasa a manos de un tercero ${ }^{381}$.

ARRANZ DE ANDRÉS considera en este sentido que el artículo 78 de la LGT produce una afección de un bien en concreto porque, de lo contrario, carecería de sentido que la ley conceda preferencia a la Hacienda Pública frente a cualquier otro adquirente, pues "la concurrencia con el mismo sólo se

\footnotetext{
Lineas para su reforma, en homenaje a Fernando Sainz de Bujanda, Vol. I, Instituto de Estudios Fiscales, Madrid, 1991, pág. 694; MUÑOZ MERINO, A., Privilegios del crédito tributario: el derecho de prelación general, op. cit., pág. 49; MANTERO SÁEZ, A., "La hipoteca legal tácita", op. cit., pág. 187; ZABALA RODRÍGUEZ-FORNOS, A., LLOPIS GINER, F. y DAGO ELORZA, I., Recaudación, aspectos sustantivos y procedimentales, op. cit., pág. 240 a 243; GONZÁLEZ-CARBALLO ALMODÓVAR, A., "Las garantías del crédito tributario", op. cit., pág. 458. La expresión "hipoteca legal tácita" es también utilizado por la jurisprudencia. Por todas, vid. Sentencia del Tribunal Constitucional 6/1986, de 21 de enero, Sentencia del Tribunal Supremo de 21 de diciembre de 1979, o Sentencia del Tribunal Superior de Justicia de Cataluña de 10 de julio de 1997.

${ }^{377}$ Como puede verse, en ocasiones se usa el término de hipoteca legal tácita para referirse a lo que no son más que créditos privilegiados, y viceversa. Y aunque es "cierto que los créditos garantizados con hipoteca legal tácita, son al mismo tiempo créditos singularmente privilegiados (...), no ocurre lo mismo a la inversa, pues el crédito singularmente privilegiado no presupone necesariamente la afección de un determinado bien sobre el que actuar la preferencia que lo caracteriza" (CARRAMOLINO, C., "La hipoteca legal tácita y crédito singularmente privilegiado (una breve reflexión a propósito de la resolución de 3 de abril de 1998)", $o p$. cit., pág. 12730).

378 AROZARENA POVES, R., "La afección registral en los Impuestos de sucesiones y de Trasmisiones Patrimoniales", en la obra Impuestos sobre Sucesiones y Transmisiones Patrimoniales y Actos Jurídicos Documentados, Vol. II, Instituto de Estudios Fiscales, Madrid, 1977, pág. 68.

${ }^{379}$ Vid. infra, Capítulo Tercero, epígrafe 1.2.3. "Otras posturas doctrinales".

380 DURÁN-SINDREU BUXADE, A., “¿Existe la hipoteca legal tácita del art. 73 LGT? Una interpretación heterodoxa”, Jurisprudencia Tributaria, núm. 15, 1998, pág. 1268 y 1271.

${ }^{381}$ SERRERA CONTRERAS, L., "La anualidad corriente en la hipoteca legal tácita por contribuciones”, op. cit., pág. 9.
} 
producirá si el bien gravado sale del patrimonio del deudor sujeto pasivo, y no habiendo éste satisfecho la deuda tributaria, pretendiera la Hacienda pública hacerla efectiva sobre dicho bien -hora en manos de un tercero ajeno a la obligación tributaria- sobre la base precisamente del ejercicio del derecho real de garantía constituido sobre el mismo" ${ }^{\text {382 }}$.

Creemos acertadas estas últimas palabras y no pensamos que con ello se produzca la subsunción del artículo 78 de la LGT en el artículo 79 de la LGT. Este último precepto determina una garantía de derecho real, el derecho de afección, que comparte con la hipoteca legal tácita la misma naturaleza jurídica. No obstante, ambas figuras disponen de elementos, sobre todo en su régimen jurídico, diferenciados, como por ejemplo los impuestos que protegen, las anualidades garantizadas, o el alcance frente a terceros adquirentes. La similitud radica en que tanto las hipotecas legales tácitas como el derecho de afección implican la sujeción de un bien determinado al cumplimiento de una obligación, cualquiera que sea su poseedor, por lo que puede decirse que son en ambos casos garantías legales de naturaleza real.

Se entiende entonces que VALLET DE GOYTISOLO se muestre crítico ante la calificación de este tipo de hipoteca legal tácita como una mera preferencia al cobro, pues esto equivaldría a negarle efectos reales y rechazar que la misma conlleva la sujeción de un bien en concepto de afección real con oponibilidad erga omnes. Existen datos para este autor que otorgan efectos reales a la hipoteca legal tácita, desde el momento en que la garantía se reconoce especial respecto a los tributos que gravan bienes inscribibles en el Registro de la Propiedad ${ }^{383}$.

Esta misma preferencia de cobro de tributos que gravan ciertos bienes se mantiene en la actualidad en el artículo 78 de la LGT, especialmente sobre bienes inmuebles, y de esta forma se configura un poder de ejecución y, por tanto, un derecho real sobre el bien gravado. De ahí que la preferencia se fije no sólo frente a cualquier otro acreedor, sino también frente a otro adquirente, sin exigir que la Administración tributaria inscriba el derecho que conlleva la traba de un bien concreto. Y esto significa, en definitiva, una reipersecutoriedad y, por tanto, un elemento esencial de un derecho real de garantía. En el caso del artículo 78 de la LGT existe, pues, una preferencia en el cobro del precio de la venta forzosa y esa preferencia es lo que algunos autores identifican como el carácter real de la hipoteca. Los seguidores de esta corriente entienden que la reipersecutoriedad no es más que la extensión de la preferencia para conservar su efectividad cuando el inmueble haya pasado a manos de un tercero poseedor. Mientras que para otros autores, la reipersecutoriedad es el efecto o la consecuencia del principio que caracteriza la naturaleza de la hipoteca. Todos estos elementos a los que nos hemos referido por sí solos no son capaces de demostrar el carácter real de la hipoteca. Por eso la doctrina civilista incorpora a la facultad de pedir su ejecución y a la preferencia de que goza el crédito hipotecario, la sujeción o afección de la cosa al pago del crédito asegurado.

ARRANZ DE ANDRÉS asegura, en síntesis, que "tanto la tipicidad, la publicidad, la especialidad como la accesoriedad son características propias de las garantías reales que la hipoteca legal tácita reproduce en su estructura. Viniendo prevista expresamente en la ley, en ella se encuentra no sólo su

\footnotetext{
382 ARRANZ DE ANDRÉS, C., Las garantías reales del crédito tributario: aspectos sustantivos y procedimentales, op. cit., pág. 111.

${ }^{383}$ VALLET DE GOYTISOLO, J., "Observaciones sobre la naturaleza jurídica de la hipoteca”, en Estudios sobre garantías reales, Montecorvo, $2^{\mathrm{a}}$ ed., Madrid, 1984, pág. 36.
} 
configuración típica, sino también su fuente directa de publicidad; además de accesoria respecto del derecho de crédito que garantiza y es especial por cuanto afecta una cosa determinada al cumplimiento de una obligación" ${ }^{\text {384 }}$.

En conclusión, la hipoteca legal tácita del artículo 78 de la LGT constituye una garantía real, cualificada con un derecho especial de prelación, porque conlleva una preferencia para el cobro con los bienes del obligado tributario, no sólo frente a otros acreedores de éste, sino también frente a cualquier adquirente de esos bienes. La ley establece una hipoteca a favor de la Hacienda Pública sin necesidad de inscripción registral, sobre bienes o derechos inscritos en un Registro Público y que se gravan con ciertos tributos periódicos de carácter real. En el caso de que se incumpla con la obligación de pago, se faculta a la Administración tributaria a la persecución erga omnes y a la ejecución forzosa. Además, se otorga una preferencia especial para que la Hacienda Pública cobre con el producto de su realización y se anteponga a todos los titulares registrarles, sean terceros adquirentes o acreedores de bienes o derechos reales inscritos con anterioridad en el registro ${ }^{385}$.

\subsubsection{Otras posturas doctrinales}

\subsubsection{Como cargas reales}

Entre otros autores, PEÑA BERNALDO DE QUIRÓS defiende el criterio de asimilar la garantía dispuesta en el artículo 78 de la LGT a las cargas reales. Esta tesis, que comparten también algunos pronunciamientos jurisprudenciales, parte de la idea de que la hipoteca legal tácita es una carga sobre el bien que confiere la facultad de obtener del bien gravado una prestación periódica, sin implicar la existencia de una deuda anterior, que se devenga con cada vencimiento y puede ser exigida al titular del bien gravado en ese momento ${ }^{386}$.

Según la doctrina civilista, las cargas son derechos que facultan a su titular a obtener una prestación periódica que debe ser satisfecha por las personas que en cada momento ostenten la condición del titular del bien gravado. La carga sujeta la cosa de tal forma que todo aquél que posea el bien está obligado no sólo a soportar la ejecución sobre la misma, sino también a realizar ciertos actos y prestaciones. La inherencia real que se produce en relación con la cosa objeto de derecho se produce

\footnotetext{
${ }^{384}$ ARRANZ DE ANDRÉS, C., Las garantías reales del crédito tributario: aspectos sustantivos y procedimentales, op. cit., pág. 124 a 126.

${ }^{385}$ GARCÍA GARCÍA indica que el privilegio, además de las notas de preferencia y prelación, implícitas en el crédito tributario, está dotado de la reipersecutoriedad propia de la hipoteca (GARCÍA GARCÍA, J. M., Código de Legislación Hipotecaria y del Registro Mercantil, Civitas, Madrid, 1986, pág. 793 a 812). LACRUZ BERDEJO afirmó por su parte que dentro de los créditos hipotecarios o pignoraticios, algunos pueden ser privilegiados, es decir, pasar por delante de los otros aunque tengan fecha posterior, contra la regla de ordenación de los derechos reales, de manera tal que la hipoteca legal tácita a favor de la Hacienda Pública une el derecho de hipoteca y el derecho de prelación frente a otros acreedores hipotecarios y no simplemente frente al deudor (LACRUZ BERDEJO, J. L., "Sobre los privilegios del salario y en particular el "superprivilegio" del artículo 32.1 del Estatuto de los Trabajadores", en la obra Estudios de Derecho Privado Común y Foral, Tomo II, Colegio de Registradores de la Propiedad y Mercantiles de España-Centro de Estudios Registrales y Ed. Bosch, Zaragoza, 1992, pág. 252).

${ }^{386}$ PEÑA BERNALDO DE QUIRÓS, M., Derechos reales. Derecho hipotecario, $2^{\mathrm{a}}$ ed., Servicio de Publicaciones de la Facultad de Derecho de la Universidad Complutense, Madrid, 1986, pág. 523. En el mismo sentido, SÁNCHEZ PINO, A. J., Problemas fiscales de la suspensión de pagos, Aranzadi, Pamplona, 1997, pág. 151. En la jurisprudencia, vid. las Sentencias del Tribunal Supremo de 26 de febrero de 1980, de 12 de diciembre de 1988, de 7 de enero de 1992, de 13 de junio de 1994, de 24 de febrero de 1995 , de 20 de julio de 1998 , o de 4 de febrero de 1999.
} 
sólo de manera mediata o indirecta, pues en realidad a quien se pretende gravar es al propietario o a sus sucesores $^{387}$.

De manera general se dice que las cargas reales son derechos que llevan implícitos una garantía y no créditos asegurados con una garantía externa. Es aquí donde se observan las diferencias con los derechos reales de garantía. Cuando la ley tributaria afecta bienes concretos al pago de los tributos, se está en presencia de una obligación tributaria idéntica a las demás, pero que a su vez se encuentra asegurada con una garantía real sobre el bien. Por eso dice ARRANZ DE ANDRÉS que el artículo 78 de la LGT “no es una prestación periódica sino una garantía real que asiste a tributos periódicos, es decir, a obligaciones tributarias que se reiteran en el tiempo acotando temporalmente su hecho imponible. Y es que la ejecución de esta garantía sólo procederá en los casos de incumplimiento de la obligación de pago de la deuda tributaria, supuesto de hecho estrictamente vinculado al libre comportamiento del contribuyente y que, por lo mismo, no puede tomarse en consideración a estos efectos desde el punto de vista de la frecuencia con que pueda producirse" ${ }^{\text {} 388}$.

\subsubsection{Como garantía de orden superior}

Otra teoría doctrinal para determinar la naturaleza jurídica de la hipoteca tácita es la que considera que se trata de una garantía de orden superior. Para CAMY SÁNCHEZ-CAÑETE ${ }^{389}$, estamos en presencia de un derecho de preferencia y no ante una hipoteca legal porque no existen las hipotecas legales tácitas, sino únicamente garantías de orden superior. Llega a esta conclusión a partir de la interpretación que hace del apartado 6 del artículo 168 de la LH, el artículo 194 de la LH y el artículo 196 de la LH, los números 1 y 2 del artículo 1.923 del Código Civil, y el entonces vigente artículo 73 de la LGT de 1963, que se refieren siempre al derecho de preferencia frente a cualquier otro acreedor.

En sentido muy parecido se pronunció el Tribunal Superior de Justicia de la Comunidad Valenciana en la Sentencia de 4 de julio de 1998, al decir que "no estamos ante ninguna hipoteca. No existen hipotecas legales tácitas. Estamos ante una garantía de orden más superior incluso a la de la hipoteca, pues la preferencia estatuida por aquélla queda fuera de todo convenio, de todo mecanismo de publicidad".

\subsubsection{Como una obligación propter rem}

Una última tesis defiende que la hipoteca legal tácita es una obligación propter rem. De las características presentes en este tipo de obligaciones se deduce que en ellas las personas quedan obligadas a cumplir con las responsabilidades que surgen durante el tiempo que ocupan la posesión del bien, sin que el abandono de la cosa los libere del cumplimiento de la obligación; que no permiten

\footnotetext{
${ }^{387}$ DÍEZ PICAZO, L., Fundamentos del Derecho Civil Patrimonial, Tomo III, Civitas, Madrid, 1995, pág. 81; CABANILLAS SÁNCHEZ, A., "Cargas", Enciclopedia Jurídica Básica, Vol. I, Civitas, Madrid, 1995, pág. 935; RIGAUD, L., El Derecho real, historia y teorías, su origen institucional, Reus, Madrid, 2004, pág. 73 y 74.

${ }^{388}$ ARRANZ DE ANDRÉS, C., Las garantías reales del crédito tributario: aspectos sustantivos y procedimentales, op. cit., pág. 115.

${ }^{389}$ CAMY SÁNCHEZ-CAÑETE, B., Comentarios a la Legislación Hipotecaria, Vol. VI, $3^{\text {a }}$ ed., Aranzadi, Pamplona, 1983, pág. 901 y, del mismo autor, Garantías patrimoniales. Estudio especial de la hipoteca, Aranzadi, Pamplona, 1993, pág. 655 a 656.
} 
exigir el cumplimiento de las obligaciones que nazcan con anterioridad a su titularidad; y que la responsabilidad de los obligados alcanza todo su patrimonio ${ }^{390}$.

No obstante, del contenido del artículo 78 de la LGT resulta improbable llegar a esta conclusión y que pueda catalogarse la figura que contempla como una obligación propter rem, porque el adquirente del bien que está sujeto al pago del tributo tendrá que hacer frente a las deudas a las que el bien está afecto con anterioridad, porque la obligación que asume este sujeto no va a comprometer todo su patrimonio, sino únicamente el valor del bien, y porque además el deudor podrá liberarse de esta obligación al abandonar el bien.

\section{3. ÁMBITO DE APLICACIÓN DE LA HIPOTECA LEGAL TÁCITA}

Una de las cuestiones importantes que atañen a la hipoteca legal tácita, además de la determinación de su naturaleza jurídica, es su ámbito de aplicación. Es decir, quiénes pueden ser los titulares de ese derecho real y cuáles son los límites a los que se ve sometida su aplicación, ya sea en relación con los tributos que se garantizan mediante esta figura, las cantidades a las que alcanza o las anualidades que se aseguran a través de su utilización.

\subsubsection{Aspecto subjetivo}

\subsubsection{Sujetos titulares de la hipoteca legal tácita}

Dentro de las modificaciones que aparecen en la actual LGT respecto a la figura de la hipoteca legal tácita se encuentra la identificación de los titulares de esta figura. La normativa anterior disponía que los acreedores protegidos por este tipo de garantía era el Estado, las Provincias y los Municipios. A este régimen pudieron incorporarse posteriormente las Comunidades Autónomas, a tenor de lo dispuesto en el apartado tercero del artículo 2 de la Ley Orgánica 8/1980, de 22 de septiembre, de Financiación de las Comunidades Autónomas (en adelante LOFCA), que dispuso que estos entes públicos gozaban del tratamiento fiscal que la ley otorgaba al Estado, y las entidades supramunicipales, en virtud del artículo 131, en relación con el artículo 12, de la Ley 39/1988, de 28 de diciembre, Reguladora de las Haciendas Locales (en adelante LRHL).

El cambio que introduce el artículo 78 de la LGT en este punto es el de permitir que la preferencia de cobro a la que hace mención este precepto sea ejercida tanto por el Estado, como por las Comunidades Autónomas, como por las Entidades Locales, término este último que incluye las entidades supramunicipales y las del ámbito inferior al municipio, todas éstas sujetas al régimen jurídico del Real Decreto Legislativo 2/2004, de 5 de marzo, por el que se aprueba el texto refundido de la Ley Reguladora de las Haciendas Locales (en adelante TRLRHL) ${ }^{391}$. GONZÁLEZCARBALLO ALMODÓVAR encuentra lógica la modificación del precepto "ya que son todas las Administraciones Territoriales que pueden tener titularidad plena o compartida de los tributos a que

\footnotetext{
${ }^{390}$ A modo de ejemplo de este tipo de obligaciones véanse las Sentencias del Tribunal Supremo de 19 de mayo de 1979 ; de 29 de febrero de 1992; de 20 de febrero de 1997; de 30 de diciembre de 2002.

${ }^{391}$ Apartado segundo del artículo 150 y apartado tercero del artículo 156 del TRLRHL.
} 
alude o tener atribuida legal o convencionalmente la función de su cobro y, consiguientemente, disfrutar del derecho de prelación especial o hipoteca legal tácita que prevé" ${ }^{392}$.

\subsubsection{Sujetos afectados por la hipoteca legal tácita}

La hipoteca legal tácita despliega sus efectos sobre los titulares actuales de los bienes o derechos inscribibles en un registro público o sus productos directos, ciertos o presuntos. Esta garantía puede ser opuesta a cualquier adquirente o acreedor aun cuando hayan inscrito sus derechos en el Registro. En este sentido, la ley contempla la concurrencia sobre el mismo bien del crédito de la Hacienda Pública y los derechos del tercer adquirente, o de otro titular de derecho real inscrito, debilitando los efectos que el principio de fe pública registral concede a los titulares inscritos. La preferencia para el cobro que dispensa el artículo 78 de la LGT es casi absoluta e impera sobre cualquiera que sea el acreedor con el que concurra.

No se produce, en cualquier caso, ningún supuesto de responsabilidad tributaria para los adquirentes o titulares de derechos reales inscritos, porque la garantía real se proyecta mediante el derecho de reipersecutoriedad, que no se ve obstaculizado por el principio de fe pública registral y cuya efectividad no se sujeta a la exigencia de una nota marginal de afección que le reserve el rango. Los adquirentes o titulares inscribieron su bien o derecho afectados por este gravamen "oculto" y, en caso que deseen desprenderse de la obligación de pago, será suficiente que se desprendan del bien afecto, situación no predicable en ningún supuesto del responsable tributario ${ }^{393}$.

\subsubsection{Aspecto objetivo}

Una de las limitaciones del ámbito de aplicación de la hipoteca legal tácita se encuentra en los créditos que puede garantizar. El artículo 73 de la LGT de 1963 y su sucesor, el artículo 78 de la LGT, conceden casi de la misma manera una preferencia especial a la Hacienda Pública para el cobro de los tributos que gravan periódicamente los bienes o derechos inscribibles en un registro público, o sus productos directos, ciertos o presuntos.

De las líneas anteriores se desprenden varias notas importantes, entre ellas que la garantía cobra sentido sólo en el ámbito de los tributos, ya que cualquier otro recurso de Derecho público quedará excluido por no presentar las características de gravar derechos o bienes. SIMÓN ACOSTA opina que la expresión de tributo que gravan los bienes debe interpretarse como aquellos que tienen como hecho imponible y como objeto la titularidad de derechos, es decir, la propiedad, la posesión o la titularidad de derechos reales de uso o disfrute. "Por tratarse de una garantía excepcional ha de interpretarse estrictamente de forma que no es aplicable a aquellos tributos que «no gravan» los bienes, a pesar de que en su hecho imponible intervengan, como un elemento más entre otros, la

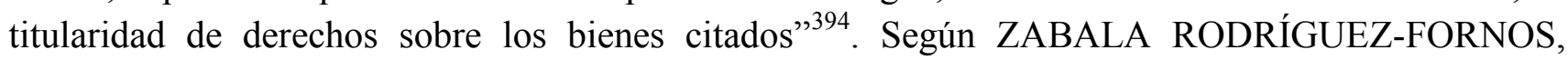
LLOPIS GINER, y DAGO ELORZA, es difícil “extrapolar la garantía más allá de los tributos -salvo

\footnotetext{
${ }^{392}$ GONZÁLEZ-CARBALLO ALMODÓVAR, A., "Las garantías del crédito tributario”, op. cit., pág. 458.

${ }^{393}$ CAMY ESCOBAR, J., “Las garantías de la deuda tributaria y su ejecución”, op. cit., pág. 127 a 133.

${ }^{394}$ SIMÓN ACOSTA, E., “La hipoteca legal tácita en garantía de deudas tributarias”, op. cit., pág. 1083 a 1084.
} 
que pudiera extenderse a obligaciones pecuniarias de índole urbanística o a determinados precios públicos o cánones, en todo caso con más precisa habilitación legal-"395.

El hecho imponible de estos tributos debe realizarse de manera continuada en el tiempo, ya que se trata de tributos periódicos. Se pone de manifiesto, además, en palabras de ARRANZ DE ANDRÉS, la relación que existe entre el hecho de que los tributos garantizados se devenguen en ejercicios sucesivos y la consecutividad de las anualidades garantizadas. Asimismo, los tributos deberán ser reales, por cuanto han de recaer sobre una manifestación de riqueza (bienes o sus productos). Esto significa que la cuota que se garantiza con la hipoteca se vincula directamente con el bien o derecho gravado, "lo que permite que en aplicación de la garantía pueda ser fácilmente identificable la cantidad para cuyo cobro disfrutará la Administración de la posibilidad de su uso", razón por la cual, también se convierten en tributos directos ${ }^{396}$.

Estos tributos, según GÓMEZ CABRERA, deben tener como objeto la titularidad del dominio o de un derecho real de goce o disfrute sobre un bien o, incluso, los productos que se produzcan directamente del bien. Por eso, dice este autor, que no se aplica la garantía a los tributos cuyo hecho imponible "es un saldo patrimonial neto, como aquellos en que dicha titularidad no es el objeto del tributo, sino un momento más de aquél". Siguiendo con esta doctrina, si la hipoteca se puede aplicar sobre el producto que se derive del bien gravado, entonces quedarán fuera los tributos cuyo hecho imponible recae sobre la "totalidad de los rendimientos de una actividad o un conjunto patrimonial, como aquellos otros que se devenguen con ocasión de una transmisión"397.

La última de las características a la que haremos referencia es quizás la que más contradicciones despierta dentro de la doctrina: que los bienes o derechos gravados deben ser susceptibles de inscripción registral. En este sentido, habrá que remitirse al artículo 2 de la LH, que señala cuáles son los actos que tienen acceso al Registro Público, y al artículo 7 del Reglamento de la LH, que incluye una cláusula abierta a través de la cual se admitirá la inscripción de derechos reales típicos y atípicos $^{398}$.

El criterio que defiende GARCÍA NOVOA es que la hipoteca legal tácita, para hacer valer la preferencia de cobro respecto a un bien concreto con las características de una garantía real, debe referirse a tributos que graven bienes y derechos potencialmente inscribibles en el Registro de la Propiedad. Sin olvidar, dice este autor, que el Derecho civil e hipotecario regula un sistema de inscripción voluntaria y declarativa $\mathrm{y}$, excepcionalmente, ciertos supuestos de inscripciones constitutivas. Por eso, afirma esta doctrina, deben tratarse de bienes y derechos susceptibles de inscripción, no siendo suficiente la aptitud para ser objeto de otros asientos registrales distintos de la inscripción $^{399}$. Como indica GONZÁLEZ-CARBALLO ALMODÓVAR, los registros

\footnotetext{
395 ZABALA RODRÍGUEZ-FORNOS, A., LLOPIS GINER, F. y DAGO ELORZA, I., Recaudación, aspectos sustantivos y procedimentales, op. cit., pág. 242.

${ }^{396}$ ARRANZ DE ANDRÉS, C., La Hipoteca legal privilegiada de la Ley General Tributaria: aproximación jurisprudencial, Aranzadi, Pamplona, 2004, pág. 45.

397 GÓMEZ CABRERA, C., La concurrencia del crédito tributario: Aspectos sustantivos y procedimentales. Prelación, garantías, tercerías, ejecuciones preferentes, suspensiones de pago y quiebras, op. cit., pág. 85.

${ }^{398}$ DÍEZ PICAZO, L y GULLÓN BALLESTEROS, A., Sistema de Derecho Civil, Vol. I. 6 a ed. Tecnos, Madrid, 1988, pág. 280.

${ }^{399}$ GARCÍA NOVOA, C., “Capítulo IV. Elementos de cuantificación de la obligación tributaria”, op. cit., pág. 349 a 350.
} 
administrativos carecen de los efectos jurídicos propios de la publicidad registral sobre los que se articula la garantía $^{400}$, siendo los únicos admisibles, según GÓMEZ CABRERA, por disponer de los efectos del principio de publicidad, el Registro de la Propiedad Inmobiliaria, los Libros de Buques y Aeronaves, el Registro de la Propiedad Intelectual y el Registro de la Propiedad Industrial ${ }^{401}$.

Entendemos, en definitiva, que la normativa que regula la hipoteca legal tácita hace referencia a bienes o derechos que puedan inscribirse en los Registros Públicos que plasmen la propiedad de los mismos, sean bienes muebles o inmuebles, y que a su vez tengan una eficacia de publicidad material que faculte la oponibilidad erga omnes. Cuando se trate de bienes muebles, algunos autores matizan que el objeto de la inscripción no sólo sean las garantías del vendedor o financiador sino también la titularidad sobre los bienes financiados o dados en arrendamiento. De esta forma, a "todos los efectos legales, se presumirá que los derechos inscritos existen y pertenecen a su titular en la forma determinada en el asiento correspondiente" ${ }^{, 402}$.

Queda por definir, por último, cuáles van a ser los tributos que actualmente reúnen las características descritas. La mayoría de la doctrina coincide en que la recaudación del Impuesto sobre Bienes Inmuebles (en adelante IBI) queda protegida por la hipoteca legal tácita ${ }^{403}$, aunque la cuestión se presenta más problemática en el resto de impuestos.

\subsubsection{Impuestos garantizados por la hipoteca legal tácita}

Las Contribuciones Territoriales Rústicas y Urbanas ${ }^{404}$ fueron el precedente inmediato del IBI y tenían por objeto gravar las rentas producidas por los bienes rústicos, la ganadería y los bienes de naturaleza urbana. Por su parte, el Arbitrio sobre Solares edificados y sin edificar constituyó un impuesto local directo, real y objetivo, cuyo hecho imponible se realizaba a partir de la titularidad de los terrenos calificados como solares o como urbanos o urbanizables según la normativa urbanística.

Con la promulgación en 1988 de la Ley de Haciendas Locales estos dos tributos fueron derogados y su contenido pasó a formar parte del IBI. En la actualidad el hecho imponible de este impuesto consiste en la titularidad de determinados derechos sobre los bienes inmuebles rústicos y urbanos y

\footnotetext{
${ }^{400}$ GONZÁLEZ-CARBALLO ALMODÓVAR, A., "Las garantías del crédito tributario”, op. cit., pág. 458.

${ }^{401}$ GÓMEZ CABRERA C., La concurrencia del crédito tributario: Aspectos sustantivos y procedimentales. Prelación, garantías, tercerías, ejecuciones preferentes, suspensiones de pago y quiebras, op. cit., pág. 85 a 86.

${ }^{402}$ ARRANZ DE ANDRÉS, C., Las garantías reales del crédito tributario: aspectos sustantivos y procedimentales, op. cit., pág. 146.

${ }^{403}$ Entre otros, CASANA MERINO, F., "Las garantías del crédito y los tributos locales”, op. cit., pág. 510; GUERVÓS MAÍLLO, M. A., y LAGO MONTERO, J. M., "Las garantías del crédito tributario (Comentario a los artículos 71, 72, 73, 75, 75 y 76 L.G.T.)”, op. cit., pág. 140 y 141; ARRANZ DE ANDRÉS, C., Las garantías reales del crédito tributario: aspectos sustantivos y procedimentales, op. cit., pág. 143 a 146 y, de la misma autora, La Hipoteca legal privilegiada de la Ley General Tributaria: aproximación jurisprudencial, op. cit., pág. 46 a 48; GARCÍA NOVOA, C., "Capítulo IV. Elementos de cuantificación de la obligación tributaria", op. cit., pág. 349 a 350; GONZÁLEZ-CARBALLO ALMODÓVAR, A., "Las garantías del crédito tributario", op. cit., pág. 458; DURÁN-SINDREU BUXADE, A., “¿Existe la hipoteca legal tácita del art. 73 LGT? Una interpretación heterodoxa”, op. cit., pág. 1266.

404 RODRÍGUEZ BEREIJO, A., "Comentarios a los artículos 71 a 76 LGT", en la obra Comentarios a las Leyes tributarias y financieras, Tomo I, Edersa, Madrid, 1982, pág. 649, y ARIAS VELASCO, J., Procedimientos tributarios, op. cit., pág. 461, consideraron sobre la base de lo que estipulaba el artículo 73 de la LGT de 1963 que la hipoteca legal tácita alcanzaba a las contribuciones territoriales cuando recayera sobre bienes inscribibles.
} 
sobre los inmuebles de características especiales ${ }^{405}$. El IBI es un impuesto directo, real y objetivo, cuyo devengo se produce periódicamente y está restringido a los bienes inmuebles inscribibles en el Registro Público de la Propiedad.

Al presentar esta figura todas estas características, resulta poco discutible que pueda garantizarse su recaudación con la hipoteca que reconoce el artículo 78 de la $\mathrm{LGT}^{406}$. Para algunos autores, incluso, como GUERVÓS MAÍLLO y LAGO MONTERO, sólo puede aplicarse la hipoteca legal tácita al IBI, porque "estamos ante un derecho de preferencia absoluto para el cobro del crédito tributario en concepto de IBI en concurso de acreedores" 407.

Un sector de la doctrina, en cambio, se manifiesta disconforme con la aplicación de la hipoteca legal tácita al IBI, porque anteriormente tenía lógica que se regulara la garantía dentro de una ley general por la importancia que en su tiempo tuvieron las contribuciones rústicas y urbanas dentro del sistema tributario, pero no en la actualidad, y además porque el artículo 64 del texto refundido de la Ley Reguladora de las Haciendas Locales determina que en los supuestos de cambio, por cualquier causa, en la titularidad de los derechos que constituyen el hecho imponible del IBI, los bienes inmuebles objeto de dichos derechos quedarán afectos al pago de la totalidad de la cuota tributaria, en régimen de responsabilidad subsidiaria, en los términos previstos en la LGT. Del precepto que comentamos se desprende que la normativa local otorga un derecho de afección a la recaudación del IBI, lo que motiva que autores como GARCÍA NOVOA expresen que la hipoteca legal tácita para este tipo de tributo carece de operatividad y que lo más acertado sería suprimirla porque como está regulada en la actualidad tiene poco margen de aplicación ${ }^{408}$.

Junto al IBI se ubican otros dos impuestos a los que podría extenderse el alcance de la hipoteca legal tácita. Nos referimos al Gravamen Especial sobre Bienes Inmuebles de Entidades No Residentes, que regula el artículo 40 y ss. del Real Decreto Legislativo 5/2004, de 5 de marzo, por el que se aprueba el texto refundido de la Ley del Impuesto sobre la Renta de no Residentes, y al Impuesto sobre Vehículos de Tracción Mecánica (en adelante IVTM), que se disciplina en los artículos 92 y siguientes del texto refundido de la Ley Reguladora de las Haciendas Locales, aunque en la doctrina no existe unanimidad en este extremo.

\footnotetext{
${ }^{405}$ Los derechos a los que nos referimos son los que establece el apartado primero del artículo 61 del Real Decreto Legislativo 2/2004, de 5 de marzo, por el que se aprueba el texto refundido de la Ley Reguladora de las Haciendas Locales.

${ }^{406}$ En relación con el artículo 73 de la LGT de 1963, vid., entre otras, las Sentencias del Tribunal Supremo de 26 de febrero del 1980 y de 3 de mayo de 1988 .

${ }^{407}$ GUERVÓS MAÍLLO, M. A., y LAGO MONTERO, J. M., "Las garantías del crédito tributario (Comentario a los artículos 71, 72, 73, 75, 75 y 76 L.G.T.)", op. cit., pág. 141. Como recuerda GARCÍA NOVOA, la hipoteca legal tácita recae sobre tributos reales, que eran los que configuraban el sistema tributario cuando se aprobó la LGT de 1963, pero que no son los más abundantes en el panorama tributario actual (GARCÍA NOVOA, C., "Capítulo IV. Elementos de cuantificación de la obligación tributaria”, op. cit., pág. 354). En un sentido similar, CALVO ORTEGA manifestó la necesidad de reformar el régimen jurídico de la hipoteca legal tácita, teniendo en cuenta que su regulación original estaba "pensada en un sistema en el que las contribuciones territoriales rústicas y urbana eran dos figuras importantes" (CALVO ORTEGA, R., "La nueva LGT y sus retos”, Revista de Contabilidad y Tributación, núm. 238, enero 2003, pág. 18).

${ }^{408}$ GARCÍA NOVOA, C., “Capítulo IV. Elementos de cuantificación de la obligación tributaria”, op. cit., pág. 354 a 355.
} 
ARRANZ DE ANDRÉS y GARCÍA NOVOA ${ }^{409}$ interpretan que la garantía del artículo 78 de la LGT es aplicable al primero de los impuestos señalados, el Gravamen Especial sobre Bienes Inmuebles de Entidades No Residentes, por cumplir todos los requisitos del precepto, pero los principales inconvenientes se presentan con el IVTM. Los autores que defienden la extensión de la garantía a este impuesto, como ARRANZ DE ANDRÉS ${ }^{410}$, DURÁN-SINDREU BUXADE ${ }^{411}$ y CASANA $\mathrm{MERINO}^{412}$, manifiestan que esta figura grava la titularidad de vehículos de naturaleza real y tiene carácter periódico, considerándose aptos para la circulación los vehículos matriculados en los registros públicos correspondientes. Por el contrario, según GARCÍA NOVOA ${ }^{413}$ y GONZÁLEZCARBALLO ALMODÓVAR ${ }^{414}$, los vehículos se inscriben en los Registros de Permisos de Circulación de Automóviles de las Jefaturas Provinciales de Tráfico, que son registros públicos pero meramente administrativos, porque no recogen la propiedad de bienes ni producen los efectos de publicidad material propios de una inscripción. Esta tesis es rebatida por ARRANZ DE ANDRÉS con el argumento de que los vehículos tienen acceso al Registro de Bienes Muebles, "lo que permite afirmar que nos encontramos ante un tributo que grava de manera periódica un bien inscribible en un Registro Público, con la consecuencia de poder ejecutarse los créditos que de él se deriven"415. También señala CASANA MERINO que la publicidad que otorga el Registro de Tráfico en relación con la titularidad de los automóviles se pone de manifiesto porque son utilizados para las anotaciones de los embargos judiciales y administrativos ${ }^{416}$.

\subsubsection{Posibilidad de incluir otras figuras dentro del ámbito de aplicación de la hipoteca legal tácita}

En principio, pueden ser protegidos por la hipoteca del artículo 78 de la LGT los créditos que se deban a la Hacienda Pública como consecuencia de la exigencia de una tasa, un precio público o una contribución especial. Sin embargo, al analizar la naturaleza y esencia de estas categorías tributarias y no tributarias comprobamos que no son susceptibles de encajar sus presupuestos de hecho dentro de los supuestos cuyo aseguramiento se pretende con la hipoteca legal tácita ${ }^{417}$. Así también lo entendió el Tribunal Superior de Justicia de Cataluña en su Sentencia de 8 de julio de 1995, que desestimó la aplicación de esa garantía real para el cobro de la tasa de recogida de basura.

El texto del artículo 78 de la LGT, como también lo hizo su antecesor el artículo 73 de la LGT de 1963, dispone expresamente que el tributo cuya deuda pretende satisfacerse a través del ejercicio de la hipoteca debe gravar directamente el bien sobre el que recae aquélla, o sus productos, ciertos o

\footnotetext{
${ }^{409}$ GARCÍA NOVOA, C., "Garantías de la deuda tributaria”, op. cit., pág. 351; ARRANZ DE ANDRÉS, C., Las garantías reales del crédito tributario: aspectos sustantivos y procedimentales, op. cit., pág. 147.

${ }^{410}$ ARRANZ DE ANDRÉS, C., Las garantías reales del crédito tributario: aspectos sustantivos y procedimentales, op. cit., pág. 146.

${ }^{411}$ DURÁN-SINDREU BUXADE, A., “¿Existe la hipoteca legal tácita del art. 73 LGT? Una interpretación heterodoxa”, op. cit., pág. 1266. Este autor entiende que sólo resulta aplicable la garantía de la hipoteca legal tácita al IVTM en la "medida en que se considere que los registros de matriculación y de permiso de circulación no son meramente administrativos, sino de carácter público".

${ }^{412}$ CASANA MERINO, F., "Las garantías del crédito y los tributos locales”, op. cit., pág. 511.

${ }^{413}$ GARCÍA NOVOA, C., "Capítulo IV. Elementos de cuantificación de la obligación tributaria”, op. cit., pág. 349 a 350.

${ }^{414}$ GONZÁLEZ-CARBALLO ALMODÓVAR, A., "Las garantías del crédito tributario”, op. cit., pág. 458.

${ }^{415}$ ARRANZ DE ANDRÉS, C., La Hipoteca legal privilegiada de la Ley General Tributaria: aproximación jurisprudencial, op. cit., pág. 48.

${ }^{416}$ CASANA MERINO, F., “Las garantías del crédito y los tributos locales”, op. cit., pág. 511.

${ }^{417}$ En este sentido, HERRERA MOLINA, P. M., Los precios públicos como recurso financiero, Civitas, Madrid, 1991, pág. 127.
} 
presuntos. Es aquí donde se muestra compleja la aplicación de la hipoteca legal a las tasas y los precios públicos, por la dificultad que implica trasladar ese requisito al objeto gravado por esta clase de ingresos, donde la obligación de pago se origina como consecuencia de la prestación de un servicio o la realización de actividades por parte de la Administración. Quiere esto decir que los presupuestos de hecho de las tasas y los precios públicos se vinculan al desarrollo de una actividad por el ente público acreedor por cuya realización se exige el pago de estas figuras, lo que implica que no se grava la titularidad sobre ningún bien concreto.

En relación con las tasas exigibles por la utilización privativa o el aprovechamiento especial del dominio público, advierte ARRANZ DE ANDRÉS que "muchas de ellas afectan a los bienes inmuebles que integran el dominio público local, y otras están conectadas con determinados bienes inmuebles de los sujetos que han de satisfacerlos". También algunas actividades recaen sobre servicios generales, y actividades económicas, y otras se encuentran ligadas a los bienes inmuebles afectos al desarrollo de actividades económicas o a la propiedad inmobiliaria. Aunque en todos los casos "lo que se grava es la utilización privativa del dominio público y no la titularidad de cualquier derecho real sobre los inmuebles públicos o privados, siendo además, por lo que respecta a las tasas por prestación de servicios o realización de actividades, siempre precisa la realización de una actividad por parte de la Administración",418.

Las contribuciones especiales también presentan el mismo problema que las tasas y los precios públicos a la hora de encajar en el supuesto de hecho que describe el artículo 78 de la LGT. El presupuesto de hecho de las contribuciones especiales precisa de la concurrencia de dos situaciones: por un lado, que se produzca un beneficio para el sujeto o que exista un aumento del valor de sus bienes, y por el otro, la realización de una obra pública o el establecimiento o ampliación de un servicio público ${ }^{419}$. En definitiva, el gravamen de esta categoría tributaria no recae sobre un bien ni sobre su producto y no puede por tanto asegurarse con la garantía del artículo 78 de la LGT. Sigue esta misma postura VEGA HERRERO, que al referirse al mandato del artículo 73 de la LGT de 1963 entendió que en virtud de su garantía sólo podía operar en el ámbito de los tributos devengados con cierta periodicidad, requisito que no reúnen las contribuciones especiales ${ }^{420}$.

En conclusión, la hipoteca legal tácita puede utilizarse como garantía para la recaudación de determinados impuestos reales, directos y periódicos, cuyos hechos imponibles recaen sobre bienes o derechos inscribibles en el Registro Público de la Propiedad, ya sea de bienes muebles o inmuebles. En este sentido, tres son las figuras que pueden asegurarse con la hipoteca del artículo 78 de la LGT: el IBI, el Gravamen sobre Bienes Inmuebles de Entidades No Residentes y el IVTM.

\subsubsection{Aspecto material}

Ante la insatisfacción de la deuda, ya sea finalizado el período voluntario de pago o una vez agotado el plazo para el pago que concede la providencia de apremio, se procede a la ejecución de las

\footnotetext{
${ }^{418}$ ARRANZ DE ANDRÉS, C., Las garantías reales del crédito tributario: aspectos sustantivos y procedimentales, op. cit., pág. 162.

${ }^{419}$ FERNÁNDEZ MARÍN, F., Estudio jurisprudencial de las contribuciones especiales, Servicio de Publicaciones de la Universidad de Almería, Almería, 2000, pág. 17; MERINO JARA, I., Contribuciones Especiales, Cuaderno de Jurisprudencia Tributaria Aranzadi, núm. 26, 2002, pág. 19 a 21 .

${ }^{420}$ VEGA HERRERO, M., Las Contribuciones Especiales en España, Instituto de Estudios Fiscales, Madrid, 1975, pág. 29 y ss.
} 
garantías, incluida la hipoteca legal tácita ${ }^{421}$. En este caso, junto a la cuantía correspondiente al crédito tributario, la garantía debe cubrir, en su caso, los intereses de demora, los recargos del período ejecutivo, la cuantía que se derive de la imposición de las costas procesales, los recargos por declaración extemporánea del artículo 27 de la $\mathrm{LGT}^{422}$, y las sanciones. Estas últimas, sin embargo, se excluyen en la ejecución de la hipoteca legal tácita porque no forman parte de la deuda tributaria, siguiendo el principio de personalidad de la pena, aplicable también a las infracciones administrativas, según prevé el apartado tercero del artículo 58 de la LGT; porque no pueden considerarse prestaciones accesorias de la obligación tributaria principal, a tenor de lo que establece el apartado 2 del artículo 25 de la LGT; y porque deben imponerse a través de un procedimiento de imposición separado ${ }^{423}$.

Así, pues, el producto de la enajenación del bien afecto por la garantía se destinará no sólo a satisfacer la cantidad que corresponde a la cuota tributaria, sino también los intereses, los recargos y las costas que aparecen como consecuencia del incumplimiento del deudor y, en su caso, del tercer adquirente del bien sujeto a la garantía, siguiendo las disposiciones del número 1 del artículo 169 de la LGT, y esto es válido tanto para las garantías voluntarias como para el derecho de afección previsto en el artículo 79 de la LGT.

La LGT de 1963, en su artículo 73, sólo hacía alusión a las deudas no satisfechas sin especificar su contenido, pero el artículo 37 del RGR de 1968 precisó que la garantía se extendía a las deudas tributarias. También se aceptó que esta garantía alcanzara los intereses porque formaban parte de la deuda tributaria que regulaba el artículo 58 de la LGT de 1963. En relación con los recargos, SIMÓN ACOSTA condicionó su inclusión al hecho de que el ente público acreedor estuviera protegido por el artículo 73 de la LGT de 1963. Por ello expresó que los recargos exigibles legalmente sobre las bases o las cuotas, ya sean a favor del Tesoro o de otros entes públicos del inciso a) del apartado 2 del artículo 58 de la LGT de 1963, eran en realidad tributos distintos del principal, aunque tuvieran su misma naturaleza. "Son, por tanto, tributos periódicos que recaen sobre los bienes o sus productos y, desde este punto de vista, no hay nada que objetar a su inclusión en el ámbito de la garantía. Pero como hemos visto, existen también limitaciones subjetivas, pues ni la Administración institucional ni las Corporaciones de Derecho Público están protegidas por el artículo 73 L.G.T." Y más adelante, al referirse a los recargos del apartado 3 del artículo 61 de la LGT de $1963^{424}$ y de apremio, entendió que "aunque por la importancia de su cuantía no son meramente resarcitorios de un daño, sino auténticas medidas disuasorias del retraso en el pago, cercanas en su función a las sanciones, son, al

\footnotetext{
${ }^{421}$ Vid. supra. Capítulo Primero, epígrafe 2.5.2.1. "Ejecución de las garantías".

${ }^{422}$ En principio estos recargos sólo serían de aplicación en el Gravamen Especial sobre Bienes Inmuebles de Entidades No Residentes, que es el único de los tres impuestos señalados a los que resulta aplicable la hipoteca legal tácita que requiere la presentación de autoliquidaciones.

${ }^{423}$ SIMÓN ACOSTA, E., "La hipoteca legal tácita en garantía de deudas tributarias”, op. cit., pág. 1085; GÓMEZ CABRERA C., La concurrencia del crédito tributario: Aspectos sustantivos y procedimentales. Prelación, garantías, tercerías, ejecuciones preferentes, suspensiones de pago y quiebras, op. cit., pág. 87.

${ }^{424}$ Prevé literalmente el precepto que "los ingresos correspondientes a declaraciones-liquidaciones o autoliquidaciones presentadas fuera de plazo sin requerimiento previo, así como las liquidaciones derivadas de declaraciones presentadas fuera de plazo sin requerimiento previo, sufrirán un recargo del $20 \%$ con exclusión de las sanciones que, en otro caso, hubieran podido exigirse pero no de los intereses de demora. No obstante, si el ingreso o la presentación de la declaración se efectúa dentro de los tres, seis o doce meses siguientes al término del plazo voluntario de presentación e ingreso, se aplicará un recargo único del 5, 10 o $15 \%$ respectivamente con exclusión del interés de demora y de las sanciones que, en otro caso, hubieran podido exigirse".
} 
menos formalmente, distintas de éstas, y forman parte de la deuda tributaria, por lo que cabe admitir que su importe está cubierto por las garantías que estudiamos" ${ }^{\text {"425. }}$.

La doctrina que sustenta la idea de utilizar las garantías y privilegios para satisfacer no sólo las cuotas tributarias propiamente dichas sino también el resto de los elementos que integran la deuda tributaria, en los términos del artículo 58 de la LGT actual, alegan que por tener estos elementos un carácter accesorio deberían tener un régimen similar al elemento principal al que se vinculan. Señala LÓPEZ MARTÍNEZ que "la obligación de pagar intereses ha tenido, desde antiguo, un claro carácter de accesoriedad, en cuanto que, (...), en su nacimiento y devengo se establece el nexo de causalidad exigido, así como que éste permanece en el tratamiento jurídico que le resulta aplicable". Y más adelante este mismo autor precisa "que estos atributos de su naturaleza jurídica no le impiden que en el curso de su desarrollo jurídico adquieran sustantividad propia con el resto de los componentes de la deuda tributaria, lo que determinará y condicionará de forma clara tanto su régimen como su naturaleza jurídica" ${ }^{\text {426. }}$.

Podríamos afirmar consiguientemente que la Administración tributaria sólo satisface con el producto de la ejecución de la garantía la cuota tributaria y los recargos del inciso $d$ ) del apartado 2 del artículo 58 de la LGT, que son los que tienen naturaleza tributaria. El resto de los componentes que aparecen en el artículo 58 de la LGT surgen por el incumplimiento del obligado tributario y no en función de la existencia de una riqueza que debe ser gravada. Al no presentar esos otros elementos una naturaleza tributaria puede parecer que no es posible su inclusión en el ámbito de aplicación de las garantías. No obstante, si una norma determina expresamente su inclusión, es factible considerar que dichos elementos queden amparados por la ejecución de las garantías reales ${ }^{427}$.

En este sentido, el apartado primero del artículo 10 de la LGP señala que

"sin perjuicio de las prerrogativas establecidas para cada derecho de naturaleza pública por su normativa reguladora, la cobranza de tales derechos se efectuará, en su caso, conforme a los procedimientos administrativos correspondientes y gozará de las prerrogativas establecidas para los tributos en la Ley General Tributaria, y de las previstas en el Reglamento General de Recaudación".

Por su parte, el apartado 2 del artículo 5 de la LGP dispone que son derechos de naturaleza pública de la Hacienda Pública estatal los tributos y los demás derechos de contenido económico cuya titularidad corresponde a la Administración General del Estado y sus organismos autónomos que se deriven del ejercicio de potestades administrativas. De la interpretación conjunta de los dos preceptos se puede concluir que tanto los intereses de demora como los recargos por impago de la deuda tributaria o por

\footnotetext{
${ }^{425}$ SIMÓN ACOSTA, E., "La hipoteca legal tácita en garantía de deudas tributarias”, op. cit., pág. 1085.

${ }^{426}$ LÓPEZ MARTÍNEZ, J., Régimen jurídico de los llamados “intereses moratorios” en materia tributaria (un análisis de su ubicación dogmática en el seno de la deuda tributaria), op. cit., pág. 184. Al respecto apunta ARRANZ DE ANDRÉS que "no menos importante ha de resultar a estos efectos la consideración de que la dependencia que implica la accesoriedad alcanza en realidad su máximo protagonismo en el momento de nacimiento o génesis del elemento considerado accesorio, sin que ello impida que en el devenir de su desarrollo jurídico pueda adquirir el mismo sustantividad propia, gozando de su propio régimen y naturaleza jurídica" (ARRANZ DE ANDRÉS, C., Las garantías reales del crédito tributario: aspectos sustantivos y procedimentales, op. cit., pág. 185).

${ }^{427}$ VARONA ALABERN, J. E., El crédito tributario en la quiebra, Lex Nova, Valladolid, 2000, pág. 187.
} 
el retraso en su satisfacción deben tenerse como ingresos de Derecho público. Si tenemos en cuenta lo dispuesto en el artículo 78 de la LGT, que se refiere a las deudas devengadas y no satisfechas, podremos concluir que la hipoteca legal tácita ampara con el producto de su ejecución la cuota tributaria propiamente dicha y las cantidades debidas en concepto de intereses de demora y los recargos del período ejecutivo ${ }^{428}$.

Finalmente, al igual que con el resto de los elementos que conforman la deuda tributaria, las costas procesales pueden ser aplicadas tanto a la hipoteca legal tácita como al derecho de afección que contempla el artículo 79 de la LGT. Estas cantidades no se encuentran recogidas dentro de los componentes de la deuda tributaria previstos en el artículo 58 de la LGT y su determinación aparece en el artículo 113 del RGR, que aglutina bajo el término de costas procesales todos aquellos gastos cuyo origen se vincula al procedimiento de apremio. Entre ellos, se encuentran los honorarios de empresas o profesionales ajenos a la Administración, los honorarios de los registradores y demás gastos que deban abonarse por las actuaciones en los registros públicos, los gastos que deban abonarse por depósito y administración de los bienes embargados, y los pagos realizados a acreedores. Se trata de cantidades que devengan terceros por actividades que ellos mismos han hecho para facilitar y procurar el adecuado desarrollo del procedimiento de ejecución forzosa, pero que no constituyen gastos ordinarios de la Hacienda Pública.

El apartado 2 del artículo 116 del RGR dispone que cuando el importe obtenido con el producto de la enajenación del bien ejecutado sea insuficiente se aplique en primer lugar a las costas y seguidamente a las deudas cuyo cobro se persigue en el procedimiento. A este precepto se critica que "privilegia de esta forma el cobro de estos créditos, situación que (...) puede suponer una violación del tan reiterado principio de legalidad que debe imperar en el establecimiento de los privilegios cuando se trate de la ejecución de una de las garantías a que nos referimos" ${ }^{\text {"49 }}$. La trascendencia de esta medida se evidencia sobre todo cuando el producto que se obtiene de la ejecución no alcanza para cubrir el total de la deuda tributaria y las costas y es necesario embargar otros bienes sobre los que el resto de los acreedores tienen puestas sus expectativas.

También LÓPEZ DÍAZ ${ }^{430}$ se opuso a la utilización de la vía de apremio por parte de la Administración tributaria para el cobro de las costas procesales y agrega que no son objeto de liquidación hasta que efectivamente no se liquida el expediente de apremio. El único argumento posible que permite justificar esta preferencia para el cobro de esas cantidades, según el autor, es que su cuantía se determine por medio de un acto administrativo.

A modo de conclusión, y quizás alejándonos un poco de lo que establecen las normas que antes citábamos, somos del criterio de que no existe reparo alguno para que se exija al poseedor del bien

\footnotetext{
${ }^{428}$ En contra de que se satisfagan los recargos con la ejecución de la hipoteca legal tácita, vid. SIERRA BRAVO, R., "Comentarios a los artículos 36 y ss. RGR”, en la obra Comentarios a las Leyes Tributarias y Financieras, Tomo XVI, Edersa, Madrid, 1983 , pág. 120. A favor de esta inclusión, vid. SIMÓN ACOSTA, E., "La hipoteca legal tácita en garantía de deudas tributarias", op. cit., pág. 1085; GÓMEZ CABRERA C., La concurrencia del crédito tributario: Aspectos sustantivos y procedimentales. Prelación, garantías, tercerías, ejecuciones preferentes, suspensiones de pago y quiebras, op. cit., pág. 87; ARRANZ DE ANDRÉS, C., Las garantías reales del crédito tributario: aspectos sustantivos y procedimentales, op. cit., pág. 188.

${ }^{429}$ ARRANZ DE ANDRÉS, C., Las garantías reales del crédito tributario: aspectos sustantivos y procedimentales, op. cit., pág. 190.

${ }^{430}$ LÓPEZ DÍAZ, A., La recaudación de deudas tributarias en vía de apremio, op. cit., pág. 294 a 296.
} 
afecto por la hipoteca legal tácita los intereses de demora, los recargos del período ejecutivo y las costas procesales que se deriven como consecuencia del inicio del procedimiento ejecutivo, siempre y cuando el adquirente del bien sea el propio deudor principal. Sin embargo, creemos que debe hacerse una distinción cuando se trate de un tercer adquirente, pues consideramos injusto que este sujeto tenga que satisfacer las cantidades que se devengan por la falta de pago del deudor principal. Lo razonable, según nuestra opinión, es que el tercero adquirente haga frente a los intereses, recargos y costas que se devenguen únicamente con motivo de su propio incumplimiento ${ }^{431}$.

\subsubsection{Aspecto temporal}

El límite temporal de la hipoteca legal tácita es una de las cuestiones que suscita controversia en la doctrina y la jurisprudencia. En un principio, la LH de 1861, en sus artículos 168 y 218, limitó la hipoteca legal a una sola anualidad. Con posterioridad, el artículo 194 de la LH, que aún sigue vigente, otorgó la preferencia sobre cualquier otro acreedor y sobre el tercer adquirente, aunque hayan inscrito sus derechos en el Registro, para el cobro de la anualidad corriente y la última vencida y no satisfecha de las contribuciones o impuestos que graven los bienes inmuebles. Por su parte, el Código Civil dispuso en su artículo 1.923 que los créditos a favor del Estado gozan de preferencia para el cobro por el importe de la última anualidad, vencida y no pagada, de los impuestos que graviten sobre ellos.

En el ámbito tributario, el artículo 12 de la Instrucción General de Recaudación y Contabilidad de 1911 restringió la preferencia de la Hacienda Pública a la anualidad corriente y la última vencida y no satisfecha. El artículo 158 del Estatuto de Recaudación de 1928 estableció que el derecho preferente de la Hacienda era indudable en cuanto a la anualidad corriente y a la última vencida, con independencia de la fecha de inscripción del derecho hipotecario o de la adquisición. Más tarde, el Estatuto de Recaudación de 1948 previó en su artículo 130 que la Hacienda tendría el derecho de absoluta preferencia para el cobro de la anualidad corriente, precisando que sería la del momento en que se inscribió el derecho hipotecario o se efectuó la transmisión del dominio de la finca, y para la última vencida, constituida por los cuatro trimestres del ejercicio económico inmediato anterior al corriente, cualesquiera que fueran las fechas de tales inscripciones o adquisiciones.

La LGT de 1963, en su artículo 73, ciñó la hipoteca legal tácita al cobro de las deudas no satisfechas correspondientes al año natural en que se ejercite la acción administrativa de cobro y al inmediato anterior. En 2003, con la entrada en vigor de la LGT, se regula de manera continuista estos límites temporales. Sin embargo, el artículo 78 de la LGT introduce una pequeña variación en su redacción respecto de su antecesor, y dispone que se trata de una preferencia para el cobro de las deudas devengadas y no satisfechas correspondientes al año natural en que se exija el pago y al inmediato anterior.

De manera general, se aprecia que la normativa tributaria limita la hipoteca legal tácita a dos anualidades, lo cual lleva a afirmar a GUERVÓS MAÍLLO y LAGO MONTERO que se trata de una

\footnotetext{
${ }^{431}$ En este sentido, ARRANZ DE ANDRÉS, C., La Hipoteca legal privilegiada de la Ley General Tributaria: aproximación jurisprudencial, op. cit., pág. 100 a 106.
} 
"prelación fuertísima pero limitada a dos créditos tributarios normalmente discretos en su cuantía"432. Por otra parte, no nos parece que sean aplicables las disposiciones del ordenamiento civil que hemos señalado porque la LGT es ley especial posterior y su función es regular completamente este tipo de garantía. También entendemos que el legislador, cuando se refiere a la acción administrativa de cobro en la LGT de 1963 o a las deudas devengadas y no satisfechas correspondientes al año natural en que se exija el pago en la LGT actual, alude al cobro forzoso o ejecutivo de la deuda, de manera que los dos años cubiertos por la hipoteca legal tácita son o deben ser el de la notificación de la providencia de apremio y el inmediato anterior.

No obstante, la normativa reglamentaria se aparta de esta interpretación. Nunca estuvo claro en la LGT de 1963 cuál sería el momento de ejercicio de la acción administrativa de cobro. El apartado 2 del artículo 37 del RGR de 1968 señaló que la acción administrativa de cobro se ejercitaba cuando se iniciara el procedimiento de recaudación en período voluntario. De esta forma, en cada ejercicio quedaba asegurada siempre la anualidad corriente y la anterior, "configurándose así como una garantía imperecedera que en la práctica servía para el cobro de todas las deudas no prescritas"433. Como advierte SIMÓN ACOSTA ${ }^{434}$, de esa forma la garantía sería temporalmente ilimitada, teniéndose en cuenta que los tributos periódicos todos los años abren un período voluntario de pago, lo que arrojaría la conclusión de que la garantía cubriría todas las deudas no satisfechas, cualquiera que hubiera sido el momento en que se iniciara la ejecución.

Para evitar esta ampliación continuada del período temporal cubierto por la hipoteca, la Regla 19 de la Instrucción General de Recaudación y Contabilidad de 1969, dispuso que

"se entiende que se ejercita la acción administrativa de cobro, cuando se inicia el procedimiento de recaudación en período voluntario de los débitos correspondientes al ejercicio económico en que se haya inscrito en el Registro el derecho o efectuado la transmisión de los bienes o derechos de que se trate".

Para GÓMEZ CABRERA, el RGR de 1968 intentaba salvar la contradicción que se observaba entre el artículo 130 del Estatuto de Recaudación de 1948 y el artículo 73 de la LGT de 1963, que fijaba la anualidad corriente en el momento en que se ejercite la acción administrativa de cobro y que, "obviamente, no podía ser el de la inscripción del derecho hipotecario o el de la transmisión del dominio de la finca"435.

Años más tarde, cuando entró en vigor el RGR de 1990, se intentó definir de forma distinta la situación temporal de la hipoteca legal tácita en el apartado 2 del artículo 35. Con arreglo a este

\footnotetext{
${ }^{432}$ GUERVÓS MAÍLLO, M. A., y LAGO MONTERO, J. M., "Las garantías del crédito tributario (Comentario a los artículos 71,72 , 73, 75, 75 y 76 L.G.T.)", op., cit., pág. 141.

${ }^{433}$ GONZÁLEZ-CARBALLO ALMODÓVAR, A., "Las garantías del crédito tributario”, op. cit., pág. 459.

${ }^{434}$ SIMÓN ACOSTA, E., "La hipoteca legal tácita en garantía de deudas tributarias", op. cit., pág. 1086. También ZABALA RODRÍGUEZ-FORNOS, A., LLOPIS GINER, F. y DAGO ELORZA, I., Recaudación, aspectos sustantivos y procedimentales, op. cit., pág. 242.

${ }^{435}$ GÓMEZ CABRERA, C., La concurrencia del crédito tributario: Aspectos sustantivos y procedimentales. Prelación, garantías, tercerías, ejecuciones preferentes, suspensiones de pago y quiebras, op. cit., pág. 88 .
} 
precepto, las deudas garantizadas por la hipoteca legal tácita eran las del año en que se produjera la adquisición por un tercero del bien inmueble o de inscripción a favor de un acreedor concurrente de un derecho de hipoteca sobre aquel bien y el inmediato anterior, lo que provocó que un sector de la doctrina manifestara que se trataba de una solución contra legem por extralimitación, en relación con la letra del artículo 73 de la LGT de $1963^{436}$.

Actualmente, con la redacción del artículo 78 de la LGT, que se refiere al cobro de las deudas devengadas y no satisfechas correspondientes al año natural en que se exija el pago, el RGR determina en el apartado primero del artículo 65 que se entiende que se exige el pago cuando se inicia el procedimiento de recaudación en período voluntario de los débitos correspondientes al ejercicio en que se haya inscrito en el registro el derecho o efectuado la transmisión de los bienes o derechos de que se trate. Este precepto reproduce casi idénticamente el contenido de su homólogo anterior el apartado 2 del artículo 35 del RGR de 1990. La problemática aquí se presenta en el hecho de si puede interpretarse, según la propia redacción del artículo 78 de la LGT, que las anualidades garantizadas serán las correspondientes al ejercicio en que se inscribe el derecho por el tercero o se transmiten los bienes y la inmediata anterior; o que la garantía se aplica para el cobro de la anualidad devengada en el ejercicio en que se inicia el procedimiento de apremio y a la anterior. Se trata, por tanto, de la misma polémica que suscitó el artículo 73 de la LGT de 1963 en la doctrina y la jurisprudencia en relación con la determinación del ámbito temporal de la hipoteca legal tácita.

1.3.4.1. Las anualidades correspondientes al ejercicio en que se inscribe o se transmiten los bienes afectos y la inmediata anterior

Puede inferirse del contenido de los distintos reglamentos que han estado vigentes que cualquier acreedor hipotecario que inscriba su bien o cualquier tercero que adquiera un bien estará sujeto al cumplimiento de las deudas correspondientes al ejercicio en que se efectúa la inscripción o se adquiriera el bien y al anterior, con la excepción de que la deuda hubiera prescrito. Esta interpretación se fundamenta para algunos autores en el objetivo de la hipoteca, que consideran que es el de proteger a la Hacienda Pública cuando el bien sobre el que recae el tributo pasa a manos de terceros que se responsabilizan por unas deudas que no son suyas, y permite afirmar que la garantía se limita al año de la adquisición y al inmediato anterior ${ }^{437}$.

\footnotetext{
436 Vid. SIMÓN ACOSTA, E., "La hipoteca legal tácita en garantía de deudas tributarias", op. cit., pág. 1086; ZABALA RODRÍGUEZ-FORNOS, A., LLOPIS GINER, F. y DAGO ELORZA, I., Recaudación, aspectos sustantivos y procedimentales, op. cit., pág. 242; GÓMEZ CABRERA, C., La concurrencia del crédito tributario: Aspectos sustantivos y procedimentales. Prelación, garantías, tercerías, ejecuciones preferentes, suspensiones de pago y quiebras, op. cit., pág. 87; GARCÍA NOVOA, C., "Capítulo IV. Elementos de cuantificación de la obligación tributaria", op. cit., pág. 356.

${ }^{437}$ SERRERA CONTRERAS, L., "La anualidad corriente en la hipoteca legal tácita por contribuciones”, op. cit., pág. 17; MARTÍN TIMÓN, M., Embargos y tercerías de la Hacienda Pública, Cuadernos de Jurisprudencia Tributaria, Instituto de Estudios Fiscales, Madrid, 1978, pág. 147; BAYOD PALLARES, R. G., "Las liquidaciones de los Impuestos sobre la Renta de las Personas Físicas, sobre Sociedades y sobre el Patrimonio, como créditos preferentes de la Hacienda Pública”, Crónica Tributaria, núm. 42, 1982, pág. 48; FALCÓN Y TELLA, R., "Las garantías del crédito tributario: perspectivas de reforma", op. cit., pág. 920; ZABALA RODRÍGUEZ-FORNOS, A., LLOPIS GINER, F. y DAGO ELORZA, I., Recaudación, aspectos sustantivos y procedimentales, op. cit., pág. 242; MOYA-ANGELER SÁNCHEZ, J., "Las obligaciones y los responsables tributarios en sus distintas formas y modalidades, hipoteca legal tácita, afección de bienes y derecho de prelación de la Hacienda", op. cit., pág. 128; CASANA MERINO, F., "Las garantías del crédito y los tributos locales", op. cit., pág. 512 a 513. En la jurisprudencia, vid., entre otras, las Sentencias del Tribunal Supremo de 21 de diciembre de 1979, de 26 de febrero de 1980, de 24 de marzo de 1983, de 23 de diciembre de 1983 , de 7 de marzo de 1985, de 3 de marzo de 1992, de 1 de abril de 1996, o de 15 de enero de 2001.
} 
Las críticas que se hacen a esta interpretación se centran principalmente en el hecho de que con la práctica de una nueva adquisición o inscripción hipotecaria se produce la modificación "del criterio de referencia para la determinación de las cantidades favorecidas por el privilegio del art. 73 LGT, desapareciendo la garantía vigente respecto de las anteriores adquisiciones"438. Ello es así porque si esta persona transmite su derecho el nuevo adquirente no responderá de las cuotas a las que estaba afecto el bien anteriormente, sino exclusivamente de las correspondientes al año de su adquisición y el inmediato anterior. Tal como expresa SIMÓN ACOSTA, "toda transmisión de derechos sobre el bien produce la caducidad de la garantía vigente respecto de anteriores adquisiciones. Se trata de una consecuencia lógica del modo en que las normas reglamentarias y la jurisprudencia interpretan el concepto legal del «año en que se inicia la acción administrativa de cobro». Si las nuevas adquisiciones no purgasen la garantía anteriormente vigente la hipoteca legal tácita extendería sus efectos a un período discontinuo. Esto produciría un grado de inseguridad jurídica en las adquisiciones de bienes y derechos que no puede entenderse querido por la ley"439.

También considera ARRANZ DE ANDRÉS que resulta complejo el ejercicio de la garantía bajo esta primera interpretación si el bien gravado no ha salido del patrimonio del deudor o no se constituye ninguna hipoteca. Para esta autora, si la determinación de la referencia temporal es el ejercicio de la acción de cobro de la administración, y ésta se relaciona con la transmisión del bien a un tercero o la constitución de una garantía de hipoteca, "no se deduce de ahí cuál sería el período respecto del que podría la Hacienda hacer valer su mejor derecho si el bien continúa en poder el deudor y no existe tampoco ningún acreedor hipotecario con pretensiones sobre el mismo objeto" 440 . En este sentido, dando continuidad a esta opinión doctrinal, el legislador sí muestra un marcado interés en la preferencia de la Hacienda Pública en el caso de que concurra con otros acreedores hipotecarios o un tercer adquirente, pero ello no significa que su interés por la ejecución del bien cese en aquellos casos en que el deudor que ha incumplido con su obligación de pago ni hipoteque ni transmita el bien sobre el que recae la garantía.

La tercera de las fundamentaciones que utilizan los defensores de la tesis que acota el ámbito temporal de la hipoteca legal tácita a las anualidades correspondientes al ejercicio en que se inscribe o se transmiten los bienes afectos y la inmediata anterior es la de aliviar las consecuencias que el ejercicio de la hipoteca puede causar sobre el tercero. Esto, sin embargo, se contradice con lo que establece la ley, porque de ser así carecería de sentido la extensión que se hace no sólo a la anualidad en que se produzca la adquisición o la inscripción, sino también a la anterior.

\footnotetext{
${ }^{438}$ ARRANZ DE ANDRÉS, C., La Hipoteca legal privilegiada de la Ley General Tributaria: aproximación jurisprudencial, op. cit., pág. 72.

${ }^{439}$ SIMÓN ACOSTA, E., "La hipoteca legal tácita en garantía de deudas tributarias”, op. cit., pág. 1088 y 1089.

${ }^{440}$ ARRANZ DE ANDRÉS, C., La Hipoteca legal privilegiada de la Ley General Tributaria: aproximación jurisprudencial, op. cit., pág. 74.
} 
Una segunda interpretación del artículo 78 de la LGT se basa en la afirmación de que el ejercicio de la hipoteca legal tácita recae sobre las anualidades en que se exige el pago, esto es, la anualidad en que se inicia el procedimiento de apremio a través de la providencia de apremio y a la anterior ${ }^{441}$.

El precepto indicado se refiere a deudas devengadas y no satisfechas correspondientes al año natural en que se exija el pago y al año anterior, mientras que el apartado primero del artículo 65 del RGR, que define el término de exigencia de pago, sitúa a éste en el momento en que se inicia el procedimiento de recaudación en período voluntario de los débitos correspondientes al ejercicio en que se haya inscrito el derecho o efectuado la transmisión de los bienes o derechos.

Como interpreta GONZÁLEZ-CARBALLO ALMODÓVAR, cuando "la Administración Tributaria inicie un procedimiento administrativo de apremio para el cobro de las deudas de IBI o GENR devengadas y no abonadas voluntariamente, y se dirija contra determinados bienes de los sujetos pasivos que han sido transmitidos a terceros o gravados con hipotecas de otros acreedores suyos, (...) tendrá un derecho preferente a cobrarse con cargo a estos bienes en cuanto a la anualidad correspondiente a la de la notificación de la providencia de apremio dictada y a la inmediata anterior, cualquiera que sea la fecha de aquellas transmisiones o cargas hipotecarias" ${ }^{\prime 42}$.

También SIMÓN ACOSTA opina que es más acorde con la naturaleza jurídica de esta institución que el inicio de la acción administrativa de cobro (a tenor del artículo 73 de la LGT de 1963) se refiera al cobro forzoso o ejecutivo, porque así se garantizan las deudas del año en que se notifica la providencia de apremio y las del año anterior; se asegura, una vez iniciada la ejecución, que la Administración cobre al menos las cuotas de dos años; y se estimula al adquirente para que compruebe la situación fiscal de los bienes en los ejercicios más recientes ${ }^{443}$.

Por nuestra parte, pensamos que esta interpretación se ajusta más a la naturaleza de la garantía real y a su funcionamiento. En primer lugar, porque independientemente de que se realicen o no transmisiones o inscripciones sobre el bien, su aplicación no pierde vigencia aunque no exista concurrencia de intereses de terceros. $\mathrm{Y}$ en segundo lugar, porque se ejercita este mecanismo de garantía cuando, una vez que se produce el incumplimiento, se precisa realizar los bienes garantizados para satisfacer la deuda, limitándose su aplicación a las deudas devengadas y no satisfechas correspondientes a aquél mismo año y al anterior en que se ejecuten los bienes garantizados. "Se consigue acercar así el momento del devengo del tributo al de la utilización de la garantía para su cobro, evitando no sólo que se puedan garantizar todas las posibles cuotas existentes devengadas y no satisfechas, sino también que su uso pudiera resultar ineficaz por encontrarse prescritas las deudas cuyo cobro se pretende" 444 .

\footnotetext{
${ }^{441}$ GARCÍA NOVOA, C., “Capítulo IV. Elementos de cuantificación de la obligación tributaria”, op. cit., pág. 356.

${ }^{442}$ GONZÁLEZ-CARBALLO ALMODÓVAR, A., "Las garantías del crédito tributario", op. cit., pág. 460.

${ }^{443}$ SIMÓN ACOSTA, E., "La hipoteca legal tácita en garantía de deudas tributarias”, op. cit., pág. 1086.

${ }^{444}$ ARRANZ DE ANDRÉS, C., Las garantías reales del crédito tributario: aspectos sustantivos y procedimentales, op. cit., pág. 179 a 181.
} 
En conclusión, pues, el límite temporal de la hipoteca legal tácita se aplica a las anualidades correspondientes al ejercicio que se inicia en el procedimiento de apremio y al anterior, porque esta interpretación, que puede contradecir el tenor literal de lo que prevé el RGR, se ajusta más a la naturaleza jurídica y al funcionamiento de la hipoteca legal tácita.

\subsection{LA HIPOTECA LEGAL TÁCITA EN VÍA DE APREMIO}

\subsubsection{Ejecución de la hipoteca legal tácita}

Sin ánimo de reiterar lo que en su momento dijimos sobre la ejecución de las garantías, nos parece oportuno retomar algunas de las ideas recogidas en el primer capítulo y hacer otras precisiones más concretas respecto a la ejecución de la hipoteca legal tácita. Ya expresamos en su momento que la ejecución de las garantías en la práctica se hace a través del trámite ordinario del procedimiento de apremio, porque no existe un procedimiento específico para la ejecución de la hipoteca legal tácita ni para ninguna de las otras garantías. El artículo 168 de la LGT dispone que si la deuda tributaria está garantizada se procede en primer lugar a ejecutar las garantías a través del procedimiento administrativo de apremio. Y además aclara el precepto que la Administración tributaria podrá optar por el embargo y enajenación de otros bienes o derechos con anterioridad a la ejecución de la garantía cuando ésta no sea proporcional a la deuda garantizada o cuando el obligado lo solicite, señalando bienes suficientes al efecto. En estos casos, la garantía prestada quedará sin efecto en la parte asegurada por los embargos.

También el apartado 6 del artículo 74 del RGR determina que la ejecución de las hipotecas y otros derechos reales constituidos en garantía de los créditos de la Hacienda Pública se realizará por los órganos de recaudación competentes a través del procedimiento de apremio. En este sentido, el apartado cuarto del propio precepto regula que si la garantía está constituida por o sobre bienes o derechos de persona o entidad distinta del obligado al pago, se comunicará a dicha persona o entidad el impago del importe garantizado, requiriéndole para que, en el plazo establecido en el apartado 5 del artículo 62 de la LGT, ponga dichos bienes o derechos a disposición del órgano de recaudación competente, salvo que pague la cuantía debida. Transcurrido dicho plazo sin que se haya producido el pago o la entrega de los bienes o derechos, se procederá a enajenarlos por el procedimiento establecido para la enajenación de bienes embargados de naturaleza igual o similar.

De ambos artículos se desprende que la hipoteca legal tácita, como cualquier otra hipoteca legal, es directamente ejecutable una vez incumplida la obligación principal, pero que deberá previamente notificarse la ejecución de la misma a posibles terceros adquirentes del bien gravado y a los titulares de derechos sobre dicho bien para que en el plazo que la ley les concede entreguen el bien gravado o efectúen el pago de la deuda. Una vez iniciada la ejecución administrativa, el órgano de recaudación competente comunicará la orden de ejecución al Registrador de la Propiedad mediante mandamiento por duplicado para que libre y remita la correspondiente certificación de dominio y cargas. Asimismo, dicho órgano recaudador notificará el inicio del procedimiento de ejecución a la persona a cuyo favor resulte practicada la última inscripción de dominio, si no ha sido requerida para el pago, y a los titulares de cargas o derechos reales constituidos con posterioridad a la hipoteca que aparezcan en la certificación. Y tanto el acreedor hipotecario como el tercero adquirente tienen derecho a exigir 
la segregación de cuotas de los bienes que les interesen, cuando se hallen englobadas en un solo recibo con otras del mismo obligado al pago.

En resumen, podemos afirmar que si la hipoteca legal tácita grava un bien que continúa siendo del dominio del obligado principal se podrá efectuar su ejecución por el órgano de recaudación competente cuando, una vez que se dicta la providencia de apremio, haya transcurrido el plazo que para su ingreso determina el inciso e) del apartado 2 del artículo 70 del RGR, en relación con el apartado 5 del artículo 62 de la LGT. Si por el contrario, el bien sobre el que recae la hipoteca está en poder de un tercer adquirente, éste debe ser requerido para que pague o entregue el bien en el mismo plazo de ingreso al que hacíamos referencia, antes de que el órgano de recaudación proceda a ejecutar directamente la garantía a través de un procedimiento ordinario de apremio.

Finalmente, se podrá continuar el procedimiento de apremio cuando la garantía haya devenido manifiestamente insuficiente, jurídica o económicamente, desde la fecha de su constitución, sin necesidad de esperar a su ejecución, mediante acuerdo motivado que deberá constar en el expediente.

\subsubsection{Actuación del tercer adquirente o acreedor inscrito}

"La vinculación real del bien al pago de la deuda que comporta este privilegio se proyecta mediante el derecho de reipersecutoriedad, inherente a las garantías reales que no se ve impedido por el principio de fe pública registral. Su efectividad no se supedita a la exigencia de una nota marginal de afección que le reserve el rango. Por este motivo, no ha de ser derivada la responsabilidad tributaria frente a los adquirentes o titulares de derechos reales inscritos. Ellos han inscrito su bien o derecho afectados por este gravamen oculto. Bastará que, una vez concluido el período voluntario de pago sin haber sido ingresada la cuota por el contribuyente, la Administración requiera el pago de la totalidad de la deuda, excluidas las sanciones por su carácter personal, a estos titulares, sin que el hecho de no haber sido tomada con anterioridad la anotación preventiva de embargo, que es opcional, modifique la preferencia y efectividad del privilegio" ${ }^{445}$. Hemos querido comenzar con estas observaciones de CAMY ESCOBAR porque el autor refleja ideas muy importantes para el desarrollo de este punto y que condicionan el actuar del sujeto afecto por el ejercicio de la garantía. Partimos del criterio de que el adquirente o el titular de derechos reales no es un responsable tributario, a pesar de que la LGT ubica a este sujeto dentro de los supuestos de responsabilidad subsidiaria ${ }^{446}$, ni tampoco un obligado tributario, lo cual implica que no puede recurrir la liquidación apremiada que, seguramente, ya tendrá firmeza.

Lo que sí puede hacer este sujeto en defensa de sus derechos es impugnar los actos administrativos que le afectan directamente, como, por ejemplo, el cómputo de las anualidades garantizadas, o los actos de segregación de cuotas, y estas reclamaciones de los adquirentes o titulares de derechos reales se ventilarán durante el procedimiento de apremio, sin que se suspenda la ejecución. También puede el adquirente o titular de derechos reales, evidentemente, efectuar el pago de la deuda: entonces estaremos en presencia del pago por tercero, que confiere a este sujeto el derecho del reembolso para reclamar al deudor principal la suma pagada, aunque la pretensión discurrirá en este supuesto por los

\footnotetext{
${ }^{445}$ CAMY ESCOBAR, J., "Las garantías de la deuda tributaria y su ejecución”, op. cit., pág. 128 a 129.

${ }^{446}$ Vid. infra, Capítulo Cuarto, epígrafe 2.4.2.3. "Adquirentes de bienes afectos".
} 
causes del derecho privado. Y se librará, por último, este sujeto de la ejecución de la hipoteca si entrega el bien gravado en el plazo previsto para ello, según lo dispuesto por el apartado 4 del artículo 74 del RGR, o si se deshace del bien afecto por la hipoteca legal tácita.

\subsubsection{La hipoteca legal tácita en situación concursal}

Partiendo de la premisa de que la hipoteca legal tácita es oponible frente a cualquier adquirente o acreedor, no cabe duda de que la preferencia que dicha garantía otorga a la Administración tributaria puede ejercitarse en un proceso concursal, porque lo que se persigue con él es dar una solución a una situación de insolvencia del deudor. Anteriormente, en el ámbito concursal existía una distinción entre los procedimientos concursales en función del carácter definitivo o no de la situación de insolvencia, así como de la naturaleza comercial o no del deudor. Con la entrada en vigor de la LC actual se ha unificado en un procedimiento único denominado "concurso" la tramitación de las situaciones de crisis patrimonial.

El concurso persigue a través de un único procedimiento agrupar los intereses de todos los acreedores. Este procedimiento único se basa en la regla de par conditio creditorum, que es aplicable ante las dificultades económicas del deudor que imposibilita satisfacer las pretensiones de todos los acreedores ${ }^{447}$. "La par conditio creditorum es el principio esencial del procedimiento concursal español, que pretende la valoración equitativa de los créditos de los acreedores. Es el elemento básico de las relaciones que se establecen en los procedimientos concursales, y en consecuencia, admite pocas excepciones (recogidas taxativamente en la Ley), como los privilegios protegidos por la naturaleza del crédito, el derecho de prelación de unos créditos sobre otros, los derechos de preferencia dentro del mismo grado o los derechos de cobro preferente sobre un determinado bien por afección real"448. Los acreedores renuncian a parte de sus derechos por la satisfacción de todos y con la apertura del concurso se suspende el inicio o se interrumpe la continuación de los procedimientos individuales de ejecución que los distintos acreedores pudieran haber desplegado con el objeto de satisfacer su crédito, a tenor del artículo 55 de la LC.

De lo anterior se infiere que existen algunas excepciones a la regla general del concurso, pues en la práctica concursal se aprecian una serie de créditos con un privilegio especial que permiten a sus titulares cobrar con preferencia sobre el resto de acreedores. El apartado 2 del artículo 89 de la LC establece que

"Los créditos privilegiados se clasificarán, a su vez, en créditos con privilegio especial, si afectan a determinados bienes o derechos, y créditos con privilegio general, si afectan a la totalidad del patrimonio del deudor".

También en el ámbito civil se determinan preferencias para el cobro de los créditos, como se prevé en el apartado primero del artículo 1.923 del Código Civil, según el cual los créditos a favor del Estado sobre los bienes de los contribuyentes gozan de preferencia. De ahí que se reconozca como crédito

\footnotetext{
${ }^{447}$ ARRANZ DE ANDRÉS, C., La Hipoteca legal privilegiada de la Ley General Tributaria: aproximación jurisprudencial, op. cit., pág. 107.

${ }^{448}$ CONTÍN TRILLO-FIGUEROA, S., "La prelación de crédito en el proyecto de la Ley Concursal española", Revista General de Derecho, núm. 682-683, julio-agosto, 2001, pág. 6637.
} 
privilegiado al crédito de la Hacienda Pública, porque ésta puede cobrar antes que el resto de los acreedores concurrentes, sin que se vea afectada por los acuerdos que de conjunto tomen los acreedores en el seno de un convenio ${ }^{449}$.Esta circunstancia se reafirma con la dicción del $1^{\circ}$ del apartado primero del artículo 89 de la LC, que clasifica como privilegios especiales los créditos garantizados con hipoteca voluntaria o legal, inmobiliaria o mobiliaria, o con prenda sin desplazamiento, sobre los bienes o derechos hipotecados o pignorados, dentro de los que se encuentra la hipoteca legal tácita ${ }^{450}$. De igual forma, se concede a la Administración tributaria la facultad de seguir adelante con los procedimientos de ejecución en los que la providencia de apremio se hubiera dictado antes de la fecha en la que se declaró el concurso.

En este ámbito, la solución más apropiada que debía asumir la normativa tributaria, según GARCÍA NOVOA, es la de "regular un derecho real al que se vincule la prelación como una cualidad o propiedad del mismo. En concordancia con lo que establecen los artículos 89.1.1 ${ }^{\circ}$ y 155 de la Ley Concursal, tal privilegio especial supondrá sujetar bienes y derechos concretos, susceptibles de ejecución" ${ }^{451}$. Siguiendo la línea de pensamiento de este autor, se podría articular el privilegio especial como excepcional en beneficio de la Administración tributaria, frente al privilegio general del crédito tributario que se integra en la masa pasiva del concurso. Dicho privilegio especial se haría efectivo por medio de la ejecución separada llevada a cabo por la Hacienda Pública, teniendo en cuenta las limitaciones que al respecto contempla la LC.

Sin embargo, no son estas las únicas rupturas del principio de la par conditio creditorum a favor de la Hacienda Pública. También se observa este mismo efecto en la apertura del procedimiento concursal, donde se hacen palpables los efectos que sobre los bienes producen los derechos reales de garantía. De esta forma, en beneficio de los acreedores garantizados por la hipoteca legal tácita está prevista la posibilidad de satisfacer su derecho fuera del procedimiento concursal, lo que la LC reconoce como "derecho de ejecución separada". Así se reconoce en la LC, aunque se introducen algunas limitaciones en su ejercicio, según lo dispuesto en el artículo 56. El límite principal que se aplica a la ejecución separada es la imposibilidad de iniciar la ejecución o la realización de los bienes afectos hasta que se apruebe un convenio cuyo contenido no afecte al ejercicio del derecho o transcurra un año desde la declaración del concurso sin que se hubieran producidos las aperturas de la liquidación. Por otra parte, las ejecuciones ya iniciadas se suspenderán desde que la declaración del concurso conste en el correspondiente procedimiento ${ }^{452}$. Esta es una de las modificaciones más importantes de la LC y su pretensión fue la de respectar la esencia de los derechos reales sobre cosa ajena procurando, al mismo tiempo, que la ejecución por separado de las garantías no perturbara el mejor

\footnotetext{
${ }^{449}$ Algunos autores opinan que los privilegios especiales de la Hacienda Pública perjudican los intereses de los acreedores ordinarios y no encuentran justificación suficiente para que la Administración tributaria goce de esas prerrogativas. En este sentido, CONTíN TRILLO-FIGUEROA, S., "La prelación de crédito en el proyecto de la Ley Concursal española”, op. cit., pág. 6651 a 6654.

${ }^{450}$ MOYA-ANGELER SÁNCHEZ, J., "Las obligaciones y los responsables tributarios en sus distintas formas y modalidades: hipoteca legal tácita, afección de bienes y derecho de prelación de la Hacienda”, op. cit., pág. 132.

${ }^{451}$ GARCÍA NOVOA, C., “Capítulo IV. Elementos de cuantificación de la obligación tributaria”, op. cit., pág. 355.

${ }^{452}$ En este sentido se pronuncian, entre otras, las Sentencias del Tribunal Supremo de 6 de mayo de 1981, de 4 de julio de 1986, de 15 de marzo de 1988, de 2 de enero de 1991, o de 22 de marzo de 1995.
} 
desarrollo del procedimiento concursal ni impidiera soluciones que pudieran ser convenientes al resto de los intereses del deudor y de la masa pasiva ${ }^{453}$.

\subsection{LA EXTINCIÓN DE LA HIPOTECA LEGAL TÁCITA}

Si transcurre el plazo para ejecutar la garantía y no se efectúa ninguna ejecución, la cuestión es determinar si se produce la prescripción o, por el contrario, la caducidad de la hipoteca. ROSSY distinguió entre la preferencia de la Administración tributaria frente a los otros acreedores para cobrar su crédito y la hipoteca legal tácita. Según este autor, si la primera de estas instituciones deja de ejercitarse oportunamente es la prescripción la apropiada para la prelación general, mientras que la hipoteca caduca, aunque en ninguno de los casos se extingue la acción. No obstante, siguiendo con la misma doctrina, aun cuando prescribiera la prelación o caducara la hipoteca legal tácita, la Hacienda Pública podría exigir al adquirente la parte de la deuda tributaria que le transmitió el vendedor del derecho real sujeto por la obligación, entendiendo que la obligación transmitida tiene carácter personal pese a que deriva de un derecho de naturaleza real ${ }^{454}$.

En un sentido similar, ARRANZ DE ANDRÉS entiende que la caducidad se aplica a la hipoteca legal tácita y opera "respecto de la misma en su conjunto, esto es, tanto por lo que atañe a la afección de bienes como en lo referido al privilegio que a la misma acompaña, a nuestro juicio, de forma inescindible". A tenor de lo que establece el artículo 78 de la LGT, la hipoteca se puede ejercitar para el cobro de las deudas devengadas y no satisfechas en el año en que se exige el pago y el anterior. Si no se efectúa la pretensión de cobro en ese año, significa que las deudas devengadas durante el mismo podrán ser exigidas mediante el uso de la hipoteca legal tácita al año siguiente. "Pasado dicho plazo podría la Hacienda todavía exigir su pago -hasta el momento en que prescriban- pero sin la posibilidad entonces de hacer valer su mejor derecho frente a terceros acreedores ni de oponer a terceros poseedores su pretensión" 455 .

Otras serían, no obstante, las conclusiones si nos acogemos al contenido del artículo 65 del RGR en el caso de que las anualidades correspondientes para exigir el cobro de los créditos fuera el año en que se produjera la transmisión o la inscripción y el anterior. En este supuesto, salvo que se produjera la prescripción de la acción, no cabría referirse a un límite temporal de la garantía, que no se extinguiría por no ejercitarse. La afectación mayor se encontraría en este caso en la identificación de los créditos garantizados, pero no en el tiempo en que procedería el ejercicio de la hipoteca, porque la hipoteca legal tácita siempre se aplicaría en el momento en que se incumpliera con la deuda, con la excepción de que hubiera prescrito la acción.

\footnotetext{
${ }^{453}$ GARCÍA NOVOA, C., “Capítulo IV. Elementos de cuantificación de la obligación tributaria”, op. cit., pág. 353.

${ }^{454}$ ROSSY, H., El tercero fiscal y la responsabilidades subsidiarias ante la Hacienda, Bosch, Barcelona, 1947, pág. 133 y 135.

${ }^{455}$ ARRANZ DE ANDRÉS, C., Las garantías reales del crédito tributario: aspectos sustantivos y procedimentales, op. cit., pág. 183 a 184.
} 


\section{EL DERECHO DE AFECCIÓN}

\subsection{RÉGIMEN JURÍDICO}

El derecho de afección es otra de las garantías del crédito tributario que reconoce la LGT. Prevé el apartado segundo del artículo 79 de la LGT un derecho de afección a favor de la Administración tributaria que puede configurarse para garantizar el pago de los tributos que graven la transmisión, adquisición o importación de bienes o derechos cuando así lo establezcan específicamente sus leyes reguladoras.

El apartado primero del artículo 74 de la LGT de 1963 también plasmaba la afección como una garantía de la deuda tributaria, pero desvinculada sistemáticamente de la figura del responsable, que se regulaba en los artículos 37 y ss. de la LGT de 1963, especialmente en el apartado primero del artículo 41 de la propia ley. Según estos artículos se consideraba a los adquirentes de bienes afectos por ley a la deuda tributaria como responsables subsidiarios de su pago, previa derivación correspondiente, una vez declarado fallido el deudor principal, y con limitación de la responsabilidad a los bienes afectos.

Por su parte, el RGR de 1968 se decantó por una postura integradora o unitaria al considerar, en su artículo 8, como responsable del pago de las deudas a los adquirentes de bienes afectos por ley al pago de determinados tributos. La afección de bienes fue considerada como una garantía real, "pero incardinada en la responsabilidad subsidiaria que con carácter general, para todos los casos de adquisiciones de bienes afectos por ley, se contempla por el artículo 41 de la LGT, siendo necesario por ello la derivación de la acción tributaria en caso de impago, que estará limitada a los bienes transmitidos",456.

Años más tarde, el RGR de 1990 se alejó de la posición que hasta ese momento asumía el legislador y se decantó por la tesis de la independencia, de modo que la afección del bien transmitido al pago de los tributos que gravaban las transmisiones, adquisiciones o importaciones se configuró como una garantía real, separada de los supuestos de responsabilidad subsidiaria, no siendo necesaria la derivación de la deuda ni la declaración de fallido del deudor principal. El artículo 10 del RGR de 1990 ya no consideraba como responsables a los adquirentes de bienes afectos por ley y desplazaba la afección hacia el ámbito de las garantías de la deuda tributaria, como claramente se deducía en el apartado segundo del artículo 37 del mismo Reglamento. A tenor de lo dispuesto por este precepto, no se necesitaba derivar la responsabilidad sobre el adquirente de bienes afectos, previa declaración de insolvencia del obligado principal, sino que bastaba con que se produjera el impago y con requerir al poseedor del bien afecto para que pagara la deuda.

Parece que el legislador actual también asume la tesis de la independencia y en el primer apartado del artículo 79 de la LGT regula lo que antes se decía en el apartado primero del artículo 41 de la LGT de 1963, omitiendo la exigencia del típico acto administrativo de derivación de la responsabilidad tributaria que contenía el apartado segundo de dicho precepto. Ahora el artículo 43 de la LGT, relativo a los responsables subsidiarios, menciona también a los adquirentes de bienes afectos por ley

\footnotetext{
${ }^{456}$ CAMY ESCOBAR, J., “Las garantías de la deuda tributaria y su ejecución”, op. cit., pág. 150.
} 
al pago de la deuda tributaria, pero precisa que su responsabilidad se conciba en los términos que prevé el artículo 79 de la LGT. Por eso dice GONZÁLEZ-CARBALLO ALMODÓVAR que la afección de bienes prevista por la LGT en el artículo 79 es "un derecho real administrativo de persecución y de realización de valor que recae sobre los bienes que hayan sido objeto de una transmisión, adquisición hereditaria o importación para garantizar el pago de las deudas tributarias devengadas por estos negocios transmisivos y cuya particularidad reside en que sólo operan en el caso de que tales bienes se transmitan a terceros (con conocimiento de la afección que pesaba sobre ellos) y de que aquellas deudas tributarias no se paguen por los sujetos pasivos" ${ }^{\text {"457. }}$.

Finalmente, el apartado tercero del artículo 79 de la LGT se ocupa del derecho de afección en garantía del pago de las liquidaciones caucionales, donde el cierre registral confiere una garantía de pago más potente a favor de las deudas derivadas de los tributos que gravan las transmisiones y adquisiciones de bienes. En el caso de las liquidaciones caucionales la verificación del requisito de cuyo cumplimiento depende el definitivo reconocimiento de la exención, bonificación o reducción, queda aplazado a un momento posterior y, consiguientemente, es posible que aparezca un tercero protegido por la fe pública registral. Por ello, en el apartado tercero del artículo 79 de la LGT, a diferencia de lo que establece el segundo apartado del mismo artículo de la LGT, se determina de forma expresa que la afección conste en el Registro por nota marginal, que el registrador practica de forma simultánea con la inscripción del documento, quedando enervada la fe pública registral en cuanto a terceros adquirentes de bienes y derechos.

\subsection{NATURALEZA JURÍDICA}

De manera general, tanto la doctrina como la jurisprudencia otorgan una naturaleza real al derecho de afección de bienes que ejercita la Hacienda Pública para el cobro de sus créditos. Se trata de un supuesto a través del cual la ley sujeta un bien al cumplimiento de una determinada obligación. De esta forma ante el incumplimiento de aquélla, el titular del derecho podrá perseguir el bien e instar su ejecución con independencia que el mismo pertenezca a otra persona distinta del deudor principal. Como afirma DE LA ROSA VARGAS, el derecho de afección se aplica sobre un sujeto pasivo colectivo e indeterminado, pero tiene su concreción en el titular del bien que constituye su objeto, otorgándole al titular del derecho de afección un poder absoluto que alcanza cuantitativamente hasta su valor actual ${ }^{458}$.

CASADO OLLERO, FALCÓN Y TELLA, LOZANO SERRANO, y SIMÓN ACOSTA afirman que se "trata de un derecho real, que otorga a la Administración acreedora la posibilidad de realizar el bien, aunque haya pasado a poder de un tercero (salvo que este resulte ser un tercero protegido por la fe pública registral o se justifique la adquisición de los bienes, con buena fe y justo título o en

\footnotetext{
${ }^{457}$ GONZÁLEZ-CARBALLO ALMODÓVAR, A., "Las garantías del crédito tributario”, op. cit., pág. 461.

${ }^{458}$ DE LA ROSA VARGAS, G., "Las garantías específicas del crédito tributario en la transmisión de bienes (I)", Carta Tributaria, núm. 211, 1994, pág. 4; LÓPEZ DÍAZ, A., La recaudación de deudas tributarias en vía de apremio, op. cit., pág. 234. En este mismo sentido, Sentencia del Tribunal Supremo de 12 de diciembre de 1988.
} 
establecimiento mercantil o industrial, en el caso de bienes muebles no inscribibles), si el deudor no cumple voluntariamente su obligación" $" 459$.

El tercer adquirente, en este caso, está obligado a tolerar la ejecución del bien afecto, aunque puede evitar esta circunstancia si paga la cantidad cuyo cobro se pretende. No obstante, la persona que adquiere un bien afecto deberá asumir la carga que éste presenta, pero no surge para él una obligación propiamente dicha, ni pasa a ocupar el lugar del deudor principal. La responsabilidad de este sujeto sólo llega hasta el valor actual del bien, sin que su patrimonio personal se vea afectado, pudiendo liberarse de dicha carga con el sólo hecho de abandonar el bien sujeto.

Tanto la doctrina como la jurisprudencia han insistido en diferenciar la persona que realiza una prestación de aquélla que sólo está expuesta a verse privada de un bien sobre el que recae un procedimiento ejecutivo. BERLIRI indicó que el sujeto que únicamente debe soportar la privación del bien afecto no puede considerarse como un sujeto pasivo de la obligación tributaria, ni de ninguna otra, porque para él no existe ninguna obligación ${ }^{460}$. Ciertamente, el adquirente del bien afecto no es un deudor obligado al pago, ni tampoco puede configurarse como responsable de la deuda tributaria. En palabras de ARRANZ DE ANDRÉS, "el tercero no es sujeto pasivo de la deuda sino únicamente de la acción ejecutiva tributaria, recayendo sobre él, más que una obligación, una mera sujeción a la eventual ejecución forzosa"461.

En cualquier caso, si el adquirente del bien afecto no paga la deuda en el plazo que se le otorga se devengarán intereses y recargos, de la misma forma que si se tratara de un obligado tributario, y para hacer frente a esas cantidades es posible acudir a su patrimonio personal, sin que este sujeto pueda desprenderse de estas últimas obligaciones con el abandono del bien sujeto. Esto significa que se convierte en obligado tributario, pero sólo en relación con aquellas cantidades cuyo devengo es imputable exclusivamente a él, nunca respecto de la deuda que se vincula al bien afecto.

La obligación de pago que nace para este sujeto adquirente por el hecho de tener la titularidad de los bienes afectos ha servido para que algunos autores entiendan que la naturaleza de la figura del artículo 79 de la LGT se identifique con una responsabilidad objetiva, por tener su origen fuera de toda idea de culpa ${ }^{462}$. Hay autores que ni siquiera se cuestionan la ubicación de la afección de bienes,

\footnotetext{
${ }^{459}$ CASAdo Ollero, G, FAlCÓN Y TElla, R, LOZANO SERRANO, C y SIMÓN ACOSTA, E., Cuestiones tributarias prácticas, op. cit., pág. 619.

${ }^{460}$ BERLIRI, A., Principios de Derecho Tributario, Vol. II, Editorial de Derecho Tributario, 1971, pág. 242. En este mismo sentido, ROSSY, H., El tercero fiscal y las responsabilidades subsidiarias ante la Hacienda, op. cit., pág. 19. RODRÍGUEZ BEREIJO, A., "Las garantías del crédito tributario", op. cit., pág. 194; LÓPEZ DE HARO, C., "El tercer poseedor de finca hipotecada", Revista General de Legislación y Jurisprudencia, núm. IV, 1931, pág. 363; DÍEZ GARCÍA, H., El tercer poseedor de finca hipotecada, Aranzadi, Pamplona, 1998, pág. 43. El Tribunal Supremo ha insistido en la necesidad de diferenciar la posición para el pago de la deuda tributaria de los contribuyentes, sustitutos y responsables (solidarios o subsidiarios) frente a los terceros adquirentes de bienes afectos, ya que para éstos últimos se produce una afección para bienes concretos pero no una obligación personal que afecte a todo su patrimonio. Vid. lo que al respecto dice la Sentencia del Tribunal Supremo de 20 de noviembre de 2000. La Resolución del TEAC de 22 de febrero de 1995 entiende que para los adquirentes de bienes afectos no surge una obligación personal y sólo tienen que soportar la ejecución de los bienes sobre los que pesa el derecho real de garantía de la Hacienda Pública. Los Tribunales Superiores de Justicia han asumido esta misma postura, como se aprecia en la Sentencia del Tribunal Superior de Justicia de Andalucía, Málaga de 21 de marzo de 2002, la Sentencia del Tribunal Superior de Justicia de Cataluña de 6 de septiembre de 2002, o la Sentencia del Tribunal Superior de Justicia de Castilla y León, Burgos de 30 de septiembre de 2005.
}

${ }^{461}$ ARRANZ DE ANDRÉS, C., Las garantías reales del crédito tributario: aspectos sustantivos y procedimentales, op. cit., pág. 124.

${ }^{462}$ ALBIÑANA GARCÍA-QUINTANA, C., Responsabilidad Patrimonial Universal, Edersa, Madrid, 1951, pág. 157; URBIARTE Y ZULUETA, M. M., "Los sujetos pasivos en el procedimiento recaudatorio", Hacienda Pública Española, núm. 2, 1970, pág. 106; 
que antes aparecía en el apartado primero del artículo 74 de la LGT de 1963 dentro de los supuestos de responsabilidad tributaria. Es el caso de MARTÍNEZ LAFUENTE, que coloca la afección de bienes en el seno de los supuestos de responsabilidad tributaria e interpreta que esta institución no estaba recogida por la LH porque se trata de un supuesto de responsabilidad ${ }^{463}$.

También GUERRA REGUERA afirmó que el caso de los adquirentes de bienes afectos a la deuda tributaria constituía un supuesto de responsabilidad, pero con características peculiares. Para este autor, la responsabilidad surge por la adquisición de bienes afectos, se limita al valor de dichos bienes y se manifiesta junto con la concesión al crédito de una preferencia especial, puntualizando que la preferencia fortalece el crédito de la Administración tributaria frente al contribuyente y frente al responsable-adquirente, y que por esto puede constituirse como un obligado propter rem ${ }^{464}$.

Por el contrario, CASADO OLLERO, FALCÓN Y TELLA, LOZANO SERRANO, y SIMÓN ACOSTA rechazan la configuración de los supuestos de afección de bienes como supuestos de responsabilidad objetiva, o de sucesión en la titularidad de la obligación, así como la construcción de la afección como un derecho real conexo con una obligación propter rem del tercero adquirente, "ya que ni el tercero está obligado, ni el sujeto pasivo deja de estarlo por el hecho de transmitir la cosa sobre la que se proyecta el derecho real de garantía" ${ }^{265}$.

Nosotros defendemos el criterio de que la afección de bienes constituye un derecho real de garantía porque se trata de un derecho accesorio respecto a la relación obligacional principal, que existe por mandato expreso de la ley. La afección otorga a la Administración tributaria la facultad de sujetar un bien o conjunto de bienes o derechos concretos para satisfacer una obligación determinada con independencia de que aquéllos hayan pasado a una tercera persona distinta del deudor principal ${ }^{466}$. El derecho de afección es una garantía real que implica la afección de una determinada cosa al aseguramiento de una obligación, en la que se concede al acreedor un derecho de realización del valor del bien para la satisfacción de su crédito en el caso de que el deudor no cumpla voluntariamente su obligación. El carácter real de este derecho también radica en el hecho de que el acreedor puede realizar el valor del bien cualquiera que sea su titular o poseedor. Aunque la cosa se

AMORÓS RICA, N., "Responsabilidades tributarias", Revista de Derecho Financiero y Hacienda Pública, núm. 86, 1970, pág. 22; BENÍTEZ DE LUGO Y GUILLÉN, F., "Responsabilidad fiscal objetiva en la adquisición de bienes afectos al pago de un impuesto", Crónica Tributaria, núm. 43, 1982, pág. 55; CALVO ORTEGA, R., "La responsabilidad tributaria solidaria por actos ilícitos", op. cit., pág. 43.

${ }^{463}$ MARTÍNEZ LAFUENTE, A., "La prelación del artículo 73 de la Ley General Tributaria en relación con el Impuesto sobre las Transmisiones Patrimoniales y Actos Jurídicos Documentados”, op. cit., pág. 275.

${ }^{464}$ GUERRA REGUERA, M., Garantías personales del crédito tributario. Algunas cuestiones, op. cit., pág. 181 y ss. SÁNCHEZ GALIANA entiende que los supuestos de afección de bienes al pago de deudas tributarias son un tipo de responsabilidad limitada, aunque "no se pueden considerar como supuestos de responsabilidad tributaria en sentido técnico" (SÁNCHEZ GALIANA, J. A., "El responsable", op. cit., pág. 660).

${ }^{465}$ CASADO OLLERO, G, FALCÓN Y TELlA, R, LOZANO SERRANO, C y SIMÓN ACOSTA, E., Cuestiones tributarias prácticas, op. cit., pág. 619.

${ }^{466}$ Como dijera DAMAS SERRANO, la afección legal de bienes al pago de deudas tributarias es un derecho real de garantía que opera tanto si los bienes se encuentran en el patrimonio del sujeto pasivo de la obligación garantizada como si han salido de éste y se encuentra en el patrimonio de un tercer adquirente (DAMAS SERRANO A. J., "Afección de bienes y derechos", en la obra Comentarios a la Ley General Tributaria y Lineas para su reforma, en homenaje a Fernando Sainz de Bujanda, Vol. I, Instituto de Estudios Fiscales, Madrid, 1991, pág. 694). En este mismo sentido, LUQUE CORTELLA, A., La Hacienda pública y el crédito tributario en los procesos concursales, Marcial Pons, Madrid, 2008, pág. 128. 
transmita a otra persona, además, el adquirente la recibe con la carga o gravamen que se representa por la existencia de la afección y tiene que soportar este derecho del acreedor ${ }^{467}$.

En conclusión, la afección de bienes puede identificarse con cuatro categorías: como obligación propter rem, como responsabilidad tributaria, como preferencia especial, o como derecho real de garantía. Aunque somos partidarios de que el derecho de afección sólo puede ser entendido como una garantía real del crédito tributario, nos parece importante hacer algunas reflexiones en torno a las otras interpretaciones.

\subsubsection{Como obligación propter rem}

Las obligaciones propter rem tienen un marcado carácter ambulatorio porque el titular de una obligación de este tipo es quien en cada momento se encuentre en cierta posición jurídica respecto de una cosa. La afección que en su momento recogía el apartado primero del artículo 74 de la LGT de 1963 debía ser considerada, según CORRAL GUERRERO, como una obligación propter rem. Este autor afirma que es más acertado hablar de una relación jurídica tributaria de afección, en lugar de un derecho real de afección, porque en el caso de la primera se advierte un derecho real de afección y a la vez una obligación propter rem a cargo del adquirente de los bienes afectos, encontrándose de esta forma unida una relación jurídica obligatoria y una relación jurídica real ${ }^{468}$.

En contra de esta tesis se manifiestan DAMAS SERRANO, CORTÉS DOMÍNGUEZ y ARRANZ DE ANDRÉS. El primero de los autores sostiene que los partidarios de concebir el derecho de afección como una obligación propter rem ignoran que el derecho de afección muestra su eficacia a través de la facultad que se concede a la Administración tributaria para perseguir los bienes afectos ante cualquiera que sea su adquirente, incluso cuando no hubieran salido del patrimonio del sujeto pasivo, por lo que la Hacienda Pública puede acceder al Registro a través de una nota marginal. Aclara DAMAS SERRANO que otorgarle al derecho de afección la misma naturaleza que la de la obligación propter rem significa que su eficacia existe sólo frente a los sucesivos adquirentes o adquirente, cuando en realidad nace incluso antes de que se conozca si existe un tercero ${ }^{469}$. CORTÉS DOMÍNGUEZ afirma por su parte que el tercero adquirente debe responder por deudas surgidas con anterioridad al momento en que el bien entra en su patrimonio, lo que resulta incompatible con aquel tipo de obligaciones propter $\mathrm{rem}^{470}$. Y ARRANZ DE ANDRÉS añade que en las obligaciones propter rem el sujeto debe responder con todo su patrimonio y "no se libera de las prestaciones surgidas durante el tiempo en que se prolongó su posesión", lo cual no sucede con el derecho de afección, porque el titular del bien debe responder por deudas surgidas con anterioridad al momento en que se inició la posesión y sólo por el límite del valor del bien, quedando, además, si lo abandona, eximido de la obligación ${ }^{471}$.

\footnotetext{
${ }^{467}$ DÍEZ PICAZO, L., Fundamentos del Derecho Civil Patrimonial II. Las relaciones obligatorias, op. cit., pág. 62.

${ }^{468}$ CORRAL GUERRERO, L., "La afección tributaria de bienes”, Boletín del Ilustre Colegio de Abogados de León, núm. 2, 1972, pág. 24 y 25. En esta misma línea, GUERRA REGUERA, M., Garantías personales del crédito tributario. Algunas cuestiones, op. cit., pág. 184.

${ }^{469}$ DAMAS SERRANO, A. J., “Afección de bienes y derechos”, op. cit., pág. 693.

${ }^{470}$ CORTÉS DOMÍNGUEZ, M., Ordenamiento tributario español, 4 a ed., Civitas, Madrid, 1985, pág. 377.

${ }^{471}$ ARRANZ DE ANDRÉS, C., Las garantías reales del crédito tributario: aspectos sustantivos y procedimentales, op. cit., pág. 135.
} 


\subsubsection{Como responsabilidad tributaria}

La LGT de 1963 determinaba en el apartado primero del artículo 41 que los adquirentes de bienes afectos por ley a la deuda tributaria responderían con ellos, por derivación, sino se pagaba la deuda. Era una previsión que no atribuía al adquirente de bienes afectos la condición de responsable y que sólo se limitaba a derivar la acción tributaria contra este sujeto. Por su parte, el inciso $d$ ) del artículo 8 del RGR de 1968 incluía a los adquirentes de bienes afectos al pago de un tributo entre los obligados al pago. La opinión que en su momento emitieron CASADO OLLERO, FALCÓN Y TELLA, LOZANO SERRANO, y SIMÓN ACOSTA, en relación con esta regulación reglamentaria, fue la de considerar que el adquirente no es deudor o responsable, porque no existe entre él y la Hacienda Pública una relación jurídica obligacional, sino una relación de derecho real, el deber general característico de los derechos reales de soportar el ejercicio del derecho ajeno sobre la cosa propia. Como indican estos autores, el tercero adquirente sufre las consecuencias de la posible ejecución del derecho real de garantía pero no es el responsable de la deuda y, en consecuencia, puede liberarse de su deber transmitiendo o abandonando la cosa objeto de garantía. Visto así, su posición no se diferencia en cuanto a su estructura y efectos a la posición del tercero poseedor de bienes hipotecados o pignorados ${ }^{472}$.

En el apartado tercero del artículo 41 de la LGT de 1963 se dispuso que la derivación sólo alcanzaría el límite previsto por la ley al señalar la afección de los bienes. Asimismo, el RGR de 1990 determinaba sendos procedimientos, uno para el adquirente de bienes afectos y el otro para los responsables, como puede observarse en los artículos 11, 12 y 37 de esa norma.

Aquella regulación jurídica diferenciaba la naturaleza del responsable tributario y del adquirente de bienes afectos. Para ARRANZ DE ANDRÉS, la confusión en torno a estas figuras, que motivó la actual regulación jurídica, se debe al carácter subsidiario de la obligación del tercer adquirente frente a la del sujeto pasivo. También afirma esta autora que el simple hecho de que el apartado primero del artículo 79 de la LGT actual indique expresamente que el adquirente de los bienes afectos responderá subsidiariamente no supone calificar al mismo como responsable subsidiario. Siendo fiel a su posición, entiende finalmente la autora que la inclusión del adquirente de bienes afectos dentro de los supuestos de responsabilidad subsidiaria del inciso $d$ ) del apartado primero del artículo 43 de la LGT es un error ${ }^{473}$.

Años antes el profesor RODRÍGUEZ BEREIJO había advertido que se producía una confusión en la doctrina cuando consideraba al adquirente de los bienes afectos como sujeto pasivo de la obligación tributaria en cuanto es responsable del pago de la deuda. Según este autor, lo que no estaba claro para un sector de la doctrina era la determinación entre lo que es un derecho real de garantía y los derechos del crédito. Al respecto apuntó que el tercero adquirente no está obligado personalmente al pago de la obligación tributaria, ya que entre ese sujeto y la Hacienda Pública no existe una relación jurídica obligacional, "sino una relación de derecho real: el derecho de persecución que el ente

\footnotetext{
472 CASAdo Ollero, G., FAlCón Y TElla, R., LOZANO SERRANO, C. y SIMÓN ACOSTA, E., Cuestiones tributarias prácticas, op. cit., pág. 619.

${ }^{473}$ ARRANZ DE ANDRÉS, C., Las garantías reales del crédito tributario: aspectos sustantivos y procedimentales, op. cit., pág. 126 y 127.
} 
público tiene sobre la cosa. En consecuencia, su responsabilidad de pago de la deuda tributaria es tan sólo el único modo de evitar la expropiación del bien afecto, nunca el resultado de una obligación personal". Por eso, concluye este autor, el adquirente no es un sujeto pasivo de la obligación tributaria, no es un sujeto pasivo de la obligación tributaria accesoria de la principal, ni tampoco puede ser considerado un responsable porque sufra las consecuencias de la ejecución de derecho real de garantía $^{474}$.

También la jurisprudencia se ha mostrado reacia a considerar al adquirente de bienes afectos como un responsable, porque no asume personalmente el cumplimiento de la deuda ${ }^{475}$. Algunos de los pronunciamientos jurisprudenciales entendieron que el carácter subsidiario predicable del cumplimento de las obligaciones a las que deben hacer frente los adquirentes de bienes afectos justificaba que para poder exigirle el pago se siguiera con el mismo procedimiento de los responsables, pronunciamientos que se validaron en el apartado 3 del artículo 12 del RGR de 1968. De igual manera, el artículo 67 del RGR actual señala que serán de aplicación para el ejercicio del derecho de afección los artículos que en la LGT se encargan de la regulación del procedimiento de derivación de responsabilidad, esto es, los artículos 174 y 176 de la LGT. El régimen jurídico vigente pretende, sin duda, garantizar la subsidiaridad en la exigibilidad del pago al tercero adquirente de bienes afectos, pero esto no implica que el adquirente asuma las cualidades de la responsabilidad ${ }^{476}$. De hecho, el apartado primero del artículo 79 de la LGT expresa que los adquirentes de bienes afectos por ley responderán subsidiariamente con ellos, lo que significa, a diferencia de lo que sucede con la responsabilidad tributaria, que si el tercero se deshace del bien afecto se libra de la obligación. DE LA HUCHA CELADOR apuntó, al referirse al artículo 10 del RGR de 1990, que una cosa es que los adquirentes de bienes afectos por ley al pago de la deuda tributaria no sean verdaderos responsables tributarios y otra distinta es que no puedan considerarse como deudores no principales de la obligación tributaria, sin que les afecte el principio general de la responsabilidad patrimonial universal $^{477}$.

Tampoco puede confundirse el supuesto que nos ocupa con los supuestos de responsabilidad limitada que la LGT recoge en el inciso b) del apartado primero del artículo 42 y que establece que los partícipes o copartícipes de las entidades jurídicas o económicas a que se refiere el apartado 4 del artículo 35 de la LGT responderán solidariamente de las obligaciones de dichas entidades, en proporción a sus respectivas participaciones. La posible confusión se despeja si se tiene en cuenta

\footnotetext{
474 RODRÍGUEZ BEREIJO, A., "Las garantías del crédito tributario", op. cit., pág. 206. En este mismo sentido, DÍEZ PICAZO, L., Fundamentos del Derecho Civil Patrimonial II. Las relaciones obligatorias, op. cit., pág. 344.

${ }^{475}$ Entre otras, las Sentencias del Tribunal Supremo de 1 de febrero de 1995 y de 12 de marzo de 1997.

${ }^{476}$ Partiendo de la redacción de este precepto, algunos autores incluyen este supuesto dentro de la responsabilidad subsidiaria, como puede verse en ORÓN MORATAL, G., "Los obligados tributarios en la Ley 58/2003, de 17 de diciembre, General Tributaria: principales novedades", en la obra La reforma de la Ley General Tributaria, Consejo General del Poder Judicial, Madrid, 2005, pág. 135, ZABALA RODRÍGUEZ-FORNOS, A., “Artículo 78”, en la obra Comentarios a la nueva Ley General Tributaria, ThomsonAranzadi, Pamplona, 2004, pág. 551. No obstante, otro sector de la doctrina considera que los adquirentes de bienes afectos no son responsables tributarios, y que estamos ante garantías reales del crédito tributario. Así puede verse en CHECA GONZÁLEZ, V. C., "Notas sobre la nueva regulación de los responsables tributarios en el anteproyecto de la LGT", Jurisprudencia Tributaria, núm. 5, 2003, pág. 2192 y 2193, y CASAS AGUDO, D., "Acerca del régimen jurídico del tercer adquirente de bienes afectos en la nueva LGT”, Revista Española de Derecho Financiero, núm. 127, 2005, pág. 505 a 533.

${ }^{477}$ DE LA HUCHA CELADOR, F., "Algunas consideraciones sobre la responsabilidad tributaria en el Reglamento General de Recaudación de 1990: I. Responsabilidad Solidaria”, Crónica Tributaria, núm. 61, 1992, pág. 69.
} 
que la responsabilidad se limita en este supuesto sólo a la cuantía de la obligación, sin que se produzca la sujeción de ningún bien concreto, y que el partícipe o copartícipe mantiene su responsabilidad limitada en relación a la deuda, aunque trasmita el bien adjudicado. Por el contrario, en el derecho de afección el adquirente del bien afecto responde sólo de la cuantía del bien mientras sea el titular del mismo, de forma que si lo abandona cesará también su relación con la Hacienda Pública.

\subsection{DISTINCIÓN CON OTRAS FIGURAS AFINES}

El derecho de afección comparte junto con otras figuras que regula la ley elementos comunes que en algunos casos producen confusión. Al analizar la naturaleza jurídica de la afección de bienes observamos que comparte junto con la hipoteca legal tácita la misma naturaleza, porque ambas son garantías reales del crédito tributario, aunque esto no implica que pueda decirse que se trate de la misma institución. Ni siquiera por tener en común el nacimiento por imperio de la ley en el momento del devengo del tributo, sin necesidad de inscripción registral, ni por recaer sobre un bien determinado sujeto a la satisfacción de la deuda tributaria y directamente ejecutable por la Administración, con independencia de su poseedor. Las diferencias entre ambas figuras se aprecian, principalmente, en elementos como el ámbito material de aplicación, el límite temporal y la eficacia frente a terceros.

\subsubsection{El derecho de afección y la hipoteca ordinaria}

La hipoteca legal constituida a favor del Estado necesita la inscripción registral para que pueda producir todos sus efectos. En cambio, la afección de bienes no requiere estar inscrita en el Registro para que nazca, ya que se deriva directamente de la ley, de forma que la inscripción registral de esta institución por medio de nota marginal sirve únicamente para garantizar los efectos frente a terceros.

Debe reconocerse, no obstante, que en el ámbito tributario las diferencias entre ambos se minimizan porque existe la posibilidad de ejecutar las garantías hipotecarias administrativamente ${ }^{478}$. En este sentido, apunta el apartado 6 del artículo 74 del RGR que

"la ejecución de las hipotecas y otros derechos reales constituidos en garantía de los créditos de la Hacienda pública se realizará por los órganos de recaudación competentes a través del procedimiento de apremio".

De esta forma, la Hacienda acreedora no necesita instar la ejecución de la hipoteca a través de un procedimiento judicial, puesto que, sobre la base del principio de la autotutela administrativa, puede proceder a la realización de aquélla por medio de un procedimiento de apremio, según dispone el artículo 163 de la LGT.

Ya con anterioridad, el RGR de 1990 determinaba, en el apartado 2 del artículo 37 y en el apartado 3 del artículo 128, que el derecho de afección como garantía del crédito tributario debía ejecutarse a

\footnotetext{
478 ZABALA RODRÍGUEZ-FORNOS, A., LLOPIS GINER, F. y DAGO ELORZA, I., Recaudación, aspectos sustantivos y procedimentales, op. cit., pág. 246.
} 
través de la vía administrativa. Por ello afirmó FALCÓN Y TELLA ${ }^{479}$ que, ante la imposibilidad de ejecución de bienes afectos por medio de un procedimiento ejecutivo hipotecario, este derecho no es un derecho de hipoteca. Actualmente el apartado 3 del artículo 74 del RGR regula el procedimiento de ejecución de garantías reales constituidas sobre bienes o derechos del obligado al pago, así como sobre los bienes o derechos de persona o entidad distinta de aquel sujeto, tal como aparece en el apartado 4 del propio artículo 74 del RGR. Asimismo, el artículo 67 del RGR se remite a los artículos 174 a 176 de la LGT, que determinan el procedimiento a seguir frente a los responsables tributarios, para el ejercicio del derecho de afección del artículo 79 de la LGT, y ello sin perjuicio de que el adquirente de bienes afectos, a pesar de su ubicación dentro de los supuestos de responsabilidad subsidiaria en el inciso d) del apartado primero del artículo 43 de la LGT, no se identifica como tal, siendo lo que busca el legislador con esta medida reconocer la subsidiariedad de la afección a efectos únicamente procedimentales.

\subsubsection{El derecho de afección y la hipoteca legal tácita}

Existe una gran similitud entre las figuras que regulan los artículos 78 y 79 de la LGT, puesto que en ambas se produce la sujeción de un bien para cumplir con una obligación concreta y se faculta al titular de las garantías a perseguir y ejecutar el bien afecto aunque éste ya no forme parte del patrimonio del deudor principal. A su vez, tanto en la hipoteca legal tácita como en el derecho de afección no se requiere de la inscripción registral para que puedan producir su eficacia erga omnes ${ }^{480}$. En todo caso, a pesar de la similitud que muestran ambas figuras, no es menos cierto que entre ellas también existen diferencias.

En primer lugar se restringe el uso de la hipoteca legal tácita a dos anualidades, límite temporal que no se observa en el derecho de afección, y tampoco son iguales los impuestos sobre los que se configura su aplicación ${ }^{481}$. Otra de las diferencias entre la hipoteca legal tácita y el derecho de afección es la eficacia que frente al tercero adquirente despliegan uno y otro derecho. En el caso de la afección de bienes se detiene ante el tercer adquirente de buena fe, según el artículo 34 de la LH, y se supedita a otros titulares de derechos reales nacidos con anterioridad al momento en que debe considerarse nacido el derecho de afección que coincide con el devengo del impuesto. La hipoteca legal tácita, en cambio, determina la posibilidad de anteponerse a cualquier otro titular o adquirente aunque hubiera inscrito su derecho primero. Debemos recordar, además, que la inscripción en el Registro no es un elemento esencial para que se origine el derecho de afección, puesto que éste se crea por imperio de la ley en el momento en que nace el crédito tributario que garantiza.

CARRAMOLINO expresó, al referirse a esta cuestión, que "no debe omitirse que entre las hipotecas legales tácitas y las afecciones en sentido estricto existen diferencias, pues mientras las primeras no requieren de "reflejo tabular" para perjudicar a terceros inscritos, las segundas sí, pues sólo de este

\footnotetext{
${ }^{479}$ FALCÓN Y TELLA, R., "Las garantías del crédito tributario”, op. cit., pág. 619.

${ }^{480}$ GARCÍA GARCÍA, J. M., Código de Legislación Hipotecaria y del Registro Mercantil, op. cit., pág. 740; CARRAMOLINO, C., "La hipoteca legal tácita y crédito singularmente privilegiado (una breve reflexión a propósito de la resolución de 3 de abril de 1998)", op. cit., pág. 12730.

${ }^{481}$ Vid. supra, Capítulo Tercero, epígrafe 1.3.2. "Aspecto objetivo”, respecto al ámbito de aplicación de la hipoteca legal tácita y vid. infra, Capítulo Tercero, epígrafe 2.4.2. "Aspecto Objetivo”, en relación al ámbito de aplicación del derecho de afección.
} 


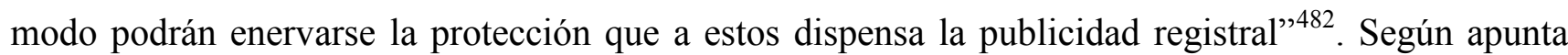
ARRANZ DE ANDRÉS, la inscripción registral se hace "para evitar que un tercero, al comprobar que no existe esta carga en el Registro, se vea protegido por la fe pública registral y no resulte para él operativa la referida garantía"483. Esto último no significa a nuestro juicio que el derecho de afección pierda su carácter real, ya que conserva su esencia al sujetar un bien al cumplimiento de la obligación y, por tanto, puede desplegar todos sus efectos aun cuando la Hacienda Pública no haya inscrito su derecho, siempre que el poseedor no se beneficie de la buena fe por incumplir algunos requisitos del artículo 34 de la LH.

CASADO OLLERO, FALCÓN Y TELLA, LOZANO SERRANO, y SIMÓN ACOSTA entendieron que el derecho de afección no es "una hipoteca legal, pues la afección registral no implica que se puedan utilizar los procedimientos de ejecución hipotecaria, sino que lo único que permite es que se pueda practicar la anotación preventiva de embargo si se cumple en el procedimiento de apremio el requisito de la derivación de la acción tributaria y se notifica el embargo al tercer adquirente" ${ }^{484}$.

En efecto, una de las diferencias fundamentales que se observa entre ambas figuras es que, a pesar de que el cumplimiento de la obligación recaiga en ambos casos sobre un bien sujeto, en el caso de la hipoteca la inscripción registral es constitutiva. Por el contrario, el derecho de afección no necesita para su nacimiento de dicha inscripción registral: puede hacerse constar registralmente a través de nota marginal para garantizar sus efectos erga omnes, o proceder a la anotación de embargo cuando se inste a la ejecución del bien, pero estos asientos no son equiparables a la inscripción registral de la hipoteca.

Por este motivo ARRANZ DE ANDRÉS destaca que la LEC casi no presta atención al derecho de afección y sólo se refiere al tercero adquirente en los apartados 2 y 3 del artículo 538, y “de ahí que se defienda la aplicación a esta figura de las reglas generales previstas para la ejecución dineraria (arts. 571 y ss.) y no de las aplicables para la ejecución de los bienes hipotecados o pignorados (arts. 681 y ss.), al ceñir el apartado primero del art. 682 el ámbito de este último procedimiento, exclusivamente, a los bienes hipotecados o pignorados" ${ }^{\text {485 }}$. Sin embargo, esta autora es del criterio que el derecho de afección como garantía real sólo se aprecia en el segundo apartado del artículo 79 de la LGT, ya que también se esconden en este precepto una hipoteca legal tácita y una hipoteca legal expresa. Según esta doctrina, tras el derecho de afección se encuentra una hipoteca legal tácita, porque las preferencias del artículo 78 de la LGT refuerzan la posición de la Hacienda Pública frente a otros acreedores hipotecarios que hubieran inscrito su derecho con anterioridad al nacimiento de la obligación tributaria, lo cual no es un elemento definitorio de la hipoteca legal tácita, sino que es un privilegio que se adiciona. No entiende que suceda lo mismo en el tercer párrafo del segundo apartado del artículo 79 de la LGT, que regula la afección de bienes en los casos de exenciones o

\footnotetext{
482 CARRAMOLINO, C., "La hipoteca legal tácita y crédito singularmente privilegiado (una breve reflexión a propósito de la resolución de 3 de abril de 1998)", op. cit., pág. 12731.

${ }^{483}$ ARRANZ DE ANDRÉS, C., Las garantías reales del crédito tributario: aspectos sustantivos y procedimentales, op. cit., pág. 133 a 135.

${ }^{484}$ CASADO OLLERO, G., FALCÓN Y TELlA, R., LOZANO SERRANO, C. y SIMÓN ACOSTA, E., Cuestiones tributarias prácticas, op. cit., pág. 619.

${ }^{485}$ ARRANZ DE ANDRÉS, C., Las garantías reales del crédito tributario: aspectos sustantivos y procedimentales, op. cit., pág. 130.
} 
bonificaciones condicionadas, aunque observa un parecido entre la afección y el derecho de hipoteca en la constancia registral que exige el tercer apartado del artículo 79 de la LGT y, por lo tanto, considera que este precepto configura un derecho de hipoteca legal expresa ${ }^{486}$.

Esta es la misma conclusión a la que llega GÓMEZ CABRERA. Para este autor la naturaleza jurídica del derecho de afección es la de hipoteca, por constituirse ope legis, sin necesidad de acto administrativo expreso, y es, además de legal, tácita ${ }^{487}$. Por el contrario, niegan expresamente que se trate de una hipoteca legal GUERVÓS MAÍLLO y LAGO MONTERO, cuando interpretan que "no es pues, una auténtica hipoteca, sino un derecho real más liviano, más fuerte que el establecido en el artículo 71 L.G.T. pero más débil que el regulado en el artículo 73 L.G.T."488.

\subsubsection{El derecho de afección y el derecho de prelación general}

Las diferencias entre el derecho de afección y el derecho de prelación general, según nuestro criterio, se observan más claramente en el ámbito concursal. Independientemente de que para algunos autores estemos ante un privilegio especial en el caso del derecho de afección y un privilegio general en el caso del derecho de prelación general, o de que el derecho de afección otorgue una protección mucho más amplia a los créditos tributarios, puesto que se refiere a obligaciones tributarias nacidas de la realización de un hecho imponible que grava la transmisión, adquisición o importaciones, aunque dichas obligaciones no estén vencidas ni satisfechas y tanto si están liquidadas como si no lo están, lo cierto es que en caso de concurrencia de acreedores se satisfacen preferentemente los créditos amparados por garantías reales. Esa preferencia funciona frente a todos los titulares de privilegios generales, entre los que se encuentran los créditos tributarios, según el artículo 77 de la LGT. Esto último significa que frente a las posibilidades de cobro de la Hacienda Pública amparadas en el derecho de prelación resultará beneficiada la posición de quienes tienen un crédito garantizado con derechos reales de garantía sobre determinados bienes.

De esta forma, si la Hacienda Pública quiere tener preferencia sobre ciertos bienes, debe promover una hipoteca o prenda sobre la base de lo que determinen las reglas generales del Derecho privado y con el requisito procedimental de la anotación preventiva del embargo. Cuando esto ocurre, el crédito tributario adquiere la condición de crédito hipotecario y, de la misma manera que sucede con éste, el derecho real se constituye mediante la inscripción en el Registro de Propiedad. "Así el crédito tributario resultará preferente, pero no en atención a lo que podríamos llamar su causa, sino que tal preferencia derivará de los propios mecanismos de la publicidad registral y atenderá a la fecha de su constitución" ${ }^{, 89}$.

\footnotetext{
${ }^{486}$ ARRANZ DE ANDRÉS, C., Las garantías reales del crédito tributario: aspectos sustantivos y procedimentales, op. cit., pág. 133 a 135.

${ }^{487}$ GÓMEZ CABRERA, C., La concurrencia del crédito tributario: Aspectos sustantivos y procedimentales. Prelación, garantías, tercerias, ejecuciones preferentes, suspensiones de pago y quiebras, op. cit., pág. 109 a 112.

${ }^{488}$ GUERVÓS MAÍLLO, M. A., y LAGO MONTERO, J. M., "Las garantías del crédito tributario (Comentario a los artículos 71, 72, 73, 75, 75 y 76 L.G.T.)", op., cit., pág. 143. En este mismo sentido, FALCÓN Y TELLA, R., "Las garantías del crédito tributario”, op. cit., pág. 619.

${ }^{489}$ GARCÍA NOVOA, C., “Garantías de la deuda tributaria”, op. cit., pág. 361.
} 


\section{4. ÁMBITO DE APLICACIÓN}

De la misma forma que hicimos cuando examinamos la hipoteca legal tácita, dedicaremos algunas líneas al análisis del ámbito de aplicación del derecho de afección. En este punto nos centraremos en aquellas limitaciones que afectan a esta garantía real, esto es, los sujetos que pueden ser titulares o no del derecho de afección, los impuestos que están garantizados o las cantidades que pueden ser amparadas con este derecho real.

\subsubsection{Aspecto subjetivo}

La LGT de 1963 no estableció limitación alguna respecto a la titularidad de esta garantía, por lo que podría cuestionarse si el derecho de afección que regulaba aquella norma se refería sólo a la Administración del Estado, ya que en el resto de los preceptos que se destinaban a las garantías la ley distinguía entre la Hacienda Pública y el resto de los posibles acreedores, como también se hizo cuando se pretendía identificar a las Administraciones Financieras (Provincia y Municipio). En este sentido, la doctrina entendió que la LGT de 1963 aludió tanto a los créditos tributarios del Estado como a los de las Provincias y Municipios, ya que de manera general estableció que sus disposiciones eran aplicables a todos los tributos, tanto estatales como locales ${ }^{490}$.

En el apartado segundo del artículo 79 de la LGT actual no existe tampoco limitación subjetiva inicial en la titularidad de esta garantía. El artículo no hace mención directamente a ningún Ente concreto como sujeto titular del derecho de afección, por lo que siempre que la deuda se derive de tributos que graven las transmisiones, adquisiciones o importaciones, el bien transmitido, adquirido o importado quedará afecto al cumplimiento de la obligación de pago, permitiendo al sujeto activo de esta obligación tributaria hacer uso de la garantía. Así pues, el titular de la afección de bienes será la Hacienda Pública Estatal, así como las Comunidades Autónomas o Corporaciones Locales, aunque el artículo 79 de la LGT no haga mención a ello. Interpretación deducible de la dicción del apartado 3 del artículo 2 de la LOFCA y el apartado 2 del artículo 2 del TRLRHL.

\subsubsection{Aspecto objetivo}

\subsubsection{Impuestos garantizados}

En cuanto a los tributos a los que puede extenderse el derecho de afección, las opiniones en la doctrina son divergentes. Existe un grupo de autores que entiende, a partir de la interpretación del apartado 1 del artículo 79 de la LGT, que establece la responsabilidad subsidiaria de los adquirentes de bienes afectos por ley al pago de la deuda, que en este caso la garantía resulta aplicable sólo cuando así lo determine la ley reguladora del tributo en cuestión, lo que ocurre en la actualidad con el ITPAJD, el ISD, el IBI y el Impuesto sobre la Renta de No Residentes, en el caso de transmisión de inmuebles por no residentes ${ }^{491}$.

\footnotetext{
${ }^{490}$ GÓMEZ CABRERA, C., La concurrencia del crédito tributario: Aspectos sustantivos y procedimentales. Prelación, garantías, tercerías, ejecuciones preferentes, suspensiones de pago y quiebras, op. cit., pág. 100. Este autor deja fuera de la titularidad del derecho de afección a la Administración Corporativa.

${ }^{491}$ En opinión de LUQUE CORTELLA, para que opere la garantía del artículo 79 de la LGT no es necesario que expresamente se recoja esta figura en una ley tributaria particular. En este sentido, recuerda que el contenido del apartado 1 del artículo 79 de la LGT ya
} 
La aplicación del derecho de afección para el cobro del ITPAJD y el ISD es aceptada de forma unánime y no despierta en la doctrina ninguna contradicción ${ }^{492}$. "En realidad, es una garantía que procede del impuesto de derechos reales, pasa a la legislación de los impuestos sobre transmisiones patrimoniales, sucesiones y donaciones y es en estos tributos donde realmente resulta operativa" ${ }^{\text {"493 }}$.

Las posiciones divergentes aparecen sobre todo en relación con la aplicación de la afección al Impuesto sobre el Valor Añadido (en adelante IVA). Las dudas quedan resueltas, según LUQUE CORTELLA, dentro del propio artículo 79 de la LGT, a la vista de las exclusiones que hace respecto a la persecución de los bienes en posesión del adquirente con buena fe y justo título o en establecimiento mercantil o industrial para el caso de bienes muebles no inscribibles. A esto añade el autor la dificultad que plantea la operatividad de la garantía "ante la especial técnica mediante la que se aplica el impuesto a través del mecanismo de la repercusión-deducción que implica una total desconexión y falta de coincidencia entre la cuota ingresada en un determinado período y la repercutida al adquirente del bien, sobre el que surgiría la afección" ${ }^{\text {"494 }}$.

ARRANZ DE ANDRÉS se muestra a favor de la incorporación del IVA en el grupo de impuestos incluidos dentro del derecho de afección con el argumento de que la finalidad de este impuesto es la de gravar el consumo de bienes y servicios, canalizándose mediante la entrega de bienes y prestaciones de servicios realizadas por empresarios o profesionales, así como de las adquisiciones intracomunitarias e importaciones de bienes $\mathrm{y}$, desde esta perspectiva, en muchos casos nos encontramos ante transmisiones, adquisiciones o importaciones de bienes y derechos, como tales, por tanto, favorables a generar una deuda que se pueda garantizar por la afección, "debiéndose entonces exceptuar los supuestos en los que no se realice propiamente ninguna de estas operaciones". También indica esta autora que el apartado 3 del artículo 167 de la Ley 37/1992, de 28 de diciembre, del Impuesto sobre el Valor Añadido, establece que reglamentariamente se determinarán las garantías que resulten procedentes para asegurar el cumplimiento de las correspondientes obligaciones tributarias, y que el reglamento de este impuesto no dispone de ninguna previsión que dé

\footnotetext{
se acogía en la LGT de 1963 en su artículo 41, y que, aunque en secciones diferentes, la intención siempre fue aclarar el carácter de garantía real del derecho de afección. Como tal, el derecho de afección de bienes aparece regulado en el segundo apartado del artículo 79 de la LGT y lógicamente también se aplicará la garantía en casos distintos, cuando lo determine la ley reguladora de cada tributo, como sucede con el IBI, en que la afección no garantiza el pago del tributo que grave la transmisión, sino la deuda del propio impuesto (LUQUE CORTELLA, A., La Hacienda pública y el crédito tributario en los procesos concursales, op. cit., pág. 130).

${ }^{492}$ Entre otros, RODRÍGUEZ BEREIJO, A., "Las garantías del crédito tributario”, op. cit., pág. 201; ARRANZ DE ANDRÉS, C., Las garantías reales del crédito tributario: aspectos sustantivos y procedimentales, op. cit., pág. 195 a 205; GARCÍA NOVOA, C., "Garantías de la deuda tributaria", op. cit., pág. 357; CAMY ESCOBAR, J., "Las garantías de la deuda tributaria y su ejecución", op. cit., pág. 156; GONZÁLEZ-CARBALLO ALMODÓVAR, A., "Las garantías del crédito tributario", op. cit., pág. 461 a 463 ; GÓMEZ CABRERA, C., La concurrencia del crédito tributario: Aspectos sustantivos y procedimentales. Prelación, garantías, tercerías, ejecuciones preferentes, suspensiones de pago y quiebras, op. cit., pág. 99.

${ }^{493}$ GUERVÓS MAÍLLO, M. A., y LAGO MONTERO, J. M., "Las garantías del crédito tributario (Comentario a los artículos 71, 72, 73, 75, 75 y 76 L.G.T.)", op., cit., pág. 143. GÓMEZ CABRERA se muestra a favor de la aplicación de la afección de bienes a los tributos que mencionamos y también a los Derechos Aduaneros (GÓMEZ CABRERA, C., La concurrencia del crédito tributario: Aspectos sustantivos y procedimentales. Prelación, garantías, tercerías, ejecuciones preferentes, suspensiones de pago y quiebras, op. cit., pág. 99).

${ }^{494}$ LUQUE CORTELLA, A., La Hacienda pública y el crédito tributario en los procesos concursales, op. cit., pág. 130.
} 
cumplimiento al precepto, sirviendo en todo caso el apartado segundo del artículo 79 de la LGT de base suficiente para justificar la aplicación del derecho de afección en el ámbito del IVA ${ }^{495}$.

Ahora bien, el argumento contrario a la aplicación del derecho de afección para el cobro del IVA se basa en que la propia estructura de este tributo "obliga al transmitente, que es el sujeto pasivo, a repercutir el importe del impuesto al adquirente, obligado al pago, y a efectuar su ingreso"496.

Algunos autores incluyen dentro de la afección a otros impuestos, como es el caso de RODRÍGUEZ BEREIJO, que considera que la afección es un derecho que va a recaer sobre el Impuesto de Sucesiones, el Impuesto General sobre Transmisiones Patrimoniales y Actos Jurídicos Documentados, el Impuesto de Tráfico de Empresas, y los Derechos Aduaneros, entre otros, pero que el problema se plantea en aquellos tributos que no gravan las transmisiones encontrándose éstas presentes en su hecho imponible ${ }^{497}$. La solución encontrada por CALVO ORTEGA para resolver esta cuestión es una posible interpretación extensiva, sobre la base de la legislación precedente, del artículo 74 de la LGT de 1963, que consiste en considerar que existe derecho real de afección de bienes respecto a todos los tributos que tienen por objetivo determinados aspectos de un bien, que se exteriorizan por medio de una transmisión, aunque el tributo no grave propiamente las transmisiones $^{498}$. Para RODRÍGUEZ BEREIJO, sin embargo, esta solución supondría una interpretación forzada del precepto y una extensión de la garantía real que debe establecerse por la ley, vulnerándose, de ese modo, no sólo el principio de legalidad tributaria, sino atentando también "gravemente a la seguridad jurídica de los particulares, cuyos derechos o bienes podrían verse gravemente limitados por una interpretación y aplicación, discrecional, de una norma más allá de sus términos estrictos" $" 499$.

Existen otros dos impuestos cuya inclusión en la aplicación del derecho de afección crea divergencias en la doctrina. Nos referimos a los Impuestos Aduaneros y los Impuestos Especiales. En el caso de los primeros, el inciso a) del apartado primero del artículo 232 del Reglamento (CE) $\mathrm{N}^{\circ}$ 450/2008 del Parlamento Europeo y del Consejo, de 23 de abril de 2008, por el que se establece el Código Aduanero Comunitario, determina que cuando el importe de los derechos de importación o exportación exigibles no hayan sido pagados en el plazo establecido, las autoridades aduaneras garantizan el pago de dicho importe por todos los medios de que dispongan con arreglo a la legislación del Estado miembro de que se trate. Esta solución implica la remisión a las normas de los ordenamientos internos, y visto así bien podría pensarse que la Administración puede hacer uso de todos los medios de garantía que estén a su alcance para hacer efectiva la deuda aduanera, incluido el derecho de afección del apartado segundo del artículo 79 de la LGT. Por lo demás, en este precepto

\footnotetext{
${ }^{495}$ ARRANZ DE ANDRÉS, C., Las garantías reales del crédito tributario: aspectos sustantivos y procedimentales, op. cit., pág. 214 y 215. En el mismo sentido, GÓMEZ CABRERA, C., La concurrencia del crédito tributario: Aspectos sustantivos y procedimentales. Prelación, garantías, tercerías, ejecuciones preferentes, suspensiones de pago y quiebras, op. cit., pág. 99.

${ }^{496}$ CAMY ESCOBAR, J., "Las garantías de la deuda tributaria y su ejecución”, op. cit., pág. 156. También asume esta posición GARCÍA NOVOA, C., "Garantías de la deuda tributaria", op. cit., pág. 357.

${ }^{497}$ RODRÍGUEZ BEREIJO, A., "Las garantías del crédito tributario”, op. cit., pág. 202.

${ }^{498}$ CALVO ORTEGA, R., “La responsabilidad tributaria subsidiaria”, Hacienda Pública Española, núm. 10, 1971, pág. 152.

${ }^{499}$ RODRÍGUEZ BEREIJO, A., "Las garantías del crédito tributario”, op. cit., pág. 202.
} 
se regula la sujeción de los bienes y derechos transmitidos al pago de las cantidades correspondientes a los tributos que graven las importaciones ${ }^{500}$.

En relación con los Impuestos Especiales, apunta ARRANZ DE ANDRÉS que el legislador lo que pretende con los mismos es gravar "la renta gastada en la adquisición de determinados bienes, siendo su objeto mediato el gravamen de las operaciones de fabricación e importación de los mismos"501, pudiendo aplicarse por tanto el derecho de afección a los Impuestos Especiales cuando el hecho realizado y gravado por estos impuestos sea el de la importación de los bienes sobre los que recae y quedando éstos afectos al pago de la deuda en caso de que la misma no se satisfaga.

En resumen, estamos ante un derecho de afección de bienes al pago de tributos que gravan las transmisiones. Aunque en principio la garantía se extiende a todos los tributos que afectan a la transmisión, la exclusión que hace la LGT respecto a la persecución de los bienes en posesión del adquirente con buena fe y justo título o en establecimiento mercantil o industrial para el caso de bienes muebles inscribibles haría pensar que no podrían garantizarse con el derecho de afección impuestos como el IVA, los Impuestos Especiales y los Impuestos Aduaneros, pero, sin embargo, entendemos que el pago de estos impuestos puede asegurarse con la afección de bienes, de la misma manera que en el ITPAJD, el ISD, el IBI y el Impuesto sobre la Renta de No Residentes.

\subsubsection{Otros tributos}

El apartado segundo del artículo 79 de la LGT se refiere a la afección en garantía de las cantidades correspondientes a tributos que graven la transmisión, adquisición o importación, de la misma forma que el artículo 74 de la LGT de 1963. Aunque el RGR de 1990, en su artículo 37, extendió la aplicación de aquella previsión a los demás recursos de Derecho público ${ }^{502}$, esta evidente extralimitación quedó salvada con la redacción de los artículos 31 y 32 de la LGP, actualmente recogida en el artículo 10 de la LGP.

Como la afección de bienes se aplica en tributos que gravan transmisiones, adquisiciones o importaciones, no es difícil concluir que dada la naturaleza jurídica de las tasas, cuando éstas tengan que ser exigidas con la entrega de un bien, pueda reconocerse en esta figura tributaria la afección sobre aquéllos bienes.

De la misma forma podría aplicarse la afección a los precios públicos, siempre en relación con bienes vendidos por los que hubiera que satisfacerse alguno de esos precios, aunque la posibilidad de

\footnotetext{
${ }^{500}$ En contra de esta conclusión se manifiesta MARTÍNEZ LAFUENTE, A., "La prelación del artículo 73 de la Ley General Tributaria en relación con el Impuesto sobre las Transmisiones Patrimoniales y Actos Jurídicos Documentados”, op. cit., pág. 274, para quien la afección al pago del impuesto no es típica de la legislación reguladora de los tributos sobre el comercio exterior, sino de los gravámenes sobre la transferencia de los bienes patrimoniales.

${ }^{501}$ ARRANZ DE ANDRÉS, C., Las garantías reales del crédito tributario: aspectos sustantivos y procedimentales, op. cit., pág. 207.

${ }^{502}$ GÓMEZ CABRERA, al referirse a este artículo del RGR de 1990, indicó que este precepto ampliaba el ámbito de aplicación del derecho de afección a los demás recursos de Derecho público y que, por tanto, podrían gozar de esta garantía las subvenciones de causa transmisoria (GÓMEZ CABRERA, C., La concurrencia del crédito tributario: Aspectos sustantivos y procedimentales. Prelación, garantías, tercerías, ejecuciones preferentes, suspensiones de pago y quiebras, op. cit., pág. 99). También asumen esta posición ZABALA RODRÍGUEZ-FORNOS, A., LLOPIS GINER, F. y DAGO ELORZA, I., Recaudación, aspectos sustantivos y procedimentales, op. cit., pág. 244. Sin embargo, esta no es la opinión de FALCÓN Y TELLA, para quien el derecho de afección no es aplicable a las deudas de naturaleza no tributaria (FALCÓN Y TELLA, R., "Las garantías del crédito tributario", op. cit., pág. 619).
} 
considerar un determinado bien afecto al pago de un precio público que grave su transmisión procederá cuando además este bien pueda ser susceptible de embargo y enajenación forzosa para satisfacer el crédito del acreedor ${ }^{503}$.

En cuanto a las contribuciones especiales, éstas no pretenden gravar el bien sobre el que se pone de manifiesto el beneficio, como tampoco su transmisión, adquisición o importación, sino únicamente el beneficio que la realización de determinadas obras o el establecimiento de servicios públicos genera sobre los bienes del obligado al pago, lo cual lleva a la conclusión de que puede utilizarse en este caso la afección como garantía de los bienes sobre los que se hubiera proyectado el incremento del valor $^{504}$.

\subsubsection{Aspecto material}

Dado el carácter real del derecho de afección, bien podría pensarse que su ámbito material se extiende a la totalidad de la deuda que garantiza, incluyendo las costas procesales y excluyendo, como es lógico, las sanciones. Así lo avaló el artículo 74 de la LGT de 1963, que aseguraba las cantidades correspondientes a los tributos, término que bien podía englobar todas las partidas del artículo 58 de la LGT de 1963. Sin embargo, el artículo 41 de la propia LGT de 1963 limitó el alcance de la garantía al disponer que la derivación de la acción recaudatoria contra el bien afecto sólo alcanzaría el límite previsto por la ley al señalar la afección del mismo. Por ello dice GÓMEZ CABRERA que, "salvo que la ley reguladora de algún tributo establezca para ella un límite distinto, dado que, conforme al artículo 74, surge al transmitente del bien, sólo se extenderá a las cantidades devengadas en ese momento, que alguna resolución judicial ha circunscrito a la cuota y a los eventuales recargos iniciales del 58.2 a), con exclusión del recargo de apremio, del 61.3, de los intereses moratorios, de las sanciones y, por supuesto, de las costas"505. Por su parte, el apartado 2 del artículo 37 del RGR de 1990 fue más allá y extendió el ámbito material de la afección a todos los componentes de la deuda del artículo 58 de la LGT de 1963, exceptuando las sanciones, aunque un sector de la doctrina entendió que era un precepto reglamentario inaplicable e ilegal ${ }^{506}$.

Cuando nos referimos a esta cuestión en el epígrafe dedicado a la hipoteca legal tácita ${ }^{507}$, aclaramos que los argumentos que allí exponíamos eran válidos tanto para las garantías voluntarias como para la afección de bienes. Sin querer repetir lo que en aquel momento dijimos, sólo pretendemos puntualizar que el derecho de afección del apartado 2 del artículo 79 de la LGT puede aplicarse como garantía para el cobro de las cantidades debidas por los intereses y los recargos, y por las costas procesales, quedando excluidas las sanciones. Sin embargo, debemos hacer distinciones cuando se trate del tercer adquirente. La doctrina entiende, a falta de criterios específicos por parte del

\footnotetext{
${ }^{503}$ HERRERA MOLINA, P. M., Los precios públicos como recurso financiero, op. cit., pág. 127; LITAGO LLEDÓ, R., La recaudación de los precios públicos, Tecnos, Madrid, 1997, pág. 224. Este último autor opina que en los precios públicos también opera el derecho de prelación general.

${ }^{504}$ ARRANZ DE ANDRÉS, C., Las garantías reales del crédito tributario: aspectos sustantivos y procedimentales, op. cit., pág. 227.

505 GÓMEZ CABRERA, C., La concurrencia del crédito tributario: Aspectos sustantivos y procedimentales. Prelación, garantías, tercerías, ejecuciones preferentes, suspensiones de pago y quiebras, op. cit., pág. 102.

${ }^{506}$ MOCHON LÓPEZ, L., Actos reclamables en el procedimiento económico-administrativo, Marcial Pons, Madrid, 1995 , pág. 192.

${ }^{507}$ Vid. supra, Capítulo Tercero, epígrafe 1.3.3. "Aspecto material”.
} 
legislador, que el tercer adquirente únicamente responde de la cuota y los recargos iniciales ${ }^{508}$. Por su parte, la jurisprudencia se pronunció a favor de que en el pago que deba hacer el adquirente pueda excluirse cualquier interés o recargo, aun cuando en el Registro de la Propiedad conste la nota de afección, lo que se deduce del carácter objetivo de esta responsabilidad y, por tanto, de interpretación restrictiva, pues el tercer adquirente no debe cargar con la culpa del anterior titular.

En contra de esta postura, CASADO OLLERO, FALCÓN Y TELLA, LOZANO SERRANO, y SIMÓN ACOSTA plantean que en todo caso, cualquiera que sea la deuda cubierta por el derecho de afección, la responsabilidad del tercero se limita al importe de los bienes sobre los que recae dicho derecho real. Y que como regla general el máximo de la afección ha de figurar en la nota marginal que en su caso se practique, salvo en los supuestos de autoliquidación en el ISD y en el ITPAJD ${ }^{509}$.

\subsection{EFICACIA DEL DERECHO DE AFECCIÓN}

La Hacienda Pública tiene un derecho erga omnes de persecución sobre la cosa objeto de la afección, es decir, goza de una preferencia para el cobro frente a cualquier otro acreedor. Sin embargo, ante la necesidad de proteger la seguridad del tráfico patrimonial, civil o mercantil, cede este derecho en dos supuestos concretos. En efecto, el derecho real de garantía de afección de bienes opera sobre todos los poseedores del bien, salvo cuando éstos resulten ser terceros protegidos por la fe pública registral, o se justifique la adquisición de los bienes con buena fe y justo título en establecimiento mercantil o industrial, esto último para el caso de bienes muebles no inscribibles, tal como se establece en el párrafo cuarto del artículo 464 del Código Civil y en el artículo 85 del Código de Comercio ${ }^{510}$.

A estos supuestos de exoneración añadió CORTÉS DOMÍNGUEZ a los adquirentes en establecimiento mercantil o industrial protegidos por la certificación administrativa negativa de deuda tributaria que regulaba el artículo 72 de la LGT de 1963 y que hoy aparecen en el inciso $c$ ) del apartado primero del artículo 42 de la LGT $^{511}$. Para este caso en concreto, no creemos que sea posible invalidar la eficacia del derecho de afección de bienes por medio de la certificación administrativa, sobre la base de que el ámbito de aplicación de esa certificación se restringe exclusivamente a la responsabilidad solidaria que contempla el inciso c) del apartado primero del artículo 42 de la LGT. Por otro lado, si la certificación es negativa o se hace fuera de plazo, el adquirente se libera de responder como responsable solidario de la deuda tributaria, pero no se deshace de su obligación como adquirente de un bien afecto al pago del tributo. Por último, debemos recordar que la afección surge en relación con los impuestos que graven las transmisiones, adquisiciones o importaciones, lo que implica que estos actos deberían conectarse con la actividad empresarial para que se pudiera justificar la incorporación de las deudas tributarias que se derivan de ellos en la certificación administrativa y ésta pudiera servir como motivo de oposición al derecho de afección.

\footnotetext{
${ }^{508}$ Vid. URIARTE y ZULUETA, M. M., "Los sujetos pasivos en el procedimiento recaudatorio. Conferencias sobre recaudación”, $o p$. cit., pág. 106, y RODRÍGUEZ BEREIJO, A., "Las garantías del crédito tributario”, op., cit., pág. 655.

509 CASADO OllerO, G., FAlCÓN Y TELlA, R., LOZANO SERRANO, C. y SIMÓN ACOSTA, E., Cuestiones tributarias prácticas, op. cit., pág. 620 .

${ }^{510}$ RODRÍGUEZ BEREIJO, A., "Las garantías del crédito tributario”, op. cit., pág. 203; GÓMEZ CABRERA, C., La concurrencia del crédito tributario: Aspectos sustantivos y procedimentales. Prelación, garantías, tercerías, ejecuciones preferentes, suspensiones de pago y quiebras, op. cit., pág. 101.

${ }^{511}$ CORTÉS DOMÍNGUEZ, M., Ordenamiento tributario español, op. cit., pág. 469.
} 
Ahora bien, cuando se trate de bienes inscribibles, el tercer adquirente que, en principio, tendrá que hacer frente a la afección, será el adquirente a título oneroso que haya adquirido de persona legitimada según registro, sin que en él conste la afección, y que haya inscrito su adquisición ${ }^{512}$. El registro deberá ser el Registro de la Propiedad que otorgue a los inscritos la fe pública registral ${ }^{513}$. No obstante, en la práctica, esta figura del tercero protegido por fe pública registral capaz de invalidar el derecho de afección difícilmente podrá darse, por lo menos si se trata de bienes inscribibles en el Registro de la Propiedad Inmobiliaria, porque el artículo 254 de la LH impide el acceso al Registro de cualquier adquisición sino se acredita previamente el pago del impuesto que la grave $\mathrm{e}^{514}$.

Como derecho real, el derecho de afección es susceptible de inscripción registral, pero esto no otorga carácter constitutivo a dicha inscripción, pues estamos ante una garantía que se deriva de la propia ley, muy parecida a la hipoteca legal tácita, que surge cuando se realiza el supuesto de hecho previsto en la norma, es decir, con la transmisión, adquisición o importación. La constancia registral mediante nota marginal constituye un medio de aseguramiento de la afección frente a posibles acreedores concurrentes, pues "si por la razón que sea (olvido administrativo, caducidad del asiento...), no existe en el momento de la adquisición onerosa por el tercero, y éste desconoce su existencia por cualquier otro cauce extrarregistral e inscribe su titularidad en el Registro, estará entonces protegido por la fe pública registral al reunir los requisitos señalados en el art. 34 de la LH y, consiguientemente, le será imponible la afección" 515 . Pero si el tercer titular del bien no tiene inscrito su derecho, la afección del bien existe, por lo que responderá de la deuda hasta el importe que alcance con la ejecución del mismo, aunque no constase la anotación registral de la afección.

En este sentido, la exigencia de que un crédito tributario deba hacerse constar en el Registro mediante nota marginal de afección es aplicable en aquellos casos en que ley reguladora del tributo conceda un beneficio de exención o bonificación cuya definitiva efectividad dependa del ulterior cumplimiento por el contribuyente de cualquier requisito por aquélla exigido, en cuyo caso la Administración tributaria hará figurar el total importe de la liquidación que hubiera debido girarse de no mediar el beneficio fiscal, lo que se hace constar por nota marginal de afección en los Registros públicos ${ }^{516}$.

Cuando en la comprobación del ITPAJD sea preciso utilizar el medio extraordinario de la tasación pericial, se procederá a practicar liquidación por los valores declarados, sin perjuicio de la liquidación complementaria que en su caso proceda, y una vez hecho el pago de la primera liquidación podrán inscribirse en el registro los bienes inscribibles con la nota de quedar afectos a las resultas de la última liquidación. En los supuestos de autoliquidación del ITPAJD, el Registrador

\footnotetext{
${ }^{512}$ En este tipo de excepción no se puede alegar cuando el poseedor del bien sea el propio sujeto pasivo, porque éste no puede considerarse como un tercero respecto de la deuda ni como un tercer poseedor del bien. Sobre estas cuestiones, vid. ROSSY, H., El tercero fiscal y la responsabilidades subsidiarias ante la Hacienda, op. cit., pág. 41.

${ }^{513}$ Vid. DE LA ROSA VARGAS, G., "Las garantías específicas del crédito tributario en la transmisión de bienes”, op. cit., pág. 4 y 5.

514 NAVARRO DÍAZ, M. R., “Artículo 5", en la obra El Impuesto sobre Transmisiones Patrimoniales y Actos Jurídicos Documentados: Normativa comentada, Centro de Estudios Registrarles, Madrid, 2005, pág. 77 a 79.

${ }^{515}$ GONZÁLEZ-CARBALLO ALMODÓVAR, A., "Las garantías del crédito tributario”, op. cit., pág. 462; GÓMEZ CABRERA, C., La concurrencia del crédito tributario: Aspectos sustantivos y procedimentales. Prelación, garantías, tercerías, ejecuciones preferentes, suspensiones de pago y quiebras, op. cit., pág. 108.

${ }^{516}$ CORRAL GUERRERO, L., "La afección tributaria de bienes”, Boletín del Ilustre Colegio de Abogados, León, núm. 2, 1972, pág. 20 a 22.
} 
hará constar, mediante nota al margen de la inscripción, que el bien o derecho transmitido queda afecto al pago de la liquidación complementaria que, en su caso, proceda practicar. En dicha nota se expresará necesariamente el importe de lo satisfecho por la autoliquidación, salvo que se haya alegado la exención o no sujeción. La nota se extenderá de oficio, quedando sin efecto y debiendo ser cancelada cuando se presente la carta de pago de la indicada liquidación complementaria y, en todo caso, transcurridos cinco años desde la fecha en que se hubiese extendido, tal como aparece estipulado en el artículo 122 del Reglamento del ITPAJD. Y, en general, en los supuestos de afección de bienes y derechos transmitidos al pago de los tributos que graven la transmisión, la nota marginal sólo se extenderá en caso de autoliquidaciones y en los supuestos marginales en que cabe inscribir sin acreditar previamente el pago, según ordenan los artículos 254 y 256 de la LH. Esta nota marginal de afección impide que el tercero que adquiere los bienes pueda alegar la protección de la fe pública registral y enervar de esta forma el derecho de la Hacienda Pública de hacer efectivo su crédito sobre los bienes de que se trate.

La segunda excepción que mencionamos al inicio de este apartado y que invalida la eficacia del derecho de afección de la Administración tributaria es la que establece el apartado segundo del artículo 79 de la LGT, y beneficia a los bienes muebles no registrables cuya adquisición se haya producido con buena fe y justo título, en establecimiento mercantil o industrial. En la normativa anterior (apartado primero del artículo 74 de la LGT de 1963) éstos dos primeros requisitos podían interpretarse como dos causas de excepción, pero con la legislación vigente se permite vincular ambas condiciones: si se pretende invalidar la afección del bien, la adquisición del bien no sólo debe ser de buena fe, sino que también habrá que presentar el justo título. Respecto de la adquisición de los bienes en establecimiento mercantil o industrial, lo que ha pretendido el legislador es conceder al adquirente la posibilidad de oponerse al ejercicio del derecho de afección, porque de esta forma se protege "el tráfico jurídico, y en suma, la confianza de quien adquiere un determinado bien en un lugar en que es habitual su fabricación o comercio, lo que, sin duda, genera una apariencia que el Derecho debe amparar, ${ }^{, 517}$.

Debemos subrayar, por último que la excepción libera la carga de la afección al tercero que adquiere un bien afecto, pero no producirá el mismo efecto cuando el adquirente resulta ser el sujeto pasivo obligado al pago del tributo. No parece lógico que se conceda al sujeto que adquiere un bien e incumple la obligación de satisfacer el impuesto correspondiente la posibilidad de oponerse a la ejecución del bien transmitido, alegando la concurrencia de la buena fe en su adquisición.

\subsection{EJECUCIÓN DEL DERECHO DE AFECCIÓN}

Al analizar en textos normativos anteriores la forma de ejecución del derecho de afección, constatamos que el artículo 41 de la LGT de 1963 ubicaba la afección en sede de los responsables y, en este sentido, el apartado primero de ese precepto señalaba que los adquirentes de bienes afectos responderían con ellos, por derivación de la acción tributaria, si la deuda no se pagaba. Y añadía el segundo párrafo del primer apartado del artículo 41 de la LGT de 1963 que la derivación de la acción tributaria contra los bienes afectos exigía acto administrativo notificado reglamentariamente, pudiendo el adquirente hacer el pago, dejar proseguir la actuación o reclamar contra la liquidación

\footnotetext{
${ }^{517}$ ARRANZ DE ANDRÉS, C., Las garantías reales del crédito tributario: aspectos sustantivos y procedimentales, op. cit., pág. 245.
} 
practicada o contra la procedencia de dicha derivación. Sobre esta misma base, el RGR de 1968 calificaba a los adquirentes de bienes afectos como responsables tributarios, y en el apartado 3 del artículo 12 disponía que la derivación de la acción administrativa contra ellos seguiría el régimen previsto para los responsables subsidiarios. Lo cual significaba que previa declaración de fallido del deudor principal se notificaba la deuda al adquirente para que efectuara el pago en período voluntario y que, de no atenderse éste, se procedería contra el bien afecto. Sin embargo, el RGR de 1968 se contradecía, al disponer en el inciso f) del artículo 124 que el Registrador podía requerir al tercero poseedor del bien afecto que solventara el débito sin recargo alguno, y, en caso que no lo hiciera, diligenciar el expediente y remitirlo a la Tesorería para que dictara providencia de apremio contra el tercero, siguiendo luego contra éste el procedimiento. La Regla $7^{\text {a }}$ de la Instrucción General de Recaudación intentó reparar la contradicción aclarando que el inciso f) del artículo 124 del RGR de 1968 sólo sería de aplicación una vez declarada la insolvencia del obligado principal. De todas formas, en este régimen jurídico era bastante claro que no podía dirigirse contra al bien afecto en tanto no hubiera terminado el procedimiento de apremio contra el obligado principal, declarándolo insolvente.

Con la entrada en vigor del RGR de 1990 las cosas cambiaron; no sólo dejó de calificarse al adquirente de bienes afectos como responsable, sino que el apartado segundo del artículo 37 determinó que si la deuda no se pagaba en período voluntario y tampoco en los plazos que estableciera la providencia de apremio (artículo 108 del RGR de 1990), se requeriría al poseedor del bien para que pagara la deuda inicial en un plazo igual al del período voluntario, de manera que, en caso de no efectuar este pago, se continuaría el procedimiento directamente sobre el bien para hacer efectiva la deuda inicial, los recargos de apremio, los intereses de demora y las costas procesales. La solución reglamentaria en este caso fue la de autorizar la derivación de la acción, una vez que se incumpliera con el pago de la deuda en los plazos previsto en el artículo 108 del RGR de 1990, sin necesidad de que antes se hubiera concluido el procedimiento contra el deudor principal. La jurisprudencia se mostró contraria a esta postura reglamentaria, y sostuvo que para dirigirse frente al bien afecto era preciso que se agotara antes la vía de apremio frente al deudor principal, ya que el artículo 41 de la LGT de 1963 exigía la declaración de fallido, aunque el adquirente de bienes afectos no era un responsable propiamente dicho y se encontraba en una posición subordinada respecto al deudor principal ${ }^{518}$.

Ahora bien, según el ordenamiento tributario vigente en aquel momento, el órgano de recaudación podía proceder a la ejecución del bien afecto, es decir, podía dictar la diligencia de embargo contra el bien afecto, que debía ser notificada, además de al deudor principal, al tercer adquirente y a los acreedores hipotecarios $^{519}$. Con posterioridad debía dirigirse mandamiento al Registro de la

\footnotetext{
${ }^{518}$ Entre otras, Sentencias del Tribunal Supremo de 1 de febrero de 1995, de 14 de noviembre de 1996, o de 20 de noviembre de 2000.

${ }^{519}$ Se muestran contrarios a este procedimiento LÓPEZ DÍAZ, A., La recaudación de deudas tributarias en vía de apremio, op. cit., pág. 199, y ZABALA RODRÍGUEZ-FORNOS, A., LLOPIS GINER, F. y DAGO ELORZA, I., Recaudación, aspectos sustantivos y procedimentales, op. cit., pág. 248. Según LÓPEZ DÍAZ la providencia de apremio contra el poseedor de los bienes sólo resultará necesaria cuando se trate de bienes inmuebles que estén inscritos a nombre del adquirente. En sentido contrario, GUERVÓS MAÍLLO y LAGO MONTERO manifiestan que "la persecución de los bienes afectos, derecho real, no exige per natura el agotamiento de la vía de apremio, como tampoco lo exige el perseguir bienes del responsable solidario (...). El legislador y el reglamentador son libres de instrumentar en este punto el procedimiento para la efectividad de las garantías, personales o reales, con mayor o menor protección de los derechos de la hacienda pública o de los derechos de los administrados" (GUERVÓS MAÍLLO, M. A., y LAGO MONTERO, J. M., "Las garantías del crédito tributario (Comentario a los artículos 71, 72, 73, 75, 75 y 76 L.G.T.)", op., cit., pág. 148).
} 
Propiedad, interesando la práctica de la anotación preventiva de embargo y el libramiento de la certificación de las cargas que figurasen en el registro contra la finca, debiendo notificarse el embargo a todos los titulares de las mismas que no lo hubieren sido ya con anterioridad. Una vez anotado el embargo se procedía a enajenar el bien según lo que establecían los artículos 139 y ss. del RGR de 1990. Finalmente, en relación con este período, GÓMEZ CABRERA ${ }^{520}$ sostuvo que cuando el bien afecto siguiera siendo de la titularidad del obligado principal no existía inconveniente para que pudiera ejecutarse contra él la vía de apremio, pero embargando y ejecutando el bien directamente. Ello significaba que no se aplicarían el artículo 41 de la LGT de 1963 y el apartado 2 del artículo 37 del RGR de 1990, ya que ambos preceptos preveían la posibilidad de requerir primero al poseedor o adquirente del bien afecto para que pagara la deuda tributaria y ejecutar el bien únicamente en caso de que no se efectuara el mismo.

En el contexto actual del régimen de afección de bienes se produce una equiparación en el apartado primero del artículo 79 de la LGT entre los adquirentes de bienes afectos y los responsables subsidiarios que regula el inciso $d$ ) del apartado primero del artículo 43 de la LGT. Y en este mismo sentido, el RGR vigente dispone que para el ejercicio del derecho de afección se requerirá la declaración de responsabilidad subsidiaria en los términos establecidos en los artículos 174 y 176 de la $\mathrm{LGT}^{521}$.

En síntesis, pues, el poseedor de los bienes afectos puede ser o no el deudor principal de la obligación tributaria, pero cualquiera que sea el poseedor del bien afecto la posición jurídica que ocupa este sujeto se caracteriza por ser el titular de un deber de soportar la ejecución de la garantía que sólo puede anular mediante la realización de la prestación tributaria material, si se trata del sujeto pasivo, o de una prestación de dar una suma de dinero coincidente con el importe de la prestación que es objeto de la obligación tributaria material garantizada, si se trata de un tercero distinto del deudor principal de la obligación principal garantizada.

Por tanto, para el ejercicio del derecho de afección se requiere la declaración de insolvencia del deudor y la derivación tributaria contra los terceros poseedores de los bienes afectos. El acto de derivación ha de notificarse reglamentariamente al tercer adquirente de los bienes dentro del propio expediente de apremio seguido contra el deudor principal. Dicho poseedor tendrá la opción de hacer el pago liberando los bienes afectos, en cuyo caso surge un derecho de regreso o de reembolso frente al sujeto pasivo de la obligación tributaria; dejar que prosiga la acción administrativa; o reclamar contra la liquidación practicada o contra la procedencia de la derivación. Si finalmente no se produce el pago, se dictará providencia de apremio contra el adquirente.

\subsection{EXTINCIÓN DE LA GARANTÍA Y PRESCRIPCIÓN}

A diferencia de lo que sucede con la hipoteca legal tácita, el derecho de afección no tiene límites temporales concretos más allá de los genéricos derivados de la prescripción. Tal previsión se

\footnotetext{
${ }^{520}$ GÓMEZ CABRERA C., La concurrencia del crédito tributario: Aspectos sustantivos y procedimentales. Prelación, garantías, tercerías, ejecuciones preferentes, suspensiones de pago y quiebras, op. cit., pág. 108.

${ }^{521}$ Estos son los artículos encargados de regular el procedimiento de derivación de la responsabilidad tributaria. Vid. infra, Capítulo Cuarto, epígrafe 3. "El procedimiento de derivación de la responsabilidad tributaria".
} 
desprende de la letra del segundo apartado del artículo 79 de la LGT $^{522}$. La LGT en su artículo 66 dispone que prescribirán a los cuatro años el derecho de la Administración tributaria para determinar la deuda mediante la oportuna liquidación; la acción para exigir el pago de las deudas tributarias liquidadas y autoliquidadas; así como el derecho a solicitar las devoluciones derivadas de la normativa de cada tributo, las devoluciones de ingresos indebidos y el reembolso del coste de las garantías. A su vez, el apartado primero del artículo 15 de la LGP también contempla el plazo de prescripción de cuatro años del derecho de la Hacienda Pública estatal para reconocer o liquidar créditos a su favor, contándose dicho plazo desde el día en que el derecho pudo ejercitarse, y para el cobro de los créditos reconocidos o liquidados, a contar desde la fecha de su notificación o, si ésta no fuera preceptiva, desde su vencimiento. A partir del contenido de estos preceptos, la mayoría de los autores consideran que cuando la LGT se refiere a la prescripción del derecho a liquidar y de la acción recaudatoria debe entenderse que se refiere a la prescripción de la obligación tributaria como consecuencia de la no actuación de esas potestades liquidatorias o recaudatorias que debe ejercitar la Administración tributaria ${ }^{523}$.

Finalmente, es importante destacar otro aspecto temporal que se vincula con la afección de bienes. Nos referimos a la caducidad de la nota marginal por la que se puede conferir constancia registral al derecho de afección. En este caso, el artículo 67 del RGR hace mención a la nota marginal de afección que se solicita expresamente y de oficio por el órgano competente, a menos que la liquidación se consigne en el documento que haya de acceder al registro, extendiéndose directamente por este último sin necesidad de solicitud al efecto. También el apartado cuarto del artículo 100 del RISD y el apartado cuarto del artículo 122 del Real Decreto 828/1995, de 29 de mayo, por el que se aprueba el Reglamento del Impuesto sobre Transmisiones Patrimoniales y Actos Jurídicos Documentados, regulan la posibilidad de anotar la afección registralmente. En ambos preceptos se establece que la nota se extenderá de oficio, quedando sin efecto y debiendo ser cancelada cuando se presente la carta de pago de las liquidaciones complementarias y, en todo caso, transcurridos cinco años desde la fecha en que se hubiese extendido. Aquí lo que caduca es la nota marginal, sin que esto signifique que no pueda prorrogarse, porque el artículo 86 de la LH prevé una vigencia de la nota de cuatro años y la posibilidad de solicitar una prórroga por el mismo período a instancia del interesado o por mandato de la Autoridad que la decretó, posibilidad que se reproduce en los mismos términos en la Disposición IX de la LEC.

\section{LA HIPOTECA LEGAL EXPRESA}

La Hacienda Pública dispone de dos tipos de hipotecas legales, la hipoteca legal tácita y la hipoteca legal expresa o especial. En el ámbito tributario, sólo el primer apartado del artículo 66 del RGR se refiere a la hipoteca especial, una figura que se inserta dentro de las hipotecas legales y que, como

\footnotetext{
${ }^{522}$ Según afirma BAS y RIVAS, la afección que surge en el momento de la trasmisión subsiste mientras tenga virtualidad la acción administrativa para exigir el tributo y no transcurran los plazos de prescripción previstos (BAS y RIVAS, F., "La afección de los bienes transmitidos al pago del Impuesto de Derechos Reales”, Revista de Derecho Financiero y Hacienda Pública, núm. 26, 1957, pág. 235).

${ }^{523}$ En este sentido, GÉNOVA GALÁN, A., "La prescripción tributaria”, Revista Española de Derecho Financiero, núm. 57, 1988, pág. 37; VEGA HERRERO, M., La prescripción de la obligación tributaria, La Ley, Valladolid, 1990, pág. 35; FALCÓN Y TELLA, R., La Prescripción en materia tributaria, La Ley, Madrid, 1992, pág. 53, y, del mismo autor, "Prescripción de tributos y sanciones", Revista Española de Derecho Financiero, núm. 98, 1998, pág. 191; MARTÍN CÁCERES, A. F., La prescripción del crédito tributario, Marcial Pons, Madrid, 1994, pág. 48; FERNÁNDEZ JUNQUERA, M., La prescripción de la obligación tributaria. Un estudio jurisprudencial, Aranzadi, Pamplona, 2001, pág. 15 y ss.
} 
veremos seguidamente, una vez constituida adopta el mismo régimen jurídico que una hipoteca legal convencional. La necesidad de su inscripción en el registro correspondiente permite diferenciar esta modalidad de hipoteca de aquéllas de las que se predica su carácter tácito. Sin embargo, es una institución que se relaciona estrechamente con la hipoteca legal tácita, con la que comparte muchas características, por lo que en las próximas líneas sólo nos referiremos a los aspectos distintivos que la configuran.

\section{1. ÁMBITO DE APLICACIÓN}

Los antecedentes de la hipoteca especial se remontan al número 1 de la Regla 20 de la Instrucción General de Recaudación y Contabilidad de 1969, que preveía la constitución de una hipoteca especial para garantizar los débitos que no resultaran amparados por la hipoteca legal tácita que regulaba el artículo 194 de la LH. Dicha previsión se extiende hasta nuestros días y, actualmente, dispone el apartado primero del artículo 66 del RGR que existe la posibilidad de constituir la hipoteca expresa para el cobro de los débitos anteriores o por mayor cantidad de aquéllos a que se refiere el artículo 65 del RGR, precepto este último encargado del desarrollo del artículo 78 de la LGT, que regula la hipoteca legal tácita.

Expresa el primer número del artículo 66 del RGR que

"podrá constituirse voluntariamente por el deudor o ser exigida por la Hacienda pública la constitución de hipoteca especial. Esta hipoteca surtirá efecto desde la fecha en que quede inscrita, de conformidad con lo establecido en el artículo 145 de la Ley Hipotecaria".

Como vemos, la dicción del artículo está en consonancia con lo dispone el apartado tercero del artículo 194 de la $\mathrm{LH}$, que establece que para tener igual preferencia por mayor suma que la correspondiente a las dos anualidades, pueden exigir el Estado, las provincias o los pueblos la constitución de una hipoteca especial, en la forma que determinen los reglamentos administrativos.

Del contenido de ambos preceptos se extrae que si los débitos por los que se ejercita la hipoteca legal tácita se limitan a dos anualidades (el año en que se exige el pago y anterior), podría concluirse que cuando el apartado primero del artículo 66 del RGR se refiere a los débitos anteriores está indicando que son las deudas que, por ser anteriores a las dos anualidades protegidas por la hipoteca legal tácita, no son aplicables a dicha garantía. En definitiva, son las cantidades que podrían estar amparadas por la hipoteca legal tácita pero que quedan excluidas al exceder el límite temporal de aplicación de esta última ${ }^{524}$.

Es importante en este punto hacer precisiones respecto al momento en que se entiende que se exige el pago. Porque si nos ajustamos a la previsión del artículo 65 del RGR, que determina que el derecho real de garantía del artículo 78 de la LGT recae sobre las cantidades correspondientes al ejercicio en que se transmitió el bien o se hizo la inscripción del derecho y al inmediato anterior, entonces la hipoteca especial se aplicaría a las deudas devengadas con anterioridad a aquellas

\footnotetext{
${ }^{524}$ CAMY ESCOBAR, J., “Las garantías de la deuda tributaria y su ejecución”, op. cit., pág. 134.
} 
cantidades. El tiempo que pasaría entre el nacimiento del crédito y el momento en que se procede a ejecutar la hipoteca especial podría determinar que muchas de estas deudas prescribieran, lo que produciría la inoperancia de la hipoteca expresa en la práctica. Por el contrario, si seguimos la tesis que considera que las cantidades protegidas por la hipoteca legal tácita son las correspondientes a las anualidades en que se inició la recaudación en vía de apremio y al año anterior, el riesgo de prescripción podría ser menor, aunque no desaparece por completo.

Otro de los elementos que debemos analizar del contenido de la norma es la utilización de la expresión "por mayor cantidad". No sería correcto entender que esa mayor cantidad es la que se deriva de los créditos que no corresponden a la anualidad en la que se exige el pago, ni la inmediata anterior, y que no están amparados por la hipoteca legal tácita. Esta explicación tampoco se ajusta al contenido del artículo 194 de la LH, porque éste dice expresamente que es la mayor suma que la correspondiente a esas dos anualidades. Además la indicación que hace el apartado primero del artículo 66 del RGR de los débitos anteriores o por mayor cantidad que aquellos a los que se refiere el artículo 65 del RGR denotan la relación que existe entre ambos preceptos. Por eso, podemos decir que la hipoteca especial tiene sentido en aquellos casos en que la limitación temporal de la hipoteca legal tácita impide su ejercicio.

Para otras deudas, el apartado segundo del artículo 66 del RGR prevé la constitución de garantías que ofrece voluntariamente el deudor a la Administración tributaria

“en los casos de aplazamiento y fraccionamiento o en los demás supuestos previstos en la normativa que resulte de aplicación, hipoteca inmobiliaria, hipoteca mobiliaria, prenda sin desplazamiento de la posesión o cualquier otro derecho real de garantía".

Por otra parte, el artículo 194 de la LH limita la hipoteca expresa a las "contribuciones e impuestos que graven los bienes inmuebles". Por lo que entiende CASANA MERINO que el precepto debe interpretarse en sentido amplio, extendiéndose a todos los tributos locales, "salvo en aquellos que por no tener su hecho imponible relación alguna con bienes inmuebles, no sea posible inscribir en el Registro" ${ }^{, 525}$.

Si aceptamos que la hipoteca legal expresa ampara las cantidades que no pueden ser garantizadas por la hipoteca legal tácita por encontrarse fuera de los límites temporales de ésta, entonces asumimos que la hipoteca legal expresa se limita en su aplicación a los impuestos y dentro de éstos los que graven bienes muebles o inmuebles y derechos susceptibles de ser inscritos en el Registro Público de la Propiedad. Es decir, la hipoteca legal expresa del apartado primero del artículo 66 del RGR otorga preferencia para el cobro de los impuestos que graven periódicamente bienes muebles o inmuebles o derechos inscribibles en registros públicos de propiedad o sus productos directos, ciertos o presuntos, cuando estos no puedan ser garantizados a través de la hipoteca legal tácita, por producirse su devengo con anterioridad a las anualidades previstas para el ejercicio de la misma.

\footnotetext{
${ }^{525}$ CASANA MERINO, F., "Las garantías del crédito y los tributos locales”, op. cit., pág. 514.
} 


\subsection{EFICACIA DE LA HIPOTECA LEGAL EXPRESA}

El apartado primero del artículo 66 del RGR establece que la preferencia que concede la hipoteca especial es la misma que la del artículo 65 del RGR. De aquí se deduce que una vez inscrita la hipoteca especial a favor de la Hacienda Pública por anualidades o cantidades distintas a las garantizadas por la hipoteca legal tácita, el efecto es el mismo que el que otorga aquella figura, con la única diferencia que es necesario la inscripción en el Registro.

En este sentido, no parece acertada la remisión que hace el artículo 66 del RGR al artículo 145 de la LH, cuya regulación se destina a las hipotecas voluntarias. Lo adecuado hubiera sido que el RGR se remitiera al artículo 159 de la LH, que ordena la inscripción del título por el cual se crean las hipotecas legales para que las mismas se establezcan válidamente. Asimismo, sería correcto mantener la remisión al artículo 24 de la LH, porque lo que se persigue es destacar que la eficacia de la hipoteca se produce desde la fecha de la inscripción, es decir, desde la fecha del asiento de presentación. Dicho de otra forma, la hipoteca expresa sólo surtirá efectos desde el momento en que quede inscrita, teniendo la inscripción un carácter constitutivo, conforme al apartado 2 del artículo 145 de la LH y el artículo 159 de la LH, aunque los efectos se retrotraen a la fecha del asiento de presentación, a tenor de lo que establece el artículo 24 de la misma LH.

Es importante destacar que la inscripción en el Registro no producirá la misma eficacia para la hipoteca legal tácita y para la hipoteca legal expresa. Así lo indica ARRANZ DE ANDRÉS, porque de no ser así "ello supondría una descarada e injustificada ruptura de las reglas de la mecánica registral, pues si bien los terceros acreedores hipotecarios o titulares de derechos reales pueden conocer que, por ley, existe un hipoteca tácita que, a pesar de su no inscripción, puede ejercitarse para el cobro de dos anualidades de impuestos, con preferencia frente a cualquiera, sería excesivo pretender que también debieran ceder ante inscripciones hipotecarias posteriores cuya existencia y cuantía garantizada no resulta fácil de prever". Y además, “conceder a la Hacienda Pública, a cambio de la carga de instar la inscripción en el Registro, un privilegio de tal entidad (...) no sólo es desproporcionado, sino también quizás contraproducente, pues en modo alguno se incentivaría la diligencia en la recaudación si con independencia del tiempo transcurrido desde el devengo de la deuda tributaria (...) pudiera la Administración pretender el cobro de las deudas atrasadas, con preferencia frente a cualquier otro acreedor que sí hubiera respetado las reglas de la publicidad registral" ${ }^{1526}$.

En nuestra opinión, la preferencia que se desprende de la hipoteca legal expresa es la misma que corresponde a cualquier hipoteca ordinaria, oponible únicamente ante los titulares de créditos ordinarios o de derechos reales no inscritos o inscritos con posterioridad a la fecha en que la misma se incorpora al Registro, aspecto, este último, que diferencia sustancialmente las dos hipotecas legales, la tácita y la expresa ${ }^{527}$.

\footnotetext{
${ }^{526}$ ARRANZ DE ANDRÉS, C., Las garantías reales del crédito tributario: aspectos sustantivos y procedimentales, op. cit., pág. 280.

${ }^{527}$ En este sentido, SIERRA BRAVO, R., “Comentarios a los artículos 36 y ss. RGR”, op. cit., pág. 125 y 126; CHICO Y ORTIZ, J. M., Estudios sobre Derecho Hipotecario, Tomo II, Marcial Pons, Madrid, 1994, pág. 1617; CASTILLO CASTILLO, J., "Comentario al art. 35 RGR", en la obra Comentarios a las Leyes Tributarias y Financieras, Tomo XVI.B.I, Edersa, Madrid, 1991, pág. 125; GÓMEZ CABRERA C., La concurrencia del crédito tributario: Aspectos sustantivos y procedimentales. Prelación, garantías, tercerías, ejecuciones preferentes, suspensiones de pago y quiebras, op. cit., pág. 98.
} 


\subsection{CONSTITUCIÓN DE LA HIPOTECA LEGAL EXPRESA}

Por tratarse de una hipoteca legal, la Hacienda Pública a cuyo favor se dispone tiene la posibilidad de exigir al deudor que proceda a su constitución, tal como estipulan los artículos 158 y siguientes de la LH, de forma que si el deudor no procede según las indicaciones que esos preceptos ordenan podrá el acreedor instar el procedimiento judicial a que se refieren los artículos 165 y 166 de la LH, con el objetivo de lograr la efectiva constitución de la hipoteca que en su beneficio prevé la ley. El artículo 167 de la LH precisa que lo dispuesto por esos dos últimos preceptos se entenderá sin prejuicio de las reglas establecidas sobre hipotecas por bienes reservables y sobre fianza de los tutores, siendo aplicable a la hipoteca legal a favor del Estado, de las provincias o de los pueblos, cuando los reglamentos administrativos no establezcan otro procedimiento para exigirla.

Esta última disposición nos conduce nuevamente al RGR, en concreto al apartado primero del artículo 66 del RGR, aunque el precepto actual, al igual que su antecesor, el apartado primero del artículo 36 del RGR de 1990, no contiene ninguna previsión sobre este punto. Esta situación se manifiesta desde el Real Decreto 448/1995, de 24 de marzo, por el que se modificó el artículo 36 del RGR de 1990. Sin embargo, el artículo 38 del RGR de 1968 y el número 6 de la Regla 20 de la Instrucción General de Recaudación y Contabilidad de 1969, sí establecían la competencia del Delegado de Hacienda, previo Informe del Servicio Jurídico del Estado, para aceptar o acordar, según los casos, la constitución de la hipoteca especial que sería inscrita en el Registro Público correspondiente. Como puede apreciarse, si bien se disponía la competencia del Delegado en estas materias, ésta se limitaba a la solicitud o aceptación de la constitución de la garantía, siguiendo los trámites que con carácter general determinaba la LH.

Actualmente, ante el vacío normativo del apartado primero del artículo 66 del RGR, para determinar el procedimiento de constitución de la hipoteca legal expresa es necesario remitirse al procedimiento ordinario que se establece en las disposiciones hipotecarias. En aquellos casos en que es exigible la hipoteca expresa por parte de la Hacienda Pública, por no haber accedido el deudor a su constitución voluntaria, tendrá que ser solicitada judicialmente por el órgano de recaudación competente en la forma prevista por el artículo 165 de la $\mathrm{LH}^{528}$, y es ésta la razón principal por la que en la práctica esta figura tiene tan poca aplicación.

Como señala CAMY SÁNCHEZ-CAÑETE, la hipoteca expresa o especial nace por una declaración voluntaria de las partes, nunca por intimidación o violencia, aunque puede obligarse a la constitución de la misma por mandato legal ${ }^{529}$. En efecto, la ley determina que debe existir el consentimiento de ambas partes para la constitución de hipotecas voluntarias, pero cuando el acreedor tiene la facultad de exigir que se constituya una hipoteca y el deudor de aceptar tal constitución, una vez que se produzca el supuesto de hecho contemplado en la ley para tales efectos, entonces podemos decir que se cumplen con los requisitos del apartado primero del artículo 66 del RGR. Al respecto expresa ARRANZ DE ANDRÉS que con la constitución de la hipoteca por voluntad del deudor el legislador no quiso decir que se otorgaba "la posibilidad de que fuera éste quien motu proprio procediera a

\footnotetext{
${ }^{528}$ GÓMEZ CABRERA C., La concurrencia del crédito tributario: Aspectos sustantivos y procedimentales. Prelación, garantías, tercerías, ejecuciones preferentes, suspensiones de pago y quiebras, op. cit., pág. 98.

${ }^{529}$ CAMY SÁNCHEZ-CAÑETE, B., Comentarios a la Legislación Hipotecaria, op. cit., pág. 865.
} 
hipotecar sus bienes a fin de garantizar el pago de los tributos, pues estaríamos entonces en el ámbito de las hipotecas voluntarias, expresamente recogidas, por otra parte, en el segundo apartado del mismo artículo 66 RGR y aplicables, por ejemplo, en los casos de aplazamiento o fraccionamiento del pago" ${ }^{, 530}$.

Normalmente es el deudor quien, siguiendo las indicaciones de la Administración tributaria, otorga escritura de hipoteca unilateralmente que, una vez inscrita, se presenta al órgano de recaudación competente. Este órgano, previo informe del órgano de funciones de asesoramiento jurídico sobre la suficiencia de la garantía, debe aceptar la garantía mediante documento administrativo, cuyo contenido provocará la oportuna nota marginal en el correspondiente registro, consolidándose así el derecho de la Hacienda Pública ${ }^{531}$. Una vez que se satisface la deuda tributaria, la Administración tributaria autoriza la cancelación de la garantía de la misma forma en que procedió a su aceptación. En caso contrario, se procederá a la ejecución de la garantía según lo que establece el artículo 74 del RGR, a partir de la remisión que hace el apartado cuarto del artículo 66 del $\mathrm{RGR}^{532}$.

En definitiva, ya sea por exigencia de la Administración tributaria o por acto unilateral del deudor, para que tenga validez la constitución de esta hipoteca legal especial se necesita la inscripción del título en cuya virtud se constituya, según el artículo 159 de la LH, y la inscripción en el Registro de la Propiedad cuando se haga voluntariamente por el deudor, a tenor del apartado 2 del artículo 145 de la LH. Surte entonces esta figura todos los efectos desde la fecha del asiento en que se presente la inscripción, tal como establece el artículo 24 de la LH, y no afectará a los titulares de derechos reales inscritos con anterioridad. Se trata entonces de una hipoteca legal que requiere una inscripción y, desde su constitución, su régimen jurídico coincide en todo con el de las hipotecas legales convencionales.

\subsection{RELEVANCIA PRÁCTICA DE LA HIPOTECA LEGAL EXPRESA}

Es casi unánime en la doctrina la opinión de que esta figura tiene muy poca relevancia práctica. Se llega a afirmar, incluso, que se trata de una garantía inoperante. Así lo expuso ROCA SASTRE, cuando manifestó que la concesión de la hipoteca expresa es pueril porque a la Administración tributaria le interesa, más que la constitución de la hipoteca, la ejecución inmediata de la misma, y dispone además del recurso de la anotación preventiva ${ }^{533}$. También BAYOD PALLARES es del criterio que nunca o casi nunca se utiliza esta hipoteca expresa, porque los preceptos que la regulan

\footnotetext{
${ }^{530}$ ARRANZ DE ANDRÉS, C., Las garantías reales del crédito tributario: aspectos sustantivos y procedimentales, op. cit., pág. 118.

${ }^{531}$ En opinión de CASADO OLLERO, FALCÓN Y TELLA, LOZANO SERRANO, y SIMÓN ACOSTA, todo este proceso resulta superfluo, "pues la Hacienda puede ejercitar directamente y practicar en el procedimiento de apremio la anotación preventiva del embargo". Aunque reconocen que la figura de la hipoteca legal expresa presenta alguna ventaja, puesto que permite embargar en el procedimiento de apremio el bien hipotecado sin plantear el orden de embargo de bienes (CASADO OLLERO, G, FALCÓN Y TELLA, R, LOZANO SERRANO, C y SIMÓN ACOSTA, E., Cuestiones tributarias prácticas, op. cit., pág. 612).

${ }^{532} \mathrm{La}$ ejecución se hará a través del procedimiento ordinario de apremio, por los mismos motivos que expusimos en vid. supra., Capítulo Tercero, epígrafe 1.4.1. "Ejecución de la hipoteca legal tácita".

533 ROCA SASTRE, R. y ROCA SASTRE, L., Derecho Hipotecario, op. cit., pág. 245. En el mismo sentido, ZABALA RODRÍGUEZ-FORNOS, A., LLOPIS GINER, F. y DAGO ELORZA, I., Recaudación, aspectos sustantivos y procedimentales, op. cit., pág. 244; GÓMEZ CABRERA, C., La concurrencia del crédito tributario: Aspectos sustantivos y procedimentales. Prelación, garantías, tercerías, ejecuciones preferentes, suspensiones de pago y quiebras, op. cit., pág. 98; CAMY ESCOBAR, J., "Las garantías de la deuda tributaria y su ejecución”, op. cit., pág. 133.
} 
no son del todo claros, y entiende que si se emplearan en la práctica las hipotecas expresas muchas e importantes sumas de dinero no se declararían fallidas ${ }^{534}$.

Según el RGR, la Hacienda Pública puede exigir que se constituya una hipoteca por las anualidades anteriores a las protegidas por la hipoteca legal tácita. No es difícil de comprender que esta medida no traerá beneficios inmediatos a la Administración tributaria porque ha de esperar a que la misma se constituya voluntariamente por el deudor o se exija judicialmente, tal como se establece en la LH, y teniendo en cuenta además que por ser deudas pendientes de pago pueden exigirse más rápidamente por la vía ejecutiva a través del procedimiento de apremio. Otro de los elementos que va en contra de la aplicación de la hipoteca expresa hay que buscarlo en la existencia del privilegio general del artículo 77 de la LGT, que dispone la anotación preventiva del embargo, ya que ésta siempre tiene preferencia sobre cualquier acreedor ordinario o titular de un derecho real no inscrito antes de la práctica de la anotación, tanto si su crédito ha nacido con anterioridad a la fecha de la anotación como si lo ha hecho con posterioridad ${ }^{535}$.

Aunque la hipoteca legal expresa tiene muy poca relevancia práctica dadas sus características, sin embargo, en algunos casos, puede resultar útil. Especialmente en aquellos supuestos en que se ha interpuesto una tercería de dominio con suspensión del procedimiento de apremio, o una tercería de mejor derecho, o embargos "que deriven en la liquidación del patrimonio ganancial u otros semejantes" 536 , puesto que en todos ellos es previsible que se produzca un pleito de larga duración. Es aquí donde la hipoteca legal expresa puede resultar efectiva si se tiene en cuenta que la anotación preventiva caduca a los cuatro años y que la prórroga de la misma dispone de igual plazo ${ }^{537}$. También resulta operativa la hipoteca legal expresa cuando existe un expediente ejecutivo en marcha y embargos debidamente anotados en los registros públicos, pues entonces el recaudador no puede aumentar los embargos preventivos a pesar de que conoce las deudas impagadas del contribuyente ${ }^{538}$.

\section{SUPUESTOS EXCLUIDOS DE LAS GARANTÍAS REALES DEL CRÉDito TRIBUTARIO}

La LGT incluye dentro de las garantías de la deuda tributaria un grupo de medidas que carecen de los requisitos necesarios para ser concebidas como garantías del crédito tributario en sentido estricto. Si bien es cierto que este conjunto de instituciones tienen como finalidad asegurar el cobro de la Hacienda Pública, con ellas no se logra la ejecución inmediata del crédito tributario. Sin embargo, la

\footnotetext{
${ }^{534}$ BAYOD PALLARES, R. G., "Las liquidaciones de los Impuestos sobre la Renta de las Personas Físicas, sobre Sociedades y sobre el Patrimonio, como créditos preferentes de la Hacienda Pública”, op. cit., pág. 65.

${ }^{535}$ Estas son las razones por las cuales CHICO Y ORTIZ entiende que en la segunda parte del artículo 271 del Reglamento Hipotecario ya no se hace referencia a esta hipoteca, sino a la anotación preventiva, cuando en él se determina que "cuando se trate de contribuciones e impuestos distintos de los señalados en el precedente párrafo, la prelación no afectará a los titulares de derechos reales inscritos con anterioridad a la fecha en que se haga constar en el Registro el derecho al cobro, mediante la correspondiente anotación preventiva de embargo" (CHICO Y ORTIZ, J. M., Estudios sobre Derecho Hipotecario, op. cit., pág. 1617).

${ }^{536}$ CAMY ESCOBAR, J., "Las garantías de la deuda tributaria y su ejecución”, op. cit., pág. 134.

${ }^{537}$ CASADO OLLERO, G., FALCÓN Y TELLA, R., LOZANO SERRANO, C. y SIMÓN ACOSTA, E., Cuestiones tributarias prácticas, op. cit., pág. 617; MARTÍN TIMÓN, M., Embargos y tercerías de la Hacienda Pública, op. cit., pág. 154; GARCÍA GARCÍA, J. M., Código de Legislación Hipotecaria y del Registro Mercantil, op. cit., pág. 797.

${ }^{538}$ BAYOD PALLARES, R. G., "Las liquidaciones de los Impuestos sobre la Renta de las Personas Físicas, sobre Sociedades y sobre el Patrimonio, como créditos preferentes de la Hacienda Pública”, op. cit., pág. 66.
} 
utilización de las mismas junto con otras figuras que tienen naturaleza real como el derecho de afección fortalece la eficacia de estas garantías. Por la función primordial que cumplen en la realización del crédito tributario decidimos referirnos brevemente a estas medidas tutelares. Concretamente haremos alusión al derecho de prelación general, al derecho de retención y a las medidas cautelares, recogidos en los artículos 77, 80 y 81 de la LGT, respectivamente.

\subsection{EL DERECHO DE PRELACIÓN GENERAL}

La preferencia del cobro que no se aplica sobre bienes concretos es sólo una cualidad del crédito y no una medida que se añade al mismo ${ }^{539}$. Sin embargo, tanto en las garantías reales como en las preferencias de cobro lo que persigue el legislador es reforzar la posición jurídica del titular de ciertos créditos tributarios. Como ya vimos, en algunos casos, los que constituyen garantías reales, este reforzamiento se logra atribuyendo una facultad de perseguir un bien concreto, y por lo tanto, con una nota de ajenidad al crédito.

La preferencia de cobro, que excluimos de las garantías reales del crédito tributario por su naturaleza jurídica de privilegio general, se regula como derecho de prelación general en el artículo 77 de la LGT. Constituye un privilegio para el cobro de los créditos de la Hacienda Pública, lo cual implica que estamos ante un crédito preferente que, como tal, se aplica en el ámbito de la concurrencia, en este caso con otros acreedores. De otra forma, si se puede satisfacer íntegramente los créditos de todos los acreedores, la preferencia sólo es un criterio para priorizar la satisfacción de los créditos. Por el contrario, ante una situación de insolvencia en el marco de un concurso, la preferencia general de cobro de la Hacienda Pública se manifiesta cuando, previo embargo y enajenación de bienes embargados, se procede a repartir el valor obtenido con la venta de los mismos. Es en ese instante cuando lo que era una simple cualidad del crédito se convierte en un derecho real sobre el valor realizado $^{540}$, y de ahí la importancia de esta figura para hacer efectivo el crédito tributario.

\subsubsection{Régimen jurídico del derecho de prelación}

La preferencia especial para hacer efectivo el cobro de los tributos ha sido una constante del ordenamiento jurídico. El Código Civil aborda la regulación de los privilegios de los créditos públicos desde dos perspectivas, estableciendo un privilegio especial inmobiliario a favor de determinados tributos del Estado y otro general que afecta a los tributos de la provincia y del municipio por el importe de la última anualidad vencida y no satisfecha. Como aclara LUQUE CORTELLA $^{541}$, no se aprecia en el régimen civil un derecho de prelación general que afecte a todos los créditos tributarios en general, dejando fuera a los tributos más importantes del sistema impositivo que no recaen sobre bienes concretos del contribuyente.

En el ordenamiento tributario el derecho de prelación general tiene sus orígenes en la Ley de Administración y Contabilidad de 1850. Con la entrada en vigor de la LGT de 1963, se incorporó este privilegio al artículo 71 en los términos siguientes

\footnotetext{
${ }^{539}$ Vid. supra, Capítulo Segundo, epígrafe 4.1.2. "Diferencias entre los privilegios y las garantías del crédito tributario".

${ }^{540}$ RODRÍGUEZ BEREIJO, A., “Las garantías del crédito tributario”, op. cit., pág. 195.

${ }^{541}$ LUQUE CORTELLA, A., La Hacienda pública y el crédito tributario en los procesos concursales, op. cit., pág. 97.
} 
"La Hacienda Pública gozará de prelación para el cobro de los créditos tributarios vencidos y no satisfechos en cuanto concurra con acreedores que no lo sean de dominio, prenda, hipoteca o cualquier otro derecho real debidamente inscrito en el correspondiente registro con anterioridad a la fecha en que se haga constar en el mismo el derecho de la Hacienda Pública, sin perjuicio de lo dispuesto en los artículos 73 y 74 de esta Ley”.

Como puede verse el derecho de prelación reconocía una preferencia para el cobro del crédito tributario de la Hacienda Pública frente a cualquier otro acreedor, con la salvedad de los que el propio precepto indicaba. En esta norma no se distinguía entre los procesos singulares o colectivos de ejecución contra el deudor, por lo que el alcance del artículo transcrito era el mismo para ambos. Con la aprobación de la LC se introdujo una modificación en este precepto, añadiéndose un segundo apartado al artículo 71 de la LGT de 1963, para disponer que los créditos tributarios se sometieran en el caso de concurso a lo que estableciera la LC.

Con la entrada en vigor de la actual LGT, el primer apartado del artículo 77 se limita a reproducir fielmente los postulados que anteriormente formaron parte del artículo 71 de la LGT de 1963, mientras que el segundo determina que

"En caso de convenio concursal, los créditos tributarios a los que afecte el convenio, incluidos los derivados de la obligación de realizar pagos a cuenta, quedarán sometidos a lo establecido en la Ley 22/2003, de 9 de julio, Concursal".

La utilización en este apartado del término "convenio concursal" en vez de "concurso" ha planteado bastantes problemas interpretativos, sobre todo si se entiende que la protección con la que el crédito tributario participa en el concurso podrá hacerse valer con el alcance que otorga el primero de los apartados del artículo 77 de la LGT y sin que le afecte el límite del cincuenta por ciento de su importe que establece con carácter general la LC. Esto significaría que las disposiciones de la LC no se aplicarían a la Hacienda Pública a no ser que se subscribiera un convenio, lo cual supondría un problema de coordinación entre ambas normas. Esta interpretación, en fín, produciría contradicciones dentro de la misma LGT, pues la Disposición Adicional Octava de esta norma establece que lo dispuesto en esa ley se aplicará de acuerdo con lo establecido en la legislación concursal vigente en cada momento; el segundo apartado del artículo 164 de la LGT indica que en caso de concurso de acreedores se aplicará lo dispuesto en la LC; el apartado cuarto de este mismo precepto reconoce el derecho de abstención en los procesos concursales, sin perjuicio de la facultad de suscribir convenios, pudiéndose aplicar este privilegio según lo previsto en la LC; y el artículo 89 de la LC excluye cualquier privilegio que no esté reconocido por dicha ley.

La solución a todas estas contradicciones, en opinión de LUQUE CORTELLA, se halla en la propia LGT. Según esta autora, la intención del legislador no es la exclusión expresa de la Hacienda Pública, en caso de liquidación de la empresa, de la regulación concursal que hace la LC, lo que se observa a través de varias remisiones a esa norma. Por el contrario, en los supuestos en los que la Hacienda Pública decida subscribir el convenio se aplicará la normativa concursal, lo cual implica el sometimiento de los créditos tributarios a lo dispuesto en la LC sobre la eficacia y el cumplimento 
del convenio y la posibilidad de que la Administración tributaria pueda renunciar a su posición de acreedor privilegiado, con el correspondiente derecho de abstención. Sobre la parte no privilegiada del crédito tributario que se desprende de la LC, el cincuenta por ciento restantes, la Hacienda podrá aceptar o rechazar la propuesta anticipada u ordinaria de convenio, así como abstenerse, pero no está facultada para subscribir acuerdos sobre condiciones singulares de pago. En suma, en caso de concurso, el privilegio de que goza la Hacienda Pública para hacer efectivo su crédito tributario es el establecido en el artículo 77 de la LGT, con el límite cuantitativo que fija el apartado cuarto del artículo 91 de la LC y con el alcance frente a terceros que se deriva de la citada ley ${ }^{542}$.

Otra de las cuestiones polémicas que tuvo en el pasado esta figura fue la contradicción entre el artículo 71 de la LGT de 1963 y el artículo 132 de la misma ley. Este último precepto, tras reconocer el derecho de la Hacienda Pública a instar la práctica de la anotación preventiva del embargo, remitía al artículo 44 de la LH, que, a su vez, se dirigía al apartado cuarto del artículo 1.923 del Código Civil. Según el artículo 71 de la LGT de 1963, la Hacienda Pública gozaba de preferencia en cuanto concurriera con acreedores que no lo fueran de dominio, prenda, hipoteca o cualquier otro derecho real debidamente inscrito en el correspondiente registro con anterioridad a la fecha en que se hiciera constar en el mismo el derecho de la Administración tributaria. Sin embargo, la remisión a la normativa civil que hacía el artículo 132 de la LGT de 1963 parecía indicar que la anotación preventiva de embargo a favor de la Hacienda únicamente otorgaba a ésta una preferencia respecto a los créditos posteriores, pero no respecto a los anteriores, aunque se inscribieran posteriormente, ya que es esta la regla general en materia de anotaciones de embargo ${ }^{543}$. En definitiva, con las remisiones que hacía el artículo 132 de la LGT de 1963 se vaciaba de contenido el artículo 71 de la propia ley.

La redacción del artículo 132 de la LGT de 1963 se modificó con la Ley 25/1995, y su contenido pasó al segundo apartado del artículo 134. Este precepto señalaba expresamente que la anotación preventiva del embargo a favor de la Administración tributaria no alteraba la prelación que para el cobro de los créditos tributarios establecía el artículo 71 de la LGT de 1963. Quedó claro entonces, según GONZÁLEZ-CARBALLO ALMODÓVAR, que cualquiera que fuera la clase y la fecha de nacimiento de los créditos tributarios, "tienen concedido ex lege, por el simple hecho de su devengo, una prelación o privilegio general que sólo cede frente a los acreedores que para asegurar el pago de sus créditos hayan constituido e inscrito en el correspondiente Registro un derecho real de garantía sobre los bienes de sus deudores con anterioridad a la fecha en que la Hacienda Pública haya hecho constar en ese Registro su derecho de prelación general a través de una anotación preventiva de embargo de aquellos mismos bienes (debiendo prescindirse por errónea, de la referencia a los acreedores de domino, que no es que tengan un crédito preferente al de la Hacienda Pública, sino que son titulares de bienes que ésta no podría embargar y, consiguientemente, disponen de una acción reivindicatoria para recuperarlos)" ${ }^{\$ 44}$. La previsión del apartado segundo del artículo 134 de la LGT de 1963, por último, se incorporó en mejores términos técnicos al apartado segundo del artículo 170

\footnotetext{
${ }^{542}$ LUQUE CORTELLA, A., La Hacienda pública y el crédito tributario en los procesos concursales, op. cit., pág. 100 a 105.

${ }^{543}$ FALCÓN Y TELLA, R., "Las garantías del crédito tributario: perspectivas de reforma”, op. cit., pág. 918.

${ }^{544}$ GONZÁLEZ-CARBALLO ALMODÓVAR, A., "Las garantías del crédito tributario”, op. cit., pág. 452.
} 
de la LGT actual, siguiendo las directrices de la resolución de la Dirección General de los Registros y del Notariado, de 15 de diciembre de 1994.

\subsubsection{Naturaleza jurídica del derecho de prelación}

Para determinar la naturaleza jurídica de esta institución habrá que preguntarse si estamos ante una garantía en sentido estricto o un privilegio. La confusión que se observa en la doctrina está motivada por la creencia de algunos autores de que se trata de una garantía real porque otorga preferencia sobre el valor del bien. En este sentido, debemos recordar que al referirnos a las diferencias entre los derechos reales y los privilegios generales decíamos, a grosso modo, que los derechos reales de garantía conceden a diferencia de los derechos de prelación la facultad de perseguir el bien sobre el que se han constituido e instar su realización con independencia de quien sea su titular. Al ser el derecho de prelación una simple cualidad del crédito, una facultad atribuida a éste, su efectividad se manifiesta sólo en el momento del concurso, o lo que es lo mismo, cuando previo embargo y enajenación de los bienes se procede a distribuir la cantidad resultante entre los distintos acreedores. Aquí no puede olvidarse que el privilegio que establece el artículo 77 de la LGT concede a la Hacienda Pública una preferencia para el cobro que le permite anteponerse al resto de los acreedores concurrentes, siempre y cuando éstos no sean de dominio, hipoteca, prenda o cualquier otro inscrito con anterioridad a la fecha en que se haga constar el de la Administración tributaria ${ }^{545}$.

Para determinar si la naturaleza de la prelación general es la de una garantía real, lo primero que debe apreciarse es si se otorga con ella al acreedor privilegiado un derecho especial sobre los bienes del deudor. La negativa a esta interrogante permite afirmar que el derecho de prelación general no es un derecho real de garantía, pues no se concede al acreedor un derecho subjetivo autónomo especial sobre los bienes del deudor. Como dijimos, el privilegio general es una simple cualidad del crédito que forma parte del contenido general de un derecho más amplio que es el propio derecho del crédito. $\mathrm{Su}$ aplicación se observa solamente cuando se produce un concurso de acreedores, esto es, previo embargo de bienes y enajenación del patrimonio o de los bienes embargados, procediéndose entonces al reparto del valor obtenido en la venta de los mismos ${ }^{546}$. Es en este momento, dice RODRÍGUEZ BEREIJO, que "el privilegio de simple cualidad del crédito, se transforma en un derecho real sobre el valor realizado, como derecho de prelación". Para este autor la verdadera naturaleza jurídica del privilegio general es la de un instituto jurídico típicamente procesal, porque "no determina el nacimiento de una obligación particular a cargo del sujeto frente al cual se ejercita por ser poseedor del bien sujeto a la garantía, ni tampoco hace a la cosa «responsable» o incluso «obligada»"547.

\footnotetext{
${ }^{545}$ Por ello GUERVÓS MAÍlLO, y LAGO MONTERO afirman que estamos ante un privilegio que es relativo y no absoluto, porque la Hacienda Pública vence a los acreedores no hipotecarios, pero cede ante acreedores hipotecarios; que es, pues, poco operativo; y que para ser preferente a éstos la Administración tributaria actuante deberá haber anotado su derecho en el Registro mediante anotación preventiva de embargo antes de que los acreedores hipotecarios anotaran el suyo, en los términos clásicamente establecidos por la legislación hipotecaria (GUERVÓS MAÍLLO, M. A., y LAGO MONTERO, J. M., "Las garantías del crédito tributario (Comentario a los artículos 71, 72, 73, 75, 75 y 76 L.G.T.)", op. cit., pág. 133).

${ }^{546}$ Esto explica que para algunos autores el derecho de prelación sea una garantía procedimental, alejándose de la clasificación tradicionalmente aceptada por la doctrina para distinguir las garantías en sentido estricto. En este sentido, MUÑOZ MERINO, A., Privilegios del crédito tributario: el derecho de prelación general, op. cit., pág. 57 a 63.

${ }^{547}$ RODRÍGUEZ BEREIJO, A., "Las garantías del crédito tributario”, op. cit., pág. 195 y 196.
} 
Es necesario precisar, en todo caso, que la constancia registral del derecho de prelación no sirve para apreciar efectos reales en el mismo, sin perjuicio de que sea necesario que la anotación se practique en el Registro para que el privilegio que concede la ley a la Hacienda Pública no se vea desplazado por los derechos de otros acreedores. En efecto, cualquier derecho que no se inscriba antes de que se practique la anotación en el Registro del derecho de prelación de la Administración tributaria quedará subordinado a la pretensión de ésta. Y ello con independencia del momento en que se originen esos derechos, que sería el criterio a seguir si se ajustara a la aplicación de la previsión del artículo 44 de la LH y el apartado 4 del artículo 1.923 del Código Civil.

Podemos decir, en síntesis, que el derecho de prelación consiste en un privilegio para el cobro, oponible frente a cualquier derecho no inscrito con anterioridad a la inscripción de la anotación del embargo de la Hacienda Pública, y no sólo, como establecen los preceptos de la LH y el Código Civil para este tipo de asientos registrales, frente a los derechos surgidos con posterioridad a la anotación. También primarán los derechos de la Administración tributaria sobre otros derechos no inscritos, sino simplemente anotados, aun cuando la anotación sea anterior o proteja un derecho nacido con anterioridad, porque éstos últimos no constituyen verdaderos derechos reales.

Por lo que se acaba de decir, es muy importante que la Hacienda Pública haga la anotación del embargo en el Registro de la Propiedad. Ello no implica que el derecho de prelación nazca de la anotación de embargo, puesto que su origen está en la ley y esta anotación es sólo el medio por el que el derecho toma vida y adquiere mayor eficacia. "La anotación es, por tanto, preceptiva, pero no constitutiva del privilegio, siendo opinión jurisprudencial consolidada la de que ni el embargo ni su anotación nada prejuzgan sobre la verdadera identidad y eficacia de los créditos ni alteran la naturaleza de las obligaciones para cuya efectividad se decretan, no adquiriendo el derecho, en virtud de la anotación, una cualidad de la que carecía con anterioridad a su constancia registral"548. La anotación registral de crédito tributario, por tanto, otorga a la Hacienda Pública un mejor derecho para el cobro, pero la práctica de dicho privilegio se sujeta al establecimiento de la correspondiente tercería de mejor derecho frente al que sería el acreedor preferente.

Finalmente, creemos que el derecho de prelación general implica una preferencia para el cobro de la que dispone un acreedor en un concurso de acreedores frente a un deudor ejecutado. La prelación del crédito aparece en vía de apremio, cuando existen dudas sobre si será suficiente el líquido obtenido con la ejecución del patrimonio del deudor para cubrir todas las deudas. En este caso, la Administración tributaria tendrá preferencia para hacer efectivo su crédito, siempre que no concurra con acreedores de dominio, prenda, hipoteca u otro derecho real debidamente inscrito en el registro correspondiente con anterioridad a la fecha en que se haga constar en el mismo la anotación preventiva del embargo por parte de la Hacienda Pública.

\footnotetext{
${ }^{548}$ ARRANZ DE ANDRÉS, C., Las garantías reales del crédito tributario: aspectos sustantivos y procedimentales, op. cit., pág. 88. En la jurisprudencia, vid. por todas la Sentencia del Tribunal Supremo de 24 de febrero de 1995.
} 


\subsection{3. Ámbito de aplicación}

\subsubsection{Aspecto subjetivo}

Al igual que hizo el artículo 71 de la LGT de 1963, la ley actual sigue atribuyendo la prelación general a los créditos de la Hacienda Pública. El hecho de que se haga la atribución a la Hacienda Pública ha producido y produce actualmente, aunque en menor medida, opiniones encontradas acerca de que si debe entenderse como titular de la prelación general exclusivamente a la Hacienda estatal o si por el contrario, se concede a todos los niveles de la Administración territorial. La doctrina en estos momentos acepta casi con unanimidad el criterio de que el derecho de prelación general se aplica a todos los créditos tributarios, ya sean estatales, autonómicos, o locales.

Sin embargo, durante el mandato de la LGT de 1963 muchos autores afirmaron que el término de Hacienda Pública se refería exclusivamente a la Hacienda del Estado y de este modo interpretaron que el privilegio del artículo 71 de la LGT de 1963 quedaba reservado para aquellos tributos en los que el sujeto activo fuera la Administración financiera del Estado. Así RODRÍGUEZ BEREIJO expresó que "el privilegio general establecido lo es a favor de la Hacienda Pública estatal, esto es la Administración financiera del Estado. Y ello, (...) por dos razones sistemáticas: Una, que en el artículo 73 el legislador se refiere a las Provincias y Municipios, lo que significa que cuando se quiere aludir a estas Administraciones financieras lo hace expresa y claramente. La segunda, se deduce del artículo 62.3 LGT, donde se distingue la Hacienda Pública de los demás entes públicos posibles acreedores de la obligación tributaria",549.

Por su parte, FALCÓN Y TELLA, fue partidario de esta misma postura a partir de la valoración que hizo del artículo 2 del Real Decreto Legislativo 1091/1988, de 23 de septiembre, Ley General Presupuestaria. No obstante, matizó sus planteamientos al señalar que las "garantías reguladas respecto al Estado en los artículos 71 y ss. LGT son en principio aplicables a las Haciendas Territoriales, incluso en los supuestos de silencio de la Ley sobre este punto, si bien ha de tenerse en cuenta que la Hacienda Pública usada en los arts. 71 y 75 de la LGT hace referencia exclusivamente a la Hacienda del Estado y de sus organismos autónomos" ${ }^{\text {,50 }}$.

Concretamente, los defensores de que el privilegio sólo es aplicable a la Hacienda estatal justifican su postura sobre la base de que cuando el legislador quiere aludir a las Haciendas territoriales se refiere a ellas expresamente, como ocurría en el artículo 73 de la LGT de 1963. También apoyan su tesis en la distinción que hacía la ley entre la Hacienda Pública y los demás entes públicos posibles acreedores de obligaciones tributarias, a tenor de lo que establecía el apartado 3 del artículo 62 de la LGT de 1963. Por otro lado, afirman que cuando concurran junto a la Hacienda estatal otros organismos autónomos, el privilegio del artículo 71 de la LGT de 1963 cedía en beneficio de aquélla, tal como aparecía estipulado en el apartado segundo del artículo 32 de la LGP de $1988^{551}$.

\footnotetext{
${ }^{549}$ RODRÍGUEZ BEREIJO, A., "Las garantías del crédito tributario", op. cit., pág. 196. En un sentido similar, CASANA MERINO, F., "Las garantías del crédito y los tributos locales", op. cit., pág. 507 a 508.

${ }^{550}$ FALCÓN Y TELLA, R., "Las garantías del crédito tributario", op. cit., pág. 612, y, del mismo autor, "Las garantías del crédito tributario: perspectivas de reforma”, op. cit., pág. 917.

551 "Respecto a los créditos nacidos en otros Estados miembros de la CEE y amparados en un título que permita su ejecución y para los que se haya tramitado petición de cobro en el marco de la asistencia mutua, que tienen la consideración de créditos nacionales,
} 
Al estudiar la normativa que venimos indicando, MUÑOZ MERINO manifiesta que existen dos puntos claves para dilucidar el titular del derecho de prelación. Lo primero que dice la autora es que no encuentra razones que avalen la distinción entre los tributos autonómicos, locales o estatales que permita excluir a los dos primeros del artículo 71 de la LGT de 1963. En segundo lugar, si se acepta que la prelación de créditos tributarios afecta sólo a los tributos estatales quedaría sin aplicación esta institución en todos aquellos casos en los que se halla cedida la gestión de estos tributos a las Comunidades Autónomas. Por eso concluye esta autora que la garantía que regulaba el artículo 71 de la LGT de 1963, "ha de ser efectiva en cualquier tributo, con independencia de quién sea el titular del poder de imposición. Para determinar el sujeto activo no sólo del derecho de crédito, sino de los derechos subjetivos o facultades que implica la garantía habrá que atender, por tanto, al Ente público al que se haya encomendado la gestión y recaudación del mismo, y todo ello con independencia de que sea un ente público estatal, autonómico o local”,552.

Para resolver la interrogante de los niveles territoriales a los que resulta aplicable el derecho de prelación habrá que dirigirse a las disposiciones de la LGT actual sobre su aplicabilidad a las distintas Administraciones públicas. En este sentido, apunta GARCÍA NOVOA que la ley adolece de un grave defecto, el no haber incorporado una disposición en la que se detallaran qué preceptos tienen carácter básico y por ende, de aplicación al Estado, Comunidades Autónomas y Entes Locales. "Por tanto, no queda claro si la prelación se refiere exclusivamente a los créditos del Estado, ya que en teoría una Comunidad Autónoma podría apartarse de la regulación de la Ley respecto a sus tributos propios". Aunque precisa el mismo autor que con la redacción actual de la norma hay que entender que la referencia a la Hacienda Pública lo es a esta Hacienda en un sentido subjetivo, es decir al Estado y los demás entes públicos ${ }^{553}$.

En sentido similar, el criterio de LUQUE CORTELLA es que la identificación de la Hacienda pública solamente con la Hacienda estatal es insostenible, porque desconoce los postulados de la LOFCA y de la LRHL, normas que a su vez determinan que los privilegios que acompañan a los créditos tributarios de la Hacienda central se extienden también a los demás niveles de Administración ${ }^{554}$.

En efecto, el apartado tercero del artículo 2 de la LOFCA dispone que las Comunidades Autónomas gozan del tratamiento fiscal que la Ley establece para el Estado. A su vez, el apartado segundo del artículo 2 de la LRHL indica que para la cobranza de los tributos y de las cantidades que como ingresos de Derecho público, tales como prestaciones patrimoniales de carácter público no tributarias, precios públicos, y multas y sanciones pecuniarias, debe percibir la Hacienda de las

expresamente, se dispone que no gozarán de los privilegios que señala el art. 71 LGT (art. 10.2 RDLeg. 1299/86 de 28 de junio, BOE del 30, por el que se modifica el TR de los Impuestos integrantes de la renta de Aduanas; y art. 24 RD 1068/1988, de 19 de septiembre, por el que se desarrollan determinadas directivas comunitarias sobre asistencia mutua en materia de recaudación, $B O E$ de 22 de septiembre)" (CASADO OLLERO, G., FALCÓN Y TELLA, R., LOZANO SERRANO, C. y SIMÓN ACOSTA, E., Cuestiones tributarias prácticas, op. cit., pág. 612).

${ }^{552}$ MUÑOZ MERINO, A., Privilegios del crédito tributario: el derecho de prelación general, op. cit., pág. 66 a 88 . En esta parte de su obra la autora analiza y critica cada uno de los argumentos que se emitieron en la doctrina a favor de la interpretación de la Hacienda Pública exclusivamente como Hacienda Estatal.

${ }^{553}$ GARCÍA NOVOA, C., "Garantías de la deuda tributaria”, op. cit., pág. 332 a 333.

${ }^{554}$ LUQUE CORTELLA, A., La Hacienda pública y el crédito tributario en los procesos concursales, op. cit., pág. 105 a 106. 
Entidades locales, ésta ostentará las prerrogativas establecidas legalmente para la Hacienda del Estado, y actuará, en su caso, conforme a los procedimientos administrativos correspondientes. Además la LGP actual, en el número 2 del artículo 9, hace referencia a los créditos de los organismos autónomos y de la Seguridad Social, para especificar la preferencia de éstos con los de la Hacienda pública.

En definitiva, entendemos que el derecho de prelación general se refiere a los créditos públicos de todos los entes de base territorial, teniendo en cuenta además que el apartado cuarto del artículo 91 de la LC atribuye la prelación general a los créditos tributarios y de Derecho público de manera general, afectando a todos los acreedores tributarios, y que esto significa que este carácter privilegiado ha de extenderse a los créditos tributarios del Estado, Comunidades Autónomas y Corporaciones Locales $^{555}$.

Por último, la LGT no resuelve cuál es la Administración que tiene preferencia para el cobro cuando concurren en un mismo procedimiento de ejecución varias Administraciones alegando la prelación de sus respectivos créditos tributarios. Éste es un asunto que se resuelve sin contratiempos cuando estamos en presencia de débitos garantizados por hipoteca legal o especial, pero no en los demás casos. Aquí debemos remitirnos al mandato del segundo apartado del artículo 9 de la LGP, que ya mencionamos, y recordar que este precepto estipula que cuando los organismos autónomos concurran con la Administración General del Estado tendrá preferencia para el cobro de los créditos esta última. Y también podremos apoyarnos en el párrafo sexto del apartado tercero del artículo 10 de la LGP, que dispone que reglamentariamente se establecerán los procedimientos para asegurar la adecuada coordinación en los procedimientos concursales en que concurran créditos de la Hacienda Pública estatal con créditos de la Seguridad Social y del resto de las entidades que integran el sector público Estatal, y en aquellos procedimientos concursales en los que se concurra con procedimientos judiciales o administrativos de ejecución singular correspondientes a las referidas entidades.

\subsubsection{Aspecto objetivo}

En relación con la limitación objetiva del derecho de prelación, la LGT se refiere a los créditos tributarios vencidos y no satisfechos. Es importante tener en cuenta la naturaleza tributaria del crédito que queda protegido por el derecho de prelación, que en principio se circunscribe a los créditos de carácter tributario. Partiendo del hecho de que los tributos tienen una finalidad recaudatoria y por ello el interés jurídico de las normas que lo regulan es un interés público y financiero ${ }^{556}$, no puede

\footnotetext{
${ }^{555}$ En este sentido, GUERVÓS MAÍLLO, M. A., y LAGO MONTERO, J. M., "Las garantías del crédito tributario (Comentario a los artículos 71, 72, 73, 75, 75 y 76 L.G.T.)", op. cit., pág. 133.

${ }^{556}$ CASADO OLLERO, G., El sistema impositivo de las Comunidades Autónomas, Publicaciones del Instituto de Desarrollo Regional, Granada, 1981, pág. 80 y ss.; CHECA GONZÁLEZ, C., "Los impuestos con fines no fiscales: notas sobre las causas que lo justifican y sobre su admisibilidad constitucional", Revista Española de Derecho Financiero, núm. 40, 1983, pág. 508 a 512; SIMÓN ACOSTA, E., El Derecho Financiero y la Ciencia Jurídica, Publicaciones del Real Colegio de España, Bolonia, 1985, pág. 148; MUÑOZ MERINO, A., Privilegios del crédito tributario: el derecho de prelación general, op. cit., pág. 89; LUQUE CORTELLA, A., La Hacienda pública y el crédito tributario en los procesos concursales, op. cit., pág. 106. En contra de esta tesis, CORTÉS DOMÍNGUEZ, M. y MARTÍN DELGADO, J. M., Ordenamiento tributario español, Civitas, Madrid, 1977, pág. 149.
} 
extenderse el derecho de prelación a otros ingresos públicos no tributarios, lo que no significa que se encuentren desprotegidos, por existir normas que establecen garantías concretas a su favor ${ }^{557}$.

Sin embargo, en otras normas se amplía el tipo de crédito que ampara el derecho de prelación general, como puede verse en el apartado cuarto del artículo 91 de la LC, que junto a los créditos tributarios alude a los demás de Derecho público. Así pues, siguiendo lo estipulado en esta norma, sería acertado extender la prelación general al ámbito de los precios públicos, cuya legislación reguladora califica como ingresos de Derecho público.

Por otra parte, se presenta la interrogante de si es aplicable el derecho de prelación general a las cantidades obtenidas de las multas y las sanciones. La solución la brinda la LGT al determinar que las sanciones impuestas por la Administración tributaria quedan fuera de los elementos que integran la deuda tributaria $\mathrm{y}$, por tanto, no entran en el ámbito de protección que el derecho de prelación concede al crédito tributario. En este sentido, el número cuatro del artículo 92 de la LC también excluye a las sanciones y multas de los privilegios que acompañan a la deuda tributaria y las coloca por detrás de los demás créditos.

Como indicamos al principio, para que pueda aplicarse el derecho de prelación general la LGT dispone también que los créditos estén vencidos y no satisfechos, es decir, que se encuentre agotado el período voluntario de pago sin que el deudor haya realizado la prestación debida en su integridad, situación que genera el inicio del período ejecutivo siempre que la deuda sea del conocimiento de la Administración tributaria. Esto significa que si existe peligro para la satisfacción del crédito tributario, incluso por insolvencia demostrada del deudor, la Administración tributaria no podrá beneficiarse de este derecho ni podrá anticiparse al vencimiento de los créditos antes de la liquidación de la deuda ${ }^{558}$, aunque LUQUE CORTELLA entiende que cuando la LGT se refiere a créditos vencidos y no satisfechos no quiere decir necesariamente que el crédito se encuentre liquidado, siendo suficiente que sea un crédito líquido, que refleje una deuda de cuantía determinada $^{559}$. El Tribunal Supremo, sin embargo, amparado en el anterior artículo 71 de la LGT de 1963, había venido exigiendo que siempre se tratara de créditos que ya estuvieran liquidados, tal como se argumenta, entre otras, en las Sentencias de 27 de febrero de 1930 y de 2 de mayo de 1963, y esta doctrina fue criticada, entre otros, por SERRERA CONTRERAS y MOLINA GARCÍA ${ }^{560}$. CASADO OLLERO, FALCÓN Y TELLA, LOZANO SERRANO, y SIMÓN ACOSTA son del criterio que, tras la generalización del sistema de autoliquidaciones, deben considerarse vencidos los

\footnotetext{
${ }^{557}$ Recuerda MUÑOZ MERINO que el artículo 31 de la LGP anterior establecía que "para la cobranza de los tributos y de las cantidades que como ingresos de Derecho Público deba percibir la Hacienda Pública ostentará las prerrogativas establecidas legalmente y actuará en su caso, conforme a los pronunciamientos administrativos correspondientes" (MUÑOZ MERINO, A., Privilegios del crédito tributario: el derecho de prelación general, op. cit., pág. 91).

${ }^{558}$ Como señala RODRÍGUEZ BEREIJO, el apartado cuarto del artículo 62 de la LGT de 1963 indicaba que "el cobro de un débito de vencimiento posterior no extingue el derecho de la Hacienda pública a percibir los anteriores en descubierto". El contenido de este precepto significa sin duda una excepción a favor de la Hacienda Pública en relación con la regla general que establece el segundo párrafo del artículo 1.110 del Código Civil, donde se dice que "el recibo del último plazo de un débito, cuando el acreedor tampoco hiciere reservas, extinguirá la obligación en cuanto a los plazos anteriores" (RODRÍGUEZ BEREIJO, A., "Las garantías del crédito tributario", op. cit., pág. 197).

${ }^{559}$ LUQUE CORTELLA, A., La Hacienda pública y el crédito tributario en los procesos concursales, op. cit., pág. 107.

${ }^{560}$ SERRERA CONTRERAS, P. L., "La prelación general de créditos tributarios (artículo 71 de la Ley General Tributaria)", en la obra Estudios de Derecho Tributario, Vol. II, Instituto de Estudios Fiscales, Madrid, 1982, pág. 926; MOLINA GARCÍA, A., La prelación general de créditos del Estado (Estudio de jurisprudencia sobre el art. 1931 CC), Montecorvo, Madrid, 1977, pág. 112 a 121.
} 
créditos que se deriven de éstas por el transcurso del plazo del período voluntario y que, por lo tanto, a los mismos puede aplicarse el contenido del artículo 71 de la $\mathrm{LGT}^{561}$.

\subsubsection{Eficacia del derecho de prelación general}

\subsubsection{El derecho de prelación en los procesos singulares de ejecución forzosa}

Como ya hemos manifestado en los apartados anteriores, la Hacienda Pública goza de preferencia para cobrar todos sus créditos liquidados o autoliquidados que se encuentren vencidos y no satisfechos, una vez que transcurre el período voluntario de pago, si concurre con acreedores que no lo sean de domino, prenda o hipoteca, o cualquier otro derecho real, que fuera inscrito en el Registro correspondiente con anterioridad a la fecha en que se haga constar en el Registro el derecho de la Hacienda Pública. Porque aun cuando el crédito tributario no es susceptible de inscripción registral ni tampoco el derecho de prelación, sí cabe la posibilidad de acceder al registro a efecto de garantizar el cobro mediante anotación de embargo, sin perjuicio de que la preferencia a la que nos referimos tenga su origen en la ley y no en la anotación y se aprecien con ello en relación con esta figura "ciertas notas de eficacia erga omnes, definitorias de toda garantía real",

Esto significa que para que la Administración tributaria sea preferente en el cobro de su crédito tendrá que haber inscrito antes que los demás acreedores ordinarios su derecho a través de la anotación preventiva de embargo ${ }^{563}$; de lo contrario, si ya con anterioridad existía inscrito un derecho real, la prelación general cederá ante este último. El único caso en que no es necesario realizar la inscripción es el de acreedores de domino, pues este tipo de acreedores son los dueños legítimos de los bienes que se encuentran en el patrimonio del deudor y no requieren de la inscripción registral de su derecho para hacerlo valer frente a terceros.

Una de las cuestiones que se debate en este tema es la necesidad de que exista la constancia registral para poder hacer valer el derecho de prelación. Según LUQUE CORTELLA, esa no era la pretensión del legislador a la hora de redactar el artículo 77 de la LGT, puesto que ello supondría vaciar de contenido el derecho de prelación general. La ley, indica esta autora, otorga a la Hacienda Pública el derecho de prelación para el cobro de los créditos tributarios vencidos y no satisfechos y los convierte en privilegiados por el mero hecho de su devengo, sin que se precise ningún otro requisito. "Condicionar la eficacia del art. 77 de la LGT a la anotación preventiva del embargo fiscal sería tanto

\footnotetext{
${ }^{561}$ CASADO OLLERO, G, FALCÓN Y TELLA, R, LOZANO SERRANO, C. y SIMÓN ACOSTA, E., Cuestiones tributarias prácticas, op. cit., pág. 612. En el mismo sentido, FALCÓN Y TELLA, R., "Las garantías del crédito tributario: perspectivas de reforma”, op. cit., pág. 920.

562 GARCÍA NOVOA, C., "Garantías de la deuda tributaria”, op. cit., pág. 329. En el mismo sentido, ARRANZ DE ANDRÉS, C., "Sobre la naturaleza del derecho de prelación general de la Hacienda Pública y su anotación en el registro: a propósito de una Sentencia del Tribunal Superior de Justicia de la Rioja de 21 de julio de 1997”, Jurisprudencia Tributaria, 1998-III, pág. 1361 a 1374.

${ }^{563}$ Existe alguna jurisprudencia del Tribunal Supremo que señala incluso que un tercero titular de un derecho real cuya adquisición se produjo con anterioridad a la anotación del derecho de la Administración tributaria tendrá preferencia en el cobro aunque no tuviera inscrito su derecho. Entre otras, las Sentencias del Tribunal Supremo de 3 de noviembre de 1984, de 20 de abril de 1987, de 3 de mayo de 1988, de 26 de marzo de 1991, de 1 de junio de 1992, de 23 de octubre de 2006. En la doctrina, puede destacarse a favor de esta postura el trabajo de SERRERA CONTRERAS, P. L., "La prelación general de créditos tributarios (artículo 71 de la Ley General Tributaria)", op. cit., pág. 932.
} 
como relegarla al rango de cualquier acreedor ordinario que inscribiera supeditando su derecho a la fecha de anotación de su crédito" ${ }^{964}$.

De esta forma podemos decir que el derecho de prelación general afecta a todos los créditos tributarios, con independencia de su constancia registral, y que sólo cede ante los acreedores de derechos reales que hayan inscrito su derecho con anterioridad a la anotación pero no ante otros que hayan logrado la anotación preventiva del embargo antes de la Hacienda pública. Es por ello que, tal como destaca GONZÁLEZ-CARBALLO ALMODÓVAR, si el crédito tributario consta en el Registro y concurre con otra garantía real, para determinar la preferencia habrá que dirigirse a la fecha de los respectivos asientos registrales, lo que convierte al privilegio general del artículo 77 de la LGT en una preferencia de grado y no de fecha ${ }^{565}$. Con ello estamos diciendo que la prelación general prevalece frente a otros titulares de derechos de créditos comunes, aunque éstos se encuentren vencidos y hayan sido anotados en el correspondiente Registro antes que los de la Hacienda Pública.

Esta interpretación puede verse respaldada con la letra del tercer párrafo del apartado segundo del artículo 170 de la LGT, según el cual

"la anotación preventiva así practicada no alterará la prelación que para el cobro de los créditos tributarios establece el artículo 77 de esta Ley, siempre que se ejercite la tercería de mejor derecho. En caso contrario, prevalecerá el orden registral de las anotaciones de embargo".

Según se desprende del precepto transcrito, en los procesos singulares de ejecución forzosa los órganos ejecutores no pueden apreciar de oficio el carácter privilegiado del crédito de la Hacienda Pública, que aparece recogido en el apartado primero del artículo 77 de la LGT, de manera que en estos casos la Administración tributaria deberá hacer valer su preferencia de cobro a través de la interposición en tiempo y forma de una tercería de mejor derecho, tal como se regula en el artículo 44 de la LH y en el apartado cuarto del artículo 1.923 del Código Civil ${ }^{566}$. De lo contrario la adjudicación se hará a favor de los rematantes de los bienes embargados y ejecutados a instancia de esos otros acreedores preferentes registralmente, lo que producirá la extinción jurídica de los embargos administrativos posteriores de la Hacienda pública, con la cancelación de sus anotaciones registrales, que sólo podrá aspirar a los sobrantes que queden de las ejecuciones realizadas.

Ésta es la regulación que asume el RGR en el apartado primero del artículo 64 al determinar que, conforme a lo que regula el artículo 77 de la LGT,

"cuando existan anotaciones de embargo en los Registros de la Propiedad y de Bienes Muebles, practicadas con anterioridad a la del crédito de la Hacienda pública sobre unos mismos bienes embargados, el órgano de

\footnotetext{
${ }^{564}$ LUQUE CORTELlA, A., La Hacienda pública y el crédito tributario en los procesos concursales, op. cit., pág. 108. En los mismos términos se manifiesta MUÑOZ MERINO en relación con el contenido del artículo 71 de la LGT de 1963 (MUÑOZ MERINO, A., Privilegios del crédito tributario: el derecho de prelación general, op. cit., pág. 120).

${ }^{565}$ GONZÁLEZ-CARBALLO ALMODÓVAR, A., "Las garantías del crédito tributario”, op. cit., pág. 452 a 453.

${ }^{566}$ Resolución de la Dirección General de los Registros y del Notario de 13 de noviembre de 1997.
} 
recaudación podrá elevar al órgano competente el expediente a efectos de acordar, si procede, el ejercicio de la acción de tercería de mejor derecho en defensa de los intereses de la Hacienda pública, previo informe del órgano con funciones de asesoramiento jurídico".

\subsubsection{El derecho de prelación en las situaciones de concurso}

Establece el Código Civil, en el segundo párrafo del artículo 1.921, que en caso de concurso la clasificación y graduación de los créditos se regirá por lo dispuesto en la LC. En este sentido, el apartado segundo del artículo 55 de la LC determina la suspensión de todo procedimiento de apremio, salvo que la fecha de la providencia de apremio sea anterior a la declaración del concurso, y sin perjuicio del tratamiento concursal que corresponda dar a los respectivos créditos. De esta forma, una vez que se declara el concurso del deudor, los privilegios y garantías del crédito tributario quedan sometidos al régimen de la LC. Por ello, los créditos tributarios pasan a considerarse créditos concursales y como tal deben integrase en la masa pasiva ${ }^{567}$.

A tenor de los artículos 89 a 92 de la LC, los créditos pueden clasificarse como créditos con privilegio especial, créditos con privilegio general, créditos ordinarios, y créditos subordinados. En los primeros, el privilegio afecta a determinados bienes o derechos, tal como se indica en el artículo 90 de la LC. El apartado primero de este precepto incluye en este grupo a los créditos garantizados con hipoteca voluntaria o legal, inmobiliaria o mobiliaria, o con prenda sin desplazamiento sobre los bienes hipotecados o pignorados. Esto implica que quedan fuera los créditos tributarios garantizados con afecciones reales. Para que estos últimos puedan ser clasificados como créditos privilegiados especiales la garantía tendrá que ser constituida con los requisitos y formalidades que determina su legislación para su oponibilidad a terceros, escritura e inscripción registral, salvo que sea de aplicación la hipoteca legal tácita del artículo 78 de la LGT.

En estos casos, si al tiempo de declarar el concurso no se ha dictado la providencia de apremio, se detiene la tramitación de dicho procedimiento concursal para la ejecución de la hipoteca legal o tácita y, a juicio de CAMY ESCOBAR, prevalece el apartado primero del artículo 55 de la LC sobre el artículo 56 de la misma ley, de modo que la fecha a tener en consideración para continuar con la ejecución separada será la que corresponda a la providencia de apremio y la publicación de los anuncios de subasta ${ }^{568}$. Además, siempre que el bien sea necesario para mantener la actividad profesional o empresarial del deudor, se detendrá provisionalmente la ejecución en tanto se negocie un convenio o se abra la liquidación. Estos créditos, por su privilegio especial, sólo se verán afectados por el convenio si la Administración firma la propuesta, vota a su favor, o posteriormente se adhiere a ella o al convenio aprobado. De no existir un convenio que afecte a estos créditos, los mismos se harán efectivos con cargo a los bienes y derechos sobre los que recaiga la garantía, si bien la ejecución se tramitará en todo caso ante el juez del concurso, que decidirá sobre su procedencia y podrá acordar su tramitación en pieza separada, acomodando las actuaciones a las normas propias del procedimiento judicial o extrajudicial que corresponda.

\footnotetext{
${ }^{567}$ A la cuestión procedimental del orden de prelación de los créditos nos referimos en vid. supra, Capítulo Primero, epígrafe 2.4.2.2. "La concurrencia con otros procesos o procedimiento concursales o universales de ejecución".

${ }^{568}$ CAMY ESCOBAR, J., “Las garantías de la deuda tributaria y su ejecución”, op. cit., pág. 209.
} 
Los créditos con privilegio general, en segundo lugar, afectan a todo el patrimonio del deudor. En el supuesto de que el concurso termine con la liquidación del patrimonio del deudor, el artículo 156 de la LC dispone que los créditos con privilegio general se abonarán en el orden que determina el artículo 91 de la LC y, en su caso, a prorrata dentro de cada número. En este sentido, el apartado segundo del artículo 91 de la LC se refiere a las cantidades correspondientes a retenciones tributarias y de Seguridad Social debidas por el concursado en cumplimiento de una obligación legal, y en su apartado cuarto relaciona

"los créditos tributarios y demás de Derecho público, así como los créditos de la Seguridad Social que no gocen de privilegio especial conforme al apartado 1 del artículo 90, ni del privilegio general del número 2 de este artículo. Este privilegio podrá ejercerse para el conjunto de los créditos de la Hacienda Pública y para el conjunto de los créditos de la Seguridad Social, respectivamente, hasta el $50 \%$ de su importe."

A los acreedores de créditos privilegiados generales sólo les afecta el convenio concursal si manifiestan su conformidad y se pagan antes que los créditos ordinarios con lo que quede tras satisfacerse los créditos contra la masa y los créditos con privilegio especial. En este contexto es en el que se introduce el novedoso segundo apartado del artículo 77 de la LGT. En él se dice que en caso de convenio concursal los créditos tributarios a los que afecte el convenio, incluidos los derivados de la obligación de realizar pagos a cuenta, quedarán sometidos a lo establecido en la LC. Con esto el legislador pretende limitar el derecho de prelación de la Hacienda Pública en los supuestos de ejecución colectiva, aunque resulta difícil concretar en qué términos, a partir de la redacción de la propia LGT y su relación con la LC.

Con la promulgación de la LC lo que se pretendió fue eliminar o recortar los numerosos privilegios crediticios que existían y que perjudicaban el principio de la par conditio creditorum $^{569}$. Precisamente uno de los privilegios de cobro preferente más característicos de la Administración tributaria era y sigue siendo el derecho de prelación. Según el anterior artículo 71 de la LGT de 1963 el crédito tributario debía ser satisfecho antes que los demás, con la única excepción de los créditos salariales y los privilegios especiales. También a través de este privilegio se otorgaba a la Hacienda Pública el denominado derecho de abstención en los procesos concursales, por el cual los convenios que se celebraran en su seno no vinculaban a la Hacienda Pública, y por tanto, permitían a ésta cobrar con los bienes de la masa antes que el resto de los acreedores convenidos. No obstante, la Administración tributaria podía no ejercitar ese derecho y subscribir los convenios con renuncia a sus privilegios crediticios.

Con la restricción que la LC introdujo a esta preferencia del crédito tributario, sólo se considera legalmente privilegiado el cien por cien de las retenciones tributarias, a tenor de lo que establece el apartado cuarto del artículo 91 de la LC. Por su parte, el apartado 7 del mismo precepto entiende que también es privilegiado el cincuenta por ciento del importe principal de los créditos tributarios, considerándose el resto como créditos comunes u ordinarios (apartado tercero del artículo 89 de la

\footnotetext{
${ }^{569}$ PULGAR EZQUERRA, J., "El proyecto de Ley Concursal de 2002. Una aproximación crítica”, Actualidad Jurídica Aranzadi, núm. 550, octubre de 2002, pág. 8 .
} 
LC) y las sanciones e intereses tributarios como créditos subordinados (artículo 92 de la LC) ${ }^{570}$. En este sentido, la LC sigue otorgando a la Hacienda Pública el derecho de abstención, pero sólo en cuanto a la parte privilegiada de sus créditos, quedando vinculada siempre respecto del resto, tal como aparece regulado en los artículos 123, 134 y 136 de la LC. Si por el contrario no se celebran los convenios y se entra en la fase de liquidación de bienes del concursado, entonces para el pago del crédito tributario se seguirá el orden que determinan los artículos 154 y ss. de la LC.

No obstante, y pese a que las intenciones de la LC fueron las de recortar el derecho de prelación general y hacer efectivo el principio de la par conditio creditorum, poco tiempo después de su aprobación el mismo legislador determinó, en el primer apartado del artículo 77 de la LGT, que se mantiene el derecho de prelación en toda su integridad cuando los procesos concursales entren en fase de liquidación y para todos los créditos tributarios, y más aún, cuando se logren convenios, para aquellos créditos tributarios que no se vean afectados por ellos. En cualquier caso, como señala GONZÁLEZ-CARBALLO ALMODÓVAR, lo que siempre ha pretendido el legislador es que predominen los criterios recogidos en la LC y que, por tanto, en caso de concurso los créditos tributarios queden sometidos a dicha norma y, más concretamente, al sistema de prelación que en ella se establece imperativamente y que rige de manera principal en la fase de liquidación de los procesos concursales $^{571}$.

En tercer lugar, tienen la calificación de créditos ordinarios el cincuenta por ciento de los créditos que no son considerados como privilegios de carácter general, por la limitación que establece el apartado cuarto del artículo 91 de la LC al conjunto de los créditos tributarios y demás de derecho público. Estos créditos se someten al principio de igualdad y el pago de los mismos se efectuará con cargo a los bienes y derechos de la masa activa que quede una vez que se paguen los créditos contra la masa y los privilegios. Estos créditos serán satisfechos a prorrata, conjuntamente con los créditos con privilegio especial, en la parte que éstos no hubiesen sido satisfechos con cargo a los bienes y derechos afectos.

Por último, los créditos subordinados son una categoría que introduce la LC de 2003 por primera vez, con el objeto de aludir a los créditos que deben ser satisfechos después de los ordinarios, entre otras causas, por su tardía comunicación a los administradores, por su carácter accesorio o por su naturaleza sancionadora.

En resumen, podemos decir que la Administración tributaria, una vez declarado el concurso, es titular de créditos privilegiados, ordinarios y subordinados. En relación con los créditos privilegiados goza del derecho de abstención y no se verá afectada por el convenio a no ser que vote a su favor o

\footnotetext{
${ }^{570}$ ALONSO LEDESMA, C., "La clasificación de los créditos en el concurso", en la obra Estudios sobre el Anteproyecto de Ley Concursal de 2000, Diles, Madrid, 2002, pág. 193.

${ }^{571}$ GONZÁLEZ-CARBALLO ALMODÓVAR, A., "Las garantías del crédito tributario", op. cit., pág. 457. El criterio de GARCÍA NOVOA es que las limitaciones a estos privilegios deben fijarse teniendo en cuenta "la necesidad de reservar una parte de los bienes y derechos del concursado para la satisfacción de los acreedores generales no privilegiados. Por tanto, las eventuales limitaciones porcentuales que pudieran preverse tendrían que venir establecidas sobre el total del activo. Por el contrario, atribuir la condición de privilegio a la mitad del importe del conjunto de los créditos tributarios y de la Seguridad Social supone, en función de un criterio cuantitativo puramente convencional, someter simultáneamente al mismo crédito a un tratamiento completamente diferenciado, como ordinario en una parte y privilegiado en otra" (GARCÍA NOVOA, C., "Garantías de la deuda tributaria", op. cit., pág. 332). En este mismo sentido, ARRANZ DE ANDRÉS, C., "La incidencia de la reforma concursal en el ámbito tributario. Análisis del proyecto de ley de 23 de julio de 2002”, Nueva Fiscalidad, núm. 7, 2002, pág. 125.
} 
después se adhiera, tal como establece el apartado segundo del artículo 134 de la LC. Esta posibilidad de la Hacienda Pública para intervenir e incluso negociar el convenio también se reconoce en el apartado tercero del artículo 10 de la LGP y en el apartado cuarto del artículo 164 de la LGT. Para la suscripción y celebración de estos convenios será necesaria la autorización del órgano competente de la Administración tributaria. En los casos en que la Hacienda Pública se adscriba uno de estos convenios o vote a su favor, el número dos del artículo 77 de la LGT dispone que el derecho de prelación de los créditos tributarios, incluidos los derivados de la obligación de realizar pago a cuenta, quedarán sometidos a los requerimientos de la LC.

\subsection{EL DERECHO DE RETENCIÓN}

El ordenamiento civil reconoce como garantía genérica del derecho del acreedor la responsabilidad patrimonial universal del deudor, en los términos del artículo 1.911 del Código Civil. En virtud de este precepto, el deudor responde del cumplimiento de sus obligaciones con todos sus bienes, presentes y futuros, recayendo en su patrimonio las consecuencias que se deriven de su incumplimiento. A su vez, la ley determina medios de tutela y garantías del derecho del acreedor con la finalidad de conseguir el cumplimiento voluntario del crédito. Dentro de estos últimos se encuentra el derecho de retención, que tiene como objetivo estimular al deudor para que voluntariamente satisfaga su deuda. Se trata de una figura cuyos antecedentes y régimen jurídico se encuentran en el Derecho privado, aunque carece de una regulación general y unitaria, observándose sólo en casos $\operatorname{aislados}^{572}$. En efecto, el derecho de retención ha recibido siempre un tratamiento casuístico, lo que ha provocado distintas interpretaciones doctrinales y jurisprudenciales en cuanto a su contenido, fundamento, constitución, naturaleza, o concepto técnico. La LGT en su artículo 80 reconoce el derecho de retención como una de las garantías de la deuda tributaria, pero como tendremos ocasión de explicar más adelante, no se trata de una garantía ni personal ni real en sentido estricto.

\subsubsection{La regulación del derecho de retención en otros ámbitos del derecho}

El derecho de retención es una de las medidas de aseguramiento más antiguas del crédito. Fue un instrumento diseñado para proteger al deudor que con el tiempo dejó de ser un mecanismo de defensa para convertirse en una garantía accesoria del crédito ${ }^{573}$. El Código Civil, en el artículo 453, consagra

\footnotetext{
${ }^{572}$ ECHEVARRÍA DE RADA, T., "En torno al derecho de retención”, en la obra Estudios Jurídicos en homenaje al profesor Luis Díez Picazo, Tomo II, Derecho Civil, Derecho de Obligaciones, Thomson-Civitas, Madrid, 2003, pág. 1765.

${ }^{573}$ Las contradicciones en el ámbito civil se observan fundamentalmente a la hora de aceptar el derecho de retención posesoria en el supuesto concreto de siembra, plantación o edificación en suelo ajeno con materiales propios y de buena fe, en cuya hipótesis el dueño de la tierra adquiere la propiedad desde el mismo momento en que se incorporan los materiales al suelo, tal como prevén los artículos 353 y 358 del Código Civil, sin perjuicio de que para adquirir la posesión aquél tenga que pagar a éste la indemnización que establecen los artículo 453 y 454 del Código Civil. Un sector de la doctrina civilista interpreta que hasta que no se satisfaga la debida indemnización, el edificante ostenta la condición de poseedor en virtud del derecho de retención que regula el artículo 453 del Código Civil. En este sentido, afirma ECHEVARRÍA DE RADA que, a pesar de que el artículo 361 del Código Civil no hace mención al derecho de retención, sí se remite al artículo 453 del Código Civil, y por tanto a "todo poseedor de buena fe que sea deudor de la entrega de una cosa", atribuyendo tal derecho al que edifica, planta o siembra, y que, en consecuencia, este último sólo puede tener la posesión de lo edificado, plantado o sembrado y no la propiedad, que se transmite al dueño del suelo (ECHEVARRÍA DE RADA, T., "En torno al derecho de retención", op. cit., pág. 1774). En este mismo sentido, DÍEZ PICAZO, L y GULLÓN BALLESTEROS, A., Sistema de derecho Civil, Vol. III, 6 ${ }^{\text {a }}$ ed., Tecnos, Madrid, 1997, pág. 179. En contra, vid. ALBALADEJO GARCÍA, M., Derecho Civil I, II, $11^{\text {a }}$ ed., Bosch, Barcelona, 2002, pág. 255, nota 12; LACRUZ BERDEJO, J. L., Elementos de Derecho Civil, Vol. III, 1, Dykinson, Madrid, 2000, pág. 134; CARRASCO PERERA, A., La construcción en suelo ajeno en el marco de los principios urbanísticos, Montecorvo, Madrid, 1986, pág. 223. Sobre la evolución legislativa del derecho de retención en el ordenamiento civil, vid. ABRIL CAMPOY, J. M., "El Derecho de retención en el ordenamiento jurídico catalán", Revista Crítica de Derecho Inmobiliario, núm. 624, septiembre-octubre 1994, pág. 1885 a 1898.
} 
el derecho de retención en garantía de los créditos que surgen para el poseedor vencido como consecuencia de un estado posesorio. También concede implícitamente el derecho de retención otros supuestos que aparecen en los artículos 464, 502, 522, 1.600, 1.730, 1.780 y 1.866 del mismo código. $\mathrm{Y}$ algunos autores incluyen dentro de este grupo a ciertos poseedores, como, por ejemplo, al gestor de negocios ajenos, el albacea, el acreedor anticrético y el receptor del pago de lo indebido ${ }^{574}$.

\subsubsection{Regulación en el ámbito tributario}

Desde la perspectiva tributaria, el artículo 80 de la LGT reconoce el derecho de retención a favor de la Administración tributaria frente a todos sobre las mercancías declaradas en las aduanas para el pago de la deuda aduanera y fiscal, por el importe de los respectivos derechos e impuestos liquidados, de no garantizarse de forma suficiente el pago de la misma ${ }^{575}$. Si comparamos el contenido de este artículo con el de su antecesor, el artículo 75 de la LGT de 1963, podemos observar que no se percibe ningún cambio sustancial aunque se utilice distinta terminología. Por tanto, al igual que sucede con el resto de garantías de la deuda tributaria que regula la LGT, son válidos para la normativa actual los pronunciamientos doctrinales y jurisprudenciales que recayeron sobre el artículo 75 de la LGT de 1963.

El derecho de retención siempre ha actuado en el ámbito aduanero y la LGT de 1963 sólo indicaba que la Hacienda Pública tenía derecho de retención sobre mercancías que se presentasen a despacho y exacción de los tributos que graven su tráfico o circulación por el respectivo importe del crédito liquidado. De la redacción del artículo 75 de la LGT de 1963 se interpretaba que sólo se aplicaba el derecho de retención a los tributos aduaneros, por ser los únicos en los que se producía la presentación a despacho de mercancías. El artículo 80 de la LGT actual determina explícitamente que la Administración tributaria tendrá derecho de retención sobre las mercancías declaradas en las aduanas para el pago de la pertinente deuda aduanera y fiscal por el importe de los respectivos derechos e impuestos liquidados. No cabe duda alguna, pues, que el derecho de retención se vincula estrechamente al ordenamiento aduanero y a los gravámenes indirectos que se relacionan con él.

El artículo 9 del Real Decreto Legislativo 1299/1986, de 28 de junio, por el que se modifica el Texto refundido de los Impuestos integrantes de la Renta de Aduanas, concede específicamente a los Servicios de Aduanas la facultad de exigir la prestación de garantías adecuadas para responder por el cumplimiento de las obligaciones que se derivan de las operaciones de importación y exportación, y a la Hacienda Pública

"el derecho de retención frente a todos, sobre las mercancías que se presenten a despacho para el pago de la deuda aduanera, por el respectivo importe de los derechos liquidados, de no garantizarse en la forma adecuada el pago".

Otra de las modificaciones que aparece en la ley actual es que otorga el derecho de retención a la Administración tributaria de forma genérica. Con esta última expresión el legislador se refiere a

\footnotetext{
${ }^{574}$ ALBALADEJO GARCÍA, M., Derecho Civil I, II, op. cit., pág. 255; BELTRÁN DE HEREDIA DE ONIS, P., El derecho de retención en el Código civil español, Universidad de Salamanca, 1995, pág. 86 y ss.

${ }^{575}$ Adviértase que este artículo hace mención a la retención material de la cosa y no a la retención de cantidades que se prevé como medida cautelar en los incisos $a$ ) y $d$ ) del apartado tercero del artículo 81 de la LGT.
} 
cualquier ente $\mathrm{u}$ organismo que pueda ser competente en estas materias, ya sea la AEAT o las Administraciones tributarias autonómicas ${ }^{576}$.

\subsubsection{Concepto y naturaleza jurídica del derecho de retención}

BELTRÁN DE HEREDIA define el derecho de retención en el ámbito del derecho civil como "una facultad que compete al acreedor, por virtud de la cual se defiende de la injusta pretensión del propietario de la cosa, que aquél retiene, negándose a entregársela, hasta que le sea satisfecho el crédito existente por razón de los gastos realizados sobre la cosa misma"577. En otras palabras, estamos ante "la facultad que, en determinados casos, concede la ley al poseedor de una cosa para que prolongue su situación posesoria después de decaído el título que la justificaba y con ella en razón de un crédito del poseedor frente al destinatario de la cosa, crédito relacionado, unas veces, con la cosa -gastos de conservación o mejora, indemnización de los perjuicios causados con ocasión de la misma- y otras veces sin más relación que la puramente ocasional de la preexistente posesión de la cosa por el acreedor -posesión prendaria-"

La doctrina tributaria ha descrito al derecho de retención como "la facultad de los órganos de aduanas ante quienes entreguen o presenten mercancías para la liquidación de los correspondientes derechos de importación o exportación o gravámenes indirectos relacionados con ellos, de retener dichas mercancías, esto es, impedir su libre retirada y disposición por sus titulares en tanto en cuanto no se pague o se garantice suficientemente el pago de las deudas aduaneras liquidadas" ${ }^{\circ 79}$.

De los conceptos transcritos se desprenden tres elementos fundamentales para configurar el derecho de retención: la existencia de un crédito por parte del titular del derecho, la situación posesoria lícita del retenedor sobre una cosa que deba entregar el deudor y, por último, la vinculación entre el crédito y la cosa retenida. Se trata de una facultad que concede la ley a la Hacienda Pública que permite a ésta retener mercancías declaradas en la aduana, siempre que no se garantice de forma suficiente el pago de la deuda aduanera, y que es oponible frente a todos, el deudor y cualquier otro tercer adquirente que solicite la entrega de las mercancías.

\subsubsection{El derecho de retención como facultad}

El derecho de retención no puede catalogarse como una garantía real del crédito tributario. Los argumentos que se esgrimen para mantener esta afirmación, que es la más defendida por la doctrina, se sustentan en la idea de que el derecho de retención no atribuye a su titular un poder directo sobre la cosa. La facultad que se otorga a la Administración tributaria con el derecho de retención no permite la ejecución forzosa de las mercancías retenidas, ni su recuperación si pasa a manos de un tercero por cualquier motivo. Tampoco otorga esta figura una preferencia para el cobro del crédito tributario frente a otros acreedores del deudor. El titular de los bienes retenidos sólo deberá soportar la retención del bien, pero no la enajenación del mismo, y por ello la posición jurídica del titular de

\footnotetext{
${ }^{576}$ En este sentido, GONZÁLEZ-CARBALLO ALMODÓVAR, A., "Las garantías del crédito tributario”, op. cit., pág. 464.

${ }^{577}$ BELTRÁN DE HEREDIA DE ONIS, P., El derecho de retención en el código civil español, op. cit., pág. 11.

${ }^{578}$ SANCHO REBULliDA, F. A., Facultad de retención posesoria, Estudios de Derecho Civil, I, Universidad de Navarra, Pamplona, 1978, pág. 247.

${ }^{579}$ GONZÁLEZ-CARBALLO ALMODÓVAR, A., “Las garantías del crédito tributario”, op. cit., pág. 464 a 465.
} 
un derecho de retención difiere de la de un garante real. Como afirma la mayoría de la doctrina civilista y tributaria, el derecho de retención no puede considerarse como un derecho real, sino como una facultad, como un poder unido al derecho de crédito que constituye una excepción que el acreedor puede utilizar ante la pretensión del deudor o de cualquier posible tercer adquirente de que se le restituya el bien.

La doctrina que sostiene que el derecho de retención no es un derecho real de garantía, a la hora de definir la naturaleza jurídica de esta institución emplea distintas denominaciones. DÍEZ PICAZO, por ejemplo, afirma que se trata de "una garantía poco vigorosa, pues el acreedor sólo ostenta la facultad de continuar la detentación y rehusar la restitución. Carece, en cambio, de un poder de realización del valor de los bienes para resarcirse de su crédito con el producto obtenido" ${ }^{\text {"580 }}$.

RODRÍGUEZ BEREIJO es de la opinión de que el derecho de retención no puede considerarse como un derecho real, sino como una facultad, un poder del derecho de crédito que constituye una exceptio que el acreedor puede alegar ante la pretensión de restitución, oponible erga omnes, tanto frente al deudor tributario que reclama la restitución como frente a un posible tercer adquirente que, sin embargo, a diferencia de las garantías reales, no genera reipersecutoriedad ${ }^{581}$.

En definitiva, el derecho de retención no es un típico derecho real de garantía. Se trata de una facultad que acompaña al derecho de crédito de la Administración tributaria, dirigida a facilitar la práctica inmediata del embargo y a obstaculizar las acciones del deudor que puedan dejar sin efectividad las demás garantías del crédito tributario ${ }^{582}$.

\subsubsection{El derecho de retención como un derecho real}

El artículo 80 de la LGT dispone que el derecho de retención es oponible frente a todos. Esta circunstancia, así como la existencia en estos casos de una relación de posesión directa e inmediata del titular sobre la cosa, ha motivado que algunos autores consideren al derecho de retención como un derecho real de garantía ${ }^{583}$. Según esta tesis, la oponibilidad es el elemento esencial del derecho de retención, que es accesorio al crédito que garantiza, manteniéndose mientras el crédito no esté satisfecho, con independencia de que quien solicita la restitución no sea el deudor sino un tercero. Se añade, además, la idea de que a través del derecho de retención se pretende conceder una garantía al sujeto obligado a restituir la cosa que tiene en su poder, con la posibilidad de poseerla mientras no se le pague. La retención carecería de sentido sino puede oponerse cuando el deudor no es el propietario

\footnotetext{
${ }^{580}$ DÍEZ PICAZO, L., Fundamentos del Derecho Civil Patrimonial II. Las relaciones obligatorias, op. cit., pág. 582 . Sobre el derecho de retención y su relación con el derecho prelación general y el derecho de afección vid. HERRERO MADARIAGA, J., "Algunas observaciones sobre el derecho de retención del artículo 75 de la Ley General Tributaria”, Hacienda Pública Española, núm. 59, 1979, pág. 257 y ss.

${ }^{581}$ RODRÍGUEZ BEREIJO, A., "Las garantías del crédito tributario", op. cit., pág. 211. En este mismo sentido, GUERVÓS MAÍlLLO, M. A., y LAGO MONTERO, J. M., "Las garantías del crédito tributario (Comentario a los artículos 71, 72, 73, 75, 75 y 76 L.G.T.)", op., cit., pág. 151; CASADO OLLERO, G., FALCÓN Y TELLA, R., LOZANO SERRANO, C. y SIMÓN ACOSTA, E., Cuestiones tributarias prácticas, op. cit., pág. 622.

${ }^{582}$ LUQUE CORTELLA, A., La Hacienda pública y el crédito tributario en los procesos concursales, op. cit., pág. 132.

${ }^{583}$ Entre otros, MIR DE LA FUENTE, T., Las retenciones tributarias, Instituto de Estudios Fiscales, Madrid, 1984, pág. 79; FERNÁNDEZ ARÉVALO, A., Extinción del Derecho de Retención (Análisis legal, doctrinal y jurisprudencial), Práctica de Derecho, Valencia, 1999, pág. 17. Ambos autores sostienen que el derecho de retención es una garantía real en cuanto supone la afección de la posesión de una cosa concreta del deudor, pero que no debe ser confundida como un derecho real de garantía o de realización del valor en sentido estricto.
} 
del bien retenido, o cuando siéndolo hubiera transmitido posteriormente su derecho, y el propietariodeudor puede enajenar el dominio de la cosa que está en posesión del acreedor, pero entonces el adquirente no podrá reclamar la posesión de la cosa mientras la persona que la enajenó o él mismo no satisfagan su deuda al poseedor ${ }^{584}$.

Los argumentos básicos de esta teoría, según ABRIL CAMPOY, son: "en primer lugar, que existe entre el retenedor y el titular de un derecho real una clara similitud, cual es el poder directo e inmediato sobre la cosa"; en segundo lugar, "la oponibilidad erga omnes como corolario de su naturaleza real"; y por último, que siendo la posesión un derecho real y el retenedor un poseedor, "la retención debe ser un derecho real" ${ }^{\text {"585 }}$.

\subsubsection{El derecho de retención como un privilegio}

Otra de las posturas que se aprecian en la doctrina considera que el derecho de retención es una preferencia o privilegio. Los partidarios de esta tesis basan su posición en la evidencia de que quien adquiere la cosa retenida debe satisfacer el crédito del tenedor del bien si pretende hacerse con la posesión, lo que representa una auténtica preferencia de hecho ${ }^{586}$.

Sin embargo, no puede decirse que el derecho de retención constituya un privilegio para el cobro, ya que la preferencia se ejercita sobre el precio sin necesidad de exigir la posesión, mientras que la retención recae sobre la cosa misma. El privilegio, que es una cualidad que acompaña al crédito y otorga preferencia para el cobro frente a otros acreedores, no surge de la retención, puede aparecer junto a ella, pero no se origina de su articulación, ni le afecta en modo alguno. Por ello, la Hacienda Pública podrá satisfacer su crédito garantizado por un derecho de retención haciendo valer su preferencia para el cobro en virtud del contenido del artículo 77 de la LGT, pero no porque se origine de la facultad retenedora ${ }^{587}$.

\subsubsection{El derecho de retención como medida cautelar}

La finalidad garantista del derecho de retención es vista por algunos autores, más que como garantía en sentido estricto, como una medida cautelar del crédito tributario ${ }^{588}$. Cuando establecimos las diferencias entre las medidas cautelares y los derechos reales de garantía vimos que uno de los criterios excluyentes entre unas y otros era, por un lado, el carácter provisional que acompaña a las medidas cautelares, que pueden ser aplicadas incluso antes de que se liquide la deuda siempre que se presuma la existencia de un concreto peligro de incumplimiento; y por otro, el carácter permanente de las garantías reales, que manifiesta sus efectos en la ejecución forzosa del crédito.

\footnotetext{
${ }^{584}$ JORDANO FRAGA, F., "Comentario a la sentencia de 7 de julio de 1987”, Cuadernos Civitas de Jurisprudencia Civil, Vol. 14, 1987, pág. 4772 y 4773.

${ }^{585}$ ABRIL CAMPOY, J. M., “El Derecho de retención en el ordenamiento jurídico catalán”, op. cit., pág. 1904.

${ }^{586}$ GULLÓN BALLESTEROS, A., "El crédito privilegiado en el Código civil”, op. cit., pág. 456.

${ }^{587}$ GARRIDO, J. M., Tratado de preferencias del crédito, Civitas, Madrid, 2000, pág. 70, apunta que es precisamente la falta de preferencia lo que distingue el derecho de retención de los verdaderos derechos reales. En este mismo sentido, BELTRÁN DE HEREDIA DE ONIS, P., El derecho de retención en el código civil español, op. cit., pág. 41. Sobre las diferencias entre el derecho de retención y el derecho de prelación, vid. HERRERO MADARIAGA, J., "Algunas observaciones sobre el derecho de retención del artículo 75 de la Ley General Tributaria", op. cit., pág. 266 a 269.
}

${ }^{588}$ ARRANZ DE ANDRÉS, C., Las garantías reales del crédito tributario: aspectos sustantivos y procedimentales, op. cit., pág. 94. 
En cualquier caso, teniendo en cuenta que el derecho de retención del artículo 80 de la LGT es válido desde que nace la deuda y hasta que el deudor no la satisface, puede sostenerse el carácter provisional del derecho de retención, sin que esto implique que no sea útil para ejecutar el bien posteriormente, aunque no sea este momento cuando produce sus efectos prácticos.

\subsubsection{El derecho de retención como un derecho personal}

Existe un sector importante dentro de la doctrina civilista que entiende que el derecho de retención es un derecho personal. Sus argumentos se basan en los antecedentes históricos del derecho de retención que niegan la naturaleza real del derecho, porque no proporciona una acción real, de modo que sólo es oponible por vía de la excepción y no por reipersecutoriedad, no permite la realización del bien y no concede preferencia alguna. En cualquier caso, los seguidores de esta doctrina no dejan de reconocer la eficacia general que acompaña al derecho de retención ${ }^{589}$.

\subsection{4. Ámbitos de aplicación}

Para que pueda aplicarse la retención será necesario, entre otras cosas, que el acreedor se encuentre en posesión del bien ${ }^{590}$. Este requisito fue una de las causas por las que tradicionalmente se relacionó este tipo de derecho con los tributos aduaneros ${ }^{591}$. La actual normativa es precisa respecto al ámbito de actuación del derecho de retención, al determinar el artículo 80 de la LGT que el objeto del derecho de retención serán las mercancías declaradas en las Aduanas para el pago pertinente de la deuda aduanera y fiscal. Esta última referencia a las deudas fiscales supone que los créditos que se ven favorecidos por el derecho de retención son los que se derivan de los impuestos que gravan el tráfico y circulación de mercancías y no únicamente los créditos surgidos en la aplicación de los impuestos aduaneros $^{592}$. Es importante recordar, no obstante, que el artículo 80 de la LGT es un precepto de origen aduanero y que en ningún otro tributo, distinto de los que se aplican con ocasión del tráfico de mercancías por la Aduana, se exige la presentación de la mercancía.

De todas formas, siguiendo los postulados del legislador tributario, podemos afirmar que la aplicación del derecho de retención puede extenderse al IVA y a los Impuestos Especiales en los supuestos en que éstos gravan el tráfico de mercancías por la Aduana. Como advierten CASADO

\footnotetext{
${ }^{589}$ Entre otros, BELTRÁN DE HEREDIA DE ONIS, P., El derecho de retención en el código civil español, op. cit., pág. 37 y ss., CARRACO PERERA, A., CORDERO LOBATO, E., MARÍN LÓPEZ M. J., Tratado de los derechos de garantía, Aranzadi, Pamplona, 2002, pág., 809. También el Tribunal Supremo reconoce la naturaleza personal del derecho de retención, ya desde su sentencia de 24 de junio de 1941.

${ }^{590}$ BELTRÁN DE HEREDIA DE ONIS, P., El derecho de retención en el código civil español, op. cit., pág. 5 y ss.

${ }^{591}$ En la normativa anterior, el artículo 75 de la LGT de 1963 y el artículo 38 del RGR de 1990 preveían que la retención se practicara sobre los bienes presentados a la Administración para despacho o exacción de los tributos que gravaran su tráfico o circulación. Por eso, afirma MIR DE LA FUENTE que es lógico pensar que existe un derecho de retención aduanero y no aduanero, aunque la mayor utilización del primero hace posible una configuración legal y doctrinal más precisa, lo que aconseja el estudio del segundo con meras referencias sobre determinadas especialidades que manifiesta en relación con el derecho de retención aduanero (MIR DE LA FUENTE, T., Las retenciones tributarias, op. cit., pág. 34). En el mismo sentido, RODRÍGUEZ BEREIJO expresó que el derecho de retención fue uno de los medios antiguos más conocidos de aseguramiento del crédito tributario, que su aplicación siempre tuvo lugar en el ámbito aduanero donde tiene sus antecedentes, y que se trata de un derecho de retención aduanero por el leguaje que utiliza la norma que lo regula, por la mecánica de la garantía, y porque no es fácil su traslación a otros impuestos sobre el tráfico (RODRÍGUEZ BEREIJO, A., "Las garantías del crédito tributario", op. cit., pág. 210).

${ }^{592}$ La Sentencia del Tribunal Supremo de 21 de enero de 1999 expresó que el artículo 75 de la LGT de 1963 daba cobertura suficiente al derecho de retención en relación con todos los tributos y no sólo a los derechos arancelarios devengados en virtud del tráfico exterior de mercancías.
} 
OLLERO, FALCÓN Y TELLA, LOZANO SERRANO, y SIMÓN ACOSTA, el "derecho de retención afecta tanto a los impuestos integrantes de la Renta de Aduanas como a los demás gravámenes de carácter indirecto que se perciben con ocasión de la importación de mercancías, incluyendo todo tipo de derechos, recargos e incluso multas liquidadas por las Aduanas"593.

GARCÍA NOVOA se muestra crítico con la inclusión del derecho de retención en la LGT. En este sentido, apunta que "el Derecho Aduanero es un ámbito jurídico extraordinariamente singular, con una regulación preferente por parte del Derecho comunitario", que dedica una parte de su normativa a regular la garantía del importe de la deuda tributaria. "Y a pesar de que en el Código Aduanero también se da amparo a la aplicación de las normas internas, las particularidades de la gestión aduanera justificarían, a nuestro entender, que no se hubiese incluido una garantía tan peculiar en una ley de pretensiones y alcance general como la LGT",594.

Por último, debemos referirnos a un tipo de retención que no puede ser incluida dentro del contenido del artículo 80 de la LGT, ni tratarse como una garantía real. Nos referimos a lo dispuesto en el artículo 54 del Texto Refundido del Impuesto sobre Transmisiones Patrimoniales y Actos Jurídicos Documentados, aprobado por el Real Decreto Legislativo 1/1993, de 24 de septiembre (en adelante ITPAJD), y el artículo 123 del Reglamento de dicho Impuesto, aprobado por Real Decreto 828/1995, de 29 de mayo. El primero de los preceptos establece que:

"Ningún documento que contenga actos o contratos sujetos a este impuesto se admitirá ni surtirá efecto en Oficina o Registro Público sin que se justifique el pago de la deuda tributaria a favor de la Administración Tributaria competente para exigirlo, conste declarada la exención por la misma, o, cuando menos, la presentación en ella del referido documento".

Por su parte, el artículo 123 del Reglamento del ITPAJD indica que

"Ningún documento que contenga actos o contratos sujetos a este impuesto se admitirá ni surtirá efecto en oficina o registro público sin que se justifique el pago, exención o no sujeción a aquél, salvo lo previsto en la legislación hipotecaria".

Algunos autores afirman, a partir de la interpretación que hacen de estos artículos, que estamos en presencia de un derecho de retención documentado. En palabras de ZABALA RODRÍGUEZFORNOS, LLOPIS GINER, y DAGO ELORZA, en estos preceptos se contiene "una facultad de la Administración de demorar la devolución del documento presentado a liquidación hasta el pago del crédito liquidado, en contra de la persona que lo presentó, (...) que constituye una garantía extraordinaria, al impedir, hasta que se haya obtenido el documento, la posibilidad de presentarlo en ninguna oficina o Registro Público. De esta forma, y dado que la presentación del documento en el Registro puede, aun no siendo constitutiva la inscripción, ser esencial, e incluso siendo necesaria en

\footnotetext{
${ }^{593}$ CASADO Ollero, G., FAlCÓN Y TElla, R., LOZANO SERRANO, C. y SIMÓN ACOSTA, E., Cuestiones tributarias prácticas, op. cit., pág. 621.

${ }^{594}$ GARCÍA NOVOA, C., "Garantías de la deuda tributaria”, op. cit., pág. 363. Son partidarios también de esta postura MIR DE LA FUENTE., T: Las retenciones tributarias, op. cit., pág. 34 y MAZORRA MANRIQUE DE L. S., "Garantías del pago de la deuda aduanera", CISS, Noticias CEE, núm. 79-80, 1991, pág. 86.
} 
caso de hipotecas, no encontrarnos en presencia de auténticos derechos de retención, que operan con independencia de la afección de los bienes a los que se refiera el documento retenido" ${ }^{\text {" } 595}$. En todo caso, debemos tener en cuenta que en estos supuestos no se otorga con la retención documental un privilegio a la Hacienda Pública frente a otros acreedores concurrentes, ni tampoco un especial poder de persecución sobre la cosa a la que el documento se refiere, por lo que esta figura tampoco puede encuadrarse dentro de las garantías del crédito tributario en sentido estricto.

\subsubsection{Eficacia del derecho de retención}

La eficacia del derecho de retención es muy limitada y se mantiene mientras dure el período voluntario de pago de las deudas aduaneras liquidadas ${ }^{596}$. Una vez transcurrido este período voluntario sin que se efectúe el pago o se asegure el mismo con la prestación de una garantía adecuada, las mercancías retenidas tendrán que pasar a disposición de los órganos de recaudación para su embargo y, en su caso, para su enajenación forzosa con el fin de poder cobrar la deuda aduanera.

Por otro lado, la retención permite al acreedor permanecer con la posesión del bien, pero no concede prioridad para el cobro en relación con los otros acreedores ni poder para ejecutar el bien. Es precisamente esa función exclusiva de aseguramiento que caracteriza al derecho de retención lo que deja sin fundamento a esta figura cuando se produce la ejecución colectiva del patrimonio del deudor. En estos casos, no existen reparos para que los bienes retenidos se reintegren en la masa, pues lo que persigue el apartado primero del artículo 76 de la LC es precisamente que todos los bienes y derechos integrados en el patrimonio del deudor queden afectos a su realización en el concurso para el pago de los acreedores. Por tanto, la Administración tributaria no puede excluir ni separar estos bienes de la masa para una satisfacción preferente de su crédito y perderá el derecho de retención que le concede el artículo 80 de la LGT.

Esto último no significa, sin embargo, que el crédito de la Hacienda Pública quede desprotegido, porque dispone de un privilegio general que le concede el artículo 77 de la LGT y el artículo 91 de la LC. En definitiva, "el derecho de retención por sí mismo no concede ningún privilegio especial para el cobro frente a otros acreedores y serán otras garantías del crédito tributario las que eviten que, ante una situación concursal, dicho crédito quede sometido a la ley del dividendo sin gozar de preferencia alguna"597.

De manera general, pues, la doctrina aboga por acompañar el derecho de retención con otras garantías del crédito tributario para fortalecerlo. Aquí es importante recordar que el propio régimen aduanero prevé esta posibilidad. El apartado 4 del artículo 9 del Real Decreto Legislativo 1299/1986, de 28 de junio, por el que se modifica el Texto Refundido de los Impuestos de la Renta de Aduanas, establece que

\footnotetext{
595 ZABALA RODRÍGUEZ-FORNOS, A., LLOPIS GINER, F. y DAGO ELORZA, I., Recaudación, aspectos sustantivos y procedimentales, op. cit., pág. 250.

${ }^{596}$ GONZÁLEZ-CARBALLO ALMODÓVAR, A., "Las garantías del crédito tributario”, op. cit., pág. 465.

${ }^{597}$ LUQUE CORTELLA, A., La Hacienda pública y el crédito tributario en los procesos concursales, op. cit., pág. 133.
} 
"las mercancías que se presenten en un recinto aduanero quedarán afectadas a las responsabilidades que sus consignatarios hayan podido contraer por los débitos a la Hacienda con antelación a sus despachos".

HERRERO MADARIAGA destaca la posibilidad de que se vincule el derecho de retención con otras garantías reales a favor de la Hacienda Pública para ampliar su eficacia aseguradora, para de esta forma otorgarle fuerza y efectividad. En opinión de este autor, la conexión del derecho de retención con el derecho de prelación general y el derecho de afección de bienes completa de forma importante esas dos instituciones, ya que al permanecer los bienes en poder de la Hacienda Pública se imposibilitan las acciones del sujeto pasivo que puedan dejar sin efectividad tanto al privilegio general como a la afección de bienes ${ }^{598}$. En todo caso "el derecho de retención tiene carácter subsidiario frente a otras garantías, pues existe, según el art. 75 LGT, «de no garantizarse de forma suficiente el pago»» ${ }^{\wedge 99}$.

\subsection{LAS MEDIDAS CAUTELARES}

Para cerrar el estudio de este tercer capítulo vamos a referirnos brevemente a las medidas cautelares que se regulan en el artículo 81 de la LGT, aunque algunas de las cuestiones que seguidamente abordaremos ya fueron analizadas con mayor profundidad en el primero y en el segundo capítulos ${ }^{600}$.

La medidas cautelares comparten con las garantías del crédito tributario la finalidad de hacer prevalecer el interés público sobre las expectativas de otros acreedores. En las medidas cautelares, sin embargo, está presente un efecto disuasorio del incumplimiento y por ello su presupuesto se basa en un riesgo inmediato de incumplimiento. Estas notas y el carácter provisional de las medidas cautelares diferencian esta figura de las garantías reales del crédito tributario. Utilizando las palabras de CORCUERA TORRES, "los derechos de prelación y afección son garantías que actúan como salvaguarda del crédito tributario en virtud de las facultades que conceden, y en cambio, las medidas cautelares se adoptan para prevenir ciertas conductas de los obligados tendentes a imposibilitar la recaudación",601.

Desde la Ley 25/1995, de 20 de junio, ya se preveían las medidas cautelares expresamente en el artículo 128 de la LGT de 1963, aunque también en otros preceptos aislados: en el apartado 5 de su artículo 37, en el artículo 133 y en el apartado tercero del artículo 142. También en otros ámbitos se incluyeron disposiciones tendentes a regular las medidas cautelares. Así, por ejemplo, los artículos 721 a 747 de la LEC y la Ley 29 /1998, de 13 de julio, reguladora de la jurisdicción contenciosoadministrativa, introdujeron la utilización de las medidas cautelares para asegurar el resultado del proceso siempre que resultara necesario. En el caso de esta última ley, los artículos 129 y siguientes

\footnotetext{
${ }^{598}$ HERRERO MADARIAGA, J., “Algunas observaciones sobre el derecho de retención del artículo 75 de la Ley General Tributaria”, op. cit., pág. 274.

${ }^{599}$ CASAdO Ollero, G., FAlCÓN Y TElla, R., LOZANO SERRANO, C. y SIMÓN ACOSTA, E., Cuestiones tributarias prácticas, op. cit., pág. 622.

${ }^{600}$ Vid. supra, Capítulo Primero, epígrafe, 1.4. "Medidas cautelares en el período voluntario” y en el Capítulo Segundo, epígrafe, 4.2. "Distinción entre las medidas cautelares y las garantías del crédito tributario".

${ }^{601}$ CORCUERA TORRES, A., Las medidas cautelares que aseguran el cobro de la deuda tributaria, op. cit., pág. 61 a 63; MUÑOZ MERINO, A., Privilegios del crédito tributario: el derecho de prelación general, op. cit., pág. 39.
} 
estipulan que la suspensión de la ejecución del acto administrativo se planteara en clave de medidas cautelares, "pues medida cautelar es toda aquella orientada a asegurar la finalidad del recurso"602.

Sin embargo, no debemos olvidar que existen diferencias entre las medidas cautelares que reconoce el artículo 81 de la LGT y las garantías de presentación voluntaria. En este sentido, la finalidad de las medidas cautelares del artículo 81 de la LGT está ligada a asegurar el cobro del crédito tributario, mientras que las garantías que debe presentar el obligado tributario para suspender la ejecución del acto impugnado tiene su razón de ser en la tutela cautelar. Como dice GARCÍA NOVOA, la suspensión se considera como una medida cautelar "a favor del particular cuya finalidad es lograr la plena eficacia fáctica o material de una futura resolución estimatoria, sobre la base, entre otras circunstancias, de la concurrencia de un periculum in mora"603.

En definitiva, las medidas cautelares que recoge el artículo 81 de la LGT persiguen asegurar el cobro del crédito de la Administración tributaria. Por el contrario, no se observa esta finalidad en las medidas cautelares que ofrecen los particulares como alternativa a las garantías en el marco de la tutela cautelar. No obstante para el caso del aplazamiento o fraccionamiento del pago sí se contempla la posibilidad de sustituir las garantías que se exigen para su concesión por medidas cautelares, tal como establece el último párrafo del apartado primero del artículo 82 de la LGT.

En la actualidad subsisten algunas de las medidas cautelares que contemplaba el ordenamiento anterior, como la posibilidad de acordar el embargo preventivo de dinero y mercancías para asegurar el pago de la deuda tributaria que proceda exigir por actividades lucrativas ejercidas sin establecimiento y que no hubieran sido declaradas, o el embargo preventivo de los ingresos de los espectáculos públicos que no hayan sido previamente declarados a la Administración tributaria. Además de estas medidas, se pueden adoptar, según el apartado cuarto del artículo 81 de la LGT, otras, como la retención del pago de devoluciones tributarias o de otros pagos que deba realizar la Administración tributaria ${ }^{604}$; el embargo preventivo de bienes y derechos, del que se practicará, en su caso, anotación preventiva, y que servirá para publicar el hecho, negocio o declaración relacionado

\footnotetext{
${ }^{602}$ GARCÍA NOVOA, C., "Garantías de la deuda tributaria”, op. cit., pág. 364. Sobre este punto expresó CHICO DE LA CÁMARA que la Ley 29/1998 tuvo el acierto en no circunscribir las medidas cautelares a la suspensión, facultando a los órganos jurisdiccionales a adoptar cualquier medida que asegure la efectividad de la sentencia (CHICO DE LA CÁMARA, P., La suspensión de la ejecución de los actos tributarios sin garantía o con garantía distinta del aval, op. cit., pág. 242). En este mismo sentido, FALCÓN Y TELLA, R., "La Ley 29/1998, reguladora de la Jurisdicción Contencioso-Administrativa (II): el nuevo régimen de las medidas cautelares", Quincena Fiscal, núm. 4, 1999, pág. 5 a 8.

${ }^{603}$ GARCÍA NOVOA, C., "Garantías de la deuda tributaria”, op. cit., pág. 364 a 365. Sobre la tutela cautelar, vid. GARCÍA DE ENTERRÍA, E., "Reflexión sobre la constitucionalización de las medidas cautelares en el contencioso administrativo", Revista Española de Derecho Administrativo, núm. 76, 1992, pág. 626; LITAGO LLEDÓ, R., "El principio de tutela judicial efectiva en las normas de procedimientos tributarios", Palau 14, núm. 24, pág. 1994, pág. 76; CHICO DE LA CÁMARA, P., La suspensión de la ejecución de los actos tributarios sin garantía o con garantía distinta del aval, op. cit., pág. 243; CHINCHILLA MARÍN, M. C., La tutela cautelar en la nueva justicia administrativa, Civitas, Madrid, 1991, pág. 29; y las Sentencias del Tribunal Supremo de 29 de enero de 1996 y de 29 de enero de 1998, entre otras.

${ }^{604}$ En relación con esta medida cautelar, apunta CORCUERA TORRES que "se integra por la potestad de la Administración tributaria que consiste en la suspensión o paralización de la actividad de otros órganos de la Hacienda Pública destinada a devolver o a pagar cantidades monetarias debidas al sujeto pasivo de la obligación tributaria que se pretende garantizar, sin que la retención alcance a la ejecución forzosa de la deuda, ni conceda por sí misma al crédito tributario un privilegio especial" (CORCUERA TORRES, A., Las medidas cautelares que aseguran el cobro de la deuda tributaria, op. cit., pág. 147). Por su parte, GARCÍA NOVOA es de la opinión que para que la LGT de 2003 recogiera satisfactoriamente el principio de proporcionalidad que informa el régimen de las medidas cautelares "debería especificar que la retención de devoluciones no procedería en los casos en que la deuda tributaria fuera notoriamente inferior a la cuantía de las devoluciones" (GARCÍA NOVOA, C., "Garantías de la deuda tributaria”, op. cit., pág. 471).
} 
con el asiento a que se refiere ${ }^{605}$; la posibilidad de enajenar, gravar o disponer de bienes o derechos; la retención de un porcentaje de los pagos de las empresas que contraten o subcontraten la ejecución de obras o prestación de servicios correspondientes a su actividad principal, en garantía de las obligaciones tributarias relativas a tributos que deban repercutirse o cantidades que deban retenerse a trabajadores, profesionales u otros empresarios, en la parte que corresponda a las obras o servicios objeto de la contratación o subcontratación; y cualquier otra legalmente prevista.

A pesar de que la LGT configura una lista abierta de medidas cautelares que puede adoptar la Hacienda Pública, estamos ante un proceso sometido a varias limitaciones. Una de ellas es la exigencia explícita que hace la ley de la notificación y motivación de la medida cautelar. Y sobre este aspecto, nada dice la norma en relación con la recurribilidad por parte del sujeto de la adopción de la medida cautelar. La doctrina que se muestra favorable a esta posibilidad, defiende su postura a partir de la idea de que la ley constituye las medidas cautelares para asegurar el cobro de la deuda tributaria $\mathrm{y}$, por tanto, como medida recaudatoria en sentido amplio, pudiendo ser aplicable a este supuesto el contenido del inciso $g$ ) del apartado 2 del artículo 227 de la LGT, que declara recurribles los actos dictados en procedimiento de recaudación. Y también que no puede negarse la recurribilidad de la motivación de la medida cautelar porque no se trata de un acto de trámite y porque es un acto decisorio que afecta a situaciones jurídico-privadas de los sujetos pasivos ${ }^{606}$.

Otra de las limitaciones que afectan a las medidas cautelares es que éstas deben ser proporcionadas al daño que se pretende evitar, sin que en ningún caso pueda producir perjuicios de difícil o imposible reparación. Por otro lado, las medidas cautelares deberán ser necesarias, lo que supone la prohibición de sobrecargar al interesado con "una medida que para él represente una carga excesiva, sobre todo si existen otras que pueden suponer un sacrificio comparativamente menor"607.

Una de las cuestiones que se modificó en la LGT actual en el régimen de las medidas cautelares fue la necesidad que de que la deuda esté liquidada y cuantificada. La LGT de 1963 y sus distintas modificaciones hasta la Ley 25/1995 exigía que para la adopción de medidas cautelares la deuda tenía que estar liquidada y cuantificada. A partir de la Ley 25/1995, se comienza a prever la posibilidad de adoptar medidas cuando aún no se hubiera practicado la liquidación de la deuda, con el único requisito formal de un trámite de audiencia al interesado. Ya con la Ley 50/1998, de 30 de diciembre, se excluyó la necesidad de que la deuda estuviese liquidada como requisito para implementar medidas cautelares y sólo se requería que se hubiera devengado y transcurrido el plazo reglamentario de pago del tributo, siempre que corresponda a cantidades retenidas o repercutidas a terceros, supuesto en que es posible la adopción de la medida cautelar por los Delegados Especiales de la AEAT.

\footnotetext{
${ }^{605}$ La vigencia de la anotación preventiva estará condicionada a la vigencia de la medida cautelar a la que se subordina. Teniendo en cuenta que el artículo 86 de la LH establece que las anotaciones preventivas caducan a los cuatro años, con posibilidades de prórroga por igual tiempo, esta caducidad afecta a la anotación preventiva pero no implica el levantamiento del embargo.

${ }^{606}$ CORCUERA TORRES, A., Las medidas cautelares que aseguran el cobro de la deuda tributaria, op. cit., pág. 122 a 128; FERNÁNDEZ LÓPEZ, R. I., "La irrecurribilidad de los actos de trámite dictados al inicio y en el curso del procedimiento inspector ¿admite excepciones?”, Jurisprudencia Tributaria, Tomo I, 2003, pág. 2060 a 2065.

${ }^{607}$ GARCÍA NOVOA, C., "Garantías de la deuda tributaria”, op. cit., pág. 372.
} 
La LGT actual amplía esta posibilidad y reconoce la facultad de adoptar medidas cautelares durante la tramitación de los procedimientos de aplicación de los tributos desde el momento que la Administración tributaria pueda acreditar de forma motivada y suficiente la concurrencia de los presupuestos de hecho contemplados en el primer apartado del artículo 81 de la LGT. Esta posibilidad de aceptar medidas cautelares sobre deudas no liquidadas, entendió MORENO FERNÁNDEZ que "produce problemas de inseguridad jurídica y va contra la exigencia de que exista un índice de capacidad económica en su vertiente relativa, pues al no conocerse de modo cierto la cuantía de la deuda para cuyo cobro se instrumentan las medidas cautelares, ni la Administración ni el Juez de Instrucción que debe autorizarlas podrán saber si es necesaria la medida, y en caso de serlo qué cantidad es la base para retener una devolución o un pago o llevar a cabo un embargo preventivo" 608 .

Otro de los rasgos que también caracteriza el régimen de las medidas cautelares es su provisionalidad. Según el apartado segundo del artículo 726 de la LEC, las medidas cautelares tienen un carácter temporal, provisional, condicionado y susceptible de modificación y alzamiento. La provisionalidad temporal de las medidas cautelares se impone en el apartado 6 del artículo 81 de la LGT, que prevé un plazo máximo de seis meses, prorrogable a otros seis meses más, desde el momento de su adopción, es decir, desde la fecha de emisión del acuerdo por el órgano competente.

En relación con la provisionalidad de las medidas cautelares en su expresión sustantiva, debemos apuntar que si las circunstancias que provocan su adopción desaparecen entonces éstas dejan de tener sentido, y esta misma circunstancia se produce si se sustituyen las medidas cautelares por otras garantías que se estime suficientes. En cualquier caso, será obligatorio levantar la medida cautelar si la garantía que se aporta es la prevista en los casos de aplazamiento o fraccionamiento de pago, esto es, aval solidario de entidad de crédito o sociedad de garantía recíproca o certificado de seguro de caución que garantice el cobro de la cuantía de la medida cautelar.

Según MARTÍN QUERALT, la provisionalidad de las medidas cautelares, por su propia esencia, excluye su modificación en situaciones jurídicas permanentes o definitivas ${ }^{609}$. Esto parece que se contradice con lo que dice el inciso a) del apartado 6 del artículo 81 de la LGT. La previsión de este precepto es que las medidas cautelares

"se conviertan en embargos en el procedimiento de apremio o en medidas cautelares judiciales, que tendrán efectos desde la fecha de adopción de la medida cautelar".

Esta situación prevista en el precepto transcrito sólo será posible si la medida cautelar que se adoptó fue el embargo preventivo de bienes y derechos. Sería imposible la conversión en la retención del pago de devoluciones tributarias, o en la retención de un porcentaje de los pagos de las empresas que contraten o subcontraten, porque ello supondría alterar la prelación de bienes embargables que prevé

\footnotetext{
${ }^{608}$ MORENO FERNÁNDEZ, J. I., El aplazamiento en el pago de los tributos, op. cit., pág. 206.

${ }^{609}$ MARTÍN QUERALT, J., "Las medidas cautelares en el ámbito tributario”, Tribuna Fiscal, núm. 67, 1996, pág. 5.
} 
el apartado 2 del artículo 169 de la LGT, que obliga a embargar, antes que los créditos del deudor, el dinero en efectivo o en cuentas abiertas a entidades de crédito $^{610}$.

En síntesis, podemos afirmar que las medidas cautelares son garantías del crédito tributario, pero en sentido amplio. Estamos ante una facultad que la ley confiere a la Administración tributaria para que adopte medidas cautelares en caso de que exista un riesgo inminente de incumplimiento del crédito tributario. Pese a que la finalidad de estas medidas es la de asegurar el cobro de la deuda tributaria, no puede identificarse a las mismas como garantías reales, por su carácter provisional, porque precisan una situación de peligro que frustre el cobro del crédito tributario y porque no otorgan a su titular las facultades de preferencia, reipersecutoriedad y oponibilidad erga omnes propias de las garantías reales. Y también deben diferenciarse las medidas cautelares de las garantías de elección voluntaria cuando se solicita el aplazamiento o fraccionamiento del pago o la suspensión del acto administrativo por presentación de una reclamación, porque en este segundo caso, cuando se presentan medidas cautelares en lugar de las garantías para aplazar o fraccionar el pago o para suspender la ejecución del acto administrativo, pierde validez la provisionalidad que caracteriza a las medidas cautelares del artículo 81 de la LGT.

${ }^{610}$ GARCÍA NOVOA, C., "Garantías de la deuda tributaria”, op. cit., pág. 374. 


\section{CAPÍTULO CUARTO \\ LAS GARANTÍAS PERSONALES TRIBUTARIAS}

Una vez concluido el estudio de las garantías reales del crédito tributario, analizamos en el presente capítulo las garantías personales que confieren a la Administración acreedora un derecho de naturaleza personal o una facultad que no se dirige hacia una cosa determinada, sino hacia la misma persona del deudor o hacia un tercero. El responsable tributario y la solidaridad tributaria pasiva son las garantías personales que en el ordenamiento tributario permiten asegurar el cobro por parte de la Administración. La solidaridad tributaria pasiva se manifiesta a través de varias modalidades, como son: la solidaridad de dos o más titulares en la realización del hecho imponible, prevista en el apartado 7 del artículo 35 de la LGT; la solidaridad entre responsables del tributo; y la solidaridad en el seno del régimen de tributación conjunta, que contempla el apartado 6 del artículo 84 de la LIRPF. Por su parte, la responsabilidad tributaria es una garantía personal que ha suscitado y sigue suscitando múltiples críticas en la doctrina y en la jurisprudencia, porque el legislador se ha decantado por la utilización exagerada y desmedida de esta institución motivado por un afán recaudatorio y por una escasa diligencia sobre el patrimonio del deudor principal.

Éstas y otras cuestiones serán analizadas en este cuarto capítulo. Comenzamos con el estudio general de la solidaridad tributaria pasiva destacando dos de sus modalidades, la solidaridad de dos o más titulares en la realización del hecho imponible y la solidaridad de la tributación conjunta, porque la solidaridad entre responsables del tributo se desarrolla en el segundo apartado del capítulo, donde también se analizan otros aspectos importantes de la responsabilidad tributaria como pueden ser sus características principales, el procedimiento de derivación de la responsabilidad, la extinción de la obligación de los responsables, y el derecho al reembolso de estos sujetos.

\section{LA SOLIDARIDAD TRIBUTARIA PASIVA}

La solidaridad tributaria pasiva es una forma de sujeción de diferentes patrimonios que pertenecen a sujetos diversos, y, tal como dijimos en la introducción de este capítulo, se manifiesta de tres formas: la solidaridad de dos o más titulares del hecho imponible, la solidaridad de varios responsables tributarios, y la solidaridad del régimen de tributación conjunta del IRPF. En este primer apartado sólo analizaremos la primera y la última modalidad de solidaridad, puesto que la solidaridad de varios responsables se estudia en el epígrafe dedicado a la pluralidad de responsables.

\subsection{LA SOLIDARIDAD COMO GARANTÍA PERSONAL}

La finalidad de la solidaridad en cualquiera de sus modalidades es conseguir un refuerzo de la posición jurídica de la Administración tributaria, cuyo derecho de crédito resulta garantizado en la medida en que todos los deudores solidarios asumen una responsabilidad completa del cumplimiento de la obligación de cada uno de ellos. La ley declara la solidaridad de quienes participen en la realización del hecho imponible porque así es posible acceder a más patrimonios de una manera razonable ${ }^{611}$.

\footnotetext{
${ }^{611}$ Profundizamos más en el tema de la solidaridad tributaria pasiva como garantía personal en el Capítulo Cuarto, vid. infra, epígrafe 2.5. "La pluralidad de los responsables tributarios".
} 


\subsection{MODALIDADES DE LA SOLIDARIDAD TRIBUTARIA PASIVA EN EL ORDENAMIENTO TRIBUTARIO}

\subsubsection{La solidaridad de dos o más titulares en la realización del hecho imponible}

La obligación tributaria se integra por un conjunto de prestaciones, una principal, el pago de la deuda tributaria, y otras accesorias. Cuando el hecho imponible es realizado por varios sujetos habrá un solo acreedor, la Administración tributaria, y varios deudores principales. En este supuesto se cuestiona cómo deben responder estos deudores principales, de forma mancomunada o solidariamente. La mancomunidad significa que cada uno de los deudores sólo está obligado a cumplir la parte de la deuda que le corresponde, mientras que en la obligación solidaria todos y cada uno de los deudores quedan sometidos a cumplir íntegramente la obligación cuando el acreedor compela a ello.

El Código Civil, de manera general, aboga por la aplicación de la mancomunidad en los casos en que se produce la concurrencia de más de un deudor, como se aprecia en el artículo 1.138. En cambio, en el ordenamiento tributario la regla general es la solidaridad, como se desprende del número 7 del artículo 35 de la LGT:

"La concurrencia de varios obligados tributarios en un mismo presupuesto de una obligación determinará que queden solidariamente obligados frente a la Administración tributaria al cumplimiento de todas las prestaciones, salvo que por Ley se disponga expresamente otra cosa".

Del supuesto de solidaridad que contiene el precepto que hemos transcrito se desprenden varias consecuencias importantes. La primera es que la Administración tributaria puede requerir el pago indistintamente a cualquier obligado tributario, lo cual permite afirmar que la solidaridad pasiva actúa como una medida garantizadora en la que el acreedor puede dirigirse contra cualquier deudor mientras no cobre su crédito completamente. La segunda consecuencia es el alcance de la solidaridad, y de la redacción del precepto transcrito se desprende que si la Hacienda Pública se dirige contra uno de los deudores este sujeto está obligado a responder del importe total de la deuda, con todos sus elementos ${ }^{612}$. El pago hecho por alguno de los deudores solidarios extingue la obligación, y este mandado que recoge el artículo 1.145 del Código Civil es la tercera de las consecuencias que se destacan de la solidaridad que reconoce la LGT. Por último, uno de los elementos definitorios de las obligaciones solidarias consiste en que, al nacer de un solo hecho imponible, existe únicamente una relación jurídica tributaria, pero esta circunstancia no evita que existan relaciones internas entre los coobligados que se rigen por el Derecho privado. La principal de estas relaciones es el derecho de reembolso a favor de quién realizó el pago que liberó a los demás frente a la Administración tributaria, de manera que el sujeto que efectúa el pago puede dirigirse contra los demás obligados buscando su resarcimiento. En este sentido, el Código Civil prevé en el artículo 1.145 que

"el que hizo el pago sólo puede reclamar de sus codeudores la parte que a cada uno corresponde, con los intereses del anticipo".

\footnotetext{
${ }^{612}$ Entre otros, GUERRA REGURA, M., “Garantías personales del crédito tributario”, op. cit., pág. 537.
} 
De este precepto se desprende que el sujeto que ingresó el tributo sólo puede reclamar a cada uno de los coobligados la parte que le corresponda del pago realizado y no puede dirigirse contra uno de ellos para que le reembolse el conjunto de las cuotas de todos los deudores ${ }^{613}$. Esto significa, en suma, que una vez satisfecho el acreedor la obligación solidaria se convierte en mancomunada.

\subsubsection{La tributación conjunta en el IRPF como supuesto de solidaridad tributaria}

La segunda modalidad de solidaridad a la que haremos referencia en este apartado es la que se produce entre los sujetos que intervienen en la tributación conjunta del IRPF. En este caso, la solidaridad en la deuda tributaria alcanza a los miembros de la unidad familiar que obtienen rentas, pues sólo ellos se someten conjuntamente al impuesto, de modo que si un cónyuge o un hijo no obtienen renta alguna, aun formando parte de la unidad familiar, no verán afectado su patrimonio al pago de la deuda tributaria. La Administración tributaria podrá dirigirse contra cualquiera de los miembros de la unidad familiar, y este sujeto deberá hacer frente al pago íntegro de la obligación liberando de esta forma a los demás, siempre y cuando haya percibido algún tipo de renta. Según el apartado 6 del artículo 84 de la LIRPF

"Todos los miembros de la unidad familiar quedarán conjunta y solidariamente sometidos al impuesto, sin perjuicio del derecho a prorratear entre sí la deuda tributaria, según la parte de renta sujeta que corresponda a cada uno de ellos."

Ahora bien, las diferencias entre este supuesto de solidaridad y el que veíamos en el primer apartado son evidentes. En el caso del número 7 del artículo 35 de la LGT se requiere la realización conjunta de un mismo hecho imponible por parte de una pluralidad de sujetos, la cotitularidad en el presupuesto de hecho del tributo. En cambio, la solidaridad en el ámbito de la unidad familiar precisa más de un presupuesto de hecho, puesto que cada miembro de la unidad familiar que obtiene renta realiza el hecho imponible del IRPF de forma individual, produciéndose una sola declaración con la acumulación de rentas de todos los miembros, y excluyéndose entonces de la solidaridad únicamente a los miembros que no han obtenido renta y no han realizado, por tanto, ningún hecho imponible del impuesto.

\section{LA RESPONSABILIDAD TRIBUTARIA}

\subsection{CONCEPTO Y CARACTERES DE LA RESPONSABILIDAD TRIBUTARIA}

La figura del responsable se recoge en el artículo 41 de la LGT:

“La Ley podrá configurar como responsables solidarios o subsidiarios de la deuda tributaria, junto a los deudores principales, a otras personas 0 entidades".

Como puede verse, la norma no contiene un concepto preciso de responsable. La búsqueda de un concepto de responsabilidad tributaria, así como la determinación de su naturaleza jurídica, son dos

\footnotetext{
${ }^{613}$ Existe una jurisprudencia consolidada sobre este tema, que tuvo sus inicios en la Sentencia del Tribunal Supremo de 11 de junio de 1955.
} 
de las cuestiones más recurrentes en la doctrina. Sobre esta materia hay que tener en cuenta que el legislador ha ido modulando a lo largo de los años una categoría de responsabilidad tributaria. En estos momentos, la LGT reconoce algunos caracteres que antes sólo podían encontrarse en distintos trabajos doctrinales. Por ejemplo, la inclusión de los responsables dentro de los elementos comprendidos en la reserva de ley; la ubicación de estos sujetos en el grupo de obligados tributarios; o el reconocimiento, por parte de la norma tributaria, del derecho al reembolso en caso de efectuar el pago.

Para identificar un concepto de responsable es importante acudir al precepto anteriormente transcrito, cuyos antecedentes inmediatos se encuentran en los artículos 37 y siguientes de la LGT de 1963. Este último artículo disponía que

"La Ley podrá declarar responsable de la deuda tributaria, junto con los sujetos pasivos o deudores principales, a otras personas solidaria o subsidiariamente".

Teniendo como base los mandatos de estas disposiciones, en la doctrina se han elaborado diferentes conceptos de responsabilidad tributaria, todos ellos surgidos de los caracteres propios de esta figura que permiten diferenciarla de los otros elementos personales del tributo ${ }^{614}$. Partiendo de la idea de que el responsable es el obligado tributario que la ley coloca junto al deudor principal para hacer frente al pago de la deuda tributaria de éste, pasamos a continuación a exponer aquellos perfiles definitorios de la responsabilidad tributaria.

\subsubsection{Los responsables en el marco de los obligados tributarios}

De la redacción de la LGT, en el apartado primero del artículo 41, puede extraerse como carácter propio de la responsabilidad tributaria que el responsable nunca se presenta solo, porque siempre intervine junto con el deudor principal, que es quien responde en primer lugar de su obligación tributaria $^{615}$. Esta misma posición es asumida por la jurisprudencia, como puede verse en la Sentencia

\footnotetext{
${ }^{614}$ MARTÍN JIMÉNEZ afirma que "responsable es aquél extraño al hecho imponible y al mismo tiempo no es sustituto o es la persona que se sitúa junto al sujeto pasivo, sin realizar el hecho imponible" (MARTÍN JIMÉNEZ, A., Los Supuestos de responsabilidad en la LGT: (hacia una configuración constitucional y comunitaria de la responsabilidad tributaria), Thomson Aranzadi, Navarra, 2007, pág. 56). MARTÍNEZ LAGO entiende que "el responsable es un obligado diferenciado de los deudores principales, que debe pagar la deuda tributaria como deudor que es de una obligación de garantía nacida de la Ley" (MARTíNEZ LAGO, M. A., La extensión de la responsabilidad a las sanciones tributarias, Tirant lo Blanch, Valencia, 2008, pág. 100). Por su parte, el Informe para la Reforma de la Ley General Tributaria del 15 de junio del 2000, proponía que el responsable se entendiera "como toda persona, natural o jurídica, que, junto al sujeto pasivo o, en su caso, a los deudores de las obligaciones tributarias a cuenta, asume la posición deudora frente a la Hacienda Pública en virtud de los supuestos de hecho previstos en cada caso por la Ley".

${ }^{615}$ SIMÓN ACOSTA manifiesta "que el responsable no es deudor principal de la obligación tributaria y, por tanto, siempre concurren en la deuda con otro deudor que es el principal. Por eso el art. 37 LGT define al responsable como la persona que es el deudor junto al sujeto pasivo. La primera característica diferenciadora de esta figura subjetiva es ésta: el responsable nunca responde solo; y siempre tiene al lado a un sujeto pasivo en sentido estricto que también responde de la deuda" (CASADO OLLERO, G., FALCÓN Y TELLA, R., LOZANO SERRANO, C., y SIMÓN ACOSTA, E., "Las garantías del crédito tributario", op. cit., pág. 218). En este mismo sentido, LÓPEZ DÍAZ, A., "La responsabilidad solidaria en el nuevo Reglamento General de Recaudación”, Tribuna Fiscal, núm. 13, 1991, pág. 35; GONZÁLEZ ORTIZ, D., La responsabilidad tributaria en el ordenamiento jurídico español, Dykinson, Madrid, 2002, pág. 29 a 32; MARTÍN JIMÉNEZ, A., Los Supuestos de responsabilidad en la LGT: (hacia una configuración constitucional y comunitaria de la responsabilidad tributaria), op. cit., pág. 25 y ss. Explica este último autor que "el término «junto a» utilizado en el artículo 37 de nuestra LGT y de significado equivalente al vocablo italiano insiere ha sido criticado por la doctrina por no responder técnicamente a los vínculos jurídicos que puede originar la responsabilidad con el sujeto activo de la obligación tributaria. En relación al derecho italiano, con el término insiere parece referirse especialmente al vínculo de solidaridad (...). El responsable, aunque sea
} 
del Tribunal Supremo de 16 de mayo de 1991, en la que se manifiesta que el responsable "es pues un tercero que se coloca junto al sujeto pasivo, pero no desplazándolo de la relación tributaria ni ocupando, en principio, su lugar, sino añadiéndose a él como otro deudor, aunque por motivos distintos y con un régimen jurídico diferenciado" "616. Como apunta GALÁN RUIZ, "el responsable es un tercero que se sitúa junto al sujeto pasivo, sin desplazarlo de la relación tributaria (como sí ocurre en los supuestos de sustitución o en la transmisión de la deuda), y sin ocupar su lugar, sino ampliando el número de obligados al pago" $" 17$.

La obligación de responder de la deuda ajena no debe ceñirse únicamente a la deuda del sujeto pasivo, sino también, según el caso, de todos los obligados tributarios que se relacionan en el apartado segundo del artículo 35 de la LGT, tal como se prevé en el número 1 del artículo 41 de la LGT. El artículo 35 de la LGT se refiere de manera general a los obligados tributarios y el artículo 36 de la LGT en cambio identifica como sujetos pasivos al contribuyente y su sustituto.

Para CALVO ORTEGA, tanto el sujeto pasivo como el obligado tributario se encuentran en una situación pasiva frente a la Administración tributaria y la denominación de obligados tributarios es inexacta en relación con la de sujeto pasivo, al poder ubicarse también a la Hacienda Pública como un obligado tributario ${ }^{618}$. En resumen, esta doctrina defiende la idea de que la introducción del término de obligados tributarios dentro del artículo 35 de la LGT es innecesaria, y entiende que la definición de sujeto pasivo ya se encontraba asimilada en la práctica tributaria y el mundo jurídico en general. MARÍN-BARNUEVO FABO manifiesta que el concepto de obligado tributario no es del todo esclarecedor y la delimitación de sujetos que hace la ley "es reiterativa y poco útil"619. Según nuestra opinión, con la definición de obligados tributarios se intenta englobar las distintas situaciones jurídicas subjetivas que nacen en los procedimientos de aplicación de los tributos ${ }^{620}$. No obstante, reiterando lo que ya dijimos, el concepto de sujeto pasivo se retoma en el artículo 36 de la LGT para delimitar una categoría específica dentro de los obligados tributarios.

Concretamente, y según el apartado 1 del artículo 35 de la LGT, son obligados tributarios las personas físicas o jurídicas y las entidades a las que la normativa tributaria impone el cumplimiento de obligaciones tributarias, mientras que en el apartado 3 del mismo precepto se indica que también tendrán el carácter de obligados tributarios aquellos sujetos a los que la normativa tributaria impone

solidario, no es un deudor principal, ni se sitúa junto a éste como obligado o deudor solidario, exigiendo su responsabilidad el incumplimiento pasivo previo del deudor principal".

${ }^{616}$ En este mismo sentido se expresan, entre otras, las Sentencias del Tribunal Superior de Valencia de 5 de diciembre de 2002 y de 20 de marzo de 2003.

${ }^{617}$ GALÁN RUIZ, J., La responsabilidad tributaria, Thomson-Aranzadi, Navarra, 2005, pág. 35 y 36.

${ }^{618}$ CALVO ORTEGA, R., "Obligados Tributarios", en la obra La nueva Ley General Tributaria, (director) CALVO ORTEGA, Thomson-Civitas, Madrid, 2004, pág. 134 a 135.

${ }^{619}$ MARÍN-BARNUEVO FABO, D., "Los sujetos pasivos", en la obra Tratado sobre la Ley General Tributaria, Tomo I, ARRIETA MARTÍNEZ DE PISÓN, J., COLLADO YURRITA, M. A., ZORNOZA PÉREZ, J. (directores), Aranzadi, Thomson Reuters, 2010, pág. 872, se lamenta de la poca claridad de los conceptos de obligados tributarios y de sujetos pasivos a la hora de delimitar estas figuras. También puede verse las valoraciones que al respecto hace FERREIRO LAPATZA, J. J., La nueva Ley General Tributaria (Ley 58/2003, de 17 de diciembre), op. cit., pág. 120.

${ }^{620}$ HURTADO GONZÁLEZ, J. F., "La recepción del concepto «Obligado Tributario» en la nueva Ley General Tributaria”, Revista Española de Derecho Financiero, núm. 122, 2004, pág. 300. Este autor es de la opinión que "dentro de la categoría de obligado tributario se encuadran todos los sujetos que han de satisfacer cualquier tipo de prestación de naturaleza tributaria, así como someterse al ejercicio de las potestades atribuidas por el legislador a la Administración tributaria en el ejercicio de sus funciones y competencias". 
el cumplimiento de obligaciones tributarias formales, lo que a simple vista constituye una reiteración de lo que ya se enunciaba en el primer apartado. Sin embargo, resulta conveniente acotar algunos elementos de esta definición de obligados tributarios, como su naturaleza jurídica o el presupuesto de hecho u origen de su posición deudora.

Por su naturaleza jurídica, los obligados tributarios pueden ser personas físicas o jurídicas y las entidades carentes de personalidad jurídica que son susceptibles de imposición. El apartado 4 del artículo 35 de la LGT define estas últimas entidades como las herencias yacentes, comunidades de bienes y demás entidades que, carentes de personalidad jurídica, constituyan una unidad económica o un patrimonio separado susceptibles de imposición. Ya desde la LGT de 1963 se mencionaba a estos entes $\sin$ personalidad en el artículo $33^{621}$. La propia doctrina se ha pronunciado en reiteradas ocasiones en relación a este tipo de obligados tributarios, pues resulta contradictorio que a un ente sin posibilidad de ser titular de derechos y obligaciones pueda atribuirse personalidad jurídica especial en el ámbito tributario ${ }^{622}$.

Para analizar el segundo aspecto al que hacíamos referencia, el origen de la posición deudora de los obligados tributarios, debemos remitirnos al primer apartado del artículo 35 de la LGT, que dispone que será el sujeto indicado por la normativa tributaria, y al número 2 de este mismo precepto, que relaciona ampliamente las clases de obligados tributarios. Esta presentación de los tipos de obligados tributarios ha suscitado en la doctrina diferentes posturas. Para algunos se trata de una desacertada redacción, una excesiva e incongruente enumeración que no contempla "en rigor supuestos distintos y por tanto excluyentes entre sí"623. Aunque CALVO ORTEGA destaca como méritos del precepto, entre otros, que ayuda a formar "conciencia de la complejidad del fenómeno tributario, de la diversidad de situaciones y de la necesidad científica de buscar un denominador común a posiciones distintas" $" 624$.

A nuestro entender el término de obligado tributario es una denominación general de sujetos tributarios con posiciones subjetivas distintas, que tienen en común una situación jurídica frente a la Administración tributaria y que la ley en su redacción confunde en algunos casos con las obligaciones tributarias que asumen. En este sentido, creemos que es posible identificar del artículo

\footnotetext{
${ }^{621}$ NIETO MONTERO, J. J., "Las herencias yacentes como obligados tributario" en la obra Tratado sobre la Ley General Tributaria, Tomo I, MARTÍNEZ DE PISÓN, J. A., COLLADO YURRITA, M. A. y ZORNOZA PÉREZ, J. (directores), Aranzadi-Thomson Reuters, Navarra, 2010, pág. 829 a 852 , afirma que colocar a estos entes sin personalidad como obligados tributarios en la parte subjetiva del hecho imponible o imponerle determinadas obligaciones tributarias no significa que se les otorgue personalidad, sobre todo si en el ámbito privado carecen de ella.

${ }^{622}$ Este es un tema que divide a la doctrina. De un lado, están los autores que manifiestan que los entes sin personalidad están dotados de subjetividad, por lo que pueden colocarse en la posición deudora dentro de la relación jurídica tributaria. Entre otros, CALVO ORTEGA, R., "Obligados Tributarios", op. cit., pág. 141, y GARCÍA NOVOA, C., "La sujeción pasiva de los entes sin personalidad”, Revista Latinoamericana de Derecho Tributario, núm. 1, 1997, pág. 58. En el otro extremo se ubican aquellos autores para los que no existe justificación para atribuir a estos entes personalidad jurídica especial diferente a la del ámbito privado. Tal es el caso de FALCÓN Y TELLA, R., "Los entes sin personalidad como sujetos pasivos en la Ley 58/2003, General Tributaria", en la obra Personalidad y capacidad jurídicas. 74 contribuciones con motivo del XXV Aniversario de la Facultad de Derecho de Córdoba, Tomo I, Servicio de Publicaciones, Universidad de Córdoba, 2005, pág. 453.

${ }^{623}$ MENÉNDEZ MORENO, A., "La posición jurídica de los obligados tributarios en la Hacienda Local”, en la obra El Estado Actual de los Derechos y de las garantías de los Contribuyentes en las Haciendas Locales, Thomson, Civitas, Navarra, 2007, pág. 256.

${ }^{624}$ CALVO ORTEGA, R., "Obligados Tributarios”, op. cit., pág. 143.
} 
35 de la LGT, como obligados tributarios ${ }^{625}$, al contribuyente, al obligado a realizar pagos fraccionados y al obligado a repercutir; al sustituto; a los retenedores y a los obligados a practicar ingresos a cuenta; a los obligados a soportar la repercusión; a los obligados a soportar la retención y a los obligados a soportar ingresos a cuenta; a los sucesores; a los obligados a cumplir con los deberes formales; a los beneficiarios de supuestos de exención, devolución o bonificaciones tributarias, cuando no tengan la condición de sujetos pasivos; y a los responsables ${ }^{626}$.

La LGT de 1963 contemplaba dentro de su redacción original la figura de los responsables tributarios, aunque posteriormente se produjeron modificaciones en el régimen de la responsabilidad que causaron dudas respecto a su configuración jurídica originaria e interrogantes sobre la constitucionalidad de esta figura ${ }^{627}$. La LGT del 2003 introdujo algunas innovaciones en el régimen de la responsabilidad, preservando la denominación y las funciones garantistas propias de esta institución, agrupó supuestos que se encontraban dispersos en la anterior LGT de 1963 y amplió sensiblemente los supuestos de responsabilidad en los artículos 42 y 43 de la LGT, en algunos casos con matices polémicos ${ }^{628}$. Además previó la posibilidad de extender la responsabilidad a las

${ }^{625}$ CALVO ORTEGA, R., "Obligados Tributarios", op. cit., pág. 143 a 144, separa a los obligados tributarios en cuatro grupos: el contribuyente y los obligados de carácter instrumental; los que buscan la incidencia definitiva del impuesto en el consumidor final; los obligados a facilitar información sobre terceros o realizar otras prestaciones de hacer autónomas; y los obligados al pago de deuda ajena, que serían los responsables y sucesores. Por su parte, MENÉNDEZ MORENO, A., "La posición jurídica de los obligados tributarios en la Hacienda Local”, op. cit., pág. 257, reconoce en el apartado 2 del artículo 35 de la LGT cinco obligados tributarios: el contribuyente, el sustituto del contribuyente, los retenedores, los repercutidos y los sucesores. Y fuera del apartado segundo del mencionado precepto, este último autor menciona también a los responsables como obligados tributarios

${ }^{626} \mathrm{La}$ doctrina administrativa ha diferenciado la figura del responsable tributario de la del sujeto pasivo y ha reiterado que los responsables no tienen carácter de obligados tributarios, como puede observarse en las Resoluciones del TEAC de 3 de diciembre de 1998 y de 15 de enero de 1999. En la doctrina se aprecian criterios divergentes. Por un lado, se encuentran los autores que están a favor de la distinción entre los sujetos pasivos y los responsables, entre otros, MAZORRA MANRIQUE DE LARA, S., Los responsables tributarios. Instituto de Estudios Fiscales-Marcial Pons, Madrid, 1994, pág. 32 y, de la misma autora, "La obligación de los responsables tributarios en el Reglamento General de Recaudación: nacimiento y exigibilidad”, Crónica Tributaria, núm. 62, 1992, pág. 69; DE LA HUCHA CELADOR, F., "Algunas consideraciones sobre la responsabilidad tributaria en el Reglamento General de Recaudación de 1990: I. Responsabilidad Solidaria”, op. cit., pág. 68; GALÁN RUIZ, J., La responsabilidad tributaria, op. cit., pág. 38; COMBARROS VILLANUEVA, V. E., "La responsabilidad tributaria, solidaria y subsidiaria, en el procedimiento de recaudación", Revista Española de Derecho Financiero, núm. 23, 1979, pág. 378 y 379; RODRÍGUEZ MÁRQUEZ, J. S. y MARTÍN FERNÁNDEZ, F. J., "La responsabilidad tributaria de los sujetos que contraten o subcontraten ejecuciones de obras o prestaciones de servicios", Jurisprudencia Tributaria Aranzadi, núm. 5, 2005, pág. 2614. Estos últimos autores afirman que los responsables tienen la condición de obligados tributarios pero no a título de sujeto pasivo. Por el contrario, un sector minoritario de la doctrina postula que el responsable es un auténtico sujeto pasivo de la deuda tributaria, posición que defienden BAYONA DE PEROGORDO, J. J., y SOLER ROCH, M. T., Compendio Derecho Financiero, Librería Compás, Alicante, 1991, pág. 296.

${ }^{627}$ Concretamente nos referimos a la introducción de nuevos supuestos de responsabilidad por parte del legislador, desoyendo las opiniones doctrinales y requerimientos del propio Informe de la Comisión de Reforma de la LGT, que abogaban por frenar la expansión excesiva de esta figura. Estamos hablando, por ejemplo, de la responsabilidad subsidiaria de personas o entidades que contraten o subcontraten ejecuciones de obras o prestaciones de servicios correspondientes a su actividad económica (inciso $f$ ) del apartado primero del artículo 41 de la LGT); la responsabilidad de administradores de personas jurídicas en caso de cese de actividades (inciso $b$ ) del apartado primero del artículo 43 de la LGT); la responsabilidad de agentes y comisionistas de Aduanas que actúan en nombre y por cuenta del comitente (Disposición Adicional Séptima de la LGT), que debería ubicarse en el artículo 42 de la LGT, y otros que detallamos en el Capítulo Cuarto, vid. Infra, epígrafe 2.4 "Supuestos de responsabilidad tributaria". Doctrinalmente, son varios los autores que reclaman prudencia legislativa para la configuración de la responsabilidad, y que entienden que las modificaciones que se llevaron a cabo en la LGT de 2003 no fueron lo profundas que se requería para este tipo de figura. Entre otros, CALVO ORTEGA, R., "Obligados tributarios", op. cit., pág. 166; FERNÁNDEZ JUNQUERA, M., "Responsables tributarios. Situación actual y perspectiva de futuro", Revista Española de Derecho Financiero, núm. 117, 2003, pág. 21; BOSCH CHOLBI, J. L., "Los responsables tributarios en la LGT 58/2003: aspectos controvertidos", Tribuna Fiscal, núm. 173, 2005, pág. 40; MARTÍN JIMÉNEZ, F.J., "Responsabilidad tributaria, Constitución y Derecho Comunitario", en la obra Tratado sobre la Ley General Tributaria, Tomo I, ARRIETA MARTÍNEZ DE PISÓN, J, COLLADO YURRITA, M. A., ZORNOZA PÉREZ, J. (directores), Aranzadi, Thomson Reuters, Navarra, 2010, pág. 917 a 929.

${ }^{628}$ Es el caso de la extensión de la responsabilidad a las sanciones cuando se produzca la sucesión en la titularidad o ejercicio de explotaciones o actividades económicas (inciso $c$ ) del apartado primero del artículo 42 de la LGT), que se califica como un supuesto de responsabilidad solidaria que se origina por la realización de un acto lícito. 
sanciones cuando la ley excepcionalmente así lo determine, en el apartado 4 del artículo 41 de la LGT. Por su parte, en el apartado 5 del artículo 41 de la LGT se dispuso que, salvo que una norma con rango de ley dispusiera otra cosa, la derivación de la acción administrativa para exigir el pago de la deuda tributaria a los responsables requiere de un acto administrativo, con lo que se abrió la posibilidad de que excepcionalmente se pueda exigir el pago de la deuda tributaria al responsable sin el requerimiento de dicho acto ${ }^{629}$. El último de los elementos novedosos del artículo 41 de la LGT fue la posibilidad de adoptar medidas cautelares previstas en el artículo 81 de la LGT, siendo la primera vez que de forma concreta se determinó este tipo de medidas para la responsabilidad solidaria o subsidiaria.

De las notas propias que distinguen la figura del responsable, la ubicación de este sujeto en el marco de los obligados tributarios puede producir confusión teniendo en cuenta la relación que hace el apartado 2 del artículo 35 de la LGT. Estamos en presencia "de una extensión excesiva"630, o una "ampliación inapropiada, por desmesurada, de su ámbito subjetivo"631 . El problema se presenta desde el propio reconocimiento que hace el apartado 2 del artículo 35 LGT de once tipos de obligados tributarios, junto alguno de los cuales resultaría controvertido colocar al responsable, como pudiera ser el caso de "los beneficiarios de supuestos de exención, devolución o bonificaciones tributarias, cuando no tengan la condición de sujetos pasivos"; los sucesores, sobre todo si es una sucesión de personas físicas; los obligados a realizar pagos fraccionados o de soportar la retención; los repercutidos; los obligados a realizar ingresos a cuenta; o incluso otros responsables, porque el apartado 2 del artículo 35 LGT incluye a estos sujetos también como obligados tributarios. La dificultad en ubicar al responsable junto a estos obligados tributarios deriva de la propia estructura y fundamento de la figura de la responsabilidad y, por tanto, de las situaciones que deberán soportar estos sujetos. De hecho, algunos autores como MARTíNEZ LAGO admiten supuestos de responsabilidad exclusivamente junto a los sujetos pasivos y los retenedores ${ }^{632}$.

Para NAVARRO EGEA no se puede articular la garantía de pago mediante la previsión de un responsable "en relación con todos y cada uno" de los obligados tributarios “(...), pues sólo en torno a la obligación tributaria principal se justifica la entrada de un tercero en garantía de su cumplimiento (...) y sorprende que el responsable aparezca como garante de las obligaciones que asumen los restantes sujetos a que se refiere el apartado 2 del art. 35 (...)”. Esta ampliación, añade la misma

\footnotetext{
${ }^{629}$ Ésta es una de las cuestiones que más se debate en la doctrina. Un grupo de autores opina que el legislador, cuando admitió excepcionalmente la aplicación del régimen de la responsabilidad sin acto administrativo previo de declaración, estaba pensando en las situaciones previstas específicamente en el texto refundido del Impuesto sobre la Renta de los No Residentes. Así lo entienden FALCÓN Y TELLA, R., "La regulación sustantiva de los responsables en el Anteproyecto de Ley General Tributaria", Quincena Fiscal, núm. 10, 2003, pág. 6; MAZORRA MANRIQUE DE LARA, S., "Aspecto formales del régimen de la responsabilidad tributaria", en la obra Tratado sobre la Ley General Tributaria, Tomo I, ARRIETA MARTÍNEZ DE PISÓN, J, COLLADO YURRITA, M. A., ZORNOZA PÉREZ, J. (directores), Aranzadi, Thomson Reuters, Navarra, 2010, pág. 953; NAVARRO EGEA, M., El responsable tributario, Iustel, Madrid, 2006, pág. 35; y ARIAS ABELLÁN, M. D., "El régimen jurídico del responsable en la nueva Ley General Tributaria”, Revista Española de Derecho Financiero, núm. 123, 2004, pág. 501.

${ }^{630}$ CALVO ORTEGA, R., “Obligados Tributarios”, op. cit., pág. 167.

${ }^{631}$ BOSCH CHOLBI, J. L., "Los responsables tributarios en la LGT 58/2003: aspectos controvertidos”, op. cit., pág. 42.

${ }^{632}$ MARTÍNEZ LAGO, M. A., La extensión de la responsabilidad a las sanciones tributarias, op. cit., pág. 101.
} 
autora, "no puede fundarse en esta remisión (...), sino que ha de tomar en consideración otros datos, como la razón de ser por la que cada uno de ellos ha adquirido la condición de deudor" ${ }^{\text {, } 33}$.

Sin embargo, existe un supuesto concreto de responsabilidad que puede ser común a todos los obligados tributarios, que contempla el inciso a) del apartado primero del artículo 42 de la LGT, y según el cual serán responsables solidarios las personas o entidades que sean causantes o colaboran activamente en la realización de una infracción tributaria. Puede suceder en este caso que cualquiera de los obligados del apartado 2 del artículo 35 de la LGT reciba colaboración activa de un tercero, por lo que sería posible articular este tipo de responsabilidad junto a cualquiera de ellos ${ }^{634}$.

\subsubsection{El carácter ex lege de la obligación de responsabilidad}

Se necesita de una ley formal para el establecimiento de tributos, según el principio constitucional de reserva de ley. En efecto, la CE determina en el apartado primero del artículo 31 que

"sólo podrán establecerse prestaciones personales o patrimoniales de carácter público con arreglo a la ley”.

Esta postura se reitera en otros preceptos del texto constitucional, como puede verse en el apartado 1 del artículo 133, a cuyo tenor

"La potestad originaria para establecer los tributos corresponde exclusivamente al Estado, mediante ley".

Por su parte, el apartado 3 de ese mismo artículo dispone que todo beneficio fiscal que afecte a los tributos del Estado debe establecerse en virtud de ley.

El alcance del principio de reserva de ley se extiende a prestaciones tributarias y a prestaciones personales y patrimoniales de carácter público. A su vez, el ordenamiento constitucional configura un principio de reserva de ley de carácter relativo, al decir que será "con arreglo a la ley" y no mediante el establecimiento por ley ${ }^{635}$. La relatividad del principio de reserva de ley se reitera y especifica en los apartados 1 y 3 del artículo 133 de la CE. Como dijimos, este precepto determina que el

\footnotetext{
${ }^{633}$ NAVARRO EGEA, M., El responsable tributario, op. cit., pág. 18, 20 y 21.

${ }^{634}$ Varios son los autores que se identifican con esta conclusión, entre otros, ARIAS ABELLÁN, M. D., "El régimen jurídico del responsable en la nueva Ley General Tributaria", op. cit., pág. 493 a 495; CALVO ORTEGA, R., "Obligados Tributarios", op. cit., pág. 167; FALCÓN Y TELLA, R., "La regulación sustantiva de los responsables en el Anteproyecto de Ley General Tributaria", $o p$. cit., pág. 5, y, del mismo autor, "Los responsables en la nueva Ley General Tributaria", Impuestos, Tomo II, 2003, pág. 162; BOSCH CHOLBI, J. L., "Los responsables tributarios en la LGT 58/2003: aspectos controvertidos", op. cit., pág. 42; HURTADO GONZÁLEZ, J. F., "La recepción del concepto «Obligado Tributario» en la nueva Ley General Tributaria", op. cit., pág. 312; NAVARRO EGEA, M., El responsable tributario, op. cit., pág. 17; CALVO ORTEGA, R., "Obligados Tributarios", op. cit., pág. 167 y 197.

${ }^{635}$ SÁINZ DE BUJANDA, F., "Organización política y Derecho financiero", en la obra Hacienda y Derecho, Tomo I, Instituto de Estudios Políticos, Madrid, 1962, pág. 120; GONZÁLEZ GARCÍA, E., "El principio de legalidad tributaria en la Constitución Española de 1978", en la obra La Constitución Española y las fuentes de Derecho, Vol. II, Instituto de Estudios Fiscales, Madrid, 1979, pág. 976 y 977; PALAO TABOADA, C., "Reserva de Ley y Reglamentos en materia tributaria", en la obra Funciones financieras de las Cortes Generales, Congreso de los Diputados, Madrid, 1985, pág. 537; FERREIRO LAPATZA, J. J., "El principio de legalidad y las relaciones Ley-Reglamento en el ordenamiento tributario español", en la obra Estudios de Derecho y Hacienda (Homenaje a César Albiñana García-Quintana), Instituto de Estudios Fiscales, Madrid, 1987, pág. 875; GALÁN RUIZ, J., La responsabilidad tributaria, op. cit., pág. 31 y 32
} 
establecimiento de los tributos y de beneficios fiscales que afecten a tributos del Estado será regulado por ley, lo cual incluye la creación y los elementos esenciales de la prestación, entendiéndose por éstos los que identifican y cuantifican la misma. Dicho de otra forma, el establecimiento de un tributo conlleva al menos la determinación de sus elementos esenciales, quedando en el ámbito de la normativa reglamentaria otros elementos de procedimiento o formales, más relacionados con la ejecución de la ley.

El Tribunal Constitucional asume esta misma posición al manifestar que el principio de reserva de ley en materia tributaria no afecta por igual a todos los elementos del tributo, precisando que el grado de concreción exigible a la ley es máximo cuando se trata del hecho imponible y es menor cuando se refiere a otros elementos como el tipo de gravamen y la base imponible. Y al afirmar que cuando se trate de prestaciones de carácter público satisfechas por la realización de un servicio o actividad administrativa, la intervención reglamentaria es mayor en la fijación y modificación de las cuantías y de otros elementos, en función de las características de los servicios en concreto ${ }^{636}$.

La LGT materializa el principio de reserva de ley en su artículo $8^{637}$, como también hizo la LGT de 1963 en su artículo 10. Este último precepto preveía una lista de materias que quedaban sujetas a la preferencia de la ley o determinaban el límite de la actuación reglamentaria.

Concretamente el inciso c) del artículo 8 de la LGT dispone que se regula en todo caso por ley

"la determinación de los obligados tributarios previstos en el apartado 2 del artículo 35 de esta ley y de los responsables".

Este mandato expreso de que la delimitación de los responsables se haga mediante ley despeja cualquier duda respecto al carácter esencial que esta figura tiene dentro del tributo y a su sujeción al principio de reserva de ley establecido en la CE. El Tribunal Supremo ha dicho, refiriéndose a la responsabilidad tributaria, que "no se presume jamás, tiene su origen legal y no cabe que sea objeto de transacción o convenio entre particulares" ${ }^{\$ 38}$. Sin embargo, persisten dentro de la doctrina posiciones contrarias a que el responsable ocupe un lugar dentro de los elementos esenciales del tributo. Los argumentos a favor de esta tesis se basan en el carácter puramente garantista de la

\footnotetext{
${ }^{636}$ Entre muchas otras, Sentencia del Tribunal Constitucional 102/2005, de 20 de abril de 2005, que reproduce la doctrina del alto tribunal en cuanto al contenido del principio de reserva de ley en materia tributaria.

${ }^{637}$ También se infiere a la necesidad de que los tributos se regulen por ley en el apartado 1 del artículo 2 y el artículo 4 de la LGT. En este sentido, dice el primero de los apartados que "los tributos son los ingresos públicos que consisten en prestaciones pecuniarias exigidas por una Administración pública como consecuencia de la realización del presupuesto de hecho al que la ley vincula el deber de contribuir", y el segundo apartado dispone que "la potestad originaria para establecer tributos corresponde exclusivamente al Estado, mediante ley". En relación con este artículo, ORÓN MORATAL apuntó que la LGT "no es la norma adecuada para establecer una «reserva de ley tributaria», como indica su rúbrica, pues la reserva sólo puede derivar del texto constitucional, y ésta alcanza a los elementos esenciales del tributo, y entre ellos deben estar al menos los criterios generales identificadores de cualquier obligación «legal», pues sólo así podrán nacer de la ley y ser exigibles” (ORÓN MORATAL, G., "Los obligados tributarios en la Ley 58/2003, de 17 de diciembre, General Tributaria: principales novedades", op. cit., pág. 121).

${ }^{638}$ Sentencia del Tribunal Supremo de 16 de mayo de 1991. Otros tribunales también han expresado lo mismo, como puede verse en las Sentencias de la Audiencia Nacional de 23 de julio de 2001, de 27 de diciembre de 2002, de 7 de noviembre de 2003, y de 5 de abril de 2004; y en diferentes Sentencias de los Tribunales Superiores de Justicia, entre otras, la Sentencia del Tribunal Superior de Justicia de Galicia de 16 de febrero de 2001, la Sentencia del Tribunal Superior de Justicia de la Comunidad Valenciana de 29 de junio de 2001, la Sentencia del Tribunal Superior de Justicia de Castilla y León, Burgos, de 22 de febrero de 2002, la Sentencia del Tribunal Superior de Justicia de Asturias de 25 de abril de 2002, o la Sentencia del Tribunal Superior de Justicia de Andalucía, Granada, de 20 de octubre de 2008 .
} 
responsabilidad, así como en la posibilidad que tiene el responsable de disponer del derecho de reembolso, lo que conlleva, en última instancia, a no tener que soportar la carga del tributo, sin que se vea afectado su patrimonio ${ }^{639}$.

Nuestra consideración, teniendo en cuenta los mandatos constitucionales y de la LGT, es que los responsables tributarios se incluyen dentro de los elementos esenciales del tributo no sólo porque la norma actual los relaciona dentro del extenso abanico de obligados tributarios, sino por asumir la obligación tributaria como terceras personas, y por ser fundamental su presencia para garantizar el crédito que corresponde a la Administración tributaria. Al exigir la $\mathrm{CE}$ que los elementos esenciales del tributo se establezcan por normas con rango de ley, el responsable queda dentro de la reserva de ley y no simplemente de la preferencia de ley ${ }^{640}$. Por tanto, la responsabilidad se determina por ley, que deberá precisar los supuestos, condiciones, características y alcance de la misma, así como el procedimiento a seguir para derivarla.

\subsubsection{El mantenimiento de la obligación de pago del obligado principal}

De los preceptos legales también se desprende que el deudor principal nunca pierde su condición frente a la Administración tributaria y que el responsable se yuxtapone al mismo ${ }^{641}$. Siempre que hay un responsable tributario existe además otro obligado tributario, puesto que la responsabilidad está sólo justificada porque previamente ha habido un obligado principal. Quien realiza el hecho imponible es el deudor principal, dando origen a la obligación tributaria principal, mientras que el responsable realiza un presupuesto de hecho distinto, el presupuesto de hecho de la responsabilidad, que se regula en la ley. De este modo estamos en presencia de dos obligados tributarios, con obligaciones diferentes, pero que a su vez se vinculan entre sí. De ahí que en ocasiones se considere a los responsables como obligados tributarios secundarios, cuya obligación nace cuando se produce el presupuesto de hecho de la responsabilidad regulado en la ley.

Según RUIZ HIDALGO, "el responsable se configura como un obligado tributario que se sitúa al lado del sujeto pasivo, pero en relación de accesoriedad, es decir, no se incorpora en la relación jurídica nacida del hecho imponible, sino que será titular de una relación jurídica accesoria (...). La responsabilidad implica la existencia de dos presupuestos de hecho. Uno que da lugar al nacimiento de la obligación tributaria principal -el hecho imponible- (...). El segundo, el presupuesto de hecho

\footnotetext{
${ }^{639}$ Son partidarios de esta posición, entre otros, CALVO ORTEGA, R., "La responsabilidad tributaria subsidiaria", op. cit., pág. 14; CASADO OLLERO, G., FALCÓN Y TELLA, R., LOZANO SERRANO, C., y SIMÓN ACOSTA, E., "Las garantías del crédito tributario", op. cit., pág. 220; MAZORRA MANRIQUE DE LARA, S., Los responsables tributarios, op. cit., pág. 23; BARBERENA BELZUNCE, I., "Naturaleza de la responsabilidad tributaria del sucesor de la empresa", Jurisprudencia Tributaria, Tomo II, 1994, pág. 1281. Otros autores, como PÉREZ ROYO, F., "Fundamento y ámbito de la reserva de ley en materia tributaria", Hacienda Pública Española, núm. 14, 1972, pág. 245, tampoco aceptan que la responsabilidad tributaria quede amparada en el principio de reserva de ley valiéndose de la interpretación que hacen del inciso a) del artículo 10 de la LGT de 1963.

${ }^{640}$ Se expresan en igual sentido PÉREZ ROYO, F., "Fundamento y ámbito de la reserva de ley en materia tributaria”, op. cit., pág. 237; FALCÓN Y TELLA, R., "La Ley como fuente del ordenamiento (arts. 10, 11 y 12 LGT)", en la obra Comentarios a la Ley General Tributaria y lineas para su reforma (Homenaje a Fernando Sainz de Bujanda), Vol. I, Instituto de Estudios Fiscales, Madrid, 1991, pág. 211; CARBAJO VASCO, D., "La responsabilidad tributaria de los administradores de sociedades mercantiles. Análisis del artículo 40.1 de la Ley General Tributaria", Foro Manchego, Colegio de Abogados de Ciudad Real, núm. 38, 1997, pág. 81; GALÁN RUIZ, J., La responsabilidad tributaria, op. cit., pág. 34; MARTÍNEZ LAGO, M. A., La extensión de la responsabilidad a las sanciones tributarias, op. cit., pág. 101. Para SÁNCHEZ GALIANA "la determinación legal del responsable tributario distingue a éste de la figura jurídico-privada del fiador, cuya obligación nace de un acuerdo de voluntades, aunque a veces pueda tener también, de forma mediata, un origen legal" (SÁNCHEZ GALIANA, J. A., "El responsable”, op. cit., pág. 630).

${ }^{641}$ Según la terminología que utiliza CALVO ORTEGA, R., “Obligados Tributarios”, op. cit., pág. 167.
} 
que origina el fenómeno de responsabilidad. El primero se realiza por el obligado principal y su existencia resulta necesaria para que pueda aparecer el fenómeno de la responsabilidad. Asimismo, la condición de accesoriedad de la obligación del responsable implica la extinción de ésta cuando se produzca la del obligado tributario principal, aunque no siempre ocurre así" ${ }^{\prime \prime 2}$.

En este sentido, MENÉNDEZ MORENO y ANIBARRO PÉREZ interpretaron del anterior artículo 37 de la LGT de 1963 que la expresión "junto a los sujetos pasivos o deudores principales" no significa que el responsable desplaza a estos sujetos de su posición deudora, como sucedía con el sustituto en relación con el contribuyente, sino que en estos casos siempre existía ante la Administración tributaria dos obligados tributarios ${ }^{643}$. De la misma manera, FERNÁNDEZ GONZÁLEZ, al referirse al responsable solidario, afirmó que si el deudor principal no satisface la deuda tributaria surgirá la obligación de pago para el responsable, pero que también es "evidente que continúa subsistiendo la obligación del sujeto pasivo o deudor principal" y "de ahí que el acreedor pueda elegir entre acudir a satisfacer su pretensión ante el deudor principal o ante el responsable"644.

\subsubsection{La acción de regreso contra el deudor principal}

La ley actual reconoce la acción de regreso a favor de los responsables, a diferencia de la LGT de 1963, que guardaba silencio respecto a este derecho de reembolso. El reclamo histórico de la doctrina formó parte de las recomendaciones del Informe para la Reforma de la LGT del 15 de junio del $2000^{645}$. Sin embargo, la ausencia de regulación en la normativa tributaria anterior no significaba que el responsable tributario no estuviera amparado por ese derecho, ya que éste podía acudir al Derecho común para obtener cobertura legal del mismo.

\footnotetext{
${ }^{642}$ RUIZ HIDALGO, C., La responsabilidad tributaria en el alzamiento de bienes en la nueva Ley General Tributaria, op. cit., pág. 23 y 24. En este sentido, SÁNCHEZ GALIANA, J. A., "El responsable", op. cit., pág. 636; PALAO TABOADA, C., "Notas a la Ley 25/1995, de 20 de julio, de modificación parcial de la Ley general Tributaria", op. cit., pág. 6; ARIAS ABELLÁN, M. D., "El estatuto jurídico del responsable del tributo en el derecho español”, op. cit., pág. 180; FERREIRO LAPATZA, J. J., "Los sujetos pasivos de la obligación tributaria", Revista Española de Derecho Financiero, núm. 72, 1991, pág. 463 a 467; HERRERO MADARIAGA, J., "El responsable tributario", Revista Española de Derecho Financiero, núm. 26, 1980, pág. 189 y ss.; MAZORRA MANRIQUE DE LARA, S., "La obligación de los responsables tributarios en el Reglamento General de Recaudación: nacimiento y exigibilidad", Crónica Tributaria, núm. 62, 1992, pág. 68; MENÉNDEZ MORENO, A. y ANIBARRO PÉREZ, S., "Aproximación al presupuesto de hecho y al alcance de la posición deudora de los obligados tributarios”, Crónica Tributaria, núm. 66, 1993, pág. 40; DURÁNSINDREU BUXADE, A., "La responsabilidad tributaria de los Administradores de sociedades", Revista Técnica Tributaria, núm. 25, 1994, pág. 46; PÉREZ ROYO, F. y AGUALLO AVILÉS, A., Comentarios a la Reforma de la Ley General Tributaria, op. cit., pág. 94; MENÉNDEZ MORENO, A. y TEJERIZO LÓPEZ, J. M., "Los obligados tributarios en el ordenamiento español: aspectos generales de su configuración", en la obra Sujetos Pasivos y Responsables Tributarios, Instituto de Estudios Fiscales-Marcial Pons, Madrid, 1997, pág. 134; DE LA HUCHA CELADOR, F., "Reflexiones para una definición dogmática de la responsabilidad en Derecho Tributario (I)", Revista Española de Derecho Financiero, núm. 94, 1997, pág. 176; DELGADO GARCÍA, A. M., La derivación de responsabilidades en la recaudación de los tributos, Marcial Pons, Madrid, 2000, pág. 146.

${ }^{643}$ MENÉNDEZ MORENO, A. y ANIBARRO PÉREZ, S., “Aproximación al presupuesto de hecho y al alcance de la posición deudora de los obligados tributarios", op. cit., pág. 41.

${ }^{644}$ FERNÁNDEZ GONZÁLEZ, C., "Un apunte sobre el concepto de responsabilidad solidaria”, Crónica Tributaria, núm. 62, 1992, pág. 19. Así también se precisa en la Sentencia del Tribunal Supremo de 16 de mayo de 1991.

${ }^{645}$ La norma es acertada en relación con la exigencia de que se reconociera expresamente el derecho al reembolso para los responsables. Sin embargo, no llegó a la profundidad que se recomendaba, sobre todo en el Informe para la Reforma de la LGT de 15 de junio del 2000, que concretamente proponía que se establecieran "multas coercitivas para obligar al contribuyente a hacer efectiva dicha obligación. Se trata, en definitiva, de tratar de otorgar una mejor tutela a quien reviste la condición de responsable frente al deudor principal, lo cual podría incluso perfeccionarse con la previsión de un derecho del responsable a solicitar de la Administración que intente el cobro de la deuda frente al contribuyente con anterioridad a la declaración de responsabilidad". De esta manera no se dejaba la acción de regreso al ámbito civil, con las implicaciones que explicamos en vid. infra, Capítulo Cuarto, epígrafe 4.3.2. "El derecho de reembolso del responsable tributario en la LGT", sino que se implicaba a la Administración tributaria en la realización efectiva de dicho derecho de reembolso por parte del responsable.
} 
La acción civil que se sigue para lograr este resarcimiento debe ser la acción de enriquecimiento injusto $^{646}$ y el derecho de repetición es ejercido por el responsable frente al deudor principal, por lo que, como ha indicado algún autor ${ }^{647}$, se torna muchas veces en un derecho de contenido vacío al haber sido declarado fallido el deudor principal, como sucede en el caso de los responsables subsidiarios.

\subsubsection{El carácter solidario o subsidiario de la responsabilidad tributaria}

Los tipos de responsabilidad se recogen en la LGT en el apartado primero del artículo 41. La ley configura la responsabilidad tanto solidaria como subsidiariamente y en los artículos 42 y 43 se regula en líneas generales los supuestos de responsabilidad solidaria y los supuestos de responsabilidad subsidiaria, respectivamente. Algunos autores, no obstante, no comulgan con la distinción entre el carácter solidario o subsidiario de la responsabilidad que aparece en la norma, y consideran más adecuado el uso de los términos de responsabilidad directa y responsabilidad subsidiaria $^{648}$.

Ambos tipos de responsabilidad se diferencian por la proximidad temporal que pueda existir entre el deudor principal y el responsable a la hora de satisfacer la deuda tributaria. Mientras que para que se derive la responsabilidad subsidiaria es necesario la declaración de fallido del deudor principal en el procedimiento de apremio y de los responsables solidarios si los hubiera, al responsable solidario podrá exigirse el pago de la deuda una vez finalizado el período de pago voluntario sin que se haya satisfecho la deuda por parte del obligado principal. "En otras palabras, el responsable subsidiario, a diferencia de lo que ocurre con el solidario, goza del beneficio de la exclusión, de tal manera que hasta que no finalice el procedimiento ejecutivo contra el deudor principal, declarándolo insolvente, no podrá la Administración dirigir la acción tendente al cobro de la deuda contra el responsable subsidiario" ${ }^{649}$.

Para completar estas primeras notas sobre los tipos de responsabilidad, debemos analizar cuáles han sido las valoraciones seguidas por el legislador para decantarse por la solidaridad o la subsidiaridad en cada tipo de responsabilidad. CALVO ORTEGA reparó en ello cuando expresó, refiriéndose al contenido de la LGT de 1963, que "los dos criterios de sistematización no están relacionados y no son coherentes lógicamente entre sí en cuanto a sus efectos. Dada la situación más favorable del responsable subsidiario sería razonable que a un presupuesto de hecho lícito correspondiese una

\footnotetext{
${ }^{646}$ Así también lo entendió SOLER ROCH cuando escribió que tiene un fundamento "genérico en la doctrina del enriquecimiento sin causa y un fundamento específico que, en el fondo, coincide con el de la obligación tributaria principal, en la medida en que el reembolso satisface las exigencias derivadas del procedimiento contributivo, garantizando que la detracción de riqueza se efectúe, en definitiva, de quien detenta la capacidad contributiva" (SOLER ROCH, M. T., "Notas sobre la configuración de las obligaciones y deberes tributarios con especial referencia al Impuesto sobre la Renta de las Personas Físicas", Revista Española de Derecho Financiero, núm. 25, 1980, pág. 18).

${ }^{647}$ OTERO NOVAS, J. M., "La supuesta responsabilidad objetiva de los administradores de sociedades que cesan en su actividad", Impuestos, Tomo I, 1997, pág. 77 y ss. GONZÁLEZ ORTIZ, D., La responsabilidad tributaria en el ordenamiento jurídico español, op. cit., pág. 69; RUIZ HIDALGO, C., La responsabilidad tributaria en el alzamiento de bienes en la nueva Ley General Tributaria, op. cit., pág. 26.

${ }^{648}$ CASADO OLLERO, G., FALCÓN Y TELLA, R., LOZANO SERRANO, C., y SIMÓN ACOSTA, E., "Las garantías del crédito tributario", op. cit., pág. 219; CHECA GONZÁLEZ, C., GARCÍA LUIS, T., MERINO JARA, I., MORENO FERNÁNDEZ, J. I., La reforma de la Ley General Tributaria, Lex Nova, Valladolid, 1996, pág. 144.

${ }^{649}$ GALÁN RUIZ, J., La responsabilidad tributaria, op. cit., pág. 41.
} 
situación de subsidiariedad y a un ilícito una situación de solidaridad. Sin embargo, no es así en la totalidad de los casos"650. GALÁN RUIZ, al aludir a la normativa actual, concluyó que "no encontramos más motivación a la hora de determinar el tipo de responsabilidad que se asigna a cada supuesto de hecho que la pura y simple voluntad arbitraria y caprichosa del legislador, lo que incluso le ha llevado en algún caso a modificar injustificadamente el tipo de responsabilidad que, originariamente, había atribuido" ${ }^{\circ 51}$.

Por último hemos de mencionar que, fuera de esta regulación sustantiva del régimen jurídico de la responsabilidad, se ubican en los artículos 175 y 176 de la LGT las cuestiones formales o procedimentales de esta figura. Sin perjuicio de la redacción confusa y de algunas omisiones que se derivan de estos preceptos ${ }^{652}$, la distinción entre la responsabilidad solidaria de la subsidiaria se basa en el hecho de que en la primera los responsables son llamados al cumplimiento de su obligación una vez vencido el período voluntario de pago del deudor principal (apartado 1 del artículo 175 de la LGT), mientras que a los responsables subsidiarios se convocan después de declararse fallido el deudor principal y los responsables solidarios si los hubiera (artículo 176 de la LGT y apartado 5 del artículo 41 de la LGT).

\subsection{NATURALEZA Y FUNDAMENTO DE LA RESPONSABILIDAD TRIBUTARIA}

La mayor parte de la doctrina sostiene que la finalidad de la responsabilidad consiste en propiciar al acreedor una mayor seguridad en el cobro de su crédito ${ }^{653}$ y sostiene que la responsabilidad tributaria es una garantía personal del crédito tributario ${ }^{654}$. En este sentido, el responsable cumple con una función de garantía ante posibles dificultades que se puedan presentar al acreedor en cualquier momento del procedimiento de aplicación de los tributos, configurándose como una garantía de índole personal.

No se trata, en nuestra opinión, de una garantía en sentido amplio, sino de una garantía en sentido estricto. Según GONZÁLEZ ORTIZ, la responsabilidad es "un nuevo derecho subjetivo o una nueva facultad que se yuxtapone al derecho de crédito que se pretende asegurar, añadiendo a este último algo que el crédito por sí mismo no tiene" ${ }^{, 655}$. Para este autor, es la aparición de un nuevo derecho de

\footnotetext{
${ }^{650}$ CALVO ORTEGA, R., “La responsabilidad tributaria solidaria por actos ilícitos”, op. cit., pág. 45.

${ }^{651}$ GALÁN RUIZ, J., La responsabilidad tributaria, op. cit., pág. 44.

${ }^{652}$ Nos referimos a la dimensión temporal del acto de derivación de responsabilidad y a la falta de plazos específicos para determinar la prescripción de la obligación del responsable.

${ }^{653}$ RUIZ HIDALGO, C., La responsabilidad tributaria en el alzamiento de bienes en la nueva Ley General Tributaria, op. cit., pág. 27; GUERRA REGUERA, M., Garantías personales del crédito tributario. Algunas cuestiones, Comares, Granada, 1997, pág. 65 y 66; SÁNCHEZ GALIANA, J. A., "El responsable", op. cit., pág. 637; CALVO ORTEGA, R., "La responsabilidad tributaria solidaria por actos ilícitos", op. cit., pág. 38. En la jurisprudencia, vid. la Sentencia del Tribunal Supremo de 16 de mayo 1991; las Sentencias de la Audiencia Nacional de 23 de julio de 2001, de 27 de diciembre de 2002, de 7 de noviembre de 2003, y de 5 de abril de 2004; y las Sentencias de los Tribunales Superiores de Justicia de Galicia de 16 de febrero de 2001, de la Comunidad Valenciana de 29 de junio de 2001, de Castilla y León, Burgos, de 22 de febrero de 2002, de Asturias de 25 de abril de 2002, o de Andalucía, Granada, de 20 de octubre de 2008 .

${ }^{654}$ HERRERO MADARIAGA, J., "El responsable tributario”, op. cit., pág. 185; ARIAS ABELLÁN, M. D., "El estatuto jurídico del responsable del tributo en el derecho español”, op. cit., pág. 180; RODRÍGUEZ BEREIJO, A., "Las garantías del crédito tributario", op. cit., pág. 187.

${ }^{655}$ GONZÁLEZ ORTIZ, D., "La figura del responsable tributario en el derecho español: concepto, naturaleza jurídica y fundamento", Crónica Tributaria, núm. 98, 2001, pág. 92 y 93. Por el contrario, PÉREZ ROYO entendió como la única finalidad de esa clasificación
} 
cobro, que nace a favor de la Hacienda Pública como consecuencia de la realización del presupuesto de hecho de la responsabilidad. Tal como expresa GALÁN RUIZ, "la Administración, sin perder su derecho contra el deudor principal, va a poder asimismo realizar forzosamente su crédito sobre el patrimonio del responsable en el supuesto de que el primero no proceda al pago en el período voluntario concedido a tal efecto" ${ }^{\circ 56}$.

Sin embargo, esta no es la única tesis sobre la naturaleza jurídica de la responsabilidad tributaria. En la medida en que el responsable queda obligado en nombre propio al pago de una deuda ajena, un grupo de autores entiende que la responsabilidad es una especie dentro del género de la fianza ${ }^{657}$. Esta teoría ha sido descartada por el origen legal que tiene la responsabilidad tributaria, que contrasta con la autonomía de la voluntad que rige en la fianza, "predominando las tesis que preconizan la autonomía conceptual de la responsabilidad tributaria frente a las categorías ius privatistas" ${ }^{658}$. Como apunta SÁNCHEZ GALIANA, esta tesis "reconduce la responsabilidad tributaria a la figura jurídica de la fianza, existiendo una semejanza estructural entre la obligaciones del responsable y el fiador, que posibilitaría la aplicación de las normas reguladoras de la fianza en el Código civil, que no supusiesen vulneración de principios del derecho tributario, o bien rechazándose los preceptos fundamentales en el origen voluntario de la fianza civil, dada la esencial indisponibilidad de la obligación tributaria". Y añade el mismo autor que "la consideración de responsable como sujeto pasivo de una obligación accesoria de garantía, fundamentada en la finalidad garantista de esta figura tributaria, precisaría de toda una construcción jurídico-tributaria nueva, que supondría completar los actuales preceptos tributarios con algunos trasladables del Derecho civil relativos a la fianza, cambiar la actual sistematización de la L.G.T. y modificar la formulación legal de otros preceptos afectados",659.

Más interés despierta la postura que explica la naturaleza de la responsabilidad desde la perspectiva del derecho sancionador. No son pocos los autores que manifiestan que existe una cierta dimensión sancionadora en la figura de la responsabilidad. En este sentido, debemos resaltar que la LGT, en el inciso a) del apartado primero del artículo $42 \mathrm{y}$ en el inciso a) del apartado primero del artículo 43, determina una responsabilidad por infracciones cometidas por los responsables o con una participación muy directa de éstos, que abarca no sólo a la deuda tributaria, sino también a las sanciones. Estos supuestos de actos ilícitos son los que califica CALVO ORTEGA como una "sanción de garantía", que pretende, además de sancionar al infractor, garantizar el pago de la deuda tributaria $^{660}$. Del mismo modo se ha expresado CHECA GONZÁLEZ cuando acepta la aplicación del principio de reserva de ley al "marcado cariz sancionador" de la figura de los responsables

consistía en un intento de aplicar al responsable las normas propias de las obligaciones de garantía (PÉREZ ROYO, F., "La sucesión en la deuda por el Impuesto de Sociedades ante el artículo 72 de la Ley General Tributaria”, op. cit., pág. 159).

${ }^{656}$ GALÁN RUIZ, J., La responsabilidad tributaria, op. cit., pág. 46.

${ }^{657}$ CALVO ORTEGA calificó a la responsabilidad tributaria como una "fianza legal pura". En esta doctrina se asume que la responsabilidad es una fianza que "no sólo tiene su fuente en la ley, sino que además surge exclusivamente de la realización de un presupuesto de hecho previsto en la misma ley" (CALVO ORTEGA, R., "La responsabilidad tributaria solidaria por actos ilícitos", $o p$. cit., pág. 38). En este mismo sentido, HERRERO MADARIAGA, J., "El responsable tributario”, op. cit., pág. 201 y ss.; y MAZORRA MANRIQUE DE LARA, S., Los responsables tributarios, op. cit., pág. 90 a 97.

${ }^{658}$ GALÁN RUIZ, J., La Responsabilidad Tributaria, op. cit., pág. 46.

${ }^{659}$ SÁNCHEZ GALIANA, J. A., "El responsable”, op. cit., pág. 635 y 637.

${ }^{660}$ CALVO ORTEGA, R., "La responsabilidad tributaria solidaria por actos ilícitos”, op. cit., pág. 38 y ss. 
tributarios ${ }^{661}$. Siguiendo esta misma postura crítica, LÓPEZ GETA ha afirmado que "el hecho de que sólo un supuesto de responsabilidad, el del número 1 del artículo 72 (LGT 1963), se incluya dentro de las garantías de la deuda, inclina el fiel de la balanza en el sentido de la apreciación de un significado acusadamente sancionador en los casos de los artículos 38, 40.1 y 40.2 (LGT 1963)",662.

En la jurisprudencia no se encuentra una posición predominante en relación con ese posible carácter sancionador de la responsabilidad. Así vemos como el Tribunal Supremo en su Sentencia de 30 de septiembre de 1993 proclamó que los actos de derivación de la responsabilidad no tenían una naturaleza sancionadora, sino que participaban de la noción de responsabilidad civil subsidiaria, y la Sentencia de la Audiencia Nacional de 21 de septiembre de 1999, en cambio, se manifestaba a favor de la aplicación al procedimiento de declaración de responsabilidad tributaria de las garantías propias de los procedimientos sancionadores.

Para GALÁN RUIZ, a la hora de aceptar o desechar la naturaleza cuasi-sancionadora de la responsabilidad tributaria, debe considerarse que la misma no siempre se aplica a quienes han realizado una conducta contraria al ordenamiento jurídico. "Por tanto, parece infundado considerar que presenta per se carácter sancionador o represivo. De hecho, (...) el responsable no tiene que pagar las sanciones que se hubieren impuesto al deudor principal (...) salvo, como aclara expresamente el artículo 42.1 a) LGT 2003, que el propio responsable hubiera causado o colaborado activamente en la realización de una infracción tributaria (...) o que, (...) se trate de administradores negligentes de personas jurídicas que hubiesen cometido una infracción tributaria”, ${ }^{\circ}$.

Si para determinar la naturaleza jurídica de la responsabilidad se requiere que exista un elemento común a todos los tipos de esta figura, entonces necesariamente habrá que acudir al carácter garantista del cobro del crédito de la Administración tributaria. Según CASADO OLLERO, FALCÓN Y TELLA, LOZANO SERRANO y SIMÓN ACOSTA "la finalidad que la ley persigue al establecer responsables de la deuda tributaria puede variar de un caso a otro, pero siempre hay un objetivo común a todos los casos de responsabilidad: se trata de asegurar el cobro del tributo, ampliando el círculo de obligados, es decir, de patrimonios que responden del pago de la deuda tributaria" 664 . La responsabilidad es, a nuestro entender, una garantía personal, con independencia de que se articulen modalidades de responsabilidad en torno a la comisión de un ilícito. Como dijera DE GANDARILLAS MARTOS, "lo que pretende el Legislador a través del responsable es el establecimiento de instituciones analógicas a las del deudor que garanticen el pago de la deuda" ${ }^{665}$. El hecho de que en algunos supuestos, que la doctrina denomina responsabilidad por actos ilícitos, el

\footnotetext{
${ }^{661}$ CHECA GONZÁLEZ, C., GARCÍA LUIS, T., MERINO JARA, I., MORENO FERNÁNDEZ, J. I., La reforma de la Ley General Tributaria, op. cit., pág. 137.

${ }^{662}$ LÓPEZ GETA, J. M., “Responsabilidad y sucesión en las deudas tributarias”, Impuestos, núm. 24, 1989, pág. 1225 y 1226. En este sentido, RUFIÁN LIZANA, M. D., "La responsabilidad tributaria de los administradores de las sociedades en las infracciones cometidas por estás”, Impuestos, núm. 3, marzo, 1987, pág. 149.

${ }^{663}$ GALÁN RUIZ, J., La responsabilidad tributaria, op. cit., pág. 48.

${ }^{664}$ CASADO OLLERO, G., FALCÓN Y TELLA, R., LOZANO SERRANO, C., y SIMÓN ACOSTA, E., "Las garantías del crédito tributario", op. cit., pág. 219.

${ }^{665}$ DE GANDARILLAS MARTOS, S., "El alcance de la responsabilidad tributaria", en la obra Tratado sobre la Ley General Tributaria, Tomo I, ARRIETA MARTÍNEZ DE PISÓN, J, COLLADO YURRITA, M. A., ZORNOZA PÉREZ, J. (directores), Aranzadi, Thomson Reuters, 2010, pág. 968.
} 
responsable tributario tenga que hacer frente a las sanciones no desvirtúa su naturaleza garantista, puesto que la sanción debe exigirse a este sujeto en su condición de infractor y no de responsable ${ }^{666}$.

\subsection{LA EXTENSIÓN DE LA OBLIGACIÓN DE LA RESPONSABILIDAD TRIBUTARIA}

El alcance de la responsabilidad es uno de los aspectos que más relevancia tiene en la aplicación práctica de esta figura. La LGT regula el alcance de la responsabilidad en los apartados tercero y cuarto del artículo 41, estipulando que alcanzará "a la totalidad de la deuda tributaria exigida en período voluntario" y que no se extenderá a las sanciones, salvo mandato legal en contra. Es preciso, pues, remitirnos a cada supuesto específico de responsabilidad para poder determinar hasta dónde llega verdaderamente el alcance en cada caso.

En primer lugar, la responsabilidad alcanza a la totalidad de la deuda tributaria, que según establece el artículo 58 de la LGT está integrada por el interés de demora, los recargos por declaración extemporánea, los recargos del período ejecutivo, y los recargos exigidos legalmente sobre las bases o las cuotas, a favor del Tesoro o de otros entes públicos, y excluyéndose actualmente las sanciones. Sin embargo, los preceptos descritos no aportan mucho a la hora de determinar el alcance de la responsabilidad, y por ello manifestamos anteriormente que debemos examinar cada supuesto concreto de responsabilidad, más aun si tenemos en cuenta que en algunos casos se esconden bajo el supuesto de responsabilidad figuras que poco o nada tienen que ver con la naturaleza jurídica de ésta.

El debate para determinar el alcance de la responsabilidad debe centrarse, y en esto coincidimos con NAVARRO EGEA ${ }^{667}$, en la delimitación de dos de los términos que utiliza la LGT: "totalidad de la deuda" y el "período voluntario". Esto reconduce el análisis a los artículos 58 y 161 de la LGT. La vinculación entre estos preceptos coloca positivamente el contenido de la obligación del responsable en relación con la deuda tributaria que se define en el artículo 58 de la LGT, quedando excluidos los intereses y recargos que se devenguen como consecuencia del inicio del período ejecutivo e integrando los recargos exigibles sobre las bases o las cuotas. Las dudas se suscitan al interpretar el artículo 41 en relación con el artículo 161 de la LGT, puesto que es preciso determinar si el responsable debe o no pagar los intereses demora y los recargos por incumplimiento extemporáneo que resulten de deudas liquidas por la Administración tributaria, o por deudas a ingresar mediante autoliquidación presentada fuera del plazo sin efectuarse el ingreso.

\footnotetext{
${ }^{666}$ En contra de nuestra postura se manifiesta MARTÍN JIMÉNEZ, que entiende que es un error buscar un fundamento unitario a la institución de la responsabilidad. "La búsqueda de un fundamento unitario para diversas manifestaciones de la responsabilidad tributaria", añade este autor, "desconoce que, en realidad, los presupuestos de responsabilidad que la LGT regula responden a tres instituciones con una naturaleza completamente diversa: la responsabilidad entendida como sanción por conductas equiparables a las infracciones tributarias, la responsabilidad de naturaleza indemnizatoria o resarcitoria (equiparable a la civil extracontractual) y la responsabilidad asimilable a las garantías de las obligaciones (en este caso, de la obligación tributaria)" (MARTÍN JIMÉNEZ, A., Los Supuestos de responsabilidad en la LGT: (hacia una configuración constitucional y comunitaria de la responsabilidad tributaria), op. cit., pág. 36 a 61). En un sentido muy parecido se pronunció DE LA HUCHA CELADOR anteriormente, cuando destacó que la responsabilidad por infracciones debía llevarse al marco del Derecho tributario sancionador, mientras que la responsabilidad por hechos no constitutivos de infracciones sí puede ser estudiada en el marco de los deudores (DE LA HUCHA CELADOR, F., "Reflexiones para una definición dogmática de la responsabilidad en Derecho Tributario (I)", op. cit., pág. 347).

${ }^{667}$ NAVARRO EGEA, M., El responsable tributario, op. cit., pág. 27.
} 


\subsubsection{La responsabilidad por la totalidad de la deuda tributaria en periodo voluntario}

De acuerdo con el apartado tercero del artículo 41 de la LGT

"Salvo lo dispuesto en el apartado 2 del artículo 42 de esta Ley, la responsabilidad alcanzará a la totalidad de la deuda tributaria exigida en período voluntario".

La redacción de este precepto, y concretamente el uso de los términos "totalidad de la deuda tributaria" y "período voluntario" $" 668$, contribuye a la determinación del alcance de la responsabilidad. Sin embargo, la ley sigue sin establecer objetivamente la extensión de ésta. La identificación del alcance de la responsabilidad es de gran interés, sobre todo porque el precepto transcrito se refiere a la "totalidad de la deuda tributaria", concepto que incluye, entre otros, además de la cuota tributaria, los intereses de demora y los recargos por declaración extemporánea o del período ejecutivo, que se incluirán o no en la deuda que hará frente el responsable en función del supuesto de que se trate. Todo ello permite afirmar que el responsable sólo tendrá que hacer frente a las obligaciones del deudor principal de carácter pecuniario, excluyéndose del alcance de la responsabilidad el resto de las obligaciones que incumben a los deudores principales, como pueden ser las obligaciones formales ${ }^{669}$.

\subsubsection{Los intereses de demora}

La inclusión en la responsabilidad de los intereses de demora es uno de los elementos de la deuda tributaria que provoca posiciones encontradas en la doctrina. El apartado tercero del artículo 41 de la LGT estipula que transcurrido el plazo voluntario de pago concedido al responsable sin haberse realizado el ingreso se iniciará el período ejecutivo y se exigirán los recargos e intereses que procedan.

Existe un sector de la doctrina que entiende que los intereses de demora deben integrar la obligación del responsable tributario, sobre la base de que se produce el devengo del interés "por el tiempo transcurrido" desde la finalización del período voluntario de pago del obligado principal hasta "el requerimiento de pago al responsable. A continuación, se abre un nuevo período voluntario de pago, propio de aquél, que no dará lugar a la exigencia de interés alguno. Por último, si el responsable no ingresa la deuda durante su plazo voluntario, se abrirá un nuevo período ejecutivo, que originará el devengo de intereses, salvo que aquél ingrese la deuda con anterioridad a la notificación de la providencia de apremio" ${ }^{\circ 70}$.

Este es un asunto que según nuestro criterio debe examinarse desde dos ángulos diferentes. Por un lado, están los intereses de demora que se adjudican al responsable que se devengan de su propia

\footnotetext{
${ }^{668}$ En palabras de BOSCH CHOLBI, este período voluntario es aquél que la ley establece para el "abono tempestivo de la cuota tributaria" o el que se "inicia tras el correspondiente procedimiento administrativo de gestión o inspección seguido contra él y que concluye con una liquidación administrativa" (BOSCH CHOLBI, J. L., "Los responsables tributarios en la LGT 58/2003: aspectos controvertidos", op. cit., pág. 44).

${ }^{669}$ Como bien afirma GALÁN RUIZ “el instituto de la responsabilidad tiene una función garantista del pago de la deuda, de tal modo que si el deudor principal no cumple con este deber el responsable debe asumir su pago. Pero esta finalidad de garantía de cobro por parte de la Hacienda Pública no podría justificar que al responsable se le hiciera asumir el cumplimiento de obligaciones formales del deudor principal, aspecto que nada tiene que ver con esta garantía" (GALÁN RUIZ, J., La responsabilidad tributaria, op. cit., pág. 68).

${ }^{670}$ RODRÍGUEZ MÁRQUEZ, J. S., El interés de demora en la Ley General Tributaria, op. cit., pág. 293 a 300 ; GUERRA REGUERA, M., Garantías personales del crédito tributario. Algunas cuestiones, op. cit., pág. 123.
} 
actuación; y por otro lado, se encuentran los intereses de demora que son atribuibles al deudor principal, todo ello sin perjuicio de la indicación de la ley de que la responsabilidad alcanzará la totalidad de la deuda tributaria exigida en período voluntario. Y es que el uso de estos términos sugiere que el legislador pretende que el responsable asuma aquellos componentes de la deuda tributaria que se ajusten exactamente al cumplimiento de su deber de contribuir. En este sentido, entendemos que deben incorporarse a la obligación del responsable los recargos o intereses que se produzcan por el inicio del período ejecutivo, al haber expirado el plazo voluntario que se concedió a este sujeto para efectuar el pago y que no se efectuó por causas que son imputables al mismo.

Ahora bien, lo más controvertido en este tema es la extensión a los responsables tributarios de los intereses de demora atribuibles al deudor principal. En este caso debe partirse de dos extremos: los intereses de demora atribuibles al deudor principal por causas imputables sólo a él; y los intereses de demora atribuibles al deudor principal pero que se ocasionan por la actuación del responsable. En el primero de los extremos coincidimos con la doctrina en que no puede extenderse la responsabilidad hasta estos intereses de demora, por las razones que esgrime un importante sector doctrinal ${ }^{671}$ : o bien porque el responsable no es el causante de los comportamientos que originan el devengo de los intereses de demora; o porque la LGT concede un nuevo período voluntario de pago al responsable, cuando se inicia un nuevo procedimiento de recaudación frente a este sujeto, sin que se le exija el pago de la deuda en el mismo procedimiento de recaudación seguido frente al deudor principal; o bien porque los intereses de demora son componentes que se originan en el procedimiento de recaudación seguido contra los obligados principales, por la ausencia de pago en período voluntario, y por tanto, una vez que finaliza dicho período.

En el otro extremo, se plantea la posibilidad de que la responsabilidad alcance a los intereses de demora atribuibles al deudor principal, pero cuando estos intereses se originen como consecuencia de la actuación de los responsables. Una parte importante de la doctrina es del criterio que bajo esa condición el retraso en el pago del deudor principal es atribuible al responsable y los intereses de demora que se generen deben engrosar la deuda del responsable ${ }^{672}$. Sin embargo, en este ámbito nos

\footnotetext{
${ }^{671}$ ARIAS ABELLÁN, M. D., "El régimen jurídico del responsable en la nueva Ley General Tributaria”, op. cit., pág. 500 y, de la misma autora, "El estatuto jurídico del responsable del tributo en el derecho español", Revista Española de Derecho Financiero, núm. 42, 1984, pág. 203; DE LA HUCHA CELADOR, F., "Algunas consideraciones sobre la responsabilidad tributaria en el Reglamento General de Recaudación de 1990: II. Responsabilidad Subsidiaria”, Crónica Tributaria, núm. 63, 1992, pág. 58; MAZORRA MANRIQUE DE LARA, S., Los responsables tributarios, op. cit., pág. 188; SIMÓN ACOSTA, E., "Obligados tributarios", en la obra Cuestiones Tributarias Prácticas, $2^{\mathrm{a}}$ ed., La ley, Madrid, 1990, pág. 226; COMBARROS VILLANUEVA, V. E., "La responsabilidad tributaria, solidaria y subsidiaria, en el procedimiento de recaudación", op. cit., pág. 391; PÉREZ ROYO, F. y AGUALLO AVILÉS, A., Comentarios a la reforma de la Ley General Tributaria, op. cit., pág. 100 y 101; FERNÁNDEZ JUNQUERA, M., "Responsables tributarios. Situación actual y perspectiva de futuro", op. cit., pág. 10.

${ }^{672}$ En efecto, como afirma PALAO TABOADA el responsable indudablemente ha de responder del retraso por él exclusivamente generado (PALAO TABOADA, C., "Notas a la Ley 25/1995, de 20 de julio, de Modificación Parcial de la Ley General Tributaria", $o p$. cit., pág. 9). Esta misma posición la sustenta LAGO MONTERO cuando considera que los responsables sólo deben responder de la cuota tributaria y recargos inicialmente liquidados al deudor principal, así como los intereses de demora, recargos de apremio, sanciones y costas, que con su conducta personal hayan generado (LAGO MONTERO, J. M., "El procedimiento de declaración de la responsabilidad tributaria: una crítica", Impuestos, Tomo II, 1995, pág. 670 y ss.). En este mismo sentido, PÉREZ ROYO, F. y AGUALlO AVILÉS, A., Comentarios a la reforma de la Ley General Tributaria, op. cit., pág. 100; DELGADO GARCÍA, A. M., “Alcance de la responsabilidad tributaria. Una cuestión abierta", Revista Española de Derecho Financiero, núm. 106, 2000, pág. 232; CHECA GONZÁLEZ, C., Los responsables tributarios. Aranzadi, Navarra, 2003, pág. 81 y, del mismo autor, "Notas sobre la nueva regulación de los responsables tributarios en el anteproyecto de la LGT", op. cit., pág. 32 Para todos estos autores resulta aceptable que el responsable satisfaga los intereses de demora en la medida en que el retraso del pago del deudor principal se origine como consecuencia de la actuación de los primeros. La inclusión de los intereses de demora en la responsabilidad se reafirma en la Instrucción del Departamento de Recaudación de la AEAT de 2 de noviembre de 1995, relativa a los responsables en el pago de las deudas tributarias, donde se reconoce que el responsable, tanto solidario como subsidiario, debe responder de los intereses de demora
} 
parece importante recordar que los intereses de demora no tienen un efecto sancionador, porque su naturaleza es reparadora ${ }^{673}$, y que además el responsable puede resarcir su patrimonio estableciendo una acción de regreso contra el deudor principal, que, en el caso de prosperar, implicaría la asunción por el deudor principal de unos intereses producidos por una actuación del responsable.

Por último queremos referirnos a la posibilidad de que la responsabilidad se extienda a los intereses de demora devengados por el deudor principal y correspondientes al período que media entre la finalización del plazo voluntario para ingresar la deuda tributaria descubierta posteriormente por la inspección y la fecha en que se emite el acta. Según la interpretación que hace ORÓN MORATAL del primer párrafo del apartado tercero del artículo 41 de la LGT y del RGR, es posible exigir los intereses de demora a los responsables subsidiarios "cuando la liquidación notificada para ser ingresada en período voluntario ya incorporarse los intereses de demora, como suele suceder en todas las liquidaciones practicadas por la Inspección tributaria. Ahora bien, los intereses exigibles sólo serán esos, los devengados desde que debió declarar o autoliquidar el sujeto pasivo o deudor principal y hasta que se practique la liquidación, pero no en los que se pudieran devengar desde ese momento hasta que se le exija el pago al responsable. En consecuencia, en los tributos gestionados de oficio por patrón o matrícula no serán exigibles intereses de demora a los responsables, pero en los autoliquidables o liquidables tras la declaración del sujeto pasivo u obligado tributario, los intereses sí podrán ser exigibles si no autoliquidó o no declaró" 674 .

Por nuestra parte, coincidimos con GALÁN RUIZ ${ }^{675}$ y creemos que se debe minimizar en la medida de lo posible la carga a la que debe hacer frente el responsable tributario, si tenemos en cuenta que éste no es el sujeto que realiza el hecho imponible y sólo por imperio de la ley debe responder de la deuda tributaria del deudor principal. Estimamos en consecuencia que sólo es posible exigir al responsable tributario aquellos intereses de demora que se devenguen con motivo de la finalización, sin ingreso, del período voluntario de pago que se concede en la derivación de la responsabilidad, y los intereses que se incorporen a las liquidaciones practicadas por la gestión o la inspección tributaria contra el obligado principal. En el primer caso porque esos intereses se devengan como resultado de la falta de

devengados por el deudor principal. También se observa igual postura en la Sentencia de la Audiencia Nacional de 21 de febrero de 2000, y en las Sentencias del Tribunal Superior de Justicia de Cantabria de 12 de julio de 2001, de Castilla y León, Burgos, de 23 de diciembre de 2002, y de Islas Canarias, Santa Cruz de Tenerife, de 21 de abril de 2005.

${ }^{673}$ Reconocen PÉREZ ROYO Y AGUALLO AVILÉS que "la Ley parece partir de que, existiendo el daño al Fisco, éste debe ser reparado conforme dictan las reglas del Derecho común, dado que los intereses de demora no constituyen sanciones, que sí están indisolublemente unidas a quienes las cometen; además el responsable -quizás se piense-, siempre podría resarcirse mediante la correspondiente acción de regreso contra el deudor principal" (PÉREZ ROYO, F. y AGUAYO AVILÉS, A., Comentarios al a reforma de la Ley General Tributaria, op. cit., pág. 100 y ss.). También NAVARRO EGEA opina que es poco convincente que "el responsable asuma los intereses de demora que acompaña a la deuda principal en el caso de que éste haya propiciado la mora en que incurrió el deudor principal, pues esta correlación puede significar el reconocimiento de un efecto sancionador en los intereses de demora extraño a su naturaleza indemnizatoria" (NAVARRO EGEA, M., El responsable tributario, op. cit., pág. 29).

${ }^{674}$ ORÓN MORATAL, G., "Los obligados tributarios en la Ley 58/2003, de 17 de diciembre, General Tributaria: principales novedades", op. cit., pág. 131. En el mismo sentido, MARTÍN JIMÉNEZ, A., Los Supuestos de responsabilidad en la LGT: (hacia una configuración constitucional y comunitaria de la responsabilidad tributaria), op. cit., pág. 154; BLÁZQUEZ LIDOY, A., "Novedades de la Ley General Tributaria 58/2003 en la regulación de la responsabilidad tributaria y de la sucesión”, Contabilidad y Tributación, núm. 255, 2004, pág. 6 y 7; GIMÉNEZ REYNA, MARTíN FERNÁNDEZ, F. J. y RODRÍGUEZ MÁRQUEZ, J. S., "La responsabilidad tributaria", en la obra La justicia en el diseño y aplicación de los tributos, Instituto de Estudios Fiscales, Madrid, 2006, pág. 175 y 176; DE GANDARILLAS MARTOS, S., "El alcance de la responsabilidad tributaria”, op. cit., pág. 980.

${ }^{675}$ GALÁN RUIZ, J., La responsabilidad tributaria, op. cit., pág. 71. 
pago en período voluntario concedido al responsable a través de la derivación de la responsabilidad. Y en el segundo porque la liquidación notificada que se debe ingresar en el nuevo plazo concedido al deudor principal ya incorpora los intereses de demora.

\subsubsection{Los recargos por declaración extemporánea}

Otro de los componentes de la deuda tributaria dispuestos en el inciso b) del apartado segundo del artículo 58 de la LGT son los recargos por declaración extemporánea. Al igual que sucede con los intereses de demora, la LGT no se refiere a ellos expresamente cuando alude en el apartado tercero del artículo 41 al alcance de la responsabilidad, como sí lo hace respecto de los recargos del período ejecutivo y las sanciones. La determinación de si estos recargos forman parte o no de la obligación del responsable debe pasar, de la misma forma que sucede con los intereses de demora, por la interpretación de los términos que se contemplan en el apartado tercero del artículo 41 de la LGT: la "totalidad de la deuda tributaria" exigible en el "período voluntario". Lo que conlleva, en principio, a extender la responsabilidad a los recargos por ingresos extemporáneos en los términos del artículo 27 de la LGT. Estos recargos son parte de la totalidad de la deuda tributaria, porque así se establece en el inciso b) del artículo 58 de la LGT y, por tanto, quedan incluidos dentro del alcance de la responsabilidad, tal como se precisa en el apartado tercero del artículo 41 de la LGT. Además el apartado segundo del artículo 68 del RGR dispone que en el caso de deudas a ingresar mediante autoliquidación presentada fuera de plazo sin realizar el ingreso o sin presentar solicitud de aplazamiento, fraccionamiento o compensación, el período voluntario concluirá el mismo día de la presentación de la autoliquidación y, consiguientemente, los recargos por declaración extemporánea se devengan, todavía, en período voluntario ${ }^{676}$.

Sin embargo, esta posición tiene sus detractores, entre otros, DELGADO GARCÍA ${ }^{677}$ o DE GANDARILLAS MARTOS. Según este último autor, dado el carácter de excusa absolutoria y reparador que presentan los recargos, la Administración tributaria puede en el momento de liquidar la deuda del responsable decantarse por el importe perteneciente a los intereses de demora y no trasladar al responsable los recargos que actuaron como excusa absolutoria para evitar la sanción. De esta forma se garantiza "que la Administración tributaria no se viera perjudicada por la falta de disposición a tiempo de la deuda, mediante el pago de interés de demora correspondiente; y segundo, que la parte

\footnotetext{
${ }^{676}$ ÁLVAREZ MARTÍNEZ, partiendo del carácter de excusa absolutoria que le confiere a estos recargos, opina que cuando el deudor principal no declara o no paga se le impone la correspondiente sanción, que por lo demás no se traslada al responsable, pero que cuando se trata de regularizar su situación tributaria a través de un ingreso extemporáneo sin requerimiento previo el recargo que exigen a este sujeto sí alcanza al responsable (ÁLVAREZ MARTÍNEZ, J., "El alcance de la responsabilidad tributaria en la nueva Ley General Tributaria: análisis jurídico y examen comparativo respecto de la Ley General Tributaria de 1963", Revista de Contabilidad y Tributación, núm. 263, 2005, pág. 37 y 38). Esta misma posición es defendida por BLÁZQUEZ LIDOY, A., "Novedades de la Ley General Tributaria 58/2003 en la regulación de la responsabilidad tributaria y de la sucesión”, op. cit., pág. 7; ROZAS VALDÉS, J. A., "Sucesores y responsables en el proyecto de la Ley General Tributaria", Gaceta Fiscal, núm. 226, 2003, pág. 29; MARTÍN JIMÉNEZ, A., Los Supuestos de responsabilidad en la LGT: (hacia una configuración constitucional y comunitaria de la responsabilidad tributaria), op. cit., pág. 157. La jurisprudencia ha reconocido la extensión de los recargos por ingresos extemporáneos a los responsables en las Sentencias del Tribunal Supremo de 15 de julio de 2000, de 6 de octubre de 2003, de 23 de diciembre de 2010, y de 5 de diciembre de 2011, entre otras, en las Sentencias de la Audiencia Nacional de 7 de marzo de 2005, de 20 de febrero de 2006, y de 27 de septiembre de 2007, y en las Sentencias de los Tribunales Superiores de Justicia de la Comunidad Valenciana de 20 de julio de 2007, de 8 de febrero de 2008; de Murcia de 30 de septiembre de 2008; de Castilla-La Mancha de 24 de noviembre de 2008; del País Vasco de 30 de julio de 2009; de Murcia de 18 de diciembre de 2009, de 25 de noviembre de 2010, de 28 de diciembre de 2011, y de 17 de febrero de 2012; y de la Comunidad Valenciana de 29 de junio de 2012.

${ }^{677}$ DELGADO GARCÍA, A. M., “Alcance de la responsabilidad tributaria. Una cuestión abierta”, op. cit., pág. 235.
} 
del recargo vinculada a la exclusión de la sanción por la conducta imputable al sujeto pasivo, no fuera trasladada al responsable" ${ }^{, 678}$.

Para GUERRA REGUERA, la naturaleza de estos recargos por declaración extemporánea es sancionadora y por ello afirma "que el hecho de que el responsable tenga que hacer frente al pago de ese recargo vulnera directamente principios como el de la personalidad o voluntariedad en la comisión de infracciones administrativas que se derivan del apartado primero del artículo 25 de la Constitución"679. En definitiva, y a pesar de lo que establece la normativa, nosotros entendemos, haciéndonos eco de esta doctrina, que los responsables no deberían asumir el pago de los recargos por declaración extemporánea imputable al deudor principal, sobre todo si se trata del recargo extemporáneo del 20 por 100, ya que este tipo tiene un carácter sancionador ${ }^{680}$.

\subsubsection{Los recargos ejecutivos}

El apartado 3 del artículo 41 de la LGT deja clara la intención de no trasladar al responsable el recargo ejecutivo en que haya incurrido el deudor principal por el incumplimiento de su obligación de pago en período voluntario. De la interpretación que se haga del primer y segundo párrafo del apartado tercero de este precepto, puede afirmarse que la totalidad de la deuda tributaria a la que hace referencia es aquélla que se adeuda en el período voluntario de pago para el deudor principal, y que los intereses y recargos ejecutivos sólo alcanzarán al responsable cuando se inicie para éste el período ejecutivo por no efectuar el pago en el período voluntario que se concedió a este sujeto en la declaración responsabilidad $^{681}$.

La única excepción que se puede aplicar a esta regla general es la que contempla el primer párrafo del apartado 3 del artículo 41, introducido por el artículo 5 de la Ley 36/2006, que extiende a la responsabilidad la totalidad de la deuda tributaria, incluidos los recargos de apremio, en aquellos supuestos de responsabilidad solidaria previstos en el apartado segundo del artículo 42, según el cual

“también serán responsables solidarios del pago de la deuda tributaria pendiente $y$, en su caso, del de las sanciones tributarias, incluidos el recargo y el interés de demora del período ejecutivo, cuando procedan, hasta el importe del valor de los bienes o derechos que se hubieran podido embargar o enajenar por la Administración tributaria".

\footnotetext{
${ }^{678}$ DE GANDARILLAS MARTOS, S., "El alcance de la responsabilidad tributaria”, op. cit., pág. 983.

${ }^{679}$ GUERRA REGUERA, M., Garantías personales del crédito tributario. Algunas cuestiones, op. cit., pág. 125.

${ }^{680}$ Sobre la naturaleza jurídica de los recargos extemporáneos, vid supra Primer Capítulo, epígrafe 1.6.2.1. "Naturaleza jurídica de los recargos por declaración extemporánea".

${ }^{681}$ En este mismo sentido, pero amparados en la legislación anterior, se manifiestan PÉREZ ROYO, F. y AGUALLO AVILÉS, A., Comentarios a la reforma de la Ley General Tributaria, op. cit., pág. 100; ARIAS ABELLÁN, M. D., "El estatuto jurídico del responsable del tributo en el derecho español", op. cit., pág. 203; CALVO ORTEGA, R., "La responsabilidad tributaria solidaria por actos ilícitos", op. cit., pág. $60 \mathrm{y}$, del mismo autor, "La responsabilidad tributaria subsidiaria", op. cit., pág. 140; GUERRA REGUERA, M., Garantías personales del crédito tributario. Algunas cuestiones, op. cit., pág. 113; PEÑA ALONSO, J. L. y CORCUERA TORRES, A., La reforma de la Ley General Tributaria, op. cit., pág. 24. En contra, HERRERO MADARIAGA, J., "E1 responsable tributario", op. cit., pág. 218.
} 


\subsubsection{La responsabilidad por las sanciones}

La LGT excluye las sanciones expresamente del alcance de la responsabilidad, con el matiz que aparece en el apartado 4 del artículo 41 de la LGT, que prevé excepciones a esta norma general $^{682}$. Estas excepciones se concretan en varios supuestos: la responsabilidad solidaria de los causantes o colaboradores directos en la comisión de una infracción (inciso a) del apartado primero del artículo 42 de la LGT); la responsabilidad solidaria de los sucesores de actividades económicas (inciso $c$ ) del apartado primero del artículo 42 de la LGT); la responsabilidad solidaria de las personas que dificulten la actividad recaudatoria (apartado segundo del artículo 42 de la LGT); la responsabilidad subsidiaria de los administradores de personas jurídicas (inciso a) del primer apartado del artículo 43 de la LGT) y los integrantes de la administración concursal y los liquidadores (inciso $c$ ) del apartado primero del artículo 43 de la LGT), cuando tengan atribuidas funciones de administrador; y la responsabilidad subsidiaria por "levantamiento del velo" (supuesto añadido por la Ley de Medidas para la Prevención del Fraude Fiscal en los incisos $g$ ) y h) del primer apartado del artículo 43 de la LGT) ${ }^{683}$.

La fundamentación constitucional de la exigencia de sanciones al responsable tributario viene dada, en estos casos, por la participación de éste en un acto ilícito que eleva a este sujeto a la condición de infractor $^{684}$. No obstante, el responsable tiene la posibilidad de ejercitar la acción de reembolso contra el deudor principal, dando lugar a que sólo uno de los dos llegue a ser sancionado: bien el responsable que no ha conseguido recuperar lo satisfecho, o bien el deudor principal en caso de que prospere el ejercicio de la acción de regreso ${ }^{685}$.

\footnotetext{
${ }^{682}$ Se evidencia un avance legislativo en este punto, si se compara con la LGT de 1963, que en su artículo 37 no hacía referencia expresa al supuesto de responsabilidad solidaria, produciendo en el terreno práctico una gran inseguridad como consecuencia de la integración de las sanciones dentro de la deuda tributaria definida por aquella norma en su artículo 58, y en particular, por la existencia de supuestos específicos de responsabilidad en los que se admitía la extensión a las sanciones. Los pronunciamientos jurisprudenciales que defendían la aplicación de los principios del orden penal al Derecho sancionador fueron decisivos para subordinar la aplicación del régimen de la responsabilidad a las exigencias del principio de culpabilidad y, en relación con éste, del principio de la pena. Estos postulados fueron acogidos en la reforma del artículo 37 de la Ley 25/1995 que excluyó por regla general las sanciones de la responsabilidad.

${ }^{683}$ Dentro de los supuestos que incluyen a las sanciones en el ámbito de la responsabilidad, existen dos que la doctrina entiende que vulneran el principio de personalidad de la pena: el de los colaboradores en la comisión de ilícitos y el de los administradores de personas jurídicas. Entre otros, vid. GALÁN RUIZ, J., La responsabilidad tributaria, op. cit., pág. 144; ORÓN MORATAL, G., "Los obligados tributarios en la Ley 58/2003, de 17 de diciembre, General Tributaria: principales novedades”, op. cit., pág. 132. RUIZ HIDALGO indica, refiriéndose a los supuestos de responsabilidad contemplados en el segundo apartado del artículo 42 de la LGT, que "vulneran el principio de culpabilidad, como manifestación de la necesidad del elemento subjetivo de la culpa y el dolo de la infracción y, por tanto, de la correlativa sanción. El principio de personalidad de las sanciones condiciona la actividad de la Administración desde el primer momento, ya que, bajo el amparo de este principio, deberá determinar frente a quién -o quiénes- dirige el expediente sancionador" (RUIZ HIDALGO, C., La responsabilidad tributaria en el alzamiento de bienes en la nueva Ley General Tributaria, op. cit., pág. 117)

${ }^{684}$ No es éste el criterio que se observa en la Exposición de Motivos de la Ley 7/2012, de 29 de octubre, de modificación de la normativa tributaria y presupuestaria y de adecuación de la normativa financiera para la intensificación de las actuaciones en la prevención y lucha contra el fraude, donde se expone literalmente que el responsable tributario "no debe ser identificado con un sujeto infractor, sino como obligado tributario en sentido estricto, aun cuando responda también de las sanciones tributarias".

${ }^{685}$ En este caso, se cuestiona NAVARRO EGEA, M., El responsable tributario, op. cit., pág. 31, si realmente la sanción ha cumplido su función y si los principios constitucionales que inspiran el Derecho sancionador se ven efectivamente realizados. ORÓN MORATAL es del criterio que si la "condición de responsable deriva de participar en la comisión de una infracción o no haber evitado su comisión, debieran ser sancionados con una sanción específica, no respondiendo de la sanción del deudor principal, entre otras razones porque si finalmente consigue reembolsarse del deudor principal, su ilícito quedará sin sanción, y si no lo consigue será el infractor deudor principal quien quede sin sanción" (ORÓN MORATAL, G., "Los obligados tributarios en la Ley 58/2003, de 17 de diciembre, General Tributaria: principales novedades", op. cit., pág. 132).
} 
MARTÍN JIMÉNEZ se pregunta "si la traslación de sanciones al responsable, solidario o subsidiario, cumple con las exigencias constitucionales derivadas de los arts. 24.2 y $25.1 \mathrm{CE}$, cuestión ya controvertida bajo la vigencia de la LGT 1963. (...) La derivación de la sanción al responsable, especialmente tras la STC 85/2006, de 27 de marzo (...), puede considerarse como una sanción en sí misma, por lo que su imposición demanda que la derivación se haga en un procedimiento que respete los derechos y garantías de los arts. 24.2 y 25.1 CE con respeto, especialmente, de la presunción de inocencia e interdicción de las inversiones de la carga de la prueba. (...) Por otra parte, también defendimos que allí donde se está derivando una sanción (...) la exigencia al responsable de la deuda tributaria tiene una naturaleza similar a la responsabilidad civil derivada del delito, por lo que la determinación de la culpabilidad del responsable es un prius para la exigencia de la responsabilidad de naturaleza indemnizatoria. Igualmente, en nuestro criterio", finaliza diciendo este autor, "la consideración de estos supuestos de responsabilidad como sanciones materiales debiera determinar que se les aplicara el régimen propio de las infracciones y sanciones" ${ }^{\prime 686}$.

Anteriormente, SÁNCHEZ GALIANA se había mostrado a favor de la "no extensión de la responsabilidad a las sanciones penales del sujeto pasivo u obligado principal, por aplicación del principio de personalidad de la pena, que entendemos debe afectar a todo tipo de responsabilidad. En el caso de la responsabilidad solidaria, la remisión al artículo 58 de la L.G.T. debería entenderse en relación a las sanciones pecuniarias de carácter administrativo o civil, pero nunca las de naturaleza estrictamente penal" ${ }^{\prime 687}$.

En los casos en que la sanción se extiende a los responsables, la obligación de éstos va más allá de la deuda del obligado principal, debiendo asumir la totalidad de la deuda más las sanciones, como consecuencia de la participación, colaboración, tolerancia, o conveniencia en la comisión de infracciones que son imputables al deudor principal $^{688}$. Se requiere para extender las sanciones al responsable que converjan tres requisitos: que la ley determine que el presupuesto de hecho de la responsabilidad se extienda hasta la sanción (apartado cuarto del artículo 41 de la LGT); que el responsable participe en la comisión de la infracción del deudor principal, para ser respetuoso con el principio de personalidad y culpabilidad; y que la Administración tributaria acredite esa participación en la derivación de la responsabilidad. El inconveniente fundamental que apreciamos es que el legislador, cada vez con más frecuencia, configura supuestos de responsabilidad con un marcado

\footnotetext{
${ }^{686}$ MARTÍN JIMÉNEZ, A., Los Supuestos de responsabilidad en la LGT: (hacia una configuración constitucional y comunitaria de la responsabilidad tributaria), op. cit., pág. 160.

${ }^{687}$ SÁNCHEZ GALIANA, J. A., "El responsable”, op. cit., pág. 651. En este mismo sentido, vid. HERRERO MADARIAGA, J., "El responsable tributario", op. cit., pág. 216 a 220.

${ }^{688}$ Son varios los autores que defienden la tesis que identifica la responsabilidad con una sanción de los causantes y colaboradores en infracciones: ARIAS ABELLÁN, M. D., "Modificaciones a la Ley General Tributaria en la regulación jurídica del responsable", Revista Española de Derecho Financiero, núm. 47-48, 1985, pág. 420; MAURICIO SUBIRANA, S., El responsable tributario y la empresa, Tirant lo Blanch, Valencia, 2008, pág. 84; ZORNOZA PÉREZ, J., El sistema de infracciones y sanciones tributarias (Los principios constitucionales del Derecho sancionador), Civitas, Madrid, 1992, pág. 195. MARTÍNEZ LAGO identifica como una de las problemáticas de la LGT la insuficiente diferenciación entre los responsables de las sanciones tributarias en el artículo 182 de la LGT (responsabilidad punitiva, por derivación de la comisión de una infracción), y los responsables tributarios de los artículos 41 a 43 de la LGT, que induce "a pensar que ésta última es la sanción por colaboración en una infracción" (MARTÍN JIMÉNEZ, A., Los Supuestos de responsabilidad en la LGT: (hacia una configuración constitucional y comunitaria de la responsabilidad tributaria), op. cit., pág. 111 y 112). A esta misma confusión alude MARTÍN JIMÉNEZ, F. J., El procedimiento de derivación de responsabilidad tributaria, Lex Nova, Valladolid, 2000, pág. 35. Por el contrario, CASADO OLLERO, G., FALCÓN Y TELLA, R., LOZANO SERRANO, C., y SIMÓN ACOSTA, E., "Las garantías del crédito tributario", op. cit., pág. 163, consideran que aunque la ilicitud pueda ser el motivo por el cual el legislador decidió establecer la responsabilidad, ésta no es una sanción.
} 
carácter sancionador, cuando lo acertado sería otorgar al responsable la condición de infractor y tratarlo como tal.

El principal problema que se observa en la extensión de la sanción al responsable se produce en la configuración que hace el legislador del supuesto de responsabilidad, sobre todo si no ha sido respetuoso con el principio de culpabilidad. El cumplimiento del principio de culpabilidad en la tipificación de las infracciones en el orden tributario "supone que no cabe la extensión de sanciones al responsable, sin la expresa previsión legal y concurso de la culpabilidad",689.

Por último, la Ley 7/2012, de 29 de octubre, introdujo algunas modificaciones en el apartado cuarto del artículo 41 de la LGT. En los supuestos en que la responsabilidad se extienda a las sanciones, cuando el deudor principal hubiera tenido derecho a la reducción que prevé el inciso b) del primer apartado del artículo 188 de la LGT (reducción del 30 por 100 por conformidad, por no haber interpuesto recurso o reclamación contra la regularización), la deuda derivada de la responsabilidad sería en principio el importe de la deuda sin esta reducción, pero se prevé un trámite de conformidad al responsable en la propuesta de declaración de responsabilidad para que este sujeto pueda beneficiarse de dicha reducción. Para que se produzca esta circunstancia, basta con que el responsable no presente ningún recurso o reclamación contra el acto de declaración de responsabilidad, fundado en la procedencia de la derivación o en las liquidaciones derivadas. En caso contrario, la reducción obtenida por el responsable se le exigirá sin más trámite desde el momento en que presente este recurso o reclamación. Por último, el apartado cuarto del artículo 41 de la LGT, en su penúltimo párrafo, precisa que a los responsables se aplicará también la reducción por pronto pago que determina el apartado tercero del artículo 188 de la LGT $^{690}$. Estas dos reducciones señaladas, en fin, no son aplicables en ningún caso en los supuestos de responsabilidad solidaria del apartado segundo del artículo 42 de la LGT, que hace referencia a diversas actuaciones que el responsable protagoniza dificultando la actividad recaudatoria en vía ejecutiva. A nuestro juicio, la exclusión de la reducción en la sanción a estos últimos responsables se justifica por el hecho de que la sanción no deriva de una infracción previa del obligado principal, sino de la propia conducta inadecuada del responsable en la fase ejecutiva de recaudación que se sigue contra ese obligado.

\subsection{SUPUESTOS DE RESPONSABILIDAD TRIBUTARIA}

Cuando introdujimos los caracteres definitorios de la responsabilidad tributaria expusimos que tanto en la LGT como en el RGR se reconocen dos tipos de responsabilidad tributaria: solidaria y subsidiaria. Al igual que sucedía en la LGT de 1963, no existe un criterio claro que permita diferenciar los rasgos de cada tipo de responsabilidad. A la hora de diferenciar si se trata de un

\footnotetext{
${ }^{689}$ DE GANDARILLAS MARTOS, S., "El alcance de la responsabilidad tributaria”, op. cit., pág. 986.

${ }^{690}$ Según este apartado "el importe de la sanción que deba ingresarse por la comisión de cualquier infracción, una vez aplicada, en su caso, la reducción por conformidad a la que se refiere el párrafo b del apartado 1 de este artículo, se reducirá en el $25 \%$ si concurren las siguientes circunstancias: a. Que se realice el ingreso total del importe restante de dicha sanción en el plazo del apartado 2 del artículo 62 de esta Ley o en el plazo o plazos fijados en el acuerdo de aplazamiento o fraccionamiento que la Administración tributaria hubiera concedido con garantía de aval o certificado de seguro de caución y que el obligado al pago hubiera solicitado con anterioridad a la finalización del plazo del apartado 2 del artículo 62 de esta Ley. b. Que no se interponga recurso o reclamación contra la liquidación o la sanción. El importe de la reducción practicada de acuerdo con lo dispuesto en este apartado se exigirá sin más requisito que la notificación al interesado, cuando se haya interpuesto recurso o reclamación en plazo contra la liquidación o la sanción. La reducción prevista en este apartado no será aplicable a las sanciones que procedan en los supuestos de actas con acuerdo".
} 
supuesto u otro de responsabilidad, MARTÍN JIMÉNEZ expresa que "el legislador los ha venido conceptuando de una manera u otra a medida que se han introducido en la LGT, prescindiendo de una explicación racional sobre la calificación en una y otra categoría",691.

La regulación de los tipos de responsabilidad tampoco ha sido igualitaria ${ }^{692}$. La LGT de 1963, antes de su modificación por la Ley 25/1995, dedicaba su atención en los apartados 3 y 4 del artículo 37 a los responsables subsidiarios, sin hacer apenas mención a los responsables solidarios que se regulaban principalmente en normas reglamentarias. Ya con la modificación del artículo 37 por la Ley 25/1995, sólo uno de sus apartados se destinó a la regulación de la responsabilidad subsidiaria. En la actualidad, como ya indicamos, la LGT mantiene la misma clasificación de responsables tributarios que su antecesora de 1963. El apartado primero del artículo 41 de la LGT reconoce la existencia del responsable solidario y el responsable subsidiario ${ }^{693}$ y aclara en su apartado segundo que, salvo precepto legal expreso en contrario, la responsabilidad será subsidiaria. En consecuencia puede defenderse el carácter excepcional de la responsabilidad solidaria, aunque en muchas ocasiones, sin embargo, la excepcionalidad de la responsabilidad solidaria se convierte en regla general, sobre todo si se tiene en cuenta que el número de supuestos de responsabilidad solidaria que regulan las normas especiales es bastante amplio. Además, como apunta NAVARRO EGEA, en estos momentos resulta complejo utilizar estos criterios general y especial para avalar la diferencia entre las distintas categorías de responsabilidad ${ }^{694}$.

Lo que diferencia a ambos tipos de responsabilidad es, principalmente, la proximidad temporal entre el deudor principal y el responsable a la hora de hacer frente a la deuda tributaria. Mientras que para la responsabilidad subsidiaria se requiere la declaración de fallido del deudor principal en el correspondiente procedimiento de apremio, para que se pueda exigir al responsable solidario la deuda del obligado principal sólo es necesario que haya transcurrido el período voluntario de pago sin que se haya efectuado el ingreso de dicha deuda por parte de este último sujeto. Ello supone que el responsable subsidiario tiene "el beneficio de la exclusión previa del patrimonio del deudor", mientras que en el caso del responsable solidario "tal beneficio no existe y la Administración puede

\footnotetext{
${ }^{691}$ MARTÍN JIMÉNEZ, A., Los Supuestos de responsabilidad en la LGT: (hacia una configuración constitucional y comunitaria de la responsabilidad tributaria), op. cit., pág. 150.

${ }^{692}$ Son varios los autores que manifiestan que la responsabilidad no ha recibido un tratamiento equitativo por parte del legislador: DE LA HUCHA CELADOR, F., "Algunas consideraciones sobre la responsabilidad tributaria en el Reglamento General de Recaudación de 1990: II. Responsabilidad Subsidiaria", op. cit., pág. 46; MAZORRA MANRIQUE DE LARA, S., "La obligación de los responsables tributarios en el Reglamento General de Recaudación: nacimiento y exigibilidad", op. cit., pág. 75; FERNÁNDEZ GONZÁLEZ, C., "Un apunte sobre el concepto de responsabilidad solidaria”, op. cit., pág. 15.

${ }^{693}$ El Informe para la Reforma de la LGT de 2001 proponía dos modalidades básicas de responsabilidad, la principal o solidaria y la subsidiaria, y entendía que era más acertada la terminología de responsable principal, directa o cualquier otra que evitara la confusión entre la responsabilidad solidaria y la solidaridad tributaria. Un sector importante de la doctrina también se mostró a favor de esta solución, entre ellos CASADO OLLERO, G., FALCÓN Y TELLA, R., LOZANO SERRANO, C., y SIMÓN ACOSTA, E., "Las garantías del crédito tributario", op. cit., pág. 219; y CHECA GONZÁLEZ, C., GARCÍA LUIS, T., MERINO JARA, I., MORENO FERNÁNDEZ, J. I., La reforma de la Ley General Tributaria, op. cit., pág. 144. Apunta MARTÍN JIMÉNEZ, en relación con los conceptos de solidaridad y subsidiaridad, que en el ámbito del Derecho civil la responsabilidad solidaria equivale a la atribución al acreedor de los obligados solidariamente de la posibilidad de dirigirse contra cualquiera de ellos, reclamando el cumplimiento de la obligación, mientras que, en el ámbito tributario, la solidaridad se configura, más bien, como una «subsidiaridad de primer grado», en la que la Administración sólo puede dirigirse contra el responsable solidario si existe incumplimiento del deudor principal en el período voluntario de pago de la deuda tributaria" (MARTÍN JIMÉNEZ, A., Los Supuestos de responsabilidad en la LGT: (hacia una configuración constitucional y comunitaria de la responsabilidad tributaria), op. cit., pág. 150 y 151).
}

${ }^{694}$ NAVARRO EGEA, M., El responsable tributario, op. cit., pág. 32. 
dirigirse directamente" contra el él ${ }^{695}$. Coincidiendo con MAURICIO SUBIRANA, entendemos que el beneficio de excusión del responsable subsidiario es el elemento que permite distinguir los dos tipos de responsabilidad ${ }^{696}$. No obstante, alerta GALÁN RUIZ que no queda claro si la Administración tributaria "puede dirigirse contra el responsable solidario antes o al mismo tiempo que contra el deudor principal, o si debe esperar a la finalización del período voluntario de pago que tiene el deudor principal para poder exigir la deuda al responsable solidario"697.

Una vez que señalados los elementos generales que configuran la responsabilidad corresponde estudiar cada uno de los supuestos que integran la responsabilidad solidaria y la responsabilidad subsidiaria. De manera que puedan ser aplicadas, a cada uno de estos supuestos recogidos en la LGT, las consideraciones expuestas anteriormente.

\subsubsection{Responsabilidad tributaria solidaria}

\subsubsection{Participación en infracciones tributarias}

La primera de las modalidades de responsabilidad solidaria que reconoce la LGT es la responsabilidad de las personas o entidades que sean causantes o que colaboren activamente en la realización de una infracción tributaria ajena. Esta figura aparece regulada en el inciso a) del apartado primero del artículo 42 de la LGT, que extiende la responsabilidad a la deuda tributaria y también a la sanción.

El antecedente de este artículo se encuentra en el artículo 38 de la LGT de $1963^{698}$, aunque la normativa vigente introduce dos modificaciones importantes para este supuesto: la extensión de la responsabilidad a las sanciones y a la exigencia de una colaboración activa por parte del responsable. Para algunos autores, este tipo de responsabilidad es en realidad un tipo de sanción por participar en un acto ilícito y, desde esta perspectiva, debería reconducirse la situación al Derecho tributario sancionador. Según expresa MARTÍN JIMÉNEZ, “tanto el art. 38 LGT 1963 como el art. 42.1 a)

\footnotetext{
${ }^{695}$ MARTÍN JIMÉNEZ, A., Los Supuestos de responsabilidad en la LGT: (hacia una configuración constitucional y comunitaria de la responsabilidad tributaria), op. cit., pág. 150; GALÁN RUIZ, J., La responsabilidad tributaria, op. cit., pág. 41.

${ }^{696}$ MAURICIO SUBIRANA, S., "El responsable tributario: concepto y clases", en la obra Tratado sobre la Ley General Tributaria, Tomo I, ARRIETA MARTÍNEZ DE PISÓN, J, COLLADO YURRITA, M. A., ZORNOZA PÉREZ, J. (directores), Aranzadi, Thomson Reuters, 2010, pág. 937. Este criterio ha sido asumido también por el Tribunal Supremo, entre otras, en la Sentencia de 16 de mayo de 1991, cuando señala que para cubrir el requisito del apartado quinto del artículo 37 de la LGT de 1963 no es suficiente "con que el sujeto pasivo no haya ingresado el tributo en el período voluntario, sino que la Administración ha de dirigir contra él el correspondiente procedimiento de apremio y culminarlo sin poder cobrar el tributo", si quiere después actuar contra el responsable subsidiario.

${ }^{697}$ GALÁN RUIZ, J., La responsabilidad tributaria, op. cit., pág. 41. Sobre estas cuestiones nos referiremos más adelante cuando analizamos el procedimiento de declaración de la responsabilidad, vid. infra, Capítulo Cuarto, epígrafe 3.3.2. "Inicio del procedimiento de derivación de la responsabilidad solidaria".

${ }^{698}$ Sobre el contenido de este artículo, vid. entre otros, HERRERO MADARIAGA, J., "El responsable tributario", op. cit., pág. 197 y ss.; ARIAS ABELLÁN, M. D., "Modificaciones a la Ley General Tributaria en la regulación jurídica del responsable", op. cit., pág. 419 a 421 y, de la misma autora, "El estatuto jurídico del responsable del tributo en el derecho español", op. cit., pág. 203 y 204; NAVARRO FAURE, A., "Los supuestos de responsabilidad tributaria solidaria en el ordenamiento tributario español (I)", op. cit., pág. 621; MAZORRA MANRIQUE DE LARA, S., Los responsables tributarios, op. cit., pág. 116 a 118; HERRERA MOLINA, P. M., Coautoría y participación en las infracciones tributarias y responsabilidad tributaria por actos ilícitos", en la obra Sujetos pasivos y responsables tributarios, Instituto de Estudios Fiscales-Marcial Pons, Madrid, 1997, pág. 704 y ss.; DE LA HUCHA CELADOR, F., "Algunas consideraciones sobre la responsabilidad tributaria en el Reglamento General de Recaudación de 1990: I. Responsabilidad Solidaria”, op. cit., pág. 342 y 343; GONZÁLEZ ORTIZ, D., La responsabilidad tributaria en el ordenamiento jurídico español, op. cit., pág. 129 y ss.
} 
LGT consagran auténticos supuestos de sanciones en el sentido constitucional del término (si bien sanciones, en cierto modo, impropias, por cuanto el pago o garantía de las mismas por el sujeto pasivo dejará sin sanción el comportamiento del colaborador)"699. Todo ello explica que gran parte de la doctrina y el Informe 2001 sobre la LGT aconsejaran la supresión de esta modalidad de responsabilidad $^{700}$. Sin embargo, el legislador de la LGT de 2003 optó por introducir en el capítulo dedicado a las infracciones y las sanciones (Capítulo II del Título IV) la responsabilidad solidaria de las sanciones, dejando la regulación sustantiva de esta figura, entre otros, al inciso a) del primer apartado del artículo 42 de la LGT. "Se ha optado, por tanto, en el art, 42.1. a) LGT 2003, por no regular expresamente como infracciones los supuestos de colaboración en las infracciones a favor del mantenimiento de un supuesto de responsabilidad que abarca a la sanción (...). En definitiva, con el art. 42.1. a) LGT, en relación con el art. 182.1 LGT, el legislador no atendió a las voces que reclamaban la supresión del antiguo art. 38 LGT 1963 y la regulación, dentro del capítulo en materia de infracciones y sanciones, de una infracción y sanción específica para quienes sean causante o colaboradores de las infracciones tributarias. Además, en la nueva regulación, se ha complicado el ámbito de aplicación del art. 42.1. a) LGT cuando éste debe ser interpretado en relación con el art. 182.1 LGT, pues que, si bien, en gran medida, el ámbito de aplicación de ambos preceptos resulta coincidente (...), el art. 182.1 LGT está creando una responsabilidad específica que, partiendo de un supuesto de hecho distinto, se remite en su regulación al art. 42.1. a) LGT"701.

En el supuesto contemplado en el inciso a) del apartado primero del artículo 42 de la LGT se imputa a un tercero, que puede ser una persona natural, jurídica o entidad sin personalidad, la responsabilidad que surge de la comisión de una infracción ajena en la que ha participado de alguna forma. En este sentido, la derivación de la responsabilidad se produce cuando el obligado principal ha cometido una infracción tributaria, pues de lo contrario no podría hablarse de responsabilidad solidaria $^{702}$. También se exige que ese tercero que es declarado responsable tenga una participación activa en la infracción del deudor principal.

La incidencia en la práctica de esta modalidad dependerá en buena medida del significado que pueda darse a los términos de causar o colaborar activamente en la realización de una infracción tributaria, que por otra parte no se encuentran definidos legalmente. Por ello, algunos autores, como ZABALA RODRÍGUEZ-FORNOS ${ }^{703}$, afirman que las conductas generadoras de la responsabilidad deben vincularse a los conceptos de autoría directa, autoría por inducción o cooperación necesaria y complicidad, recogidos en los artículos 27 a 29 del Código Penal. Igualmente, en esta doctrina, la conducta determinante de la responsabilidad del inciso a) del apartado primero del artículo 42 de la

\footnotetext{
${ }^{699}$ MARTÍN JIMÉNEZ, A., Los Supuestos de responsabilidad en la LGT: (hacia una configuración constitucional y comunitaria de la responsabilidad tributaria), op. cit., pág. 190.

${ }^{700}$ El Informe 2001, en la pág. 77 defendió el criterio de que debía eliminarse el artículo 38 de la LGT de 1963 "porque, de acuerdo con una configuración mayoritariamente considerada por la Comisión, debería llevarse al ámbito de la responsabilidad por infracción tributaria, es decir, al Título dedicado al ámbito sancionador, que debe abordar la responsabilidad que se deriva en los casos de coautoría y otras formas de participación en la comisión de infracciones tributarias".

${ }^{701}$ MARTÍN JIMÉNEZ, A., Los Supuestos de responsabilidad en la LGT: (hacia una configuración constitucional y comunitaria de la responsabilidad tributaria), op. cit., pág. 191.

${ }^{702}$ Así lo confirma el Tribunal Superior de Justicia de Cataluña, en su Sentencia de 11 de febrero de 1997.

${ }^{703}$ ZABALA RODRÍGUEZ-FORNOS, A., “Comentario al artículo 41 de la LGT”, en la obra Comentarios a la nueva Ley General Tributaria, HUESCA BOADILLA, R. (coordinador), Thomson- Aranzadi, Navarra, 2004, pág. 305.
} 
LGT admite la comisión por omisión cuando las conductas omisivas puedan ser determinantes en la realización de la infracción. Por esto, se considera al "causante" como autor directo o en ejecución; y la "colaboración" como un concepto amplio en el que entran la coautoría, la inducción, la cooperación necesaria y la complicidad ${ }^{704}$.

En cuanto a la referencia que hace la ley a la conducta activa en la realización de la infracción, la reforma del artículo 38 de la LGT de 1963 por la Ley 10/1985 suprimió las indicaciones que en aquel precepto se hacían a la necesidad de que el responsable actuase de forma "dolosa" y de "manera directa y principal con el sujeto pasivo", lo cual generó no pocas críticas en la doctrina ${ }^{705}$, porque se entendió que el precepto no exigía, desde la reforma de 1985, que la intervención del responsable en la comisión de la infracción fuese dolosa, directa y principal. La referencia a la conducta «activa» que hace ahora en el inciso a) del apartado primero del artículo 42 de la LGT "parece que podría tratar de recoger estas críticas y reforzar la vinculación del causante o colaborador con la comisión de la infracción, de manera que sólo las conductas más importantes de éste, determinantes de la comisión de la infracción, estarán ahora cubiertas" por este precepto ${ }^{706}$. Esto permite relacionar la actuación del responsable con el resultado antijurídico que produce la infracción y solucionar de esta forma la identificación entre este tipo de responsabilidad solidaria frente a la responsabilidad subsidiaria de los administradores regulada en el inciso a) del apartado primero del artículo 43 de la LGT. La calificación de la actuación del colaborador o causante como activa o pasiva podría ser, de este modo, el elemento base para distinguir entre los tipos de responsabilidad previstos en ambos preceptos, porque la infracción surgida de la participación activa del responsable aparta los supuestos de responsabilidad de los administradores que se originan por conductas pasivas, en este caso el deber de vigilancia que caracteriza a estos sujetos ${ }^{707}$.

La LGT tampoco hace mención al carácter doloso o culpable de la conducta que origina la responsabilidad que nos ocupa ${ }^{708}$ y utiliza términos imprecisos o jurídicamente indeterminados que ocasionan problemas de interpretación. Lo primero que se evidencia de la intervención activa del tercero como causante o colaborador es que se reduce el círculo de aplicación de esta responsabilidad. Según MARTÍN JIMÉNEZ, "será necesario el dolo o culpa del causante o colaborador, pues faltando éste, no resultará posible derivar la responsabilidad que regula" el inciso a) del apartado primero del artículo 42 de la $\mathrm{LGT}^{709}$. Por el contrario, en determinados momentos los

\footnotetext{
${ }^{704}$ NAVARRO EGEA, M., El responsable tributario, op. cit., pág. 80.

${ }^{705}$ ARIAS ABELLÁN, M. D., "El estatuto jurídico del responsable del tributo en el derecho español”, op. cit., pág. 420 y 421 ; MAZORRA MANRIQUE DE LARA, S., Los responsables tributarios, op. cit., pág. 116.

${ }^{706}$ MARTÍN JIMÉNEZ, A., Los Supuestos de responsabilidad en la LGT: (hacia una configuración constitucional y comunitaria de la responsabilidad tributaria), op. cit., pág. 195.

${ }^{707}$ De manera muy parecida se pronunció el TEAC, a través de su Resolución de 15 de enero de 1999. Vid. infra, Capítulo Cuarto, epígrafe 2.4.2.1. "Administrador de personas jurídicas".

${ }^{708}$ Cuestión que resuelve la Resolución del TEAC de 21 de febrero de 1996, determinando el reconocimiento del elemento sancionador que adquiere la responsabilidad por necesitar la prueba del animus de cometer o contribuir a efectuar la infracción.

${ }^{709}$ MARTÍN JIMÉNEZ, A., Los Supuestos de responsabilidad en la LGT: (hacia una configuración constitucional y comunitaria de la responsabilidad tributaria), op. cit., pág. 195.
} 
tribunales han fallado a favor de la ampliación de la responsabilidad solidaria admitiendo intervenciones pasivas ${ }^{710}$.

Sobre el alcance de la responsabilidad, anteriormente el apartado primero del artículo 38 de la LGT de 1963 la extendía a las obligaciones tributarias, sin limitarse a la cuota. Ahora el inciso a) del apartado primero del artículo 42 de la LGT impone la responsabilidad no sólo en relación con la deuda tributaria, sino también con las sanciones. Para CALVO ORTEGA, "se trata, a todas luces, de una respuesta sancionadora desproporcionada, desigual e injusta para los llamados causantes y colaboradores activos"

Estamos ante una responsabilidad que se exige a partir de un acto ilícito que comete otro sujeto (el obligado principal) y que alcanza a la sanción como castigo de la infracción tributaria, con la justificación de que el presunto responsable causó o colaboró activamente en dicha infracción tributaria. Frente a este presupuesto de hecho de responsabilidad se encuentran autores que proponen que se regule un supuesto específico de responsabilidad "en la comisión de la infracción que tuviera en cuenta las circunstancias personales en que se desenvuelve el responsable de una deuda ajena, y que si bien ha tenido una participación o colaboración activa en su comisión, no es el autor material de la misma" ${ }^{\text {712. }}$. Por su parte, CALVO ORTEGA advierte que cuando el presunto responsable comete sus propias infracciones tributarias éstas son autónomas y entonces se está en presencia de dos sujetos y dos infracciones tributarias. Como solución más justa, este autor opina que cada uno debe responder de su propia infracción tributaria y a su vez, convertirse en responsable solidario por la infracción del otro sujeto con el que se relaciona de forma dolosa ${ }^{713}$.

Sobre este particular escribió MARTÍNEZ LAGO que "la declaración de responsabilidad por colaboración en la comisión de infracciones tributarias debería tener, como ha señalado la mejor doctrina, un previo pronunciamiento sobre la existencia de la infracción tributaria, para lo cual había que seguir el procedimiento previsto en el ordenamiento para ello, que no es otro que, al menos con carácter general, un procedimiento separado para sancionar del seguido para la fijación de la deuda tributaria; procedimiento en el que debería darse entrada como interesado al presunto responsable"714.

Nosotros entendemos que este supuesto de responsabilidad solidaria se aleja de la verdadera naturaleza de esta institución y adquiere un carácter sancionador. Según nuestro criterio, y coincidiendo con un sector importante de la doctrina, lo acertado sería que el responsable fuera tratado como un infractor y se siguiera contra él un procedimiento sancionador, observando todos los derechos y garantías de este tipo de procedimientos.

\footnotetext{
${ }^{710}$ Así puede verse en la Sentencia de la Audiencia Nacional, de 16 de febrero de 1995, y en la Sentencia del Tribunal Superior de Justicia de Castilla La Mancha, de 4 de abril de 1995.

${ }^{711}$ CALVO ORTEGA, R., “Obligados tributarios”, op. cit., pág. 173.

${ }^{712}$ BOSCH CHOLBI, J. L., "Análisis crítico de los supuestos de responsabilidad tributaria solidaria en la LGT 58/2003", Tribuna Fiscal, núm. 174, 2005, op. cit. pág. 19.

${ }^{713}$ CALVO ORTEGA, R., “Obligados tributarios”, op. cit., pág. 173.

${ }^{714}$ MARTÍNEZ LAGO, M. A., La extensión de la responsabilidad a las sanciones tributarias, op. cit., pág. 217.
} 
La responsabilidad de los partícipes o cotitulares de las entidades a que se refiere el apartado cuarto del artículo 35 de la LGT ya se conocía en la LGT de 1963. Esta modalidad de responsabilidad solidaria fue la segunda propuesta de eliminación del Informe para la Reforma de la LGT de 2001, al entender la Comisión que los partícipes de los entes sin personalidad son codeudores solidarios. No obstante, la fórmula se repite casi en idénticos términos en la LGT del 2003, indicándose en el inciso b) del apartado primero del artículo 42 que son responsables solidarios de la deuda tributaria

"los partícipes o cotitulares de las entidades a que se refiere el apartado 4 del artículo 35 de esta Ley, en proporción a sus respectivas participaciones respecto a las obligaciones tributarias materiales de dichas entidades".

En este supuesto se deriva la responsabilidad solidaria hacia los copartícipes o cotitulares de las entidades, respondiendo solidariamente de las obligaciones materiales contraídas por las entidades donde participan, pero en proporción a sus respectivas participaciones. El presupuesto de hecho de la responsabilidad se conforma de dos elementos: la condición jurídica de los partícipes o cotitulares de la entidad y el impago por parte de ésta. Es muy importante atender en este caso a la forma jurídica que pueden adquirir estos entes sin personalidad para establecer una derivación de responsabilidad, puesto que la misma puede configurarse en los supuestos de comunidades de bienes que actúan en el tráfico como una sociedad o como sociedades irregulares, pero no cuando se trata de herencias yacentes $^{715}$. FALCÓN Y TELLA considera que este régimen de responsabilidad no puede ser aplicado a la herencia yacente porque lo que caracteriza a esa figura no es la participación de varios cotitulares, sino la indeterminación transitoria del titular del patrimonio del causante. "Constituye una situación jurídica de dependencia que resulta de la indeterminación de los titulares de la masa hereditaria, lo que conlleva a la ausencia de uno de los elementos fácticos exigidos por la ley para que se active este mecanismo de garantía del crédito tributario: la condición de copartícipe o de cotitular de la entidad". Entiende este autor que es inviable que se derive la responsabilidad a los llamados a la herencia, aun cuando los bienes de la herencia sean insuficientes, y propone hacer efectivas las deudas nacidas durante el período de pendencia sobre los bienes de la propia herencia $\mathrm{o}$ esperar a que alguno de los herederos acepte la herencia para derivar la responsabilidad sobre él ${ }^{716}$.

En este supuesto existen dos aspectos que despiertan la crítica de la doctrina. El primero es el referido a la exigencia de la obligación tributaria directamente al partícipe o cotitular, en lugar de actuar contra el patrimonio de la entidad a la que el ordenamiento tributario dotó de personalidad y que constituye un patrimonio separado ${ }^{717}$; y el segundo, el que los partícipes paguen la deuda tributaria en proporción a la participación que tengan dentro de la entidad, a pesar de tratarse de una

\footnotetext{
${ }^{715}$ FALCÓN Y TELLA, R., "La responsabilidad de los copartícipes de las entidades sin personalidad”, Impuestos, 1985-II, pág. 81 y "Los responsables en la nueva Ley General Tributaria”, Impuestos, núm. 15-16, 2003, pág. 41.

${ }^{716}$ FALCÓN Y TELLA, R., “La responsabilidad de los copartícipes de las entidades sin personalidad”, op. cit., pág. 8.

${ }^{717}$ MAZORRA MANRIQUE DE LARA, S., Los responsables tributarios, op. cit., pág., 128 y 129. Hemos de recordar que este tipo de sujeto carece, en el ámbito privado, de la facultad para ser titular de obligaciones y derechos, pero que en el ordenamiento tributario se dota de una especial personalidad jurídica. Vid, supra, Capítulo Cuarto, epígrafe 2.1.1. "Los responsables en el marco de los obligados tributarios".
} 
responsabilidad solidaria, sin que sea necesario establecer la acción de repetición del que pagó la totalidad de la deuda frente a los restantes copartícipes ${ }^{718}$.

Respecto a los razonamientos que anteceden, FALCÓN Y TELLA es de la opinión que el problema en la LGT actual se presenta a raíz del mantenimiento del mismo régimen de responsabilidad del artículo 39 de la LGT de 1963, lo que implica una separación injustificada de las comunidades o las sociedades irregulares del marco jurídico privado que les es aplicable, en el que los socios "responden según el régimen de la colectiva, es decir, subsidiariamente respecto de la entidad, pero solidariamente entre sí",719. En este sentido, según el autor, los acreedores privados sólo pueden dirigirse contra los cotitulares si antes se ha declarado insolvente el ente, pudiendo reclamar a cualquier socio o partícipe la totalidad de la deuda. Sin embargo, en este supuesto de responsabilidad tributaria, la Administración sólo puede dirigirse contra los partícipes en proporción a su participación (mancomunidad) sin requerir anteriormente el agotamiento de los bienes comunes. Por ello, entiende FALCÓN Y TELLA que la actuación de la Hacienda Pública tendría sentido si la responsabilidad de los socios se configurara solidaria entre ellos mismos y ante la entidad y que lo que carece de sentido es que "la responsabilidad de los socios o cotitulares sea mancomunada entre sí" 720 .

Más adelante, cuando estudiemos la concurrencia de varios responsables en la realización del hecho imponible de la responsabilidad, profundizaremos en la introducción dentro del régimen tributario de los dos supuestos que configuran obligaciones mancomunadas, como excepción al régimen general, que es el de la solidaridad, según el apartado 7 del artículo 35 de la LGT. También es importante en este caso señalar que, al ser mancomunada la responsabilidad interna, cualquier actuación de la Administración sobre uno de los cotitulares de la entidad sin personalidad provoca la interrupción del plazo de prescripción en relación con él, pero no para el resto de los implicados.

Otro aspecto a destacar sobre este supuesto de responsabilidad solidaria es la determinación de si su aplicación excluye o no la responsabilidad solidaria del inciso a) del apartado primero del artículo 42 de la LGT, en el caso que la entidad hubiera cometido una infracción tributaria con la participación activa de los cotitulares o partícipes. En este caso, las interrogantes surgen con la posible aplicación de las sanciones a los cotitulares. MARTíN JIMÉNEZ expresó que "la responsabilidad por infracciones del párrafo a) estaba vinculada a las infracciones reguladas en los arts. 191 a 197 LGT 2003. (...) El párrafo b) art. 42.1 LGT tampoco serviría para trasladar a los partícipes la responsabilidad por estas infracciones, pues limita la responsabilidad de los mismos a los casos de obligaciones materiales (no formales, por tanto). Adquiere sentido, de esta forma, la frase que añade

\footnotetext{
${ }^{718}$ NAVARRO EGEA, M., El responsable tributario, op. cit., pág. 87. Como advierte la autora, en estos supuestos los inconvenientes pueden plantearse cuando el codeudor paga íntegramente la deuda liquidada a través de un acto administrativo donde no se detallan el resto de los copartícipes tributario ni su respectiva cuota de participación.

${ }^{719}$ FALCÓN Y TELLA, R., "La responsabilidad de los copartícipes de las entidades sin personalidad”, op. cit., pág. 7 y 8.

${ }^{720}$ FALCÓN Y TELLA, R., "La responsabilidad de los copartícipes de las entidades sin personalidad”, op. cit., pág. 8. En el mismo sentido, ARGÜELLES PINTOS, J. y FELTRER BAUZÁ, F., Régimen jurídico de la responsabilidad tributaria y su aplicación práctica, Aranzadi, Pamplona, 2002, pág. 95. Algunos autores consideran que estamos ante una solidaridad impropia, porque existe una obligación solidaria en relación con la entidad pero mancomunada entre los partícipes o cotitulares: CALVO ORTEGA, R., "Obligados tributarios", op. cit., pág. 174; BOSCH CHOLBI, J. L., "Análisis crítico de los supuestos de responsabilidad tributaria solidaria en la LGT 58/2003”, op. cit., pág. 19 y 20; MAURICIO SUBIRANA, S., El responsable tributario y la empresa, op. cit., pág. 945 .
} 
el art. 182 LGT declarando la responsabilidad solidaria por las sanciones «derivadas o no de una deuda tributaria»: en el marco del art. 42.1. b) LGT no se podrá declarar la responsabilidad solidaria del partícipe cuando exista una infracción, mientras que, en los supuestos de infracciones imputables al ente del art. 35.4 LGT, con independencia de que se deriven del incumplimiento de obligaciones materiales o formales, la responsabilidad que procede exigir será la declarada en el art. 42.1. a) LGT a quien con su comportamiento, con dolo o negligencia fuera causante de la infracción" ${ }^{\text {"721. Se }}$ muestra contraria a esta doctrina NAVARRO EGEA ${ }^{722}$, que entiende que la responsabilidad por sanción podrá derivarse del inciso a) del apartado primero del artículo 42 de la LGT y la deuda tributaria del propio inciso b) del apartado primero del artículo 42 de la LGT. Esta última postura se corresponde con la Ley 38/2003, de 17 de noviembre, General de Subvenciones, que regula en el apartado primero del artículo 69 que

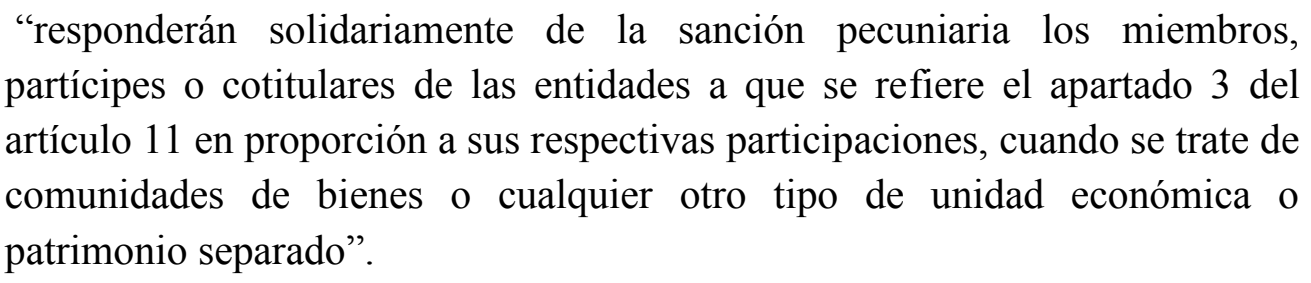

De la exigencia de las sanciones a los cotitulares o partícipes por su colaboración activa en las infracciones tributarias que cometan las entidades sin personalidad, se desprende el problema de cómo determinar la responsabilidad que corresponde a cada uno de los partícipes en la comisión de la infracción y concretar su proporción respecto a la sanción. En este sentido, BOSCH CHOLBI propone "determinar la proporción en que responderá de las sanciones cada partícipe atendiendo a sus respectivas participaciones en la entidad sin personalidad, o que los partícipes o cotitulares de la entidad respondan solidariamente de la sanción sin ese límite" ${ }^{, 723}$. Esta segunda variante, es la que asume la norma, al disponer el primer apartado del artículo 182 de la LGT que responderán solidariamente del pago de las sanciones tributarias las personas o entidades que se encuentren en los supuestos de los incisos a) y c) del primer apartado del artículo 42 de la LGT.

En relación con la responsabilidad prevista en el inciso b) del apartado primero del artículo 42 de la LGT, coincidimos con el Informe 2001 en que es preciso sustituir este tipo de responsabilidad solidaria, que en aquel momento se encontraba prevista en el artículo 39 de la LGT de 1963, por el otorgamiento a los cotitulares o partícipes de las entidades relacionadas en el apartado cuarto del artículo 35 de la LGT actual, con excepción de las herencias yacentes, de la posición jurídica de codeudores solidarios de la deuda tributaria.

\footnotetext{
${ }^{721}$ MARTÍN JIMÉNEZ, A., Los Supuestos de responsabilidad en la LGT: (hacia una configuración constitucional y comunitaria de la responsabilidad tributaria), op. cit., pág. 201 y 202.

${ }^{722}$ NAVARRO EGEA, M., El responsable tributario, op. cit., pág. 87.

${ }^{723}$ BOSCH CHOLBI, J. L., “Análisis crítico de los supuestos de responsabilidad tributaria solidaria en la LGT 58/2003”, op. cit., pág. 20. En relación con estas dos posturas, el autor se inclina por "la imputación de la cantidad proporcionalmente correspondiente con su participación en la entidad". En este mismo sentido, MARTÍN JIMÉNEZ, A., Los Supuestos de responsabilidad en la LGT: (hacia una configuración constitucional y comunitaria de la responsabilidad tributaria), op. cit., pág. 202.
} 


\subsubsection{Sucesión de empresas}

El inciso c) del apartado primero del artículo 42 de la LGT indica que serán responsables solidarios de la deuda tributaria las personas o entidades que

"sucedan por cualquier concepto en la titularidad o ejercicio de explotaciones o actividades económicas, por las obligaciones tributarias contraídas del anterior titular y derivadas de su ejercicio. La responsabilidad también se extenderá a las obligaciones derivadas de la falta de ingreso de las retenciones e ingresos a cuenta practicadas o que se hubieran debido practicar".

Éste es un supuesto que ya se incluía en la LGT de 1963, pero que se encontraba dentro de las garantías de la Sección V, en los apartados primero y segundo del artículo 72 de la LGT de 1963 y en el artículo 13 del RGR de 1990, y fue una figura que suscitó debate en la doctrina y la jurisprudencia $^{724}$. Al no determinar el primer apartado del artículo 72 de la LGT de 1963 el tipo de responsabilidad aplicable al supuesto, un sector de la doctrina afirmó que ésta era subsidiaria, sobre la base de lo dispuesto en el número 2 del artículo 37 de la misma ley, que establecía que la responsabilidad sería siempre subsidiaria ${ }^{725}$, aunque también es cierto que la ubicación de este supuesto en sede de garantías impedía poder aplicar la regla general de la subsidiaridad que se determina para la responsabilidad. El RGR de 1990, por su parte, en el número 3 del artículo 13, disponía expresamente que la responsabilidad del adquirente no relevaba al transmitente de la obligación de pago y que ambos solidariamente respondían de ésta ${ }^{726}$.

El precepto se retomó en la LGT de 2003, ya dentro de los supuestos de responsabilidad solidaria del artículo 42 de la LGT, como señalamos al inicio de este apartado, reproduciendo en términos muy parecidos el contenido del apartado primero del artículo 72 de la LGT. Las novedades presentes en la normativa actual son fundamentalmente cuatro: que declara como responsables solidarios a las personas o entidades que sucedan en la titularidad o ejercicio de explotaciones o actividades económicas; que prevé su extensión a los adquirentes de los elementos aislados cuando éstos permitieran continuar la explotación o actividad; que excluye la sucesión mortis causa, ubicada en el artículo 39 de la LGT; y que no será aplicable en aquellos supuestos de explotación o ejercicio en los que el deudor se encuentre implicado en un proceso concursal.

Se trata de un supuesto de responsabilidad solidaria que obliga a responder de deudas tributarias a personas o entidades ajenas al hecho imponible del tributo que se pretende gravar, siempre que se

\footnotetext{
${ }^{724}$ FALCÓN Y TELLA, R., "Las garantías del crédito tributario: perspectivas de reforma”, op. cit., pág. 7. Hay Sentencias del Tribunal Supremo en las que se afirma que se trataba de un supuesto de responsabilidad subsidiaria (entre otras, las Sentencias de 26 de enero de 1994, de 24 de septiembre de 1999, de 6 de octubre de 2003, de 23 de diciembre de 2010, de 5 de diciembre de 2011 , y de 17 de mayo de 2012), mientras que en otras Sentencias estimaban que la responsabilidad prevista en el apartado primero del artículo 72 de la LGT de 1963 era solidaria (entre otras, las Sentencias de la Audiencia Nacional de 7 de diciembre de 1994; de 28 de marzo de 1995; de 21 de octubre de 1997; de 29 de febrero de 2000; y de 23 de marzo de 2000).

${ }^{725}$ BARRACHINA JUAN, E., "Responsabilidad tributaria del adquirente de una empresa: supuesto irregular de sucesión", Gaceta Fiscal, núm. 169, 1998, pág. 68.

${ }^{726}$ El Tribunal Supremo, en la Sentencia de 26 de enero de 1994, reconoció la responsabilidad subsidiaria del adquirente de instalaciones o explotaciones económicas y, más tarde, en la Sentencia de 15 de junio de 2000, declaró la nulidad de los preceptos del RGR de 1990 que establecían la responsabilidad solidaria.
} 
produzca una transmisión inter vivos en la titularidad o cuando esta transmisión sea en el ejercicio de explotación o actividad económica ${ }^{727}$. En relación con la transmisión de la titularidad inter vivos, esta figura presenta aún elementos por esclarecer, como es el caso de algunas operaciones mercantiles que producen consecuencias similares a una sucesión mortis causa y pueden situarse dentro de los límites de la "sucesión por cualquier concepto". Entre estos supuestos, NAVARRO EGEA sitúa a la fusión, escisión, cesión de activo y pasivo, que tienen como común denominador el desplazamiento de patrimonios y la extinción de la sociedad por el efecto de la sucesión universal, posicionándose la entidad resultante en lugar de la que se extingue ${ }^{728}$.

Son varias las interrogantes que surgen de este supuesto de responsabilidad, empezando por su clasificación como solidaria. CALVO ORTEGA encuentra desproporcionada dicha clasificación al considerar que el "transmitente es un empresario y que normalmente tendrá un enraizamiento y una estabilidad que permite dirigirse en primer lugar contra él, lo que hubiese permitido declarar la responsabilidad como subsidiaria"729. En igual sentido, BOSCH CHOLBI es de la opinión que "hubiera resultado más respetuoso con los derechos de los administrados su calificación como subsidiaria, para exigir a la Administración que se dirigiese con carácter previo al deudor principal y

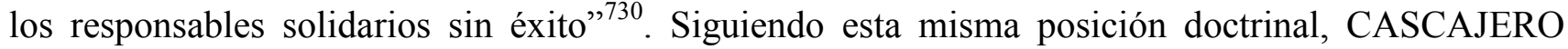
SÁNCHEZ señaló que "desde este punto de vista, si la responsabilidad tributaria se ajustara estrictamente a su fundamento y naturaleza originarios, probablemente debería haber sido concebida como un supuesto de responsabilidad subsidiaria, ya que el daño sólo se produciría si no se lograse cobrar la deuda del obligado principal como consecuencia de la despatrimonialización sufrida, cuya acreditación pasaría por declararle fallido tras la persecución del resto de su activo patrimonial en el procedimiento de apremio"

La explicación que encuentra MARTÍN JIMÉNEZ a la ubicación de esta figura dentro de la responsabilidad solidaria es la función que a la misma se pretende atribuir en la lucha contra el fraude fiscal, atacando "comportamientos, bastantes habituales, en los que el ejercicio de una misma empresa se disfraza bajo la apariencia de distintas titularidades, precisamente con la finalidad de eludir, entre otras, las obligaciones tributarias", aunque no es menos cierto que estas conductas son perseguida por la ley con el supuesto de responsabilidad subsidiaria por levantamiento del velo ${ }^{732}$.

\footnotetext{
${ }^{727}$ El artículo 72 de la derogada LGT de 1963 permitía la aplicación del régimen de responsabilidad tanto en la sucesión mortis causa como en la transmisión inter vivos, lo que condujo a pronunciamientos contradictorios de los tribunales. El Tribunal Supremo se pronunció en contra de la aplicación de la normativa fiscal a la sucesión mortis causa, aunque, este mismo Tribunal, años más tarde flexibilizó su postura, como puede verse en las Sentencias de 8 de marzo de 1995, de 24 de septiembre de 1999, y de 18 de noviembre de 2005

${ }^{728}$ NAVARRO EGEA, M., El responsable tributario, op. cit., pág. 91.

${ }^{729}$ CALVO ORTEGA, R., “Obligados tributarios”, op. cit., pág. 176.

${ }^{730}$ BOSCH CHOLBI, J. L., “Análisis crítico de los supuestos de responsabilidad tributaria solidaria en la LGT 58/2003”, op. cit., pág. 22.

731 CASCAJERO SÁNCHEZ, A., Las clausulas anti-abuso en el ámbito de la recaudación, Instituto de Estudios Fiscales, Madrid, 2006, pág. 112. En un sentido similar, CHECA GONZÁLEZ, C., "La responsabilidad tributaria por sucesión en la titularidad de explotaciones y actividades económicas. El nuevo titular debe responder también por las deudas pendientes, en concepto de retenciones, devengadas por el anterior empresario", Jurisprudencia Tributaria Aranzadi, núm. 19, 2007, pág. 384.

732 MARTÍN JIMÉNEZ, A., Los Supuestos de responsabilidad en la LGT: (hacia una configuración constitucional y comunitaria de la responsabilidad tributaria), op. cit., pág. 203.
} 
Otro de los puntos contradictorios en la regulación legal de esta figura de responsabilidad es el referido al término de sucesión, utilizado por la norma tributaria de la misa forma que su antecesora en 1963, porque no se produce un cambio de sujetos y la persona a la que "suceden" no queda fuera del ámbito jurídico ${ }^{733}$. La declaración de la responsabilidad supondría la colocación, por mandato de la ley, del adquirente junto al deudor principal, que no se desprende nunca de sus obligaciones frente a la Hacienda Pública ${ }^{734}$. También se deduce del número 3 del artículo 40 de la LGT que la sucesión a título universal de personas jurídicas y entidades se encuentra fuera de los supuestos de responsabilidad $^{735}$.

La sucesión mortis causa, que es uno de los tipos de sucesión en sentido estricto, se excluye del presupuesto de hecho para derivar esta responsabilidad porque el propio precepto así lo determina, al considerar el tercer párrafo del inciso c) del primer apartado del artículo 42 de la LGT que

"la responsabilidad a la que se refiere el primer párrafo de ésta letra, no será aplicable a los supuestos de sucesión por causa de muerte, que se regirán por lo establecido en el artículo 39 de esta Ley".

En definitiva, el presupuesto de hecho de este tipo de responsabilidad lo constituye la transmisión de la titularidad, no sólo a través de un negocio jurídico correctamente acreditado e informado a la Administración, sino también en ejercicio de explotaciones o actividades económicas, sin importar que el cese sea total o no, formal o aparente. BARRACHINA JUAN comenta que se trata de una transmisión de una actividad real empresarial que no admite una transmisión transitoria o provisional, siendo fundamental que sea una transmisión donde haya consecutividad en el ejercicio jurídico y económico de la titularidad ${ }^{736}$.

Para delimitar positivamente el ámbito de aplicación del inciso c) del apartado primero del artículo 42 de la LGT debemos remitirnos a tres elementos necesarios que permiten concluir que se ha producido el presupuesto de hecho de la responsabilidad solidaria por la sucesión de empresa. Nos referimos a la existencia de una actividad o explotación económica; a la sucesión en la titularidad de la actividad o explotación económica; y a la continuidad en el ejercicio de la actividad o explotación económica. No está muy claro qué se entiende por el contenido del conjunto patrimonial transmitido, es decir, cómo interpretar la expresión "actividad o explotación económica". Será necesario a la hora de originar supuestos de responsabilidad diferenciar la transmisión de la titularidad y del ejercicio de la explotación o actividad económica, además de identificar la transmisión de los elementos patrimoniales aislados que condicionen la continuidad del ejercicio o explotación.

\footnotetext{
${ }^{733}$ BARRACHINA JUAN, E., "Responsabilidad tributaria del adquirente de una empresa: supuesto irregular de sucesión”, op. cit., pág. 72 a 74.

${ }^{734}$ CALVO ORTEGA, R., “Obligados tributarios”, op. cit., pág. 175.

${ }^{735}$ Considera por ello NAVARRO EGEA, M., El responsable tributario, op. cit., pág. 91, que "quizás hubiera sido más clarificador que la nueva redacción del art. 42.1. c) hubiese incorporado una remisión al artículo citado, similar a la introducida para la sucesión de empresa entre personas físicas o, en su caso, que hubiese omitido cualquier alusión relativa a la sucesión por tratarse de un instituto del Derecho privado".

${ }^{736}$ BARRACHINA JUAN, E., "Responsabilidad tributaria del adquirente de una empresa: supuesto irregular de sucesión”, op. cit., pág. 72 .
} 
La doctrina de los tribunales ha buscado un concepto de actividad o explotación económica autónoma, vinculado a la noción de empresa. La Audiencia Nacional definió este concepto como "universalidad, conjunto o complejo organizado y en funcionamiento de bienes y servicios dirigidos, con la nota de habitualidad, a la obtención del lucro"737. En este sentido, la ley actual determina que la sucesión se producirá cuando se adquiera el conjunto de bienes y derechos que permita continuar con la explotación, "por lo que el concepto de actividad o explotación económica necesariamente debe ser autónomo y vinculado a la actividad o explotación de la empresa"738.

En relación con el segundo de los elementos, la sucesión por cualquier concepto en la titularidad o ejercicio de explotaciones o actividades económicas, los tribunales entendieron en un primer momento que la sucesión del artículo 72 de la LGT de 1963 tenía un carácter jurídico ${ }^{739}$. Sin embargo, más recientemente estos mismos tribunales se decantan por considerar suficiente la existencia de una sucesión de hecho o de facto para aplicar la responsabilidad por sucesión de empresa $^{740}$. La sucesión de hecho es entendida por esta doctrina jurisprudencial como la continuación de una misma empresa bajo una apariencia distinta, empleando en gran medida los elementos personales y materiales de la anterior. Tal sucesión de hecho, indican los tribunales, debe quedar acreditada por elementos indiciarios. La carga de acreditar la sucesión corresponde a la Administración, pero una vez probados los elementos indiciarios que hace presumible una sucesión corresponde al obligado tributario demostrar que tal sucesión no existe ${ }^{741}$.

En el supuesto de empresas que vacían sus patrimonios para aparentar un cese de funciones, cuando en realidad lo que pretenden es evadir las obligaciones tributarias y, por ende, la responsabilidad, más conocida como sucesión de facto, se requiere el análisis de elementos más concretos que se encuentran en cada caso, al no poder demostrarse la existencia de la transmisión de un negocio jurídico. Desde esta perspectiva, la Administración tributaria deberá observar aspectos relativos a la continuidad de los trabajadores; las relaciones de parentesco entre los administradores de ambas empresas; la actividad que se desarrolla; o el local que ocupa, entre otros, con el objetivo de delimitar si la naturaleza de la actividad que se ha efectuado puede incluirse dentro del presupuesto de hecho de la responsabilidad. Sobre este aspecto en concreto, alerta NAVARRO EGEA ${ }^{742}$ que puede confundirse la sucesión de empresa con "supuestos de arrendamiento de negocio" o "situaciones de crisis empresarial” y que podría resultar difícil para la Administración probar la continuidad de la

\footnotetext{
${ }^{737}$ Sentencia de la Audiencia Nacional de 12 de mayo de 1997.

${ }^{738}$ MARTÍN JIMÉNEZ, A., Los Supuestos de responsabilidad en la LGT: (hacia una configuración constitucional y comunitaria de la responsabilidad tributaria), op. cit., pág. 208.

${ }^{739}$ Sentencia del Tribunal Supremo de 8 de marzo de 1995; y, dentro de la doctrina administrativa, Resolución del TEAC de 9 de febrero de 1995.

${ }^{740}$ Entre otras, las Sentencias de la Audiencia Nacional de 8 de octubre de 2001; de 11 de enero de 2002; de 20 de octubre de 2003; y de 11 de abril de 2005 .

${ }^{741}$ Sentencia del Tribunal Superior de Justicia de Sevilla de 10 de mayo de 2002. Sobre las circunstancias que deberán tener en cuenta los órganos de recaudación con el objetivo de poder determinar si se ha producido una sucesión, vid. ARGUELLES PINTO, J., y FELTRER BAUZÁ, F., Régimen jurídico de la responsabilidad tributaria y su aplicación práctica, op. cit., pág. 76 a 78.

${ }^{742}$ NAVARRO EGEA, M., El responsable tributario, op. cit., pág. 96.
} 
actividad por medio de otro titular, y que sería por ello conveniente utilizar otras técnicas para detectar el fraude de ley ${ }^{743}$.

Por último, el alcance de la responsabilidad se extiende a las obligaciones tributarias del anterior titular de la explotación o actividad económica que estuvieran vinculadas con el ejercicio, y se amplía el alcance de la responsabilidad por la sucesión de empresas a las retenciones no ingresadas por el anterior titular y a las sanciones impuestas o que puedan imponerse. En relación con las primeras, las obligaciones tributarias, la LGT se refiere a las devengadas por los anteriores titulares, estuvieran o no liquidadas ${ }^{744}$. Con la indicación "del anterior titular" se deduce que sólo serán las obligaciones tributarias devengadas por el primer titular y en el ámbito de su ejercicio. En el caso de las segundas, las obligaciones tributarias derivadas de la falta de ingreso de las retenciones e ingresos a cuenta practicadas o que se hubieran debido practicar, constituyen un avance de la normativa actual respecto de su antecesora.

La extensión de la responsabilidad a las sanciones se fundamenta en el hecho de que la propia Administración concibe este supuesto como un instrumento para combatir el fraude fiscal, aunque la doctrina y la jurisprudencia han puesto en tela de juicio la inclusión de las sanciones en el alcance de la responsabilidad por sucesión de empresas ${ }^{745}$. Según MARTíN JIMÉNEZ, "la extensión de la responsabilidad por sucesión de empresas a las sanciones no resultará, (...) constitucional allí donde la Administración realice derivaciones automáticas, en las que sólo se constate la sucesión, y no pruebe la culpabilidad del adquirente en la relación con la sanción que se pretenda derivar" ${ }^{\text {,76 }}$. También MARTÍNEZ LAGO afirma que "la inclusión de las sanciones dentro del ámbito de responsabilidad solidaria de quien sucede en la titularidad o ejercicio de una explotación o actividad económica, resulta totalmente inadmisible y no es jurídicamente viable porque pugna abiertamente en estos casos más que en otros supuestos de responsabilidad deducida de actos ilícitos- con el principio de personalidad de la pena. (...) La referencia a las sanciones no parece tener en cuenta que cuando existan infracciones de la entidad, el administrador -incluso el de hecho- habrá incurrido en un supuesto de responsabilidad subsidiaria o incluso solidaria por haber participado en la realización de aquellas infracciones, y no parece muy conforme a Derecho acudir primero contra el adquirente de la empresa y posteriormente contra el administrador. Aparte de que hubiese sido más adecuado que la responsabilidad por la sucesión en explotaciones y actividades económicas fuese subsidiaria y no solidaria, lo señalado prueba lo rechazable que resulta que la responsabilidad del adquirente se extienda a las sanciones tributarias" ${ }^{, 747}$.

\footnotetext{
${ }^{743}$ Así también lo entiende CASCAJERO SÁNCHEZ, A., Las clausulas anti-abuso en el ámbito de la recaudación, op. cit., pág. 112.

${ }^{744}$ Así se indicaba en el apartado primero del artículo 13 del RGR de 1990 y en la Sentencia del Tribunal Superior de Justicia del País Vasco de 22 de febrero de 2002.

${ }^{745}$ CALVO ORTEGA, R., "Obligados tributarios”, op. cit., pág. 176; BOSCH CHOLBI, J. L., "Análisis crítico de los supuestos de responsabilidad tributaria solidaria en la LGT 58/2003”, op. cit., pág. 26; FALCÓN Y TELLA, R., "Las garantías del crédito tributario: perspectivas de reforma", op. cit., pág. 7; NAVARRO EGEA, M., El responsable tributario, op. cit., pág. 104 y 105; ARGUELLES PINTO, J., y FELTRER BAUZÁ, F., Régimen jurídico de la responsabilidad tributaria y su aplicación práctica, op. cit., pág. 83 y 84. En la jurisprudencia, vid. las Sentencias de la Audiencia Nacional de 23 de marzo de 2000 y de 11 de abril de 2005 , y en la doctrina administrativa, vid. Resoluciones del TEAC de 7 de septiembre de 2000 y de 9 de octubre del 2003.

${ }^{746}$ MARTÍN JIMÉNEZ, A., Los Supuestos de responsabilidad en la LGT: (hacia una configuración constitucional y comunitaria de la responsabilidad tributaria), op. cit., pág. 211.

${ }^{747}$ MARTÍNEZ LAGO, M. A., La extensión de la responsabilidad a las sanciones tributarias, op. cit., pág. 243.
} 
Coincidiendo con esta doctrina, entendemos que la Administración deberá demostrar en este tipo de responsabilidad la culpabilidad del responsable y que, para poder derivar las sanciones a los responsables, tendrán que cumplirse los principios constitucionales recogidos en el apartado segundo del artículo 24 y en el apartado primero del artículo 25, ambos de la CE. Si se demuestra la culpabilidad del responsable y éste ha colaborado en la comisión de la infracción imputable al transmitente, entendemos que el precepto aplicable sería el inciso a) del apartado primero del artículo 42 de la LGT. Pero si se aprecia otro comportamiento distinto del anterior, y el sucesor presunto responsable pretende ayudar al transmitente a eludir la deuda tributaria, es decir, no existe un comportamiento que constituya la base de la infracción previamente cometida, podría constituirse un supuesto de responsabilidad previsto en el segundo apartado del artículo 42 de la LGT. Asimismo, si se constata que todo es un artificio y que el sucesor está controlado o es la misma persona que el transmitente, lo adecuado sería aplicar la doctrina del levantamiento del velo, recogida en los incisos g) y h) del apartado primero del artículo 43 de la LGT.

La ley reconoce, no obstante, un mecanismo que limita el traspaso de las sanciones a los responsables. Nos referimos a la solicitud administrativa por parte del adquirente de un certificado con las deudas, sanciones y responsabilidades tributarias pendientes derivadas del ejercicio de la actividad o explotación. En este sentido, el responsable puede quedar exonerado del pago de las sanciones si en el certificado que formula la Administración no las contempla o éste no se emite en el término que determina el apartado segundo del artículo 175 de la LGT, ampliado de dos a tres meses con respecto a la LGT de 1963. Por lo demás, según reza este último precepto,

"El que pretenda adquirir la titularidad de explotaciones y actividades económicas y al objeto de limitar la responsabilidad solidaria (...), tendrá derecho, previa la conformidad del titular actual, a solicitar de la Administración certificación detallada de las deudas, sanciones y responsabilidades tributarias derivadas de su ejercicio. La Administración tributaria deberá expedir dicha certificación en el plazo de tres meses desde la solicitud. En tal caso quedará la responsabilidad del adquirente limitada a las deudas, sanciones y responsabilidades contenidas en la misma. Si la certificación se expidiera sin mencionar deudas, sanciones o responsabilidades o no se facilitara en el plazo señalado, el solicitante quedará exento de la responsabilidad a la que se refiere dicho artículo".

De todo lo que acabamos de señalar se desprende, a nuestro juicio, que la responsabilidad por sucesión de empresa debería ubicarse dentro de los supuestos de responsabilidad subsidiaria, y que sólo en el caso de que el transmitente no tuviera bienes suficientes para satisfacer su deuda tributaria y su sanción debería ser llamado el adquirente que no obró con la diligencia debida. Se trata de un tipo de responsabilidad que no tiene finalidad garantista, sobre todo, por los efectos que se atribuyen al certificado, bastando con que la deuda no esté liquidada para que, si nada dice el certificado expedido, se excluya la responsabilidad del sucesor, lo que conlleva a que desaparezcan sus efectos como garantía. 


\subsubsection{Actuaciones que dificultan la actividad recaudatoria}

El segundo apartado del artículo 42 de la LGT dispone que son responsables solidarios del pago de la deuda tributaria pendiente y, en su caso, de las sanciones tributarias, incluidos el recargo y el interés de demora del período ejecutivo, cuando procedan, hasta el importe del valor de los bienes o derechos que se hubieran podido embargar o enajenar por la Administración tributaria, las siguientes personas o entidades

“a. Las que sean causantes o colaboren en la ocultación o transmisión de bienes o derechos del obligado al pago con la finalidad de impedir la actuación de la Administración tributaria.

b. Las que, por culpa o negligencia, incumplan las órdenes de embargo.

c. Las que, con conocimiento del embargo, la medida cautelar o la constitución de la garantía, colaboren o consientan en el levantamiento de los bienes o derechos embargados, o de aquellos bienes o derechos sobre los que se hubiera constituido la medida cautelar o la garantía.

d. Las personas o entidades depositarias de los bienes del deudor que, una vez recibida la notificación del embargo, colaboren o consientan en el levantamiento de aquéllos".

El precepto que se acaba de transcribir asume elementos de la LGT de 1963, concretamente de su artículo 131 y del artículo 116 del RGR de 1990. Se trata de un supuesto dirigido a proteger el crédito tributario ante actuaciones $\mathrm{u}$ omisiones de personas o entidades destinadas a afectar la satisfacción del crédito de la Administración tributaria. La LGT de 2003 amplió los supuestos de responsabilidad solidaria de los sujetos que causen o colaboren en la ocultación o transmisión de bienes o derechos del obligado al pago, suprimió la utilización del término maliciosamente que se utilizaba en la LGT de 1963 en el inciso a) del apartado quinto del artículo 131, y además extendió el presupuesto de hecho no sólo a la ocultación, sino también a la transmisión.

Esta modalidad de responsabilidad incluye un conjunto de supuestos que vinculan la actuación de un tercero con el obligado principal que se encuentra en la fase ejecutiva de recaudación. Se trata de una forma de responsabilidad que tiene diferencias notables con el apartado primero del artículo 42 de la LGT. En primer lugar, la responsabilidad nace vinculada a ciertas conductas del responsable realizadas, principalmente, aunque no de forma exclusiva, en el período ejecutivo de la deuda o con anterioridad a éste, que impiden la realización de la deuda sobre los bienes y derechos del obligado principal. En el caso que nos ocupa el responsable no tiene ningún vínculo relevante con el hecho imponible que genera la deuda tributaria, a diferencia de lo que ocurre con los restantes responsables que prevé el artículo 42 de la LGT, “donde existe conexión entre el responsable y la deuda tributaria del contribuyente, por la especial posición que ocupa el responsable frente al contribuyente, como partícipe de la entidad que actúa como sujeto pasivo o adquirente de la empresa con respecto a la cual surgió la deuda para el contribuyente" ${ }^{, 48}$.

\footnotetext{
${ }^{748}$ MARTÍN JIMÉNEZ, A., Los Supuestos de responsabilidad en la LGT: (hacia una configuración constitucional y comunitaria de la responsabilidad tributaria), op. cit., pág. 218.
} 
En segundo lugar, por la naturaleza que caracteriza la responsabilidad del apartado segundo del artículo 42 de la LGT, se persigue hacer responder del daño causado a la persona a la que dicho daño es imputable cuando su actuación determine poner en peligro el procedimiento ejecutivo en relación a un bien o derecho determinado, ya se haya iniciado aquél procedimiento o se trate de conductas anteriores $^{749}$. Por ello, destaca MARTÍN JIMÉNEZ que a la responsabilidad del apartado segundo del artículo 42 de la LGT no se puede aplicar los mismos principios que a los responsables del apartado primero del artículo 42 de la LGT. "Por su especial naturaleza", nos dice este autor, "la derivación del importe de la sanción al responsable del art. 42.2 LGT no necesariamente debe cumplir los principios de los arts. 24.2 y 25.1 CE, pues no es materialmente una sanción. En este caso, la derivación de responsabilidad en relación con la sanción no cumple una función sancionadora, sino específicamente resarcitoria: se trata de derivar una deuda (vinculada a la sanción) a quien, con su comportamiento, dificultó el cobro de la misma"750.

En una posición opuesta, GONZÁLEZ ORTIZ, entiende que la sanción jamás podrá derivarse, a fin de cumplir con los principios constitucionales, en este tipo de responsabilidad ${ }^{751}$, y CALVO ORTEGA advierte que el mandato es contrario al principio non bis in idem, que estamos ante una responsabilidad solidaria con carácter de sanción, dada la coincidencia que existe entre estos presupuestos de hecho y el delito de alzamiento de bienes que recoge el Código Penal en su artículo $257^{752}$.

Por su parte, CALVO VÉRGEZ interpreta que este supuesto de responsabilidad solidaria "no persigue tanto la garantía de una obligación tributaria, sino más bien la regulación de una forma específica de responsabilidad extracontractual destinada hace responder del daño causado a aquella persona a la que resulta imputable el mismo, al haber puesto en peligro con su conducta el procedimiento administrativo de ejecución respecto de un bien o derecho determinado, ya se haya iniciado el procedimiento o se trate de conductas anteriores al mismo",753.

Por otro lado, la LGT actual restringe la responsabilidad al pago de una parte de la deuda tributaria ya liquidada que no se ha podido cobrar cuando se hubiere podido enajenar o embargar unos bienes o derechos para cubrir la cuantía que corresponde y no se ha procedido de esta manera por actuaciones

\footnotetext{
${ }^{749}$ Así lo entendió ZABALA RODRÍGUEZ-FORNOS, A., "La responsabilidad tributaria solidaria por conductas obstativas del embargo en el apremio administrativo", Tribuna Fiscal, núm. 109, 1999, pág. 66 y ss., y, del mismo autor, "Comentario a los arts. 41, 42 y 43”, en la obra Comentarios a la nueva Ley General Tributaria, Thomson-Aranzadi, Pamplona, 2004, pág. 315 y 316 . También la Resolución del TEAC de 18 de diciembre de 2003 reconoció que "de la misma redacción del precepto citado, se deduce que la responsabilidad solidaria que en el mismo se establece no es responsabilidad de carácter tributario, sino más bien una responsabilidad por actos ilícitos que encuentra su fundamento en lo establecido en el artículo 1902 del Código Civil”.

${ }^{750}$ MARTÍN JIMÉNEZ, A., Los Supuestos de responsabilidad en la LGT: (hacia una configuración constitucional y comunitaria de la responsabilidad tributaria), op. cit., pág. 219. En este mismo sentido, RUIZ HIDALGO, C., La responsabilidad tributaria en el alzamiento de bienes en la nueva Ley General Tributaria, op. cit., pág. 29; NAVARRO FAURE, A., "Los supuestos de responsabilidad tributaria solidaria en el ordenamiento tributario español (II)", op. cit., pág. 869; Resolución del TEAC de 18 de diciembre de 2003.

${ }^{751}$ GONZÁLEZ ORTIZ, D., La responsabilidad tributaria en el ordenamiento jurídico español, op. cit., pág. 143.

${ }^{752}$ CALVO ORTEGA, R., “Obligados tributarios”, op. cit., pág. 178.

${ }^{753}$ CALVO VÉRGEZ, J., "La responsabilidad de los causantes o colaboradores en acciones que impidan el embargo o la ejecución de bienes de los obligados tributarios”, Quincena Fiscal, núm. 1-2, 2011, pág. 22.
} 
esquivas a la Administración ${ }^{754}$, y es, además, una responsabilidad limitada "hasta el importe del valor de los bienes o derechos que se hubieran podido embargar o enajenar por la Administración tributaria".

En relación con cada uno de los supuestos que integran el segundo apartado del artículo 42 de la LGT, el procedimiento se inicia, en primer lugar, con la derivación de la responsabilidad solidaria a las personas o entidades que causen o colaboren en la ocultación o transmisión de bienes o derechos del obligado al pago con la finalidad de impedir la actuación de la Administración tributaria. En relación con su predecesor, el inciso a) del apartado quinto del artículo 131 de la LGT de 1963, el inciso a) del apartado segundo del artículo 42 de la LGT introduce dos novedades. Por un lado, se vincula la conducta generadora de la responsabilidad a actuaciones que impidan la actuación de la Administración, cuando anteriormente se mencionaban las actuaciones tendentes a impedir la traba, y se suprime la mención a la ocultación maliciosa de bienes o derechos.

De las dos modificaciones, entiende MARTÍN JIMÉNEZ que sólo la primera tiene relevancia porque si se refiere "la responsabilidad a conductas dirigidas a impedir la ejecución de bienes o derechos que se hubieran podido embargar o enajenar, se obtiene como resultado que este tipo de responsabilidad puede existir en relación con conductas anteriores al inicio del período ejecutivo, simultáneas al desarrollo del mismo, o simplemente tendentes a obstaculizar la enajenación del bien o derecho una vez que ha sido embargado", y que con ello "se amplía de una forma importante las conductas que pueden generar este tipo de responsabilidad con respecto al art. 131.5 LGT 1963"755. NAVARRO EGEA considera, en relación con este supuesto, que se trata de "maniobras de distracción de bienes que pueden tener lugar en el procedimiento de apremio con anterioridad a la apertura de la fase de embargo e, incluso antes, con ocasión de la adopción de medidas cautelares", y esto porque no se exige un "conocimiento de la actuación administrativa mediante la oportuna notificación al tercero"756. Por el contrario, CALVO VÉRGEZ es de la opinión que "la derivación de responsabilidad requiere siempre del desarrollo de una actividad probatoria por parte del órgano competente a través de la cual resulte acreditada la finalidad de impedir el embargo y la enajenación de los elementos patrimoniales del deudor principal, quedando imposibilitada así la satisfacción del crédito tributario" y que para ello "es necesario partir del conocimiento formal de la actuación administrativa mediante la realización de la oportuna notificación al tercero" ${ }^{\text {,757. }}$.

El segundo supuesto de responsabilidad, recogido en el inciso b) del apartado segundo del artículo 42 de la LGT, hace responsable solidario de una deuda tributaria ajena, pendiente de pago, al sujeto que por culpa o negligencia incumpla las órdenes de embargo. La conducta exigida para que concurra este supuesto está relacionada con la no ejecución del mandamiento de embargo en sus propios

\footnotetext{
${ }^{754}$ Por ello, puntualiza NAVARRO EGEA, M., El responsable tributario, op. cit., pág. 109, estas características son las notas identificativas de la figura, mediante la cual no se pretende "afianzar la obligación tributaria" sino "responder por la cantidad en la que se concreta el perjuicio a los intereses recaudatorios de la Hacienda Pública”.

${ }^{755}$ MARTÍN JIMÉNEZ, A., Los Supuestos de responsabilidad en la LGT: (hacia una configuración constitucional y comunitaria de la responsabilidad tributaria), op. cit., pág. 220. En el mismo sentido, ARGÜELLES PINTOS, J. y FELTRER BAUZÁ, F., Régimen jurídico de la responsabilidad tributaria y su aplicación práctica, op. cit., pág. 149.

${ }^{756}$ NAVARRO EGEA, M., El responsable tributario, op. cit., pág. 108.

${ }^{757}$ CALVO VÉRGEZ, J., "La responsabilidad de los causantes o colaboradores en acciones que impidan el embargo o la ejecución de bienes de los obligados tributarios”, op. cit., pág. 29.
} 
términos. En este tipo de responsabilidad no sólo debe haberse iniciado el procedimiento de apremio, sino que se requiere una diligencia de embargo de bienes concretos con notificación a un tercero y que este sujeto incumpla con el embargo, ya fuera por culpa o negligencia, impidiendo a la Administración disponer de dichos bienes. El ámbito subjetivo de este supuesto también es amplio porque no es necesario que el responsable haya sido nombrado depositario de los bienes o derechos embargados, bastando sólo con que su conducta posibilite el incumplimiento de la orden del embargo $^{758}$.

El tercer supuesto califica como responsables solidarios a las personas o entidades que colaboren o consientan en el levantamiento de los bienes o derechos embargados o sobre los que se hubiera constituido la medida cautelar o la garantía. El ámbito de aplicación de este supuesto se ha ampliado considerablemente respecto a su homólogo anterior, el inciso c) del apartado quinto del artículo 131 de la LGT de 1963. Éste es un supuesto que no prevé solamente la participación activa en la colaboración del levantamiento de los bienes o derechos, sino también la conducta omisiva, bastando con que el presunto responsable consienta dicho levantamiento, cuando el bien ya hubiera sido embargado o por lo menos se estableciera una medida cautelar o una garantía sobre él. Para MARTÍN JIMÉNEZ, la responsabilidad se puede dar ahora "en un momento temporal anterior al embargo de los bienes o derechos, en relación con bienes o derechos afectados por medidas cautelares o que garanticen una deuda tributaria. En cualquier caso, se exigirá el conocimiento del embargo, la medida cautelar o la constitución de la garantía, ya que la actuación previa de estos actos, por más que perjudique a la Hacienda Pública, no desencadenará este tipo de responsabilidad" ${ }^{, 759}$. La diferencia más importante entre este tipo de responsabilidad del inciso $c$ ) del apartado segundo del artículo 42 de la LGT y el inciso a) del mismo precepto, la encontramos en el hecho de que éste último está dirigido a evitar la actuación administrativa posterior sobre ciertos bienes o derechos, mientras que en el primer precepto el embargo, la medida cautelar o la garantía ya existen y son conocidas por quien colabora o consiente en el levantamiento de los bienes o derechos. Una de las interrogantes que podría esgrimirse sobre este supuesto en particular es si la responsabilidad se origina como consecuencia de comportamientos negligentes o si se exige siempre la voluntad dirigida al levantamiento. Un sector jurisprudencial presume la voluntad maliciosa tendente a frustrar la efectividad del embargo, ya que existen otros supuestos dentro del propio precepto dirigidos a los comportamientos negligentes; mientras que otros tribunales han entendido que el consentimiento en el levantamiento de los bienes o derechos embargados es una conducta que puede realizarse por negligencia ${ }^{760}$.

El inciso d) del apartado segundo del artículo 42 de la LGT incorpora un supuesto, calificado como innecesario por la doctrina, que no presenta cambios significativos respecto a la normativa anterior y

\footnotetext{
${ }^{758}$ CALVO VÉRGEZ, J., "La responsabilidad de los causantes o colaboradores en acciones que impidan el embargo o la ejecución de bienes de los obligados tributarios", op. cit., pág. 32.

${ }^{759}$ MARTÍN JIMÉNEZ, A., Los Supuestos de responsabilidad en la LGT: (hacia una configuración constitucional y comunitaria de la responsabilidad tributaria), op. cit., pág. 223.

${ }^{760}$ Vid. Sentencia del Tribunal Superior de Justicia de las Islas Baleares de 20 de febrero de 1998. CALVO VÉRGEZ interpreta que en el inciso a) del apartado segundo del artículo 42 de la LGT "no se está aludiendo a una ocultación o transmisión que imposibilite el desarrollo de la actuación administrativa, sino a un «levantamiento», al menos por omisión, pero sin necesidad de que concurra una intencionalidad específica dirigida a perjudicar a la Hacienda Pública acreedora o a la obtención de un beneficio" (CALVO VÉRGEZ, J., "La responsabilidad de los causantes o colaboradores en acciones que impidan el embargo o la ejecución de bienes de los obligados tributarios", op. cit., pág. 36).
} 
que determina la responsabilidad solidaria de las personas o entidades depositarias de los bienes del deudor que, una vez recibida la notificación del embargo, colaboren o consientan en el levantamiento de aquéllos ${ }^{761}$. El inciso b) del número 2 del artículo 42 de la LGT que antes mencionábamos extiende la responsabilidad por culpa o negligencia a quienes incumplan una orden de embargo, sin que la indicación de que haya recibido la notificación del embargo aporte algún cambio, e incluye el incumplimiento de las órdenes del embargo dentro de la participación en la colaboración o consentimiento.

En cuanto a la extensión de la responsabilidad en los cuatro supuestos que se acaban de señalar, el segundo apartado del artículo 42 de la LGT establece la responsabilidad por las sanciones, los recargos y los intereses de demora del período ejecutivo, cuando procedan, hasta el valor de los bienes o derechos que se hubieran podido embargar o enajenar por la Administración tributaria. En relación con el valor de estos bienes y derechos, RUIZ HIDALGO recuerda que "debe cifrarse siempre y con arreglo a las circunstancias concretas de cada caso y, por su puesto en un valor estimativo de los bienes y derechos, ya que concretar el valor real resulta imposible, justamente, porque los bienes o derechos no se han podido embargar o ejecutar", y que para ello "la determinación del valor de estos últimos deberá regirse por lo dispuesto en el art. 97 del RGR, como una forma de evitar que el alcance de la responsabilidad quede determinado de forma arbitraria» ${ }^{, 762}$.

En los supuestos del segundo apartado del artículo 42 de la LGT las sanciones se configuran como una deuda más y, por lo tanto, no son de aplicación los postulados del Tribunal Constitucional que mantienen que la naturaleza sancionadora de la responsabilidad por sanciones puede derivarse de su inclusión en el artículo 182 de la LGT y que es necesario, por ello, respetar los derechos y garantías que reconoce la CE en el apartado segundo del artículo 24 y en el apartado primero del artículo $25^{763}$. Entendemos que, en este tipo de responsabilidad que nos ocupa del segundo apartado del artículo 42 de la LGT, la naturaleza de esta figura no es constitucionalmente sancionadora si tenemos en cuenta la finalidad que la misma persigue. Por otra parte, el propio Tribunal Constitucional ha dispuesto que se excluye la aplicación de los derechos y garantías inherentes a las medidas de naturaleza sancionadora allí donde la sanción se integre como una deuda más ${ }^{764}$.

RUIZ HIDALGO manifiesta, sin embargo, su desacuerdo en la inclusión de las sanciones dentro del alcance de este tipo de responsabilidad. Según esta autora, "la posición legislativa y doctrinal adoptada resulta contraria al instituto del responsable y al principio de personalidad de la pena. Es cierto que en determinadas ocasiones la deuda que se pretende cobrar puede ser una sanción y que la conducta del obligado principal y el tercero ocultando o levantando bienes y derechos, impida la satisfacción de la misma. Pero a nuestro juicio, se conculca la naturaleza del responsable, así como la

\footnotetext{
${ }^{761}$ En relación con la responsabilidad del apartado segundo del artículo 42 de la LGT cuando el depositario es un banco, vid. a ARGÜELLES PINTOS, J. y FELTRER BAUZÁ, F., Régimen jurídico de la responsabilidad tributaria y su aplicación práctica, op. cit., pág. 70 a 72.

${ }^{762}$ RUIZ HIDALGO, C., La responsabilidad tributaria en el alzamiento de bienes en la nueva Ley General Tributaria, op. cit., pág. 113.

${ }^{763}$ Sentencias del Tribunal Constitucional 254/2007, de 17 de diciembre, 73/2009, de 23 de marzo, 208/2009, de 26 de noviembre, 3/2011, de 14 de febrero, 39/2010, de 19 de julio, 64/2010, de 18 de octubre, 25/2012, de 27 de febrero.

${ }^{764}$ Sentencias del Tribunal Constitucional 331/2006, de 20 de noviembre, y 23/2010, de 27 de abril.
} 
aplicación de los principios penales en el Derecho tributario" ${ }^{\text {765 }}$. En la misma línea, para CALVO VÉRGEZ "resulta preferible sacar del alcance de la responsabilidad a aquellas sanciones cometidas por el deudor principal, con independencia de poder imponer al responsable solidario del art. 42.2 de la LGT la sanción correspondiente por las acciones u omisiones que perjudicasen el cobro de la deuda tributaria. De este modo la declaración de responsabilidad, al no incluir las sanciones impuestas al deudor principal, resultaría respetuosa con los principios de culpabilidad y de personalidad, pudiendo como decimos sancionarse al responsable que hubiese incurrido en la infracción tipificada dentro del correspondiente procedimiento señalado al efecto y cumpliéndose los necesarios requisitos de motivación, culpabilidad e individualización", de manera que entonces "cabría exigir al responsable única y exclusivamente el importe de los daños originados"766.

\subsubsection{Comunidades Autónomas y Corporaciones Locales}

El último tipo de responsabilidad solidaria se ubica en la Disposición Adicional Séptima de la LGT, que tiene su antecedente en la Disposición Adicional Cuarta del Real Decreto Legislativo 2/2004, de 5 de marzo. En concreto, se establece la responsabilidad solidaria de las Corporaciones Locales respecto del pago de las deudas tributarias de los Organismos Autónomos locales que dependan de ellas (incisos b) y c) del apartado tercero del artículo 85 de la Ley 7/1985, de 2 de abril, reguladora de las Bases de Régimen Local), las sociedades mercantiles cuyo capital social pertenezca íntegramente a la Corporación Local, y las mancomunidades, comarcas, áreas metropolitanas, entidades de ámbito inferior al municipio y cualesquiera instituciones asociativas voluntarias públicas en las que participen. Aunque la novedad de la Disposición Adicional Séptima de la LGT radica en el contenido del primer párrafo, que extiende la responsabilidad solidaria también a las Comunidades Autónomas respecto del pago de las deudas tributarias contraídas por las entidades de Derecho público que dependan de ellas, las sociedades mercantiles cuyo capital social pertenezca íntegramente a la Comunidad Autónoma o las instituciones asociativas voluntarias públicas en las que participen.

De ambos supuestos se extraen dos ideas relevantes. Por un lado, que estamos ante supuestos de responsabilidad impropia, porque no se exigen otros requisitos adicionales que los que aparecen en la Disposición Adicional Séptima de la LGT, pudiendo dirigirse la Hacienda Pública indistintamente contra la Comunidad Autónoma o la Corporación Local o contra el deudor principal, y respondiendo las dos primeras sólo en proporción a sus respectivas cuotas de participación en las entidades públicas que ocupan esta posición de deudor principal. Y por otra, que asiste a estos entes públicos el derecho de repetición contra el deudor principal que haya ocasionado la deuda tributaria.

\footnotetext{
${ }^{765}$ RUIZ HIDALGO, C., La responsabilidad tributaria en el alzamiento de bienes en la nueva Ley General Tributaria, op. cit., pág. 119 y 120. De esta misma manera, pero con otros argumentos, se pronunció MARTíNEZ LAGO, al defender que los supuestos contemplados en el apartado segundo del artículo 42 de la LGT deberían pasar a formar parte del catálogo de infracciones merecedora de una respuesta y un procedimiento de Derecho sancionador (MARTíNEZ LAGO, M. A., La extensión de la responsabilidad a las sanciones tributarias, op. cit., pág. 270).

${ }^{766}$ CALVO VÉRGEZ, J., "La responsabilidad de los causantes o colaboradores en acciones que impidan el embargo o la ejecución de bienes de los obligados tributarios", op. cit., pág. 42 y 43 . Quizás por ello, añade este autor, "sería conveniente encuadrar su regulación en otra parte de la Ley, bien procediendo a su tipificación como infracción propia del procedimiento de recaudación, como una garantía del cobro o incluso un supuesto de responsabilidad no tributaria".
} 


\subsubsection{Responsabilidad tributaria subsidiaria}

\subsubsection{Administrador de personas jurídicas}

Este primer tipo de responsabilidad subsidiaria se recogía en la LGT de 1963, que en su artículo 40 regulaba la derivación de la responsabilidad para los administradores de las personas jurídicas que participaran de manera activa u omisiva en las infracciones tributarias cometidas por estas últimas. A su vez, el precepto derivaba la responsabilidad para los administradores de las sociedades que hubieran cesado en sus actividades dejando obligaciones tributarias pendientes.

E1 Informe de 2001 proponía que este supuesto se mantuviera en sus líneas generales y consideraba que "el administrador sería responsable siempre que no realice los actos necesarios de su incumbencia para el cumplimento de las obligaciones tributarias infringidas según el contenido de los Estatutos sociales". De esta forma resulta necesario precisar si dentro de las atribuciones que la sociedad otorga al administrador se incluye el cumplimiento de las obligaciones tributarias, o de lo contrario, esta atribución se desplaza a otros sujetos, pues "defender esta posibilidad conduciría, obviamente, a una formulación de este supuesto de responsabilidad que permitiera su extensión a tales sujetos carentes de la condición de administradores".

La LGT de 2003 siguió de manera muy similar los postulados de su antecesora, en líneas generales, como se recomendaba en el Informe de 2001. El primer apartado del artículo 43 de la LGT expresa literalmente que serán responsables subsidiarios de la deuda tributaria

"a. los administradores de hecho o de derecho de las personas jurídicas que, habiendo éstas cometido infracciones tributarias, no hubiesen realizado los actos necesarios que sean de su incumbencia para el cumplimiento de las obligaciones y deberes tributarios, hubiesen consentido el incumplimiento por quienes de ellos dependan o hubiesen adoptado acuerdos que posibilitasen las infracciones. Su responsabilidad también se extenderá a las sanciones.

b. Los administradores de hecho o de derecho de aquellas personas jurídicas que hayan cesado en sus actividades, por las obligaciones tributarias devengadas de éstas que se encuentren pendientes en el momento del cese, siempre que no hubieran hecho lo necesario para su pago o hubieren adoptado acuerdos o tomado medidas causantes del impago".

En relación con estos dos supuestos de responsabilidad subsidiaria debemos plantearnos en primer lugar qué se entiende por administrador de personas jurídicas. La LGT de 1963 sólo hacía mención a estos sujetos, sin más precisión, por lo que era necesario acudir a otros ordenamientos especiales para entender quiénes se consideran administradores de las sociedades. En este sentido, el Tribunal Superior de Justicia de Murcia, en Sentencia de 26 de junio de 1996, determinó que el término "administrador" incluye a "todo aquél que actúe como órgano de administración de la sociedad anónima, sea unipersonal o pluripersonal”. Por su parte, el Informe de 2001 propuso como definición de administradores de derecho o de hecho "quienes, en las personas jurídicas, ostenten cargos de administración o dirección, de hecho o de derecho". 
El término de "administrador" sufrió modificaciones con la LGT de 2003. En los incisos a) y b) del apartado primero del artículo 43 se hace referencia a los "administradores de hecho o de derecho de las personas jurídicas". De esta forma se consideran administradores no sólo a los sujetos que ostentan dicha condición según las normas mercantiles, sino también a aquéllos otros que, por las funciones que llevan a cabo, puede considerarse que administran la sociedad. En consecuencia, entiende MARTÍN JIMÉNEZ que "a los efectos de la responsabilidad regulada en el art. 43.1. a) y b) LGT 2003, el administrador de hecho queda equiparado al de derecho, si bien la auténtica novedad de esta norma se refiere a la posibilidad de interpretar que, con esta denominación, se quiere hacer referencia al administrador oculto, además de al notorio. (...) Probablemente, sin embargo, la indefinición del término "administrador de hecho", que la LGT comparte con el Código Penal o con la normativa mercantil, sea deliberada, de tal manera que corresponderá a la jurisprudencia determinar cuándo un sujeto que no ocupa la posición de administrador legalmente nombrado puede ser considerado como administrador de hecho por ejercer la gestión y control de una determinada persona jurídica" ${ }^{, 767}$.

Según MARTÍN FERNÁNDEZ, RODRÍGUEZ MÁRQUEZ, GALÁN SÁNCHEZ, adquieren la condición de administradores de hecho los administradores con cargo caducado; los administradores que ocupan formalmente el cargo; los sujetos que, de hecho, controlan la gestión y administración de la entidad sin haber sido nombrados formalmente, pero que aparecen en las relaciones exteriores de la sociedad como administradores; y los sujetos que, sin ofrecer esta apariencia exterior, controlan de hecho la gestión y administración de la sociedad, ejerciendo una influencia decisiva sobre los administradores. Y todo ello, en opinión de estos autores, sin perjuicio de que también otorguen la condición de administradores de hecho determinadas circunstancias, como tener la condición de socio mayoritario de la entidad o familiar cercano de los socios; desempeñar funciones de apoderado general con amplias facultades; percibir una remuneración importante; o tener un trato personal y continuo con proveedores y clientes y una relación inmediata con los trabajadores de la sociedad ${ }^{768}$.

Por su parte, MARTÍN JIMÉNEZ aboga por no adoptar una interpretación estricta o amplia del concepto, y afirma que "simplemente el contorno de esta figura deberá venir determinado por la existencia del control o influencia decisiva en la gestión y administración de la persona jurídica en cuestión", de manera que "será sencillo alcanzar tal conclusión cuando una persona actúe como tal frente a terceros sin que el administrador legal despliegue sus funciones propias" y que "bastará, a

\footnotetext{
${ }^{767}$ MARTÍN JIMÉNEZ, A., Los Supuestos de responsabilidad en la LGT: (hacia una configuración constitucional y comunitaria de la responsabilidad tributaria), op. cit., pág. 242 y 243. Comparte esta opinión ÁLVAREZ MARTíNEZ, J., La responsabilidad de los administradores de las personas jurídicas en la nueva Ley General Tributaria, Thomson-Aranzadi, Madrid, 2004 , pág. 62 y 63.

${ }^{768}$ MARTÍN FERNÁNDEZ, J, RODRÍGUEZ MÁRQUEZ, J. S., y GALÁN SÁNCHEZ, R. M., "Los administradores de sociedades como responsables tributarios", en la obra Tratado sobre la Ley General Tributaria, Tomo I, ARRIETA MARTÍNEZ DE PISÓN, J, COLLADO YURRITA, M. A., ZORNOZA PÉREZ, J. (directores), Aranzadi, Thomson Reuters, 2010, pág. 1049. Anteriormente BLÁZQUEZ LIDOY y CARBAJO VASCO también se refirieron a ciertas circunstancias que debían producirse para que fuera posible la existencia de un administrador de hecho: vid. BLÁZQUEZ LIDOY, A., "La responsabilidad tributaria del administrador de hecho en la LGT/2003 (RCL 2003, 2945): elementos del régimen de responsabilidad”, Jurisprudencia Tributaria Aranzadi, núm. 2, 2005, pág. 2278; CARBAJO VASCO, D., "Algunas consideraciones sobre la responsabilidad en la nueva Ley General Tributaria", Crónica Tributaria, núm. 115, 2005, pág. 91.
} 
estos efectos, acreditar tal actuación y los actos de gestión y administración realizados vinculando a la persona jurídica que «representa»" ${ }^{, 769}$.

ZABALA RODRÍGUEZ-FORNOS manifiesta, por su parte, que lo esencial es "una injerencia decisoria directa -no meramente asesora o coadyuvante- en la gestión directiva de la persona jurídica, de manera duradera y a través de actos reiterados"770. Y CHECA GONZÁLEZ afirma que este tipo de responsabilidad "será exigible a quien realmente ejerza de forma efectiva la gestión y lleve la dirección de la entidad de que se trate" ${ }^{\natural 71}$. En definitiva, tendrán la calificación de administradores de hecho aquellas personas que, sin tener atribuido formalmente el cargo de administradores de derecho, realicen actividades de gestión, dirección y administración de manera independiente y con carácter continuado dentro de la sociedad.

Por lo que respecta al administrador de derecho, concepto derivado del Derecho mercantil, suscitan algunas dudas los efectos de la inscripción del cargo en el Registro a la hora de determinar su condición. En este sentido, son dos los problemas a resolver: por un lado, si la Administración puede dirigirse contra un administrador que ha cesado en su cargo pero que sigue inscrito en el Registro; y, por otro, si la Administración puede realizar la misma acción cuando un sujeto ha aceptado el cargo de administrador de derecho sin haberse realizado la inscripción de la misma. La respuesta a ambas interrogantes podemos hallarla en la Sentencia del Tribunal Supremo de 14 de junio de 1993, que determinó que "la inscripción no tiene carácter constitutivo o de validez del nombramiento de los administradores sociales", especificando que el nombramiento "surtirá efectos desde su aceptación".

Según destaca ÁLVAREZ MARTÍNEZ, “el contenido del Registro Mercantil no será definitivo a la hora de concretar quiénes ostentan o no legalmente la condición de administrador de una persona jurídica a los efectos de exigir las responsabilidades cuyo examen nos ocupa, pudiendo demostrarse la inexactitud del mismo a través de los oportunos mecanismos probatorios. Ello no significa que los órganos de la Administración tributaria no puedan acudir, con este objeto, al citado Registro -tal y como viene siendo habitual en la práctica-, sino solamente el reconocimiento, a los sujetos que figuren en aquél como administradores, de la posibilidad de poder destruir dicha apariencia mediante prueba en contrario; es más, tampoco la propia Administración tributaria puede verse vinculada por los datos registrales, pudiendo derivar la acción de responsabilidad contra quien, siendo jurídicamente administrador (por haber aceptado el cargo para el que fue nombrado), no figure aún como tal en el referido Registro (por no haberse practicado la inscripción pertinente), si bien, como es obvio, serán los órganos de aquélla a quienes incumbirá, en estos casos, la carga de probar las posibles inexactitudes registrales" ${ }^{, 72}$.

\footnotetext{
${ }^{769}$ MARTÍN JIMÉNEZ, A., Los Supuestos de responsabilidad en la LGT: (hacia una configuración constitucional y comunitaria de la responsabilidad tributaria), op. cit., pág. 243.

${ }^{770}$ ZABALA RODRÍGUEZ-FORNOS, A., “Comentario a los arts. 41, 42 y 43”, op. cit., pág. 325.

${ }^{771}$ CHECA GONZÁLEZ, C., "Alcance de la noción de cese para decretar la responsabilidad de los administradores de las personas jurídicas que hubiesen cesado en sus actividades”, Jurisprudencia Tributaria Aranzadi, núm. 5, 2007, pág. 211.

772 ÁLVAREZ MARTÍNEZ, J., La Responsabilidad de los administradores de las personas jurídicas en la Ley General Tributaria, op. cit., pág. 66 y 67. Esta postura es mayoritaria en la doctrina, como puede verse en HERRERA MOLINA, P. M., "La responsabilidad de los Administradores por actos ilícitos”, Revista Técnica Tributaria, núm. 57, abril-junio, 2002, pág. 89; FERNÁNDEZ AMOR, J. A., La Responsabilidad fiscal de los administradores y sucesores de personas jurídicas, Bosch, Barcelona, 2005, pág. 77 y 78; GALIANO ESTEVAN, J., e IZQUIERDO RIVAS, J., La responsabilidad tributaria, CISS, Valencia, 1997, pág. 74; NAVARRO ALCÁZAR, J.
} 
En suma, el presupuesto de hecho de la responsabilidad se produce desde que se realiza el nombramiento de administrador de derecho, independientemente que se haya inscrito o no en el Registro el mismo, mientras que, por el contrario, cuando se produce el cese de la actividad del administrador no se podrá exigir a este sujeto la responsabilidad aunque se mantuviera inscrito en el Registro $^{773}$.

Una vez concretados los distintos tipos de administradores sobre los que puede derivarse la responsabilidad subsidiaria, debemos detenernos en el estudio de las dos modalidades de responsabilidad de los administradores de personas jurídicas que contemplan los incisos a) y b) del primer apartado del artículo 43 de la LGT: la responsabilidad por colaboración en las infracciones de la sociedad y la responsabilidad por el cese de las actividades de ésta, teniendo en cuenta que la exigencia de la responsabilidad del inciso a) no excluye la posibilidad de que la Administración tributaria, con posterioridad, derive la responsabilidad del inciso b), ambos comprendidos en el primer apartado del artículo 43 de la $\mathrm{LGT}^{774}$.

\section{A. La responsabilidad por colaboración en las infracciones de la entidad}

El inciso a) del primer apartado del artículo 43 de la LGT dispone que son responsables subsidiarios de las deudas tributarias los administradores de hecho o de derecho de las personas jurídicas por las infracciones tributarias cometidas por éstas, en las que los administradores no hubiesen realizado los actos necesarios que sean de su incumbencia para el cumplimiento de sus obligaciones y deberes tributarios, hubiesen consentido el incumplimiento por quienes de ellos dependan o hubiesen adoptado acuerdos que posibilitasen las infracciones ${ }^{775}$.

De este presupuesto de hecho destacan tres requisitos fundamentales: que debe tratarse de un administrador de hecho o de derecho, en los términos que hemos señalado al inicio del presente apartado; que este sujeto debe realizar algunas de las conductas que describe el precepto; y que la persona jurídica debe cometer una infracción tributaria. En cuanto al presupuesto de hecho de este tipo de responsabilidad, se requiere pues la comisión de una infracción tributaria por parte de la entidad y la concurrencia de una conducta ilícita por parte del administrador que colabora en la realización de la infracción tributaria de la sociedad, y por ello es necesario determinar el grado de culpabilidad del administrador para que se configure el presupuesto de hecho.

\footnotetext{
V., "La responsabilidad tributaria de los administradores de las sociedades mercantiles", op. cit., pág. 84; BARRACHINA JUAN, E., "Responsabilidad tributaria de los administradores de sociedades: el acto de derivación de la responsabilidad (I)", Gaceta Fiscal, núm. 167, 1998, pág. 28 y, del mismo autor, "Responsabilidad tributaria de los administradores de sociedades: el acto de derivación de la responsabilidad (II)”, Gaceta Fiscal, núm. 168, 1998, pág. 40.

${ }^{773}$ La jurisprudencia que avala estos pronunciamientos es amplia. Entre otras, vid. las Sentencias del Tribunal Supremo de 10 de mayo de 1999; de 23 de diciembre de 2002; de 28 de mayo de 2005; de 14 de junio de 2007; de 18 de octubre de 2010; de 22 de noviembre de 2010; de 14 de marzo de 2011; de 30 de junio de 2011; y de 12 de mayo de 2012.

${ }^{774}$ Los tribunales declararon la compatibilidad de los dos párrafos del primer apartado del artículo 40 de la LGT de 1963, como puede verse en la Sentencia del Tribunal Superior de Justicia de Murcia de 26 de junio de 1996 y en la Sentencia del Tribunal Superior de Justicia de Cantabria de 28 de septiembre de 1998.

775 Según CARBAJO VASCO se trata de un tipo de responsabilidad de segundo orden, "pues la infractora es la entidad y el administrador deviene responsable por haber hecho dejación de sus funciones" (CARBAJO VASCO, D., "Algunas consideraciones sobre la responsabilidad en la nueva Ley General Tributaria", op. cit., pág. 91).
} 
En la LGT de 1963 se incluía inicialmente en el supuesto que nos ocupa únicamente las conductas dolosas, no así la culpa simple, pero la LGT de 2003 admite la simple negligencia en el presupuesto de hecho de este tipo de responsabilidad. No obstante, de acuerdo con la redacción legal, sólo quedarán afectados aquellos administradores que no hayan cumplido con "el nivel de diligencia exigible en el cumplimiento de las obligaciones tributarias de la entidad"776. Concretamente, el inciso a) del apartado primero del artículo 43 de la LGT se refiere a tres tipos de conductas: la de no realizar los actos necesarios que sean de su incumbencia para el cumplimiento de las obligaciones y deberes tributarios; la de consentir el incumplimiento por quienes de ellos dependan; y la de adoptar acuerdos que posibiliten las infracciones. En la primera de las conductas se distinguen dos elementos diferentes, la omisión por parte del sujeto de los actos necesarios para el cumplimiento de los deberes tributarios y la necesidad de que la realización de esos actos sea de la incumbencia del mismo, debiéndose tener en cuenta para ello la estructura de la entidad y la distribución de competencias existente en su seno. La segunda conducta se relaciona con una falta de control por parte de los administradores sobre el personal al servicio de la entidad. Mientras que el tercer comportamiento tiene que ver con los acuerdos que se toman en la sociedad y la conexión que debe existir entre la decisión que se ha tomado y la realización de las infracciones tributarias atribuibles a la entidad.

Un elemento negativo destacable derivado de la redacción del inciso a) del apartado primero del artículo 43 de la LGT es la confusión que pudiera crear el mismo con el inciso a) del apartado primero del artículo 42 de la LGT. La anterior legislación tributaria tampoco tenía bien establecidas las diferencias entre el número 1 del artículo 38 y el número 1 del artículo 40 de la LGT de 1963. En el primero de los artículos se regulaba la responsabilidad solidaria por colaborar con la infracción y en el segundo la responsabilidad subsidiaria de los administradores que colaboraban en la comisión de un ilícito de la entidad ${ }^{777}$.

En la actualidad la realidad es otra, porque el inciso $a$ ) del apartado primero del artículo 43 de la LGT utiliza la expresión "sin prejuicio de lo dispuesto en el párrafo a) del apartado 1 del artículo 42", lo que puede inducir a que si se cumplen los requisitos del supuesto de responsabilidad del inciso a) del apartado primero del artículo 42 de la LGT será éste el precepto de aplicación al administrador. Sobre este sujeto se derivaría entonces una responsabilidad solidaria, por el hecho de haber colaborado activamente en la realización de un ilícito, descartando las omisiones o negligencias. En definitiva, cuando los administradores tengan una participación activa en las infracciones societarias se producirá un supuesto de responsabilidad solidaria prevista en el inciso a) del primer apartado del artículo 42 de la LGT, mientras que las actuaciones pasivas darán lugar a la responsabilidad subsidiaria del inciso a) del primer apartado del artículo 43 de la LGT $^{778}$. Según ÁLVAREZ

\footnotetext{
${ }^{776}$ MARTÍN FERNÁNDEZ, J., RODRÍGUEZ MÁRQUEZ, J. S., y GALÁN SÁNCHEZ, R. M., "Los administradores de sociedades como responsables tributarios", op. cit., pág. 1050, afirman que no se trata de un supuesto de responsabilidad objetiva.

777 Así lo entendió la doctrina, al considerar que el apartado primero del artículo 40 de la LGT de 1963 era una norma especial, de aplicación prioritaria frente al apartado primero del artículo 38 de la LGT de 1963. Mientras que la doctrina de los tribunales era contradictoria, pues en ocasiones defendió la aplicación prioritaria del apartado primero del artículo 38 de la LGT de 1963, y en otros casos concluyó que conductas activas de los administradores debían incardinarse en el primer apartado del artículo 40 de la LGT de 1963. Vid. ÁLVAREZ MARTÍNEZ, J., La responsabilidad de los administradores de las personas jurídicas en la nueva Ley General Tributaria, op. cit., pág. 190 y ss.

${ }^{778}$ En la doctrina se constata este mismo pronunciamiento, entre otros: ÁLVAREZ MARTíNEZ, J., La responsabilidad de los administradores de las personas jurídicas en la nueva Ley General Tributaria, op. cit., pág. 197; BLÁZQUEZ LIDOY, A., "Obligados tributarios", en la obra Comentario Sistemático a la nueva Ley General Tributaria, PALAO TABOADA, C. (coordinador), Centro de
} 
MARTÍNEZ “el primero de los preceptos en cuestión está pensando, en exclusiva, en aquellas actuaciones que, además de ser determinantes y decisivas en la efectiva comisión de la infracción, vengan a poner de manifiesto un especial grado de implicación, así como una culpabilidad especifica -cuando no una evidente intencionalidad-, en quienes las realizan, aspectos todos éstos que, como es obvio, deberán ser debidamente probados por la Administración tributaria, teniendo la última palabra en este punto, a la vista de las circunstancias concurrentes en cada caso concreto, nuestros órganos jurisdiccionales" ${ }^{, 79}$.

En lo que concierne a la extensión de estos tipos de responsabilidad que estamos analizando, la LGT determina que en el caso de los responsables por la colaboración en las infracciones de la entidad la responsabilidad alcanzará a las deudas tributarias de las personas jurídicas y a las sanciones. Expresamente, el apartado segundo del artículo 182 de la LGT establece que

"responderán subsidiariamente del pago de las sanciones tributarias las personas o entidades que se encuentren en los supuestos de los párrafos a), g) y h) del apartado 1 del artículo 43”.

CALVO ORTEGA ${ }^{780}$ es de los autores que rechaza la inclusión de las sanciones imputables al contribuyente en el contenido de la obligación del responsable, porque supone la transgresión del principio de la personalidad de la pena y del principio de la LGT que establece que la responsabilidad no alcanzará a las sanciones, salvo las excepciones que determine la propia ley. De manera muy parecida se pronuncia MARTÍN JIMÉNEZ, cuando advierte que "la jurisprudencia constitucional (la STC 85/2006, de 27 de marzo, especialmente) ha servido para poner de manifiesto que, al vincular la sanción de la sociedad con la responsabilidad del administrador, la responsabilidad que regula el art. 43.1. a) LGT [al igual que el art. 42.1. a)] es de naturaleza sancionadora, con la consecuencia de que sólo podrá exigirse con respecto de los principios y garantías del procedimiento sancionador" ${ }^{\text {781 }}$.

Es importante insistir en el caso que nos ocupa en la Sentencia del Tribunal Constitucional 85/2006, de 27 de marzo, que, al referirse al anterior apartado primero del artículo 40 de la LGT de 1963 y en el supuesto específico de derivación de sanciones, determinó en su Fundamento Jurídico Tercero que "la derivación de responsabilidad respecto de las sanciones tiene su origen en un comportamiento ilícito de los recurrentes", y, por tanto, debe concluirse "que las cantidades reclamadas a éstos por la Administración tributaria en calidad de responsables, aunque no tengan su origen en la comisión por ellos de ninguna de las infracciones tributarias tipificadas en los arts. 78 y ss. LGT, tienen naturaleza claramente punitiva, y en consecuencia la responsabilidad exigida es materialmente sancionadora". Al clasificar como sanción en sentido propio la derivación al administrador de las sanciones impuestas a la sociedad, continúa diciendo esta Sentencia 85/2006 en el mismo Fundamento Jurídico

Estudios Financieros, Madrid, 2004, pág. 153 y 154; ZABALA RODRÍGUEZ-FORNOS, A., "Comentario a los arts. 41, 42 y 43”, op. cit., pág. 326.

779 ÁLVAREZ MARTÍNEZ, J., La Responsabilidad de los administradores de las personas jurídicas en la Ley General Tributaria, $3^{\mathrm{a}}$ ed., Thomson Reuters Aranzadi, Navarra, 2012, pág. 263.

${ }^{780}$ CALVO ORTEGA, R., “Obligados tributarios”, op. cit., pág. 183.

${ }^{781}$ MARTÍN JIMÉNEZ, A., Los Supuestos de responsabilidad en la LGT: (hacia una configuración constitucional y comunitaria de la responsabilidad tributaria), op. cit., pág. 272 y 273. En el mismo sentido, MARTínEZ LAGO, M. A., La extensión de la responsabilidad a las sanciones tributarias, op. cit., pág. 293. 
Tercero, "resultan aplicables las garantías materiales y procesales que se deducen de los arts. $25.1 \mathrm{y}$ 24.2 CE". La conclusión que se desprende de esta Sentencia y que puede ser aplicable al inciso a) del primer apartado del artículo 43 de la LGT es que la derivación de la sanción al administrador societario tiene una finalidad represiva $\mathrm{y}$, por tanto, su naturaleza es constitucionalmente sancionadora, por lo que es exigible el respeto de las garantías constitucionales que reconoce la $\mathrm{CE}$ en el segundo apartado del artículo 24 y en el primer apartado del artículo 25. No se trata tanto de trasladar al administrador responsable el daño que su actuación provoca a la Administración tributaria, sino de sancionar a éste por la vía de la traslación al mismo de la sanción que corresponde a la persona jurídica.

En definitiva, ante la posibilidad de derivación de las sanciones a los administradores y la vinculación de la derivación con la existencia de una infracción por parte de la sociedad, la LGT ha terminado por configurar la responsabilidad del inciso a) del apartado primero del artículo 43 como una auténtica sanción en el sentido constitucional del término. Por ello, no deberá producirse la derivación automática de sanciones a los administradores societarios si antes no se demuestra por parte de la Administración tributaria que éste actuó, al menos, negligentemente ${ }^{782}$.

\section{B. Responsabilidad por cese en las actividades de la persona jurídica}

El segundo tipo de responsabilidad subsidiaria de los administradores de personas jurídicas se recoge en el inciso b) del apartado primero del artículo 43 de la LGT. El presupuesto de hecho para este tipo de responsabilidad se compone de varios elementos: tener la condición de administrador de hecho o de derecho de una persona jurídica que cesa en sus actividades; que persistan deudas tributarias correspondientes a la persona jurídica; y que se produzca el cese de la actividad de la persona jurídica.

Se trata de un tipo de responsabilidad que se diferencia de las demás responsabilidades subsidiarias que actúan en garantía del crédito tributario porque en él no estamos inmersos en un procedimiento de liquidación, lo cual impide que pueda derivarse una responsabilidad subsidiaria de los liquidadores $^{783}$. Cuando una entidad cesa en sus actividades los administradores quedan encargados de tutelar los intereses de la Hacienda Pública frente al resto de los acreedores y para no incurrir en una responsabilidad tributaria deberán realizar los pagos; solicitar el aplazamiento o fraccionamiento; comunicar a la Administración tributaria las obligaciones pendientes, ofreciendo bienes para que ésta pueda adoptar medidas cautelares; o instar la propia disolución de la persona jurídica o un procedimiento concursal.

Este es un supuesto de responsabilidad por la realización de un ilícito en el que el administrador deja de hacer las gestiones necesarias para el cumplimiento de las obligaciones tributarias cuando dichas acciones forman parte de sus actividades como administrador de la persona jurídica. No se necesita, en esta modalidad, que se produzca una infracción como consecuencia de la actuación del

\footnotetext{
${ }^{782}$ CARBAJO VASCO, D., “Algunas consideraciones sobre la responsabilidad en la nueva Ley General Tributaria”, op. cit., pág. 94.

${ }^{783}$ MARTÍN FERNÁNDEZ, J, RODRÍGUEZ MÁRQUEZ, J. S., y GALÁN SÁNCHEZ, R. M., "Los administradores de sociedades como responsables tributarios", op. cit., pág. 1053.
} 
administrador, pues se responde por la simple falta de asistencia por parte del administrador con la Hacienda Pública cuando se produce el cese de las actividades de la persona jurídica.

También es importante resaltar que para que el administrador se configure como responsable subsidiario debe tener la condición de administrador de hecho o de derecho en el momento que se produce el cese de las actividades de la entidad, sin tener en cuenta la fecha en la que la persona jurídica debió haber cumplido con las obligaciones tributarias que le atañen. De modo que no podrá exigirse la responsabilidad al administrador que al momento de producirse el cese ya no se encuentra en sus funciones, y aun cuando dicho cese no figure en el Registro.

Por último, el cese de la actividad de la persona jurídica tiene que ser un cese total de la actividad, sin que se llegue a la pérdida de la personalidad jurídica por la disolución o liquidación, y no es suficiente una paralización o suspensión parcial de la actividad ${ }^{784}$. También puede originarse el presupuesto de hecho de esta modalidad de responsabilidad por la realización de una actividad aparente que se asemeje al cese, sin que sea necesario que se produzca una desaparición íntegra de toda actividad de la persona jurídica. Como expresa el TEAC, en su Resolución del 30 de enero de 1998, "la mera declaración formal de una mínima actividad, residual, no materializada en la realidad en ninguno de los locales en los que habitualmente operaba la empresa, no tiene valor probatorio alguno, pues ello es indicativo únicamente de que se requiere mantener una situación confusa y de incertidumbre por tiempo indefinido, propiciada por la existencia de un grupo de empresas interrelacionadas entre sí, con trabajadores comunes, actividades similares, etc., con la finalidad de poner a salvo los bienes de valor que todavía le quedaban, al tiempo que se realizan los cambios necesarios en el órgano de dirección para eludir las responsabilidades".

La extensión de la responsabilidad por el cese en las actividades de la entidad alcanza las obligaciones tributarias devengadas y pendientes de la persona jurídica y, siguiendo el régimen general, no incluye las sanciones ${ }^{785}$, al no evidenciarse actitud infractora alguna por parte de la entidad que conlleve a una posible participación del administrador. Por el contrario, de existir alguna conducta infractora se configuraría un presupuesto de hecho de responsabilidad resultante de las deudas tributarias de las personas jurídicas que cometen infracciones tributarias.

\subsubsection{Liquidadores de las sociedades en concurso}

La responsabilidad de los liquidadores y administradores concursales se estableció en la LGT de 1963, en el segundo apartado del artículo 40. Este supuesto se recoge en la LGT actual en el inciso c) del apartado primero del artículo 43, según el cual son responsables subsidiarios de la deuda tributaria las personas o entidades

“integrantes de la administración concursal y los liquidadores de sociedades y entidades en general que no hubiesen realizado las gestiones necesarias para el íntegro cumplimiento de las obligaciones tributarias devengadas con anterioridad a dichas situaciones e imputables a los respectivos obligados tributarios. De las

\footnotetext{
${ }^{784}$ Entre otras, Sentencias del Tribunal Supremo de 30 de enero de 2007, de 10 de febrero de 2011, y de 14 de abril de 2011.

${ }^{785}$ Sentencias de la Audiencia Nacional de 25 de enero y de 8 de febrero de 2001; Resoluciones del TEAC de 26 de abril y 10 de mayo de 2001; y de 22 de mayo de 2003; Sentencia del Tribunal Superior de Justicia de Cantabria de 12 de julio de 2001.
} 
obligaciones tributarias y sanciones posteriores a dichas situaciones responderán como administradores cuando tengan atribuidas funciones de administración".

A pesar de la similitud entre el apartado segundo del artículo 40 de la LGT de 1963 y el inciso $c$ ) del apartado primero del artículo 43 de la LGT, se aprecian diferencias en la legislación vigente respecto a su antecesora, que exigía que "las gestiones necesarias para el íntegro cumplimiento de las obligaciones tributarias" no se realizaran con "negligencia o mala fe". En el precepto actual sólo se precisa que no se hayan realizado las gestiones necesarias para el íntegro cumplimiento de las obligaciones tributarias, excluyéndose a los interventores. Sobre esta última cuestión, CALVO ORTEGA opina que si bien los interventores sólo realizan la función de fiscalización y no de gestión y disposición como los liquidadores, sí pueden efectuar observaciones y peticiones y hacer constatar su disconformidad $\mathrm{y}$, aunque, si bien es cierto que su responsabilidad es menor que la de los liquidadores, podrían tener algún tipo de responsabilidad en determinados casos en concreto ${ }^{786}$.

Por otro lado, estamos ante un supuesto de responsabilidad con dos modalidades distintas que involucra tanto a los liquidadores como a los administradores concursales, independientemente de que ambas figuras converjan en algún momento en la misma persona. El presupuesto de hecho de la responsabilidad se origina en función del devengo de las deudas a las que alcanza la responsabilidad. Deben ser deudas devengadas con anterioridad al momento en que se produzca la situación de la administración concursal o el proceso de liquidación, que derivarán la responsabilidad para los administradores concursales y para los liquidadores si éstos permiten el incumplimiento de las obligaciones tributarias de la persona jurídica.

\section{A. La responsabilidad de los liquidadores}

Como acabamos de indicar, en el apartado segundo del artículo 40 de la LGT de 1963 se vinculaba la responsabilidad a la existencia de negligencia o mala fe. La jurisprudencia estableció que se producía el presupuesto de hecho de este tipo de responsabilidad subsidiaria cuando, por ejemplo, el liquidador realizaba pagos a otros acreedores distintos de la Administración tributaria, sin tener en cuenta el derecho preferente de los créditos tributarios (artículo 71 de la LGT de 1963 y actualmente artículo 77 de la LGT); o cuando no probaba que había realizado todas las actuaciones tendentes a la satisfacción de la deuda tributaria o, al menos, a lograr el aplazamiento o fraccionamiento de la misma $^{787}$; o cuando no incluía la deuda contraída con la Hacienda Pública en los balances de liquidación $^{788}$. La doctrina también se manifestó de igual forma, al entender que para exigir este tipo de responsabilidad tributaria a los liquidadores el órgano ejecutivo debía demostrar "la existencia de alguna conducta negligente, que no era preciso que fuera grave o dolosa, en el ejercicio de sus funciones, y que, de resueltas de sus acciones, se hubiera ocasionado un perjuicio económico para la Hacienda Pública" ${ }^{\text {789. }}$.

\footnotetext{
${ }^{786}$ CALVO ORTEGA, R., “Obligados tributarios”, op. cit., pág. 185.

${ }^{787}$ Sentencia del Tribunal Superior de Justicia de Cantabria de 28 de septiembre de 1998.

${ }^{788}$ Este requisito también se encuentra en la doctrina administrativa, como puede verse en la Resolución del TEAC de 25 de febrero de 1998.

${ }^{789}$ ARGÜELLES PINTOS, J. y FELTRER BAUZÁ, F., Régimen jurídico de la responsabilidad tributaria y su aplicación práctica, op. cit., pág. 232.
} 
El liquidador realizará el presupuesto de hecho de la responsabilidad previsto en el inciso c) del apartado primero del artículo 43 de la LGT cuando no haya actuado con la diligencia debida, comportamiento que "se identifica con la falta de respeto de la prelación del crédito tributario o con la falta de realización de las gestiones necesarias para la satisfacción del mismo, su aplazamiento o fraccionamiento. Es decir, el liquidador responde por los daños causados, por lo que se trata de una variante de la responsabilidad aquiliana o extracontractual"790. Para la derivación de este supuesto de responsabilidad será necesario que se haya producido un daño a la Administración tributaria y que ese daño pueda ser imputado al liquidador. Lo que permite afirmar a GONZÁLEZ ORTIZ ${ }^{791}$ y MARTÍN JIMÉNEZ ${ }^{792}$ que la responsabilidad de los liquidadores tiene una naturaleza reparadora o indemnizatoria, más que garantista de la deuda tributaria o sancionadora. No obstante, cuando se imponga al liquidador la responsabilidad por las obligaciones tributarias y sanciones posteriores a la aceptación del cargo, ésta tendrá un carácter sancionador, y deberemos trasladar aquí las reflexiones que hicimos al referirnos al supuesto de responsabilidad que contempla el inciso a) del primer apartado del artículo 43 de la LGT $^{793}$.

En relación con la extensión de la responsabilidad de los liquidadores, la ley deja claro que éstos no responden por las sanciones impuestas a la persona jurídica que se vinculan a hechos que ocurrieron con anterioridad a su nombramiento. Lo que no queda claro en el texto legal es la referencia que hace a "obligaciones tributarias devengadas", porque parece que hace responsable al liquidador tanto de las deudas exigibles con anterioridad a la aceptación del cargo como a las exigidas cuando ya ha aceptado el cargo pero que fueron devengadas con anterioridad a la aceptación. Nos parece excesivo que se exija la responsabilidad a los liquidadores por deudas devengadas con anterioridad a la aceptación de su cargo cuando las mismas surgen como consecuencia de una inspección posterior a la persona jurídica que ya se encuentra liquidada y disuelta, si se tiene en cuenta que esta responsabilidad se exige al liquidador para evitar que se disuelva o liquide una persona jurídica dejando deudas pendientes. Además, según MARTÍN JIMÉNEZ ${ }^{794}$ y ARGÜELLES PINTOS y FELTRER BAUZÁ ${ }^{795}$, la naturaleza extracontractual del supuesto de responsabilidad determina que ésta deba vincularse con el daño causado a la Administración y no con la deuda tributaria devengada, de manera que si la actuación de liquidador es la que propicia que el crédito tributario quede parcialmente impagado debe ser esta cifra la que fije el techo de la responsabilidad del liquidador y no la referencia a la obligación tributaria devengada con anterioridad.

Cuando se trate de deudas devengadas con posterioridad a la aceptación del cargo por el liquidador, la ley introduce una novedad que no contenía la LGT de 1963. Dispone el precepto actual que los

\footnotetext{
${ }^{790}$ MARTÍN JIMÉNEZ, A., Los supuestos de responsabilidad en la LGT: (hacia una configuración constitucional y comunitaria de la responsabilidad tributaria), op. cit., pág. 289.

${ }^{791}$ GONZÁLEZ ORTIZ, D., La responsabilidad tributaria en el ordenamiento jurídico español, op. cit., pág. 187.

${ }^{792}$ MARTÍN JIMÉNEZ, A., Los supuestos de responsabilidad en la LGT: (hacia una configuración constitucional y comunitaria de la responsabilidad tributaria), op. cit., pág. 290.

${ }^{793}$ Vid. supra, Capítulo Cuarto, epígrafe 2.4.2.1. "Administrador de personas jurídicas”.

${ }^{794}$ MARTÍN JIMÉNEZ, A., Los supuestos de responsabilidad en la LGT: (hacia una configuración constitucional y comunitaria de la responsabilidad tributaria), op. cit., pág. 291.

${ }^{795}$ ARGÜELLES PINTOS, J. y FELTRER BAUZÁ, F., Régimen jurídico de la responsabilidad tributaria y su aplicación práctica, op. cit., pág. 234.
} 
liquidadores responderán como administradores de las obligaciones tributarias y sanciones posteriores a la situación de liquidación cuando tengan atribuidas funciones de administración. Esto significa que por las deudas devengadas con posterioridad a la liquidación o disolución de la persona jurídica se aplicará al liquidador el mismo régimen que a los administradores, esto es, el previsto en el inciso a) del apartado primero del artículo 42 y en el inciso a) del apartado primero del artículo 43, ambos de la LGT. En consecuencia, la responsabilidad que se exija de conformidad con la segunda frase del inciso c) del apartado primero del artículo 43 de la LGT puede tener un carácter sancionador, lo que nos lleva a las mismas conclusiones que emitimos cuando nos referimos a la responsabilidad por colaboración en las infracciones de la entidad. Por lo que respecta a la responsabilidad del inciso b) del apartado primero del artículo 43 de la LGT, entienden MARTÍN JIMÉNEZ y ARGÜELLES PINTOS y FELTRER BAUZÁ ${ }^{796}$ que si la sociedad se mantiene inactiva por hechos imputables al liquidador también será aplicable a éste, por lo que resultan compatibles los mandatos de los incisos b) y c) del apartado primero del artículo 43 de la LGT.

\section{B. La responsabilidad de los integrantes de la administración concursal}

Ésta es una materia que se regula en la LC, específicamente en sus artículos 27, 32 y 36, partiendo del hecho de que los administradores concursales no tienen como prioridad velar por la satisfacción del crédito tributario ${ }^{797}$. Para NAVARRO EGEA, la falta de actuación de los administradores concursales es entendida como la no realización de los deberes formales del administrador concursal que provoca el incumplimiento de las obligaciones tributarias ${ }^{798}$. Según ZABALA RODRÍGUEZFORNOS, se impone en estos casos al administrador concursal una responsabilidad que le exige un comportamiento diferente al que regula el artículo 36 de la $\operatorname{LC}^{799}$ y deberá apreciarse si la Administración tributaria se comportó con diligencia en el concurso, porque cuando todo o parte del crédito tributario resulte incobrable por causas imputables a aquélla no podrá exigirse la deuda tributaria acudiendo a la responsabilidad de la administración concursal ${ }^{800}$. "Además, debido a la

\footnotetext{
${ }^{796}$ MARTÍN JIMÉNEZ, A., Los supuestos de responsabilidad en la LGT: (hacia una configuración constitucional y comunitaria de la responsabilidad tributaria), op. cit., pág. 292; ARGÜELLES PINTOS, J. y FELTRER BAUZÁ, F., Régimen jurídico de la responsabilidad tributaria y su aplicación práctica, op. cit., pág. 235 y ss.

${ }^{797}$ Sobre la problemática de los créditos tributarios en el concurso, vid. PÉREZ ROYO, F., "El privilegio general de los créditos tributarios (según la «interpretación auténtica» contenida en el Proyecto de Ley de Ejecución Singular)", Quincena Fiscal, núm. 1, 2007, pág. 12.

${ }^{798}$ NAVARRO EGEA, M., El responsable tributario, op. cit., pág. 131.

${ }^{799}$ Según el artículo 36 de la LC, "los administradores concursales y los auxiliares delegados responderán frente al deudor y frente a los acreedores de los daños y perjuicios causados a la masa por los actos y omisiones contrarios a la Ley o realizados sin la debida diligencia. Los administradores concursales responderán solidariamente con los auxiliares delegados de los actos y omisiones lesivos de éstos, salvo que prueben haber empleado toda la diligencia debida para prevenir o evitar el daño. La acción de responsabilidad se sustanciará por los trámites del juicio declarativo que corresponda, ante el juez que conozca o haya conocido del concurso. La acción de responsabilidad prescribirá a los cuatro años, contados desde que el actor tuvo conocimiento del daño o perjuicio por el que reclama $\mathrm{y}$, en todo caso, desde que los administradores concursales o los auxiliares delegados hubieran cesado en su cargo. Si la sentencia contuviera condena a indemnizar daños y perjuicios, el acreedor que hubiera ejercitado la acción en interés de la masa tendrá derecho a que, con cargo a la cantidad percibida, se le reembolsen los gastos necesarios que hubiera soportado. Quedan a salvo las acciones de responsabilidad que puedan corresponder al deudor, a los acreedores o a terceros por actos u omisiones de los administradores concursales y auxiliares delegados que lesionen directamente los intereses de aquellos".
}

${ }^{800}$ ZABALA RODRÍGUEZ-FORNOS, A., “Comentario a los arts. 41, 42 y 43”, op. cit., pág. 332. 
naturaleza de la responsabilidad, debe ser posible, como en el caso de los liquidadores, imputar el daño a la conducta de la administración concursal” ${ }^{\prime 01}$.

Finalmente, la extensión de la responsabilidad de la administración concursal será diferente en función de si la deuda tributaria es anterior o posterior al auto de declaración del concurso. En el primer caso, la responsabilidad alcanzará las deudas tributarias devengadas menos las sanciones; y en el segundo, la responsabilidad se rige por el inciso a) del primer apartado del artículo 43 de la LGT y podrá abarcar las sanciones, si la administración concursal tiene funciones de administración ${ }^{802}$.

\subsubsection{Adquirentes de bienes afectos}

La responsabilidad subsidiaria de los adquirentes de bienes afectos por la ley al pago de la deuda tributaria se remite al régimen jurídico de las garantías del crédito tributario, previsto en el artículo 79 de la LGT, que se refiere al derecho de afección. De esta misma forma lo hacía la LGT de 1963, al disponer en el primer apartado de su artículo 41 que

"Los adquirentes de bienes afectos por Ley a la deuda tributaria responderán con ellos, por derivación de la acción tributaria, si la deuda no se paga".

Y más adelante, en el primer apartado del artículo 74 de la LGT de 1963, añadía que

"Los bienes y derechos transmitidos quedarán afectos a la responsabilidad del pago de las cantidades, liquidadas o no, correspondientes a los tributos que graven tales transmisiones, adquisiciones o importaciones, cualquiera que sea su poseedor, salvo que éste resulte ser un tercero protegido por la fe pública registral o se justifique la adquisición de los bienes con buena fe y justo título o en establecimiento mercantil o industrial, en el caso de bienes muebles no inservibles".

El inciso d) del apartado primero del artículo 43 de la actual LGT ha clarificado en gran medida el régimen aplicable al adquirente de bienes afectos por ley al pago de la deuda tributaria, ya que ha configurado a este sujeto definitivamente como un responsable subsidiario al que es posible aplicar el régimen sustantivo y procedimental de este tipo de responsabilidad previsto en los artículos 41, 174 y 176 de la LGT.

Según expresa el inciso d) del primer apartado del artículo 43 de la LGT, serán responsables subsidiarios de la deuda tributaria

"Los adquirentes de bienes afectos por la ley al pago de la deuda tributaria, en los términos del artículo 79".

\footnotetext{
${ }^{801}$ MARTÍN JIMÉNEZ, A., Los supuestos de responsabilidad en la LGT: (hacia una configuración constitucional y comunitaria de la responsabilidad tributaria), op. cit., pág. 294. En este mismo sentido, ARGÜELLES PINTOS, J. y FELTRER BAUZÁ, F., Régimen jurídico de la responsabilidad tributaria y su aplicación práctica, op. cit., pág. 113 y 114.

${ }^{802}$ FALCÓN Y TELLA, R., “Las garantías del crédito tributario: perspectivas de reforma”, op. cit., pág. 7.
} 
Cuando nos referimos en el tercer capítulo al derecho de afección ya decíamos que el derecho de afección era un derecho real de garantía ${ }^{803}$. Como afirma RODRÍGUEZ BEREIJO ${ }^{804}$, a partir de la legislación anterior, el nacimiento de este derecho no se vincula al presupuesto de hecho de la responsabilidad, sino al propio nacimiento de la deuda tributaria garantizada. Por más que la ley califique al adquirente del bien afecto como un responsable no estamos aquí ante un auténtico supuesto de responsabilidad. El adquirente de un bien afecto no se coloca junto al deudor principal, respondiendo con todos sus bienes presentes y futuros, sino que, como dice el artículo 79 de la LGT, no responde ni siquiera con el importe del valor de ese bien, sino que lo hace con el propio bien adquirido. "Parece como si la voluntad del legislador, más que crear un supuesto de responsabilidad en sentido estricto, hubiera sido trasladar al titular del bien afecto los derechos y garantías del responsable, pero sin variar la naturaleza de garantía real propia de la figura" ${ }^{\text {} 805}$. La consecuencia inmediata de esta situación es que nos encontramos ante una garantía real que se ejecuta a través de un procedimiento cuya finalidad es hacer efectiva las garantías personales. La jurisprudencia se ha pronunciado de forma muy similar, aproximando la afección de bienes a los esquemas propios de las garantías reales. Por lo que entendemos que, probablemente, en relación con el inciso $d$ ) del primer apartado del artículo 43 de la LGT se aplicará la doctrina de los tribunales, especialmente la Sentencia del Tribunal Supremo de 24 de enero de 2004, que permite a la Administración reclamar la deuda tributaria al propietario actual y no a quién adquirió el bien devengando la deuda tributaria que desencadenó la aplicación de esta garantía.

\subsubsection{Agentes y comisionistas de aduanas}

Esta modalidad de responsabilidad fue recomendada en el Informe para la Reforma de la LGT de 2001, que propuso la configuración como responsables subsidiarios del pago de la deuda aduanera a los Agentes y Comisionistas de Aduanas cuando actúen en nombre y por cuenta de sus comitentes. De esta forma quedaba zanjado el problema del engarce de la regulación común del responsable con la normativa aduanera, teniendo presente el hecho de que el Código Aduanero Comunitario desconoce tal figura. Sin embargo, los verdaderos orígenes de la responsabilidad del inciso e) del primer apartado del artículo 43 de la LGT los encontramos en el artículo 4 del Real Decreto Legislativo 1299/1986, de 28 de junio, que modificó el Texto Refundido de los Impuestos Integrantes de la Renta de Aduanas, y el apartado tercero del artículo 87 de la Ley 37/1992, de 28 de diciembre, del IVA. Sólo se diferencian estas normas del precepto actual en que aquéllas tenían limitada su aplicación al arancel aduanero o al IVA, mientras que el inciso e) no aclara a qué tributos se refiere.

Dispone el inciso e) del apartado primero del artículo 43 de la LGT que serán responsables subsidiarios de la deuda tributaria

\footnotetext{
${ }^{803}$ Para completar el análisis del derecho de afección nos remitimos al análisis que hicimos en el Tercer Capítulo, vid. supra, epígrafe 2. "El derecho de afección".

${ }^{804}$ RODRÍGUEZ BEREIJO, A., “Las garantías del crédito tributario”, op. cit., pág. 205 a 207.

${ }^{805}$ MARTÍN JIMÉNEZ, A., Los supuestos de responsabilidad en la LGT: (hacia una configuración constitucional y comunitaria de la responsabilidad tributaria), op. cit., pág. 298 y 299. En este mismo sentido, MARTÍN RODRÍGUEZ, A., "La afección del bien inmueble como garantía real del IBI: análisis jurídico de su naturaleza, alcance y realización", Revista de Contabilidad y Tributación, núm. 255, 2004, pág. 142 y 143.
} 
"Los agentes y comisionistas de aduanas, cuando actúen en nombre y por cuenta de sus comitentes. No obstante, esta responsabilidad subsidiaria no alcanzará a la deuda aduanera".

El Reglamento (CE) No 450/2008 del Parlamento Europeo y del Consejo, de 23 de abril de 2008, por el que se establece el Código Aduanero Comunitario, en el apartado segundo del artículo 11 determina que los Estados miembros podrán determinar, de conformidad con el Derecho comunitario, las condiciones en las que un representante aduanero podrá prestar servicios en el Estado miembro en que esté establecido. Así, el artículo 3 del Real Decreto 335/2010, de 19 de marzo, por el que se regula el derecho a efectuar declaraciones en aduana y la figura del representante aduanero, prevé que toda persona, física o jurídica que se haga representar ante las autoridades aduaneras para efectuar declaraciones en aduana, con el fin de asignar un destino aduanero a las mercancías, deberá valerse de un representante aduanero. En consecuencia, donde no se exija la representación directa de las autoridades aduaneras cualquier obligado podrá presentar la declaración correspondiente. Por tanto, cuando el inciso e) del apartado primero del artículo 43 de la LGT se refiere a la responsabilidad de los agentes cuando actúen "en nombre y por cuenta de sus comitentes" está haciendo alusión a aquellos supuestos en que el propio agente actúa con carácter exclusivo frente a la Administración tributaria, actuando como representante directo del deudor.

Respecto a la naturaleza de esta responsabilidad subsidiaria, subraya MARTÍN JIMÉNEZ que "ineludiblemente, cumple una función de garantía, pero no puede desconocerse, por otra parte, que responde a parámetros indemnizatorios o resarcitorios: en la medida que la gestión de las declaraciones vinculadas a importaciones se encomiende al agente de aduanas (...), corresponderá a éste el exacto cumplimiento de las formalidades aduaneras y la declaración de los tributos, respondiendo ante la administración de las inexactitudes en las declaraciones presentadas. (...) La responsabilidad del agente de aduanas única y exclusivamente pudiera concebirse desde una perspectiva indemnizatoria o resarcitoria, por lo que sólo podrá ser exigida como resultado del incumplimiento del deber de diligencia inherente a la actividad del Agente de Aduanas" ${ }^{„ 06}$.

\subsubsection{Contratistas o subcontratistas}

Dentro del régimen de la responsabilidad tributaria, el supuesto del inciso f) del apartado primero del artículo 43 de la LGT fue una de las novedades cuya introducción suscitó más polémicas ${ }^{807}$. No se recogía nada parecido en la LGT de 1963 y los antecedentes de este precepto debemos buscarlos en el Real Decreto Legislativo 1/1995, de 24 de marzo, por el que se aprueba el texto refundido de la Ley del Estatuto de los Trabajadores, que en su artículo 42 reconocía la responsabilidad solidaria del empresario principal por

\footnotetext{
${ }^{806}$ MARTÍN JIMÉNEZ, A., Los supuestos de responsabilidad en la LGT: (hacia una configuración constitucional y comunitaria de la responsabilidad tributaria), op. cit., pág. 303.

${ }^{807}$ Así lo indican RODRÍGUEZ MÁRQUEZ, J. S., "Un nuevo problema en el supuesto de responsabilidad de las personas o entidades que contraten o subcontraten la realización de obras y servicios: el caso particular de la Diputación Foral de Vizcaya", Jurisprudencia Tributaria Aranzadi, núm. 11, 2005, pág. 2361; CALVO ORTEGA, R., “Obligados tributarios”, op. cit., pág. 188.
} 
"las obligaciones de naturaleza salarial contraídas por los contratistas y subcontratistas con sus trabajadores y de las referidas a la Seguridad Social durante el período de vigencia de la contrata".

Literalmente dice el inciso f) del apartado primero del artículo 43 de la LGT que serán responsables subsidiarios

"Las personas o entidades que contraten o subcontraten la ejecución de obras o la prestación de servicios correspondientes a su actividad económica principal, por las obligaciones tributarias relativas a tributos que deban repercutirse o cantidades que deban retenerse a trabajadores, profesionales $u$ otros empresarios, en la parte que corresponda a las obras o servicios objeto de la contratación o subcontratación".

El supuesto de responsabilidad subsidiaria que ahora reconoce la LGT tiene por finalidad, según el Informe sobre el borrador del anteproyecto de la nueva LGT de 2003, "salir al paso de ciertas prácticas actuales, donde la contratación o subcontratación sólo se realiza por motivos de elusión fiscal" $" 808$.

La norma, advierte MARTÍN JIMÉNEZ, “más que solucionar la situación de insolvencia de ese tipo de sociedades, trata de poner cerco a la contratación con ellas. Éste es el único fin de la responsabilidad regulada en el art. 43.1. f) LGT, pero para el logro de tal fin crea un supuesto de responsabilidad -objetiva, podríamos denominarla- en el que no se tiene en cuenta si la sociedad contratista o subcontratista persigue alguna finalidad fraudulenta o no o si existe o no algún tipo de vinculación con el contratante. No se exige comportamiento negligente del contratante, basta con que se verifique la existencia de una contrata o subcontrata relativa a la actividad principal del mismo, con independencia de su finalidad" ${ }^{\prime 809}$.

Con esta figura se amplía la responsabilidad a los contratistas o subcontratistas, que CALVO ORTEGA denomina "principales o primarios en relación con otro empresario con el cual han contratado todo o parte de su prestación ordinaria" ${ }^{\sharp 10}$. Se trata, además, según el mismo autor, de una "colaboración forzosa en la gestión tributaria", que a diferencia de la responsabilidad por la sucesión en la titularidad o ejercicio de explotaciones o actividades económicas muestra una mayor permanencia.

\footnotetext{
${ }^{808}$ Informe sobre el borrador del anteproyecto de la nueva LGT de 23 de enero de 2003, pág. 25.

${ }^{809}$ MARTÍN JIMÉNEZ, A., Los supuestos de responsabilidad en la LGT: (hacia una configuración constitucional y comunitaria de la responsabilidad tributaria), op. cit., pág. 304. En el mismo sentido, RODRÍGUEZ MÁRQUEZ, J. S., "Los sujetos que contratan o subcontratan una obra o servicio: un supuesto de responsabilidad poco meditado", Jurisprudencia Tributaria Aranzadi, núm. 12, 2004, pág. 15.

${ }^{810}$ CALVO ORTEGA, R., “Obligados tributarios”, op. cit., pág. 189.
} 
A. Presupuesto de hecho de la responsabilidad de los sujetos que contraten o subcontraten una obra o $\underline{\text { servicio de su actividad principal }}$

La delimitación del presupuesto de hecho de esta modalidad de responsabilidad debe plantearse desde dos vertientes: el elemento subjetivo y el elemento objetivo. En cuanto al elemento subjetivo, el inciso f) se refiere a personas o entidades, lo que conlleva a pensar que dentro del presupuesto de hecho están comprendidas las personas físicas o jurídicas y los entes sin personalidad del apartado cuarto del artículo 35 de la LGT, siempre que externalicen parte de su actividad que será desempeñada por los contratistas o subcontratistas. "En consecuencia, si el ente sin personalidad contrata o subcontrata, será responsable cual si se tratase de una entidad" 811.

Intentando reunir en una sola posición la definición de quién es el responsable en este supuesto, consideramos que el legislador y las diferentes posturas doctrinales asumen como responsable subsidiario, en su caso, al pagador, comitente de la obra, contratista primario o principal o empresario principal que contrata o subcontrata una obra o un servicio. Consecuentemente, el obligado tributario principal será el contratado o subcontratado o el contratista o empresario secundario, que es a quien se hace el encargo y el que tiene a su cargo los deberes de retención y repercusión ${ }^{812}$.

Ahora bien, debemos abordar dos casos que despiertan dudas. Uno es la posibilidad de que los entes públicos se conviertan en responsables, según el inciso f) del primer apartado del artículo 43 de la LGT; y el otro es el alcance de la responsabilidad cuando se sucedan múltiples contratas o subcontratas. En primer lugar, si bien es cierto que los entes públicos pueden configurarse como obligados tributarios de una deuda tributaria de forma general porque nada lo impide, la interrogante que puede surgir es si pueden estos entes convertirse en responsables subsidiarios cuando actúen como empresarios principales y contraten o subcontraten obras o servicios de terceras empresas particulares que hayan incumplido con sus deberes de retención y repercusión.

La legislación tributaria no dice nada al respecto, como tampoco lo hace la jurisprudencia, lo que lleva a la doctrina a la necesidad de acudir a los pronunciamientos de la jurisprudencia social para hallar respuestas ${ }^{813}$. En la Sentencia del Tribunal Supremo de 29 de octubre de 1998, se interpreta que la Administración queda dentro del ámbito de aplicación del artículo 42 de los Estatutos de los Trabajadores, al entender "que la doctrina y la jurisprudencia han observado que la responsabilidad solidaria de las deudas salariales atribuida al empresario que contrata o subcontrata obras o servicios no se limita a los negocios jurídicos formalizados como contrato de ejecución de obra, sino que puede

\footnotetext{
811 VAQUERA GARCÍA, A., y RUIZ GARIJO, M., "Aspectos problemáticos de la responsabilidad de los contratistas y subcontratistas”, Jurisprudencia Tributaria Aranzadi, núm. 15-22, 2005, pág. 337.

812 Consideramos importante hacer esta acotación porque del contenido de la ley se desprenden dudas acerca de quién es el responsable, ya que el propio inciso $f$ ) indica que la responsabilidad prevista "no será exigible cuando el contratista o subcontratista haya aportado al pagador un certificado específico". Por lo tanto, el pagador es el que contrata, pero la propia LGT se refiere a él como el contratista o subcontratista, lo que permite nombrar como contratado o subcontratado al sujeto encargado de la ejecución de obras o la prestación de servicios.

${ }^{813}$ Entre otros: VAQUERA GARCÍA, A. y RUIZ GARIJO, M., "Aspectos problemáticos de la responsabilidad de los contratistas y subcontratistas", op. cit., pág. 338 y 339; MARTÍN JIMÉNEZ, A., Los supuestos de responsabilidad en la LGT: (hacia una configuración constitucional y comunitaria de la responsabilidad tributaria), op. cit., pág. 306; RODRÍGUEZ MÁRQUEZ, J. S. y MARTÍN FERNÁNDEZ, F. J., "La responsabilidad tributaria de los sujetos que contraten o subcontraten ejecuciones de obras o prestaciones de servicios", op, cit., pág. 2618 y 2619; CLEMENTE, V., "La responsabilidad tributaria en la contratación: Perspectiva actual", Jurisprudencia Tributaria Aranzadi, núm. 1, 2007, pág. 447.
} 
extenderse a otros supuestos equivalentes como los contratos administrativos que adjudican la realización de un servicio público". Y reitera su posición el Tribunal Supremo al indicar que "la relación entre empresarios o entidades que genera la responsabilidad por deudas salariales no es cualquier relación de colaboración productiva, sino que ha de ser, atendiendo a la finalidad del artículo 42 del ET, una relación especial de descentralización productiva o subcontratación sobre la propia actividad entre una empresa principal y una empresa auxiliar o subsidiaria".

MARTÍN JIMÉNEZ considera que es trasladable la doctrina del Tribunal Supremo que acabamos de reseñar al supuesto del inciso f) del primer apartado del artículo 43 de la LGT, y afirma que "a pesar de que el ente público, en sentido estricto, no realiza actividad económica, ciertas funciones, si fueran realizadas por el sector privado, serían calificadas como tales, por lo que no cabe excluir este tipo de responsabilidad cuando el comitente es un ente público, especialmente cuando acude a formas de gestión indirecta de un servicio público" ${ }^{\text {814. }}$.

En relación con la segunda cuestión, el alcance de la responsabilidad cuando exista encadenamiento de contratas y subcontratas, debemos decir que la responsabilidad se encuentra limitada a un solo eslabón de la cadena de contratación y subcontratación, porque, como señala RODRÍGUEZBEREIJO LEÓN, "aunque el precepto hable del contratista o subcontratista, se está refiriendo siempre a una relación bipolar entre dos únicas empresas, principal y auxiliar, como evidencia el hecho de que el certificado para exonerarse de responsabilidad se prevé que haya de aportarlo el contratista o subcontratista al pagador". Y añade esta autora que, "si ya resulta difícil admitir que el empresario o empresa principal pueda llegar a ejercer un control sobre el cumplimiento de las obligaciones tributarias de la empresa con la que él contrata de modo directo, lo que resulta no ya ilógico, sino inadmisible por desmesurado y desproporcionado, es hacerle responsable por las obligaciones tributarias derivadas de las sucesivas subcontratas, que él no puede controlar, por cuanto no es él quien celebra esos posteriores negocios jurídicos. No es justo ni ponderado. Por último, tampoco puede obviarse el hecho de que la responsabilidad establecida en materia tributaria, pese a tener una finalidad de tutela o garantía, lo es respecto de los Derechos de la Hacienda Pública y no, como ocurre en materia laboral, respecto de los derechos fundamentales de los trabajadores" ${ }^{\prime \prime}$.

Por último, de la lectura del inciso f) del apartado primero del artículo 43 de la LGT se deducen tres aspectos que permiten definir los elementos objetivos sobre los que se concreta esta responsabilidad: el primero es que el comitente ha de acudir a la contratación o subcontratación; el segundo es que ésta ha de ser precisamente la ejecución de obras o la prestación de servicios; y el último es que las obras o los servicios han de corresponder con su actividad económica principal.

\footnotetext{
${ }^{814}$ MARTÍN JIMÉNEZ, A., Los supuestos de responsabilidad en la LGT: (hacia una configuración constitucional y comunitaria de la responsabilidad tributaria), op. cit., pág. 306; CLEMENTE, V., "La responsabilidad tributaria en la contratación: Perspectiva actual", op. cit., pág. 447; RODRÍGUEZ-BEREIJO LEÓN, M., La Responsabilidad Tributaria en la Contratación y Subcontratación de Obras y Servicios, Aranzadi, Madrid, 2005, pág. 65 a 91.

${ }^{815}$ RODRÍGUEZ-BEREIJO LEÓN, M., La Responsabilidad Tributaria en la Contratación y Subcontratación de Obras y Servicios, op. cit., pág. 93. Comparten este criterio, CALVO ORTEGA, R., "Obligados tributarios", op. cit., pág. 189; RODRÍGUEZ MÁRQUEZ, J. S. y MARTÍN FERNÁNDEZ, F. J., "La responsabilidad tributaria de los sujetos que contraten o subcontraten ejecuciones de obras o prestaciones de servicios", op. cit., pág. 2633. En contra de esta postura, vid. VAQUERA GARCÍA, A., y RUIZ GARIJO, M., “Aspectos problemáticos de la responsabilidad de los contratistas y subcontratistas”, op. cit., pág. 341.
} 
El concepto de contrata o subcontrata debemos buscarlo fuera de la LGT y del Estatuto de los Trabajadores. El Real Decreto 1627/1997, de 24 de octubre, por el que se establecen disposiciones mínimas de seguridad y de salud en las obras de construcción, estableció las disposiciones mínimas de seguridad y salud en las obras de la construcción y definió algunos conceptos como los de promotor, contratista y subcontratista. Años más tarde estas definiciones se incluyeron, en términos muy similares, en el artículo 3 de la Ley 32/2006, de 18 de octubre, reguladora de la subcontratación en el Sector de la Construcción. Según esta última legislación, el promotor es cualquier persona física o jurídica por cuenta de la cual se realice la obra; el contratista o empresario principal es la persona física o jurídica que asume contractualmente ante el promotor, con medios humanos y materiales, propios o ajenos, el compromiso de ejecutar la totalidad o parte de las obras con sujeción al proyecto y al contrato; y el subcontratista es la persona física o jurídica que asume contractualmente ante el contratista $\mathrm{u}$ otro subcontratista comitente el compromiso de realizar determinadas partes o unidades de obra, con sujeción al proyecto por el que se rige su ejecución.

Sin embargo, estas acepciones, para algunos autores, no pueden ser incorporadas al contenido del artículo 42 de Estatuto de los Trabajadores que, como dijimos, es el antecedente más próximo del inciso f) del apartado primero del artículo 43 de la LGT $^{816}$. Un sector de la doctrina se inclina por atribuir el origen de las contratas o subcontratas al contrato de arrendamiento de obra y servicio contemplado en el artículo 1.544 del Código Civil ${ }^{817}$. Aunque aclara RODRÍGUEZ-BEREIJO LEÓN que "el concepto de contrata debe extenderse más allá de los contratos de obras o servicios en sentido estricto, a otras formas contractuales que tengan una estructura obligacional similar, respondan a una misma función económica y tengan por objeto tareas incluidas en la actividad económica principal de la empresa". En definitiva, y según esta autora, para determinar los negocios jurídicos comprendidos en el ámbito de aplicación de la responsabilidad tributaria del inciso $f$ ) del primer apartado del artículo 43 de la LGT, deberá observarse la existencia de "un contrato entre dos o más personas físicas, jurídicas o, incluso, entidades sin personalidad jurídica del artículo 35.4 LGT. En el ámbito tributario, como ya hemos dicho, no han de tener la condición de empresarios en sentido jurídicolaboral del término, pero sí han de realizar una actividad económica. Este contrato puede ser civil (...), mercantil, en algunas de las formas contractuales típicas o atípicas (...), administrativo, en la medida que la Administración también puede actuar como sujeto contratante. Es indiferente la denominación que las partes den a ese negocio, habiendo de abstenerse para su conceptuación y al contenido del contrato. (...) El objeto del negocio ha de consistir en una obligación de hacer, en un facere, a cambio de un precio. Esa obligación puede consistir tanto en la producción de objetos o bienes materiales, como en la prestación de servicios, siendo indiferente que sea una obligación de medios, donde lo comprometido es una mera actividad, como de resultado. Eso sí, ha de tratarse de una obligación de hacer algo concreto y determinado, la obligación de hacer debe estar definida como encargo bien delimitado", y "por último, la más moderna doctrina laboralista exige también,

\footnotetext{
${ }^{816}$ Entre otros, MARTÍN JIMÉNEZ, A., Los supuestos de responsabilidad en la LGT: (hacia una configuración constitucional y comunitaria de la responsabilidad tributaria), op. cit., pág. 310; RODRÍGUEZ-BEREIJO LEÓN, M., La Responsabilidad Tributaria en la Contratación y Subcontratación de Obras y Servicios, op. cit., pág. 93.

${ }^{817}$ Por todos, MONEREO PÉREZ, J. L., La responsabilidad empresarial en los procesos de subcontratación: puntos críticos, Ibidem, Madrid, 1994, pág. 66, y LLANO SÁNCHEZ, M., Responsabilidad empresarial en las contratas y subcontratas, La Ley, Madrid, 1999, pág. 41 y ss.
} 
para poder hablar de contratas y subcontratas, el elemento de la subordinación o dependencia de la actividad del contratista o subcontratista respecto de la actividad productiva del principal" ${ }^{\prime \prime 18}$.

Terminamos el análisis de los elementos que son necesarios para delimitar el presupuesto de hecho de la responsabilidad subsidiaria que ahora nos ocupa partiendo de la idea de que para que se produzca el presupuesto de responsabilidad la contratación o subcontratación tiene que ser realizada en el ámbito de la actividad económica principal del comitente, según se precisa en el propio inciso f) del primer apartado del artículo 43 de la LGT. El concepto de actividad económica principal funciona como el elemento delimitador del alcance de este tipo de responsabilidad. En este sentido, observa RODRÍGUEZ-BEREIJO LEÓN que "en el ámbito tributario resulta imposible desvincular la noción de contrata y subcontrata del concepto de «actividad económica principal», pues, en definitiva, parece que cualquier obra o servicio relativa a la misma que la empresa externalice podría considerarse comprendida en el ámbito de aplicación del artículo" ${ }^{\text {819. }}$.

Para interpretar este supuesto de responsabilidad subsidiaria será necesario comprobar qué se entiende por actividad económica principal. En la doctrina se encuentran hasta tres tesis que conciben de manera diferente el concepto de actividad económica principal: "la actividad económica principal se puede considerar como la que se haya declarado de forma primordial por el sujeto (tesis restrictiva), la constitutiva de su objeto social (tesis intermedia) o la correspondiente a su propia actividad de su finalidad productiva (tesis más genérica) ${ }^{\$ 820}$.

En el ámbito tributario se ha seguido la tesis intermedia, adoptando el concepto de "propia actividad" que elaboró la jurisprudencia social a partir de la interpretación que hizo del artículo 42 del Estatuto de los Trabajadores ${ }^{821}$. La Resolución de la Dirección General de Tributos de 16 de julio de 2004 acudió a esa doctrina jurisprudencial para determinar el concepto de actividad económica principal. La doctrina coincide en que esa Resolución amplía el círculo de actividades comprendidas en el inciso $f$ ) respecto al ámbito laboral, llegando a admitirse "varias actividades del sujeto (y no sólo la principal), con lo que se desvirtúa el tenor literal del art. 43.1. f) y, además, dirige su atención al objeto social de la entidad de que se trate (si es una persona jurídica, pues, de ser una persona física este extremo no estaría presente), lo cual hace pensar de nuevo que el precepto (...) carece de una técnica legislativa depurada y se trata de una copia, ciertamente alterada y de forma algo precipitada,

\footnotetext{
${ }^{818}$ RODRÍGUEZ-BEREIJO LEÓN, M., La Responsabilidad Tributaria en la Contratación y Subcontratación de Obras y Servicios, op. cit., pág. 79 a 82. En sentido similar, GOERLICH PESET, J. M., "Determinación del supuesto: la noción de contrata y subcontrata de obras y servicios", en la obra Descentralización productiva y protección del trabajo en contratas, Tirant lo Blanch, Valencia, 2000, pág. 89 y ss.; MONTOYA MEDINA, D., Trabajo en contratas y protección de los trabajadores, Tirant lo Blanch, Valencia, 2004, pág. 70 y ss.

${ }^{819}$ RODRÍGUEZ-BEREIJO LEÓN, M., La Responsabilidad Tributaria en la Contratación y Subcontratación de Obras y Servicios, op. cit., pág. 83.

${ }^{820}$ VAQUERA GARCÍA, A. y RUIZ GARIJO, M., "Aspectos problemáticos de la responsabilidad de los contratistas y subcontratistas", op. cit., pág. 346. Sobre este tema, vid. RODRÍGUEZ MÁRQUEZ, J. S. y MARTÍN FERNÁNDEZ, F. J., "La responsabilidad tributaria de los sujetos que contraten o subcontraten ejecuciones de obras o prestaciones de servicios", op. cit., pág. 2621 a 2629; NAVARRO EGEA, M., El responsable tributario, op. cit., pág. 150 a 154; MARTÍN JIMÉNEZ, A., Los supuestos de responsabilidad en la LGT: (hacia una configuración constitucional y comunitaria de la responsabilidad tributaria), op. cit., pág. 309 a 324 .

${ }^{821}$ Por todas, Sentencia del Tribunal de Supremo de 29 de octubre de 1998.
} 
del mismo supuesto de responsabilidad laboral" ${ }^{\text {822 }}$. Como dicen RODRÍGUEZ MÁRQUEZ y MARTÍN FERNÁNDEZ, "la Administración tributaria (...) viene a formular una advertencia, señalando que el objeto social puede ser interpretado de forma amplia y (...), además, nunca se excluye la posibilidad de que se realicen actividades no incluidas en el mismo pero que puedan estimarse auxiliares o complementarias. De esta forma se introduce, de nuevo, un factor adicional de inseguridad jurídica para los ciudadanos" $" 823$.

"La expresión de contratación o subcontratación de obras o servicios correspondientes a la «actividad económica principal» vendría a incluir en el ámbito de aplicación del supuesto, la contratación de: a) actividades principales o auxiliares «inherentes» al ciclo productivo de la empresa contratante; b) actividades complementarias o auxiliares con respecto a las que integran el ciclo productivo; c) actividades indispensables para el funcionamiento de la empresa, pero que no están vinculadas a su ciclo productivo. De modo que en el ámbito de aplicación de la responsabilidad prevista en el artículo 43.1. f) LGT podría quedar incluida la contratación o subcontratación de servicios tales como: comedor, jardinería, limpieza, vigilancia y seguridad, transporte, mantenimiento de equipos informáticos o de instalaciones de la empresa (...)"824.

Normativamente, el RGR siguió con la misma línea que la Resolución de la Dirección General de Tributos de 16 de julio de 2004, al acoger también el criterio de la indispensabilidad que permite incorporar en el concepto de actividad económica principal las actividades auxiliares o complementarias, según se desprende del primer apartado del artículo 126, cuando indica que

"se considerarán incluidas en la actividad económica principal de las personas o entidades que contraten o subcontraten la ejecución de obras o la prestación de servicios todas las obras o servicios que, por su naturaleza, de no haber sido contratadas o subcontratadas, deberían haber sido realizadas por la propia persona o entidad que contrata o subcontrata por resultar indispensables para su finalidad productiva".

\section{B. Alcance de la responsabilidad}

En relación con la extensión de la responsabilidad, la ley prevé que alcance a

"las obligaciones tributarias relativas a tributos que deban repercutirse o cantidades que deban retenerse a trabajadores, profesionales u otros empresarios, en la parte que corresponda a las obras o servicios objeto de la contratación o subcontratación".

\footnotetext{
822 VAQUERA GARCÍA, A. y RUIZ GARIJO, M., "Aspectos problemáticos de la responsabilidad de los contratistas y subcontratistas", op. cit., pág. 345. En el mismo sentido, CLEMENTE, V., "La responsabilidad tributaria en la contratación: Perspectiva actual”, op. cit., pág. 452.

${ }^{823}$ RODRÍGUEZ MÁRQUEZ, J. S. y MARTÍN FERNÁNDEZ, F. J., "La responsabilidad tributaria de los sujetos que contraten o subcontraten ejecuciones de obras o prestaciones de servicios", op. cit., pág. 2629.

${ }^{824}$ RODRÍGUEZ-BEREIJO LEÓN, M., La Responsabilidad Tributaria en la Contratación y Subcontratación de Obras y Servicios, op. cit., pág. 88. En esta misma línea, MARTíN JIMÉNEZ, A., "La responsabilidad subsidiaria en los supuestos de contratación o subcontratación del art. 43.1. f) LGT: algunas cuestiones controvertidas", Revista Española de Derecho Financiero, núm. 124, 2005, pág. 807.
} 
Ello implica que el legislador hace responsable al comitente que contrata con el contratista o con el subcontratista de las cuotas de IVA y de las retenciones del IRPF.

Ahora bien, según CLEMENTE es posible realizar dos interpretaciones del precepto. La primera, es que el artículo no se refiere expresamente a obligaciones de ingreso, alcanzando la responsabilidad del comitente "al importe del IVA devengado por el contratista o subcontratista en la ejecución de la obra o presentación de servicios, hubiera sido este IVA repercutido o no al comitente; y una segunda interpretación, en cuya virtud, la responsabilidad lo sería por el importe de la deuda tributaria en el IVA del contratista o subcontratista". Aunque para este autor "la responsabilidad del comitente en el IVA alcanza exclusivamente al importe de la deuda tributaria por el IVA a ingresar, esto es, al resultado positivo de restar del IVA devengado, el IVA soportado deducible, ya que si no hay deuda tributaria no habrá obligación de ingreso, y por ello tampoco responsabilidad de la misma" ${ }^{\$ 25}$.

En todo caso, como bien advierte CALVO ORTEGA, la referencia que hace la ley a los tributos que deban repercutirse se identifican con las cantidades que deben ser objeto de repercusión al contratista y subcontratista "y no a la que el que contrata con ellos debe ingresar en la Administración una vez deducido el impuesto soportado", porque en caso contrario se exigiría "al empresario-responsable (vía responsabilidad) lo que no se le repercutió en su momento por vía repercusión”826.

Por otra parte, varios autores han manifestado la posibilidad de que el artículo pudiera resultar incompatible con el Derecho Comunitario ${ }^{827}$, porque "hacer responsable al comitente del IVA devengado por el contratista o subcontratista en la práctica equivale a negar al comitente el derecho a la deducción del IVA soportado. En efecto, devengado el IVA por la ejecución de la obra o la prestación del servicio, el contratista o subcontratista, repercutirá el IVA al comitente, quien lo considerara IVA soportado y lo deducirá del importe de su IVA repercutido. El ingreso en la Hacienda Pública del IVA del contratista, efectuado por el comitente responsable subsidiario, equivale en la práctica, a negar la deducibilidad del mismo, (...) si bien es cierto que como el supuesto «de facto» limita la deducibilidad de las cuotas del IVA soportadas por el comitente, entendemos que deberá interpretarse restrictivamente, so pena de colisionar con el Derecho Comunitario" ${ }^{828}$. SANZ CLAVIJO entiende que la LGT no está exigiendo un nuevo requisito para la deducción del IVA soportado por el comitente, sino que la regulación de este supuesto de responsabilidad subsidiaria "habilita a otro obligado tributario, el comitente, para que haga frente junto con el sujeto pasivo contribuyente, el contratista o subcontratista, al pago de la deuda de este último, deuda, que de derivársele al comitente, pasaría a ser autónoma de la suya propia por el mismo

\footnotetext{
${ }^{825}$ CLEMENTE, V., "La responsabilidad tributaria en la contratación: Perspectiva actual”, op. cit., pág. 455 y 456. En este mismo sentido, VAQUERA GARCÍA, A. y RUIZ GARIJO, M., "Aspectos problemáticos de la responsabilidad de los contratistas y subcontratistas", op. cit., pág. 347; FALCÓN Y TELLA, R., "La responsabilidad subsidiaria en los supuestos de contratación y subcontratación en el Anteproyecto de LGT: su inaplicabilidad en el IVA”, Quincena Fiscal, núm. 8, 2003, pág. 6, y, del mismo autor, "Los responsables en la nueva Ley General Tributaria", op. cit., pág. 15.

${ }^{826}$ CALVO ORTEGA, R., “Obligaciones tributarias”, op. cit., pág. 190. Este autor pone de relieve, además, que la problemática se presenta a la hora de precisar la cantidad que en las retenciones corresponde a cada contrato o subcontrato, pues "un mismo trabajador o profesional dependiente de un mismo empresario puede prestar sus servicios dentro del período de tiempo a que se circunscribe la responsabilidad a más de una contrata o subcontrata".

${ }^{827}$ Por todos, FALCÓN Y TELLA, R., "Los responsables en la nueva Ley General Tributaria”, op. cit., pág. 16.

${ }^{828}$ CLEMENTE, V., "La responsabilidad tributaria en la contratación: Perspectiva actual”, op. cit., pág. 457. En la misma línea, RODRÍGUEZ MÁRQUEZ, J. S. y MARTÍN FERNÁNDEZ, F. J., "La responsabilidad tributaria de los sujetos que contraten o subcontraten ejecuciones de obras o prestaciones de servicios”, op. cit., pág. 2632.
} 
concepto tributario, no incidiendo jurídicamente ni en su obligación de soportar la repercusión ni en su derecho a la deducción" 829 .

También se declarará la responsabilidad, en segundo lugar, de las cantidades que deban retenerse a trabajadores, profesionales u otros empresarios, a cuenta, normalmente del IRPF y excepcionalmente del IS y del Impuesto sobre la Renta de los No Residentes. Para RODRÍGUEZ-BEREIJO LEÓN, "la responsabilidad tributaria que se imputa al empresario principal o comitente con respecto a las retenciones en el marco de las contratas de obras y servicios lo que pretende, como es propio del instituto del responsable, es servir de garantía respecto del cumplimiento de la obligación de retener e ingresar el importe de lo retenido que tenga el contratista o subcontratista con sus trabajadores o con otros profesionales o empresarios en relación con las obras o servicios que han sido objeto de la contratación o subcontratación. Es decir, hace responder por las retenciones o ingresos a cuenta que deban practicarse con ocasión de los pagos que el contratista o subcontratista realice a sus trabajadores asalariados o a profesionales o empresas como contraprestación de una actividad profesional que se haya realizado para la obra o el servicio que han sido objeto del contrato principal"830. Aquí el problema aparece cuando el comitente normalmente no conoce a los trabajadores, profesionales o empresarios con los que el contratista o subcontratista mantiene la relación de la que deriva la obligación de retener, por lo que desconoce la situación personal, familiar y laboral de éstos, y no puede verificar si las retenciones son correctas. Por este motivo, MARTÍN JIMÉNEZ considera que imponer este tipo de responsabilidad subsidiaria puede resultar "excesivo, en términos de capacidad económica, e incluso de derecho de defensa y posibilidad de una mínima contradicción, puesto que el contratante no tendría arma alguna para rebatir la eventual deuda en concepto de retenciones que le derive la Administración" ${ }^{\text {"831. }}$.

Por otra parte, FALCÓN Y TELLA reconoce que el derecho de reembolso lo es frente al deudor principal, en este caso frente al retenedor-contratista, y no frente a los trabajadores del contratista, pues la exigencia de la responsabilidad al empresario principal por las retenciones que el contratista no ha practicado a sus trabajadores "supondría colocar a cargo de éste una parte del impuesto que han de abonar los trabajadores. Es decir, supondría un enriquecimiento sin causa de los trabajadores del contratista a costa del empresario principal, que no podría en la práctica dirigirse contra el retenedor, al ser éste insolvente", ni contra los trabajadores del contratista o subcontratista, que habrían cobrado sin retención, al no tener reconocida acción de reembolso frente a ellos ${ }^{832}$.

\section{La exención de la responsabilidad}

Por último, es posible que el contratista o subcontratista quede liberado de este tipo de responsabilidad si aporta un certificado conforme se encuentra al corriente de sus obligaciones

\footnotetext{
${ }^{829}$ SANZ CLAVIJO, A., "La responsabilidad tributaria en la contratación y subcontratación: cuestiones problemáticas y aspectos prácticos", Gaceta Fiscal, núm. 248, 2005, pág. 36 y 37.

${ }^{830}$ RODRÍGUEZ-BEREIJO LEÓN, M., La Responsabilidad Tributaria en la Contratación y Subcontratación de Obras y Servicios, op. cit., pág. 109.

${ }^{831}$ MARTÍN JIMÉNEZ, A., "La responsabilidad subsidiaria en los supuestos de contratación o subcontratación del art. 43.1. f) LGT: algunas cuestiones controvertidas", op. cit., pág. 812.

${ }^{832}$ FALCÓN Y TELLA, R., "Los responsables en la nueva Ley General Tributaria”, op. cit., pág. 18 y 19.
} 
tributarias anteriores al pago de cada factura correspondiente a la contratación o subcontratación ${ }^{833}$. Se trata de un certificado administrativo similar al que se exige para la responsabilidad en la sucesión de la titularidad o ejercicio de explotaciones o actividades económicas y que también se incluye en el artículo 42 de los Estatutos de los Trabajadores.

El contratista o subcontratista es el encargado de solicitar el certificado y no el pagador. Como apunta RODRÍGUEZ-BEREIJO LEÓN, es sorprendente que la exoneración de la responsabilidad no dependa, en sentido estricto, de la conducta del responsable sino de la propia actuación diligente del contratista mediante la aportación del certificado correspondiente y de la Administración en la emisión del mismo. "Ahora no se trata ya de que el responsable cargue con el cumplimiento de una deuda ajena, sino que incluso su posible exoneración de responsabilidad queda a expensas de la diligencia del contratista y del buen funcionamiento de la Administración Tributaria, es decir, de sujetos distintos de aquel a quien la responsabilidad se imputa. (...) En definitiva, se establece una causa de exoneración de responsabilidad que queda completamente fuera del control del empresario principal. Éste, al no poder solicitar de la Administración Tributaria el certificado específico exonerativo de responsabilidad, quedará a expensas de que sea el contratista o subcontratista el que lo aporte oportunamente con carácter previo al cobro de su factura, así como a que la Administración lo emita en plazo" ${ }^{\$ 34}$. Esta regulación pone de manifiesto la auténtica finalidad del supuesto de responsabilidad que estamos analizando: "que el contratante fuerce a las personas con quienes contrata (contratista o subcontratista), a que, al menos formalmente, se vean obligados a cumplir con

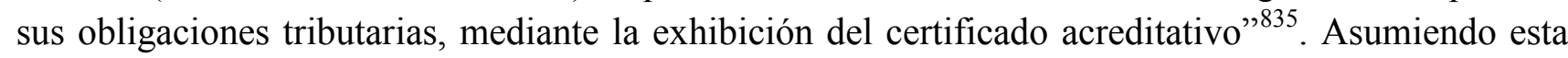
misma postura, CLEMENTE se pregunta "si el verdadero objetivo del certificado exonerador no será el de operar como filtro previo, un control preventivo para expulsar del mercado a los incumplidores con la Hacienda Pública, o para proporcionar esta información que pueda utilizar en posteriores comprobaciones tributarias" ${ }^{\prime 36}$.

Otro aspecto controvertido dentro de la configuración de este tipo de responsabilidad subsidiaria relativo al certificado lo encontramos en el contenido que este documento debe contener. Tal como dispone el apartado segundo del artículo 126 del RGR, el certificado debe acreditar que el contratista se encuentra al corriente de sus obligaciones tributarias, extendiendo éstas, más allá del IVA o de las retenciones, otros aspectos, tales como: estar dado de alta en el Censo de Empresarios, Profesionales y Retenedores, cuando se trate de personas o entidades obligados a estar en dicho censo, y estar dado de alta en el Impuesto sobre Actividades Económicas, cuando se trate de sujetos pasivos no exentos dicho impuesto; haber presentado las autoliquidaciones que correspondan por el IRPF, el IS o el Impuesto sobre la Renta de no Residentes; haber presentado las autoliquidaciones y la declaración resumen anual correspondiente a las obligaciones tributarias de realizar pagos a cuenta; haber presentado las autoliquidaciones, la declaración resumen anual y, en su caso, las declaraciones

\footnotetext{
${ }^{833}$ Sobre la regulación del certificado, con anterioridad a la publicación del RGR, vid. RODRÍGUEZ-BEREIJO LEÓN, M., La Responsabilidad Tributaria en la Contratación y Subcontratación de Obras y Servicios, op. cit., pág. 12 y ss.

${ }^{834}$ RODRÍGUEZ-BEREIJO LEÓN, M., La Responsabilidad Tributaria en la Contratación y Subcontratación de Obras y Servicios, op. cit., pág. 129.

${ }^{835}$ MARTÍN JIMÉNEZ, A., Los supuestos de responsabilidad en la LGT: (hacia una configuración constitucional y comunitaria de la responsabilidad tributaria), op. cit., pág. 330.

${ }^{836}$ CLEMENTE, V., "La responsabilidad tributaria en la contratación: Perspectiva actual”, op. cit., pág. 462.
} 
recapitulativas de operaciones intracomunitarias del IVA; haber presentado las declaraciones y autoliquidaciones correspondientes a los tributos locales; haber presentado las declaraciones exigidas con carácter general en cumplimiento de la obligación de suministro de información reguladas en los artículos 93 y 94 de la LGT; no mantener con la Administración tributaria expedidora del certificado deudas o sanciones tributarias en período ejecutivo, salvo que se trate de deudas o sanciones tributarias que se encuentren aplazadas, fraccionadas o cuya ejecución estuviese suspendida; y finalmente, no tener pendientes de ingreso responsabilidades civiles derivadas de delito contra la Hacienda Pública declaradas por sentencia firme ${ }^{837}$.

Por lo demás, el procedimiento de emisión del certificado y las consecuencias jurídicas que, para la exoneración de la responsabilidad, tiene el retraso en la emisión del certificado por parte de la Administración, se contienen en la mencionada Resolución de 16 de julio de 2004 de la Dirección General de Tributos. Dicha Resolución determina que la consecuencia para los interesados si la Administración no emite el certificado en el plazo de tres días será que "el solicitante podrá entender provisionalmente emitido el citado certificado a partir del día siguiente al de finalización del plazo establecido por la norma, a cuyo efecto tendrá derecho a obtener de la Administración Tributaria una comunicación acreditativa de tal circunstancia, que habrá de expedirse de forma inmediata". Además el RGR en el apartado cuarto del artículo 126 prevé un plazo de un mes cuando el certificado se solicite con ocasión de la presentación telemática de las declaraciones del IRPF o del IS y de seis meses para las declaraciones presentadas por otros medios ${ }^{838}$. Por último, este mismo apartado regula que los efectos de este certificado se extienden a los pagos realizados durante los doce meses posteriores a la fecha en que el certificado se entienda emitido, teniendo también la consideración de pagos la aceptación de efectos cambiarios durante ese período, aunque el vencimiento se produzca con posterioridad a la finalización de dicho plazo.

\section{Valoración final}

Tras el análisis de las circunstancias que rodean la responsabilidad subsidiaria de las personas o entidades que contraten o subcontraten la realización de obras o servicios debemos decir que ha sido objeto de críticas por un sector amplio de la doctrina. Estas críticas se centran fundamentalmente en la justificación o fundamento de la medida y su configuración técnica por parte del legislador.

Según CLEMENTE, se ha establecido un supuesto de responsabilidad objetivo "que resulta de aplicación en todo caso, aun entre partes no vinculadas, y que no toma en consideración la intención del responsable, de eludir, o no, el pago del tributo", y que "más acertado hubiera sido supeditar su aplicación al dolo o culpa del comitente, lo que habría convertido a éste en responsable solidario en virtud de lo dispuesto en el artículo 42.1. a) LGT, pudiendo haber suplido la dificultad de probar el ánimo defraudatorio mediante el establecimiento de presunciones «iuris tantum» en supuestos de vinculación, o de subordinación de cualquier otro modo, entre el comitente y el contratista. $\mathrm{O}$ incluso

\footnotetext{
${ }^{837}$ Apartado primero del artículo 74 del Real Decreto 1065/2007, de 27 de julio, por el que se aprueba el Reglamento General de las actuaciones y los procedimientos de gestión e inspección tributaria y de desarrollo de las normas comunes de los procedimientos de aplicación de los tributos.

${ }^{838}$ Sobre este precepto, véanse las valoraciones que hace MARTÍN JIMÉNEZ, A., Los supuestos de responsabilidad en la LGT: (hacia una configuración constitucional y comunitaria de la responsabilidad tributaria), op. cit., pág. 333 a 336.
} 
establecer la obligación al comitente pagador de efectuar retención en los pagos al contratista o subcontratista, lo que hubiera permitido llegar al mismo resultado, pero de una forma pacífica" ${ }^{\$ 3}$.

De manera muy parecida, RODRÍGUEZ MÁRQUEZ y MARTÍN FERNÁNDEZ sostienen que el problema reside en la propia redacción que utiliza la norma, "al haber optado por una configuración objetiva del supuesto de responsabilidad, unida a la posibilidad de eludirla mediante la emisión de un certificado. Sobre todo, si tenemos en cuenta que este último, tal y como aparece regulado en el PRGR, únicamente garantiza, que las declaraciones han sido presentadas y que no existe ninguna deuda liquidada o autoliquidada impagada. Pero no evita que se pueda disponer de tal certificado con exclusión de la responsabilidad- habiendo presentado una autoliquidación total o parcialmente falseada. Todos los problemas descritos podrían solucionarse si se condiciona la aplicación del precepto al ánimo subjetivo de los intervinientes en la contratación. Es decir, en caso de que se exija que la contratación o subcontratación se efectúe con la finalidad de eludir el pago del impuesto, sin que sea posible, en tal caso, evitar la responsabilidad mediante certificación alguna" ${ }^{\$ 40}$.

Para RODRÍGUEZ-BEREIJO LEÓN el escollo más importante que presenta el supuesto de responsabilidad en relación con su fundamento "no es tanto el de su legitimidad a los fines de la lucha contra el frauda fiscal, cuanto el de su adecuación a la función propia del instituto de la responsabilidad tributaria. (...) Pues a la vista de la amplitud e indeterminación con que se ha configurado el supuesto de hecho de esta responsabilidad, su función parece ser más bien «profiláctica» y preventiva, para expulsar del mercado aquellas empresas y aquellos fenómenos de colaboración empresarial claramente fraudulentos. De ahí, quizás, que la ambigüedad del precepto haya sido deliberadamente buscada y en mayor medida de lo que a primera vista pudiera parecer. Ello, con el propósito tanto de disuadir lo más posible de simples descuidos a la hora de contratar con sujetos incumplidores de sus obligaciones fiscales, como de evitar fenómenos más graves, como el empleo de esta forma de contratación como mecanismo de elusión fiscal" ${ }^{141}$.

En resumen, no cabe duda que la función que persigue el legislador con esta figura no se corresponde con este tipo de garantía y que su finalidad no es otra que la de tratar de expulsar del mercado ciertas empresas que se han creado con fines fraudulentos. La configuración del precepto que regula esta responsabilidad es, además, desacertada, al estar construida sobre conceptos indeterminados, especialmente en relación con los términos de actividad económica principal, de contrata o subcontrata, y con el propio alcance de la responsabilidad, que acrecienta la inseguridad jurídica del contribuyente. Entendemos que se ha asumido una figura del Derecho laboral de manera arbitraria y desproporcionada al "imponer al contratante la responsabilidad por las retenciones de personas con las que no tiene ningún vínculo contractual y cuya situación personal, familiar y laboral o profesional

\footnotetext{
${ }^{839}$ CLEMENTE, V., "La responsabilidad tributaria en la contratación: Perspectiva actual”, op. cit., pág. 464.

${ }^{840}$ RODRÍGUEZ MÁRQUEZ, J. S. y MARTÍN FERNÁNDEZ, F. J., "La responsabilidad tributaria de los sujetos que contraten o subcontraten ejecuciones de obras o prestaciones de servicios”, op. cit., pág. 2636. Postura que ratifica RODRÍGUEZ MÁRQUEZ, J., "Un nuevo problema en el supuesto de responsabilidad de las personas o entidades que contraten o subcontraten la realización de obras y servicios: el caso particular de la Diputación Foral de Vizcaya”, op. cit., pág. 2365, cuando dice que debe hacerse "una mejor configuración de este nuevo supuesto de responsabilidad, de manera que, introduciendo el elemento subjetivo de la intencionalidad fraudulenta, lo limite a las conductas que pretendían atajarse".

${ }^{841}$ RODRÍGUEZ-BEREIJO LEÓN, M., La Responsabilidad Tributaria en la Contratación y Subcontratación de Obras y Servicios, op. cit., pág. 159 .
} 
le resulta desconocida", lo que "puede resultar excesivo, en términos de capacidad económica, e incluso de derecho de defensa y posibilidad de una mínima contradicción, puesto que el contratante no tendría arma alguna para rebatir la eventual deuda en concepto de retenciones que le derive la Administración" $" 842$.

\subsubsection{Levantamiento del velo}

La Ley 36/2006, de 29 noviembre, de medidas para la prevención del fraude fiscal, introdujo nuevos supuestos de responsabilidad subsidiaria, en las letras $g$ ) y $h$ ) del apartado 1 del artículo 43 de la LGT, con la intención de permitir a la Administración tributaria la utilización de la figura del levantamiento del velo de la personalidad jurídica. La primera Sentencia que aplicó la consideración del socio como tercero frente a la sociedad fue la Sentencia del Tribunal Supremo de 7 de junio de 1927, pero no es hasta la Sentencia de 28 de mayo de 1984 que se recoge directamente la teoría del levantamiento del velo. En el orden contencioso tributario la primera referencia a la doctrina del levantamiento del velo aparece en la Sentencia del Tribunal Supremo de 19 de abril de 2003.

El inciso g) del apartado primero del artículo 43 de la LGT evidencia que el deudor principal es una persona jurídica que supuestamente es el obligado principal insolvente. Así, y según lo previsto por la norma, puede declararse como responsable a aquél que haya creado esta entidad para hacer recaer sobre ella la deuda tributaria con independencia que dicha persona o entidad sea titular o no de una actividad económica. Se levanta el velo de la sociedad creada para aparentar un falso sujeto pasivo, propiciando, a través de su insolvencia, el incumplimiento de la obligación tributaria principal. En el caso del inciso $h$ ) del mismo artículo se configura como responsable subsidiario a una persona jurídica por las deudas de los socios que la controlan. Este es el caso en que la figura del obligado principal (persona física o jurídica) se declara insolvente, situación que faculta a la Hacienda Pública para que determine como responsable subsidiario a la persona que controla la "voluntad" de ese deudor, aunque exteriormente no aparezca relación alguna entre ambas sociedades. El legítimo obligado tributario aparenta falsamente una insolvencia a través de la creación de una persona jurídica cuyo patrimonio en verdad pertenece al primero ${ }^{843}$.

Al aludir a esta doctrina DE GANDARILLAS MARTOS expresa que "el carácter meramente instrumental de la trama societaria, se desvela como uno de los argumentos esenciales para la aplicación de la doctrina. Lo cual debe ser valorado con enorme prudencia ya que de por sí, la institución societaria y la personación jurídica tiene una función meramente instrumental, y no significa que toda sociedad, cuando no pueda hacer frente a sus responsabilidades, deba ser objeto de destape y comprobación de sus integrantes, para hacerles extensivo el pago de las deudas sociales. Lo

\footnotetext{
${ }^{842}$ MARTÍN JIMÉNEZ, A., Los supuestos de responsabilidad en la LGT: (hacia una configuración constitucional y comunitaria de la responsabilidad tributaria), op. cit., pág. 328.

${ }^{843}$ DE GANDARILLAS MARTOS opina que este supuesto no se ajusta a la doctrina del levantamiento del velo, entendiendo que se trata de una conducta delictiva y que lo que se hace con ello es otorgar a la Administración, "al margen del procedimiento penal", la posibilidad de declarar la presencia de dicha conducta y proceder a hacer efectivo el crédito frente a un tercero, hasta entonces alejado de la relación jurídico tributaria (DE GANDARILLAS MARTOS, S., "Las modificaciones introducidas por la Ley 36/2006 de prevención del fraude fiscal en la responsabilidad tributaria: levantamiento del velo", Crónica Tributaria, núm. 128, 2008, pág. 101).
} 
determinante de cara a valorar el carácter instrumental de la sociedad o de la trama societaria, es que la instrumentalidad sea la única finalidad perseguida en la personificación jurídica” ${ }^{\$ 44}$.

Según ZORNOZA PÉREZ, gran parte de los pronunciamientos de los tribunales apuntan en ocasiones a la doctrina del levantamiento del velo para "eludir la aplicación de otras normas tributarias, que suscitan problemas de prueba o exigen el desarrollo de procedimientos de alguna complejidad"845. MARTÍN JIMÉNEZ considera que la introducción de la doctrina del levantamiento del velo en la legislación financiera es un absurdo en la forma como se regula ${ }^{846}$. Este autor entiende que "la aplicación limitada o excepcional de la doctrina del levantamiento del velo, con el respecto al principio de libertad de empresa y a la seguridad jurídica, debe ser la regla general (...), y sólo cuando el deudor principal no tenga bienes o derechos suficientes y no existan responsables solidarios se podrá exigir este tipo de responsabilidad" 847 .

Del estudio de estos supuestos de responsabilidad subsidiaria por levantamiento del velo puede apreciarse que, a pesar de sus diferencias, tienen un carácter similar. Su finalidad, según DE GANDARILLAS MARTOS, es la aplicación del principio de responsabilidad patrimonial universal $^{848}$. Mientras que para MARTÍN JIMÉNEZ es una "mera garantía de la obligación tributaria y de las sanciones correspondientes a sujetos que utilizan sociedades como medio para evitar la recaudación de deudas y, en su caso, sanciones" ${ }^{\text {} 849}$. En ambos se produce un abuso de la forma societaria, con la intención de evadir el pago de la deuda tributaria. Y su ámbito de aplicación queda reducido sólo a la fase recaudatoria, lo que convierte la responsabilidad por levantamiento del velo en uno de los instrumentos en manos de la Administración tributaria que permite paliar las limitaciones

\footnotetext{
${ }^{844}$ DE GANDARILLAS MARTOS, S., "Las modificaciones introducidas por la Ley 36/2006 de prevención del fraude fiscal en la responsabilidad tributaria: levantamiento del velo", op. cit., pág. 99. Por su parte, MARTÍnEZ LAGO, M. A y ALMUDÍ CID, J. M., "Autotutela tributaria, «el levantamiento del velo» y derivación de la responsabilidad a las sanciones (análisis de los nuevos supuestos de responsabilidad incorporados a la Ley General Tributaria por la Ley 36/2006, de 29 de noviembre, y el procedimiento de derivación de la responsabilidad a las sanciones tributarias)", Revista de Contabilidad y Tributación, núm. 296, 2007, pág. 8, identifican la doctrina del levantamiento del velo para evitar el fraude fiscal en el proceso de recaudación en algunos preceptos de la normativa foral.

${ }^{845}$ ZORNOZA PÉREZ, J., "Levantamiento del velo y determinación de la cuota en el delito de defraudación tributaria", Derecho de los Negocios, enero de 2002, pág. 7.

${ }^{846}$ MARTÍN JIMÉNEZ, A., "Responsabilidad tributaria, Constitución y Derecho Comunitario", en la obra Tratado sobre la Ley General Tributaria, Tomo I, ARRIETA MARTÍNEZ DE PISÓN, J., COLLADO YURRITA, M. A., ZORNOZA PÉREZ, J. (directores), Aranzadi, Thomson Reuters, Navarra, 2010, pág. 928.

${ }^{847}$ MARTÍN JIMÉNEZ, A., Los supuestos de responsabilidad en la LGT: (hacia una configuración constitucional y comunitaria de la responsabilidad tributaria), op. cit., pág. 341.

${ }^{848}$ Este autor es de la opinión que la finalidad de ambos preceptos no es en el sentido técnico tributario de fraude de ley o conflicto en la aplicación de la norma, sino "en la intención premeditada del obligado tributario de eludir el pago de la deuda, mediante la falaz apariencia de la personación" (DE GANDARILLAS MARTOS, S., "Las modificaciones introducidas por la Ley 36/2006 de prevención del fraude fiscal en la responsabilidad tributaria: levantamiento del velo”, op. cit., pág. 101).

${ }^{849}$ MARTÍN JIMÉNEZ, A., Los supuestos de responsabilidad en la LGT: (hacia una configuración constitucional y comunitaria de la responsabilidad tributaria), op. cit., pág. 342. Por el contrario, para ALONSO GONZÁLEZ, L. M., "El proyecto de Ley de Medidas para la Prevención del Fraude Fiscal”, Temas Tributarios de Actualidad, núm. 7-10, 2006, pág. 24 y 25, y CAYÓN GALLARDO, A. M., "El Proyecto de Ley de Medidas para la Prevención del Fraude Fiscal: otro enfoque", Revista de Técnica Tributaria, núm. 72 , 2006, pág. 16, la regulación y naturaleza del levantamiento del velo en los incisos $g$ ) y h) del apartado primero del artículo 43 de la LGT tiene carácter sancionador.
} 
que ésta se encuentra en la fase recaudatoria para aplicar la figura del fraude de ley o de la simulación $^{850}$.

Ahora bien, de los presupuestos de hecho a través de los cuales la Administración tributaria declara el carácter de responsable de estos sujetos, destacan el control efectivo, total o parcial, directo o indirecto; la voluntad rectora común; la unicidad de persona o esferas económicas; la confusión patrimonial; y la desviación patrimonial. En este sentido, MARTÍNEZ LAGO, y ALMUDÍ CID, entienden que es correcto que la norma no precise el porcentaje del control, pues asumen el criterio de que lo determinante es que los socios ejerzan "el control efectivo de la sociedad en términos políticos o de facto, esto es, ostentando directa o indirectamente la mayoría de derechos de voto, por su influencia decisiva en el nombramiento o destitución del órgano de administración de la entidad, por controlar de hecho la gestión y administración sin designación formal” ${ }^{, 851}$.

El segundo de los presupuestos de hecho, la voluntad rectora común, parte del deseo del legislador de configurar un presupuesto que determine el control horizontal que ubica en el mismo nivel a deudores y responsables. En este caso la ley omite cualquier comentario al respecto, por lo que se aceptan los supuestos en los que puede proceder el levantamiento del velo ${ }^{852}$.

Con los presupuestos de unicidad de personas o esferas económicas y la confusión o desviación patrimonial lo que se pretende es determinar la falta de voluntad propia o autónoma de la persona jurídica y su dependencia con la voluntad ajena o externa. Corresponde en todo caso a la Administración tributaria demostrar el empleo abusivo o fraudulento de la persona jurídica en los casos de sociedades ficticias que no disponen de funcionamiento real, por lo que carecen de consistencia y se conforman como un instrumento de otra personalidad, o la existencia de un único deudor que se sirve de sucesivas sociedades para evadir los pasivos fiscales y continuar con la actividad económica valiéndose del hermetismo de las personas jurídicas. La confusión o desviación patrimonial se destina a entidades cuyo funcionamiento es el mismo, ya fuera interna o externamente. A su vez, la confusión del patrimonio se refiere a la confusión evidente y plena a través de la cual un tercero debe utilizar el patrimonio social como si fuera el suyo propio sin que medie contraprestación alguna.

Por último, para determinar la desviación patrimonial deberá diferenciarse entre la infracapitalización y la descapitalización. Este presupuesto objetivo permite identificar el traslado del patrimonio de una persona jurídica o física hacia otra sociedad. Esta operación por sí sola no justifica levantar el velo,

\footnotetext{
${ }^{850}$ Explica ECHEVARRIETA SAZATORNIL J. M., "Los nuevos supuestos de responsabilidad”, op. cit., pág. 39, que la Ley de Medidas de Prevención del Fraude Fiscal limita el levantamiento del velo sólo a la fase de ejecución dentro del procedimiento tributario, alegando, precisamente, la naturaleza jurídica de la figura de la responsabilidad.

${ }^{851}$ MARTÍNEZ LAGO, M. A y ALMUDÍ CID, J. M., “Autotutela tributaria, «el levantamiento del velo» y derivación de la responsabilidad a las sanciones (análisis de los nuevos supuestos de responsabilidad incorporados a la Ley general Tributaria por la Ley 36/2006, de 29 de noviembre, y el procedimiento de derivación de la responsabilidad a las sanciones tributarias), op. cit., pág. 19.

${ }^{852}$ Los relaciona SÁNCHEZ CASAL, A., El "levantamiento del velo" y su plasmación en la Ley General Tributaria. Análisis del artículo $43.1 \mathrm{~g}$ ) y h) de la Ley 58/2003, op. cit., pág. 59, de la siguiente forma: "Cuando varias sociedades o entidades actúan coordinadamente entre ellas, sin que exista la subordinación vertical o un tercero, tal y como sucede, por ejemplo en el caso de la Uniones Temporales de Empresas. (...) Cuando varias sociedades o entidades sometidas a una dirección unitaria por otra persona, físico jurídica, se encuentran en un mismo plano respecto de quien ejerce esa voluntad unitaria. Este sería el caso de dos sociedades dominadas por un mismo grupo sobre las cuales ejerce el control efectivo una misma sociedad dominante o bien de dos sociedades instrumentales de una misma familia".
} 
pues para ello se requiere, además, la concurrencia de actuaciones irregulares fraudulentas que ocasionan daño a los acreedores sociales.

Para que la Administración tributaria pueda levantar el velo, necesita, según la propia norma sustantiva, que se pruebe que la sociedad fue creada o utilizada de forma abusiva o fraudulenta con la intención de eludir la responsabilidad patrimonial universal frente a la Hacienda Pública. Por tanto, corresponde a aquélla demostrar que la finalidad que se persigue con su creación es la evadir el pago de los tributos, independientemente que pueda ir acompañada o no de intereses económicos, sin olvidar que esta doctrina constituye un recurso de última instancia.

Finalmente, la responsabilidad subsidiaria prevista en el inciso $g$ ) del apartado primero del artículo 43 de la LGT determina que la responsabilidad se extienda a las obligaciones tributarias y a las sanciones de dichas personas jurídicas. De la misma manera se pronuncia el legislador en el inciso $h$ ) del precepto, al extender las sanciones a esos tipos de responsabilidad. Asumiendo las críticas de FALCÓN Y TELLA ${ }^{853}$ y DE GANDARILLAS MARTOS ${ }^{854}$, MARTÍNEZ LAGO expresó que los supuestos de responsabilidad tributaria por levantamiento del velo están "configurados con tal ambigüedad e imprecisión que difícilmente resultará constitucionalmente admisible la responsabilidad tributaria, y menos aún respecto de las sanciones, pues se trata de exigir la deuda o la sanción a una persona distinta, la cual no puede conocer de antemano si incurre en el supuesto de hecho previsto en la norma. Por otro lado, la práctica totalidad de las conductas incorporadas a la LGT, si se prueban, pueden constituir insolvencias punibles tipificadas en los artículos 257 a 261 del $\mathrm{CP}$, de manera que, o bien se ha cometido un delito, en cuyo caso la Hacienda Pública no puede actuar, o bien no existe voluntad de impedir la eficacia de un embargo administrativo, en cuyo caso no puede exigirse la deuda ni la sanción a una persona distinta del obligado" ${ }^{~} 55$.

2.4.2.7. Administradores de personas jurídicas obligadas a efectuar la declaración e ingreso de las deudas tributarias que deban repercutirse o de cantidades que deban retenerse

Con la entrada en vigor de la Ley $7 / 2012$, se introdujo un nuevo supuesto de responsabilidad subsidiaria. El nuevo apartado segundo del artículo 43 de la LGT regula la responsabilidad subsidiaria de los administradores de hecho o de derecho de las personas jurídicas obligadas a efectuar la declaración e ingreso de las deudas tributarias que deban repercutirse o de cantidades que deban retenerse.

En este sentido, dispone dicho precepto que

"Serán responsables subsidiarios de las deudas tributarias derivadas de tributos que deban repercutirse o de cantidades que deban retenerse a trabajadores, profesionales u otros empresarios, los administradores de hecho o de derecho de las personas jurídicas obligadas a efectuar la declaración e ingreso de tales deudas

\footnotetext{
${ }^{853}$ FALCÓN Y TELLA, R., "Otras medidas para la prevención del fraude contenidas en la Ley 36/2006, de 29 de diciembre (y II)", Quincena Fiscal, núm. 3-4, 2007, pág. 9 y 10.

${ }^{854}$ DE GANDARILLAS MARTOS, S., "Las modificaciones introducidas por la Ley 36/2006 de prevención del fraude fiscal en la responsabilidad tributaria: levantamiento del velo", Documentos- Instituto de Estudios Fiscales, núm. 26, 2007, pág. 21.

${ }^{855}$ MARTÍNEZ LAGO, M. A., La extensión de la responsabilidad a las sanciones tributarias, op. cit., pág. 338.
} 
cuando, existiendo continuidad en el ejercicio de la actividad, la presentación de autoliquidaciones sin ingreso por tales conceptos tributarios sea reiterativa y pueda acreditarse que dicha presentación no obedece a una intención real de cumplir la obligación tributaria objeto de autoliquidación".

Según la Exposición de Motivos de la Ley 7/2012, la finalidad de este supuesto es la de "facilitar la acción de cobro contra los administradores de aquellas empresas que carentes de patrimonio, pero con actividad económica regular, realizan una actividad recurrente y sistemática de presentación de autoliquidaciones formalmente pero sin ingreso por determinados conceptos tributarios con ánimo defraudatorio".

Se trata de otro supuesto de responsabilidad cuyo ámbito subjetivo involucra a los administradores de personas jurídicas. Sobre la condición de administrador de hecho o de derecho nos hemos referido cuando analizábamos la responsabilidad subsidiaria que regula los incisos a) y b) del apartado primero del artículo 43 de la LGT, y creemos que es posible trasladar los criterios que sostuvimos en aquel momento para este nuevo supuesto de responsabilidad subsidiaria. Aquí también hemos de destacar que el precepto no hace alusión al tipo de actuación, lícita o ilícita del administrador. Además del requisito de que debe ser un administrador de hecho o derecho, el presupuesto de hecho de esta modalidad de responsabilidad precisa que la persona jurídica presente autoliquidaciones sin ingreso de manera reiterativa con la intención de aparentar un posible cumplimiento de la obligación tributaria objeto de la autoliquidación.

Como puede apreciarse, se configura una responsabilidad objetiva que se articula ante la imposibilidad de hacer efectivo el cobro por parte de la Administración tributaria, sin tener en cuenta la actuación del administrador. No se produce en este supuesto ninguna infracción de la persona jurídica, por lo que resulta conveniente diferenciar este tipo de responsabilidad subsidiaria del supuesto que aparece regulado en el inciso b) del primer apartado del artículo 43 de la LGT. En el caso de este último tipo de responsabilidad subsidiaria debemos recordar que su presupuesto de hecho se integra por la conducta ilícita pasiva del administrador de hecho o de derecho, que no existe infracción por parte de la persona jurídica, y que además se produce el cese de la actividad de ésta. Apuntábamos más arriba que la responsabilidad por cese en las actividades de la persona jurídica requiere, para que se produzca su presupuesto de hecho, que el cese sea total, sin que llegue a la pérdida de la personalidad jurídica por la disolución o liquidación, y sin que se acepte tampoco una paralización o suspensión parcial de la actividad. En cambio, este nuevo apartado segundo del artículo 43 de la LGT exige expresamente la continuidad en el ejercicio de la actividad.

Por otra parte, la ley determina algunos de los términos que se integran al presupuesto de hecho de este nuevo tipo de responsabilidad. Así vemos como el precepto dispone que existe reiteración en la presentación de autoliquidaciones cuando

"en un mismo año natural, de forma sucesiva o discontinua, se hayan presentado sin ingreso la mitad o más de las que corresponderían, con independencia de que se hubiese presentado solicitud de aplazamiento o fraccionamiento y de que la presentación haya sido realizada en plazo o de forma extemporánea". 
Y más adelante aclara que no se computarán aquellas autoliquidaciones que se presentaron junto con una solicitud de aplazamiento o fraccionamiento concedida en virtud de una resolución expresa, salvo que posteriormente se produzca el incumplimiento de los plazos y con independencia del momento de dicho incumplimiento, no computándose, en ningún caso, aquéllos que hubiesen sido concedidos con garantía debidamente formalizada.

A su vez, a los efectos de este tipo de responsabilidad subsidiaria, se entiende que la presentación de las autoliquidaciones se efectúa sin ingreso cuando, aun existiendo ingresos parciales en relación con todas o algunas de las autoliquidaciones presentadas, el importe total resultante de tales ingresos durante el año natural no supere el 25 por 100 del sumatorio de las cuotas a ingresar autoliquidadas.

Por otra parte, creemos que corresponde a la Administración tributaria demostrar que la presentación de la autoliquidación no obedece a una intención real de cumplir la obligación tributaria objeto de la misma. Para ello, la norma prevé que no existe intención real de cumplimiento de las obligaciones contempladas en la autoliquidación que presenta la persona jurídica

"cuando se hubiesen satisfecho créditos de titularidad de terceros de vencimiento posterior a la fecha en que las obligaciones tributarias a las que se extiende la responsabilidad establecida en esta disposición se devengaron o resultaron exigibles y no preferentes a los créditos tributarios derivados de estas últimas".

Por otro lado, el elemento objetivo del presupuesto de hecho lo integran los tributos que deban repercutirse o las cantidades que deban retenerse a trabajadores, profesionales u otros empresarios. El legislador establece la responsabilidad de los administradores sobre deudas del IVA y los Impuestos Especiales. También declara la responsabilidad de las cantidades que deban retenerse a trabajadores, profesionales u otros empresarios, a cuenta, normalmente del IRPF y en algunas ocasiones del IS y del Impuesto sobre la Renta de los No Residentes. Finalmente, la responsabilidad se extenderá a las deudas tributarias devengadas de estos impuestos, con excepción de las sanciones, que, siguiendo el régimen general previsto en el apartado cuarto del artículo 41 de la LGT, quedarán fuera del alcance de la responsabilidad.

En resumen, nuevamente el legislador recurre a este tipo de garantía ante la imposibilidad de cobro del crédito tributario sin tener en consideración la participación del presunto responsable en las actuaciones de la persona jurídica que tiene la intención de defraudar. El administrador se convierte en responsable por el sólo hecho de desempeñar esta función dentro de aquélla. Creemos que en este caso lo apropiado sería que se configurara el presupuesto de hecho de la responsabilidad a partir de la actuación ilícita, activa o pasiva, del administrador de hecho o de derecho de la persona jurídica obligada a presentar autoliquidaciones e ingresos de las deudas tributarias que deban repercutirse o de cantidades que deban retenerse a trabajadores, profesionales u otros empresarios, cuando, existiendo continuidad en el ejercicio de la actividad, la presentación de autoliquidaciones sin ingreso por tales conceptos tributarios sea reiterativa y pueda acreditarse que dicha presentación no obedece a una intención real de cumplir la obligación tributaria objeto de autoliquidación. 


\subsection{LA PLURALIDAD DE RESPONSABLES TRIBUTARIOS}

Una de las cuestiones que resulta interesante y a la vez controvertida de las situaciones en las que puede verse involucrado el responsable tributario es la concurrencia de varios responsables en la realización del presupuesto de hecho. El número 7 del artículo 35 de la LGT establece que la concurrencia de varios obligados tributarios en un mismo presupuesto de una obligación determinará que queden solidariamente obligados frente a la Administración tributaria, salvo que por ley se disponga expresamente otra cosa. Anteriormente, el artículo 34 de la LGT de 1963 establecía que la concurrencia de dos o más titulares en el hecho imponible determinará que quedarán solidariamente obligados frente a la Hacienda Pública, salvo que la ley propia de cada tributo dispusiere lo contrario. El presupuesto legal de la regla de la solidaridad fue una constante en las normas que se sucedieron en el tiempo. Así, el apartado sexto del artículo 37 de la propia LGT de 1963 reconocía que cuando fueran dos o más los responsables solidarios o subsidiarios de una misma deuda se podría exigir ésta íntegramente a cualquiera de ellos. En estos mismos términos se decantó la Ley 25/1995, al modificar el artículo 37, y se reprodujo posteriormente en el número 7 del artículo 35 de la LGT del 2003.

En el ámbito reglamentario, el RGR de 1968 determinaba en el apartado 4 del artículo 10 y en el apartado segundo del artículo 11 que la presencia de varios responsables solidarios o subsidiaros en una misma deuda colocaba a estos sujetos solidariamente frente a la Administración tributaria. Asimismo, el RGR de 1990 dispuso en el apartado 7 de su artículo 12 que

"cuando sean varios los responsables solidarios de una misma deuda, la responsabilidad de los mismos frente a la Hacienda Pública será a su vez solidaria, salvo que la Ley disponga expresamente otra cosa”.

Como se puede apreciar, en el Derecho tributario se ha venido utilizando el instituto de la solidaridad, aunque no de manera muy clara. Así lo pone de manifiesto NAVARRO FAURE, cuando dice que "la Ley General Tributaria y las leyes tributarias particulares utilizan de una forma ambigua y poco depurada los términos de responsabilidad, solidaridad y responsabilidad tributaria solidaria" ${ }^{\circledR 56}$. Y es que la norma tributaria utiliza un mismo término para identificar dos relaciones obligacionales distintas, ya que el término de solidaridad en el Derecho civil es único, pero no sucede lo mismo en el ámbito tributario.

En el Derecho tributario se pueden diferenciar varias relaciones obligacionales, entre otras: deudor principal y responsable; pluralidad en la realización del hecho imponible; pluralidad de responsables solidarios o subsidiarios; y pluralidad de sucesores de la deuda tributaria. Podemos apreciar que en la normativa tributaria se distinguen dos formas de solidaridad, pero sólo en la primera de las relaciones obligacionales (deudor principal y responsable) los sujetos se encuentran en diferente posición en relación con la deuda tributaria. Así, siguiendo con lo dispuesto en la legislación, tanto la anterior como la actual, podemos obtener una regla que permite identificar cuándo la norma tributaria se refiere a la solidaridad en su acepción civil o cuándo lo hace con el alcance de la ley tributaria. En este sentido, apoyándonos en la doctrina de GALÁN RUIZ, "si la relación obligacional se estable

\footnotetext{
${ }^{856}$ NAVARRO FAURE, A., "Los supuestos de responsabilidad tributaria solidaria en el ordenamiento tributario español (II)”, Revista de Derecho Financiero y Hacienda Pública, núm. 227, 1993, pág. 867.
} 
entre sujetos que se encuentran en la misma posición frente a la deuda, como ocurre en las relaciones entre cotitulares del hecho imponible, entre responsables, o entre sucesores de la deuda, entre otros, el término solidaridad habrá que entenderlo en su acepción civil. Sin embargo, si los obligados tributarios están en una posición distinta frente a la deuda tributaria, como ocurre en el caso de las relaciones entre el deudor principal y responsable solidario, el alcance que debemos otorgar al término es el establecido por la norma tributaria" ${ }^{~}{ }^{25}$.

\subsubsection{La solidaridad en el ámbito civil y la responsabilidad tributaria solidaria}

La doctrina coincide en que las relaciones obligacionales en el ámbito civil y en el ámbito tributario no puede identificarse de la misma manera ${ }^{858}$. El Código Civil hace referencia, respecto a los sujetos de la relación obligacional, a la mancomunidad y la solidaridad, mientras que en la LGT se habla de responsabilidad solidaria y subsidiaria. Las diferencias fundamentales se manifiestan en la cuantía de la deuda que debe exigirse y en el procedimiento que se sigue para su cobro. En la regulación civil, en el caso de que los sujetos estén obligados solidariamente, se podrá demandar la totalidad de la deuda a cualquiera de los deudores, y si lo están en la forma mancomunada la cuantía se fijará en función de la parte que a cada sujeto le corresponde. En el ámbito tributario esto no es así, porque el responsable tributario solidario no responde en todos los casos de la totalidad de la deuda tributaria. Es el caso de la LGT de 1963, que regulaba en su artículo 39 el supuesto de responsabilidad de los copartícipes o cotitulares de entidades jurídicas, que actualmente se reconoce en el inciso b) del apartado primero del artículo 42 de la LGT. En este caso la responsabilidad, pese a denominarse solidaria, es equivalente a la mancomunada, ya que estos responsables asumen sólo la proporción que corresponde a sus respectivas participaciones, por lo que algunos autores la califican de responsabilidad impropia ${ }^{859}$. De igual manera podemos citar el apartado cuarto del artículo 89 de la LGT de 1963, que dispuso la responsabilidad solidaria de las sociedades o entidades disueltas y liquidadas, y en cuyo ámbito las obligaciones tributarias pendientes se transmitiesen a los socios o partícipes en el capital, respondiendo de ellas solidariamente pero teniendo como límite la cuota de liquidación adjudicada. Asimismo, en el Derecho civil, lo solidario se contrapone a lo mancomunado. Sin embargo, la responsabilidad subsidiaria no es contraria a la solidaria en el sentido que atribuye la normativa civilista. Esto se debe a que en el ámbito civil los obligados de forma mancomunada responden de la parte y en cambio los que están obligados solidariamente deberán satisfacer la

\footnotetext{
${ }^{857}$ GALÁN RUIZ, J., La responsabilidad tributaria, op. cit., pág. 51. FALCÓN Y TELLA considera que la solidaridad desde el ámbito civil para los cotitulares del hecho imponible tampoco coincide plenamente con la solidaridad recogida en el Código Civil. Según este autor, "la doctrina tributarista, sin embargo, construye el concepto de solidaridad en base no sólo a la existencia de una pluralidad de sujetos y a la identidad de la prestación, sino que añade una tercera característica basada en la existencia de una misma causa obligandi, entendida ésta como la realización del mismo hecho imponible" (FALCÓN Y TELLA, R., "La solidaridad tributaria", Crónica Tributaria, núm. 50, 1984, pág. 143). Sobre la solidaridad tributaria, vid. supra, Capítulo Cuarto, epígrafe, 1. "La solidaridad tributaria pasiva".

${ }^{858}$ CALVO ORTEGA, R., "La responsabilidad tributaria solidaria por actos ilícitos”, op. cit., pág. 47 a 50; MORILLO MÉNDEZ, A., "Responsabilidades solidarias y subsidiarias después de la Ley 10/1985 de modificación parcial de la Ley General Tributaria", Crónica Tributaria, núm. 53, 1985, pág. 226.

${ }^{859}$ CASADO OLLERO, G., FALCÓN Y TELLA, R., LOZANO SERRANO, C., y SIMÓN ACOSTA, E., "Las garantías del crédito tributario", op. cit., pág. 219; FERNÁNDEZ JUNQUERA, M., "Reflexiones en torno al responsable solidario y a la solidaridad en Derecho tributario", en la obra Sujetos Pasivos y Responsables Tributarios, Instituto de Estudios Fiscales-Marcial Pons, Madrid, 1997, pág. 641; MORILLO MÉNDEZ, A., "Responsabilidades solidarias y subsidiarias después de la Ley 10/1985 de modificación parcial de la Ley General Tributaria", op. cit., pág. 230; LÓPEZ DÍAZ, A., "La responsabilidad solidaria en el nuevo Reglamento General de Recaudación", op. cit., pág. 36; BANACLOCHE PÉREZ-ROLDÁN, J., "La nueva Ley General Tributaria. Responsables e infractores", Impuestos, Tomo II, 1985, pág. 10.
} 
totalidad de la deuda tributaria ${ }^{860}$. Por su parte, en el caso de la responsabilidad tributaria solidaria, no ocurre siempre lo mismo: como vimos, existen supuestos de responsabilidad solidaria en que los sujetos responsables no tendrán que hacer frente a la totalidad de la deuda tributaria.

Otra diferencia entre la solidaridad en el ámbito civil y la responsabilidad tributaria solidaria aparece en el procedimiento para el cobro de la deuda. En el caso de la solidaridad civil, los deudores están en un plano de igualdad y cualquiera de ellos puede responder totalmente de la deuda. En la responsabilidad tributaria solidaria, tanto en la LGT como en el RGR, el deudor principal no se encuentra en el mismo plano que el responsable, puesto que para exigir la deuda a éste último será necesario que haya transcurrido el período voluntario de pago y que el deudor principal no haya satisfecho la deuda ${ }^{861}$. Es decir, "para que ambos obligados al pago, el deudor principal y el responsable solidario, se encuentren en una misma situación respecto de la exigibilidad del pago ha de darse el incumplimiento de ingreso en período voluntario del deudor principal" ${ }^{\prime \prime 62}$. Y ni siquiera en este momento ambos sujetos ocuparán la misma posición, pues el deudor principal no pierde su condición frente a la Hacienda Pública y el responsable solidario, por su parte, puede resarcirse con el derecho de reembolso que le confiere la ley. Este derecho de reembolso no presenta las mismas características que se encuentran en la solidaridad civil. En efecto, según el 1.145 del Código Civil, el obligado solidario tiene derecho de repetición contra el resto de los demás deudores, pero éstos sólo reintegrarán la cuota que les corresponde.

\subsubsection{Supuestos de solidaridad civil y de mancomunidad en la LGT}

Anteriormente hemos indicado que la solidaridad referida una pluralidad de individuos en el lado pasivo de la relación jurídica tiene un alcance diferente en el ámbito tributario en función de la relación obligacional que aparezca, ya sea por la existencia de varios titulares en la realización del

\footnotetext{
${ }^{860}$ Para CASADO OLLERO, FALCÓN Y TELLA, LOZANO SERRANO, y SIMÓN ACOSTA, "la solidaridad es un concepto jurídico que se contrapone a la mancomunidad simple, de forma que si una forma de responsabilidad es solidaria, la otra debería ser, lógicamente, mancomunada. Pero es evidente que el responsable no responde mancomunadamente, sino que su responsabilidad se extiende -salvo excepciones- a la totalidad de la deuda, por lo que también es responsable solidario. Cosa distinta es que el responsable subsidiario sólo responda una vez que se haya hecho excusión de los bienes del deudor principal" (CASADO OLLERO, G., FALCÓN Y TELLA, R., LOZANO SERRANO, C., y SIMÓN ACOSTA, E., "Las garantías del crédito tributario", op. cit., pág. 219). En cambio para LÓPEZ DÍAZ, la solidaridad y la subsidiaridad se oponen no en relación a la cuantía, sino en lo relativo al momento en que van hacer llamados por la Administración tributaria para que respondan por la totalidad de la deuda tributaria (LÓPEZ DÍAZ, A., "La responsabilidad solidaria en el nuevo Reglamento General de Recaudación”, op. cit., pág. 36).

${ }^{861}$ Según PÉREZ ROYO y AGUALLO AVILÉS cuando existan dos o más responsables ya sean solidarios o subsidiarios, éstos deben responder frente a la Administración tributaria de manera solidaria. Solidaridad que en este caso se contrapone a la mancomunidad, tal como afirma la Sentencia del Tribunal Superior de Justicia de Galicia de 30 de septiembre de 1994 (PÉREZ ROYO, F y AGUALLO AVILÉS, A., Comentarios a la Reforma de la Ley General Tributaria, op. cit., pág. 107).

${ }^{862}$ GALÁN RUIZ, J., La responsabilidad tributaria, op. cit., pág. 55. LAGO MONTERO manifiesta que "la solidaridad es un concepto «importado» por el Derecho tributario procedente del derecho civil, que, aplicado al responsable, necesita aclaraciones y ajustes. Ello es así porque es la esencia de la solidaridad civil el que el acreedor pueda exigir indistintamente el cumplimiento de la prestación a uno u otro deudor solidario. Pues bien, en nuestro Derecho tributario creemos que la Hacienda Pública carece de ese poder de elección cuando se encuentra ante un deudor y un responsable «solidario». De ahí que la llamada solidaridad aplicada a un responsable lo sea con carácter atemperado o impropio" (LAGO MONTERO, J. M., "El procedimiento de declaración de la responsabilidad tributaria: una crítica", op. cit., pág. 667 y 668). Para COMBARROS VILLANUEVA y MAZORRA MANRIQUE DE LARA, si la Administración tributaria pudiera dirigirse indistintamente al deudor principal y al responsable solidario los contornos jurídicos de la responsabilidad solidaria desaparecerían, observándose perfiles que el legislador tiene concebidos para la figura de la solidaridad (COMBARROS VILLANUEVA, V. E., "La responsabilidad tributaria, solidaria y subsidiaria, en el procedimiento de recaudación", op. cit., pág. 380; MAZORRA MANRIQUE DE LARA, S., "La obligación de los responsables tributarios en el Reglamento General de Recaudación: nacimiento y exigibilidad", op. cit., pág. 72).
} 
hecho imponible, por la presencia de varios responsables o sucesores, o bien por la concurrencia de la responsabilidad solidaria en el pago de la deuda tributaria.

La LGT de 1963 recogía dos supuestos en los que el alcance de la solidaridad era la prevista en el Derecho civil: el artículo 34 y el apartado 6 del artículo 37. El primero de los preceptos se aplicaba cuando existía una pluralidad de personas que ocupaban la misma posición ante la deuda, y en ella todos estos sujetos eran considerados como deudores principales y quedaban obligados solidariamente al pago de la deuda. Este artículo fue interpretado por la Sentencia del Tribunal Superior de Justicia de Castilla y León, de 10 de junio de 1994, afirmando que el acreedor "puede dirigirse por el «totum» de la deuda frente a cualquier deudor solidario, sin perjuicio de que en el ámbito interno de los deudores la deuda sea mancomunada o «a pro rata», cuestión ajena al Derecho fiscal".

Por su parte, el número 6 del artículo 37 de la LGT de 1963 dispuso que

"Cuando sean dos o más los responsables solidarios o subsidiarios de una misma deuda, ésta podrá exigirse íntegramente a cualquiera de ellos".

Ahora bien, en la LGT de 1963 también se reconocían dos tipos de obligaciones mancomunadas, en los artículos 39 y el apartado cuarto del artículo 89. Este último precepto preveía que

"En el caso de Sociedades o Entidades disueltas y liquidadas, sus obligaciones tributarias pendientes se transmitirán a los socios o partícipes en el capital, que responderán de ellas solidariamente y hasta el límite del valor de la cuota de liquidación que se les hubiere adjudicado".

En este supuesto no se puede hablar de una solidaridad civil porque el sujeto no responde de toda la deuda, dado que el límite se encuentra en su cuota de liquidación, acercándose más a un caso de obligaciones mancomunadas, toda vez que el responsable no hace frente a la totalidad de la deuda tributaria sino sólo a una cuota-parte.

Esta misma circunstancia se observa en el mandato del artículo 39 de la LGT de 1963, según el cual

"Los copartícipes o cotitulares de las Entidades jurídicas o económicas a que se refiere el artículo 33 de la Ley General Tributaria responderán solidariamente, y en proporción a sus respectivas participaciones de las obligaciones tributarias de dichas Entidades".

En este supuesto, según GALÁN RUIZ, la solidaridad sólo se refiere "al momento en que los responsables pueden ser impelidos al pago de la deuda, pero la obligación de pago de la deuda es mancomunada, pues sólo responde cada uno en proporción a sus participaciones sociales" ${ }^{\text {"863. }}$.

En la actualidad, y teniendo en cuenta el contenido del apartado 7 del artículo 35 de la LGT, podemos decir que los obligados al pago responden solidariamente ante la Administración tributaria. Sin

\footnotetext{
${ }^{863}$ GALÁN RUIZ, J., La responsabilidad tributaria, op. cit., pág. 58.
} 
embargo, algunos preceptos que configuran determinados obligados regulan de forma expresa una obligación mancomunada. Tal es el caso del apartado primero del artículo 40 de la LGT que determina que

"Las obligaciones tributarias pendientes de las sociedades y entidades con personalidad jurídica disueltas y liquidadas en las que la Ley limita la responsabilidad patrimonial de los socios, partícipes o cotitulares se transmitirán a éstos, que quedarán obligados solidariamente hasta el límite del valor de la cuota de liquidación que les corresponda".

A su vez, el inciso b) del apartado primero del artículo 42 de la LGT establece que los partícipes o colaboradores de las herencias yacentes, comunidades de bienes y demás entidades, que sin tener personalidad jurídica, constituyan una unidad económica o un patrimonio separado, susceptible de imposición, serán responsables solidarios

"en proporción de sus respectivas participaciones respecto a las obligaciones tributarias materiales de dichas entidades".

En aplicación del apartado 7 del artículo 35 de la LGT, se impondrá el régimen de solidaridad cuando la Administración tributaria conozca sólo la identidad de uno de los obligados, practicándose sobre éste las liquidaciones. Por el contrario, si conoce la identidad de cada uno de los obligados, así como su participación, se practicará liquidación sobre cada uno de ellos en la porción que le corresponda. Asimismo, este precepto facilita al deudor del que se conoce la identidad que solicite la división, aportando los datos del resto de coobligados, así como la proporción en que cada uno de ellos participa en el dominio o derecho trasmitido.

Con la introducción de la mancomunidad el legislador tributario permite la coexistencia de ambos regímenes, pero no resulta claro cuándo se aplica cada uno de ellos. Según FALCÓN Y TELLA, el régimen que se regula, en estos casos, es de la mancomunidad con carácter general, salvo que la Administración tributaria no conozca la identidad de los coobligados o la proporción que corresponden a cada uno de ellos, en cuyo caso se aplicaría la solidaridad. De lo contrario, si el obligado que identifique la Administración tributaria aporta los datos personales y el domicilio, así como la proporción del resto de obligados, se emplearía el régimen de la mancomunidad ${ }^{864}$. El fundamento de esta interpretación que hace FALCÓN Y TELLA parte del criterio defendido también por CALVO ORTEGA de que el legislador seguía la línea de "individualización y desagregación económica de los concurrentes" $" 865$. Sobre estos planteamientos de FALCÓN Y TELLA es posible oponer críticas por dos razones: por la posibilidad de que la pluralidad de obligados tributarios se produzca sobre sujetos para garantizar el crédito tributario, apartándose de las exigencias propias derivadas de la capacidad económica, y por el hecho de que algunos obligados tributarios carezcan de

\footnotetext{
${ }^{864}$ FALCÓN Y TELLA, R., "El art. 35.6 de la nueva LGT (II): ¿un régimen de mancomunidad con la carga de identificar a los coobligados?", Quincena Fiscal, núm. 3-4, enero, 2004, pág. 5 a 8. En esta línea, vid. LÓPEZ LÓPEZ, H., “Aspectos controvertidos en la regulación de la pluralidad de obligados tributarios en el mismo presupuesto de una obligación", en la obra Tratado sobre la Ley General Tributaria, Tomo I, ARRIETA MARTÍNEZ DE PISÓN, J., COLLADO YURRITA, M. A., ZORNOZA PÉREZ, J. (directores), Aranzadi, Thomson Reuters, 2010, pág. 865 a 868.

${ }^{865}$ CALVO ORTEGA, R., “Obligados tributarios”, op. cit., pág. 139.
} 
porcentajes respecto de la deuda tributaria. Por otro lado, si el régimen general es el de la mancomunidad y la Administración tributaria conoce sólo la identidad de uno de los obligados y éste a su vez desconoce la identidad del resto de los obligados, no tendría sentido el párrafo primero del apartado 7 del artículo 35 de la LGT, que determina la solidaridad.

\subsubsection{El carácter mancomunado o solidario de la obligación de pago en el supuesto de pluralidad de responsables tributarios}

La mancomunidad es la regla general para el ámbito civil, mientras que en el Derecho tributario la concurrencia de cotitulares en el hecho imponible o la concurrencia de responsables determina que estos sujetos queden obligados solidariamente frente a la Administración tributaria, según dispone el apartado 7 del artículo 35 de la LGT. Solidaridad que, como ya dijimos, debe ser entendida en su acepción civil $^{866}$.

Sobre la base de este precepto, GUERRA REGUERA interpreta que "si concurre un responsable solidario y un responsable subsidiario, terminado el período voluntario, la Administración podría dirigirse contra el solidario, no contra el subsidiario", porque ésta "debe primero agotar las acciones de cobro contra el responsable solidario para poder dirigirse con posterioridad al subsidiario", y "en consecuencia, la solidaridad entre ambos obligados se hace prácticamente inviable. De modo que sólo los responsables solidarios pueden ser solidarios entre sí, y lo mismo debe decirse respecto de los responsables subsidiarios" ${ } 867$.

Para MARTÍN JIMÉNEZ, el apartado 7 del artículo 35 de la LGT está pensado para supuestos distintos: "asumiendo que los responsables que comparten presupuesto (...) no tienen el beneficio de la división y que la responsabilidad, entre ellos, es solidaria, se plantea hasta qué punto no puede ser arbitrario que la Administración se dirija contra uno y no contra todos. Debemos recordar la doctrina de los tribunales en este punto que exige que el ius variandi del que goza la Administración no sea ejercido de forma arbitraria (...) o que la Administración emita, a fin de facilitar la repercusión a los codeudores, tantas declaraciones de responsabilidad como deudores existan, aunque sea notificada sólo a uno de ellos" ${ }^{\prime 868}$.

En definitiva, según nuestro parecer, es posible realizar varios pronunciamientos en relación con el apartado 7 del artículo 35 de la LGT $^{869}$. Lo primero destacable es la alusión de este precepto a la

\footnotetext{
${ }^{866}$ DE LA HUCHA CELADOR, F., "Algunas consideraciones sobre la responsabilidad tributaria en el Reglamento General de Recaudación de 1990: II. Responsabilidad Subsidiaria”, op. cit., pág. 65.

${ }^{867}$ GUERRA REGUERA, M., Garantías personales del crédito tributario. Algunas cuestiones, op. cit., pág. 550. En esta línea, se pronuncian la Resolución del TEAC de 22 de febrero de 1995 y la Sentencia del Tribunal Superior de Justicia de Castilla y León, Burgos, de 17 de mayo de 2001. En contra, vid. la Sentencia del Tribunal Superior de Justicia de Galicia, de 30 de septiembre de 1994, y, en la doctrina, MARTÍN JIMÉNEZ, A., Los Supuestos de responsabilidad en la LGT: (hacia una configuración constitucional y comunitaria de la responsabilidad tributaria), op. cit., pág. 185.

${ }^{868}$ MARTÍN JIMÉNEZ, A., Los Supuestos de responsabilidad en la LGT: (hacia una configuración constitucional y comunitaria de la responsabilidad tributaria), op. cit., pág. 184.

${ }^{869}$ En relación con este precepto, LÓPEZ LÓPEZ alertó que no se tuvo "en cuenta las particularidades de cada figura subjetiva" y que no "abarca la totalidad de los casos de pluralidad de responsables, que carecen hoy en día de un tratamiento adecuado" (LÓPEZ LÓPEZ, H., "Aspectos controvertidos en la regulación de la pluralidad de obligados tributarios en el mismo presupuesto de una obligación”, op. cit., pág. 855). En este mismo sentido, ZORNOZA PÉREZ, J., "Los obligados tributarios en la aplicación de los tributos", en la obra La aplicación de los tributos en la Nueva Ley General Tributaria, XLIX semana de estudios de Derecho Financiero, Instituto de Estudios Fiscales, Madrid, 2005, pág. 301.
} 
realización de un presupuesto de hecho por varios obligados tributarios. Ello implica asumir que, en el caso que nos ocupa, este apartado 7 es aplicable cuando aparecen varios responsables que realizan un mismo presupuesto de hecho. Sin embargo, no dice nada el precepto respecto de la participación de varios responsables en distintos presupuestos de hechos. Esta última circunstancia genera otros interrogantes sobre el régimen que debe primar entre los responsables y entre éstos y el deudor principal. Del texto del apartado 7 del artículo 35 de la LGT y del apartado 6 del artículo 41 de la LGT, se infiere que los responsables siempre responderán solidariamente de la misma obligación, por lo cual podrán resarcirse frente al deudor principal a través de su derecho de reembolso ${ }^{870}$. Ello significa que cuando los responsables se encuentren en la misma posición frente a la deuda, la Administración tributaria podrá exigir a cualquiera de ellos la totalidad de la deuda. Una vez extinguida la obligación, en este caso el responsable tendrá la posibilidad de ejercer su acción de regreso contra el deudor principal para resarcir su patrimonio, salvo en los supuestos en que se haya estipulado expresamente la mancomunidad. Finalmente, si concurrieran responsables subsidiarios y solidarios, la solidaridad entre ellos no sería probable, porque los primeros sólo tendrán que hacer frente a la deuda tributaria cuando se declaren fallidos el deudor principal y los responsables solidarios $^{871}$.

\section{EL PROCEDIMIENTO DE DERIVACIÓN DE LA RESPONSABILIDAD TRIBUTARIA}

En esta tercera parte del capítulo pretendemos analizar el procedimiento para derivar la responsabilidad y su exigencia. Para ello será necesario determinar el cuándo y el cómo puede declararse la responsabilidad, con independencia de que se trate de un responsable solidario o subsidiario, y la exigibilidad de la deuda al responsable. Antes de adentrarnos en el procedimiento de derivación de la responsabilidad en sentido estricto, nos gustaría referirnos a una cuestión previa que tiene gran repercusión en el ámbito del procedimiento para derivar la responsabilidad, como es la determinación del momento en que se produce el nacimiento y la exigibilidad de la obligación del responsable.

\subsection{NACIMIENTO Y EXIGIBILIDAD DE LA OBLIGACIÓN DEL RESPONSABLE}

La profesora MAZORRA MANRIQUE DE LARA destaca que existen dos momentos bien diferenciados en relación con la obligación del responsable: el nacimiento de ésta y el momento en que se produce la exigibilidad de esta obligación. Como advierte esta autora, "la obligación del responsable no surge con la mera realización del presupuesto de hecho previsto en la norma, sino que además es necesaria la realización del hecho imponible en virtud del cual queda obligado el sujeto pasivo. En este sentido, se ha afirmado que el presupuesto de hecho que origina la obligación del responsable es dependiente del presupuesto de hecho que origina la obligación tributaria principal, es decir, el presupuesto de hecho de tal responsabilidad tributaria depende del hecho imponible. Por

\footnotetext{
${ }^{870}$ En opinión de CALVO ORTEGA, la ley debió establecer "la división de la deuda entre todos los responsables como forma más justa o al menos una acción de regreso en relación con la cuota que pudiera corresponder a cada responsable" (CALVO ORTEGA, R., "Obligados tributarios", op. cit., pág. 170).

${ }^{871}$ Subraya ARIAS ABELLÁN que "el establecimiento de la solidaridad entre los posibles responsables solidarios o subsidiarios significa que, una vez cumplidos los requisitos legales de declaración y derivación de la responsabilidad, la Administración acreedora podrá dirigirse contra cualquiera de ellos de manera indistinta y por la totalidad del crédito" (ARIAS ABELLÁN, M. D., "El estatuto jurídico del responsable del tributo en el derecho español", op. cit., pág. 198).
} 
tanto, para que exista un presupuesto de responsabilidad tienen que darse dos presupuestos de hecho" $" 872$.

Otros autores, como GALÁN RUIZ ${ }^{873}$, afirman que la obligación del responsable atraviesa cuatro etapas diferentes: la primera es la que tiene al deudor principal como único sujeto obligado al pago; la segunda etapa es aquella en la que se produce el nacimiento de la obligación del responsable; un tercer momento es aquél en que puede ser exigible la deuda a los responsables; y por último, la cuarta etapa, es aquélla en la que el responsable adquiere la condición de obligado al pago. Valiéndonos de estos criterios doctrinales, haremos una serie de precisiones relacionadas con cada uno de estos momentos.

La primera etapa surge en el momento en que el deudor principal realiza el hecho imponible y aparece como único sujeto obligado al pago, situación que se mantiene durante todo el tiempo que dure el período voluntario de pago.

El segundo momento, en el que nace la obligación del responsable, se produce con la realización del presupuesto de hecho de la responsabilidad fijado por la ley. El nacimiento de la obligación para el responsable no provoca que éste se convierta en obligado al pago, porque el deudor principal ostenta en exclusiva esta posición. La jurisprudencia y la doctrina administrativa reconocen que para que se produzca la situación de responsabilidad es necesario que, además de realizarse el presupuesto de hecho imponible determinante de la obligación del deudor principal, se realice el presupuesto de hecho en virtud del cual se genera la obligación del responsable ${ }^{874}$. En la doctrina pueden encontrarse otros criterios como los de LÓPEZ DÍAZ que distingue, a la hora de determinar el nacimiento de la obligación del responsable, los supuestos en que la responsabilidad se deriva de la realización de presupuestos lícitos y aquellos en que el presupuesto se corresponde con hechos ilícitos. En estos últimos casos, en opinión de este autor, "la obligación del responsable sólo puede considerarse nacida una vez que se dicte la resolución final del correspondiente procedimiento sancionador, en que se acredite la realización del acto ilícito por el sujeto pasivo, el cual, a partir de ese momento se convertirá en responsable" ${ }^{\circledR 75}$.

Vencido el período voluntario de pago, en el caso del responsable solidario, o una vez finalizado la vía de apremio con la declaración de fallido del deudor principal y los responsables solidarios, en el supuesto de la responsabilidad subsidiaria, y siempre que se realizaran los presupuestos de hecho previstos por la ley para exigir la responsabilidad en ambos casos, puede ser exigida la deuda a los responsables solidarios o subsidiarios, siendo entonces estos sujetos "obligados al pago potenciales pues no tendrán la condición de obligados al pago de la deuda hasta que se les notifique el acto de

\footnotetext{
${ }^{872}$ MAZORRA MANRIQUE DE LARA, S., "La obligación de los responsables tributarios en el Reglamento General de Recaudación: nacimiento y exigibilidad", op. cit., pág. 75. En esta línea, FERNÁNDEZ JUNQUERA, M., "Reflexiones en torno al responsable solidario y a la solidaridad en Derecho tributario", op. cit., pág. 631.

${ }^{873}$ GALÁN RUIZ, J., La responsabilidad tributaria, op. cit., pág. 234 a 237.

${ }^{874}$ Sentencia del Tribunal Supremo de 16 de mayo de 1991. Así también lo interpreta una parte de la doctrina: CALVO ORTEGA, R., "La responsabilidad tributaria solidaria por actos ilícitos", op. cit., pág. 37 y 42; DE LA HUCHA CELADOR, F., "Reflexiones para una definición dogmática de la responsabilidad en Derecho Tributario (I)", op. cit., pág. 176 y 177; NAVARRO FAURE, A., "Los supuestos de responsabilidad tributaria solidaria en el ordenamiento tributario español (I)”, op. cit., pág. 616; PÉREZ ROYO, F. y AGUALLO AVILÉS, A., Comentarios a la Reforma de la Ley General Tributaria, op. cit., pág. 94 y 95.

${ }^{875}$ LÓPEZ DÍAZ, A., “La responsabilidad solidaria en el nuevo Reglamento General de Recaudación”, op. cit., pág. 43 y 44.
} 
derivación o declaración de responsabilidad," lo cual "puede tener lugar, bien desde la finalización del período voluntario de pago, en el caso de los responsables solidarios, o bien una vez declarado fallido el deudor principal, en el caso de los responsables subsidiarios" ${ }^{\prime 876}$.

El momento en que el responsable adquiere la condición de obligado al pago se produce cuando se notifica a este sujeto el acto de derivación o declaración de la responsabilidad. En este sentido, apunta DE LA HUCHA CELADOR que en "el lapso temporal que media entre la realización del presupuesto de hecho de la responsabilidad subsidiaria y la notificación del acto administrativo de derivación de la responsabilidad, el responsable subsidiario es un deudor de segundo grado de la obligación tributaria, pero no puede ser considerado todavía como un obligado al pago de la deuda tributaria" $" 777$. Asumiendo esta misma postura, GALÁN RUIZ afirma que "hasta que no se produce la notificación de la declaración o derivación de responsabilidad no se puede exigir efectivamente la deuda al responsable, y es en ese momento cuando el responsable se convierte de potencial obligado al pago en obligado al pago stricto sensu" ${ }^{\text {878 }}$. En este misma línea, FERNÁNDEZ JUNQUERA subraya que cuando en la declaración de responsabilidad solidaria notificada se habla de una obligación exigible "no puede entenderse dicha exigibilidad como el cobro inmediato de la deuda correspondiente de la Administración, tal y como sucede en un procedimiento ejecutivo", puesto que "se trata más bien de saber que es a partir de ese momento desde el que" el responsable queda obligado "a realizar el pago correspondiente" 879 .

En definitiva, para que el responsable tributario se convierta en un obligado al pago deben darse tres supuestos: que se realice el presupuesto de hecho de la responsabilidad exigido por la ley; que transcurra el período voluntario de pago, en el caso del responsable solidario, o que se declare fallido el deudor principal y los responsables solidarios, en los responsables subsidiarios; y por último, que se notifique al responsable el acto de derivación o declaración de responsabilidad.

\subsection{RÉGIMEN JURÍDICO DEL PROCEDIMIENTO DE DERIVACIÓN DE RESPONSABILIDAD}

La actual LGT ha supuesto un avance en relación con la LGT de 1963 al regular los aspectos formales de la responsabilidad, estableciendo a nivel legal el régimen de los procedimientos de declaración y exigibilidad de la responsabilidad en sus dos modalidades, solidaria y subsidiaria, que con anterioridad se contemplaban exclusivamente en el ámbito reglamentario. No obstante, MARTÍN JIMÉNEZ se muestra crítico con la normativa legal vigente por la regulación separada que hace de los aspectos materiales y formales de la responsabilidad, siendo preciso acudir, para conocer el régimen completo del procedimiento de derivación de responsabilidad, al apartado 5 del artículo 41,

\footnotetext{
${ }^{876}$ GALÁN RUIZ, J., La responsabilidad tributaria, op. cit., pág. 235.

877 DE LA HUCHA CELADOR, F., "Algunas consideraciones sobre la responsabilidad tributaria en el Reglamento General de Recaudación de 1990: II. Responsabilidad Subsidiaria", op. cit., pág. 48 y 51. En esta línea, DURÁN-SINDREU BUXADE, A., "La responsabilidad tributaria de los Administradores de sociedades", op. cit., pág. 56.

${ }^{878}$ GALÁN RUIZ, J., La responsabilidad tributaria, op. cit., pág. 237.

${ }^{879}$ FERNÁNDEZ JUNQUERA, M., "Reflexiones en torno al responsable solidario y a la solidaridad en Derecho tributario", op. cit., pág. 632. En este mismo sentido, LÓPEZ DÍAZ, A., "La responsabilidad solidaria en el nuevo Reglamento General de Recaudación", op. cit., pág. 48.
} 
a los artículos 174 a 176 y los apartados primero y segundo del artículo 182, todos de la LGT $^{880}$. El artículo 41 de la LGT no determina el momento exacto en que se produce el nacimiento de la obligación del responsable y sólo establece que la obligación del responsable tendrá lugar cuando así lo disponga la ley. Respecto a la exigibilidad de esta obligación, el apartado 5 del mismo artículo 41 de la LGT determina concretamente, de manera general, que puede exigirse la obligación al responsable tributario de conformidad con los artículos 174 a 176 de la LGT.

Según lo que se desprende del articulado de la ley, el procedimiento se divide en dos grandes fases: la declaración de responsabilidad y la exigencia de la responsabilidad declarada, aunque no siempre la LGT distingue claramente estos dos momentos ${ }^{881}$.

\subsubsection{Evolución normativa}

El artículo 37 de la LGT de 1963 indicaba únicamente que la derivación de la acción administrativa para exigir el pago de la deuda tributaria a los responsables requeriría un acto administrativo, que declarase la responsabilidad y determinase su alcance. Con la notificación de ese acto administrativo, que debía contener los elementos esenciales de la liquidación de la deuda del responsable, se confería a éstos los mismos derechos del deudor principal. En el caso del responsable subsidiario, el apartado 5 del artículo 37 de la LGT de 1963 determinaba exclusivamente que, una vez declarados fallidos los sujetos pasivos, debía notificarse el acto administrativo de derivación de responsabilidad, sin perjuicio de las medidas cautelares que, en su caso, se hubiera tomado antes de dicha acción administrativa.

En este marco jurídico tan reducido, eran las normas reglamentarias las que desarrollaban el procedimiento de exigencia de la responsabilidad. En el caso del responsable solidario, el artículo 10 del RGR de 1968 disponía que la deuda del responsable

"se hará efectiva sin más, o será declarada en el acto administrativo resolutorio de expediente de liquidación de obligaciones tributarias en que existan infracciones calificadas de defraudación contra las personas que, aun no afectándoles directamente aquellas obligaciones, dolosamente sean causantes, o de igual modo colaboren directa y principalmente con el sujeto pasivo en tales infracciones".

La Administración tributaria podía, pues, dirigir su acción contra los responsables solidarios en cualquier momento del procedimiento, previo requerimiento para efectuar el pago.

La Regla $5^{a}$ de la Instrucción General de Recaudación y la Contabilidad (en adelante IGRC), aprobada mediante Decreto 2260/1990, de 24 de julio, aclaraba que la liquidación se notificaría al responsable solidario "al tiempo de serlo al sujeto pasivo", al disponerse en la Regla $3^{\text {a }}$ de la IGRC, que "la acción administrativa de cobro se dirigirá contra los contribuyentes, sustitutos y responsables solidarios como deudores principales". Al estar equiparados los sujetos descritos a los deudores

\footnotetext{
${ }^{880}$ MARTÍN JIMÉNEZ, A., Los Supuestos de responsabilidad en la LGT: (hacia una configuración constitucional y comunitaria de la responsabilidad tributaria), op. cit., pág. 161.

${ }^{881}$ GONZÁLEZ ORTIZ, D., La responsabilidad tributaria en el ordenamiento jurídico español, op. cit., pág. 83 y ss.
} 
principales, era acertado el criterio de que el responsable solidario asumiera la totalidad de la deuda del sujeto pasivo, incluidas las sanciones y las costas de apremio.

Para el responsable subsidiario, el artículo 11 del RGR de 1968 determinaba como requisitos para su declaración que el deudor principal hubiera sido declarado insolvente y que existiera un acto administrativo de derivación de responsabilidad. Asimismo disponía el precepto que

"el responsable subsidiario, como tal declarado, pasa a ocupar el lugar de dicho primer obligado, como titular de la liquidación, que le será notificada a efectos de su pago en período voluntario y con todos los demás derechos inherentes a tal titularidad".

La Regla $6^{\text {a }}$ de la IGRC reafirmaba estos postulados, al declarar que el acto administrativo de derivación de responsabilidad contra los responsables subsidiarios sería dictado por el órgano a quien correspondiera la determinación de la deuda, una vez que obrara en su poder el expediente administrativo de apremio con la aprobación por la Tesorería de la declaración de insolvencia de los obligados principales al pago.

Como se observa, sobre todo en el apartado 3 del artículo 11 del RGR de 1968, el procedimiento de apremio concluía con la declaración de insolvencia del deudor principal y en ese momento el responsable subsidiario pasaba a ocupar el lugar de este último sujeto. En la Regla 54a de la IGRC se decía textualmente que "el procedimiento de apremio se entenderá ultimado cuando haya sido aprobado el respectivo expediente con solvencia del débito o con la declaración de partida incobrable" y "en los casos de incobro total o parcial por insolvencia el procedimiento de apremio ultimado se reanudará cuando el deudor o responsables hayan mejorado de fortuna, dentro del plazo de prescripción del crédito respectivo".

El RGR de 1990 estableció el acto declarativo de responsabilidad para los responsables solidarios, que debía contener los elementos esenciales de la liquidación y los medios de impugnación que podían ser ejercidos por aquéllos, así como el lugar, el plazo y forma en que debían satisfacer la deuda (apartado segundo del artículo 12 del RGR de 1990). Si el acto declarativo se notificaba antes de que venciera el período voluntario de pago del deudor principal, era suficiente requerir al pago al responsable solidario una vez finalizado este plazo y de haberse expedido el correspondiente título ejecutivo. En caso contrario, si no se dictaba y notificaba el acto declarativo dentro del término voluntario de pago, el órgano de recaudación dictaría y notificaría el acto declarativo con las liquidaciones y el título ejecutivo. Se exigía al responsable solidario, en fin, el ingreso en período ejecutivo por la totalidad de la deuda, incluidas las sanciones y las costas del apremio del obligado principal.

Por lo que respecta a la responsabilidad subsidiaria, el artículo 14 del RGR de 1990 ordenaba al órgano de recaudación dictar y notificar el acto declarativo tras la declaración de insolvencia del sujeto pasivo y los responsables solidarios. En este acto debía contenerse los elementos esenciales de la liquidación, por la deuda inicial exigida al sujeto pasivo en período voluntario, con exclusión de las sanciones pecuniarias impuestas al deudor principal. La terminación del procedimiento de apremio se regulaba de la misma manera que lo hacía el apartado tercero del artículo 11 del RGR 
anterior, el artículo 164 establecía que una vez comprobada en el curso del procedimiento de apremio la insolvencia de los deudores principales y de los responsables solidarios éstos serían declarados fallidos por el órgano de recaudación. Con el acuerdo de fallido total o parcial del deudor principal y de los responsables solidarios finalizaba el procedimiento de apremio, según el inciso $b$ ) del artículo 102 del RGR de 1990, en relación con el artículo 70 del propio cuerpo normativo. Estos preceptos introdujeron como novedad la declaración de fallidos no sólo del deudor principal sino también de los responsables solidarios.

Más tarde, en 1995, al modificarse el artículo 37 de la LGT de 1963, mediante la Ley 25/1995, se exigió para cualquier tipo de responsabilidad el acto administrativo de derivación, que se emitía con posterioridad a la audiencia del interesado. En él se plasmaban los elementos necesarios de la liquidación, y se excluían, definitivamente, todos los recargos de apremio y las sanciones, aunque se mantuvieron el resto de elementos que integraban la deuda. A través de este acto administrativo se concedía al responsable un período voluntario de pago y se le conferían todos los derechos del deudor principal.

Más adelante, en 1998, la Ley 1/1998, de 26 de febrero, de Derechos y Garantías de los Contribuyentes, incluyó en su Capítulo VI de "Derechos y garantías en el procedimiento de recaudación”, la derivación de la acción administrativa para exigir el pago de la deuda tributaria al responsable, exigiendo la notificación del mismo, previa audiencia al interesado.

Las principales modificaciones del régimen jurídico del procedimiento de derivación de responsabilidad se encuentran, sin embargo, en la legislación vigente, tanto en la LGT como en el RGR, incluyéndose de manera específica en la LGT un procedimiento para exigir la responsabilidad. En la normativa actual se puede identificar un procedimiento administrativo para derivar la responsabilidad con todos sus elementos: el acto inicial y el acto resolutorio, el objeto y la finalidad, que permiten diferenciarlo del resto de procedimientos de recaudación, en particular del procedimiento de apremio.

El procedimiento de derivación de responsabilidad se regula actualmente en la LGT en los artículos 174 al 176, en correspondencia con los mandatos que aparecen en el artículo 41 de la propia ley. El procedimiento sólo se efectúa sobre deudas cuantificadas mediante liquidación administrativa o a través de las autoliquidaciones que deben presentar los obligados principales. La finalidad de este procedimiento es que pueda apreciarse el presupuesto de hecho de la responsabilidad y derivarse y exigir la deuda al responsable. Es necesario para ello la existencia de una deuda tributaria y su liquidación previa, por lo que no se admite la exigencia de la responsabilidad cuando la deuda del obligado principal no se encuentra determinada. 
"salvo que una norma con rango de ley disponga otra cosa, la derivación de la acción administrativa para exigir el pago de la deuda tributaria a los responsables requerirá un acto administrativo en el que previa audiencia al interesado, se declare la responsabilidad y se determine su alcance y extensión, de conformidad con lo previsto en los artículos 174 a 176" de la LGT.

El precepto mantiene el mismo orden que establecía el artículo 37 de la LGT de 1963, tras su modificación por medio de la Ley 25/1995, con la salvedad que la propia ley determina. "Salvo que una norma con rango de ley disponga otra cosa", para derivar la responsabilidad será imprescindible un acto administrativo de declaración de responsabilidad. Es posible, por tanto, que excepcionalmente sea exigible la obligación al responsable sin que exista previamente un acto administrativo que derive su responsabilidad. No obstante, dadas las características que acompañan a la figura del responsable, parece poco probable que éste pueda configurarse sin que antes se haya declarado su carácter de responsable, garantizando la seguridad jurídica y la defensa de los derechos de los responsables. La introducción de la salvedad mencionada se justifica según algunos autores porque el legislador estaba pensando en el Impuesto sobre la Renta de los no Residentes, concretamente en el apartado tercero del artículo 9 de la ley que regula este impuesto, que establece la posibilidad de exigir la deuda al responsable, "sin que sea necesario el acto de liquidación previo de derivación de responsabilidad", cuando se trate del pagador de rendimientos devengados sin mediación de establecimiento permanente. En este caso, sin embargo, la doctrina entiende que se configura no un supuesto de responsabilidad, sino de sustitución ${ }^{882}$.

Por su parte, el RGR de 2005, en su artículo 124, desarrolla los mandatos de la LGT. Este precepto contempla tres etapas del procedimiento de declaración de responsabilidad: una fase de iniciación; otra fase que se conforma de manera exclusiva por el trámite de audiencia; y la fase de terminación. Determina el propio artículo 124 del RGR que el procedimiento frente al responsable se inicia con un acuerdo adoptado por el órgano competente, que se notifica al interesado para que pueda presentar las alegaciones y documentos que estime conveniente, en cualquier momento del proceso, y sin prejuicio del trámite de audiencia que se realizará en el término de 15 días, tras el cual se dictará la resolución con la que se concluye el procedimiento y con la que se declara la responsabilidad, cuya notificación no puede superar el plazo de seis meses contados a partir de la fecha en la que se notificó el acuerdo de la Administración tributaria con el que se daba inicio al procedimiento de declaración de la responsabilidad.

\footnotetext{
${ }^{882}$ La posibilidad de que se adquiera la condición de responsable sin que exista un acto de derivación de responsabilidad no es admitida en la doctrina. Entre otros, MAZORRA MANRIQUE DE LARA, S., "Aspecto formales del régimen de la responsabilidad tributaria", op. cit., pág. 953; FALCÓN Y TELLA, R., "La regulación sustantiva de los responsables en el Anteproyecto de Ley General Tributaria", op. cit., pág. 5; NAVARRO EGEA, M., El responsable tributario, op. cit., pág. 35; ARIAS ABELLÁN, M. D., "El régimen jurídico del responsable en la nueva Ley General Tributaria", op. cit., pág. 501; MARTÍN JIMÉNEZ, A., Los Supuestos de responsabilidad en la LGT: (hacia una configuración constitucional y comunitaria de la responsabilidad tributaria), op. cit., pág. 161.
} 


\subsubsection{Naturaleza jurídica del procedimiento de derivación de responsabilidad}

La derivación de responsabilidad exige no sólo que haya nacido la obligación del responsable, sino también que ésta sea declarada (apartado quinto del artículo 41 de la LGT). El procedimiento administrativo para derivar la responsabilidad se localiza, como ya dijimos, en la LGT dentro de las actuaciones y procedimientos de recaudación, en los artículos 174 a 176, aunque no se trate de actuaciones y procedimientos de este tipo ${ }^{883}$. No es ésta, sin embargo, la posición que observamos en la doctrina administrativa. Según el TEAC el "procedimiento seguido para la declaración de responsabilidad no es distinto ni independiente del procedimiento recaudatorio seguido contra el obligado tributario principal" 884 , y "procede conceptuar las actuaciones seguidas contra el responsable como a modo de pieza separada del procedimiento ejecutivo o expediente de apremio" $^{, 885}$.

Como bien indica LOZANO SERRANO, "el procedimiento de apremio era ejecutivo de una deuda, en torno a la que ordenaban sus actuaciones; mientras que, en la vigente normativa, resultaría más exacto decir que el procedimiento de apremio es ejecutivo respecto de un obligado, debiendo separarse y diferenciarse del seguido contra cualquier otro obligado aun por la misma deuda originaria" ${ }^{\nexists 86}$. La mayoría de la doctrina plantea en definitiva que el procedimiento de derivación de responsabilidad no es un procedimiento de recaudación, por la finalidad que persigue el acto administrativo, que no es otra que la de concretar la obligación que nace por la realización de un presupuesto de hecho de responsabilidad fijado en la ley.

Algunos autores, como NAVARRO EGEA o GARCÍA DELGADO, afirman que el procedimiento que nos ocupa es una fase diferenciada del procedimiento que se sigue frente a los responsables, un procedimiento puente, que se sitúa en posición intermedia entre el procedimiento de recaudación seguido contra el deudor principal y el procedimiento de recaudación que se inicia frente al responsable, sin que exista diferencia, a estos efectos, entre los distintos tipos de responsabilidad ${ }^{887}$.

A nuestro juicio, el procedimiento de derivación de responsabilidad es un procedimiento de liquidación, que tiene por finalidad la cuantificación de la deuda tributaria del responsable. La declaración de responsabilidad requiere de la existencia de una obligación ya liquidada que pueda exigirse mediante un procedimiento de recaudación. PÉREZ ROYO y AGUALLO AVILÉS señalan que sin deudor principal efectivo no es posible "comenzar un procedimiento contra los posibles responsables", porque "si se desconoce cuál es exactamente la deuda tributaria o la sanción que se va

\footnotetext{
883 MARTÍN FERNÁNDEZ, RODRÍGUEZ MÁRQUEZ, GALÁN SÁNCHEZ., "Los administradores de sociedades como responsables tributarios", op. cit., pág. 1069, entienden que se trata de un procedimiento que forma parte de la gestión tributaria, independientemente que cuál sea el órgano competente para declarar la responsabilidad, los órganos de inspección o los órganos de recaudación.

${ }^{884}$ Resolución del TEAC de 24 de febrero de 2000.

${ }^{885}$ Resolución del TEAC de 8 de marzo de 2000.

${ }^{886}$ LOZANO SERRANO, C., "El procedimiento de derivación de responsabilidad", en la obra Tratado sobre la Ley General Tributaria, Tomo II, ARRIETA MARTÍNEZ DE PISÓN, J., COLLADO YURRITA, M. A., ZORNOZA PÉREZ, J. (directores), Aranzadi, Thomson Reuters, Navarra, 2010, pág. 722.

${ }^{887}$ NAVARRO EGEA, M., El responsable tributario, op. cit., pág. 36; DELGADO GARCÍA, A. M., “Alcance de la responsabilidad tributaria. Una cuestión abierta”, op. cit., pág. 19.
} 
a aplicar no es posible notificar un acto de derivación de responsabilidad que debe contener éste entre otros extremos" ${ }^{\prime 888}$.

En consecuencia, cuando se produce el acto administrativo de declaración de responsabilidad, la Administración tributaria lo que hace es concretar la existencia de la obligación para el responsable y su cuantía (apartado cuarto del artículo 174 de la LGT), por lo que realiza una liquidación tributaria $^{889}$, a tenor de lo que dispone el apartado primero del artículo 101 de la LGT, que expresa literalmente que

"la liquidación tributaria es el acto resolutorio mediante el cual el órgano competente de la Administración realiza las operaciones de cuantificación necesarias y determina el importe de la deuda tributaria".

En cualquier caso, estamos ante un procedimiento de liquidación diferente al que se sigue frente al deudor principal, pues se trata de una obligación diferente de la obligación que nace de la realización del hecho imponible, aunque la obligación del deudor principal sirva de base para cuantificar la obligación del responsable. Como dijera ARIAS ABELLÁN, no se está en presencia de varios obligados que se presentan en diferentes momentos al mismo procedimiento, sino que se trata de procedimientos diferentes, uno de recaudación y otro de liquidación que son posibles por la realización de presupuestos de hecho distintos, el presupuesto de hecho que da origen a la obligación principal y el presupuesto de hecho de la responsabilidad cuya realización hace nacer la obligación para el responsable ${ }^{890}$. También MARTÍN JIMÉNEZ advierte que, “en la medida en que este acto se determina la cuantía de la obligación a cargo del responsable, pues no supone una mera traslación a éste de la liquidación correspondiente al sujeto pasivo, su naturaleza es asimilable a la propia de las liquidaciones tributarias" ${ }^{\prime 9}$.

Otro de los argumentos que permite reforzar la idea de que el acto de declaración de responsabilidad es un acto de liquidación lo brinda la propia LGT en el número 5 del artículo 174, al especificarse en él que el responsable puede impugnar tanto el presupuesto de hecho de la responsabilidad como las propias liquidaciones. Con ello se evidencia la existencia de dos liquidaciones, la del responsable, que puede impugnarse por éste, y la del deudor principal, que cuando es independiente y firme no puede verse afectada por el recurso de impugnación al que tiene derecho el responsable ${ }^{892}$.

\footnotetext{
${ }^{888}$ PÉREZ ROYO, F y AGUALLO AVILÉS, A., Comentarios a la Reforma de la Ley General Tributaria, op. cit., pág. 104 y 105. En este mismo sentido, ATAZ HERNÁNDEZ, J., "La responsabilidad de los administradores de sociedades en materia fiscal", en la obra Estudios de Derecho Fiscal, Homenaje a Jaime Basanta, Civitas, Madrid, 1994, pág. 91 y 92.

${ }^{889}$ Este criterio se encuentra bastante extendido en la doctrina. Vid. GARCÍA NOVOA, C., "El procedimiento de derivación de responsabilidad de administradores de sociedades. Aspectos sustantivos y procedimentales", Revista Técnica Tributaria, núm. 57, 2002, pág. 32 y ss.; FALCÓN Y TELLA, R., "La prescripción de la obligación en relación con el responsable: un problema mal planteado, Quincena Fiscal, núm. 12, 2001, pág. 6 a 7; MAZORRA MANRIQUE DE LARA, S., Los responsables tributarios, op. cit., 141 y ss.; COMBARROS VILLANUEVA, V. E., "La responsabilidad tributaria, solidaria y subsidiaria, en el procedimiento de recaudación”, op. cit., pág. 384; NAVARRO EGEA, M., El responsable tributario, op. cit., pág. 38.

${ }^{890}$ ARIAS ABELLÁN, M. D., "El régimen jurídico del responsable en la nueva Ley General Tributaria”, op. cit., pág. 504.

${ }^{891}$ MARTÍN JIMÉNEZ, A., Los Supuestos de responsabilidad en la LGT: (hacia una configuración constitucional y comunitaria de la responsabilidad tributaria), op. cit., pág. 162.

892 SAINZ DE BUJANDA apuntó que estamos ante un acto administrativo en el que la Administración aprecia la existencia del presupuesto de hecho de la responsabilidad y lo da a conocer al responsable, "abriendo, a partir de ese instante, a este último, todas las posibilidades de impugnación que específicamente deriven de ese acto administrativo" (SÁINZ DE BUJANDA, F., "La
} 
En esta misma línea RUIZ HIDALGO afirma que "la liquidación del responsable resulta distinta subjetiva y cuantitativamente a la del obligado principal. En primer lugar, son diferentes porque se declara un obligado tributario, distinto del principal, por la realización de un presupuesto de hecho previsto en la Ley. También dicha liquidación resulta distinta cuantitativamente, como hemos señalado anteriormente, respecto de los elementos de la deuda del obligado principal. Así las cosas, finaliza diciendo este autor que, "nos encontramos ante un acto de liquidación donde se fija el alcance de la obligación de pago del responsable cuantificada por la correspondiente liquidación”893.

Todo lo anterior nos permite afirmar, en definitiva, que el procedimiento seguido frente al responsable tiene una naturaleza liquidadora, que es un procedimiento de liquidación ${ }^{894}$, previo y necesario, para poder exigir posteriormente al responsable el cumplimento de su obligación a través de un procedimiento ordinario de recaudación.

\subsection{INICIO DEL PROCEDIMIENTO DE DERIVACIÓN DE RESPONSABILIDAD}

La Administración tributaria iniciará de oficio el procedimiento frente al responsable y lo concluirá con el acto administrativo declarativo de la responsabilidad. El artículo 174 de la LGT establece el procedimiento para derivar la responsabilidad, completando los postulados del artículo 41 de la LGT. El primero de los preceptos no hace distinciones entre los dos tipos de responsabilidad, mientras que los artículos 175 y 176 de la LGT determinan el procedimiento para los responsables solidarios y subsidiarios, respectivamente, concretándose, además, el momento temporal en que se inicia el procedimiento de recaudación frente a cada uno de ellos. Del articulado de la LGT se desprenden dos momentos diferentes para iniciar el procedimiento de derivación de responsabilidad: el procedimiento frente al responsable solidario, que puede ser llamado como tal antes o después del vencimiento del período voluntario de pago del deudor principal, y el procedimiento contra el responsable subsidiario, que sólo puede ser llamado si se ha producido la declaración de fallido del deudor principal y de los responsables solidarios, si los hubiere ${ }^{895}$.

El apartado 5 del artículo 41 de la LGT indica que el procedimiento de derivación de la responsabilidad se inicia de oficio, por iniciativa de la Administración tributaria, en cumplimiento de las facultades que el propio ordenamiento le concede. No obstante, la normativa legal tributaria no se refiere a las formalidades procedimentales que debe seguir el órgano competente para iniciar el procedimiento de declaración de responsabilidad. Para ello, habrá que remitirse a lo previsto con carácter general en los artículos 98 y 109 de la LGT, así como a la LRJ-PAC y al artículo 124 del RGR. Este último precepto, en su apartado 1, dispone que el procedimiento de derivación de responsabilidad se inicia mediante acuerdo dictado por el órgano competente que debe ser notificado

\footnotetext{
responsabilidad tributaria en régimen de solidaridad", en la obra Hacienda y Derecho, Vol. VI, Instituto de Estudios Políticos, Madrid, 1973, pág. 304 y 305).

${ }^{893}$ RUIZ HIDALGO, C., La responsabilidad tributaria en el alzamiento de bienes en la nueva Ley General Tributaria, op. cit., pág. 139.

${ }^{894}$ NAVARRO EGEA, M., El responsable tributario, op. cit., pág. 37; DELGADO GARCÍA, A. M., La derivación de las responsabilidades en la recaudación de los tributos, op. cit., pág. 107; MARTÍN FERNÁNDEZ, F. J., RODRÍGUEZ MÁRQUEZ, J. S., GALÁN SÁNCHEZ, R. M., "Los administradores de sociedades como responsables tributarios”, op. cit., pág. 1069.

${ }^{895}$ NAVARRO EGEA, M., El responsable tributario, op cit., pág. 39.
} 
al interesado. De esta forma, la norma reglamentaria regula una cuestión que quedó sin tratamiento en la LGT.

Según el apartado 1 del artículo 174 de la LGT, la responsabilidad puede ser declarada en cualquier momento posterior a la práctica de la liquidación o a la presentación de la autoliquidación sin haberse realizado el ingreso correspondiente. Exige para la derivación de la responsabilidad la existencia de una deuda liquidada o autoliquidada a cargo del deudor principal, junto al que se colocará el responsable, y cuyo importe sirve de base para determinar la cuantía de la obligación de éste último. Además esta deuda liquidada o autoliquidada podrá encontrarse tanto en período voluntario de pago como en período ejecutivo.

Otro aspecto de interés que condiciona el inicio del procedimiento de declaración de responsabilidad viene dado por la existencia de supuestos en que la responsabilidad alcanza a las sanciones, pues no basta en ellos que se produzca el presupuesto de hecho de la responsabilidad y que la deuda esté liquidada o autoliquidada. Es necesario, además, que exista una sanción firme, pero el régimen jurídico del procedimiento de derivación de responsabilidad nada dice en concreto sobre la derivación de la responsabilidad a las sanciones.

Esta omisión queda cubierta por el Real Decreto 1065/2007, de 27 de julio por el que se aprueba el Reglamento General de las Actuaciones y los Procedimientos de Gestión e Inspección Tributaria y de Desarrollo de las Normas Comunes de los Procedimientos de Aplicación de los Tributos (en adelante RGGI), que en el apartado primero de su artículo 196 dispone que, cuando el alcance de la responsabilidad incluya las sanciones, para acordar el inicio del procedimiento para declarar la misma es necesario que se haya iniciado previamente el procedimiento sancionador. Más adelante, el apartado tercero del mismo artículo determina que el acuerdo de declaración de responsabilidad podrá dictarse con posterioridad a la imposición de la sanción al sujeto infractor. Estos son supuestos que producen debate y ocasionan interpretaciones diversas, "bien para defender que el procedimiento de derivación de responsabilidad no puede tener lugar en tanto no se conozca la cuantía de la deuda garantizada (deuda tributaria y sanción), bien para entender que han de concurrir de forma sucesiva dos actos de derivación de responsabilidad como resultado de sendos procedimientos" ${ }^{\text {} 896}$.

Nuestro criterio ya fue expuesto al analizar el alcance de la responsabilidad con la exigencia de las sanciones. En el caso de que la responsabilidad se extienda a las sanciones, sobre todo cuando las infracciones son el resultado de una actuación ilícita del responsable, el procedimiento debe llevarse a cabo con las mismas garantías constitucionales y derechos que lo previstos en un procedimiento administrativo sancionador para el sujeto infractor. Como estiman algunos tribunales y buena parte de la doctrina, para poder derivar la responsabilidad a las sanciones deben mantenerse las mismas garantías de un procedimiento sancionador, respetando los principios que integran el Derecho administrativo sancionador ${ }^{897}$. Aunque, como indicamos en aquel momento, lo acertado sería que se

\footnotetext{
${ }^{896}$ NAVARRO EGEA, M., El responsable tributario, op. cit., pág. 40. ANEIROS PEREIRA, J., Las sanciones tributarias, Marcial Pons, Madrid, 2005, pág. 192, entiende que la sanción debe estar impuesta antes de poder exigir la misma al responsable.

${ }^{897}$ Vid. la Sentencia del Tribunal Constitucional 85/2006, de 27 de marzo, y la Sentencia del Tribunal Supremo de 30 de septiembre de 1993. En la doctrina, asumen esta misma posición, entre otros, ANÍBARRO PÉREZ, S y SESMA SÁNCHEZ, B., Infracciones y sanciones tributarias, Lex Nova, Valladolid, 2005, pág. 84; SESMA SÁNCHEZ, B., "Responsabilidad subsidiaria de administradores: aplicación objetiva y automática", Jurisprudencia Tributaria, núm. 21, 2002; MARTíNEZ LAGO, M. A. y ALMUDÍ CID, J. M., "Autotutela tributaria, «levantamiento del velo» y derivación de la responsabilidad a las sanciones”, op. cit., pág. 33; GONZÁLEZ
} 
desarrollara un procedimiento de derivación de responsabilidad que alcanzara únicamente a la deuda tributaria y que la imposición de las sanciones se realizara a través de un procedimiento sancionador al responsable infractor, pues de esta forma se obtiene una mayor seguridad jurídica, sobre todo para aquellos tipos de responsabilidad que alcanzan a las sanciones cuyo nacimiento se produce de un hecho lícito, como es el caso del cambio en la titularidad o ejercicio de explotaciones o actividades económicas (inciso c) del apartado primero del artículo 42 de la LGT) ${ }^{898}$.

\subsection{1. Órganos competentes}

En el apartado 2 del artículo 174 de la LGT se atribuye la competencia para la derivación de responsabilidad a los órganos de liquidación o de recaudación, en función del momento en que se dicte el acto de derivación de responsabilidad. Según reza este segundo apartado,

"en el supuesto de liquidaciones administrativas, si la declaración de responsabilidad se efectúa con anterioridad al vencimiento del período voluntario de pago, la competencia para dictar el acto administrativo de declaración de responsabilidad corresponde al órgano competente para dictar la liquidación. En los demás casos, dicha competencia corresponderá al órgano de recaudación".

Sobre la base de este precepto, la competencia para declarar la responsabilidad será del órgano liquidador si todavía no ha concluido el período voluntario de pago para el deudor principal, mientras que si ya finalizó dicho plazo el órgano competente será el de recaudación. En el caso de la responsabilidad subsidiaria, por tanto, siempre será el órgano de recaudación el competente para declarar la responsabilidad, y ello a pesar que en el número primero del artículo 196 del RGGI se establezca que en estos casos los órganos de recaudación acreditarán, a petición de los de inspección, la condición de fallido de los deudores principales y responsables solidarios.

RUIZ HIDALGO afirma que, "a pesar de que la LGT atribuya la competencia a los órganos de recaudación, a nuestro juicio, el órgano competente para declarar la responsabilidad sería la inspección de los tributos, en la medida que tiene asumidas competencias liquidadoras, y se establecen claras conexiones entre este orden de gestión y el procedimiento de derivación de la responsabilidad tributaria. Otra cosa es que, una vez que la declaración de responsabilidad ha quedado delimitada por los órganos de inspección, sean los órganos de recaudación los competentes para requerir el pago a los responsables solidarios" ${ }^{\prime 999}$.

DELGADO GARCÍA asumió una posición contraria a la que se acaba de indicar, sobre la base de la normativa anterior a la LGT actual, y sostuvo que el órgano encargado de dictar el acto de

ORTIZ, D., La figura del responsable en el Derecho Español, Servicio de Publicaciones de la Universidad de Valencia, 2003, pág. 212; RUFIÁN LIZANA, D. M., "La responsabilidad tributaria de los administradores de sociedades en las infracciones cometidas por estas”, Impuestos, Vol. I, núm. 3, 1987, pág. 641.

${ }^{898}$ Vid. supra, Capítulo Cuarto, epígrafe 2.3.2. "La responsabilidad por las sanciones".

${ }^{899}$ RUIZ HIDALGO, C., La responsabilidad tributaria en el alzamiento de bienes en la nueva Ley General Tributaria, op. cit., pág. 142 y 143. En esta línea, LÓPEZ MARTÍNEZ, J., "Los responsables de las deudas tributarias y el procedimiento de gestión", op. cit., pág. 278 a 280; ALLER RODRÍGUEZ, C., "La derivación de la acción declaratoria, en el caso de la responsabilidad solidaria o subsidiaria", Crónica Tributaria, núm. 18, 1976, pág. 26. 
declaración de responsabilidad es el mismo órgano de recaudación que tiene a su cargo la tramitación del expediente de la falta de pago del deudor principal, porque esta solución "responde a la nueva organización de la recaudación, en la que son órganos administrativos los que desarrollan dicha función, y, en consecuencia, pueden desarrollar el procedimiento administrativo de derivación de la acción recaudatoria"900.

Podemos afirmar, de todas formas, teniendo en cuenta los postulados del apartado segundo del artículo 174 de la LGT, que cuando se trate de una autoliquidación el órgano competente para derivar la responsabilidad será en todo caso el órgano de recaudación, al igual que si se tratara de liquidaciones administrativas donde la responsabilidad no se declara antes del vencimiento del plazo voluntario de pago por parte del deudor principal. En ambos casos, las deudas debidas por el obligado principal se encuentran ya en el período ejecutivo, al tratarse de deudas tributarias liquidadas y vencidas por haber transcurrido el período voluntario de pago previsto en la LGT o en la ley propia de cada tributo al que corresponde la autoliquidación. Cuando estemos ante situaciones distintas a éstas, el órgano competente para declarar la responsabilidad será el órgano encargado de liquidar la deuda del obligado principal.

\subsubsection{Inicio del procedimiento de derivación de la responsabilidad solidaria}

El inciso a) del número primero del artículo 175 de la LGT regula el procedimiento para exigir la responsabilidad solidaria cuando ésta haya sido declarada y notificada al responsable en cualquier momento anterior al vencimiento del período voluntario de pago de la deuda que se deriva, bastando con requerirle el pago una vez transcurrido dicho período. De la lectura del inciso se puede concluir que lo que determina el mismo es el procedimiento para exigir una obligación del responsable que previamente ya fue liquidada, a través, precisamente, de los mandatos que aparecen en el apartado quinto del artículo 41 y el artículo 174, ambos de la LGT $^{901}$. Una vez vencido el período voluntario de pago para el obligado principal, se requiere el pago al responsable, comunicando en ese momento a este sujeto que se inicia su período voluntario de pago. De acuerdo con el número 6 del artículo 174 de la LGT, una vez transcurrido este segundo plazo, la deuda del responsable se entiende vencida y, por tanto, apremiable, a través del procedimiento ejecutivo correspondiente.

En este supuesto se declara la responsabilidad solidaria y se concreta la deuda del responsable solidario en un mismo acto administrativo, una vez practicada la liquidación por parte del órgano inspector, y notificada al responsable con anterioridad al vencimiento del período voluntario de pago correspondiente al deudor principal. Transcurrido este último plazo, la Administración tributaria podrá iniciar el procedimiento para exigir el pago de la deuda al responsable, bastando sólo para ello de un requerimiento de pago ${ }^{902}$, siempre que el deudor principal no haya satisfecho su deuda. En definitiva, como señala MARTÍN JIMÉNEZ “se admite ya sin problemas que, especialmente en el caso de responsables solidarios, la declaración de responsabilidad pueda hacerse con anterioridad a la

\footnotetext{
${ }^{900}$ DELGADO GARCÍA, A. M., La derivación de responsabilidades en la recaudación de los tributos, op. cit., pág. 124.

${ }^{901}$ ARIAS ABELLÁN M. D., "El régimen jurídico del responsable en la Nueva Ley General Tributaria”, op. cit., pág. 507.

${ }^{902}$ Requerimiento que no tiene otra finalidad que la de informar al responsable que se ha iniciado el cómputo del plazo voluntario de pago en los términos del artículo 62 de la LGT. Este criterio es defendido por ARIAS ABELLÁN M. D., "Precisiones sobre el procedimiento de declaración de la responsabilidad tributaria: a propósito del artículo 124 del Reglamento General de Recaudación", Revista Española de Derecho Financiero, núm. 131, julio-sept., 2006, pág. 571.
} 
expiración del período voluntario de pago para el deudor principal, si bien en un momento en el que pueda ya ser notificada la cuantía de su obligación al responsable" ${ }^{903}$. Este mismo supuesto es el que se reconoce en el apartado primero y segundo del artículo 196 del RGGI. Sobre el contenido de este precepto entendió LOZANO SERRANO que fuerza enormemente la legalidad, al simultanear el procedimiento liquidatario del sujeto pasivo con el procedimiento de declaración del responsable ${ }^{904}$.

El inciso b) del apartado primero del artículo 175 de la LGT dispone que en los demás casos, una vez que haya transcurrido el período voluntario de pago de la deuda que se deriva, el órgano competente dictará acto de declaración de responsabilidad que se notificará al responsable solidario. Este es un precepto que se aplica a aquellos casos que no se regulan por el apartado segundo del artículo 174 y el inciso a) del apartado primero del artículo 175, los dos recogidos en la LGT. En este supuesto el órgano competente es el de recaudación, que dictará acto administrativo de declaración de responsabilidad y lo notificará al responsable, quien dispondrá de un período voluntario de pago como se estipula en el número 6 del artículo 174 de la LGT. Aquí sí se contempla por la LGT el inicio del procedimiento para la derivación de la responsabilidad.

\subsubsection{Inicio del procedimiento de derivación de la responsabilidad subsidiaria}

Para iniciar el procedimiento de derivación de responsabilidad subsidiaria, según la LGT, en el número 5 de su artículo 41, se requiere previamente la declaración de fallido del deudor principal y de los responsables solidarios. El artículo 176 de la LGT reproduce este mandato, al disponer que una vez declarados fallidos el deudor principal y, en su caso, los responsables solidarios, la Administración tributaria dictará acto de declaración de responsabilidad, que se notificará al responsable subsidiario. A su vez, el apartado primero del artículo 196 del RGGI señala que la derivación de la acción administrativa a los responsables subsidiarios requiere la previa declaración de fallido del deudor principal y, si los hubiera, de los responsables solidarios, y más adelante precisa que de aquella declaración se debe dejar constancia en la comunicación de inicio del procedimiento de declaración de responsabilidad. Sin embargo, estos preceptos no desarrollan de manera exhaustiva el procedimiento a seguir en estos casos, lo que obliga a acudir a las normas reguladoras del procedimiento de apremio.

La necesidad de que exista una declaración formal de fallido no ha sido respetada por la Administración en muchos casos, cuando se ha exigido la deuda al responsable subsidiario sin haber finalizado el procedimiento de apremio contra el deudor principal. Esta vulneración del procedimiento establecido para la derivación de la responsabilidad ha sido subsanada por los tribunales $^{905}$, que han afirmado con rotundidad que la declaración formal de fallido no puede ser sustituida por otro documento o acuerdo.

\footnotetext{
${ }^{903}$ MARTÍN JIMÉNEZ, A., Los Supuestos de responsabilidad en la LGT: (hacia una configuración constitucional y comunitaria de la responsabilidad tributaria), op. cit., pág. 165. Sobre la situación anterior a la LGT de 2003, vid. GONZÁLEZ ORTIZ, D., La responsabilidad tributaria en el ordenamiento jurídico español, op. cit., pág. 96 y ss.

${ }^{904}$ LOZANO SERRANO, C., "El procedimiento de derivación de responsabilidad”, op. cit., pág. 719.

${ }^{905}$ La nulidad del procedimiento de derivación de la responsabilidad por la ausencia de la declaración de fallido ha sido reconocida en múltiples sentencias: vid., entre otras, las Sentencias del Tribunal Supremo de 16 de mayo de 1991; de 8 de junio de 1994 ; de 19 de julio de 1995; de 24 de mayo de 1997; y de 20 de septiembre de 2001; y también las Sentencias de la Audiencia Nacional de 28 de noviembre de 2002; y de 23 de septiembre de 2004; y la Sentencia del Tribunal Superior de Justicia de Galicia de 29 de mayo de 2002.
} 
Por otra parte, los apartados 5 y 6 del artículo 124 del RGR permiten declarar la insolvencia parcial del deudor principal y de los responsables solidarios para poder derivar la responsabilidad a los responsables subsidiarios. Si se declarara también la insolvencia de la parte de la deuda no derivada, entonces se declarará la insolvencia total del obligado principal y el responsable solidario y será necesario un nuevo acto de derivación de responsabilidad para el responsable subsidiario por la parte de la deuda pendiente de cobro ${ }^{906}$. Por todo ello se hace imprescindible la coordinación entre los principios que sustentan la responsabilidad (subsidiaridad, proporcionalidad y prudencia) y la eficacia del cobro en los supuestos de insolvencia parcial del deudor principal o del responsable solidario, así como cuando no es posible la adjudicación de los bienes o derechos a la Hacienda Pública. El apartado 5 del artículo 124 del RGR, sobre la base del principio de prudencia valorativa, limita el alcance de la responsabilidad en el caso de insolvencia parcial del deudor principal y de los responsables solidarios, disponiendo en su apartado 6 que si éstos fueran declarados insolventes por la parte no declarada de responsabilidad subsidiaria podrá procederse, una vez efectuada la declaración de fallido por insolvencia total, a la derivación de estos responsables subsidiarios del resto de la deuda pendiente de cobro.

Otro aspecto a tener en cuenta es que la Administración no está obligada, para declarar la responsabilidad subsidiaria, a notificar la declaración de insolvencia del deudor principal y del responsable solidario. Según lo que se interpreta del artículo 176 de la LGT, en ningún momento se prevé la necesidad de notificar la declaración de fallido al responsable subsidiario. Esta declaración de fallido, por una parte, pone fin al procedimiento de apremio seguido frente al deudor principal, con la notificación al interesado; y por otra, permite iniciar el procedimiento de derivación de responsabilidad, en el que se comunica al responsable subsidiario la insolvencia del deudor principal con el fin de que el primero pueda presentar trámite de audiencia previo a la declaración de responsabilidad, teniendo siempre en cuenta que la falta de notificación de fallido del deudor principal no impide el inicio del procedimiento de declaración de responsabilidad ${ }^{907}$.

\subsection{DESARROLLO DEL PROCEDIMIENTO DE DERIVACIÓN DE RESPONSABILIDAD}

\subsubsection{Trámite de audiencia previa}

En el trámite de audiencia que se sigue una vez iniciado el procedimiento de derivación de responsabilidad subsidiaria se da acceso al responsable al expediente que se lleva contra él, con el fin de que pueda presentar las alegaciones que estime pertinentes, antes de dictarse el acto administrativo en el que se declara la responsabilidad.

La audiencia previa al responsable no tuvo reflejo en la LGT de 1963. No fue hasta la reforma de 1995, con la entrada en vigor de la Ley 25/1995, que se introdujo en la LGT el requisito de la

\footnotetext{
${ }^{906}$ El RGR, en los apartados 5 y 6 de su artículo 124, establece que "en aquellos casos en los que como consecuencia del desarrollo del procedimiento recaudatorio seguido frente al deudor principal o, en su caso, frente al responsable solidario, se haya determinado su insolvencia parcial en los términos del artículo 76.1 de la Ley 58/2003, de 17 de diciembre, General Tributaria, se podrá proceder a la declaración de fallido de aquellos, a los efectos previstos en su artículo 41 (...). Si el deudor principal o los responsables solidarios fueran declarados insolventes por la parte no derivada a los responsables subsidiarios, podrá procederse, en su caso y tras la correspondiente declaración de fallido por insolvencia total, a la derivación a dichos responsables subsidiarios del resto de deuda pendiente de cobro".

${ }^{907}$ Entre otras, Sentencia del Tribunal Supremo de 24 de mayo de 1997, y Sentencia de la Audiencia Nacional de 2 de octubre de 2001.
} 
audiencia previa a los interesados con carácter previo a la derivación de la acción administrativa al responsable para exigir el pago. Con posterioridad a esta modificación, la Ley 1/1998, reconoció en su artículo 32 este derecho, y, a nivel general, la LRJ-PAC plasmó la exigencia del trámite de audiencia en el apartado primero del artículo 84, al disponer este precepto que

"instruidos los procedimientos, e inmediatamente antes de redactar la propuesta de resolución, se pondrán de manifiesto a los interesados o, en su caso, a sus responsables".

\section{DE LA NUEZ SÁNCHEZ-CASADO, FERNÁNDEZ CUEVAS y OGEA MARTÍNEZ-OROZCO} señalaron que el trámite de audiencia presupone "la puesta de manifiesto al interesado del expediente de derivación de responsabilidad y la concesión de un plazo para efectuar alegaciones. La norma", con anterioridad a la Ley 25/1995, "no señala cuál debe ser ese plazo, por lo que puede aplicarse supletoriamente lo previsto en el artículo 84.2 LRJ-PAC, según el cual los interesados, en un plazo no inferior a diez días ni superior a quince podrán alegar y presentar los documentos y justificaciones que estimen pertinentes" $" 908$. La doctrina administrativa mantuvo durante algún tiempo que no era preceptivo el trámite de audiencia previa a los interesados para la declaración de la responsabilidad $^{909}$, pero la jurisprudencia, en contra de la posición del TEAC, abogó por la necesidad de la audiencia previa, incluso, antes de la entra en vigor de la Ley 25/1995 ${ }^{910}$.

La normativa legal vigente despeja toda duda sobre la necesidad de observar el trámite de audiencia del interesado antes de emitirse el acto administrativo de declaración de responsabilidad. El tercer apartado del artículo 174 de la LGT determina, expresamente, que

“el trámite de audiencia previo a los responsables no excluirá el derecho que también les asiste a formular con anterioridad a dicho trámite las alegaciones que estimen pertinentes y a aportar la documentación que consideren necesaria".

Se permite incluso al responsable intervenir en cualquier momento antes del trámite de audiencia, sin que esto implique prescindir de este trámite. El número 8 del artículo 99 de la LGT prevé la posibilidad de que se obvie el trámite de audiencia en aquellos procedimientos específicos que prevén, entre otras, la posibilidad de presentar alegaciones posteriores a la resolución. Ahora bien, ni el apartado 3 del artículo 41 de la LGT, ni el apartado tercero del artículo 174 de la misma ley, contemplan la posibilidad de presentar alegaciones una vez declarada la responsabilidad, por lo que

\footnotetext{
908 DE LA NUEZ SÁNCHEZ-CASCADO, E., FERNÁNDEZ CUEVAS, A., y OGEA MARTÍNEZ-OROZCO, M., El estatuto del Contribuyente. Comentarios a la Ley 1/1998, de Derechos y Garantías de los Contribuyentes, Aranzadi, Pamplona, 1998, pág. 230. La necesidad del trámite de audiencia ha sido reivindicada por la doctrina. Entre otros, PÉREZ ROYO, F. y AGUALLO AVILÉS, A., Comentarios a la Reforma de la Ley General Tributaria, op. cit., pág. 101; FERNÁNDEZ JUNQUERA, M., "Reflexiones en torno al responsable solidario y a la solidaridad en Derecho tributario", Revista Española de Derecho Financiero, núm. 91, 1996, pág. 424 y, de la misma autora, "Reflexiones en torno al responsable solidario y a la solidaridad en Derecho tributario", en la obra Sujetos Pasivos y Responsables Tributarios, Instituto de Estudios Fiscales-Marcial Pons, Madrid, 1997, pág. 632.

${ }^{909}$ Resoluciones del TEAC de 10 de enero de 1996 y de 26 de junio de 1997.

${ }^{910}$ Sentencia del Tribunal Superior de Justicia de Baleares de 24 de septiembre de 1991.
} 
se reafirma el criterio de que el trámite de audiencia es imprescindible dentro del procedimiento de derivación de la responsabilidad ${ }^{911}$.

La LGT no determina un plazo para el trámite de audiencia, pero el primer apartado del artículo 124 del RGR dispone que el plazo para el trámite de audiencia es de quince días contados a partir del día siguiente al de la notificación de la apertura de dicho plazo. Plazo que es el que se prevé a nivel general en el segundo apartado del artículo 84 de la LRJ-PAC. Por su parte, el tercer número del artículo 174 de la LGT matiza que el trámite de audiencia no excluye el derecho de los presuntos responsables a formular las alegaciones y a aportar documentación con anterioridad al mismo y que dentro de este plazo no deben tenerse en cuenta las demoras en las que incurra la Administración tributaria o las que sean por fuerza mayor.

\subsubsection{Adopción de medidas cautelares}

El apartado quinto del artículo 41 LGT reconoce que con anterioridad a la declaración de responsabilidad la Administración competente puede adoptar medidas cautelares, cuyo régimen general se encuentra en el artículo 81 de la LGT, y realizar actuaciones de investigación con las facultades previstas en los artículos 142 y 162 de la misma ley. No se trata aquí de analizar el régimen general que acompaña a este tipo de medidas, ya que fue examinado anteriormente ${ }^{912}$, sino de valorar su inserción dentro del procedimiento de derivación de responsabilidad.

La ley faculta a la Administración tributaria para que adopte medidas cautelares una vez que se inicia el procedimiento frente al responsable y antes de que culmine, en su caso, con la declaración de la responsabilidad. Esta acción no implica a los deudores principales, sino exclusivamente a los responsables, siempre que se haya iniciado el procedimiento frente a éstos, tal como se establece en el primer apartado del artículo 124 del RGR.

Las medidas cautelares pueden tomarse en el seno de un procedimiento de comprobación o inspección y de un procedimiento de recaudación. Carece de sentido que el número quinto del artículo 41 de la LGT reconozca expresamente la atribución de competencia para adoptar medidas cautelares a los órganos competentes para declarar la responsabilidad. Aunque no es del todo ilógico que en la redacción de ese apartado se reproduzca esta atribución, porque, como dijimos anteriormente, el procedimiento de declaración de responsabilidad no es un procedimiento de recaudación, ni de inspección o comprobación. Se trata, como dijimos en su momento, de un procedimiento de liquidación y esto se confirma con lo dispuesto en este precepto de la ley.

Al remitirnos a la regulación de la adopción de las medidas cautelares que hacía la LGT de 1963, observamos que ya se preveía este tipo de acción por parte de la Administración contra los responsables subsidiarios antes de que fueran declarados fallidos los deudores principales y los responsables solidarios, por lo que puede afirmarse que cabía la actuación cautelar frente a un sujeto

\footnotetext{
911 "Nos hallamos ante una garantía incorporada al régimen regulador de la responsabilidad que viene a poner de manifiesto el carácter esencial del trámite de audiencia, coadyuvando además a la consideración de la declaración de responsabilidad como procedimiento de carácter diferenciado" (CALVO VÉRGEZ, J., La derivación de responsabilidad tributaria, Thomson Reuters, Pamplona, 2011, pág. $38)$.

912 Vid. supra. Capítulo Primero, epígrafe 1.4. "Medidas cautelares en el período voluntario".
} 
que aún no había sido declarado responsable y, a veces, sin tener certeza de que se hubiera producido el presupuesto de hecho de la responsabilidad. Específicamente, el apartado 5 del artículo 37 de la LGT de 1963 preveía la posibilidad de que antes de que se produjera la declaración de la responsabilidad, la Administración adoptara frente a los responsables subsidiarios las oportunas medidas cautelares $^{913}$. Esta situación se modificó con la LGT de 2003. En el quinto apartado de su artículo 41 de la LGT se reconoce la posibilidad de establecer medidas cautelares contra cualquiera de los dos tipos de responsables, solidarios o subsidiarios, antes de que sean declarados como tales, y remite a su vez, a los artículos 81, 142 y 162 de la LGT. Sin embargo, la LGT, a diferencia de su predecesora, sólo permite la adopción de medidas cautelares una vez iniciado el procedimiento de derivación y no antes.

La adopción de medidas cautelares está prevista en el procedimiento de inspección. El artículo 146 de la LGT autoriza que en ese procedimiento se adopten medidas cautelares, al disponer que

“en el procedimiento de inspección se podrán adoptar medidas cautelares debidamente motivadas para impedir que desaparezcan, se destruyan o alteren las pruebas determinantes de la existencia o cumplimiento de obligaciones tributarias o que se niegue posteriormente su existencia o exhibición".

Este precepto se completa con los postulados del artículo 181 del RGGI, que determina, entre otras cosas, que la adopción de medidas cautelares se efectúe por diligencia, en la que se informará al obligado tributario de su derecho a formular alegaciones en el término improrrogable de cinco días ante el órgano competente para liquidar ${ }^{914}$. Por su parte, el artículo 162 de la LGT reconoce esta misma potestad a los órganos de recaudación, en las mismas condiciones que las que se recogen en el artículo 146 de la LGT.

Un tema conflictivo es la posibilidad de adoptar medidas cautelares antes de que se produzca la declaración de responsabilidad y, por tanto, antes de que sea liquidada la deuda del responsable. Coincidimos con GALÁN RUIZ en que la adopción de medidas cautelares respecto de los responsables subsidiarios "sería factible dentro del plazo voluntario de ingreso que se otorga al responsable subsidiario tras la notificación del acto de derivación de responsabilidad, pero nunca antes"915. La fundamentación de esta postura radica en el hecho de que hasta que no se declarare fallido el deudor principal sólo su patrimonio debe estar afecto al pago de la deuda tributaria. Se

\footnotetext{
913 Sobre la extensión de la adopción de medidas cautelares a los responsables solidarios, FALCÓN Y TELLA expresó que "ningún inconveniente hay para ello, siempre que los indicios racionales de que el cobro se verá frustrado o dificultado -que constituye el presupuesto habilitante de la medida cautelar- se aprecien y motiven en relación con el responsable al que se vaya a afectar dicha medida" (FALCÓN Y TELLA, R., "Los responsables en la nueva Ley General Tributaria”, op. cit., pág. 6).

${ }^{914}$ Para BARRACHINA JUAN, "no basta con la mera sospecha para adoptar una medida cautelar contra el administrador (...) sino que el órgano de recaudación deberá acreditar documentalmente la existencia de enajenaciones patrimoniales que evidencien de forma racional e indubitada que efectivamente el administrador pretende eludir la posible acción administrativa de cobro que se le puede dirigir contra él" (BARRACHINA JUAN, E., "Responsabilidad tributaria de los administradores de sociedades: el acto de derivación de la responsabilidad", op. cit., pág. 44).

${ }^{915}$ GALÁN RUIZ, J., La responsabilidad tributaria, op. cit., pág. 172. CARBAJO VASCO considera inadmisible la posibilidad de introducir medidas cautelares contra el responsable antes de la derivación de su responsabilidad (CARBAJO VASCO, D., "La responsabilidad tributaria de los administradores de sociedades mercantiles. Análisis del artículo 40.1 de la Ley General Tributaria", Crónica Tributaria, núm. 76, 1996, pág. 72).
} 
deben, en principio, agotar todas las gestiones de cobro frente al deudor principal y sólo si con éste fuera imposible satisfacer la deuda tributaria, la Administración tributaria podría dirigirse contra los responsables subsidiarios, adoptando dentro de su período voluntario de pago las medidas cautelares sobre su patrimonio si existieran indicios racionales de que dicho cobro se verá gravemente dificultado. Así, también podrían mantenerse las medidas cautelares mientras durara el período voluntario de pago, e incluso, durante su período ejecutivo. De no ser éste el planteamiento aceptado, se estarían imponiendo al responsable subsidiario unas medidas cautelares para asegurar un pago sin saber el monto exacto del mismo, y además se estarían exigiendo estas medidas sin haber dado a este sujeto la oportunidad de impugnar el fundamento de su responsabilidad, pudiendo darse el caso, en último término, de que las medidas cautelares se hubieran adoptado sobre un patrimonio que podría no tener que responder finalmente de la deuda tributaria ${ }^{916}$.

DE LA HUCHA CELADOR considera que "parece más correcto postular, de lege ferenda, que la adopción de medidas cautelares vaya precedida, en todo caso, de la notificación de un acto de responsabilidad subsidiaria, cuyo contenido sea, estrictamente, la declaración de la citada responsabilidad fundada en la constatación de la realización del presupuesto de hecho establecido por el ordenamiento jurídico. Ello serviría para dotar de cobertura y fundamento a las medidas cautelares que ulterior o coetáneamente pueda adoptar el órgano de recaudación y, además, permitiría que el responsable subsidiario conociese su condición administrativa de deudor no principal de la obligación principal antes de producirse la declaración de fallido del obligado principal y del responsable solidario. Declarada la falencia de éstos, el órgano de recaudación únicamente debería notificar al responsable subsidiario -como tal previamente declarado- la cantidad a que se extiende su obligación, con sujeción a lo dispuesto en el artículo 14.3 del RGR"917.

Para algunos autores, no obstante, las medidas cautelares pueden adoptarse en cualquier momento del procedimiento. PÉREZ ROYO y AGUALLO AVILÉS expresaron que "del artículo 128 LGT se deduce claramente que las medidas cautelares se pueden adoptar en cualquier momento o fase del procedimiento. (...) Es más, de los supuestos que se contemplan en la Ley General Tributaria tras la reforma, se deduce que las medidas cautelares pueden ser acordadas no sólo en período voluntario o en período de apremio, sino incluso antes de que se haya iniciado siquiera el plazo voluntario de ingreso o, aún más, antes de que se haya constituido formalmente la relación jurídico tributaria respecto del obligado al pago" $" 918$.

Por otro lado, la ley no prevé la posibilidad de que los responsables puedan presentar reclamaciones contra la adopción por parte de la Administración tributaria de medidas cautelares, dada su condición de acto de trámite. Aunque si aceptamos la tesis mencionada anteriormente de que esta adopción se

\footnotetext{
${ }^{916}$ El TEAC, en su Resolución de 9 de septiembre de 1998, estableció que cuando no esté declarada ni cuantificada la obligación del responsable subsidiario se debe tomar como base para adoptar las medidas cautelares la deuda total de la que era responsable el deudor principal, garantizándose de esta forma el pago de conceptos expresamente excluidos de la deuda del responsable, como el recargo ejecutivo y las sanciones.

917 DE LA HUCHA CELADOR, F., "Algunas consideraciones sobre la responsabilidad tributaria en el Reglamento General de Recaudación de 1990: II. Responsabilidad Subsidiaria”, op. cit., pág. 64. En el mismo sentido, DURÁN-SINDREU BUXADE, A., "La responsabilidad tributaria de los administradores de sociedades", op. cit., pág. 58; COMBARROS VILLANUEVA, V. E., "La responsabilidad tributaria, solidaria y subsidiaria, en el procedimiento de recaudación”, op. cit., pág. 386.

${ }^{918}$ PÉREZ ROYO, F. y AGUALLO AVILÉS, A., Comentarios a la Reforma de la Ley General Tributaria, op. cit., pág. 515.
} 
produce dentro del período voluntario de pago del responsable, esto es, una vez declarado fallido el obligado principal, habrá que concluir que sí será posible impugnar estos actos, puesto que el inciso g) del apartado segundo del artículo 227 de la LGT admite la reclamación económica-administrativa contra los actos dictados en el seno de un procedimiento de recaudación.

\subsubsection{Actuaciones de investigación}

El órgano competente para declarar la responsabilidad puede, con carácter previo, realizar actuaciones de investigación con las facultades previstas en los artículos 142 y 162 de la LGT, iniciando un procedimiento que debe ser notificado al posible responsable. Es necesario, para ello, que anteriormente se haya iniciado un procedimiento inspector o de recaudación contra el deudor principal y que en el mismo hayan aparecido indicios de la existencia de un posible responsable.

La función de garantía que ha de cumplir el responsable queda sujeta de este modo a una actividad de control. Las actuaciones de naturaleza comprobatoria e investigación a que están sujetos los responsables se diferencian del resto de los obligados tributarios, al efectuarse en un momento anterior a la liquidación de la deuda, pues lo que se pretende aquí es verificar la condición de responsable del sujeto y de esta forma asegurar el cobro de la deuda tributaria. En particular, la adopción de las medidas cautelares implica la realización de determinadas actuaciones de comprobación con el objetivo de identificar la ocurrencia o no de indicios racionales de que el cobro puede resultar frustrado o gravemente afectado y, por tanto, indagar sobre la existencia y situación de los bienes y derechos integrantes del patrimonio.

Para el ejercicio de estas actividades, el número 5 del artículo 41 de la LGT atribuye competencias a la Administración tributaria con las facultades recogidas en los artículos 142 y 162 de la LGT, atribuciones que coinciden con las prerrogativas de los órganos de inspección y de recaudación, respectivamente. Esta previsión resulta coherente con la atribución de la competencia a estos dos órganos en el procedimiento de declaración de responsabilidad.

\subsection{TERMINACIÓN DEL PROCEDIMIENTO DE DERIVACIÓN DE RESPONSABILIDAD}

El procedimiento de derivación de la responsabilidad se inicia de oficio y finaliza con la resolución de declaración de responsabilidad, que debe ser notificada al responsable, como se contempla en el apartado 5 del artículo 41 y en el apartado cuarto del artículo 174, ambos de la LGT, dentro del período de los seis meses desde que se notificó el acuerdo de inicio del procedimiento. Este acto debe contener el texto íntegro del acuerdo de declaración de responsabilidad, con indicación del presupuesto de hecho habilitante y las liquidaciones a las que alcanza dicho presupuesto, de acuerdo con el régimen de las liquidaciones tributarias que aparecen en los artículos 101 y 102 de la LGT $^{919}$.

\footnotetext{
${ }^{919}$ MARTÍN JIMÉNEZ, F. J., El procedimiento de derivación de responsabilidad tributaria, Lex Nova, Valladolid, 2000 , pág. 155.
} 


\subsubsection{Acto administrativo de declaración de responsabilidad}

\subsubsection{Notificación y contenido}

El apartado cuarto del artículo 174 de la LGT, al regular los elementos que debe contener el acto de declaración de la responsabilidad, incluye, además del texto íntegro del acuerdo de declaración de responsabilidad, con indicación del presupuesto de hecho habilitante y las liquidaciones a las que alcanza dicho presupuesto, los medios de impugnación que pueden ser ejercitados contra dicho acto, órganos ante los que han de presentarse estas reclamaciones y el plazo para interponer las mismas, así como el lugar, plazo y forma en que debe ser satisfecho el importe exigido al responsable.

Para que este acto administrativo de declaración de responsabilidad produzca sus efectos se requiere su notificación al responsable, de manera que la omisión del acto de declaración de responsabilidad, cuya finalidad es la protección de los derechos de los responsables, determina la nulidad del procedimiento $^{920}$

Se equipara de este modo a este procedimiento con cualquiera de los procedimientos de liquidación que de manera general contempla la LGT. En contra de esta conclusión se muestra, sin embargo, NAVARRO ALCÁZAR, cuando afirma que "no resulta admisible equiparar la acción contra el responsable como una acción de liquidación y el acto administrativo de derivación de responsabilidad como un acto de liquidación, pues ello supondría admitir que al responsable se le practica una nueva liquidación, lo cual es incorrecto" "921. En este mismo sentido, GONZÁLEZ ORTIZ apuntó "que el acto de declaración de responsabilidad tributaria no es un acto de liquidación; no liquida o calcula el quantum de la obligación exigible al responsable tributario, sino, tan sólo, declara motivadamente la obligación del responsable de pagar la deuda tributaria ajena"922.

Nosotros asumimos en esta materia la misma posición de MAZORRA MANRIQUE DE LARA, cuando señala que "la liquidación no es más que una declaración de las oficinas gestoras de la Administración sobre el an o el quantum de una obligación tributaria", y que "por tanto, la liquidación notificada al responsable no es más que la cuantificación de la obligación del responsable que es distinta de la obligación del sujeto pasivo"923.

Por otra parte, el apartado cuarto del artículo 174 de la LGT resulta insuficiente para aclarar las dudas que puedan surgir en relación con el alcance del contenido que debe incluir el acto de derivación de responsabilidad. Las dificultades fundamentales aparecen en la determinación de los elementos esenciales de esta liquidación en los supuestos en que la responsabilidad se extiende a las sanciones. En este ámbito, NAVARRO EGEA entiende que, de la interpretación de los artículos 174 y el apartado cuarto del artículo 41, ambos de la LGT, el acuerdo de derivación de responsabilidad ha de

\footnotetext{
${ }^{920}$ Sentencias del Tribunal Supremo de 3 de marzo de 1989; de 19 de julio de 1993; o de 19 de julio de 1995.

${ }^{921}$ NAVARRO ALCÁZAR, J. V., "La responsabilidad tributaria de los administradores de las sociedades mercantiles", Tribunal Fiscal, núm. 75, 1995, pág. 88 .

922 GONZÁLEZ ORTIZ, D., La responsabilidad tributaria en el ordenamiento jurídico español, op. cit., pág. 88.

${ }^{923}$ MAZORRA MANRIQUE DE LARA, S., "La obligación de los responsables tributarios en el Reglamento General de Recaudación: nacimiento y exigibilidad”, op. cit., pág. 73 y 74. En la misma línea, RUIZ HIDALGO, C., La responsabilidad tributaria en el alzamiento de bienes en la nueva Ley General Tributaria, op. cit., pág. 151.
} 
integrar los datos relativos a la realización del hecho imponible o cualquier otro supuesto del que se derive la obligación garantizada, la identificación del deudor principal y los componentes de aquella obligación, es decir, con el detalle suficiente para determinar el montante de la prestación en el período voluntario, y que en los casos en que la responsabilidad se extienda a las sanciones éstas integrarán el acto de derivación de responsabilidad ${ }^{924}$.

De forma similar, GALÁN RUIZ opina que, "dado que el responsable está legitimado para impugnar los efectos en los que se pudo incurrir a la hora de practicar la liquidación al deudor principal”, es "esencial la notificación de la misma al responsable", y que "no sólo debe tener acceso el responsable subsidiario a la liquidación practicada al deudor principal, (...) sino a todo el expediente en el que se recojan los distintos actos que llevaron a la práctica de la liquidación, pues el responsable podrá impugnar tanto la cuantía de la liquidación practicada al deudor principal, como el procedimiento seguido por la Administración tributaria hasta llegar a dicha liquidación”. Ello implica, según el mismo autor, que "cuando afirmamos que el responsable podrá impugnar la liquidación debemos entender ese término no sólo como un acto administrativo de liquidación, sino como un procedimiento liquidatorio, por lo que los defectos en los que se hubiera podido incurrir son plenamente impugnables por el responsable subsidiario" ${ }^{, 925}$.

Otro aspecto relevante del contenido del acto de declaración de responsabilidad es el que se refiere al plazo de pago, que se regula en el número 6 del artículo 174 de la LGT, adoptando los mismos plazos que se establecen para el régimen general en el segundo apartado del artículo 62 de la LGT. La deuda tributaria del responsable se pagará de la misma forma que si se tratara de cualquier deuda tributaria surgida de liquidaciones practicadas por la Administración tributaria. Si el responsable no pagara en el término establecido por el apartado dos del artículo 62 de la LGT, su deuda se exigirá por la vía de apremio, lo que implica que se extenderá a los recargos del período ejecutivo que procedan.

Sin embargo, la determinación del plazo de pago en que el responsable debe dar cumplimiento a su obligación en período voluntario es en ocasiones de difícil concreción. Es poco probable que pueda cumplirse con las exigencias del plazo dispuesto en el apartado segundo del artículo 62 de la LGT en el supuesto previsto en el inciso a) del apartado primero del artículo 175 de la LGT, en que se declara y notifica la responsabilidad en cualquier momento anterior al vencimiento del período voluntario de la deuda que se deriva y en el que basta con requerir el pago una vez transcurrido dicho período. No es posible aquí que el plazo que se otorga a este responsable solidario tenga los mismos efectos que cualquier acto de liquidación, si se tiene en cuenta que para que ello se produzca debe transcurrir el período voluntario de pago del deudor principal y que el inicio del plazo se condiciona al requerimiento de pago que haga la Administración tributaria.

\footnotetext{
${ }^{924}$ NAVARRO EGEA, M., El responsable tributario, op. cit., pág. 43.

${ }^{925}$ GALÁN RUIZ, J., La responsabilidad tributaria, op. cit., pág. 194. Como advierte DE LA HUCHA CELADOR, dado que la deuda del responsable subsidiario "se extiende a la deuda inicialmente liquidada al deudor principal en período voluntario, es inexcusable, para que el responsable pueda ejercitar las acciones impugnatorias que considere procedentes contra la cuantía de su obligación, que conozca la liquidación notificada al deudor principal, ya que de la validez o nulidad de ésta depende la validez o no de la cuantificación de su obligación propia efectuada por el órgano de recaudación" (DE LA HUCHA CELADOR, F., "Algunas consideraciones sobre la responsabilidad tributaria en el Reglamento General de Recaudación de 1990: II. Responsabilidad Subsidiaria”, op. cit., pág. 57).
} 


\subsubsection{Impugnación}

Una vez notificado el acto de declaración de responsabilidad, el responsable tiene dos posibles alternativas de actuación: la satisfacción de la deuda en un período voluntario de pago o la impugnación de su responsabilidad o de la liquidación establecida en el acto de declaración ${ }^{926}$.

La LGT de 1963 otorgaba al responsable los mismos derechos que a los deudores principales desde el momento en que se declaraba su responsabilidad, a tenor lo que disponía el número cuarto del artículo 37 de la LGT de 1963. De este precepto se desprendían dos consecuencias importantes, no sólo para el responsable sino también para el deudor principal. Por una parte, el responsable podía impugnar la declaración de responsabilidad tanto por los motivos vinculados a la realización o no del presupuesto de hecho de la responsabilidad como por razones que afectaran a la liquidación. Asimismo, si el recurso del responsable prosperaba por entenderse improcedente la liquidación, el fallo afectaba al deudor principal, aun cuando estuviera firme. Esta perspectiva legislativa avalaba la posición de la Administración e incluso de la jurisprudencia de que la declaración de responsabilidad trasladaba al responsable la misma liquidación que se exigía al obligado principal, de manera que, al existir un solo acto de liquidación, su anulación beneficiaba a todos los destinatarios.

Con la entrada en vigor de la LGT de 2003, esta situación se modificó, y se optó por el criterio de que el acto de declaración de responsabilidad constituye en realidad un acto de naturaleza liquidadora para el responsable. Coexisten de esta forma dos liquidaciones, la del deudor principal y la del responsable. Por ello el apartado cuarto del artículo 174 de la LGT reconoce la impugnabilidad del acto de declaración de responsabilidad y el apartado 5 del mismo precepto especifica que podrán impugnarse el presupuesto de hecho habilitante de la declaración de responsabilidad y las liquidaciones a las que alcanza el mismo, incluida la liquidación practicada al deudor principal de la que se deriva la deuda del responsable. Esta impugnación por parte del responsable de la liquidación practicada al deudor principal podrá efectuarse contra la cuantía de la liquidación y contra los defectos formales en que haya incurrido la Administración tributaria al practicar la liquidación ${ }^{927}$. Aunque la propia ley aclara que si la liquidación hubiera adquirido firmeza para el deudor principal, solamente se podrá revisar el importe de la obligación del responsable que haya interpuesto el recurso o la reclamación, sin alterarse la liquidación girada al deudor principal ${ }^{928}$.

\footnotetext{
${ }^{926}$ En relación con la impugnación del acto de declaración de la responsabilidad, VALENTÍN-FERNÁNDEZ SANTACRUZ manifiesta que "como indica el art. 37.4 LGT, desde el momento en que se produzca la notificación del acuerdo al responsable se le confieren todos los derechos del deudor principal. Ello supone, tal como disponen los arts. 12.3.2. c) y 14.2. b) RGR, que se le conceden los correspondientes medios de impugnación tanto contra el propio acto de derivación o declaración de responsabilidad como contra las liquidaciones que se le requieren, las cuales, aun pudiendo ser firmes para el deudor principal, vuelven a ser recurribles por el responsable" (VALENTÍN-FERNÁNDEZ SANTACRUZ, M. J., "La Ley de Derechos y Garantías del Contribuyente en materia de recaudación”, Actualidad Jurídica Aranzadi, núm. 356, 1998, pág. 4).

${ }^{927}$ GALÁN RUIZ, J., La responsabilidad tributaria, op. cit., pág. 199 y 200.

${ }^{928}$ La posibilidad de que el responsable pueda impugnar la liquidación del deudor principal, aunque sea firme, fue reconocida tanto por la doctrina como por la jurisprudencia y la doctrina administrativa. En este sentido, CHECA GONZÁLEZ, C., El estatuto del Contribuyente (estudio de la nueva Ley), Lex Nova, Valladolid, 1998, pág. 468. En la jurisprudencia, vid. las Sentencias del Tribunal Superior de Justicia de Murcia de 28 de junio de 1995; del Tribunal Superior de Justicia de Cataluña de 15 de enero de 1997; del Tribunal Superior de Justicia de Baleares de 23 de enero de 1997; del Tribunal Superior de Justicia de Cantabria de 17 de febrero de 1998; del Tribunal Superior de Justicia de Andalucía, Sevilla, de 18 de noviembre de 2005. En la doctrina administrativa, por todas vid. la Resolución del TEAC de 13 de mayo de 1997.
} 
Efectivamente, para los casos en que la liquidación del deudor principal ha devenido firme, la ley determina que el responsable podrá plantear un recurso, pero especifica el quinto apartado del artículo 174 de la LGT que

"sin que como consecuencia de la resolución de estos recursos o reclamaciones puedan revisarse las liquidaciones que hubieran adquirido firmeza para otros obligados tributarios, sino únicamente el importe de la obligación del responsable que haya interpuesto el recurso o la reclamación",929.

Existen interpretaciones más restrictivas de los tribunales que niegan que un acto que ha adquirido firmeza pueda ser objeto de impugnación a través de los recursos ordinarios, sosteniendo que tan sólo cabría la impugnación contra la liquidación "en aquellos supuestos en los que el deudor principal, por cualquier motivo (supongamos que la liquidación no fue notificada correctamente) no pudo impugnar ni cuestionar a través de los recursos admitidos en derecho la deuda tributaria originaria" ${ }^{\text {. }}$. La doctrina busca dar solución a la legitimación del responsable para impugnar el acto de declaración de responsabilidad por cualquier motivo relacionado con el supuesto de hecho de la responsabilidad o con la liquidación ${ }^{931}$, expresándose en ocasiones en contra de la revisión cuando lo que se discute es una liquidación que ha devenido firme, a pesar de que se trate de obligaciones independientes ${ }^{932}$.

Finalmente, no todos los elementos que integran la obligación del deudor principal pueden ser impugnados por el responsable, a tenor de lo que establece el tercero de los apartados del artículo 41 de la LGT, según el cual quedan excluidas de la revisión las sanciones, salvo en los casos en que expresamente se exijan; los intereses de demora devengados durante el período ejecutivo; y los recargos que se originan en ese período. Aunque nada dice el artículo 174 de la LGT sobre la posibilidad de que el responsable ejerza su defensa antes de que se produzca la declaración de responsabilidad. En este sentido, NAVARRO EGEA se lamenta que la norma no haya "acotado mejor el perfil del responsable como obligado tributario desde que realiza el supuesto de hecho de la responsabilidad, reconociendo su legitimación para llevar a cabo ciertas actuaciones (por ejemplo el pago de la deuda garantizada y la impugnación de la liquidación)"933.

\footnotetext{
${ }^{929}$ CALVO ORTEGA se opone a esta medida restrictiva, pues entiende que la condición de firmeza sólo puede afectar al obligado principal y que su negligencia al recurrir o la demora de la Administración en la apertura del procedimiento frente al responsable, no puede ser un impedimento para que éste reclame contra la obligación principal (CALVO ORTEGA, R., "Obligados tributarios", $o p$. cit., pág. 180). Sin embargo, BOSCH CHOLBI entiende que la restricción del precepto no se refiere a los motivos que puede oponer el responsable, sino a los efectos derivados de la resolución, intentando evitar que ésta pueda beneficiar al deudor principal (BOSCH CHOLBI, J. L., "Los responsables tributarios en la LGT 58/2003: aspectos controvertidos", op. cit., pág. 39).

${ }^{930}$ Sentencia del Tribunal Superior de Justicia de Madrid de 18 de diciembre de 2003.

${ }^{931}$ DELGADO GARCíA, A. M., La Derivación de responsabilidades en la recaudación de los tributos, op. cit., pág. 288.

${ }^{932}$ ARIAS ABELLÁN, M. D., "El estatuto jurídico del responsable del tributo en el derecho español”, op. cit., pág. 192 a 194.

${ }^{933}$ NAVARRO EGEA, M., El responsable tributario, op. cit., pág. 53. En la misma línea, SÁNCHEZ GALIANA, J. A., "El responsable", op. cit., pág. 648. Otros autores se han referido también a la posibilidad de que el responsable pueda impugnar la declaración de fallido del deudor principal y de los responsables solidarios. Entre otros, DE LA HUCHA CELADOR, F., "Algunas consideraciones sobre la responsabilidad tributaria en el Reglamento General de Recaudación de 1990: II. Responsabilidad Subsidiaria", op. cit., pág. 53; DURÁN-SINDREU BUXADE, A., "La responsabilidad tributaria de los administradores de sociedades", op. cit., pág. 56.
} 


\subsubsection{Duración del procedimiento de derivación de responsabilidad}

Otro aspecto de interés dentro del régimen jurídico de la responsabilidad tributaria es la duración del procedimiento que se sigue frente a los responsables. Como ya se ha expresado en reiteradas ocasiones, la ubicación que tiene el procedimiento de derivación de responsabilidad dentro de la LGT, en el seno de los procedimientos de recaudación, no se corresponde con la verdadera naturaleza liquidadora del mismo. Al ser un procedimiento administrativo distinto del procedimiento de apremio $^{934}$, el plazo dispuesto para la declaración de responsabilidad será el previsto en el primero de los apartados del artículo 104 de la misma ley, es decir, el plazo fijado por la normativa reguladora del correspondiente procedimiento, sin que pueda exceder de seis meses. Por lo demás, al tratarse de un procedimiento que se inicia de oficio, el cómputo del plazo se inicia desde la fecha de notificación del acuerdo de inicio y la consecuencia jurídica que se vincula a la falta de resolución en el plazo indicado es la caducidad del procedimiento.

\subsubsection{Falta de resolución expresa}

La falta de resolución expresa dentro del plazo de seis meses contados a partir de la notificación del acuerdo de inicio del procedimiento también provoca la terminación del procedimiento de derivación de responsabilidad.

Según puntualiza el propio artículo 104 de la LGT, en su apartado 4, en los procedimientos iniciados de oficio el vencimiento del plazo máximo establecido sin que se haya notificado resolución expresa producirá los efectos previstos en la normativa reguladora de cada procedimiento de aplicación de los tributos. Al no existir una regulación expresa para este tipo de procedimiento, los efectos serán los que determina el inciso b) del cuarto apartado del artículo 104 de la LGT. Si bien es cierto que la LGT no dispone de preceptos específicos que regulen esta materia, el RGR establece en el tercer apartado de su artículo 124 que cuando el procedimiento para derivar la responsabilidad se inicie por los órganos competentes para dictar la liquidación y dicha declaración no se haya notificado con anterioridad al vencimiento del período voluntario de pago de la deuda resultante de la liquidación, el procedimiento para declarar la responsabilidad se entenderá por concluido sin más trámite, sin perjuicio de que con posterioridad pueda iniciarse un nuevo procedimiento por los órganos de recaudación.

De los dos artículos anteriores se pueden extraer las consecuencias jurídicas que se producirán en el supuesto de que la Administración tributaria no cumpla con el plazo máximo para emitir la resolución y notificar la misma al presunto responsable. Estamos en presencia de un procedimiento que no es de recaudación, ni de apremio, que se inicia de oficio y que puede producir efectos de gravamen, y este conjunto de características nos permiten concluir que el efecto de la falta de resolución expresa por regla general será el de la caducidad. Si se produce ésta, el procedimiento se considera inexistente, por lo que nada impide que pueda volver a iniciarse otro procedimiento de igual naturaleza dentro del período de prescripción. Concretamente, en caso de incumplimiento de la Administración tributaria, el procedimiento caducará, aplicándose el tercer apartado y el segundo párrafo del apartado 5 del artículo 104 de la LGT. Esto significa que podrá iniciarse, con

\footnotetext{
${ }^{934}$ ARIAS ABELLÁN M. D., "El régimen jurídico del responsable en la Nueva Ley General Tributaria”, op. cit., pág. 507.
} 
posterioridad, otro procedimiento de igual naturaleza, pero distinto del caducado. En este caso, la Administración deberá cumplir todos los requisitos legales y reglamentarios exigidos, pudiendo incorporar las actuaciones, documentos y los elementos de pruebas que se presentaron en el procedimiento caducado, que mantienen por mandato legal la misma validez y eficacia.

El RGR, en el número primero de su artículo 124, prevé que la duración del procedimiento de derivación de responsabilidad sea de seis meses, plazo que también contempla la LGT en el primer apartado de su artículo 104, aunque en ninguno de estos dos mandatos se precisan las consecuencias del incumplimiento del mismo. Por este motivo es posible aplicar el contenido del inciso b) del apartado cuarto del artículo 104 de la LGT, que prevé la caducidad cuando se trata de procedimientos que se inician de oficio con posibles efectos desfavorables o de gravamen, como es sin duda el procedimiento de derivación de responsabilidad.

La caducidad del procedimiento, según el apartado 5 del artículo 104 de la LGT, será declarada de oficio o a instancia del interesado, pero no producirá, por sí sola, la prescripción de los derechos de la Administración tributaria. En cualquier caso, las actuaciones realizadas en los procedimientos caducados no interrumpirán el plazo de prescripción ni se considerarán requerimientos administrativos a los efectos previstos en el apartado 1 del artículo 27 de la LGT, lo que permite a la Administración tributaria iniciar un nuevo procedimiento, siempre que no se haya producido la prescripción de acuerdo con el artículo 66 de la LGT.

Como bien aclara RUIZ HIDALGO, una cosa es que caduque el procedimiento, "sin que ello afecte a la acción administrativa de liquidar -que es lo que se produce en el procedimiento de derivación de responsabilidad-, salvo que hubiera transcurrido el correspondiente plazo de prescripción, y otra que el procedimiento caducado interrumpa el plazo de prescripción. Ello supone que si el derecho de la Administración a liquidar la obligación tributaria sigue vivo, se pueda iniciar otro nuevo procedimiento" "935. Y también SOLER ROCH apunta que es "cierto que si se produce la caducidad de un procedimiento, el efecto práctico es el mismo que si no se hubiera interrumpido la prescripción, ya que al tenerse por no realizadas las actuaciones administrativas, éstas no han tenido efecto interruptivo de la prescripción: pero esta situación no impide que, si un procedimiento ha finalizado por caducidad pero todavía no se ha consumado el plazo (no interrumpido) de prescripción, pueda iniciarse un nuevo procedimiento para hacer valer el ejercicio del derecho, con el consiguiente efecto interruptivo de la prescripción"

Las normas reglamentarias también se refieren, finalmente, a la posibilidad de que caduque el procedimiento de derivación de responsabilidad, disponiendo el apartado tercero del artículo 124 del RGR que

"Cuando el procedimiento para declarar la responsabilidad se inicie por los órganos competentes para dictar la liquidación y dicha declaración no se haya notificado con anterioridad al vencimiento del periodo voluntario de

\footnotetext{
${ }^{935}$ RUIZ HIDALGO, C., La responsabilidad tributaria en el alzamiento de bienes en la nueva Ley General Tributaria, op. cit., pág. 144.

${ }^{936}$ SOLER ROCH, M. T., "Plazos (art. 23)", en la obra Comentarios a la Ley de Derechos y Garantías de los Contribuyentes, Centro de Estudios Financieros, Madrid, 1999, pág. 417.
} 
pago de la deuda resultante de la liquidación, el procedimiento para declarar la responsabilidad se dará por concluido sin más trámite, sin perjuicio de que con posterioridad pueda iniciarse un nuevo procedimiento por los órganos de recaudación; a tal efecto, las actuaciones realizadas en el curso del procedimiento inicial, así como los documentos y otros elementos de prueba obtenidos en dicho procedimiento, conservarán su validez y eficacia a efectos probatorios en relación con el mismo u otro responsable".

El problema en este caso se presenta porque el órgano de recaudación puede iniciar el procedimiento de derivación contra el mismo responsable o contra otros e, incluso en algunos casos en que la persona contra la que se dirija el procedimiento sea distinta del responsable contra el que se inició el expediente originario, el RGR establece que se conservará la validez de las actuaciones, documentos y otros elementos de prueba obtenidos en el primer procedimiento. Sobre este particular, advierte MARTÍN JIMÉNEZ que "cuando la persona contra la que se dirija el segundo procedimiento sea distinta de aquella contra la que se dirigió el primero, su falta de intervención en el primer procedimiento podría generar problemas de indefensión (desde la óptica del art. 24.1 o incluso del art. 24.2 CE), por lo que es probable que no todos los actos realizados o pruebas obtenidas en el primer procedimiento puedan ser automáticamente trasladables al segundo"937.

\subsection{EXIGIBILIDAD DE LA DEUDA TRIBUTARIA AL RESPONSABLE}

La exigencia de la obligación del responsable ocurre en un momento distinto del de la declaración de la responsabilidad, aunque puede suceder que coincidan en el tiempo. Para determinar el momento en que se produce la derivación de la responsabilidad y la exigibilidad de la obligación al responsable, la LGT diferencia en los artículos 175 y 176 el procedimiento frente a un responsable solidario y frente a un responsable subsidiario, respectivamente.

El artículo 175 de la LGT reconoce dos supuestos en los que puede ser declarada la responsabilidad solidaria: antes del vencimiento del período voluntario de pago del deudor principal y después del vencimiento de dicho período voluntario de pago (esto es, en el período ejecutivo). Teniendo en cuenta los postulados de la normativa vigente para esta figura, es posible afirmar que el momento para exigir la obligación al responsable solidario será el mismo para ambos supuestos, una vez transcurrido el período voluntario de pago de la deuda. En el primero de los casos, cuando la declaración de la responsabilidad se produjo antes del vencimiento el período voluntario de pago, sólo será necesario que se cumpla el plazo para el ingreso en período voluntario de pago para el deudor principal, de manera que si éste no cumple con su obligación de pago la deuda del responsable solidario se podrá exigir sin más requisito, con un simple requerimiento y sin que la Administración tributaria tenga que emitir un título ejecutivo para exigir la acción de cobro ${ }^{938}$. Por el contrario, cuando la derivación de responsabilidad no es declarada y notificada antes del vencimiento del período voluntario de pago del deudor principal, la Administración tendrá que dictar el acto de

\footnotetext{
${ }^{937}$ MARTÍN JIMÉNEZ, A., Los Supuestos de responsabilidad en la LGT: (hacia una configuración constitucional y comunitaria de la responsabilidad tributaria), op. cit., pág. 165.

${ }^{938}$ DAGO ELORZA, I., "Comentario al artículo 174 de la LGT", en la obra Comentarios a la Nueva Ley General Tributaria, HUESCA BOADILLA, R. (coordinador), Thomson-Aranzadi, Navarra, 2004, pág. 47.
} 
derivación de responsabilidad en el que se exija el pago de la deuda a cargo del responsable. En este supuesto se dicta un acto de declaración de responsabilidad y de requerimiento de pago por parte de los órganos de recaudación ${ }^{939}$.

Asimismo, el segundo apartado del artículo 175 de la LGT se refiere al procedimiento de derivación de responsabilidad en un caso determinado, la responsabilidad de los sucesores en la titularidad o ejercicio de explotaciones o actividades económicas. Específicamente en este supuesto de responsabilidad solidaria se otorga al adquirente de las explotaciones o actividades económicas unas garantías que no tienen el resto de los responsables, con la pretensión de "paliar los graves efectos y la inseguridad jurídica" que se pueden provocar en estos supuestos ${ }^{940}$. En efecto, los sujetos que pretendan adquirir la titularidad de estas explotaciones o actividades económicas con el objetivo de limitar su responsabilidad solidaria pueden solicitar a la Administración tributaria con el consentimiento del titular que transmite una certificación de las deudas y responsabilidades tributarias derivadas del ejercicio de aquéllas. La Administración tributaria tendrá el plazo de tres meses para emitir dicha certificación, en cuyo caso la responsabilidad del adquirente se reducirá a las deudas que consten en la certificación. Si en el término de tres meses no se facilitara por parte de la Administración la citada certificación o la misma se expidiera sin mencionar deudas, sanciones o responsabilidades, el adquirente quedará exento de la responsabilidad de las deudas del anterior titular $^{941}$.

Por su parte, el artículo 176 de la LGT determina el procedimiento para exigir la responsabilidad subsidiaria en líneas muy generales. Al respecto prevé que una vez declarados fallidos el deudor principal y, en su caso, los responsables solidarios, la Administración tributaria debe dictar un acto de declaración de responsabilidad que se notifica al responsable subsidiario. De aquí se desprende claramente que la declaración de responsabilidad subsidiaria se producirá con posterioridad a la declaración de fallido del deudor principal y de los responsables solidarios. Con esto se limita la posibilidad que se produzca la declaración de la responsabilidad subsidiaria antes de que se practique la liquidación al deudor principal. Sin embargo, puede decirse que el artículo 176 de la LGT constituye una excepción al primer apartado del artículo 174 de la LGT, al determinar éste último una regla general y una posible excepción a ella. La regla general es que la responsabilidad puede declararse en cualquier momento posterior a la liquidación o autoliquidación, y la salvedad es que ello no será así en el caso de que la ley disponga otra cosa, y es aquí donde debemos ubicar la regla del artículo 176 de la LGT. Al tratarse de responsables subsidiarios no puede declararse la responsabilidad de estos sujetos en cualquier momento, sino únicamente tras la declaración de fallido del deudor principal y, si los hubiera, de los responsables solidarios.

El artículo 124 del RGR permite que el órgano de recaudación, una vez apreciado que el patrimonio del deudor principal y, en su caso, de los responsables solidarios no permite cubrir el importe

\footnotetext{
${ }^{939}$ Aclaran MARTÍN JIMÉNEZ y SANTOLAYA BLAY que la LGT admite expresamente en el artículo 175 la división entre el acto de declaración que puede realizar la inspección y la exigencia de la responsabilidad que compete a los órganos de recaudación (MARTÍN JIMÉNEZ, A., Los Supuestos de responsabilidad en la LGT: (hacia una configuración constitucional y comunitaria de la responsabilidad tributaria), op. cit., pág. 171, y SANTOLAYA BLAY, M., "El procedimiento de derivación de responsabilidad tributaria en la Ley 58/2003”, Revista de Contabilidad y Tributación, núm. 271, 2006, pág. 150).

${ }^{940}$ DAGO ELORZA, I., “Comentario al artículo 174 de la LGT”, op. cit., pág. 1237.

${ }^{941}$ Vid. supra., Capítulo Cuarto, epígrafe 2.4.1.3. "Sucesión de empresas".
} 
completo de la deuda, se dirija contra los responsables subsidiarios. Esta cuantía se determina entonces de modo aproximado, y esta circunstancia puede entrar en contradicción con el artículo 176 de la LGT, que al referirse a la insolvencia del deudor principal no especifica si se trata de una insolvencia total o parcial, pero sí en todo caso cierta y cuantificada de modo exacto. Por ello, entendemos que el artículo 124 del RGR contradice la norma legal que pretende desarrollar y esta vulneración no puede subsanarse apelando, como hace este precepto reglamentario, a los principios de subsidiaridad, proporcionalidad y prudencia en el ejercicio de la acción de cobro frente al responsable.

Por otro lado, la ley precisa cuál es el procedimiento mediante el cual la Administración tributaria exigirá el cumplimiento de la obligación tributaria a los responsables. ARIAS ABELLÁN interpreta que aquí la LGT se está refíriendo al "ejercicio de la función recaudatoria que debe llevarse a efecto de acuerdo con los procedimientos recaudatorios previstos en esa ley pero advirtiendo que para su materialización se requiere previamente un acto administrativo en el que se declare la responsabilidad y su alcance y extensión" "942. Es decir, que para poder exigir el cumplimiento de la obligación prevista, es necesario que se concrete su existencia, cuantía y el sujeto que quedará obligado a satisfacerla.

Una vez notificado el acto al responsable éste tiene un período voluntario de pago, que es el período general dispuesto en el apartado 2 del artículo 62 de la LGT, de acuerdo con la remisión que hace el número 6 del artículo 174 de la LGT. Es en este momento cuando se inicia el procedimiento de recaudación para el responsable, en los términos establecido por el régimen general que aparece recogido en los artículos 160 y siguientes de la LGT.

Por último, los apartados 2 y 4 del artículo 124 del RGR circunscriben a cada obligado el efecto de sus actos, lo cual implica que la suspensión del procedimiento o el aplazamiento o fraccionamiento de la deuda sólo afectará al responsable que haya presentado la reclamación o la solicitud correspondientes. Literalmente expresa el segundo apartado del artículo 124 del RGR que

"las solicitudes de aplazamiento de deudas o las soluciones de suspensión del procedimiento de recaudación efectuadas por un responsable no afectarán al procedimiento de recaudación iniciado frente a los demás responsables de las deudas a las que se refieran dichas solicitudes".

Podría entenderse que el reglamento rompe con la regla de la solidaridad del apartado 7 del artículo 35 de la LGT y que por ello excede el contenido de ésta. No obstante, esta presunta ilegalidad podría quedar saldada si se entiende que se está en presencia de varios responsables cuyas obligaciones se originan por la realización de diferentes presupuestos de hechos de responsabilidad. O bien, a pesar de existir pluralidad de responsables que responden de la misma deuda, que se produce la división de esta última, como lo contempla el propio precepto $^{943}$.

\footnotetext{
942 ARIAS ABELLÁN, M. D., "El régimen jurídico del responsable en la nueva Ley General Tributaria”, op. cit., pág. 501.

${ }^{943}$ Vid. ARIAS ABELLÁN M. D., "Precisiones sobre el procedimiento de declaración de la responsabilidad tributaria: a propósito del artículo 124 del Reglamento General de Recaudación”, op. cit., pág. 581.
} 
Por otra parte, desde el propio artículo 41 de la LGT se determina en su apartado 3 que la obligación de pago alcanzará a la totalidad de la deuda exigida en período voluntario y que además, se concede al responsable un período voluntario de pago. La ausencia de pago en este período provoca el inicio del período ejecutivo, pudiéndose exigir al responsable los recargos e intereses que procedan por la vía de apremio y la aplicación del embargo ejecutivo, tal como establece el apartado 6 del artículo 174 de la LGT.

Las deudas del responsable y deudor principal, en fin, volverían a diferenciarse, incluso en la vía ejecutiva, aun cuando ésta tuviera lugar dentro del mismo período, aunque se apremien en la misma fecha. Pues no será suficiente una misma providencia de apremio, tal como se prevé en el artículo 167 de la LGT.

Tampoco existe comunicabilidad entre los efectos del pago que se efectúe por el responsable y por el obligado principal. Aun cuando se trate de procedimientos ejecutivos seguidos contra ambos sujetos, la obligación de cada uno tiene diferentes conceptos e importes. En este sentido, la satisfacción de la deuda por el responsable no implica la extinción de la deuda del obligado principal y de los demás responsables, si los hubiera, ni la terminación del procedimiento ejecutivo que se siguiera contra ellos mientras no satisfagan su importe total, como estipula el número 1 del artículo 116 del RGR.

La incomunicación entre los actos de los sujetos pasivos y de los responsables se observa también claramente en los efectos de las reclamaciones y recursos que se interpongan frente a las liquidaciones, en los términos del quinto apartado del artículo 174 de la LGT y más concretamente en el apartado cuarto del artículo 124 del RGR. E indica el apartado 2 de este último artículo que las solicitudes de aplazamiento, fraccionamiento y suspensión, de un responsable no afectan al procedimiento de recaudación iniciado frente a los demás responsables, ni siquiera a los del mismo tipo.

Como excepción, cuando se exige al responsable su deuda dentro de un período voluntario y el mismo no se efectúa, el incumplimiento provoca el devengo de los correspondientes recargos ejecutivos e intereses, pero si uno de los responsables satisface la deuda, ésta se extingue para todos y dejan de devengarse intereses y recargos, porque son obligaciones accesorias de la deuda inicial extinguida con el pago, sin perjuicio de la pervivencia de los ya devengados.

\section{LA EXTINCIÓN DE LA OBLIGACIÓN DEL RESPONSABLE Y SU DERECHO AL REEMBOLSO}

Nada dice el artículo 41 de la LGT sobre la forma en que se extingue la obligación del responsable. ARIAS ABELLÁN y NAVARRO EGEA son de la opinión que, dada la similitud que tiene la figura del responsable con la fianza, se aplican los mismos criterios que se utilizan para extinguir la obligación del fiador, además de las otras causas que se exigen para el resto de las obligaciones ${ }^{944}$. Dado el carácter accesorio que se reconoce a la obligación del responsable, muchos autores otorgan a ésta la misma suerte que a la obligación principal que garantiza. Esta particularidad ha motivado que una buena parte de la doctrina aplique directamente a la obligación del responsable las causas de

\footnotetext{
${ }^{944}$ ARIAS ABELLÁN, M. D., "El estatuto jurídico del responsable del tributo en el derecho español”, op. cit., pág. 205; NAVARRO EGEA, M., El responsable tributario, op. cit., pág. 63.
} 
extinción de las deudas tributarias que regula el artículo 59 de la LGT. Según este precepto, las deudas tributarias pueden extinguirse por pago, prescripción, compensación o condonación, por medios previstos en la normativa aduanera y por los demás medios previstos en el resto de las leyes. Si bien podría pensarse que todas estas formas de extinción son aplicables a la obligación del responsable, debemos precisar varios elementos en el caso del pago y la prescripción, por las peculiaridades que concurren cuando se trata de la responsabilidad tributaria.

\subsection{EL PAGO}

El pago es una de las formas de extinción de la obligación tributaria que reconoce la LGT y es también la forma ordinaria de extinción de la obligación del responsable. A lo que ya expusimos en el primer capítulo, cuando estudiamos la institución del pago, sólo queremos añadir algunos comentarios en relación a una circunstancia determinada que puede ocurrir cuando el responsable paga antes de que se inicie su propio período voluntario de pago. Ciertamente, éste es un comportamiento poco habitual de los responsables, pero no debe descartarse, pues existe la posibilidad de que el responsable garantice de esta forma sus intereses con el fin de ejercer la acción de regreso frente al deudor principal antes de que se declare insolvente o bien para aprovechar las reducciones previstas en el régimen de las sanciones (artículo 188 de la LGT).

Para NAVARRO EGEA ${ }^{945}$ los pagos que realice el responsable antes de que sea declarada su responsabilidad deben ser tenidos como pago por tercero, aunque para el responsable el ejercicio de esta acción restringiría sus derechos a los que se derivan del acto material del pago. Esta postura es correcta si se tiene en consideración que al pagador no se confiere la condición de obligado tributario, porque todavía no ha sido declarada su responsabilidad, pero a la vez resulta insuficiente si este pago se efectúa una vez que ha sido derivada la responsabilidad ${ }^{946}$, porque el tercero no es un presunto responsable que hace frente a la obligación principal del deudor principal.

\subsection{LA PRESCRIPCIÓN COMO FORMA DE EXTINCIÓN DE LA OBLIGACIÓN TRIBUTARIA}

La prescripción es una de las formas de extinción de las obligaciones tributarias, tal como estipula la LGT en el artículo 66. En palabras de GARCÍA NOVOA, la prescripción es una categoría general del Derecho "cuya finalidad es modular el efecto del paso del tiempo sobre la inactividad de quien pudiendo ejercer un derecho no lo hace. (...) Su fundamento radica en la seguridad jurídica, pues las pretensiones deben ejercitarse en un lapso temporal razonable no siendo aceptable que cualquier sujeto de Derecho quede indefinidamente a merced de la actuación de otro"947.

En la prescripción concurren dos requisitos: por un lado, el silencio de la relación jurídica, y por otro, el mantenimiento de ese silencio durante un tiempo determinado. Según FALCÓN Y TELLA, la prescripción consiste en la "inadmisibilidad del ejercicio tardío de un derecho -es decir, del ejercicio del derecho cuando ha existido un continuado silencio de la relación jurídica-, y funciona mediante la

\footnotetext{
${ }^{945}$ NAVARRO EGEA, M., El responsable tributario, op. cit., pág. 65.

${ }^{946}$ SÁNCHEZ GALIANA, J. A., "El responsable”, op. cit., pág. 641.

${ }^{947}$ GARCÍA NOVOA, C., Iniciación, interrupción y cómputo del plazo de prescripción de los tributos, Marcial Pons, Madrid, 2011, pág. 13.
} 
atribución al sujeto pasivo o a un tercer interesado de la facultad para detener, enervar o repeler dicho ejercicio tardío, o -en el Derecho público- mediante la imposición al acreedor de una obligación de abstenerse de ejercitar las facultades y acciones tendentes a la tutela de su crédito" ${ }^{948}$. Se trata de un "hecho jurídico, esto es, un acontecimiento de la realidad independiente de la voluntad de las partes, que tiene influencia en la relación jurídica, en este caso, el transcurso de un determinado período de tiempo sin ejercitar las titularidades inherentes a la citada relación jurídica"949.

La fundamentación que la doctrina civil otorga a la prescripción tiene en cuenta dos consideraciones. La primera, que la prescripción es una consecuencia de la necesaria certidumbre de las relaciones jurídicas, una exigencia de la seguridad jurídica. La segunda es de índole subjetiva, porque la ausencia de ejercicio de un derecho durante algún tiempo suele interpretarse como un abandono o una renuncia del mismo. Sin embargo, en materia tributaria no es posible aplicar de manera mecánica los esquemas del Derecho privado y el principio de indisponibilidad de la obligación tributaria excluye que el silencio de la Administración tributaria pueda ser interpretado como una renuncia a la efectividad del crédito tributario. Por tanto, en el ámbito tributario la prescripción sólo tiene una fundamentación objetiva, que debe reconducirse al principio de seguridad jurídica y también al principio de capacidad económica.

El régimen de la prescripción, como dijimos al principio, se encuentra en el artículo 66 de la LGT, dentro del Título II dedicado a la deuda tributaria, configurándose como una de las causas de extinción de la obligación tributaria. Este precepto indica que prescribe a los cuatro años el derecho de la Administración tributaria para determinar la deuda tributaria mediante la oportuna liquidación; el derecho de la Administración tributaria para exigir el pago de las deudas tributarias liquidadas y autoliquidadas; y el derecho de los obligados a obtener las devoluciones derivadas de la normativa de cada tributo, las devoluciones de los ingresos indebidos y el reembolso del coste de las garantías. Además, el apartado 2 del artículo 67 de la LGT recoge específicamente un plazo de prescripción para exigir la obligación de pago a los responsables solidarios, produciéndose la independencia de la prescripción de la obligación de responsable respecto de la obligación del deudor principal, debido al carácter garantista que tiene la primera.

\subsubsection{La prescripción de la obligación del responsable tributario}

El profesor FALCÓN Y TELLA apuntó que en la aplicación de los tributos se manifiestan una variedad considerable de situaciones jurídicas, tales como la obligación tradicional que es susceptible de prescripción y otras a las que se aplica la caducidad, y también determinados vínculos obligacionales, como las obligaciones formales o accesorias, que no poseen una prescripción autónoma y que se ven afectadas por la prescripción de la obligación principal ${ }^{950}$. Siguiendo con estos razonamientos, podría pensarse que una vez que ha prescrito la obligación tributaria principal no tiene sentido el ejercicio de la garantía de la responsabilidad. Sin embargo, la posible prescripción

\footnotetext{
${ }^{948}$ FALCÓN Y TELLA, R., La prescripción en materia tributaria, op. cit., pág. 67.

${ }^{949}$ ALONSO ARCE, I., La prescripción en los procedimientos tributarios y el régimen de Concierto Económico con la Comunidad Autónoma del País Vasco, Thomson-Aranzadi, Navarra, 2003, pág. 54.

${ }^{950}$ FALCÓN Y TELLA, R., La prescripción en materia tributaria, op. cit., pág. 26, 27 y 45.
} 
de la obligación del responsable al margen o independientemente de la prescripción de la obligación del deudor principal ha sido un tema que ha suscitado opiniones contradictorias.

Una posición contraria a la autonomía de la prescripción de la obligación del responsable ha sido argumentada en el Informe de la Dirección General de la Inspección Financiera y Tributaria, de 21 de diciembre de $1990^{951}$. En este informe se aboga por la existencia de un único plazo de prescripción, tanto para el sujeto pasivo como para el responsable, "entendiendo que en el vínculo del responsable subsidiario estará vigente en tanto en cuanto subsista la deuda tributaria. En otras palabras", concluye este órgano administrativo, "no cabe hablar simultáneamente de dos plazos de prescripción, uno relativo al sujeto pasivo y otro concerniente al responsable, sujetos a sus propias reglas cada uno de ellos. De forma que en un primer estadio, la prescripción atañe exclusivamente al sujeto pasivo del tributo, se interrumpe por las causas señaladas en el artículo 66 de la LGT y, una vez cumplida, podrá ser alegada por el sujeto pasivo o, en su caso, por el responsable". También contrario a la admisión de un plazo propio de prescripción para el responsable se encuentra MARTÍN CÁCERES, que sustenta este criterio en la idea de que la prescripción opera sobre la deuda tributaria y no sobre los obligados al pago ${ }^{952}$.

Por el contrario, están a favor de la existencia de plazos de prescripción diferentes para el deudor principal y para el responsable, entre otros, ARRANZ DE ANDRÉS, RODRÍGUEZ MÁRQUEZ o DELGADO GARCÍA. Esta última autora señala que se puede defender el criterio de un plazo independiente de prescripción para el responsable porque se determina el alcance de su deuda a través de un acto de derivación de responsabilidad y se otorga un período voluntario para el pago de su obligación" ${ }^{953}$. RODRÍGUEZ MÁRQUEZ, por su parte, entiende que "la seguridad jurídica y, sobre todo, el más elemental derecho de defensa reclaman que sea la Administración la que dicte un acto administrativo por el que se declare la existencia de responsabilidad y su alcance y que sea susceptible de revisión judicial", y que, por ello, el obligado no puede estar sujeto a la obligación de manera ilimitada, pues "la certeza de las relaciones jurídicas exige que, transcurrido determinado plazo, aquélla se extinga por prescripción" "954. También ARRANZ DE ANDRÉS se manifiesta a favor de un plazo autónomo de prescripción para el responsable porque la propia legislación civil establece que la obligación del fiador se extingue al mismo tiempo que la del deudor y por las mismas causas que las demás obligaciones, de manera que si la propia obligación principal prescribe por la "inactividad de las potestades que a la Administración le corresponde desarrollar para lograr la efectividad de dicha obligación (...) otro tanto ocurrirá con la obligación surgida para el responsable" ${ }^{, 955}$.

A nuestro entender, a pesar de que la obligación del responsable está estrechamente ligada a la obligación del deudor principal y que en gran medida ésta última sirve de base para la configuración

\footnotetext{
${ }^{951}$ Vid. este informe en la revista Impuestos, núm. 8, 1991, pág. 31 y ss.

${ }^{952}$ MARTÍN CÁCERES, A. F., La prescripción del crédito tributario, op. cit., pág. 188.

${ }^{953}$ DELGADO GARCÍA, A. M., La derivación de responsabilidades en la recaudación de los tributos, op. cit., pág. 174.

${ }^{954}$ RODRÍGUEZ MÁRQUEZ, J. S., "La prescripción de la obligación del responsable en la nueva LGT”, Nueva Fiscalidad, núm. 4 , 2004, pág. 21.

955 ARRANZ DE ANDRÉS, C., "La prescripción de la obligación del responsable tributario", en la obra Estudio de Derecho Financiero y Tributario en Homenaje al Profesor Calvo Ortega, Tomo I, Lex Nova, Valladolid, 2005, pág. 538.
} 
de la primera, no debemos olvidar que estamos ante obligaciones independientes. En el caso de la deuda del responsable, debe ser determinada por la Administración tributaria la existencia de la responsabilidad por haberse realizado el presupuesto de hecho que aparece en la ley y, además, debe concretarse su cuantía. De ahí que podamos decir que la obligación del responsable es autónoma, y por ende, susceptible de prescripción de forma independiente. Por otra parte, y a pesar de la similitud de esta obligación con la fianza, no puede aplicarse a la primera de manera supletoria la normativa civil porque presenta peculiaridades propias del ordenamiento tributario, como es, por ejemplo, el carácter ex lege de la obligación del responsable, opuesto al origen voluntario que acompaña al fiador. Debemos tener en cuenta, en fin, que la LGT actual incluyó expresamente por primera vez la prescripción para exigir la obligación del responsable solidario y subsidiario en el apartado 2 de su artículo $67^{956}$.

La LGT vigente aborda este aspecto de la responsabilidad siguiendo las tesis administrativas. El segundo apartado del artículo 67 de la LGT determina el momento inicial para el cómputo de la prescripción dependiendo del tipo de responsabilidad. En los casos de responsabilidad solidaria, el precepto señalado dispone que el plazo de prescripción para exigir la obligación de pago del responsable comienza a contar desde el día siguiente a la finalización del plazo de pago en período voluntario del deudor principal. La Ley 7/2012, sin embargo, introdujo una excepción a esta regla para los casos en que los hechos que constituyen el presupuesto de la responsabilidad se produzcan con posterioridad al período voluntario de pago, iniciándose entonces el plazo de prescripción en el momento en que tengan lugar dichos hechos. Cuando se trate de responsables subsidiarios, el cómputo de la prescripción comienza a computar desde la notificación de la última actuación recaudatoria seguida contra el deudor principal y los responsables solidarios.

Pero lejos de resolver las interrogantes que anteriormente se suscitaban en relación con la prescripción de la obligación del responsable, el apartado 2 del artículo 67 de la LGT viene a plantear nuevas dudas. La interpretación de este precepto indica que el plazo de prescripción previsto es para exigir la obligación de pago. Sin embargo, la propia LGT, en sus artículos 174 a 176, permite diferenciar entre la fase declarativa de la responsabilidad y la fase de exigencia de la misma. Por el contrario, el apartado segundo del artículo 67 de la LGT se refiere sólo a la fase de exigencia de la responsabilidad, pero no se pronuncia sobre la prescripción en la fase de declaración de la obligación" 957 . "Así, el art. 67.2 LGT no ha hecho más que recoger por vía legislativa una doctrina jurisprudencial que adolecía de importantes defectos: la ausencia de distinción entre la fase declarativa y recaudatoria de la derivación de responsabilidad y la teoría de la actio nata conducía a entender que la prescripción sólo se produciría desde el momento en que la responsabilidad resulte exigible. (...) Evidentemente, la consecuencia para el responsable, en términos de seguridad jurídica,

\footnotetext{
${ }^{956}$ Con anterioridad, la doctrina administrativa había reconocido el plazo de prescripción para exigir las obligaciones liquidadas al responsable en la Resolución del TEAC de 8 de marzo de 2000, a pesar de entender que el procedimiento seguido frente a los responsables solidarios y subsidiarios forma parte del procedimiento de recaudación contra el deudor principal. Sobre el contenido de esta Resolución, vid. el trabajo de LOZANO SERRANO, C., “¿Cabe la caducidad de la derivación de responsabilidad? (Comentario los nuevos argumentos del TEAC contra la caducidad)", Jurisprudencia Tributaria Aranzadi, núm. 13, 2000, pág. 2154. La Audiencia Nacional también ha reconocido un período de prescripción para el responsable diferente al del obligado principal en las Sentencias de 7 y 14 de octubre de 2002, y de 13 y 16 de enero de 2003.

${ }^{957}$ ARIAS ABELLÁN, M. D., "Precisiones sobre el procedimiento de declaración de la responsabilidad tributaria: a propósito del artículo 124 del Reglamento General de Recaudación”, op. cit., pág. 31; GIMÉNEZ REYNA, MARTíN FERNÁNDEZ, F. J. y RODRÍGUEZ MÁRQUEZ, J. S., “La responsabilidad tributaria”, op. cit., pág. 186.
} 
es deficiente: su situación de pendencia, por ejemplo, si el deudor principal recurre puede prolongarse todo el tiempo que tarden en resolverse los recursos correspondiente o bien puede verse en la situación de que la espera no se prolongue demasiado pero la exigencia de la misma penda sobre él hasta que los tribunales decidan al respecto con relación al deudor principal"958.

\subsubsection{La prescripción del plazo para declarar la responsabilidad tributaria}

El apartado segundo del artículo 67 de la LGT sólo se refiere a los plazos de prescripción para ejercitar la acción de cobro por parte de la Administración tributaria, sin efectuar ninguna referencia al plazo de prescripción para ejercitar el derecho a liquidar la deuda del responsable tributario. Con el fin de colmar esta laguna legal, algunos autores han defendido que el cómputo de la prescripción de la declaración de responsabilidad se inicia cuando finaliza el plazo voluntario de presentación de la declaración o autoliquidación del deudor ${ }^{959}$ o, más específicamente, cuando se produce el devengo de la obligación del responsable, que coincide con la realización del presupuesto de hecho de la responsabilidad $^{960}$. La LGT, sin embargo, en el primer apartado del artículo 174, condiciona la posibilidad de que el plazo para el cómputo de la prescripción para que la Administración tributaria ejerza su derecho para declarar la responsabilidad pueda iniciarse desde el momento en que se realizó el presupuesto de hecho de la responsabilidad al hecho de que con anterioridad se encuentre liquidada la deuda del obligado principal. En un sentido similar, ARRANZ DE ANDRÉS propone que el plazo de prescripción, cuando no exista una disposición especial que determine otra cosa, se inicie desde el día en que la Administración tributaria pudo ejercer su derecho a reconocer o liquidar créditos a su favor, sobre la base del artículo 1.969 del Código Civil y el artículo 15 de la LGP de $2003^{961}$. También la jurisprudencia mantuvo esta interpretación, siguiendo el principio de la actio nata, al indicar que el plazo de prescripción para la obligación del responsable se inicia desde que puede ejercerse la acción sobre él, mediante la notificación a este sujeto de la derivación de responsabilidad $^{962}$.

Como bien señala GARCÍA NOVOA. la interpretación del término de obligación de pago a que hace referencia el segundo apartado del artículo 67 de la LGT deberá hacerse "respecto a responsabilidades declaradas en el plazo máximo de cuatro años sin interrupciones desde el momento en que se dicta la liquidación o se presenta la autoliquidación", pues "de esta manera se aseguraría la plena separación, a efectos de cómputo del plazo de prescripción, de la declaración de

\footnotetext{
${ }^{958}$ MARTÍN JIMÉNEZ, A., Los Supuestos de responsabilidad en la LGT: (hacia una configuración constitucional y comunitaria de la responsabilidad tributaria), op. cit., pág. 178.

959 GIMÉNEZ REYNA, MARTÍN FERNÁNDEZ, F. J. y RODRÍGUEZ MÁRQUEZ, J. S., "La responsabilidad tributaria”, op. cit., pág. 186.

${ }^{960}$ ARIAS ABELLÁN, M. D., "Precisiones sobre el procedimiento de declaración de la responsabilidad tributaria: a propósito del artículo 124 del Reglamento General de Recaudación”, op. cit., pág. 38. En el mismo sentido, GONZÁLEZ ORTIZ, D., La responsabilidad tributaria en el ordenamiento jurídico español, op. cit., pág. 110 y ss.; MAZORRA MANRIQUE DE LARA, S., Los responsables tributarios, Instituto de Estudios Fiscales-Marcial Pons, Madrid, 1994, 2001, pág. 164; CALVO ORTEGA, R., "La responsabilidad tributaria subsidiaria”, op. cit., pág. 142; DELGADO GARCÍA, A. M., La derivación de la responsabilidades en la recaudación de los tributos, op. cit., pág. 176; FERNÁNDEZ JUNQUERA, M., Sujetos pasivos y responsables tributarios, Instituto de Estudios Fiscales-Marcial Pons, Madrid, 1997, pág. 635.

${ }^{961}$ ARRANZ DE ANDRÉS, C., "La prescripción de la obligación del responsable tributario”, op. cit., pág. 541 a 542.

${ }^{962}$ Por todas, vid. sentencias de la Audiencia Nacional de 21 de febrero de 2000 y de 4 de marzo de 2004; sentencias de los Tribunales Superiores de Justicia de Islas Canarias, Santa Cruz de Tenerife, de 21 de abril de 2005, y de Las Palmas, de 23 de junio de 2006 ; y Resoluciones del TEAC de 15 de enero de 1999 y de 25 de mayo de 2000.
} 
responsabilidad y de la acción de cobro ante el responsable y se superaría definitivamente la actio nata" "963. No obstante, ARRANZ DE ANDRÉS advierte que "difícilmente se producirá desde la práctica de la liquidación o presentación de la autoliquidación el necesario transcurso de cuatro años de inactividad para poder apreciar la prescripción de la obligación del responsable solidario, y ello por ser la terminación de dicho período voluntario -por otra parte de duración tasada-, la causa que habilita a la Administración para exigir el pago al responsable solidario, computándose precisamente desde ese momento la prescripción de su obligación en relación con la referida acción para exigirle el pago" 964 .

En definitiva, entendemos que el plazo de prescripción del derecho de la Administración tributaria para declarar la responsabilidad es de cuatro años contados a partir de la práctica de la liquidación o de la presentación de la autoliquidación, aunque en muchas ocasiones la determinación de la responsabilidad y su exigencia se hace a través de un acto único, por lo que puede tener poco sentido entonces que la LGT regule un plazo para el cómputo de la prescripción del derecho que tiene la Administración tributaria para declarar la responsabilidad ${ }^{965}$.

\subsubsection{La prescripción del derecho a exigir el pago al responsable}

El segundo de los plazos de prescripción a los que se encuentra sometida la obligación del responsable es el relativo a la acción para exigir el pago de la deuda. En el caso del responsable solidario, el plazo de prescripción comenzará a partir de la finalización del período voluntario de pago del deudor principal. Este mandato se adecúa al contenido del artículo 175 de la LGT, que no permite que se realice ninguna acción de cobro frente al responsable hasta que no finalice el período voluntario de pago para el obligado principal. Sin embargo, esta regla general tiene sus matices dentro de la propia LGT, porque el artículo 67 de esta ley indica que este momento inicial del cómputo del plazo se sitúa en el momento en que se realizan los hechos constitutivos del presupuesto de la responsabilidad cuando los mismos se producen con posterioridad al período voluntario de pago ${ }^{966}$. Por el contrario, para los responsables subsidiarios el plazo de prescripción se inicia desde la notificación de la última actuación recaudatoria practicada al deudor principal o a cualquiera de los responsables solidarios.

Si tenemos en cuenta que en la responsabilidad solidaria no se precisa la declaración de fallido del deudor principal y que la responsabilidad puede ser declarada en cualquier momento posterior a la práctica de la liquidación o a la presentación de la autoliquidación, salvo que la ley disponga otra cosa, debemos concluir que se desvincula el inicio del plazo de prescripción para exigir la obligación

\footnotetext{
${ }^{963}$ GARCÍA NOVOA, C., Iniciación, interrupción y cómputo del plazo de prescripción de los tributos, op. cit., pág. 174.

${ }^{964}$ ARRANZ DE ANDRÉS, C., "La prescripción de la obligación del responsable tributario”, op. cit., pág. 543.

${ }^{965}$ Algunos autores, entre otros FALCÓN Y TELLA o ÁLVAREZ MARTÍNEZ, abogan por el establecimiento con carácter general de un plazo específico de caducidad para todo tipo de responsabilidad: FALCÓN Y TELLA, R., "La prescripción de la obligación en relación con el responsable: un problema mal planteado, op. cit., pág. 7; ÁLVAREZ MARTíNEZ, J., La Responsabilidad de los administradores de las personas jurídicas en la Ley General Tributaria, op. cit., pág. 314.

${ }^{966}$ MARTÍN JIMÉNEZ expresó que "la regla del art. 67.2 LGT para los responsables ex art. 42.2 LGT tendrá sentido cuando el presupuesto de hecho se haya realizado con posterioridad a la concesión del período de pago voluntario al deudor principal, pero parece olvidar el legislador que la responsabilidad del art. 42.2 LGT también se refiere a conductas acaecidas con anterioridad a ese momento", de manera que, "en este último caso, sería más razonable acudir a la regla principal del art. 67.2 LGT que a la especial" (MARTÍN JIMÉNEZ, A., Los Supuestos de responsabilidad en la LGT: (hacia una configuración constitucional y comunitaria de la responsabilidad tributaria), op. cit., pág. 180).
} 
al responsable del momento de declaración de la responsabilidad solidaria. Dicha declaración puede, por tanto, ser anterior o posterior al momento en que comienza el plazo de prescripción ${ }^{967}$. La solución que brinda la ley para este tipo de responsabilidad, según ÁLVAREZ MARTÍNEZ, “además de resultar hasta cierto punto lógica, contribuye a proporcionar un mínimo de seguridad o certeza en este punto, dado que, cuando menos, se indica un instante cierto, concreto $\mathrm{y}$, sobre todo, fácilmente constatable para el inicio del plazo de prescripción en lo que concierne a los mencionados responsables" $" 968$.

Por lo que respecta a los responsables subsidiarios, condicionar el inicio del cómputo del plazo de prescripción a partir de la notificación de la última actuación de recaudación seguida frente al deudor principal o cualquiera de los responsables solidarios produce un resultado insatisfactorio y carente de seguridad jurídica, porque en este caso la ley no especifica si la última actuación de recaudación debe ser notificada al responsable. "Una interpretación que entienda que la eficacia de los actos en materia de prescripción depende de su comunicación formal, exige entender que la norma quiere referirse a la última actuación recaudatoria notificada", y "ello excluye que se pueda admitir que esa última actuación es siempre la declaración de fallido del deudor principal o del responsable solidario, ya que la declaración de fallido (que es un acto interno, no una actuación recaudatoria en sentido estricto) no se notifica"969. Además, el procedimiento de apremio no se somete a un plazo máximo de terminación, según el apartado primero del artículo 104 de la LGT, ni tampoco se sanciona la inactividad del órgano recaudatorio con la pérdida de virtualidad interruptiva de la prescripción ${ }^{970}$. Puede suceder, no obstante, como advierte BLÁZQUEZ LIDOY, que con posterioridad a la declaración de fallido se produzcan actuaciones tendentes a rehabilitar el crédito y se notifiquen nuevas actuaciones recaudatorias ${ }^{971}$.

A tenor del artículo 174 de la LGT, al responsable se debe notificar el lugar, el plazo y forma en que debe satisfacer su obligación y conceder un período voluntario de pago, que es el previsto en el apartado segundo del artículo 62 de la LGT con carácter general. Una vez vencido este plazo, si no se ha producido el pago por parte del responsable se inicia la vía de apremio. Se distinguen, por tanto, dos acciones diferentes con diversa incidencia en la determinación del cómputo del plazo de prescripción para exigir el pago al responsable. Nos referimos a la acción inicial de la Administración tributaria para exigir la obligación al responsable y a la acción administrativa posterior cuando el responsable no ha satisfecho su deuda en período voluntario y es compelido a hacerlo por la vía de apremio. ARRANZ DE ANDRÉS es del criterio que debe resolverse en consecuencia esta dualidad teniendo en cuento lo establecido en el inciso $b$ ) del artículo 66 de la LGT, que reconoce el plazo de prescripción de cuatro años para el derecho de la Administración tributaria a exigir el pago de las deudas tributarias liquidadas y autoliquidadas, en relación con el artículo 67 de la LGT, que

\footnotetext{
${ }^{967}$ MARTÍN JIMÉNEZ, A., Los Supuestos de responsabilidad en la LGT: (hacia una configuración constitucional y comunitaria de la responsabilidad tributaria), op. cit., pág. 179.

968 ÁLVAREZ MARTÍNEZ, J., La Responsabilidad de los administradores de las personas jurídicas en la Ley General Tributaria, op. cit., pág. 311 y 312 .

${ }^{969}$ GARCÍA NOVOA, C., Iniciación, interrupción y cómputo del plazo de prescripción de los tributos, op. cit., pág. 176.

${ }^{970}$ ARRANZ DE ANDRÉS, C., “La prescripción de la obligación del responsable tributario”, op. cit., pág. 548.

${ }^{971}$ BLÁZQUEZ LIDOY, A., "Novedades de la Ley General Tributaria 58/2003 en la regulación de la responsabilidad tributaria y de la sucesión", op. cit., 16.
} 
determina para este supuesto que el cómputo de los plazos de prescripción comenzarán a contarse desde el día siguiente a aquel en que finalice el plazo de pago en período voluntario del obligado principal, sin perjuicio de lo dispuesto en el apartado 2 del mismo artículo, que se refiere al plazo de prescripción para exigir la obligación a los responsables solidarios y subsidiarios ${ }^{972}$.

\subsubsection{La interrupción de la prescripción de la obligación del responsable}

La LGT contempla la posibilidad de que se produzca la interrupción de la prescripción de la obligación del responsable, ya sea por acciones de la propia Administración tributaria o por acciones de los obligados tributarios, lo que conlleva al reinicio del cómputo. El número 8 del artículo 68 de la LGT dispone que, una vez interrumpido el plazo de prescripción para uno de los obligados tributarios, dicho efecto se extienda a todos los demás, incluidos los responsables. Y el apartado primero del artículo 69 de la LGT prevé que la prescripción ganada aprovecha por igual a todos los obligados al pago de la deuda tributaria.

La comunicación de los efectos interruptivos de la prescripción de la obligación principal a la obligación del responsable, sin embargo, es una tema de divide a la doctrina. ZABALA RODRÍGUEZ-FORNS, LLOPIS GINER, y DAGO ELORZA interpretan que la interrupción de la prescripción de la deuda liquidada afecta a todos los obligados al pago, pero que deben continuar transcurriendo los plazos de prescripción de la obligación del responsable, tanto sobre la acción de derivación como sobre su cobro, con independencia de la interrupción que se produzca, en su caso, de la prescripción que afecta a la obligación del obligado principal, por el hecho de que la primera precisa un acto administrativo de derivación de la responsabilidad ${ }^{973}$. En esta misma línea, GUERRA REGUERA parte de la idea de que mientras no se derive la responsabilidad el responsable no es un obligado al pago, en los términos del RGR, lo que induce a pensar que puede interrumpirse la prescripción para el deudor principal y continuar el curso de la que afecta al responsable ${ }^{974}$. Por último, GALÁN RUIZ recuerda que "los únicos actos administrativos que tendrán efectos interruptivos de la prescripción para el responsable serían los que la Administración dirija contra el propio responsable, tendentes al cobro de la deuda tributaria, como sería la notificación de la declaración de fallido, la puesta de manifiesto del expediente para alegaciones (trámite de audiencia), la notificación del acto de derivación de responsabilidad, y, en el caso de la responsabilidad subsidiaria, la imposición de medidas cautelares tales como el embargo preventivo de bienes" ${ }^{\text {975. }}$.

Otro sector de la doctrina, en cambio, se muestra a favor de la comunicación de los efectos de la interrupción de la prescripción del deudor principal a la del responsable, pero también por distintas razones, sobre la base de lo establecido en el segundo apartado del artículo 62 del RGR de $1990^{976}$. A

\footnotetext{
${ }^{972}$ ARRANZ DE ANDRÉS, C., "La prescripción de la obligación del responsable tributario”, op. cit., pág. 549.

973 ZABALA RODRÍGUEZ-FORNS, A., LLOPIS GINER, F. y DAGO ELORZA, I., Recaudación, aspectos sustantivos y procedimentales, op. cit., pág. 305.

${ }^{974}$ GUERRA REGUERA, M., “¿Cuándo prescribe la obligación del responsable?, Carta Tributaria, núm. 321, 1999 , pág. 10 y 11.

975 GALÁN RUIZ, J., La responsabilidad tributaria, op. cit., pág. 260 y 261. A igual conclusión llegan BANACLOCHE PÉREZROLDÁN, J., La Ley General Tributaria reformada. Ensayo histórico y práctico, La Ley-Actualidad, Madrid, 1995, pág. 22; y GALIANO ESTEVAN, J. e IZQUIERDO RIVAS, J., La responsabilidad tributaria, CISS, Valencia, 1997, pág. 31.

976 Vid. GIMÉNEZ REYNA, MARTÍN FERNÁNDEZ, F. J. y RODRÍGUEZ MÁRQUEZ, J. S., "La responsabilidad tributaria", op. cit., pág. 187; ARIAS ABELLÁN, M. D., "El estatuto jurídico del responsable del tributo en el derecho español”, op. cit., pág. 207; MARTÍN CÁCERES, A. F., La prescripción del crédito tributario, op. cit., pág. 187 y 188. En esta misma línea se expresan la
} 
juicio de DELGADO GARCÍA ${ }^{977}$, la interrupción de la prescripción de la obligación del responsable por las actuaciones dirigidas frente al deudor principal se deriva del carácter accesorio y dependiente de aquélla, argumento que también asume la Resolución del TEAC de 23 de julio de 1996.

La LGT, en el apartado 8 del artículo 68, considera que los efectos interruptivos de la prescripción de actuaciones dirigidas contra el obligado principal se extienden a los responsables. "Por tanto, este efecto viene a desactivar en cierta medida el plazo propio de prescripción que el art. 67.2 de la LGT reconoce al responsable subsidiario, ya que una interrupción antes del inicio del cómputo del plazo del responsable impide que la prescripción por el transcurso de cuatro años opere a su favor, dejándolo en una situación de pendencia poco compatible con la seguridad jurídica"978.

El segundo apartado del artículo 67 de la LGT se refiere a los plazos de prescripción para ejercitar la acción de cobro frente a los responsables. Debemos determinar, entonces, cuáles van hacer los actos interruptivos ante el deudor principal que a su vez interrumpen el plazo de prescripción del responsable, puesto que el régimen de extensión de efectos no puede ser el mismo para los actos de liquidación y para los de recaudación. En el caso de los responsables, los actos de liquidación se incluyen en la declaración de responsabilidad y, por lo tanto, podemos asumir que no se comunican los efectos de la interrupción de la prescripción del derecho a liquidar, de modo que la comunicación de efectos interruptivos está pensada sólo para las acciones recaudatorias ${ }^{979}$. En otras palabras, que la comunicación de la interrupción sólo se produce respecto a responsabilidades que hayan sido declaradas dentro del plazo de prescripción del derecho a liquidar. Y esto es así porque, según GALÁN RUIZ, los responsables no han adquirido la condición de obligados al pago y sólo lo son «potencialmente», lo que implica que sólo desde que el responsable adquiera tal condición los actos interruptivos de otros obligados al pago pueden afectarle. La conclusión, según este autor, "no puede ser otra que la de que sólo será aplicable el art. 62.2 RGR a los que tienen la condición de obligados al pago en el momento en que se produce el acto que interrumpe la prescripción, por lo que ninguno de estos actos afectará a la interrupción de la prescripción de la deuda del responsable hasta que esté no adquiera también la condición de obligado al pago con la notificación del acto de derivación o declaración de responsabilidad"980.

La comunicación de la interrupción, por último, es posible cuando el responsable tiene conocimiento formal del acto de interrupción a través de la correspondiente notificación. "Entendemos que la

Resolución del TEAC de 13 de mayo de 1998 y las Sentencias del Tribunal Superior de Justicia de Cataluña de 15 de enero de 1997 y de Cantabria de 17 de febrero de 1998.

${ }^{977}$ DELGADO GARCÍA, A. M., La derivación de responsabilidades en la recaudación de los tributos, op. cit., pág. 179 y 180.

978 ÁLVAREZ MARTÍNEZ, J., La Responsabilidad de los administradores de las personas jurídicas en la Ley General Tributaria, op. cit., pág. 71.

979 ÁLVAREZ MARTÍNEZ, J., La Responsabilidad de los administradores de las personas jurídicas en la Ley General Tributaria, op. cit., pág. 72. Destaca FALCÓN Y TELLA que el acto de declaración de responsabilidad es un acto de liquidación, y que por ello no se verá afectada su prescripción por los efectos interruptivos que puedan alcanzar al deudor principal durante la actividad recaudatoria seguida contra él (FALCÓN Y TELLA, R., "La prescripción de la obligación tributaria en relación con el responsable: un problema mal planteado", op. cit., pág. 7). Por su parte, la Audiencia Nacional, en su Sentencia de 7 de julio de 1999, dispuso que los supuestos de prescripción "se hallan plenamente interrelacionados ya que si prescribiera el derecho a determinar la deuda tributaria deja de tener sentido la acción recaudatoria, aunque ésta no hubiera prescrito, y si, por el contrario, prescribiera (...) la acción para exigir en este caso el pago, es claro que se produciría también la prescripción del derecho a determinar la deuda tributaria por carencia de objeto".

${ }^{980}$ GALÁN RUIZ, J., La responsabilidad tributaria, op. cit., pág. 261. 
seguridad jurídica exige que las actuaciones seguidas frente al sujeto pasivo no interrumpan la prescripción del responsable, salvo que, como mínimo, este haya tenido conocimiento formal de las mismas" y que, en definitiva, "puede y debe sostenerse que las actuaciones dirigidas contra el deudor principal sin conocimiento del responsable no interrumpen la prescripción de este último", o "al menos, no la interrumpen si no existe una notificación al responsable de dichas actuaciones" 981 . De esta forma, cuando el apartado 8 del artículo 68 de la LGT establece la extensión de los efectos de la interrupción de la prescripción a los demás obligados tributarios, incluidos los responsables, "debe entenderse que dicha extensión sólo se produce en caso de que se cumpla con el requisito previsto en el propio precepto, es decir, que las actuaciones se notifiquen al responsable. Eso quiere decir que, cuando se afirma que las actuaciones ejercidas frente al deudor principal interrumpen la prescripción del responsable, debe entenderse que ello sólo es así si el responsable ha tenido conocimiento formal de dichas actuaciones" $" 982$. Siguiendo esta doctrina, podemos afirmar que cuando la ley dispone que los actos de interrupción de la prescripción del obligado principal interrumpen la prescripción del responsable, se está refiriendo únicamente a actos de recaudación que interrumpen la prescripción de la acción recaudatoria del responsable, siempre y cuando éste tenga conocimiento formal de los mismos.

\subsection{EL DERECHO DE REEMBOLSO DEL RESPONSABLE TRIBUTARIO}

\subsubsection{Fundamento de la acción de regreso que corresponde al responsable tributario}

Dado el carácter garantista de la responsabilidad, es justo plantearse que el responsable pueda resarcirse con el patrimonio del deudor principal a través de una acción de regreso ${ }^{983}$. Téngase en cuenta que el responsable no es el titular de la capacidad económica y que su obligación nace de la realización del presupuesto de hecho de la responsabilidad recogido en ley. Y según la estructura lógica del tributo, el pagador final de la deuda tributaria debe ser aquel sujeto que realiza el hecho imponible y manifiesta la capacidad económica que se quiere gravar.

Por otro lado, el responsable se hace cargo de una deuda que inicialmente la ley exige pagar al deudor principal, por lo que no aparece en la relación jurídica-tributaria hasta que no se produce el incumplimiento de pago por parte del obligado principal. De esta forma, cuando el responsable

\footnotetext{
${ }^{981}$ RODRÍGUEZ MÁRQUEZ, J. S., “La prescripción de la obligación del responsable en la nueva LGT”, op. cit., pág. 56 y 58.

982 ÁLVAREZ MARTÍNEZ, J., La Responsabilidad de los administradores de las personas jurídicas en la Ley General Tributaria, op. cit., pág. 72. Se opone a esta idea MARTÍN JIMÉNEZ, por entender que carece de sentido la exigencia de notificación formal al responsable del acto interruptivo de la prescripción realizado frente a otro obligado tributario. Según el autor, esta tesis sólo tendría lógica si la ley hubiera previsto un plazo de prescripción independiente para la declaración de la responsabilidad. Y apunta que "en el esquema legal, el responsable, con anterioridad al plazo de prescripción del art. 67.2 LGT podrá invocar la prescripción de la obligación principal", pero que, "para ello, es preciso que no haya existido acto alguno interruptivo de la prescripción para el deudor principal. Si tal acto existió, con independencia de que fuera notificado o no al responsable, la obligación de este último permanecerá viva hasta que no se produzca la prescripción del art. 67.2 LGT (MARTÍN JIMÉNEZ, A., Los Supuestos de responsabilidad en la LGT: (hacia una configuración constitucional y comunitaria de la responsabilidad tributaria), op. cit., pág. 183).

${ }^{983}$ La expresión "derecho de reembolso" o "derecho de repetición" ha sido utilizada indistintamente, entre otros, por SÁINZ DE BUJANDA, F., "La responsabilidad tributaria en régimen de solidaridad", op. cit., pág. 319; ARIAS ABELLÁN, M. D., "El estatuto jurídico del responsable del tributo en el derecho español”, op. cit., pág. 196; MARTÍN JIMÉNEZ, F. J., El procedimiento de derivación de responsabilidad tributaria, op. cit., pág. 233. Otros autores, sin embargo, han preferido utilizar la terminología "derecho de regreso", como es el caso de MAZORRA MANRIQUE DE LARA, S., "El régimen jurídico de la responsabilidad tributaria", Crónica Tributaria, núm. 64, 1992, pág. 84; y PEÑA ALONSO, J. L. y CORCUERA TORRES, A., La reforma de la Ley General Tributaria, op. cit., pág. 27.
} 
efectúa el pago se produce un enriquecimiento injusto del deudor principal, que conlleva la restitución del patrimonio del responsable a través de un derecho al reembolso ${ }^{984}$.

\subsubsection{El derecho de reembolso del responsable tributario en la $L G T$}

La actual LGT reconoce el derecho de reembolso del responsable frente al deudor principal. Ésta era una reivindicación de la doctrina y la jurisprudencia ante el silencio de la LGT de 1963 al respecto. El apartado sexto del artículo 41 de la LGT actual establece que los responsables tienen derecho al reembolso frente al deudor principal en los términos previstos en la legislación civil. Este precepto tiene sus antecedentes en las recomendaciones del Informe para la Reforma de la LGT de 2001, que proponía "completar el régimen jurídico actual de la responsabilidad con la introducción, de modo expreso, de una acción de regreso a favor del responsable", y el establecimiento de "multas coercitivas para obligar al contribuyente a hacer efectiva dicha obligación. Se trata, en definitiva, de tratar de otorgar una mejor tutela a quien reviste la condición de responsable frente al deudor principal, lo cual podría incluso perfeccionarse con la previsión de un derecho del responsable a solicitar de la Administración que intente el cobro de la deuda frente al contribuyente con anterioridad a la declaración de responsabilidad".

El legislador tributario, sin embargo, ha sido escueto a la hora de regular el derecho de reembolso del responsable. Según NAVARRO EGEA, se trata de una "mera declaración de intenciones, pues no se acompaña de un cauce específico que agilice la legítima reparación del patrimonio del responsable" y se opta "por una remisión al Derecho civil" " En este sentido, la LGT podría haber previsto la posibilidad de tramitar esta acción de regreso dentro del ámbito tributario, disponiendo una vía concreta para hacer efectiva la reparación del patrimonio del responsable, tal como se proponía en el Informe, sobre todo para los supuestos de responsabilidad subsidiaria, donde la inseguridad es mayor, al ser requisito fundamental para derivar dicha responsabilidad la declaración de insolvencia del deudor principal.

En cualquier caso, debemos reconocer algunos aspectos positivos en la regulación que hace la LGT en esta materia. Existe una declaración expresa de la acción de regreso para el responsable y además se permite la aplicación de la misma a todos los supuestos de responsabilidad, sin distinciones. Visto así, es plausible justificar la aplicación del derecho de reembolso incluso en aquellos casos en que el presupuesto de hecho de la responsabilidad se produce por la realización de un ilícito. Esta afirmación permitiría entender la postura del Tribunal Supremo cuando afirma que el lugar que ocupa

\footnotetext{
984 SIMÓN ACOSTA, E., “Obligados tributarios", op. cit., pág. 227, y DELGADO GARCÍA, A. M., La Derivación de responsabilidades en la recaudación de los tributos, op. cit., pág. 298 y 299. En este mismo sentido, MAZORRA MANRIQUE DE LARA, S., "El régimen jurídico de la responsabilidad tributaria", op. cit., pág. 85; FALCÓN Y TELLA, R., "La solidaridad tributaria", op. cit., pág. 148; CARBAJO VASCO, D., "La responsabilidad tributaria de los administradores de las sociedades mercantiles", $o p$. cit., pág. 61; OTERO NOVAS, J. M., "La supuesta responsabilidad objetiva de los administradores de sociedades que cesan en su actividad", op. cit., pág. 83.

${ }^{985}$ NAVARRO EGEA, M., El responsable tributario, op. cit., pág. 73. Años antes, DELGADO GARCÍA, al referirse a las causas por lo que la Administración tributaria no se pronunciaba respecto a la acción de regreso que corresponde la responsable, había dicho que "se trata de una relación privada entre el deudor inicial y el responsable y el adquirente, y regida, por tanto, por el Derecho privado porque, una vez reconocida la acción de regreso al responsable, no existe un interés público en que su ejercicio sea efectivo, y para regular dicha acción entra en escena la autonomía de la voluntad. Por tanto, al constituir una obligación extratributaria, esta acción no se sujeta a las previsiones de la normativa tributaria, sino, naturalmente, al cauce jurídico-privado, debiendo sustanciarse en la vía jurisdiccional ordinaria" (DELGADO GARCÍA, A. M., La Derivación de responsabilidades en la recaudación de los tributos, op. cit., pág. 300).
} 
el responsable no es el de un sancionado, reconociéndose en la ley la acción de regreso al responsable a cargo del patrimonio del infractor ${ }^{986}$. A nuestro entender, sin embargo, las sanciones deben ser impuestas al deudor principal y al responsable en procedimientos sancionadores independientes, con lo que no habría lugar en este supuesto al derecho de reembolso.

\subsubsection{Configuración práctica de la acción de regreso del responsable}

Uno de los problemas más complejos que se presenta la elaboración normativa del instituto jurídico de la acción de regreso es la remisión que hace la LGT al ordenamiento civil ${ }^{987}$. Aquí las interrogantes se ciernen en torno a la configuración de la acción de regreso en la práctica y a su fundamento normativo, lo que ha desembocado en posiciones doctrinales distintas.

Una primera posibilidad es interpretar que la LGT efectúa una remisión al artículo 1.145 del Código Civil $^{988}$. En este precepto se establece que

"el pago hecho por uno de los deudores solidarios extingue la obligación. El que hizo el pago sólo puede reclamar de sus codeudores la parte que a cada uno corresponda, con los intereses del anticipo (...) y la falta de cumplimiento de la obligación por insolvencia del deudor solidario será suplida por sus codeudores, a prorrata de la deuda de cada uno".

En contra de esta tesis se argumenta que el responsable tributario no es un codeudor solidario porque no es un cotitular, ya que no realiza el hecho imponible ${ }^{989}$.

\footnotetext{
${ }^{986}$ Sentencia del Tribunal Supremo de 30 de septiembre de 1993 Dentro de los méritos de esta Sentencia habría que reconocer la aceptación de la existencia del derecho de reembolso del responsable con anterioridad a la LGT y a las normas reglamentarias. HERRERA MOLINA, que se muestra a favor de esta postura, afirma que "por una parte, no es pacífico que la acción de regreso del responsable respecto de las sanciones quede enervada en el caso de los actos ilícitos (...). Además, el negar la acción de regreso respecto de las sanciones no soluciona nada: si paga el sujeto pasivo, el responsable partícipe de la infracción quedaría impune; si paga el responsable, sería el propio sujeto infractor quien quedaría sin sanción" (HERRERA MOLINA, P. M., "Coautoría y participación en las infracciones tributarias y responsabilidad tributaria por actos ilícitos", op. cit., pág. 699). Asimismo, GUERRA REGUERA entendió que no se debía negar el derecho al reembolso tratándose de sanciones en los supuestos de responsabilidad por actos ilícitos porque "tendría la ventaja de eliminar la impunidad del partícipe en la comisión de infracciones, pero, claro está, a cambio de la injusta ausencia de represión para quien directamente la ha cometido, por tanto", solucionando un problema y "creando otro todavía mayor. Si la sanción es pagada por el responsable, liberando al autor principal y sin posibilidad de reembolso, se crea una situación escasamente acorde con un sistema sancionatorio construido sobre la base de la eficacia y la justicia" (GUERRA REGUERA, M., "Consideraciones en torno al artículo 38 de la Ley General Tributaria", op. cit., pág. 55). Por el contrario, CALVO ORTEGA entendió que a la responsabilidad por actos ilícitos no le correspondía el derecho de reembolso (CALVO ORTEGA, R., "La responsabilidad tributaria solidaria por actos ilícitos", op. cit., pág. 51 a 53 y, del mismo autor, "La responsabilidad tributaria subsidiaria", op. cit., pág. 156). De manera similar, MARTÍN JIMÉNEZ opina que "la necesidad de reconocimiento de la acción de reembolso se diluirá allí donde la responsabilidad tenga función sancionadora o indemnizatoria" (MARTÍN JIMÉNEZ, A., Los Supuestos de responsabilidad en la LGT: (hacia una configuración constitucional y comunitaria de la responsabilidad tributaria), op. cit., pág. 186).

${ }^{987}$ Remisión que encuentran lógica SIMÓN ACOSTA y MAZORRA MANRIQUE DE LARA porque la relación que se establece entre los responsables y el deudor principal, aunque haya nacido en el ámbito tributario, es una relación de Derecho privado, en la medida que una vez otorgada la acción de regreso no existe interés público en que se haga efectivo su ejercicio (SIMÓN ACOSTA, E., "Obligados tributarios", op. cit., pág. 227; MAZORRA MANRIQUE DE LARA, S., "El régimen jurídico de la responsabilidad tributaria”, op. cit., pág. 85).

${ }^{988}$ PALAO TABOADA, C., “Apogeo y crisis del principio de capacidad contributiva” en la obra Estudios jurídicos en Homenaje a Federico de Castro, vol. II, Tecnos, Madrid, 1976, pág. 399.

${ }^{989}$ HERRERO MADARIAGA, J., "El responsable tributario", op. cit., pág. 225; MAZORRA MANRIQUE DE L. S., "El régimen jurídico de la responsabilidad tributaria", Crónica Tributaria, núm. 64, 1992, pág. 85; SÁNCHEZ GALIANA, J. A., "El responsable", op cit., pág. 655, y DELGADO GARCÍA, A. M., La Derivación de responsabilidades en la recaudación de los tributos, op. cit., pág. 300 .
} 
La segunda de las interpretaciones posibles sostiene que la LGT está efectuando una remisión a los artículos que reconocen el derecho de reembolso para el tercero que paga la deuda: el artículo 1.158 del Código Civil, que determina que el que pagare por cuenta de otro podrá reclamar del deudor lo que hubiese pagado, de no haberlo hecho contra su expresa voluntad; el artículo 1.159 del mismo código, que regula que el que pague en nombre del deudor, ignorándolo éste, no podrá compeler al acreedor a subrogarle en sus derechos; el artículo 1.209 del Código Civil, que estipula que la subrogación de un tercero en los derechos del acreedor no puede presumirse fuera de los casos expresamente mencionados en aquél; y finalmente, el artículo 1.210 del Código Civil, que contempla la presunción de subrogación en la posición acreedora cuando un tercero, no interesado en la obligación, pague con aprobación expresa o tácita del deudor.

Los autores que rechazan esta segunda postura alegan que no es apropiado efectuar la remisión de la acción de regreso a los preceptos que regulan las consecuencias del pago por tercero, porque éstos prevén la posible subrogación del responsable en el lugar del acreedor, cuestionando la autonomía de la obligación del responsable ${ }^{990}$. Hay que tener en cuenta, por tanto, que el responsable no es un simple tercero que paga la deuda ajena, sino un sujeto que paga su propia deuda, lo que le permite ejercer frente a la Administración tributaria los derechos que le corresponde como obligado tributario $^{991}$.

Quizás por la similitud que existe entre la responsabilidad y la fianza, un tercer sector doctrinal es partidario de aplicar en el ámbito que nos ocupa los mandatos de los artículos 1.838 y 1.839 del Código Civil. En ellos se dispone que el fiador que paga por el deudor debe ser indemnizado por éste y que la indemnización comprende la cantidad total de la deuda; los intereses legales de ella desde que se haya hecho saber el pago al deudor, aunque no los produjese para el acreedor; los gastos ocasionados al fiador después de poner éste en conocimiento del deudor que ha sido requerido para el pago; y los daños y perjuicios, cuando procedan. En suma, los preceptos mencionados reconocen, de manera general, la acción de regreso frente al deudor y la subrogación de fiador en la posición del acreedor para satisfacer su derecho de reembolso. Se opone, sin embargo, a esta solución la dificultad de colocar al responsable en el lugar de la Administración tributaria ${ }^{992}$ y su ineficacia en los presupuestos de hecho de responsabilidad por la realización de actos ilícitos, porque la fianza siempre se deriva de un acto lícito.

En última instancia, se podría apelar a la acción por enriquecimiento sin causa para resolver la cuestión planteada, a fin de que el responsable pueda resarcir su patrimonio aunque fuera

\footnotetext{
${ }^{990}$ NAVARRO EGEA, M., El responsable tributario, op. cit., pág. 75.

${ }^{991}$ DELGADO GARCÍA, A. M., La Derivación de responsabilidades en la recaudación de los tributos, op. cit., pág. 301. Otros autores que han manifestado su desacuerdo con esta solución son CALVO ORTEGA, R., "La responsabilidad tributaria subsidiaria", Hacienda Pública Española, núm. 10, 1971, pág. 140 y 141; ARIAS ABELLÁN, M. D., "El estatuto jurídico del responsable del tributo en el derecho español", op. cit., pág. 197; LÓPEZ MARTíNEZ, J., "Los responsables de las deudas tributarias y el procedimiento de gestión", Revista Española de Derecho Financiero, núm. 74, 1992, pág. 263; y SÁNCHEZ GALIANA, J. A., "El responsable", op. cit., pág. 655.

${ }^{992}$ ARIAS ABELLÁN, M. D., "El estatuto jurídico del responsable del tributo en el derecho español”, op. cit., pág. 197; MAZORRA MANRIQUE DE L. S., "El régimen jurídico de la responsabilidad tributaria", Crónica Tributaria, núm. 64, 1992, pág. 86; SÁNCHEZ GALIANA, J. A., "El responsable”, op. cit., pág. 655; CARRASCO PERERA, A, CORDERO LOBATO, E y MARÍN LÓPEZ M, J., Trato de los derechos de garantía, Aranzadi, Pamplona, 2002, pág. 253.
} 
parcialmente ${ }^{993}$. Esta cuarta y última posición doctrinal, no obstante, no tiene en cuenta que no sería justo el ejercicio de la acción de regreso en los supuestos en que se haya adquirido la condición de responsable por la realización de actos ilícitos, debido a que no se cumple el requisito de la ausencia de causa jurídica y a que la conducta ilícita del responsable "actúa como justificante del desplazamiento patrimonial"994. Desde esta perspectiva, al deudor principal se le puede exigir parte de la sanción, la parte no imputable al responsable colaborador, y este último sólo responderá de la porción derivada de su actuación ilícita, en relación con la cual no podrá interponer la acción de regreso por enriquecimiento injusto.

En relación con esta cuarta posición doctrinal, no debemos olvidar que para que el enriquecimiento sin causa se produzca se requiere la concurrencia de cuatro requisitos fundamentales: el enriquecimiento de una de las partes, el empobrecimiento de la otra, la relación de causalidad entre los dos sujetos y la falta de causa que justifique el desplazamiento patrimonial ${ }^{995}$. Cierto es que en la posición de la figura del responsable se manifiestan todos estos requisitos. Primero, un empobrecimiento indebido del patrimonio del responsable, porque este sujeto está obligado a pagar la deuda tributaria, liberando al deudor principal del cumplimiento de la suya. Segundo, un enriquecimiento del obligado principal injustificado, porque el responsable cumple una función de garantía, por la que debe pagar la deuda, pero no soporta indefinidamente la carga tributaria. En tercer lugar, una relación de causalidad entre el enriquecimiento del deudor principal y el empobrecimiento del responsable. $\mathrm{Y}$ finalmente, un injustificado enriquecimiento del obligado principal a costa del responsable, porque es precisamente el deudor principal el que realiza el hecho imponible y, por tanto, el que ostenta la capacidad económica que se pretende gravar con el tributo y a quien corresponde soportar de manera indefinida la carga tributaria.

En definitiva, coincidiendo con la mayoría de la doctrina y la jurisprudencia, entendemos que el enriquecimiento injusto o sin causa del deudor principal y el correspondiente empobrecimiento del responsable justifica la acción de regreso a favor de éste, dado el carácter garantista que acompaña a la responsabilidad y la necesidad de no conculcar el principio constitucional de capacidad económica. Se trata de una acción personal que pretende restituir del patrimonio enriquecido el equivalente en el patrimonio del responsable. El Tribunal Supremo ha reiterado que se trata de una acción subsidiaria que sólo procede cuando no se dispone de otras acciones para reparar el patrimonio afectado y que no puede ejercerse cuando el empobrecimiento es imputable a quien lo sufre o se origina en una conducta que no puede brindarle un justo título para reclamar.

\footnotetext{
${ }^{993}$ Posición que defiende gran parte de la doctrina, entre otros, ARIAS ABELLÁN, M. D., "El estatuto jurídico del responsable del tributo en el derecho español”, op. cit., pág. 197, PÉREZ ROYO, F., "El pago de la deuda tributaria”, op. cit., pág. 269 y 292, NAVARRO EGEA, M., El responsable tributario, op. cit., pág. 75; DELGADO GARCÍA, A. M., La Derivación de responsabilidades en la recaudación de los tributos, op. cit., pág. 302; URBIARTE Y ZULUETA, M. M., "Los sujetos pasivos en el procedimiento recaudatorio", op. cit., pág. 44; CARBAJO VASCO, D., "La responsabilidad tributaria de los administradores de las sociedades mercantiles", op. cit., pág. 69.

${ }^{994}$ CALVO ORTEGA, R., "La responsabilidad tributaria solidaria por actos ilícitos”, op. cit., pág. 50 y, del mismo autor, "La responsabilidad tributaria subsidiaria”, Hacienda Pública Española, núm. 10, 1971, pág. 141; CARBAJO VASCO, D., "La responsabilidad tributaria de los administradores de las sociedades mercantiles", Crónica Tributaria, núm. 76, 1995, pág. 69; ZABALA RODRÍGUEZ-FORNS, A., LLOPIS GINER, F. Y DAGO ELORZA, I., Recaudación, aspectos sustantivos y procedimentales, op. cit., pág. 125.

${ }^{995}$ DELGADO GARCíA, A. M., La Derivación de responsabilidades en la recaudación de los tributos, op. cit., pág. 304.
} 


\section{CAPÍTULO QUINTO \\ LAS GARANTÍAS DEL CRÉDITO TRIBUTARIO EN CASO DE APLAZAMIENTO O FRACCIONAMIENTO DEL PAGO O INTERPOSICIÓN DE UN RECURSO}

Después de haber analizado las garantías reales y personales que el ordenamiento tributario reconoce específicamente a favor de la Administración para el cobro de las deudas tributarias corresponde en el presente capítulo referirnos a las denominadas garantías "voluntarias" (de elección voluntaria, aunque de presentación obligatoria), cuyo ámbito de actuación se circunscribe a los procedimientos dispuestos para solicitar el aplazamiento o fraccionamiento del pago o la suspensión de la ejecución de actos administrativos en caso de interposición de reclamaciones. No estamos en presencia de garantías dispuestas a favor de la Administración por la normativa tributaria, sino de las garantías generales de Derecho civil que el ordenamiento tributario simplemente obliga a presentar a los obligados tributarios en determinados procedimientos. El objeto mediato de la presentación de las garantías voluntarias sigue siendo el mismo, el aseguramiento de la efectividad del crédito tributario, y su finalidad específica inmediata consiste en procurar a la Administración tributaria un medio de defensa ante el aplazamiento que concede o ante la suspensión del acto administrativo de pago acordado en vía de recurso. Por ello se ha dicho que las garantías voluntarias se aproximan más a la naturaleza de las medidas cautelares que se aplican frente a situaciones reales de peligro, afirmación que se refuerza si tenemos en cuenta que la LGT permite el intercambio o sustitución de unas por $\operatorname{otras}^{996}$.

En este quinto y último capítulo abordaremos de manera general las garantías reales y personales que debe presentar el interesado cuando presenta una solicitud de aplazamiento o fraccionamiento del pago o de suspensión de la ejecución de un acto administrativo en caso de interposición de reclamaciones, centrándonos en las especificidades que presentan estos procedimientos más que en el régimen sustantivo de estas garantías, cuyo régimen pertenece al Derecho privado.

\section{LAS GARANTÍAS EN EL APLAZAMIENTO O FRACCIONAMIENTO DEL PAGO}

La LGT permite aplazar o fraccionar el pago de la deuda tributaria cuando la situación económica financiera del deudor le impide de forma transitoria hacer frente al pago dentro de los plazos establecidos legalmente. Por tanto, con estas instituciones lo que se pretende es facilitar al deudor el cumplimiento de su obligación de pago, a través de la concesión de un nuevo y único plazo (aplazamiento) o bien para que pueda cumplir su obligación por partes (fraccionamiento).

Se trata de un acto administrativo donde la discrecionalidad se aprecia en alguno de sus elementos, principalmente en la determinación de los plazos y las fracciones, y donde también se insertan otros elementos reglados. Cabe, en todo caso, el control jurisdiccional de los elementos reglados del acto administrativo y, si se concede el aplazamiento o fraccionamiento, puede exigirse la presentación de garantías.

\footnotetext{
${ }^{996}$ Para GARCÍA NOVOA estas garantías denominadas voluntarias tampoco debían encontrarse dentro del grupo de garantías del crédito tributario en sentido estricto, aun cuando reúnen todos los requisitos para serlo, sobre la base de que "son un requisito para lograr la suspensión del acto impugnado en vía administrativa. Aunque la suspensión automática únicamente condicionada a la aportación de garantía está más próxima a una previsión de carácter cautelar, la figura de la suspensión debería concebirse en clave de medida cautelar, dentro de la llamada tutela cautelar", y "en este sentido, estas garantías desarrollan una función que se aproxima a las medidas cautelares" (GARCÍA NOVOA, C., "Garantías de la deuda tributaria”, op. cit., pág. 322).
} 
Entre las garantías del crédito tributario que reconoce el artículo 82 de la LGT se encuentran las garantías para el aplazamiento o fraccionamiento del pago de la deuda tributaria. Este precepto, en su apartado primero, dispone que cuando se acuerde el aplazamiento o fraccionamiento de la deuda tributaria la Administración tributaria podrá exigir que se constituya a su favor aval solidario de entidad de crédito o sociedad de garantía recíproca o certificado de seguro de caución. Ante la imposibilidad de obtener dichas garantías, o de que su aportación comprometa gravemente la viabilidad de la actividad económica del obligado tributario, el segundo párrafo del apartado primero del artículo 82 de la LGT indica que la Hacienda Pública podrá admitir garantías que consistan en hipoteca, prenda, fianza personal u otra que se estime suficiente. Además, el tercer párrafo del precepto descrito faculta al deudor principal a que solicite a la Administración tributaria la adopción de medidas cautelares en sustitución de aquéllas.

Por su parte, el segundo apartado del artículo 82 de la LGT otorga la dispensa total o parcial de la constitución de garantías por parte del obligado tributario en los supuestos señalados cuando las deudas tributarias sean de cuantía inferior a la que se fije en la normativa tributaria. Esta excepción podrá limitarse a solicitudes formuladas en determinadas fases del procedimiento de recaudación y, asimismo, se concederá dispensa total o parcial de presentación de garantías cuando el obligado al pago carezca de bienes suficientes para garantizar la deuda y la ejecución de su patrimonio afecte sustancialmente el mantenimiento de la capacidad productiva y el nivel de empleo de la actividad económica, o pueda producirse graves quebrantos para los intereses de la Hacienda Pública.

Como puede verse la ley, establece con detalle las garantías que deben presentarse en el supuesto de aplazamiento y fraccionamiento del pago de la deuda tributaria. Anteriormente, el artículo 76 de la LGT de 1963 se encargaba de regular estas cuestiones junto con el apartado cuarto del artículo 61 de la propia LGT de 1963 y los artículos 52 a 58 del RGR de 1968. No obstante, estos antecedentes legislativos eran más limitados, porque sólo preveían, para los casos de aplazamiento o fraccionamiento, que el Estado, las Provincias y los Municipios exigieran la constitución a su favor de aval bancario, hipoteca o prenda sin desplazamiento u otra garantía suficiente.

En la normativa vigente destaca la consideración de garantías idóneas a efectos de los aplazamientos o fraccionamientos del pago de la deuda tributaria a los avales o seguros de caución de entidades financieras, admitiéndose otras distintas sólo cuando se justifique que no es posible la obtención de aquéllas o que su aportación puede perjudicar la actividad económica del deudor solicitante; y, por otro lado, la posibilidad de dispensa total o parcial de la presentación de garantías cuando se aprecien las condiciones exigidas en los incisos a), b) y c) del apartado segundo del artículo 82 de la LGT, con la diferencia, en este último caso, de que la legislación actual permite a la Administración tributaria, si lo considera oportuno, acordar la dispensa de la garantía.

La primera de estas dos reglas generales ha suscitado la crítica de la doctrina. GÓMEZ CABRERA apunta que si la finalidad de la garantía es el aseguramiento del cobro de la deuda, daría lo mismo que se cumpliera ofreciendo un aval o cualquier otra garantía, y más teniendo en cuenta que la exigencia de la primera lleva un mayor coste para un deudor que, precisamente, solicita el aplazamiento o fraccionamiento por presentar una difícil situación financiera que no le permite hacer 
frente al crédito tributario ${ }^{997}$. En cualquier caso, como precisa ARRANZ DE ANDRÉS, la constitución de garantías distintas al aval, como una prenda o una hipoteca, por ejemplo, también supone un evidente coste para el particular, y la crítica debe centrarse más bien, según esta autora, en la previsión que hace el apartado primero del artículo 82 de la LGT, que se desarrolla en el artículo 49 del RGR, de la posibilidad que tiene el obligado tributario de solicitar a la Administración tributaria la sustitución de las garantías por medidas cautelares ${ }^{998}$. Según GONZÁLEZ-CARBALLO ALMODÓVAR, el legislador estaba pensando en este caso en las medidas cautelares del embargo preventivo y de la prohibición de disponer de bienes y de derechos, que sin ser auténticos derechos reales de garantía "comportan cierta sujeción o retención del patrimonio de los deudores que sirven para asegurar de algún modo (...) el pago de sus débitos". El resto de las medidas cautelares que prevé la ley, para este autor, carecen de sentido cuando se trate de solicitudes de aplazamiento o fraccionamiento del pago, como es el caso de las retenciones de dinero, porque es precisamente la falta de liquidez lo que motiva la solicitud de aquéllos ${ }^{999}$.

\section{1. LAS GARANTÍAS VOLUNTARIAS REALES}

Las garantías personales, como el aval bancario o de sociedad de garantía recíproca o el certificado de seguro de caución, son acogidas por la normativa tributaria con carácter preferente para asegurar una deuda que se pretende aplazar o fraccionar. Sin embargo, la ley permite que se aporten otras garantías cuando no sea posible obtener el aval o certificado o cuando la aportación de los mismos comprometa gravemente la viabilidad de la actividad económica del obligado. Si concurre alguna de estas circunstancias, la Administración tributaria, para aplazar o fraccionar el pago, puede admitir la presentación de garantías reales que consistan en hipoteca o prenda, garantías personales como la fianza personal o solidaria, u otras que estime suficiente.

\section{$\underline{\text { A. Las garantías reales en el aplazamiento o fraccionamiento del pago de la deuda tributaria }}$}

De entre todas las garantías enumeradas en el artículo 82 de la LGT la hipoteca y la prenda son las únicas garantías que tienen un carácter real. Y son precisamente estas garantías, la hipoteca mobiliaria o inmobiliaria y la prenda con o sin desplazamiento, las que puede presentar el solicitante para obtener el aplazamiento o fraccionamiento del pago de su deuda ante la imposibilidad de aportar un aval o certificado de seguro de caución. La garantía real que se presente, en todo caso, deberá recaer sobre un bien o derecho concreto y además deberá ser susceptible de ejecución y enajenación para satisfacer la deuda si se produce el incumplimiento de la obligación de pago.

La hipoteca es un derecho real de garantía que produce la afección de un bien o derecho, pudiendo afectar tanto a un bien inmueble susceptible de inscripción, como a un derecho real enajenable, a partir de la interpretación que se haga del artículo 1.874 del Código Civil y el artículo 160 de la LH. BLASCO GASTÓN, al referirse a la necesidad de que la hipoteca afecte a bienes inscribibles en registros, estimó que, salvo en el caso de bienes inmuebles, la referencia al resto de bienes parece

\footnotetext{
${ }^{997}$ GÓMEZ CABRERA, C., La discrecionalidad de la Administración Tributaria: su especial incidencia en el procedimiento de la inspección, McGraw-Hill, Madrid, 1998, pág. 116.

998 ARRANZ DE ANDRÉS, C., Las garantías reales del crédito tributario: aspectos sustantivos y procedimentales, op. cit., pág. 286.

${ }^{999}$ GONZÁLEZ-CARBALLO ALMODÓVAR, A., "Las garantías del crédito tributario”, op. cit., pág. 467.
} 
redundante, porque si la inscripción de la hipoteca tiene carácter constitutivo difícilmente podrá recaer sobre bienes que no sean inscribibles ${ }^{1000}$.

Siendo la hipoteca un derecho real de garantía, resulta evidente que los bienes sobre los que recae han de ser susceptibles de enajenación. Cuando se refiere a los derechos reales enajenables, reconoce el artículo 107 de la LH la posibilidad de hipotecar el derecho de usufructo, la mera propiedad de los bienes que estuvieran ya anteriormente hipotecados, el derecho de superficie, las concesiones administrativas, e incluso otras hipotecas. Para estos casos, tal como dice DÍEZ PASTOR, el titular del crédito hipotecario que quiera servirse de él como garantía deberá afectar conjuntamente el crédito y el derecho real que lo asegura. Según este autor, el derecho de garantía que se constituya tendrá por objeto directo e inmediato el crédito y como objeto mediato el derecho real de hipoteca, y existe la posibilidad de crear un derecho de garantía sobre otro derecho, ya que una cosa incorporal puede servir como objeto de responsabilidad de igual manera que una cosa corporal, siempre que tenga un valor realizable ${ }^{1001}$.

La prenda, por su parte, puede recaer sobre cualquier cosa mueble que, estando en el comercio, pueda ser poseída, a tenor de lo que dispone el artículo 1.864 del Código Civil. Para ARRANZ DE ANDRÉS, debe admitirse que los bienes muebles enajenables son igualmente susceptibles de prenda $^{1002}$. De la misma forma, DÍEZ PICAZO y GULLÓN BALLESTEROS manifiestan que, aunque los simples créditos no sean bienes que se puedan poseer, puede aceptarse un derecho de prenda sobre los mismos, puesto que al producirse la cesión al acreedor pignoraticio y su correspondiente notificación al deudor cedido se colocan estos bienes en un estado de indisponibilidad para el deudor pignorante ${ }^{1003}$.

Para la satisfacción del crédito por medio de una prenda de crédito, matiza GONZÁLEZCARBALLO ALMODÓVAR, es preciso diferenciar entre la cesión del crédito con finalidad de pago, con finalidad de cobro, o con finalidad de garantía, y sólo en el caso de esta última es susceptible de ser presentada y de estimarse como suficiente para garantizar la deuda aplazada. La cesión con la finalidad de pago es, por definición, incompatible con una solicitud de aplazamiento o fraccionamiento de aquél, por lo que afirma este autor que es un absurdo aplazar el pago de algo que ya está pagado. De la misma forma, si se tiene en cuenta que la cesión con la finalidad de cobro no constituye sino un supuesto de pago por cesión de bienes convencionales, se estaría igualmente ante una forma especial de pago de la que no se puede decir que exista una función de garantía del cumplimiento de la obligación de pago, de manera que la función de garantía sólo se produce con la cesión del crédito con finalidad de garantía o prenda de crédito ${ }^{1004}$.

\footnotetext{
${ }^{1000}$ BLASCO GASTÓN, F., "La hipoteca inmobiliaria (II)”, en la obra Derechos Reales y Derecho Inmobiliario Registral, Tirant lo Blanch, Valencia, 1994, pág. 678 y 679. Una posición contraria es la que asume CARPI MARTÍN, R., La tutela del acreedor ante el prejuicio de la hipoteca inmobiliaria, Colegio de Registradores de la Propiedad y Mercantiles, Madrid, 2005, pág. 37 y ss.

${ }^{1001}$ DÍEZ PASTOR, J. L., "Notas acerca de la naturaleza y el contenido de la subhipoteca", Revista Crítica de Derecho Inmobiliario, 1930, pág., 440 a 441 .

${ }^{1002}$ ARRANZ DE ANDRÉS, C., Las garantías reales del crédito tributario: aspectos sustantivos y procedimentales, op. cit., pág. 287.

${ }^{1003}$ DÍEZ PICAZO, L y GULlÓN BALlESTERO, A., Sistema de derecho Civil, Vol. III, 5ª ed., Tecnos, Madrid, 1990, pág. 508 a 509.

1004 GONZÁLEZ-CARBALLO ALMODÓVAR, A., "La prenda de créditos. Una garantía jurídica idónea a efectos del aplazamiento del pago de deudas de derecho tributario y demás de derecho público”, Tribuna Fiscal, núm. 50, 1994, pág. 43 a 44.
} 
Por último, también podrán presentarse como garantías reales para aplazar o fraccionar el pago de la deuda tributaria la hipoteca mobiliaria y la prenda sin desplazamiento. Al respecto, los bienes sobre los que se pueden constituir estos derechos reales de garantía, según el artículo 12 de Ley de 16 de diciembre de 1954, sobre Hipoteca Mobiliaria y Prenda sin Desplazamiento de Posesión son: establecimientos mercantiles, automóviles y otros vehículos de motor, aeronaves, maquinaria industrial y propiedad intelectual.

\subsection{LAS GARANTÍAS VOLUNTARIAS PERSONALES}

Si el obligado tributario está interesado en que se produzca la suspensión automática de los actos de contenido económico que impugna, debe presentar, según el apartado segundo del artículo 233 de la LGT, alguna de las siguientes garantías: depósito de dinero o valores públicos, aval o fianza de carácter solidario de entidad de crédito o sociedad de garantía recíproca o certificado de seguro de caución, o fianza personal y solidaria de otros contribuyentes de reconocida solvencia para los supuestos que se establezcan en la normativa tributaria. Por su parte, si lo que pretende es el aplazamiento o fraccionamiento del pago, se debe presentar, a tenor de lo dispuesto en el artículo 82 de la LGT, aval solidario de entidad de crédito o sociedad de garantía recíproca o certificado de seguro de caución.

Como puede verse, en ambos supuestos el legislador prefiere la constitución de garantías personales como la fianza, ya sea aval solidario de entidad de crédito o sociedad de garantía recíproca o bien fianza personal y solidaria, y sólo en el caso que sea imposible para el interesado aportar dichas garantías admite la presentación de otras, entre ellas, las reales, en los términos indicados en el anterior apartado.

\section{$\underline{\text { A. La fianza en los supuestos de aplazamiento o fraccionamiento del pago }}$}

La fianza es una de las garantías de carácter personal que se utiliza para asegurar la satisfacción del acreedor de su derecho de crédito en previsión de que el deudor no pueda cumplir con su obligación de pago. Es una garantía personal porque los bienes que aseguran el crédito no se determinan directamente, sino en atención a su titular, reforzándose el derecho de crédito con el patrimonio del que fía. Según el artículo 1.822 del Código Civil

"Por la fianza se obliga uno a pagar o cumplir por un tercero, en el caso de no hacerlo éste".

Como dijimos anteriormente, el legislador incluye a la fianza como una modalidad de garantía personal del crédito tributario que opera para asegurar la satisfacción del mismo y como requisito indispensable para obtener el aplazamiento o fraccionamiento del pago. Es una figura que presenta similitudes con la responsabilidad tributaria, que hemos examinado en el capítulo cuarto, pero en la que juega un papel muy importante la autonomía de voluntad de las partes.

Para gozar del aplazamiento o fraccionamiento del pago de las deudas tributarias se precisa, en principio, la presentación de un aval de entidad de crédito o sociedad de garantía recíproca. El aval bancario es una fianza con la única particularidad de que el sujeto fiador es una entidad de crédito o una sociedad de garantía recíproca y el acreedor la Hacienda Pública. Este aval debe ser practicado 
en régimen de solidaridad, esto es, sin beneficio de excusión, y está sometido al régimen general del Código Civil. Si atendemos a su origen, el aval contenido en la LGT con garantía del crédito tributario está concebido como una fianza legal, un mandato normativo impuesto a un particular, en cuya virtud el sujeto solicitante de un aplazamiento o fraccionamiento del pago de su deuda tributaria deberá hallar una entidad financiera dispuesta a obligarse como fiador ante la Administración tributaria.

\section{LAS GARANTÍAS EN LA SUSPENSIÓN DE LA EJECUCIÓN DE LOS ACTOS POR LA INTERPOSICIÓN DE RECURSOS}

Una de las manifestaciones más importantes de la supremacía de la Administración tributaria se encuentra en la posibilidad de ejecutar inmediatamente los actos administrativos. Frente a estas prerrogativas se ubican los principios que aseguran los derechos de los contribuyentes. Como observa FABRA VALLS ${ }^{1005}$, es necesario entonces saber si la recaudación de los tributos puede, en determinados casos, suspenderse por un período de tiempo, que permita conocer a través de un pronunciamiento sobre la legalidad de la liquidación tributaria, o por el contrario, si existe un interés constitucional que justifica que la recaudación se haga sin más demora. Es aquí donde, en palabras de ARRANZ DE ANDRÉS, “adquiere relevancia la posibilidad de suspensión de los actos objeto de impugnación, institución cuya naturaleza jurídica permite su encuadramiento dentro de las medidas cautelares que el juez puede adoptar a fin de evitar que la dependencia del proceso pueda causar perjuicios de imposible o difícil reparación"1006.

\subsection{APTITUD DE LAS GARANTÍAS REALES PARA LA OBTENCIÓN DE LA SUSPENSIÓN}

El artículo 233 de la LGT determina la suspensión automática de los actos de contenido económico impugnados siempre y cuando el interesado presente alguna de las siguientes garantías: depósito de dinero o valores públicos, aval o fianza de carácter solidario de entidad de crédito o sociedad de garantía recíproca o certificado de seguro de caución, o fianza personal y solidaria de otros contribuyentes de reconocida solvencia para los supuestos que se establezcan en la normativa tributaria. El desarrollo de este precepto se hace en los artículos 43 y siguientes del Real Decreto 520/2005, de 13 de mayo, por el que se aprueba el Reglamento General de Desarrollo de la Ley 58/2003, de 17 de diciembre, General Tributaria, en materia de revisión en vía administrativa (en adelante RRVA).

En esta misma dirección se proyectaron los anteriores reglamentos de procedimiento de las reclamaciones económicas-administrativas, aprobados por el Real Decreto 1999/1981, de 20 de agosto, y el Real Decreto 391/1996, de 1 de marzo. En ambos reglamentos se contenían las mismas garantías que podía presentar el interesado para el logro de la suspensión de la ejecutividad del acto $^{1007}$, aunque en la doctrina hubo varios pronunciamientos contra el carácter cerrado de estas disposiciones. Se subrayó en este sentido que existía un trato desigual entre el régimen del

\footnotetext{
${ }^{1005}$ FABRA VALLS, M. J., La suspensión de los actos impugnados en materia tributaria, Tecnos, Madrid, 2001, pág. 35 y ss.

${ }^{1006}$ ARRANZ DE ANDRÉS, C., Las garantías reales del crédito tributario: aspectos sustantivos y procedimentales, op. cit., pág. 293 a 294.

${ }^{1007}$ DAGO ELORZA, I., "La suspensión de los actos impugnados en vía económico-administrativa”, Tribuna Fiscal, núm. 78, 1997, pág. 69 .
} 
aplazamiento y fraccionamiento del pago en relación con la suspensión de la ejecución del acto tributario, y también se afirmó que, pese a incluirse varios medios para asegurar el pago, en la práctica era el aval el más empleado ${ }^{1008}$.

No obstante, el artículo 76 del RPREA intentó equiparar el régimen de suspensión en vía económicaadministrativa con el previsto en el artículo 111 de la LRJ-PAC y dispuso que cuando el interesado no pudiera presentar ninguna de las garantías que exige la normativa tributaria la ejecución del acto impugnado podría ser, excepcionalmente, suspendida por el Tribunal Económico-Administrativo competente para resolver la reclamación. De igual forma, el Tribunal podría decretar la suspensión cuando se justificara por el interesado que la ejecución causaría perjuicios de imposible o difícil reparación, bajo el ofrecimiento de garantía suficiente de cualquier tipo, e, incluso, cuando el interesado no pudiera aportar las garantías con los requisitos anteriores, acordar la suspensión sin presentación de garantía alguna si se apreciaban los referidos perjuicios. Ésta es la misma proyección que se observa actualmente en el tercer apartado del artículo 233 de la LGT y el artículo 44 del RRVA. En ambos preceptos se concreta que, si el interesado no puede presentar las garantías necesarias para la suspensión, la misma podrá acordarse previa presentación de otras garantías ${ }^{1009}$.

Con anterioridad a la entrada en vigor de la LGT vigente, el segundo párrafo del segundo apartado del artículo 22 del Real Decreto legislativo 2795/1980, de 12 de diciembre, por el que se articula la Ley 39/1980, de 5 de julio, de Bases sobre Procedimiento Económico-Administrativo, determinaba que

"las garantías podrán consistir en hipoteca inmobiliaria, hipoteca mobiliaria, prenda con o sin desplazamiento, fianza personal y solidaria, y cualesquiera otras que se estimen suficientes".

De todo este entramado normativo se desprende que el legislador ha optado siempre por garantías de fácil ejecución pero que no están siempre al alcance de los interesados, primando "la constitución en estos casos de garantías de más fácil ejecución, cercenando la libertad del contribuyente de elegir la que más le pudiera convenir y sin tomar en consideración que las dificultades que pudiera encontrar el interesado para la presentación de un aval o una fianza le podrían influir igualmente a la hora de

1008 GUERRA REGUERA, M., Suspensión de actos administrativos tributarios, Comares, Granada, 1999, pág. 88 y ss.; CHECA GONZÁLEZ, C., La Revisión de los Actos Tributarios Locales. Análisis teórico y jurisprudencial de los procedimientos especiales de revisión y del recurso de reposición, Edersa, Madrid, 1999, pág. 152 y ss., y, de este mismo autor, La Suspensión en Via EconómicoAdministrativa de la Ejecución de los Actos Administrativos Tributarios, Aranzadi, Pamplona, 1999, pág. 46 y ss. Esta misma posición fue asumida en relación con la normativa anterior, entre otros: LÓPEZ DÍAZ, A., "Algunas cuestiones en relación al aplazamiento y fraccionamiento del pago en el nuevo RGR", op. cit., pág. 87 y ss.; MARTÍN QUERALT, J., "La suspensión en vía económicaadministrativa", Tribuna Fiscal, núm. 14, 1991, pág. 4; TEJERIZO LÓPEZ, J. M., "Ejecutividad y suspensión de los actos administrativos tributarios. Algunos aspectos relevantes". Información Fiscal, Lex Nova, núm. 1, 1994, pág. 15; GONZÁLEZ CARRERA, F., "La inmediata ejecutividad del acto de liquidación tributaria y las posibilidades de suspensión en la vía económicaadministrativa y contenciosa”, Quincena Fiscal, núm. 6, 1993, pág. 165; LAGO MONTERO, J. M., La suspensión de liquidaciones tributarias en la reposición y en la vía económica-administrativa, Tecnos, Madrid, 1994, pág. 17 y 18; PONT I CLEMENTE, J. F., "Las garantías del crédito tributario ante los supuestos de aplazamiento y fraccionamiento de pago, así como ante la suspensión de la ejecutividad del acto de liquidación. En particular la suspensión en el recurso de reposición", en la obra La suspensión de los actos de liquidación tributaria y el problema de las garantías, Marcial Pons, Madrid, 1994, pág. 46 y 47; GALÁN RUIZ, J., "Algunas cuestiones en torno a la suspensión de la ejecución de liquidaciones tributarias”, Impuestos, núm. 2, 1995, pág. 6 o 124.

${ }^{1009}$ CHECA GONZÁLEZ, C., "La suspensión en vía económico-administrativa: medios admisibles para alcanzarla y posibilidad de obtenerla sin presentar garantías”, Actualidad Tributaria, 1993-1, pág. D-399. 
prestar una garantía de otro tipo"1010. Incluso más de un autor ha defendido la conveniencia de conceder la suspensión automáticamente sin necesidad de presentar garantía alguna ${ }^{1011}$.

El apartado primero del artículo 44 del RRVA, por su parte, prevé que la presentación de otras garantías distintas de las previstas en el número 2 del artículo 233 de la LGT producirá la suspensión cautelar del procedimiento de recaudación relativo al acto recurrido si la deuda se encuentra en período voluntario en el momento de presentarse la solicitud. Ahora bien, si la deuda se encuentra en período ejecutivo, la solicitud de suspensión no impedirá la continuación de las actuaciones de la Administración tributaria, sin perjuicio de que proceda la anulación de las efectuadas con posterioridad a la fecha de solicitud si la suspensión es concedida finalmente.

En resumen, la LGT prevé la suspensión automática de la ejecución del acto impugnado, previa solicitud del interesado, siempre y cuando éste presente las garantías que establece el apartado 2 del artículo 233 de la LGT. Sin embargo, cuando el solicitante no pueda aportar aquellas garantías, podrán constituirse otras consistentes en hipoteca mobiliaria e inmobiliaria y prenda con o sin desplazamiento, que son las mismas garantías reales que pueden presentarse para solicitar el aplazamiento o fraccionamiento del pago. Finalmente, se contempla la posibilidad de que el Tribunal pueda suspender la ejecución del acto con la dispensa total o parcial de garantías cuando dicha ejecución pudiera causar perjuicios de difícil o imposible reparación para el interesado.

\subsubsection{Suficiencia de las garantías presentadas}

Según el apartado tercero del artículo 233 de la LGT, en el caso de la impugnación de una liquidación el interesado podrá obtener la suspensión del pago de su deuda tributaria previa presentación de otras garantías suficientes diferentes de las incluidas en el número 2 del mismo precepto. "Desde el punto de vista jurídico", afirma ARRANZ DE ANDRÉS, "puede entenderse la suficiencia en referencia a la susceptibilidad de las garantías ofrecidas para ser objeto de ejecución y, por tanto, idóneas para recuperar el crédito impugnado en caso de levantamiento de la suspensión o desestimación de la reclamación"1012. Desde una perspectiva económica, la ley estipula que la garantía ha de cubrir el importe del acto, los intereses de demora que genere la suspensión y los recargos que pudieran proceder, a tenor de lo que dispone el apartado primero del artículo 233 de la $\mathrm{LGT}^{1013}$. Por su parte, el segundo párrafo del apartado primero del artículo 41 del RRVA determina que

“cuando la garantía consista en el depósito de dinero o valores públicos, los intereses de demora serán los correspondientes al plazo de seis meses si el

\footnotetext{
${ }^{1010}$ ARRANZ DE ANDRÉS, C., Las garantías reales del crédito tributario: aspectos sustantivos y procedimentales, op. cit., pág. 296.

1011 Tal es el caso DE LA NUEZ SÁNCHEZ-CASCADO, E., "La suspensión del acto impugnado", en la obra Las reclamaciones económicas-administrativas, Comentarios al nuevo Reglamento de Procedimiento, Aranzadi, Pamplona, 1997, pág. 547 a 553 ; CHICO DE LA CÁMARA, P., La suspensión de la ejecución de los actos tributarios sin garantía o con garantía distinta del aval, Aranzadi, Pamplona, 2001, pág. 153 a 157.

${ }^{1012}$ ARRANZ DE ANDRÉS, C., Las garantías reales del crédito tributario: aspectos sustantivos y procedimentales, op. cit., pág. 297.

${ }^{1013}$ FABRA VALLS propuso que cuando se fuera a fijar la cuantía por la que debe el sujeto presentar la caución se atendiera a la duración media de los procedimientos y a la pretensión del interesado en cuanto a la vía a agotar, ofreciendo el compromiso de completar el depósito si la cantidad no fuera suficiente. FABRA VALLS, M. J., La suspensión de los actos impugnados en materia tributaria, op. cit., pág. 188.
} 
procedimiento de la reclamación es el abreviado, de un año si el procedimiento de la reclamación es el general y de dos años si la resolución es susceptible de recurso de alzada ordinario".

En este punto es destacable la ausencia de las sanciones entre las cantidades que deberán garantizarse, que se excluyen expresamente en el apartado primero del artículo 233 de la LGT al no formar parte de la deuda tributaria definida en el apartado tercero del artículo 58 de la LGT. Idea que se reafirma también a partir de la dicción del inciso a) del apartado tercero del artículo 212 de la LGT, según el cual la interposición en tiempo y forma de un recurso o reclamación administrativa contra una sanción producirá la suspensión automática de la ejecución de las sanciones en período voluntario sin necesidad de aportar garantías hasta que sean firmes en vía administrativa.

Finalmente, de la misma forma que no apreciamos la discrecionalidad administrativa en todos los elementos que componen el acto de concesión o denegación del aplazamiento y fraccionamiento del pago, somos del criterio de que en el caso de la solicitud de suspensión tampoco puede existir discrecionalidad en la Administración tributaria, que sólo tendrá competencia para distinguir las circunstancias que manifieste el solicitante, a fin de proceder a la estimación de la suspensión que éste solicita y aceptar las garantías que para ello ofrece. Por eso la Hacienda Pública deberá concretar un concepto jurídico indeterminado, como es la apreciación de la existencia o no de un perjuicio efectivo de imposible o difícil reparación para concederse la suspensión con la garantía $\operatorname{prestada}^{1014}$.

\subsubsection{Formalización de las garantías}

Dispone el artículo 45 del RRVA que la garantía que se ofrezca deberá constituirse en el plazo de dos meses, contados a partir del día siguiente al de la notificación del acuerdo de concesión, y su eficacia estará condicionada a su formalización. Dicha garantía deberá ser objeto de aceptación, en su caso y según su naturaleza, por el órgano de recaudación que dictó la resolución de concesión.

De la misma manera que sucede para las garantías reales que se presentan para aplazar y fraccionar el pago de la deuda tributaria (la hipoteca mobiliaria e inmobiliaria y la prenda con o sin desplazamiento), las que se presten para la suspensión deberán hacerse constar en documento público, anotándose cuando proceda en el Registro Público correspondiente, conforme a lo que establece la Instrucción $12^{\mathrm{a}}$ de la Circular de 24 de octubre de 1991, que exige para la constitución de la hipoteca o la prenda que se formalice por escritura pública y que se inscriba en el Registro Público que corresponda. Asimismo, determina el artículo 1.865 del Código Civil que no surtirá efecto la prenda contra tercero si no consta por instrumento público la certeza de la fecha. Y finalmente el artículo 145 de la LH dispone que para que las hipotecas voluntarias queden válidamente constituidas se requiere la incorporación de las mismas en escritura pública y su inscripción en el Registro de la

\footnotetext{
${ }^{1014}$ Así lo han defendido GÓMEZ CABRERA, C., La discrecionalidad de la Administración Tributaria, op. cit., pág. 119; MORENO FERNÁNDEZ, J. I., El aplazamiento en el pago de los tributos, Lex Nova, Valladolid, 1996, pág. 135 y 136, del mismo autor La discrecionalidad en el Derecho Tributario: condonación, comprobación, aplazamientos y suspensión, Lex Nova, Valladolid, 1998, pág. 166 y ss.; MARTÍN FERNÁNDEZ, F. J., "La suspensión de la ejecución del acto tributario impugnado en el recurso de reposición", op. cit., pág. 42; GALÁN RUIZ, J., "Algunas cuestiones en torno a la suspensión de la ejecución de liquidaciones tributarias”, op. cit., pág. 6; CHICO DE LA CÁMARA, P., La suspensión de la ejecución de los actos tributarios sin garantía o con garantía distinta del aval, op. cit., pág. 131 y 132.
} 
Propiedad, requisito, este último, que se extiende a la hipoteca mobiliaria y la prenda sin desplazamiento.

Finalmente, el órgano correspondiente deberá manifestar la aceptación de la garantía presentada a través de un acuerdo expreso, que deberá ser remitido a los Registros Públicos correspondientes.

\subsubsection{Las garantías reales para la suspensión en los distintos procedimientos impugnatorios}

\subsubsection{Recurso de reposición y reclamación económico-administrativa}

El apartado 2 del artículo 11 del Real Decreto 2244/1979, de 7 de septiembre, remitía, en relación con el recurso de reposición, a lo que establecía el Real Decreto 1999/1981, sobre las reclamaciones económicas-administrativas, cuyo contenido se trasladó con posterioridad al Real Decreto 391/1996, de procedimiento de las reclamaciones económicas-administrativas. En este sentido, entendió MONTERO DOMÍNGUEZ que lo que pretendía el Real Decreto 448/1995, de 25 de mayo, por el que se modificó el artículo 11 del Real Decreto 2244/1979, era subsanar las diferencias existentes entre el recurso de reposición y la reclamación económica-administrativa, porque carecía de lógica que el interesado pudiera presentar garantías diferentes para ambas reclamaciones. Para este autor, lo determinante a la hora de conceder o denegar la suspensión debía ser la situación económica de solvencia del obligado, independientemente de cuál fuera el procedimiento impugnatorio seleccionado $^{1015}$.

En la actualidad estas diferencias se mantienen. El apartado segundo del artículo 224 de la LGT, que remite al artículo 25 del RRVA, establece que cuando se presenta un recurso de reposición las garantías necesarias para obtener la suspensión automática son, exclusivamente, el depósito de dinero o valores públicos, el aval o fianza de carácter solidario de entidad de crédito o sociedad de garantía recíproca o certificado de seguro de caución y la fianza personal y solidaria de otros contribuyentes de reconocida solvencia para los supuestos que se establezcan en la normativa tributaria. No permite este precepto que se constituyan otras garantías, como sí lo hace el artículo 233 de la LGT para el caso de la suspensión de la ejecución del acto impugnado en vía económico-administrativa. De todo lo anterior se deduce que en el caso del recurso de reposición no podrán presentarse garantías reales para solicitar la suspensión del acto impugnado.

\subsubsection{Recurso contencioso-administrativo}

Al referirse al recurso contencioso-administrativo, el artículo 129 de la Ley 29/1998, de 13 de julio, reguladora de la Jurisdicción Contencioso-Administrativa (en adelante LJCA), determina que los interesados podrán solicitar en cualquier estado del proceso la adopción de cuantas medidas aseguren la efectividad de la sentencia.

Más adelante, en los números 1 y 2 del artículo 133 de la LJCA, se establece que si de la medida cautelar se derivan perjuicios de cualquier naturaleza, podrán acordarse las medidas que sean adecuadas para evitar o paliar dichos perjuicios, de la misma forma que podrá exigirse la

\footnotetext{
1015 MONTERO DOMÍNGUEZ, A., "Sobre la suspensión de la ejecutividad de los actos administrativos de naturaleza tributaria", Tribuna Fiscal, núm. 78, 1997, pág. 79 y ss.
} 
presentación de caución o garantía suficiente para responder de aquéllos. La caución o garantía se constituirán en cualquiera de las formas admitidas en Derecho y la medida cautelar acordada no se llevará a efecto hasta que la caución o garantía esté constituida y acreditada en autos, o hasta que conste el cumplimiento de las medidas acordadas para evitar o mitigar los perjuicios a los que hacíamos referencia ${ }^{1016}$.

La doctrina del Tribunal Supremo se ha ido adaptando a la regulación de la $\mathrm{LJCA}^{1017}$, pues carece de sentido que para la suspensión en vía contenciosa judicial se exijan requisitos adicionales a los previstos en la vía administrativa. Lo acertado sería que se procediera a la suspensión en los casos que se aleguen daños o perjuicios de inmediata producción y se presente caución para garantizar suficientemente el pago de la deuda tributaria ${ }^{1018}$.

El artículo 133 de la LJCA sólo se refiere a la constitución de caución o garantía en cualquiera de las formas que determine el Derecho, y esta disposición genérica debe ser completada con lo dispuesto en el Real Decreto 520/2005, que aprueba el reglamento de las reclamaciones económicasadministrativas. En el apartado 6 del artículo 43 de este reglamento se indica que si se hubiese solicitado la suspensión al amparo del apartado segundo del artículo 233 de la LGT y la garantía aportada no fuera una de las previstas en dicho artículo, se aplique lo dispuesto en las sucesivas subsecciones, siendo posible constituir un derecho real de garantía como caución necesaria para la obtención de la suspensión ante la jurisdicción contenciosa.

No debemos olvidar, en todo caso, que en la normativa reguladora de las reclamaciones económicoadministrativas la constitución de las garantías reales tiene un carácter subsidiario, por lo que se puede interpretar que el deudor tiene la oportunidad de solicitar la adopción de otra garantía distinta más cercana a sus posibilidades o intereses ${ }^{1019}$. En esta línea, varios autores manifiestan la necesidad de que la Administración actúe con cierta indulgencia en los criterios que sigue para exigir las garantías, ya que la tendencia en la práctica es la de admitir la constitución de garantías de fácil ejecución, sin tener en cuenta la disponibilidad o los intereses del obligado tributario ${ }^{1020}$.

\footnotetext{
${ }^{1016}$ Entendió la doctrina que la exigencia de la caución para la obtención de la suspensión no representa sino la adopción de una medida cautelar en sentido inverso, ya que se dirige a la protección de los peligros que puedan surgir de la medida cautelar principal: GONZÁLEZ PÉREZ, J., Comentarios a la Ley de la Jurisdicción Contencioso-Administrativa (Ley 29/1998, de 13 de julio), Vol. II, $3^{\text {a }}$ ed., Civitas, Madrid, 1998, pág. 2076.

1017 Según CHECA GONZÁLEZ, el Tribunal Supremo extendió al ámbito del recurso contencioso la legislación sobre la suspensión automática que se aplica en el marco de las reclamaciones económicas-administrativas (CHECA GONZÁLEZ, C., Reclamaciones y Recursos Tributarios, Aranzadi, Pamplona, 1997, pág. 232 y ss.).

${ }^{1018}$ Así lo entienden entre otros, CHICO DE LA CÁMARA, P., La suspensión de la ejecución de los actos tributarios sin garantía o con garantía distinta del aval, op. cit., pág. 252 y ss.; y ARRANZ DE ANDRÉS, C., Las garantías reales del crédito tributario: aspectos sustantivos y procedimentales, op. cit., pág. 301. En la jurisprudencia, vid. por todas la Sentencia del Tribunal Constitucional 110/1984 de 26 de noviembre, la Sentencia del Tribunal Supremo de 6 de octubre de 1998, o la Sentencia del Tribunal Superior de Justicia de Madrid de 9 de mayo de 2001.

${ }^{1019}$ MARTÍN FERNÁNDEZ, F. J., "Incidencia de la nueva Ley de la Jurisdicción Contencioso-Administrativa en materia tributaria: suspensión de la ejecución del acto impugnado y extensión de los efectos de una sentencia firme a personas que no han sido parte en el procedimiento", Información Fiscal, núm. 32, 1999, pág. 31 y 32.

${ }^{1020}$ FALCÓN Y TELLA, R., "Un ataque a la línea de flotación del carácter inmediatamente ejecutivo de las liquidaciones tributarias", Quincena Fiscal, núm. 22, 1996, pág. 7; CHECA GONZÁLEZ, C., Reclamaciones y Recursos Tributarios, op. cit., pág. 236.
} 


\subsection{LA FIANZA EN LA SUSPENSIÓN DE LOS ACTOS ADMINISTRATIVOS POR INTERPOSICIÓN DE RECURSOS}

Como ya hemos señalado en líneas anteriores, la norma tributaria admite la suspensión del ingreso de la deuda tributaria en caso de presentación de reclamación si se garantiza la misma mediante aval, fianza o depósito. En el supuesto de que el interesado no pudiera presentar alguna de estas garantías, el tribunal puede aceptar otra medida de garantía del crédito y acceder a la suspensión del acto. Ello significa que, para obtener la suspensión del acto administrativo que se impugna, es necesaria la presentación, preferentemente, de las garantías personales reguladas en el ordenamiento civil, aunque la normativa tributaria admite otros mecanismos cuando sea imposible al obligado presentar dichas garantías. 


\section{CONCLUSIONES}

\section{LAS MEDIDAS CAUTELARES COMPARTEN CON LAS GARANTÍAS DEL CRÉDITO TRIBUTARIO LA FINALIDAD DE HACER PREVALECER EL INTERÉS PÚBLICO SOBRE LAS EXPECTATIVAS DE OTROS ACREEDORES}

Las medidas cautelares se introducen en el procedimiento de recaudación para asegurar el resultado del proceso y se pueden considerar garantías del crédito tributario en sentido amplio. No pueden identificarse con las garantías reales en sentido estricto debido a su carácter provisional; a que precisan una situación de peligro que ponga en riesgo el cobro del crédito tributario; y a que no confieren a la Hacienda Pública las facultades de preferencia, reipersecutoriedad y oponibilidad erga omnes. Las medidas cautelares pueden ser recurribles en su condición de actos dictados en el seno del procedimiento de recaudación porque no constituyen un acto de trámite, sino un acto decisorio que afecta situaciones jurídico-privadas de los obligados tributarios. Se desprende de todo ello que la adopción de medidas cautelares debe ser notificada y motivada y dichas medidas deben ser necesarias y proporcionales al daño que se pretende evitar y no pueden producir perjuicios de difícil o imposible reparación.

\section{EL RÉGIMEN DE LOS SUJETOS LEGITIMADOS Y LAS CAUSAS DE IMPUGNACIÓN EN EL PROCEDIMIENTO DE APREMIO DEBE SER INTERPRETADO DE FORMA AMPLIA}

La oposición al procedimiento de apremio se manifiesta fundamentalmente con la presentación de reclamaciones contra la providencia de apremio o contra la diligencia de embargo, aunque también puede impugnarse el acuerdo de enajenación de los bienes embargados cuando el embargo se ha dado por notificado por no haber comparecido el obligado tributario o su representante. Dado que la LGT no determina expresamente los sujetos que están legitimados para impugnar el procedimiento de apremio, entendemos que, además del obligado tributario, está legitimado para oponerse a dicho procedimiento cualquier persona que pueda verse perjudicada en el procedimiento. Por otra parte, las causas de oposición a la providencia de apremio (apartado tercero del artículo 167 de la LGT) y a la diligencia de embargo (apartado tercero del artículo 170 de la LGT) se disponen en la LGT de forma tasada, aunque gran parte de la doctrina y la jurisprudencia consideran que debe permitirse a los obligados tributarios alegar otras causas de oposición a las indicadas.

3. EL INCUMPLIMIENTO DE LOS PLAZOS PARA RESOLVER LA SOLICITUD DE APLAZAMIENTO O FRACCIONAMIENTO DE PAGO NO DEBERÍA IMPLICAR EL DEVENGO DE INTERESES DE DEMORA CUANDO EL RETRASO ES IMPUTABLE A LA ADMINISTRACIÓN TRIBUTARIA

Una de las novedades que introduce la LGT, en el apartado cuarto del artículo 26, es la inexigibilidad de intereses de demora cuando la Administración tributaria incumple los plazos máximos que la ley prescribe para dictar resoluciones. Sin embargo, esta consecuencia del incumplimiento a que hace referencia dicho apartado no se aplica, por disposición expresa del mismo precepto, a los plazos para resolver las solicitudes de aplazamiento o fraccionamiento del pago. Esta excepción es cuestionable si observamos que, por un lado, se produce una discriminación en función del procedimiento y, por 
otro, se rompe con la regla general de no exigir intereses de demora en los procedimientos tributarios cuando el retraso sea imputable a la Administración tributaria y no al obligado. Por otro lado, esta exclusión resulta aún más criticable si tenemos en cuenta que la equiparación entre el interés de demora y el interés legal que efectúa el párrafo segundo del apartado 6 del artículo 26 de la LGT se limita a los supuestos en que se presente como garantía para solicitar el aplazamiento o fraccionamiento un aval solidario de entidad de crédito o sociedad de garantía recíproca o un certificado de seguro de caución, y que al resto de casos se aplica en concepto de interés de demora el interés legal incrementado en 25 puntos porcentuales. Resulta evidente, entonces, que cuando no existe implicación del solicitante del aplazamiento o fraccionamiento del pago en el retraso, la aplicación de este interés de demora incrementado difícilmente puede casar con la función exclusivamente indemnizatoria que debe tener esta figura, lo que supone una penalización injustificada.

\section{LA RESPONSABILIDAD PATRIMONIAL UNIVERSAL NO PUEDE CONCEBIRSE COMO UN DERECHO DE GARANTÍA DEL CRÉDITO TRIBUTARIO}

La previsión del artículo 1.911 del Código Civil de que el deudor responde con todos sus bienes presentes o futuros es la manifestación del principio de responsabilidad patrimonial universal aplicable a todas las obligaciones, incluidas las tributarias. Se trata de un derecho que se concede al acreedor para ejecutar los bienes del deudor por una cantidad equivalente al valor de la prestación debida y no satisfecha. La responsabilidad patrimonial del deudor constituye la esencia del derecho de crédito y no puede concebirse, por ello, como una garantía del crédito en sentido estricto, si tenemos en cuenta que los derechos de garantía refuerzan el derecho de crédito que tiene el acreedor ampliando el poder jurídico de éste y que los mismos atribuyen un derecho subjetivo o una nueva facultad que antes no tenía el crédito que se pretende asegurar.

\section{LA EJECUCIÓN INMEDIATA DEL CRÉDITO TRIBUTARIO SE ASEGURA CON LAS GARANTÍAS EN SENTIDO ESTRICTO}

La garantía del crédito tributario incluye todas las prerrogativas a disposición de la Administración tributaria para que ésta pueda realizar su derecho de crédito de una forma rápida y eficaz. El derecho de garantía debe ser establecido por ley y, a pesar de gozar de autonomía, mantiene una relación de subordinación o accesoriedad con el crédito tributario. En el seno de las garantías en sentido amplio que la ley confiere a la Administración tributaria, las garantías en sentido estricto deben ser reconducidas al momento de la ejecución del crédito y se concretan en derechos, facultades o potestades que la ley otorga a la Hacienda Pública con la finalidad de satisfacer su crédito mediante la realización de determinados bienes y derechos. 


\section{EL ORDENAMIENTO ASEGURA EL CRÉDITO TRIBUTARIO A TRAVÉS DE LA EJECUCIÓN DE GARANTÍAS REALES Y PERSONALES, ALGUNAS DE LAS CUALES TIENEN SU RÉGIMEN JURÍDICO EN EL DERECHO CIVIL}

En este trabajo hemos centrado nuestra atención exclusivamente en las garantías del crédito tributario en sentido estricto, es decir, las que resultan operativas en el momento de la ejecución de crédito. Algunas de estas garantías se regulan en el propio ordenamiento tributario y se establecen como facultades que puede ejercer la Administración tributaria. Es el caso de la hipoteca legal tácita, el derecho de afección, y la hipoteca legal expresa, todas de carácter real, además de la responsabilidad tributaria y la solidaridad tributaria pasiva, que tienen naturaleza personal. Junto a ellas, la normativa tributaria también se apoya del régimen general del ordenamiento civil que contempla diversas garantías reales y personales en las relaciones crediticias para utilizar estas figuras en determinados casos, exigiendo su presentación a los obligados tributarios cuando solicitan el aplazamiento y fraccionamiento del pago o la suspensión del ingreso por interposición de reclamaciones o recursos. Nos referimos a las garantías reales de la hipoteca o la prenda y a la garantía personal de la fianza.

\section{LOS DERECHOS DE GARANTÍA DEL CRÉDITO TRIBUTARIO EN SENTIDO ESTRICTO SE DIVIDEN EN GARANTÍAS REALES Y PERSONALES}

Las garantías del crédito tributario en sentido estricto pueden ser reales o personales. Esta clasificación tradicional de las garantías tributarias permite distinguir potestades diferentes del acreedor, ya sea un poder jurídico sobre cosas concretas y determinadas en el caso de las garantías reales, o un derecho o una facultad que se dirige hacia la persona del deudor o hacia una tercera persona cuando se trata de garantías personales. El acreedor titular de una garantía real tiene el derecho a ejecutar el bien incluso cuando éste haya pasado al poder de una tercera persona. En cambio, el titular de un derecho de garantía personal dispone de una facultad que no recae sobre una cosa determinada o concreta, sino sobre una persona que debe responder de la deuda.

Entre las medidas que confieren al acreedor tributario una garantía de naturaleza personal, la más importante es la extensión de la responsabilidad a terceros ajenos a la realización del hecho imponible, que se concreta en dos figuras: la responsabilidad solidaria y la responsabilidad subsidiaria. Pero la LGT también contempla la utilización de otras modalidades de garantías personales, como son la solidaridad de los responsables solidarios $\mathrm{y}$, en los supuestos en que el obligado tributario solicita un aplazamiento o fraccionamiento del pago de la deuda tributaria o la suspensión del mismo en caso de presentar una reclamación o recurso, la fianza -mediante aval bancario o fianza personal y solidaria- regulada en el ordenamiento civil.

Con las garantías reales, en cambio, se atribuye al acreedor la facultad de reipersecutoriedad, la preferencia y la oponibilidad erga omnes sobre un bien concreto. El legislador tributario ha tenido el desacierto de colocar bajo la rúbrica de garantías de la deuda tributaria un conjunto de instituciones que tienen como finalidad común asegurar el cumplimiento de la obligación tributaria, pero que en esencia no tienen la misma naturaleza jurídica. En el ámbito tributario, sólo pueden tener el carácter de derecho real de garantía la hipoteca legal tácita, la hipoteca legal expresa y el derecho de afección. Además, de la misma forma que sucede con las garantías personales, el ordenamiento tributario permite al interesado que solicita un aplazamiento o fraccionamiento del pago o la suspensión de la 
ejecución del mismo por la interposición de una reclamación o recurso, presentar como garantías reales una hipoteca o una prenda, cuyo régimen jurídico se encuentra en el ordenamiento civil.

\section{LOS PRIVILEGIOS DEL CRÉDITO TRIBUTARIO NO CONSTITUYEN VERDADEROS DERECHOS DE GARANTÍA}

El carácter privilegiado de un crédito supone la ruptura del principio de igualdad de trato de los acreedores y se produce cuando la ley concede a un acreedor la facultad de cobrar con preferencia a los demás sobre el producto obtenido de la realización de los bienes del deudor. Estos privilegios otorgan facultades que, al igual que las garantías, acompañan y son accesorias al derecho de crédito, sin que sea posible negociar ni disponer sobre ellas separadamente.

Si asumimos como privilegio especial el derecho o preferencia o prelación que un acreedor despliega frente a los otros acreedores sobre el producto que se obtenga de la venta de un determinado bien, entonces este derecho de preferencia se asemeja mucho a un derecho real de garantía porque incorpora un derecho de persecución. Sin embargo, son distintos los efectos que producen las garantías y los privilegios sobre los bienes gravados. El titular de un derecho real de garantía tiene la facultad de perseguir un bien determinado e instar su ejecución para satisfacer su crédito en todo caso, independientemente de quién sea titular o poseedor del mismo. El crédito asegurado con garantía otorga un poder al acreedor para realizar directamente determinados bienes y destinarlos al pago y no necesita de la concurrencia de créditos. Por el contrario, el acreedor privilegiado no tiene la facultad de dirigirse directamente contra los bienes del deudor y mucho menos contra los de un tercero. Posee únicamente una preferencia o prelación para cobrar el producto de la realización de determinados bienes en relación con el resto de los acreedores, porque los privilegios sólo son operativos en situaciones de concurrencia de crédito. Desde esta perspectiva, el privilegio ordena el cobro entre los distintos créditos concurrentes contra un mismo deudor, señalando cuál de ellos tendrá preferencia sobre los demás, ya sea sobre todo el patrimonio del deudor o sobre el producto de la realización de determinados bienes.

\section{LA HIPOTECA LEGAL TÁCITA ES UNA GARANTÍA REAL DE EFICACIA LIMITADA}

La hipoteca legal tácita es un derecho real de hipoteca que puede utilizarse como garantía para la recaudación de determinados impuestos, reales, directos y periódicos, que incorporan hechos imponibles sobre bienes o derechos inscribibles en el Registro Público de la Propiedad. En el sistema tributario vigente, cumplen estos requisitos actualmente el IBI, el Gravamen sobre bienes Inmuebles de Entidades No Residentes y el IVTM.

Mediante el ejercicio de esta garantía real, se puede exigir al poseedor del bien afecto por la hipoteca legal tácita la cuota tributaria y los intereses de demora, los recargos del período ejecutivo y las costas procedimentales que se deriven como consecuencia del inicio del procedimiento ejecutivo, siempre y cuando el poseedor del bien sea el propio deudor principal. Sin embargo, creemos que debe hacerse una distinción cuando se trata de ejercer el derecho frente un tercer adquirente, sobre la base de que resulta injusto que este sujeto tenga que satisfacer las cantidades que se devengan por la 
falta de pago del deudor principal. Lo razonable es que el tercer adquirente haga frente únicamente a los intereses, recargos y costas que se devenguen con motivo de su propio incumplimiento.

Por otra parte, la hipoteca legal tácita está limitada a dos anualidades. Los dos años que cubre esta garantía real deben ser, a nuestro juicio, el de la notificación de la providencia de apremio y el inmediato anterior. Y ello por dos razones. En primer lugar, porque independientemente de que se realicen o no transmisiones o inscripciones sobre el bien afecto no pierde vigencia la aplicación de la hipoteca legal tácita en caso de que no concurran intereses de terceros. Y en segundo lugar, porque se ejercita este mecanismo de garantía cuando, una vez que se produce el incumplimiento, se precisa ejecutar los bienes garantizados para satisfacer la deuda tributaria.

\section{LA HIPOTECA LEGAL TÁCITA Y EL DERECHO DE AFECCIÓN SON DERECHOS REALES DE GARANTÍAS SEMEJANTES, AUNQUE CON ELEMENTOS DIFERENCIADOS}

Existe una gran similitud entre la hipoteca legal tácita y el derecho de afección en su condición de garantías reales del crédito tributario, puesto que en ambas se produce la sujeción de un bien para cumplir con una obligación concreta y se faculta al titular a perseguir y ejecutar el bien aunque éste ya no forme parte del patrimonio del deudor principal. En el caso de la hipoteca legal tácita, el legislador confiere a la Hacienda Pública una hipoteca sin necesidad de inscripción registral, sobre bienes o derechos inscritos en el Registro público que se gravan con ciertos tributos periódicos de carácter real. En el caso de que se incumpla con la obligación de pago, con esta garantía real se atribuyen a la Administración tributaria las facultades de persecución erga omnes y de ejecución forzosa sobre los bienes y, además, se otorga una preferencia especial para que la Hacienda acreedora cobre con el producto de la realización de los mismos con preferencia frente a los titulares registrales, incluso si estos últimos son terceros adquirentes o acreedores de bienes o derechos reales inscritos con anterioridad en el registro. La hipoteca legal tácita, por tanto, constituye una garantía real cualificada con un derecho especial de prelación, uniendo el derecho de hipoteca y el derecho de prelación frente a otros acreedores hipotecarios y no simplemente frente al deudor. Por su parte, con la afección se otorga a la Administración tributaria la facultad de sujetar un bien o un conjunto de bienes o derechos concretos para satisfacer con su realización una obligación determinada, con independencia de que el bien o los bienes hayan pasado a una tercera persona distinta del deudor principal. La afección concede al titular de la garantía un derecho de realización del valor del bien para la satisfacción de su crédito en el caso de que el deudor no cumpla voluntariamente con su obligación. El carácter real de esta figura se aprecia además en el hecho de que el acreedor puede realizar el valor del bien cualquiera que sea el titular o poseedor del mismo.

A pesar de la similitud que presentan la hipoteca legal tácita y la afección, existen elementos que permiten diferenciarlas. En primer lugar, se restringe el uso de la hipoteca legal tácita a dos anualidades, límite temporal que no se aplica al derecho de afección. Tampoco coinciden las dos garantías reales señaladas en los impuestos afectados. El derecho de afección se aplica en el ITPAJD, el ISD, el IVA, los Impuestos Especiales, los Impuestos Aduaneros, el IRNR y el IBI, mientras que sólo a este último impuesto, al Gravamen Especial sobre Bienes Inmuebles de Entidades No Residentes y al IVTM puede afectar la hipoteca legal tácita. Por último, una tercera diferencia entre del derecho de afección y la hipoteca legal tácita tiene relación con la eficacia que frente al tercero 
adquirente despliegan uno y otro derecho real de garantía, pues la afección de bienes se detiene ante el tercer adquirente de buena fe, según el artículo 34 de la LH, y se supedita a otros titulares de derechos reales nacidos con anterioridad al momento en que deba considerarse nacido el derecho de afección, mientras que la hipoteca legal tácita determina la posibilidad de anteponerse a cualquier otro titular o adquirente aunque éste hubiera inscrito su derecho previamente.

\section{EN EL DERECHO DE AFECCIÓN EL ADQUIRENTE DEL BIEN AFECTO NO ES UN RESPONSABLE SUBSIDIARIO}

La afección de bienes otorga a la Administración tributaria la facultad de sujetar un bien o conjunto de bienes o derechos concretos para satisfacer con su realización una obligación determinada, con independencia de que los mismos hayan pasado o no a una tercera persona distinta del deudor principal. El adquirente de estos bienes o derechos recibe, en estos casos, el bien con la carga o el gravamen de la afección y debe soportar el derecho del acreedor, pero no surge para él una obligación propiamente dicha, ni pasa a ocupar el lugar del deudor principal en la relación crediticia que mantiene éste con la Hacienda Pública. Este tercero adquirente sufre únicamente las consecuencias de la posible ejecución del derecho real de garantía, recayendo sobre él una sujeción a la eventual ejecución forzosa más que una obligación. Consecuentemente, el tercero adquirente puede librarse de su deber transmitiendo o abandonando la cosa objeto de garantía, cesando también en este supuesto la relación que mantenía con la Administración tributaria.

De todo lo anterior se deduce que, aunque la ley confiera al adquirente de bienes afectos el carácter de responsable subsidiario, no estamos estrictamente ante un supuestos de responsabilidad tributaria, sino ante una garantía real que se ejecuta a través de un procedimiento cuya finalidad es hacer efectiva las garantías personales, esto es, el procedimiento de responsabilidad tributaria, sin que esto implique que el adquirente asuma las características propias del responsable.

\section{EL DERECHO DE PRELACIÓN GENERAL DESPLIEGA SU MAYOR EFICACIA EN SITUACIONES DE CONCURSO}

La efectividad del derecho de prelación general que la ley reconoce a los créditos tributarios en el artículo 77 de la LGT manifiesta su mayor efectividad cuando, previo embargo y enajenación de los bienes, se procede a distribuir la cantidad resultante entre distintos acreedores. El legislador otorga en este caso a la Administración tributaria una preferencia para el cobro frente a acreedores concurrentes, siempre y cuando éstos no sean titulares de derechos reales de garantía inscritos con anterioridad a la fecha en que se haga constar la anotación preventiva del embargo de la Hacienda Pública. La prelación general tributaria prevalece, por el contrario, frente a otros acreedores titulares de derechos de créditos comunes, aunque éstos se encuentren vencidos y hayan sido anotados en el correspondiente Registro antes que los de la Hacienda Pública. En cualquier caso, si se trata de procesos singulares de ejecución forzosa, los órganos ejecutores no pueden apreciar de oficio el carácter privilegiado del crédito tributario y la Administración tributaria deberá hacer valer su preferencia de cobro a través de una tercería de mejor derecho.

En caso de concurso, la graduación y clasificación de los créditos se regirá por lo dispuesto en la Ley 22/2003, de 9 de julio, Concursal. Según esta norma, los créditos tributarios son entendidos como 
créditos concursales y como tal deben integrarse a la masa pasiva, lo cual implica que las garantías y privilegios de los créditos tributarios queden sometidos al régimen concursal. Éste, por su parte, clasifica los créditos en cuatro categorías: créditos con privilegio especial, créditos con privilegio general, créditos ordinarios, y créditos subordinados. Y sólo adquieren la condición de privilegio especial, según la Ley Concursal, la hipoteca legal tácita, la hipoteca legal stricto sensu, la hipoteca inmobiliaria o mobiliaria, y la prenda. El derecho de afección, por tanto, quedaría fuera de esta relación, aunque si tenemos en cuenta que este derecho tiene una naturaleza real y, por tanto, es ejercitable por la Hacienda Pública para el cobro de los créditos garantizados por derechos reales, esta exclusión no estaría justificada. Por lo que respecta a los créditos con privilegio general, en esta categoría se reduce hasta un 50 por 100 el importe de los créditos tributarios amparados, de forma que los créditos tributarios serán en parte privilegiados y en parte ordinarios o subordinados. Específicamente, se reconoce que gozan de privilegio general la cuota tributaria y las otras prestaciones que comparten su misma naturaleza y fundamento, los recargos a favor del Tesoro $\mathrm{u}$ otros entes públicos, las cantidades a ingresar en el Tesoro como consecuencia de las autoliquidaciones o liquidaciones administrativas, y las cantidades a ingresar a cuenta del tributo cuando no se trate de créditos dotados de otros privilegios.

\section{EL DERECHO DE PRELACIÓN GENERAL, EL DERECHO DE RETENCIÓN Y LAS MEDIDAS CAUTELARES NO PUEDEN SER CALIFICADOS COMO GARANTÍAS REALES EN SENTIDO ESTRICTO, PERO DESPLIEGAN SU MÁXIMA EFICACIA CUANDO SE APLICAN JUNTO A ÉSTOS}

El ordenamiento tributario reconoce dentro de las garantías del crédito tributario el derecho general de prelación, el derecho de retención y las medidas cautelares. Estas instituciones se configuran, respectivamente, como un privilegio para el cobro oponible frente a cualquier derecho no inscrito con anterioridad a la inscripción de la anotación del embargo de la Hacienda Pública, como una facultad para retener mercancías declaradas en la aduana siempre que no se garantice de forma suficiente el pago de la deuda aduanera o como un conjunto de medidas aplicables cuando exista un riesgo inminente de incumplimiento del crédito tributario.

Todas estas prerrogativas, sin embargo, no pueden ser concebidas como garantías reales en sentido estricto, porque, entre otras cosas, tienen un carácter provisional (en el caso del derecho de retención y de las medidas cautelares) y no otorgan a su titular facultades de reipersecutoriedad o eficacia erga omnes. Ahora bien, la aplicación de estas tres figuras junto a las garantías reales permite ampliar la eficacia aseguradora de estas últimas, produciéndose una relación de reciprocidad entre ambas. En este sentido, la conexión del derecho de retención o de las medidas cautelares con el derecho de prelación general y el derecho de afección de bienes amplía la eficacia de esas dos últimas instituciones, porque al permanecer los bienes en poder de la Administración tributaria se imposibilita cualquier acción que pueda dejar sin efectividad tanto la prelación general como el derecho de afección. 


\section{SERÍA CONVENIENTE SUPRIMIR LA HIPOTECA LEGAL EXPRESA}

Dentro de las garantías que en sentido estricto contiene actualmente el ordenamiento tributario, entendemos que la hipoteca legal expresa debería ser eliminada de la legislación tributaria vigente por distintos motivos. Se trata de una garantía real de poca relevancia práctica que no concede beneficios inmediatos a la Administración tributaria, porque para que sea efectiva hay que esperar a que la misma se constituya voluntariamente por el deudor o se exija judicialmente, tal como dispone la Ley Hipotecaria. Además, al afectar a deudas pendientes de pago, la Administración puede exigir las mismas por la vía ejecutiva a través de la providencia de apremio, sin necesidad de acudir a esta garantía. También hay que tener en cuenta, que el derecho de prelación general que la LGT confiere al crédito tributario, previa anotación preventiva del embargo, ya implica la preferencia del crédito tributario frente a cualquier acreedor ordinario o titular de un derecho real no inscrito antes de la práctica de la anotación, con independencia de que el crédito de este acreedor hubiera nacido con anterioridad o posterioridad a la fecha de la anotación.

\section{LA RESPONSABILIDAD TRIBUTARIA ES UNA GARANTÍA PERSONAL DEL CRÉDITO TRIBUTARIO Y DEBE CONSTITUIRSE SÓLO CON ESTA FINALIDAD}

En la normativa aplicable a la responsabilidad tributaria se observa una marcada tendencia a utilizar cada vez más esta figura para actuar como instrumento de represión de conductas que afectan a los intereses recaudatorios. Así sucede con la introducción de supuestos de responsabilidad por participación en una acción infractora, que supone la utilización de la obligación que incumbe al responsable para cubrir el objetivo reservado propiamente a la sanción. La responsabilidad tributaria es una garantía personal del crédito tributario cuya ineficacia se acrecienta cuando se utiliza en ámbitos que no le corresponde, como en la esfera sancionadora. Entendemos que es preciso, por ello, establecer claramente los conceptos, debiéndose tipificar una sanción tributaria y no una modalidad de responsabilidad si lo que se pretende es reprimir una conducta infractora, porque la figura del responsable debe concebirse exclusivamente como una medida garantista del crédito tributario.

\section{LAS SANCIONES NO SON EXIGIBLES A LOS RESPONSABLES TRIBUTARIOS DE FORMA AUTOMÁTICA}

La derivación de las sanciones a los responsables tributarios ha sido uno de los temas más debatidos por la doctrina y la jurisprudencia, sin que exista, en estos momentos, consenso en cuanto a su exigencia o no dentro de la obligación de pago del responsable. La LGT dispone en el apartado cuarto del artículo 41 que las sanciones no alcanzarán a la responsabilidad, salvo las excepciones que esa u otra ley determinen. Creemos que esta regla general obedece a la intención del legislador de ser respetuoso con el principio de personalidad de la pena. Sin embargo, se sigue cuestionando si procede derivar las sanciones hacia aquellos supuestos de responsabilidad por actos ilícitos, como los contemplados en el inciso a) del apartado primero del artículo 42 de la LGT y el inciso a) del primer apartado del artículo 43 de la LGT.

El criterio que hemos mantenido en el desarrollo de este trabajo es que no deben exigirse las sanciones a los responsables y que en supuestos como los del colaborador en la comisión de infracciones tributarias se incluya el pago de las sanciones que correspondan a este sujeto en la 
condición de infractor y no de responsable, $\mathrm{y}$, en consecuencia, a través de un procedimiento sancionador y no de derivación de responsabilidad. De esta forma se evitarían los muchos problemas que se producen de esta opción legislativa como son que si paga el deudor principal, la obligación del responsable se extingue en virtud del carácter accesorio de su obligación y la conducta reprochable de aquel sujeto permanece impune o que si paga el responsable y la acción de reembolso que se le reconoce prospera, estaremos de nuevo ante una situación de impunidad de la conducta del responsable, mientras que si dicha acción no prospera la impunidad beneficiará entonces al deudor principal, que es al mismo tiempo autor principal de la infracción.

La determinación de la sanción en estos casos debería pasar, en síntesis, por la fijación de una única sanción en su grado mínimo tanto para el colaborador como para el deudor principal y el prorrateo de la misma entre ambos sujetos en función de la participación respectiva en la comisión de la infracción. Posteriormente debería aplicarse a cada sujeto infractor de forma separada, además de las sanciones que correspondan en su grado mínimo, las circunstancias que gradúen la sanción respectiva. Si la infracción es la misma tanto para el colaborador como para el deudor principal, entonces la sanción debería ser común para ambos. Lo difícil sería determinar cuál ha sido el grado de participación del colaborador en la comisión de la infracción, pues la solidaridad no rige respecto de las sanciones por aplicación del principio de personalidad de la pena. Una posible solución a este problema podría ser, en el caso de que no pudiera determinarse el grado de participación de cada sujeto infractor, imputar por partes iguales, exigiendo un 50 por 100 de la sanción mínima a cada uno de los dos sujetos, sin que la parte del deudor principal pudiera exigirse al responsable.

\section{LA RESPONSABILIDAD SOLIDARIA POR SUCESIÓN DE EMPRESA DEBERÍA SER REFORMULADA}

Son muchas las cuestiones polémicas que suscita la figura de la responsabilidad solidaria por sucesión de empresa. Se trata de un supuesto de responsabilidad que no tiene finalidad garantista. La LGT introduce esta figura en el inciso c) del apartado primero del artículo 42 con la intención de combatir el fraude fiscal. Sin embargo, esta función de la responsabilidad por la sucesión de empresa es muy cuestionable si tenemos en cuenta que dentro de la ley se regulan otros supuestos de responsabilidad subsidiaria que permiten a la Hacienda Pública levantar el velo y hacer frente a este tipo de comportamiento. Además, basta con que el certificado expedido por la Administración tributaria no diga nada y si la deuda no está liquidada para que desaparezcan los efectos como garantía de la responsabilidad del sucesor.

La ubicación de este tipo de responsabilidad en el seno de los supuestos de responsabilidad solidaria también provoca el rechazo de gran parte de la doctrina, que considera más acertada su ubicación dentro de la responsabilidad subsidiaria. Configurar la responsabilidad por la sucesión de empresa como solidaria parece excesivo, porque sólo en el caso que el transmitente no tuviera bienes suficientes para satisfacer la deuda tributaria y su sanción, podría ser llamado el adquirente que no obró con la diligencia debida. Resulta contradictorio que se acuda primero al adquirente de la empresa y con posterioridad al administrador de la entidad por haber participado, éste último, en las infracciones cometidas por la entidad. 
Por otra parte, la inclusión de las sanciones dentro del ámbito de la responsabilidad por la sucesión de empresa es inadecuada y rompe abiertamente con el principio de personalidad de la pena. En este caso, se tendría que demostrar la culpabilidad del responsable y su participación en la comisión de la infracción del transmitente. Pero de ser esto así, el precepto aplicable no sería el inciso c) del apartado primero del artículo 42 de la LGT sino su inciso a). De la misma forma, si el comportamiento del sucesor presunto responsable es el de colaborar con el transmitente a eludir la deuda tributaria y/o la sanción, podría constituirse un supuesto de responsabilidad previsto en el segundo apartado del artículo 42 de la LGT. De lo contrario, si todo es un artificio y el sucesor está controlado por el transmitente o se trata de la misma persona, lo correcto sería aplicar la doctrina del levantamiento del velo prevista en los incisos $g$ ) y $h$ ) del apartado primero del artículo 43 de la LGT.

\section{LA RESPONSABILIDAD SUBSIDIARIA POR CONTRATAS O SUBCONTRATAS DEBERÍA SER MODIFICADA}

La responsabilidad subsidiaria de las personas o entidades que contraten o subcontraten la realización de obras o servicios es uno de los supuestos de responsabilidad más controvertidos que actualmente contempla la LGT. La función que persigue el legislador con este supuesto de responsabilidad, que es tratar de expulsar del mercado ciertas empresas que se han creado con fines fraudulentos, no se corresponde con las funciones propias de la responsabilidad como garantía personal. Su mantenimiento en la ley después de la incorporación de los supuestos de responsabilidad por levantamiento del velo, conlleva a pensar que con el inciso f) del apartado primero del artículo 43 de la LGT lo que se persigue realmente es incrementar el número de altas de actividades que no hayan sido declaradas.

La configuración de esta responsabilidad subsidiaria está cimentada en conceptos indeterminados y su alcance supone una grave inseguridad jurídica para los afectados. El ordenamiento tributario asumió en este caso una figura del Derecho laboral de manera poco adecuada, al imponer al contratante una responsabilidad por las retenciones efectuadas a personas con las que no mantiene ningún vínculo contractual y cuya situación personal, laboral o familiar desconoce. Como observa la mayoría de la doctrina, esta responsabilidad por contrata o subcontrata puede llegar a ser excesiva, desde la perspectiva de la capacidad económica e incluso del derecho de defensa, ya que el contratante no dispone de mecanismo alguno que le permita rebatir la deuda en concepto de retenciones que le derive, en su caso, la Administración tributaria. Resulta sorprendente que incluso cuando el contratante actúe con la diligencia extrema, la única forma que tenga para eludir la aplicación de este supuesto de responsabilidad sea a través del certificado que regula la ley y el RGR.

\section{LA ADOPCIÓN DE MEDIDAS CAUTELARES EN RELACIÓN CON EL RESPONSABLE SUBSIDIARIO DEBE PRODUCIRSE SOLO CON POSTERIORIDAD AL INICIO DEL PERÍODO VOLUNTARIO DE PAGO DE ESTE SUJETO}

Tras la modificación de la LGT por la Ley 7/2012, se permite la adopción de medidas cautelares durante la tramitación de los procedimientos de aplicación de los tributos desde el momento en que la Administración tributaria pueda acreditar de forma motivada y suficiente la concurrencia de indicios racionales de que el cobro de las deudas tributarias se verá frustrado o gravemente dificultado. Esta facultad de la Hacienda Pública es reconocida también en los casos en que el obligado tributario es 
un responsable, una vez iniciado el procedimiento contra el responsable y antes de que se derive la responsabilidad, y ello implica que la adopción de medidas cautelares puede tener lugar antes de que se liquide la deuda del responsable.

Entendemos, sin embargo, que cuando se trate de un responsable subsidiario la previsión que se acaba de indicar no debe ser la postura a seguir, porque hasta que no se declaren fallidos el deudor principal y los responsables solidarios sólo el patrimonio de éstos debe encontrarse afecto al pago de la deuda tributaria y ser objeto de todas las gestiones de cobro. Se evitaría de esta manera la aplicación de unas medidas cautelares sobre el patrimonio de un sujeto que no ha tenido ni siquiera la posibilidad de impugnar su responsabilidad para asegurar un pago cuya cuantía no está aún determinada.

Somos partidarios, en fin, de que la adopción de medidas cautelares contra el responsable subsidiario se haga una vez que adquiera este sujeto la condición de obligado al pago, es decir, cuando se produzca la notificación del acto administrativo de derivación de responsabilidad y durante el plazo de su período voluntario dispuesto a su favor. A partir de este momento, la Administración tributaria ya estará capacitada para determinar la extensión de la responsabilidad subsidiaria y las medidas cautelares que, en su caso, pudiera adoptar.

\section{LA REGULACIÓN DE LA PRESCRIPCIÓN EN EL CASO DE LOS RESPONSABLES TRIBUTARIOS PRESENTA DOS ASPECTOS CONTROVERTIDOS: LA FIJACIÓN DE UN MOMENTO DE INICIO DEL PLAZO DE PRESCRIPCIÓN PARA EL EJERCICIO DEL DERECHO A LIQUIDAR Y LA COMUNICACIÓN DE LOS EFECTOS DE LA INTERRUPCIÓN DE LA PRESCRIPCIÓN ENTRE EL OBLIGADO TRIBUTARIO PRINCIPAL Y EL RESPONSABLE}

El responsable tributario es un garante independiente al que corresponde un régimen jurídico exclusivo y, por tanto, la acción para dirigirse contra el mismo es una acción o derecho autónomo con sus propias reglas de prescripción. Así es apreciado por el legislador actual que prevé en el segundo apartado del artículo 67 de la LGT un plazo único de prescripción para la obligación del responsable. Ahora bien, la ley no distingue, a la hora de precisar el plazo de prescripción, entre la fase declarativa y la fase recaudatoria de la derivación de responsabilidad, y sólo dispone el momento de inicio del plazo de prescripción para que la Administración exija la obligación de pago del responsable, pero no del plazo de prescripción para liquidar la deuda. Aplicando la regla general del artículo 66 de la LGT, a nuestro juicio este último plazo de prescripción se inicia desde el momento en que se practica una liquidación al obligado principal o desde el momento en que éste último presenta su autoliquidación, y siempre que en ambos supuestos se haya producido el presupuesto de hecho de la responsabilidad. Ello implica que sólo se aplicará el apartado segundo del artículo 67 de la LGT a responsabilidades declaradas en el plazo máximo de cuatro años sin interrupciones desde el momento en que se haya dictado la mencionada liquidación o presentado la autoliquidación por parte del obligado principal.

Por otra parte, asumimos que en general no se comunican los efectos de la interrupción de la prescripción del derecho de liquidar entre el deudor principal y los responsables, porque la comunicación de la interrupción entre ambos sujetos sólo se producirá respecto de responsabilidades que hayan sido declaradas dentro del plazo de prescripción del derecho a declarar. Lo que nos 
permite afirmar que cuando la ley dispone que los actos de interrupción de la prescripción del obligado principal interrumpen la prescripción del responsable se está refiriendo sólo a los actos de recaudación que interrumpan la prescripción de la acción recaudatoria del responsable, siempre y cuando éste tenga conocimiento formal de los mismos. 


\section{BIBLIOGRAFÍA}

ABRIL CAMPOY, J. M., "E1 Derecho de retención en el ordenamiento jurídico catalán”, Revista Crítica de Derecho Inmobiliario, núm. 624, septiembre-octubre 1994.

ACEBES FERNÁNDEZ, M., Impugnación de la providencia de apremio, Bayer Hermanos SA, Barcelona, 2000.

AGUILAR RUBIO, M., Crédito tributario y concurso de acreedores, La Ley, Madrid, 2009.

AGULLÓ AGÜERO, A., "La legitimidad del pago por tercero en la deuda tributaria y régimen jurídico de la devolución de ingresos indebidos”, Crónica Tributaria, núm. 35, 1981.

ALBALADEJO GARCÍA, M., Derecho Civil I, II, $11^{\mathrm{a}}$ ed., Bosch, Barcelona, 2002.

ALbIÑANA GARCÍA-QUINTANA, C., Responsabilidad Patrimonial Universal, Edersa, Madrid, 1951.

- "Responsabilidades patrimoniales tributarias", Revista de Derecho Privado, Madrid, 1951.

- "El interés de demora en espera de una regulación coherente", Tapia, núm. 52, 1990.

- "El ajetreado artículo 61 de la Ley General Tributaria", Tapia, núm. 86, 1996.

ALLER RODRÍGUEZ, C., "La derivación de la acción declaratoria, en el caso de la responsabilidad solidaria o subsidiaria”, Crónica Tributaria, núm. 18, 1976.

- "Una interpretación sobre los motivos de oposición a la providencia de apremio", Crónica Tributaria, núm. 42, 1982.

ALFONSO GALÁN, R. M., "La naturaleza jurídica del recargo único del artículo 61.2 de la Ley General Tributaria", Jurisprudencia Tributaria, núm. 73, 1996.

- Los intereses por retaso o demora a favor de la Hacienda Pública, Dykinson, Madrid, 1998.

ALONSO ARCE, I., La prescripción en los procedimientos tributarios y el régimen de Concierto Económico con la Comunidad Autónoma del País Vasco, Thomson-Aranzadi, Navarra, 2003.

ALONSO GONZÁLEZ, L. M., "El proyecto de Ley de Medidas para la Prevención del Fraude Fiscal”, Temas Tributarios de Actualidad, núm. 7-10, 2006.

ALONSO LEDESMA, C., "La clasificación de los créditos en el concurso", en la obra Estudios sobre el Anteproyecto de Ley Concursal de 2000, Diles, Madrid, 2002.

ALONSO MURILLO, F. y PÉREZ DE VEGA, L. M., "Actuaciones y procedimientos de recaudación", en la obra Estudios de la Ley General Tributaria, Lex Nova-Landewell, Valladolid, 2006. 
ALTAVA LAVALL, M. G., "El orden de prelación civil y tributario en el embargo de bienes. Especial referencia al embargo de dinero", en la obra Historia y Derecho. Estudios jurídicos en Homenaje al Profesor Arcadio García Sanz, Tirant lo Blanch, Valencia, 1995.

ÁLVAREZ ARROYO, F., "Derivación de responsabilidad a los administradores de sociedades", Jurisprudencia Tributaria Aranzadi, núm. 12, 2002.

ÁLVAREZ MARTÍNEZ, J., La responsabilidad de los administradores de las personas jurídicas en la nueva Ley General Tributaria, Thomson-Aranzadi, Madrid, 2004.

- "El alcance de la responsabilidad tributaria en la nueva Ley General Tributaria: análisis jurídico y examen comparativo respecto de la Ley General Tributaria de 1963”, Crónica Tributaria, núm. 263, 2005.

- La Responsabilidad de los administradores de las personas jurídicas en la Ley General Tributaria, $3^{\mathrm{a}}$ ed., Thomson Reuters Aranzadi, Navarra, 2012.

ÁLVAREZ MORALES, C. J., “Consideraciones jurídico-financieras sobre la modificación del interés legal del dinero", Revista Jurídica Española La Ley, Vol. 2, 1985.

AMORÓS RICA, N., "Responsabilidades tributarias", Revista de Derecho Financiero y Hacienda Pública, núm. 86, 1970.

ANEIROS PEREIRA, J., Las sanciones tributarias, Marcial Pons, Madrid, 2005.

ANÍBARRO PÉREZ, S y SESMA SÁNCHEZ, B., Infracciones y sanciones tributarias, Lex Nova, Valladolid, 2005.

ARAGONÉS BELTRÁN, E., “Comentarios al artículo 79 de la LGT”, en la obra La Reforma de la Ley General Tributaria. Análisis de la Ley 25/1995, de 20 de julio, Cedecs, Madrid, 1995.

ARgüElles PINTOS, J. y FELTRER BAUZÁ, F., Régimen jurídico de la responsabilidad tributaria y su aplicación práctica, Aranzadi, Pamplona, 2002.

ARIAS ABELLÁN, M. D., "El estatuto jurídico del responsable del tributo en el derecho español", Revista Española de Derecho Financiero, núm. 42, 1984.

- "Modificaciones a la Ley General Tributaria en la regulación jurídica del responsable", Revista Española de Derecho Financiero, núm. 47-48, 1985.

- "El régimen jurídico del responsable en la nueva Ley General Tributaria", Revista Española de Derecho Financiero, núm. 123, 2004.

- "Precisiones sobre el procedimiento de declaración de la responsabilidad tributaria: a propósito del artículo 124 del Reglamento General de Recaudación”, Revista Española de Derecho Financiero, núm. 131, julio-sept., 2006.

- "Sobre la prescripción de las obligaciones de los responsables tributarios, el régimen contenido en la Ley 7/2012, de 29 de octubre, de modificación de la normativa tributaria y presupuestaria y de adecuación de la normativa financiera para la intensificación de las actuaciones en la prevención y lucha contra el fraude", Revista Española de Derecho Financiero, núm. 158, 2013. 
ARIAS VELASCO, J., Procedimientos tributarios, Marcial Pons, Madrid, 1990.

- Procedimientos tributarios, Ministerio de Economía y Hacienda, Madrid, 1984.

ARIAS VElASCO, J. y SARTORIO ALBAlAT, S., Procedimientos Tributarios, $6^{\mathrm{a}}$ ed., Marcial Pons, Madrid, 1996.

AROZARENA POVES, R., "La afección registral en los Impuestos de sucesiones y de Trasmisiones Patrimoniales", en la obra Impuestos sobre Sucesiones y Transmisiones Patrimoniales y Actos Jurídicos Documentados, Vol. II, Instituto de Estudios Fiscales, Madrid, 1977.

ARRANZ DE ANDRÉS, C., "La incidencia de la reforma concursal en el ámbito tributario. Análisis del proyecto de ley de 23 de julio de 2002", Nueva Fiscalidad, núm. 7, 2002.

- La Hipoteca legal privilegiada de la Ley General Tributaria: aproximación jurisprudencial, Aranzadi, Pamplona, 2004.

- "La prescripción de la obligación del responsable tributario", en la obra Estudios de Derecho Financiero en Homenaje al Profesor Calvo Ortega, Lex Nova, 2005.

- Las garantías reales del crédito tributario: aspectos sustantivos y procedimentales, Aranzadi, Pamplona, 2006.

ATAZ HERNÁNDEZ, J., "La responsabilidad de los administradores de sociedades en materia fiscal”, en la obra Estudios de Derecho Fiscal, Homenaje a Jaime Basanta, Civitas, Madrid, 1994.

BALLARÍN ESPUÑ̃, M., Los ingresos tributarios fuera de plazo sin requerimiento previo, Marcial Pons, Madrid, 1997.

BANACLOCHE PÉREZ-ROLDÁN, J., "La nueva Ley General Tributaria. Responsables e infractores", Impuestos, Tomo II, 1985.

- La Ley General Tributaria reformada. Ensayo histórico y práctico, La Ley-Actualidad, Madrid, 1995.

- "La responsabilidad de los administradores”, Impuestos, Año no 28, núm. 2, 2012.

BARBERENA BELZUNCE, I., "Las responsabilidad tributaria del adquirente de explotaciones económicas y el nuevo Reglamento General de Recaudación”, Impuestos, núm. 23, 1991.

- "Naturaleza de la responsabilidad tributaria del sucesor de la empresa", Jurisprudencia Tributaria, Tomo II, 1994.

BARRACHINA JUAN, E., "Responsabilidad tributaria de los administradores de sociedades: el acto de derivación de la responsabilidad”, Gaceta Fiscal, núm. 167, 1998.

- "Responsabilidad tributaria de los administradores de sociedades: el acto de derivación de la responsabilidad”, Gaceta Fiscal, núm. 168, 1998.

- "Responsabilidad tributaria del adquirente de una empresa: supuesto irregular de sucesión", Gaceta Fiscal, núm. 169, 1998.

BARRIOS FLORES, L. F., "Ejecución de actos y resoluciones administrativas: caracteres generales", en la obra El procedimiento administrativo común (Comentarios, jurisprudencia, Formularios), Tomo II, GARBERÍ LLOBREGAT, J. (director), Tirant lo Blanch, Valencia, 2007. 
BAS y RIVAS, F., "La afección de los bienes transmitidos al pago del Impuesto de Derechos Reales", Revista de Derecho Financiero y Hacienda Pública, núm. 26, 1957.

BAYOD PALLARES, R. G., "Las liquidaciones de los Impuestos sobre la Renta de las Personas Físicas, sobre Sociedades y sobre el Patrimonio, como créditos preferentes de la Hacienda Pública", Crónica Tributaria, núm. 42, 1982.

BAYONA DE PEROGORDO, J. J., y SOLER ROCH, M. T., Compendio Derecho Financiero, Librería Compás, Alicante, 1991.

BEGOÑA DE LA MANO, B., "Sección 4a .- Otras formas de extinción de la deuda tributaria. Capítulo IV- La deuda tributaria. Título II- Los tributos", en la obra La Nueva Ley General Tributaria Comentada, La Ley, Madrid, 2004.

BELTRÁN DE HEREDiA DE ONIS, P., El derecho de retención en el código civil español, Universidad de Salamanca, 1995.

BENÍTEZ DE LUGO y GUILLÉN, F., "Responsabilidad fiscal objetiva en la adquisición de bienes afectos al pago de un impuesto", Crónica Tributaria, núm. 43, 1982.

BERLIRI, A., Principios de Derecho Tributario, Vol. II, Editorial de Derecho Tributario, Madrid, 1971.

BLASCO GASTÓN, F., "La hipoteca inmobiliaria (II)", en la obra Derechos Reales y Derecho Inmobiliario Registral, Tirant lo Blanch, Valencia, 1994.

BLÁZQUEZ LIDOY, A., "Novedades de la Ley General Tributaria 58/2003 en la regulación de la responsabilidad tributaria y de la sucesión”, Contabilidad y Tributación, núm. 255, 2004.

- "Obligados tributaros", en la obra Comentario Sistemático a la nueva Ley General Tributaria, PALAO TABOADA, C. (coordinador), Centro de Estudios Financieros, Madrid, 2004.

- "La responsabilidad tributaria del administrador de hecho en la LGT/2003 (RCL 2003, 2945): elementos del régimen de responsabilidad", Jurisprudencia Tributaria Aranzadi, núm. 2, 2005 .

BORRERO MORO, C. J., El pago de la deuda tributaria a través de las entidades colaboradoras, San Antonio de Benagéber, Diálogo, Madrid, 2001.

BOSCH CHOLBI, J. L., "Los responsables tributarios en la LGT 58/2003: aspectos controvertidos", Tribuna Fiscal, núm. 173, 2005.

- “Análisis crítico de los supuestos de responsabilidad tributaria solidaria en la LGT 58/2003”, Tribuna Fiscal, núm. 174, 2005.

CABANILlaS SÁNCHEZ, A., "Cargas”, en la obra Enciclopedia Jurídica Básica, Vol. I, Civitas, Madrid, 1995.

CALERO GARCÍA, M. L., "La nueva regulación del recargo único. El art. 61.3 de la LGT", Impuesto, núm. 18, 1995. 
CALVO ORTEGA, R., "La responsabilidad tributaria solidaria por actos ilícitos", Hacienda Pública Española, núm. 5, 1970.

- "La responsabilidad tributaria subsidiaria", Hacienda Pública Española, núm. 10, 1971.

- "El proyecto de Ley General Tributaria: aportaciones y aspectos críticos", Nueva Fiscalidad, núm. 8, 2003.

- "La nueva LGT y sus retos", Revista de Contabilidad y Tributación, núm. 238, enero 2003.

- "Obligados tributarios", en la obra La nueva Ley General Tributaria, CALVO ORTEGA, R. (director), Thomson-Civitas, Madrid, 2004.

- "Capítulo VI. Aplazamiento y fraccionamiento del pago", en la obra Los nuevos Reglamentos Tributarios, CALVO ORTEGA, R. (director), Thomson-Civitas, Navarra, 2006.

- "Obligados tributarios", en la obra Comentarios a la Ley General Tributaria, $2^{\mathrm{a}}$ ed., CALVO ORTEGA, R. (director), Civitas, Navarra, 2009.

CALVO VÉRGEZ, J., "Capítulo II. Ámbito de aplicación del reglamento: administraciones, recursos, órganos y entidades de recaudación", en la obra Los nuevos reglamentos tributarios, CALVO ORTEGA, R. (director), Thomson-Civitas, Navarra, 2006.

- "La prescripción de la obligación del responsable tributario: algunas consideraciones", Gaceta Fiscal, núm. 282, enero 2009.

- "Principales cuestiones planteadas en el aplazamiento y fraccionamiento de deudas tributarias: análisis normativo y jurisprudencia”, Gaceta Fiscal, núm. 295, 2010.

- La derivación de la responsabilidad tributaria, Thomson Reuters, Pamplona, 2011.

- "La responsabilidad de los causantes o colaboradores en acciones que impidan el embargo o la ejecución de bienes de los obligados tributarios", Quincena Fiscal, núm. 1-2, 2011.

- "La responsabilidad tributaria solidaria derivada de la sucesión en la titularidad o ejercicio de explotaciones o actividades económicas”, Crónica Tributaria, núm. 143, 2012.

- "La responsabilidad tributaria de los miembros de la Administración concursal y de los liquidadores de sociedades y entidades”, Gaceta Fiscal, núm. 319, 2012.

CAMY ESCOBAR, J., “Las garantías de la deuda tributaria y su ejecución”, en la obra Propiedad y Derecho Fiscal, Colegio de Registradores de la Propiedad y Mercantiles de España, Madrid, 2005.

CAMY SÁNCHEZ-CAÑETE, B., Comentarios a la Legislación Hipotecaria, Vol. VI, $3^{\mathrm{a}}$ ed., Aranzadi, Pamplona, 1983.

- Garantías patrimoniales. Estudio especial de la hipoteca, Aranzadi, Pamplona, 1993.

CANALS BRAGE, F., "Carga real y preferencia crediticia en las ejecuciones inmobiliarias", Revista Crítica de Derecho Inmobiliario, núm. 598, 1990.

CARBAJO VASCO, D., "Interés legal del dinero e intereses de demora”, Crónica Tributaria, núm. $53,1985$.

- "La responsabilidad tributaria de los administradores de las sociedades mercantiles", Crónica Tributaria, núm. 76, 1995.

- "La responsabilidad tributaria de los administradores de sociedades mercantiles. Análisis del artículo 40.1 de la Ley General Tributaria”, Crónica Tributaria, núm. 76, 1996. 
- "La responsabilidad tributaria de los administradores de sociedades mercantiles. Análisis del artículo 40.1 de la Ley General Tributaria", Foro Manchego, Colegio de Abogados de Ciudad Real, núm. 38, 1997.

- "Algunas consideraciones sobre la responsabilidad en la nueva Ley General Tributaria", Crónica Tributaria, núm. 115, 2005.

CARPI MARTÍN, R., La tutela del acreedor ante el prejuicio de la hipoteca inmobiliaria, Colegio de Registradores de la Propiedad y Mercantiles, Madrid, 2005.

CARRAMOLINO, C., "La hipoteca legal tácita y crédito singularmente privilegiado (una breve reflexión a propósito de la resolución de 3 de abril de 1998)", Revista General de Derecho, año LIV, núm. 649-650, 1998.

CARRASCO PARRILla, P. J., Consecuencias del retraso en el pago de las deudas tributarias, Ediciones de la Universidad de Castilla-La Mancha, Cuenca, 2000.

CARRASCO PERERA, A., La construcción en suelo ajeno en el marco de los principios urbanísticos, Montecorvo, Madrid, 1986.

CARRASCO PERERA, A, CORDERO lobATO, E y MARÍN LÓPEZ M, J., Trato de los derechos de garantía, Aranzadi, Pamplona, 2002.

CARRERAS MANERO, O. B., "El procedimiento de declaración de responsabilidad tributaria del adquirente de explotaciones empresariales", Impuestos, Año nº 27, núm. 13, 2011.

- "El derecho de prelación general de la Hacienda Pública para el cobro de los créditos tributarios frente al resto de acreedores concurrentes y sus efectos en el procedimiento concursal", Revista de Contabilidad y Tributación, núm. 346, 2012.

CASADO OLLERO, G., FALCÓN Y TELLA, R., LOZANO SERRANO, C., y SIMÓN ACOSTA, E., "La vía de apremio", en la obra Cuestiones tributarias prácticas, 2 da ed., La Ley, Madrid, 1990.

- "Las garantías del crédito tributario", en la obra Cuestiones tributarias prácticas, 2a ed., La Ley, Madrid, 1990.

CASANA MERINO, F., "Las garantías del crédito y los tributos locales", Revista de Hacienda Local, núm. 75, septiembre/diciembre, 1995.

CASAS AGUDO, D., “Acerca del régimen jurídico del tercer adquirente de bienes afectos en la nueva LGT”, Revista Española de Derecho Financiero, núm. 127, 2005.

CASCAJERO SÁNCHEZ, A., “Actuaciones y procedimientos de recaudación”, en la obra Ley General Tributaria. Comentarios y casos prácticos, Centro de Estudios Financieros, Madrid, 2004.

- Las clausulas anti-abuso en el ámbito de la recaudación, Instituto de Estudios Fiscales, Madrid, 2006.

CASTÁN TOBEÑAS, J., Derecho Civil Español Común y Foral, Tomo III, 13a ed., Madrid, 1983. 
CASTILlO CASTILLO, J., "Comentario al art. 35 RGR", en la obra Comentarios a las Leyes Tributarias y Financieras, Tomo XVI.B.I, Edersa, Madrid, 1991.

CASTILlO SOlSONA, M. M., "La Paulatina ampliación de los supuestos de responsabilidad tributaria: la responsabilidad por "levantamiento del velo", Instituto de Estudios Fiscales, DL 2009.

CAYÓN GALLARDO, A. M., "El Proyecto de Ley de Medidas para la Prevención del Fraude Fiscal: otro enfoque", Revista Técnica Tributaria, núm. 72, 2006

- "El inicio del procedimiento de apremio: presupuestos materiales y formales", en la obra Recaudación ejecutiva y Hacienda Local, SERRANO ANTÓN, F. (director), ThomsonCivitas, Navarra, 2008.

- "La impugnación de la derivación de responsabilidad por los administradores sociales y los efectos limitados de la resolución”, Revista Técnica Tributaria, núm. 96, 2012.

CERDEIRA BRAVO DE MANSILLA, G., Derecho o carga real: naturaleza jurídica de la hipoteca, Cedecs, Barcelona, 1998.

CERVANTES SÁNCHEZ-RODRIGO y OTROS., Guía de la Ley General Tributaria, CISS, Valencia, 2004.

CHECA GONZÁLEZ, C., "Los impuestos con fines no fiscales: notas sobre las causas que lo justifican y sobre su admisibilidad constitucional”, Revista Española de Derecho Financiero, núm. 40, 1983.

- La revisión de los actos tributarios en vía administrativa, Lex Nova, Valladolid, 1988.

- "La suspensión en vía económico-administrativa: medios admisibles para alcanzarla y posibilidad de obtenerla sin presentar garantías", Actualidad Tributaria, 1993-1.

- Reclamaciones y Recursos Tributarios, Aranzadi, Pamplona, 1997.

- El estatuto del Contribuyente (estudio de la nueva Ley), Lex Nova, Valladolid, 1998.

- La Revisión de los Actos Tributarios Locales. Análisis teórico y jurisprudencial de los procedimientos especiales de revisión y del recurso de reposición, Edersa, Madrid, 1999.

- La Suspensión en Vía Económico-Administrativa de la Ejecución de los Actos Administrativos Tributarios, Aranzadi, Pamplona, 1999.

- Los responsables tributarios. Aranzadi, Navarra, 2003.

- "Notas sobre la nueva regulación de los responsables tributarios en el anteproyecto de la LGT”, Jurisprudencia Tributaria, núm. 5, 2003, versión disponible en www.westlaw.es (BIB 2003, 702).

- "Alcance de la noción de cese para decretar la responsabilidad de los administradores de las personas jurídicas que hubiesen cesado en sus actividades", Jurisprudencia Tributaria Aranzadi, núm. 5, 2007.

- $\quad$ "La responsabilidad tributaria por sucesión en la titularidad de explotaciones y actividades económicas. El nuevo titular debe responder también por las deudas pendientes, en concepto de retenciones, devengadas por el anterior empresario", Jurisprudencia Tributaria Aranzadi, núm. 19, 2007. 


\section{CHECA GONZÁLEZ, C., GARCÍA LUIS, T., MERINO JARA, I., MORENO FERNÁNDEZ,}

J. I., La reforma de la Ley General Tributaria, Lex Nova, Valladolid, 1996.

CHICO DE LA CÁMARA, P., La suspensión de la ejecución de los actos tributarios sin garantía o con garantía distinta del aval, Aranzadi, Pamplona, 2001.

CHICO Y ORTIZ, J. M., Estudios sobre Derecho Hipotecario, Tomo II, Marcial Pons, Madrid, 1994.

CHINCHILla MARÍN, M. C., La tutela cautelar en la nueva justicia administrativa, Civitas, Madrid, 1991.

CLEMENTE, V., "La responsabilidad tributaria en la contratación: Perspectiva actual", Jurisprudencia Tributaria Aranzadi, núm. 1, 2007.

COLLADO YURRITA, M. A., "Los intereses de demora en la Ley General Tributaria", Revista Española de Derecho Financiero, núm. 56, 1987.

COMBARROS VILLANUEVA, V. E., "La responsabilidad tributaria, solidaria y subsidiaria, en el procedimiento de recaudación”, Revista Española de Derecho Financiero, núm. 23, 1979.

CONTÍN TRILLO-FIGUEROA, S., "La Prelación de crédito en el proyecto de la Ley Concursal española”, Revista General de Derecho, núm. 682-683, julio-agosto, 2001.

CORCUERA TORRES, A., La reforma de la Ley General Tributaria, McGraw-Hill, Madrid, 1995.

- Las medidas cautelares que aseguran el cobro de la deuda tributaria, Marcial Pons, Madrid, 1998.

CORRAL GUERRERO, L., "La afección tributaria de bienes", Boletín del Ilustre Colegio de Abogados, León, núm. 2, 1972.

CORTÉS DOMíNGUEZ, M., Ordenamiento tributario español, $1^{\mathrm{a}}$ ed. Tecnos, Madrid, 1968.

- Ordenamiento tributario español, $4^{\mathrm{a}}$ ed., Civitas, Madrid, 1985.

CORTÉS DOMÍNGUEZ, M. y MARTÍN DELGADO, J. M., Ordenamiento tributario español, Civitas, Madrid, 1977.

CRISTÓBAL MONTES, A., El pago o cumplimiento de las obligaciones, Tecnos, Madrid, 1986.

DAGO ELORZA, I., "La suspensión de los actos impugnados en vía económico-administrativa", Tribuna Fiscal, núm. 78, 1997.

- "Título II: Capítulo IV. La deuda tributaria", en la obra Comentarios a la Nueva Ley General Tributaria, HUESCA BOADILLA, R. (coordinador), Thomson Aranzadi, Navarra, 2004.

- "Título III: Capítulo V. Actuaciones y procedimientos de recaudación", en la obra Comentarios a la Nueva Ley General Tributaria, HUESCA BOADILLA, R. (coordinador), Thomson Aranzadi, Navarra, 2004. 
- "Comentario al artículo 174 de la LGT", en la obra Comentarios a la Nueva Ley General Tributaria, HUESCA BOADILLA, R. (coordinador), Thomson-Aranzadi, Navarra, 2004.

DAMAS SERRANO, A. J., "Afección de bienes y derechos", en la obra Comentarios a la Ley General Tributaria y Líneas para su reforma, en homenaje a Fernando Sainz de Bujanda, Vol. I, Instituto de Estudios Fiscales, Madrid, 1991.

DE GANDARILlAS MARTOS, S., "Las modificaciones introducidas por la Ley 36/2006 de prevención del fraude fiscal en la responsabilidad tributaria: levantamiento del velo", DocumentosInstituto de Estudios Fiscales, núm. 26, 2007.

- "Las modificaciones introducidas por la Ley 36/2006 de prevención del fraude físcal en la responsabilidad tributaria: levantamiento del velo", Crónica Tributaria, núm. 128, 2008.

- "El alcance de la responsabilidad tributaria", en la obra Tratado sobre la Ley General Tributaria, Tomo I, ARRIETA MARTÍNEZ DE PISÓN, J., COLLADO YURRITA, M. A., ZORNOZA PÉREZ, J. (directores), Aranzadi, Thomson Reuters, Navarra, 2010.

DE LA GARZA, S. F., Derecho Financiero Mexicano, Porrúa, México, D.F., 1976.

DE LA HUCHA CELADOR, F., “Algunas consideraciones sobre la responsabilidad tributaria en el Reglamento General de Recaudación de 1990: I. Responsabilidad Solidaria”, Crónica Tributaria, núm. 61, 1992.

- "Algunas consideraciones sobre la responsabilidad tributaria en el Reglamento General de Recaudación de 1990: II. Responsabilidad Subsidiaria”, Crónica Tributaria, núm. 63, 1992.

- "Reflexiones para una definición dogmática de la responsabilidad en Derecho Tributario (I)", Revista Española de Derecho Financiero, núm. 94, 1997.

DE LA NUEZ SÁNCHEZ-CASCADO, E., "La suspensión del acto impugnado", en la obra Las reclamaciones económicas-administrativas, Comentarios al nuevo Reglamento de Procedimiento, Aranzadi, Pamplona, 1997.

DE LA NUEZ SÁNCHEZ-CASCADO, E., FERNÁNDEZ CUEVAS, A., y OGEA MARTÍNEZOROZCO, M., El estatuto del Contribuyente. Comentarios a la Ley 1/1998, de Derechos y Garantías de los Contribuyentes, Aranzadi, Pamplona, 1998.

DE LA PEÑA VELASCO, G., "La ejecución separada del crédito tributario en el Concurso de Acreedores", Quincena Fiscal, núm. 11, 2010.

DE LA ROSA VARGAS, G., "Las garantías específicas del crédito tributario en la transmisión de bienes", Carta Tributaria, núm. 211, 1994.

DE MIGUEL ARIAS, S., La práctica del embargo para el cobro de la deuda tributaria, Thomson Reuters-Aranzadi, Pamplona, 2011.

- "La concurrencia del procedimiento de apremio con el concurso de acreedores tras la reforma de la Ley Concursal”, Revista de Contabilidad y Tributación, núm. 344, 2011. 
- "Las competencias de las Entidades Locales en el ámbito de la recaudación: el embargo de bienes situados fuera de término municipal: Comentario a la Sentencia del Tribunal Supremo (Sala de lo Contencioso-Administrativo, Sección 4a) de 16 de marzo de 2011”, núm. 1, 2011.

DE VICENTE DE LA CASA, F., "Los principios tributarios del artículo 31.1 de la Constitución y la concurrencia de tributos”, Revista de Información Fiscal, núm. 109, 2012.

DELGADO GARCÍA, A. M., "Alcance de la responsabilidad tributaria. Una cuestión abierta", Revista Española de Derecho Financiero, núm. 106, 2000.

- La derivación de responsabilidades en la recaudación de los tributos, Marcial Pons, Madrid, 2000 .

DELGADO PACHECO, A., "Artículos 160 a 173 de la LGT", en la obra Ley General Tributaria. Antecedentes y Comentarios, MANTERO SÁENZ, A., y GIMÉNEZ-REYNA RODRÍGUEZ, E. (coordinadores), Asociación de Abogados Especializados en Derecho Tributario-Asociación Española de Asesores Fiscales, Madrid, 2005.

DÍEZ GARCÍA, H., El tercer poseedor de finca hipotecada, Aranzadi, Pamplona, 1998.

DÍEZ PASTOR, J. L., "Notas acerca de la naturaleza y el contenido de la subhipoteca", Revista Crítica de Derecho Inmobiliario, 1930.

DÍEZ PICAZO, L., "La extinción de la deuda tributaria", Revista de Derecho Financiero y Hacienda Pública, núm. 54, 1964.

- Fundamentos del Derecho Civil Patrimonial II. Las relaciones obligatorias, Civitas, Madrid, 1993.

- Fundamentos del Derecho Civil Patrimonial, Tomo III, Civitas, Madrid, 1995.

DÍEZ PICAZO, L. y GULLÓN BALLESTEROS, A., Sistema de Derecho Civil, Vol. I, 6 ${ }^{\mathrm{a}}$ ed., Tecnos, Madrid, 1988.

- Sistema de Derecho Civil, Vol. III, $5^{\text {a }}$ ed., Tecnos, Madrid, 1990.

- Sistema de Derecho Civil, Vol. II. 6ª ed. Tecnos, Madrid, 1994.

DÍEZ SOTO, C. M., Concurrencia y prelación de créditos: teoría general, Reus, Madrid, 2006.

DUPUY LÓPEZ, A., "Las obligaciones tributarias ante el concurso de acreedores", Impuestos, Año nº 26, núm. 5, 2010.

DURÁN-SINDREU BUXADE, A., "La responsabilidad tributaria de los administradores de sociedades", Revista Técnica Tributaria, núm. 25, 1994.

- “Existe la hipoteca legal tácita del art. 73 LGT? Una interpretación heterodoxa”, Jurisprudencia Tributaria, núm. 15, 1998.

ECHEVARRÍA DE RADA, T., "En torno al derecho de retención”, en la obra Estudios jurídicos en homenaje al profesor Luis Díez-Picazo, Tomo II, Derecho Civil, Derecho de Obligaciones, Thomson-Civitas, Madrid, 2003. 
ECHEVARRIETA SAZATORNIL, J. M., "Los nuevos supuestos de responsabilidad", Quincena Fiscal, núm. 17, 2008.

ESCRIBANO LÓPEZ, F., "Notas sobre la futura regulación de la responsabilidad tributaria", Quincena Fiscal, núm. 13, 1995.

ESEVERRI MARTÍNEZ, E., "Sobre la naturaleza jurídica de las autoliquidaciones tributarias", Revista Española de Derecho Financiero, núm. 37, 1983.

- "El ingreso extemporáneo de las deudas autoliquidadas", Crónica Tributaria, núm. 61, 1992.

- "Comentario al artículo 61 de la LGT", en la obra La reforma de la Ley General Tributaria. Análisis de la Ley 25/1995, de 20 de julio, Cedecs, Madrid, 1995.

FABRA VALLS, M. J., La suspensión de los actos impugnados en materia tributaria, Tecnos, Madrid, 2001.

FALCÓN Y TELLA, R., "La solidaridad tributaria”, Crónica Tributaria, núm. 50, 1984.

- "La responsabilidad de los copartícipes de las entidades sin personalidad”, Impuestos, 1985 II.

- "Problemática del pago en especie: una nota sobre la facultad solutoria de las obligaciones tributarias", Revista Española de Derecho Financiero, núm. 54, 1987.

- "Las garantías del crédito tributario", Cuestiones Tributarias Prácticas, $2^{\mathrm{a}}$ ed., La Ley, Madrid, 1990.

- "Comentario General de Jurisprudencia", Revista Española de Derecho Financiero, núm. 68, 1990.

- "El interés de demora", en la obra Cuestiones Tributarias Prácticas, 2 ed., La Ley, Madrid, 1990.

- "La Ley como fuente del ordenamiento (arts. 10, 11 y 12 LGT)", en la obra Comentarios a la Ley General Tributaria y líneas para su reforma (Homenaje a Fernando Sainz de Bujanda), Vol. I, Instituto de Estudios Fiscales, Madrid, 1991.

- "Las garantías del crédito tributario: perspectivas de reforma", Revista de Derecho Financiero y de Hacienda Pública, núm. 215, septiembre-octubre 1991.

- "Las decisiones de la Comisión relativas al gravamen CECA: ejecución judicial versus ejecución administrativa", Impuestos, núm. 4, 1992.

- La Prescripción en materia tributaria, La Ley, Madrid, 1992.

- "Hipoteca Legal Tácita", en la obra Enciclopedia Jurídica Básica, Vol. II. Civitas, Madrid, 1995.

- Editorial de Quincena Fiscal, núm. 21, 1995.

- "Un ataque a la línea de flotación del carácter inmediatamente ejecutivo de las liquidaciones tributarias", Quincena Fiscal, núm. 22, 1996.

- "Prescripción de tributos y sanciones", Revista Española de Derecho Financiero, núm. 98, 1998.

- "La Ley 29/1998, reguladora de la Jurisdicción Contencioso-Administrativa (II): el nuevo régimen de las medidas cautelares", Quincena Fiscal, núm. 4, 1999.

- "La prescripción de la obligación en relación con el responsable: un problema mal planteado, Quincena Fiscal, núm. 12, 2001. 
- "La doctrina constitucional en materia de recargos por ingreso extemporáneo", Quincena Fiscal, núm. 8, 2001.

- "Los responsables en la nueva Ley General Tributaria”, Impuestos, núm. 15-16, 2003.

- "La responsabilidad subsidiaria en los supuestos de contratación y subcontratación en el Anteproyecto de LGT: su inaplicabilidad en el IVA", Quincena Fiscal, núm. 8, 2003.

- "La regulación sustantiva de los responsables en el Anteproyecto de Ley General Tributaria", Quincena Fiscal, núm. 10, 2003.

- "La prescripción en el proyecto de Ley General Tributaria”, Quincena Fiscal, núm. 14, 2003.

- "El art. 35.6 de la nueva LGT (I): supuestos de solidaridad tributaria”, Quincena Fiscal, núm. 2, 2004.

- "El art. 35.6 de la nueva LGT (II): ¿un régimen de mancomunidad con la carga de identificar a los coobligados?", Quincena Fiscal, núm. 3-4, enero, 2004.

- "Los entes sin personalidad como sujetos pasivos en la Ley 58/2003, General Tributaria", en la obra Personalidad y capacidad jurídicas. 74 contribuciones con motivo del XXV Aniversario de la Facultad de Derecho de Córdoba, Tomo I, Servicio de Publicaciones, Universidad de Córdoba, 2005.

- "Otras medidas para la prevención del fraude contenidas en la Ley 36/2006, de 29 de diciembre (y II)”, Quincena Fiscal, núm. 3-4, 2007.

FENECH, M., Principios del Derecho Procesal Tributario, Vol. III, Bosch, Barcelona, 1951.

FERNÁNDEZ AMOR, J. A., La Responsabilidad fiscal de los administradores y sucesores de personas jurídicas, Bosch, Barcelona, 2005.

FERNÁNDEZ ARÉVALO, A., Extinción del derecho de retención (análisis legal, doctrinal y jurisprudencial), Práctica de Derecho, Valencia, 1999.

FERNÁNDEZ GONZÁLEZ, C., "Un apunte sobre el concepto de responsabilidad solidaria", Crónica Tributaria, núm. 62, 1992.

FERNÁNDEZ JUNQUERA, M., "Reflexiones en torno al responsable solidario y a la solidaridad en Derecho tributario", Revista Española de Derecho Financiero, núm. 91, 1996.

- "Reflexiones en torno al responsable solidario y a la solidaridad en Derecho tributario", en la obra Sujetos Pasivos y Responsables Tributarios, Instituto de Estudios Fiscales-Marcial Pons, Madrid, 1997.

- La prescripción de la obligación tributaria. Un estudio jurisprudencial, Aranzadi, Pamplona, 2001.

- "Responsables tributarios. Situación actual y perspectiva de futuro", Revista Española de Derecho Financiero, núm. 117, 2003.

- "La dación en pago", en la obra Estudio de Derecho Financiero y Tributario en Homenaje al profesor Calvo Ortega, Tomo I, Lex Nova, Valladolid, 2005.

FERNÁNDEZ LÓPEZ, E., "Los intereses de demora en los expedientes de inspección”, Crónica Tributaria, núm. 10, 1974. 
FERNÁNDEZ LÓPEZ, M. A., Derecho Procesal Civil III. La ejecución forzosa. Las medidas cautelares, $4^{\mathrm{a}}$ ed., Centro de Estudios Ramón Areces, Madrid, 1996.

FERNÁNDEZ LÓPEZ, R. I., "La irrecurribilidad de los actos de trámite ¿admite excepciones?”, Jurisprudencia Tributaria, núm. 9, 2003.

FERNÁNDEZ MARÍN, F., Estudio jurisprudencial de las contribuciones especiales, Servicio de Publicaciones de la Universidad de Almería, Almería, 2000.

FERRANDIS VILELLA, J., "Introducción al estudio de los derechos reales de garantías", Anuario de Derecho Civil, Tomo XIII-I, 1960.

FERREIRO LAPATZA, J. J., "El principio de legalidad y las relaciones Ley-Reglamento en el ordenamiento tributario español", en la obra Estudios de Derecho y Hacienda (Homenaje a César Albiñana García-Quintana), Instituto de Estudios Fiscales, Madrid, 1987.

- "Los sujetos pasivos de la obligación tributaria", Revista Española de Derecho Financiero, núm. 72, 1991.

- La nueva Ley General Tributaria (Ley 58/2003, de 17 de diciembre), Marcial Pons, Madrid, 2004.

FRANCO ARIAS, J., El procedimiento de apremio, Bosch, Barcelona. 1987.

FUSTER ASENCIO, C., "Efectos tributarios de la dación en pago", Revista de Contabilidad y Tributación, núm. 346, 2012.

GALÁN RUIZ, J., “Algunas cuestiones en torno a la suspensión de la ejecución de liquidaciones tributarias", Impuestos, núm. 2, 1995.

- La Responsabilidad Tributaria: Ley 230/1963 y Ley 58/2003, Thomson Aranzadi, Navarra, 2005.

GALAPERO FLORES, R., "Recargos por declaración extemporánea sin requerimiento previo", Jurisprudencia Tributaria Aranzadi, Tomo III, 2007.

- El procedimiento de recaudación de los tributos. Estudio de su regulación en la Ley General Tributaria y en el Reglamento General de Recaudación, Universidad de Extremadura, Servicio de Publicaciones, Extremadura, 2008.

- "Responsabilidad tributaria subsidiaria por sucesión en la empresa.: comentario a la Sentencia de la Audiencia Nacional de 7 diciembre 2009”, Quincena Fiscal, núm. 8, 2010.

GALIANO ESTEVAN, J., e IZQUIERDO RIVAS, J., La responsabilidad tributaria, CISS, Valencia, 1997.

GARCÍA DE ENTERRÍA, E., "Reflexión sobre la constitucionalización de las medidas cautelares en el contencioso administrativo", Revista Española de Derecho Administrativo, núm. 76, 1992.

GARCÍA GARCÍA, J. M., Código de Legislación Hipotecaria y del Registro Mercantil, Civitas, Madrid, 1986. 
GARCÍA GÓMEZ, A. J., "La falta de ingreso en plazo de las deudas tributarias. Los instrumentos de respuesta en manos de la Administración al hilo de la Ley 25/1995, de modificación parcial de la LGT, con especial referencia a los regímenes de recargos”, Revista Española de Derecho Financiero, núm. 91, 1996.

GARCÍA LUIS, T., "El procedimiento de apremio", en la obra La reforma de la Ley General Tributaria, Lex Nova, Valladolid, 1996.

GARCÍA NOVOA, C., "Las consecuencias del impago del tributo tras la reforma de la Ley General Tributaria”, Impuestos, núm. 19, 1996.

- "La sujeción pasiva de los entes sin personalidad", Revista Latinoamericana de Derecho Tributario, núm. 1, 1997.

- "El procedimiento de derivación de responsabilidad de administradores de sociedades. Aspectos sustantivos y procedimentales”, Revista Técnica Tributaria, núm. 57, 2002.

- "La necesaria modificación de las garantías del crédito tributario en una nueva futura Ley General Tributaria", Crónica Tributaria, núm. 107, 2003.

- Garantías de la deuda tributaria", en la obra La nueva Ley General Tributaria, ThomsonCivitas, Madrid, 2004.

- "Capítulo IV. Elementos de cuantificación de la deuda tributaria”, en la obra La nueva Ley General Tributaria, CALVO ORTEGA, R. (director), Thomson-Civitas, Madrid, 2004.

- Iniciación, interrupción y cómputo del plazo de prescripción de los tributos, Marcial Pons, Madrid, 2011.

GARCÍA PALACIOS, J., "El nuevo régimen de las medidas cautelares", en la obra Estudios sobre la nueva Ley General Tributaria (Ley 58/2003, de 17 de diciembre), Homenaje a Pedro Luis Serrera Contreras, Instituto de Estudios Fiscales, 2004.

GARCÍA PRATS, F. J., “Acerca del art. 61.2 de la LGT y su posible inconstitucionalidad”, Tribuna Fiscal, núm. 15, enero, 1992.

GARCÍA-OVIES SARANDESES, I., "La suspensión de la ejecución de actos en materia tributaria: presupuestos y formas de obtención”, en la obra Tratado sobre la Ley General Tributaria. Homenaje a Álvaro Rodríguez Bereijo, Tomo II, Thomson-Reuters-Aranzadi, Navarra, 2010.

GARCÍA SINDE, I., El Embargo de bienes, la reclamación administrativa previa a la tercería judicial de dominio y la enajenación forzosa de bienes en el reglamento general de recaudación, Comares, Granada, 2000.

GARCÍA SOLÉ, F., y GÓMEZ GALLIDO, F. J., Derechos de Bienes Muebles, Asnef-Marcial Pons-Registradores de España, Madrid-Barcelona, 2002.

GARRETA SUCH, J. M., La responsabilidad civil, fiscal y penal de los administradores de las sociedades, Marcial Pons, Madrid, 1997. 
GARRIDO CUENCA, N., "Modalidades de ejecución", en la obra El procedimiento administrativo común (Comentarios, jurisprudencia, Formularios), Tomo II, GARBERÍ LLOBREGAT, J. (director), Tirant lo Blanch, Valencia, 2007.

GARRIDO, J. M., Tratado de preferencias del crédito, Civitas, Madrid, 2000.

GÉNOVA GALÁN, A., "La prescripción tributaria”, Revista Española de Derecho Financiero, núm. 57, 1988.

GIMÉNEZ REYNA, MARTÍN FERNÁNDEZ, F. J. y RODRÍGUEZ MÁRQUEZ, J., "La responsabilidad tributaria", en la obra La justicia en el diseño y aplicación de los tributos, Instituto de Estudios Fiscales, Madrid, 2006.

GIULIANI FONROUGE, C. M., Derecho Financiero, Vol. I, $3^{\text {a }}$ ed., actualizada y ampliada, Depalma, Buenos Aires, 1976.

GOERLICH PESET, J. M., "Determinación del supuesto: la noción de contrata y subcontrata de obras y servicios", en la obra Descentralización productiva y protección del trabajo en contratas, Tirant lo Blanch, Valencia, 2000.

GÓMEZ CABRERA, C., La discrecionalidad de la Administración Tributaria: su especial incidencia en el procedimiento de la inspección, McGraw-Hill, Madrid, 1998.

- La concurrencia del crédito tributario: aspectos sustantivos y procedimentales: prelación, garantias, tercerías, ejecuciones preferentes, suspensiones de pagos y quiebras, Aranzadi, Pamplona, 2000.

GÓMEZ MARTÍN, F., "Los créditos públicos en sede concursal”, Revista Técnica Tributaria, núm. $89,2010$.

GONZÁlEZ-CARBALLO ALMODÓVAR, A., "La prenda de créditos. Una garantía jurídica idónea a efectos del aplazamiento del pago de deudas de derecho tributario y demás de derecho público", Tribuna Fiscal, núm. 50, 1994.

- "Las garantías del crédito tributario", en la obra Estudios sobre la Nueva Ley General Tributaria (Ley 58/2003, de 17 de diciembre) en homenaje a Serrera Contreras, P. L, Instituto de Estudios Fiscales, Madrid, 2004.

GONZÁLEZ CARRERA, F., "La inmediata ejecutividad del acto de liquidación tributaria y las posibilidades de suspensión en la vía económica-administrativa y contenciosa", Quincena Fiscal, núm. 6, 1993.

GONZÁLEZ CUÉLLAR-SERRANO, M. L., Los procedimientos tributarios: su terminación transaccional, Colex, Madrid, 1998.

GONZÁLEZ FELGUEROSO, A. y MARÍN BENÍTEZ, G., "Hipotecas unilaterales en garantía de deudas tributarias: consideraciones críticas sobre la interpretación administrativa de los artículos 2.2 y 29 del TRLITP”, Revista Técnica Tributaria, núm. 97, 2012. 
GONZÁLEZ GARCÍA, A., "Los intereses moratorios a favor de la Hacienda", Cuadernos de Jurisprudencia Tributaria Aranzadi, 1998.

GONZÁLEZ GARCÍA, E., "El principio de legalidad tributaria en la Constitución Española de 1978”, en la obra La Constitución Española y las fuentes de Derecho, Vol. II, Instituto de Estudios Fiscales, Madrid, 1979.

GONZÁLEZ MÉNDEZ, A., El pago de la obligación tributaria, Ministerio de Economía y Hacienda, Instituto de Estudios Fiscales, Madrid, 1988.

GONZÁLEZ PÉREZ, J., Comentarios a la Ley de la Jurisdicción Contencioso-Administrativa (Ley 29/1998, de 13 de julio), Vol. II, $3^{\text {a }}$ ed., Civitas, Madrid, 1998.

GONZÁLEZ ORTIZ, D., "La figura del responsable tributario en el derecho español: concepto, naturaleza jurídica y fundamento", Crónica Tributaria, núm. 98, 2001.

- La responsabilidad tributaria en el ordenamiento jurídico español, Dykinson, Madrid, 2002.

- La figura del responsable en el Derecho Español, Tesis Doctoral, Servicio de Publicaciones de la Universidad de Valencia, 2003.

- "Los responsables de las sanciones como obligados al pago de una sanción ajena", Revista Española de Derecho Financiero, núm. 147, 2010.

GONZÁLEZ SÁNCHEZ, M., "El interés de demora en materia tributaria”, Crónica Tributaria, núm. 55, 1985.

- “Art. 58", en la obra Comentarios a las Leyes Tributarias y Financieras, Tomo I, Edersa, Madrid, 1983.

- "Procedimiento de apremio y sus consecuencias (artículo 128)", en la obra Comentarios a la Ley General Tributaria y líneas para su reforma, libro-homenaje al profesor Dr. D. Fernando Sainz de Bujanda, Vol. II, Ministerio de Economía y Hacienda, Instituto de Estudios Fiscales, Madrid, 1991.

- "Capítulo VIII.-La extinción de la obligación tributaria”, en la obra La Nueva Ley General Tributaria, CALVO ORTEGA, R. (director), Thomson-Civitas, Madrid, 2004.

GUERRA REGUERA, M., Garantías personales del crédito tributario. Algunas cuestiones, Comares, Granada, 1997.

- “Cuándo prescribe la obligación del responsable?, Carta Tributaria, núm. 321, 1999.

- "Consideraciones en torno al artículo 38 de la Ley General Tributaria”, Tribuna Fiscal, núm. 105, 1999.

- Suspensión de actos administrativos tributarios, Comares, Granada, 1999.

- 100 cuestiones prácticas en torno al aplazamiento o fraccionamiento de deudas tributarias, Comares, Granada, 2010.

GUERVÓS MAÍlLO, M. A., y LAGO MONTERO, J. M., "Las garantías del crédito tributario (Comentario a los artículos 71, 72, 73, 75, 75 y 76 L.G.T.)", Revista de Hacienda Local, Vol. 30, núm. 88, 2000. 
GUIO MONTERO, F., "El acto administrativo de derivación de responsabilidad", Estudios Financieros, núm. 128, 1993.

GULLÓN BALLESTEROS, A., "El crédito privilegiado en el Código civil”, Anuario de Derecho Civil, Tomo XI- II, 1958.

- La prelación de créditos en el Código Civil, Bosch, Barcelona, 1962.

- $\quad$ Sistema de Derecho Civil, Vol. I. $6^{\text {a }}$ ed. Tecnos, Madrid, 1988.

GUTIÉRREZ BENGOECHEA, M., “Causas eximentes de responsabilidad tributaria”, Quincena Fiscal Aranzadi, núm. 6, 2004.

HERNÁNDEZ MORENO, A., El pago del tercero, Bosch, Barcelona, 1983.

HERNÁNDEZ VERGARA, A., HERRERO DE EGAÑA y ESPINOSA DE LOS MONTEROS, J. M., "Artículos 160 a 177 de la LGT", en la obra Comentarios a la Ley General Tributaria, (coordinador) HERRERO DE EGAÑA Y ESPINOSA DE LOS MONTEROS, J. M., ThomsonAranzadi, Navarra, 2008.

HERRERO MADARIAGA, J., “Algunas observaciones sobre el derecho de retención del artículo 75 de la Ley General Tributaria”, Hacienda Pública Española, núm. 59, 1979.

- "El responsable tributario", Revista Española de Derecho Financiero, núm. 26, 1980.

HERRERA MOLINA, P. M., Los precios públicos como recurso financiero, Civitas, Madrid, 1991.

- "Coautoría y participación en las infracciones tributarias y responsabilidad tributaria por actos ilícitos", en la obra Sujetos pasivos y responsables tributarios, Instituto de Estudios FiscalesMarcial Pons, Madrid, 1997.

- "La responsabilidad de los Administradores por actos ilícitos", Revista Técnica Tributaria, núm. 57, abril-junio, 2002.

HERRERA MOLINA, M. A., "El recargo por cumplimiento extemporáneo sin requerimiento previo: problemas de constitucionalidad y su nueva regulación en la Ley General Tributaria y en el Código Penal", Impuestos, núm. 21, 1995.

HERRERO DE GAÑA ESPINOSA DE LOS MONTEROS, J. M., “Título II. Los tributos”, en la obra Comentarios a la Nueva Ley General Tributaria, HUESCA BOADILLA, R. (coordinador), Thomson-Aranzadi, Navarra, 2004.

HINOJOSA TORRALVO, J. J., "Los aspectos temporales del pago de la deuda tributaria en la Ley 25/1995”, Impuestos, núm. 18, 1995.

HUESCA BOADILLA, R., "Título III. La aplicación de los tributos", en la obra Comentarios a la nueva Ley General Tributaria, HUESCA BOADILLA, R. (coordinador), Thomson-Aranzadi, Navarra, 2004.

HURTADO GONZÁLEZ, J. F., "Los motivos de oposición del deudor a la providencia de apremio", Revista de Derecho Financiero y Hacienda Pública, núm. 260, 2001. 
- "La recepción del concepto «Obligado Tributario» en la nueva Ley General Tributaria", Revista Española de Derecho Financiero, núm. 122, 2004.

JARACH, D., Curso superior de Derecho Tributario, Tomo I, 2a ed., Cima, Buenos Aries, 1969.

JORDANO FRAGA, F., "Comentario a la sentencia de 7 de julio de 1987”, Cuadernos Civitas de Jurisprudencia Civil, Vol. 14, 1987.

JUNOY PINTOS, R., La Nueva Ley General Tributaria comentada, GÓMEZ- MOURELO, C. (director), La Ley, Madrid, 2004.

LACRUZ BERDEJO, J. L., "Sobre los privilegios del salario y en particular el "superprivilegio" del artículo 32.1 del Estatuto de los Trabajadores", en la obra Estudio de Derecho Privado Común y Foral, Tomo II, Colegio de Registradores de la Propiedad y Mercantiles de España-Centro de Estudios Registrales y Ed. Bosch, Zaragoza, 1992.

- Elementos de Derecho Civil, Vol. III, 1, Dykinson, Madrid, 2000.

LAGO MONTERO, J. M., "El procedimiento de declaración de la responsabilidad tributaria: una crítica", Impuestos, Tomo II, 1995.

- La suspensión de liquidaciones tributarias en la reposición y en la vía económicaadministrativa, Tecnos, Madrid, 1994.

LAMELA FERNÁNDEZ, M., “Aproximación a la reforma de la Ley General Tributaria”, Crónica Tributaria, núm. 75, 1995.

LAMOCA ARENILLAS, A., "Aplazamiento o fraccionamiento de débitos tributarios", Carta Tributaria, núm. 5, 2012.

- "Responsabilidad tributaria (práctica administrativa)", Revista de Información Fiscal, núm. 107, 2012.

LEZCANO ARTAL, A., "Suspensión sin garantías en determinados supuestos de derivación de responsabilidad tributaria", Tribuna Fiscal, núm. 247, 2011.

LITAGO LLEDÓ, R., "El principio de tutela judicial efectiva en las normas de procedimientos tributarios", Palau 14, núm. 24, pág. 1994.

- La recaudación de los precios públicos, Tecnos, Madrid, 1997.

LLANO SÁNCHEZ, M., Responsabilidad empresarial en las contratas y subcontratas, La Ley, Madrid, 1999.

LÓPEZ DE HARO, C., "El tercer poseedor de finca hipotecada", Revista General de Legislación y Jurisprudencia, núm. IV, 1931.

LÓPEZ DÍAZ, A., “La responsabilidad solidaria en el nuevo Reglamento General de Recaudación”, Tribuna Fiscal, núm. 13, 1991. 
- "Cuota y deuda tributaria", en la obra Comentarios a la Ley General Tributaria y líneas para su reforma. Libro homenaje a F. Sáinz de Bujanda, Vol. I, Instituto de Estudios Fiscales, Madrid, 1991.

- La recaudación de deudas tributarias en vía de apremio, Marcial Pons, Madrid, 1992.

- "Algunas cuestiones en relación al aplazamiento y fraccionamiento del pago en el nuevo RGR”, Impuestos, Tomo I, 1992.

- "Pluralidad de sujetos obligados y prescripción de la obligación tributaria", en la obra Sujetos pasivos y responsables tributarios, Instituto de Estudios Fiscales-Marcial Pons, Madrid, 1997.

- Período Ejecutivo. Procedimiento de Apremio y Recargo, Cuadernos de Jurisprudencia Tributaria, Aranzadi, Navarra, 2001.

- "Sobre la necesidad de pronunciamiento del juez del concurso para la prosecución de los apremios preferentes", Quincena Fiscal, núm. 13, 2010.

LÓPEZ GETA, J. M., “Responsabilidad y sucesión en las deudas tributarias”, Impuestos, núm. 24, 1989.

- "La Ley 25/1995, de 20 de julio, de modificación parcial de la Ley General Tributaria", Impuesto, núm. 17, 1995.

LÓPEZ MARTÍNEZ, J., "Los responsables de las deudas tributarias y el procedimiento de gestión”, Revista Española de Derecho Financiero, núm. 74, 1992.

- Régimen jurídico de los llamados "intereses moratorios" en materia tributaria. Un análisis de su ubicación en el seno de la deuda tributaria, Civitas, Estudio de Derecho Financiero y Tributarios, Madrid, 1994.

LÓPEZ LÓPEZ, H., “Aspectos controvertidos en la regulación de la pluralidad de obligados tributarios en el mismo presupuesto de una obligación", en la obra Tratado sobre la Ley General Tributaria, Tomo I, ARRIETA MARTÍNEZ DE PISÓN, J, COLLADO YURRITA, M. A., ZORNOZA PÉREZ, J. (directores), Aranzadi, Thomson Reuters, Navarra, 2010.

LORENZO GIL, L., "El recargo único del art. 61.2 de la Ley General Tributaria”, Impuestos, tomo I, 1994.

LOZANO CUTANDA, B., "El artículo 61.2 de la LGT: La exención de penalidad de los ingresos tardíos sin requerimiento previo", Revista Española de Derecho Financiero, núm. 63, 1989.

LOZANO SERRANO, C., La responsabilidad del adquirente de empresas por deudas tributarias anterior a la transmisión, Aranzadi, Pamplona, 1998.

- “Cabe la caducidad de la derivación de responsabilidad?”, Jurisprudencia Tributaria Aranzadi, núm. 13, 2000.

- "El procedimiento de derivación de responsabilidad", en la obra Tratado sobre la Ley General Tributaria, Tomo II, ARRIETA MARTÍNEZ DE PISÓN, J, COLLADO YURRITA, M. A., ZORNOZA PÉREZ, J. (directores), Aranzadi, Thomson Reuters, Navarra, 2010.

LUCHENA MOZO, G. M., "La suspensión del procedimiento de apremio (I)”, Crónica Tributaria, núm. 87, 1998. 
LUQUE CORTELLA, A., La Hacienda pública y el crédito tributario en los procesos concursales, Marcial Pons, Madrid, 2008.

MALVÁREZ PASCUAL, L. A., "Estudio sobre la naturaleza de la actividad declarativa de la responsabilidad tributaria y el contenido del acto resultante de la misma", en la obra Estudios jurídicos en memoria de D. César Albiñana García-Quintana, Vol. II, Instituto de Estudios Fiscales, Madrid, 2008.

- "Las consecuencias del fallo que estime el recurso de un responsable y su posible extensión a los obligados ajenos al proceso. Estudio del artículo 174.5 de la LGT en el marco del ordenamiento jurídico", Quincena Fiscal, parte Estudio, núm. 7, 2009.

MALVÁREZ PASCUAL, L. A. y LEANDRO SERRANO, M., El procedimiento de recaudación tributaria: estudio de la práctica administrativa mediante casos comentados, Madrid, Centro de Estudios Financieros, 2010.

MANTERO SÁEZ, A., "Rectificación de liquidaciones, graduación de sanciones e intereses de demora", Crónica Tributaria, núm. 21, 1977.

- “La hipoteca legal tácita”, Crónica Tributaria, núm. 35, 1981.

MANRESA Y NAVARRO, J. M., Comentarios al Código civil español, Tomo IV, 7ª ed., Reus, Madrid, 1972.

MARÍN-BARNUEVO FABO, D., "Los sujetos pasivos", en la obra Tratado sobre la Ley General Tributaria, Tomo I, ARRIETA MARTÍNEZ DE PISÓN, J., COLLADO YURRITA, M. A., ZORNOZA PÉREZ, J. (directores), Aranzadi, Thomson Reuters, Navarra, 2010.

MARTín CÁCERES, A. F., La prescripción del crédito tributario, Marcial Pons, Madrid, 1994.

MARTÍN CANO, R. A., "Motivos de oposición a la providencia de apremio", Nueva Fiscalidad, núm. 5, 2007.

MARTÍN FERNÁNDEZ, F. J., "Intereses de demora y expedientes de rectificación en la reciente jurisprudencia”, Revista Española de Derecho Financiero, núm. 73, 1992.

- "La suspensión de la ejecución del acto tributario impugnado en el recurso de reposición", Quincena Fiscal, núm. 1, 1997.

- "Incidencia de la nueva Ley de la Jurisdicción Contencioso-Administrativa en materia tributaria: suspensión de la ejecución del acto impugnado y extensión de los efectos de una sentencia firme a personas que no han sido parte en el procedimiento", Información Fiscal, núm. 32, 1999.

- La suspensión de la ejecución de los actos tributarios en vía de recurso, Marcial Pons, Madrid, 1999.

- "Una visión general del Anteproyecto de Nueva Ley General Tributaria", Asociación Española de Asesores Fiscales, mayo, 2003.

- "La responsabilidad tributaria de los sujetos que contraten o subcontraten ejecuciones de obras o prestaciones de servicios”, Jurisprudencia Tributaria Aranzadi, núm. 5, 2005. 
MARTÍN FERNÁNDEZ, F. J., GALÁN SÁNCHEZ, R. M., y RODRÍGUEZ MÁRQUEZ, J. S., "Los recargos por declaración extemporánea en la Ley General Tributaria", Revista de Estudios Financieros, núm. 161-162, 1995.

- "Los administradores de sociedades como responsables tributarios", en la obra Tratado sobre la Ley General Tributaria, Tomo I, ARRIETA MARTÍNEZ DE PISÓN, J., COLLADO YURRITA, M. A., ZORNOZA PÉREZ, J. (directores), Aranzadi, Thomson Reuters, Navarra, 2010.

MARTÍN JIMÉNEZ, F. J., El procedimiento de derivación de responsabilidad tributaria, Lex Nova, Valladolid, 2000.

- "Responsabilidad tributaria por sucesión en la actividad: criterio del Tribunal EconómicoAdministrativo Central", Revista de información fiscal, núm. 68, 2005.

- "Aplazamiento y fraccionamiento de pago de deudas tributarias: criterio administrativo", Revista de Información Fiscal, núm. 107, 2012.

MARTÍN JIMÉNEZ, A., "La responsabilidad subsidiaria en los supuestos de contratación o subcontratación del art. 43.1. f) LGT: algunas cuestiones controvertidas", Revista Española de Derecho Financiero, núm. 124, 2005.

- Los Supuestos de responsabilidad en la LGT: (hacia una configuración constitucional y comunitaria de la responsabilidad tributaria), Thomson Aranzadi, Navarra, 2007.

- "Responsabilidad tributaria, Constitución y Derecho Comunitario", en la obra Tratado sobre la Ley General Tributaria, Tomo I, ARRIETA MARTÍNEZ DE PISÓN, J., COLLADO YURRITA, M. A., ZORNOZA PÉREZ, J. (directores), Aranzadi, Thomson Reuters, Navarra, 2010.

MARTÍN QUERALT, J., "La suspensión de los procedimientos recaudatorios”, Revista Española de Derecho Financiero, núm. 7, 1976.

- "Comentario a los artículos 136 a 139 de la LGT", en la obra Comentarios a las leyes tributarias y financieras, AMORÓS RICA, N. (director), Tomo II, Edersa, Madrid, 1983.

- "La suspensión en vía económica- administrativa", Tribuna Fiscal, núm. 14, 1991.

- "Las medidas cautelares en el ámbito tributario", Tribuna Fiscal, núm. 67, 1996.

- "Novedades en el procedimiento de recaudación", en la obra La reforma de la Ley General Tributaria, Estudios de Derecho Judicial, Madrid, 2005.

MARTíN RODRÍGUEZ, A., "La afección del bien inmueble como garantía real del IBI: análisis jurídico de su naturaleza, alcance y realización”, Revista de Contabilidad y Tributación, núm. 255, 2004.

MARTín TIMÓN, M., Embargos y tercerías de la Hacienda Pública, Cuadernos de Jurisprudencia Tributaria, Instituto de Estudios Fiscales, Madrid, 1978.

MARTÍNEZ GINER, L. A., "La suspensión del plazo de los procedimientos tributarios", Revista de Contabilidad y Tributación, núm. 343, 2011. 
MARTÍNEZ LAFUENTE, A., "La prelación del artículo 73 de la Ley General Tributaria en relación con el Impuesto sobre las Transmisiones Patrimoniales y Actos Jurídicos Documentados", Crónica Tributaria, núm. 24, 1978.

- "El enjuiciamiento de los actos y de las normas emanadas de la Hacienda Pública a la luz de la Constitución", en la obra Hacienda y Constitución, Instituto de Estudios Fiscales, Madrid, 1979.

- “La extinción de las sanciones tributarias”, Crónica Tributaria, núm. 53, 1985.

MARTÍNEZ LAGO, M. A., La extensión de la responsabilidad a las sanciones tributarias, Tirant lo Blanch, Valencia, 2008.

MARTÍNEZ LAGO, M. A y ALMUdí CID, J. M., “Autotutela tributaria, "levantamiento del velo" y derivación de la responsabilidad a las sanciones", Estudios financieros. Revista de contabilidad y tributación. Comentarios, casos prácticos, núm. 296, 2007.

MARTÍNEZ MICÓ, J. G., "Responsabilidad tributaria por sucesión en la actividad: criterio del Tribunal Económico-Administrativo Central”, Revista de Información Fiscal, núm. 68, 2005.

- "El alcance de la responsabilidad tributaria de los administradores de sociedades: su extensión a las sanciones", Quincena Fiscal, núm. 22, 2009.

MAS BADÍA, D., Derechos reales de garantía y de adquisición, Dykinson, Madrid, 2010.

MAURICIO SUBIRANA, S., El responsable tributario y la empresa, Tirant lo Blanch, Valencia, 2008.

- "El responsable tributario: concepto y clases", en la obra Tratado sobre la Ley General Tributaria, Tomo I, ARRIETA MARTÍNEZ DE PISÓN, J, COLLADO YURRITA, M. A., ZORNOZA PÉREZ, J. (directores), Aranzadi, Thomson Reuters, Navarra, 2010.

MAZORRA MANRIQUE DE LARA, S., "Garantías del pago de la deuda aduanera", CISS, Noticias CEE, núm. 79-80, 1991.

- "La obligación de los responsables tributarios en el Reglamento General de Recaudación: nacimiento y exigibilidad”, Crónica Tributaria, núm. 62, 1992.

- "El régimen jurídico de la responsabilidad tributaria", Crónica Tributaria, núm. 64, 1992.

- Los responsables tributarios, Instituto de Estudios Fiscales-Marcial Pons, Madrid, 1994.

- "Aspecto formales del régimen de la responsabilidad tributaria", en la obra Tratado sobre la Ley General Tributaria, Tomo I, ARRIETA MARTÍNEZ DE PISÓN, J., COLLADO YURRITA, M. A., ZORNOZA PÉREZ, J. (directores), Aranzadi, Thomson Reuters, Navarra, 2010 .

MEDRANO IRAZOLA, S., "Las obligaciones tributarias accesorias: El interés de demora y los recargos", en la obra Estudios sobre la Nueva Ley General Tributaria (Ley 58/2003, de 17 de diciembre) en homenaje a Serrera Contreras, P. L, Instituto de Estudios Fiscales, Madrid, 2004.

MENÉNDEZ MORENO, A., "La posición jurídica de los obligados tributarios en la Hacienda Local", en la obra El Estado Actual de los Derechos y de las garantías de los Contribuyentes en las Haciendas Locales, Thomson, Civitas, Navarra, 2007. 
MENÉNDEZ MORENO, A y ANIBARRO PÉREZ, S., "Aproximación al presupuesto de hecho y al alcance de la posición deudora de los obligados tributarios”, Crónica Tributaria, núm. 66, 1993.

MENÉNDEZ MORENO, A y TEJERIZO LÓPEZ, J. M., "Los obligados tributarios en el ordenamiento español: aspectos generales de su configuración”, en la obra Sujetos Pasivos y Responsables, Instituto de Estudios Fiscales-Marcial Pons, Madrid, 1997.

MERINO JARA, I., "Infracciones y sanciones", en la obra La reforma de la Ley General Tributaria, Lex Nova, Valladolid, 1996.

- "Contribuciones Especiales", Cuaderno de Jurisprudencia Tributaria Aranzadi, núm. 26, 2002.

MIR DE LA FUENTE, T., La Retención como garantía del crédito tributario, Instituto de Estudios Fiscales, Madrid, 1984.

MOCHON LÓPEZ, L., Actos reclamables en el procedimiento económico-administrativo, Marcial Pons, Madrid, 1995.

MOLINA GARCÍA, A., La prelación general de créditos del Estado (Estudio de jurisprudencia sobre el art. 1931 CC), Montecorvo, Madrid, 1977.

MONEDERO MONTERO DE ESPINOSA, J. I., "La extinción de la deuda tributaria: Análisis especial de la compensación”, en la obra Estudios sobre la nueva Ley General Tributaria. Homenaje a D. Pedro Luis Serrera Contreras, MARTÍNEZ LAFUENTE, A. (director), Instituto de Estudios Fiscales, Madrid, 2004.

MONEREO PÉREZ, J. L., La responsabilidad empresarial en los procesos de subcontratación: puntos críticos, Ibidem, Madrid, 1994.

MONTERO DOMÍNGUEZ, A., "Sobre la suspensión de la ejecutividad de los actos administrativos de naturaleza tributaria”, Tribuna Fiscal, núm. 78, 1997.

- El Nuevo Reglamento General de Recaudación comentado, La Ley, Madrid, 2006.

MONTOYA MEDINA, D., Trabajo en contratas y protección de los trabajadores, Tirant lo Blanch, Valencia, 2004.

MORENO FERNÁNDEZ, J. I., El aplazamiento en el pago de los tributos, Lex Nova, Valladolid, 1996.

- "Los recargos por pagos extemporáneos con o sin requerimiento previo de la Administración; análisis de los artículos 61.3 y 127.1 de la LGT”, en la obra La reforma de la Ley General Tributaria, Lex Nova, Valladolid, 1996.

- La discrecionalidad en el Derecho Tributario, condonación, comprobación, aplazamientos y suspensión, Lex Nova, Valladolid, 1998.

MORILLO MÉNDEZ, A., "Responsabilidades solidarias y subsidiarias después de la Ley 10/1985 de modificación parcial de la Ley General Tributaria”, Crónica Tributaria, núm. 53, 1985. 
- "La morosidad en el cumplimiento de las obligaciones tributarias y la Ley 10/1985, de modificación parcial de la LGT”, Impuestos, núm. 11, 1985.

- "Los recargos en la Ley General Tributaria: tipología, naturaleza y compatibilidades", Impuestos, núm. 23, 1995.

MORREL Y TERRY, J., Comentarios a la Legislación Hipotecaria, Tomo IV, 2a ed., Reus, Madrid, 1930.

MOYA-ANGELER SÁNCHEZ, J., "Las obligaciones y los responsables tributarios en sus distintas formas y modalidades: hipoteca legal tácita, afección de bienes y derecho de prelación de la Hacienda", Revista de Hacienda Autonómica y Local, núm. 61, 1994.

MUÑOZ MERINO, A., Privilegios del crédito tributario: el derecho de prelación general, Aranzadi, Pamplona, 1996.

NAVARRO ALCÁZAR, J. V., "La responsabilidad tributaria de los administradores de las sociedades mercantiles", Tribunal Fiscal, núm. 75, 1995.

NAVARRO DÍAZ, M. R., “Artículo 5”, en la obra El Impuesto sobre Transmisiones Patrimoniales y Actos Jurídicos Documentados: Normativa comentada, Centro de Estudios Registrarles, Madrid, 2005.

NAVARRO EGEA, M., El responsable tributario, Iustel, Madrid, 2006.

NAVARRO FAURE, A., "Los supuestos de responsabilidad tributaria solidaria en el ordenamiento tributario español (I)", Revista de Derecho Financiero y Hacienda Pública, núm. 225-226, 1993.

- "Los supuestos de responsabilidad tributaria solidaria en el ordenamiento tributario español (II)”, Revista de Derecho Financiero y Hacienda Pública, núm. 227, 1993.

NIETO MONTERO, J. J., "Las herencias yacentes como obligados tributario" en la obra Tratado sobre la Ley General Tributaria, Tomo I, ARRIETA MARTÍNEZ DE PISÓN, J., COLLADO YURRITA, M. A., ZORNOZA PÉREZ, J. (directores), Aranzadi, Thomson Reuters, Navarra, 2010.

ORENA DOMÍNGUEZ, A., "La sucesión de empresa y el principio de personalidad de la pena en el proyecto de la nueva Ley General Tributaria”, Jurisprudencia Tributaria Aranzadi, núm. 19, 2003.

ORDUÑa MORENO, F. J. y TAMAYO HAYA, S., La Protección patrimonial del crédito, Aranzadi, 2006-2010.

ORÓN MORATAL, G., "Los obligados tributarios en la Ley 58/2003, de 17 de diciembre, General Tributaria: principales novedades", en la obra La reforma de la Ley General Tributaria, Consejo General del Poder Judicial, Madrid, 2005.

ORTELLS RAMOS, M., El embargo preventivo, Bosch, Barcelona, 1984.

- Las medidas cautelares, La Ley, Madrid, 2000. 
OTERO NOVAS, J. M., "La supuesta responsabilidad objetiva de los administradores de sociedades que cesan en su actividad”, Impuestos, Tomo I, 1997.

PALAO TABOADA, C., "Los Bancos y Cajas de Ahorro como Entidades colaboradoras en la recaudación tributaria”, Crónica Tributaria, núm. 15, 1975.

- "Apogeo y crisis del principio de capacidad contributiva" en la obra Estudios jurídicos en Homenaje a Federico de Castro, Vol. II, Tecnos, Madrid, 1976.

- "Reserva de Ley y Reglamentos en materia tributaria", en la obra Funciones financieras de las Cortes Generales, Congreso de los Diputados, Madrid, 1985.

- "Notas a la Ley 25/1995, de 20 de julio, de modificación parcial de la Ley general Tributaria", Revista de Contabilidad y Tributación o Estudios Financieros, núm. 158, 1996.

PASCUAL ESTEVILL, L., El pago, Bosch, Barcelona, 1986.

PEDREIRA MENÉNDEZ, J., Beneficios e incentivos fiscales del patrimonio cultural, Thomson Aranzadi, Madrid, 2004.

PELÁEZ MARTOS, J. M. y SANTOLAYA BLAY, M., Comentarios a la lucha contra el fraude fiscal y el régimen sancionador Ley 7/2012, CISS, Valencia, 2013.

PEÑA BERNALDO DE QUIRÓS, M., Derechos reales. Derecho hipotecario, $2^{\mathrm{a}}$ ed., Servicio de Publicaciones de la Facultad de Derecho de la Universidad Complutense, Madrid, 1986.

PEÑA ALONSO, J. L. y CORCUERA TORRES, A., La reforma de la Ley General Tributaria, McGraw-Hill, Madrid, 1995.

PEÑUELAS I REIXACH, LL., El pago de impuestos mediante obras de arte y bienes culturales: la dación de bienes del Patrimonio Histórico Español, Marcial Pons, Madrid, 2001.

PÉREZ-CRESPO PAYÁ, F., "La Hacienda Pública y las situaciones concursales", en la obra Estudios sobre la Nueva Ley General Tributaria (Ley 53/2003, de 17 de diciembre) Homenaje a D. Pedro Luis Serrera Contreras, Instituto de Estudios Fiscales, Madrid, 2004.

PÉREZ DE VEGA, L. M., La iniciación del procedimiento de apremio de las deudas tributarias, Lex Nova, Valladolid, 1998.

- "Algunas consideraciones sobre la concurrencia del procedimiento de apremio con otros procedimientos de ejecución”, Carta Tributaria, núm. 13, 2005.

- "Actuaciones y procedimientos de recaudación", en la obra Estudios de la Ley General Tributaria, Lex Nova-Landewell, Valladolid, 2006.

- "El embargo por deudas tributarias en la LGT y en las normas de desarrollo", en la obra Tratado sobre la Ley General Tributaria. Homenaje a Álvaro Rodríguez Bereijo, Tomo I, Thomson-Reuters-Aranzadi, Navarra, 2010.

PÉREZ HERRERO, L., "El cumplimiento extemporáneo de las obligaciones tributarias", Actualidad Financiera, núm. 1, 1996. 
PÉREZ NIETO, R., "Los intereses de demora del art. 26 LGT y el ius puniendi tributario. Desmesura y conveniencia de una reconsideración constitucional en el ámbito penal-sancionador", Tribuna Fiscal, núm. 243, 2011.

PÉREZ ROYO, F., Infracciones y sanciones tributarias, Instituto de Estudios Fiscales, Madrid, 1972.

- "La sucesión en la deuda por el Impuesto de Sociedades ante el artículo 72 de la Ley General Tributaria", Crónica Tributaria, núm. 3, 1972.

- "Fundamento y ámbito de la reserva de ley en materia tributaria", Hacienda Pública Española, núm. 14, 1972.

- "El pago de la deuda tributaria por un tercero", Revista Española de Derecho Financiero, núm. 2, 1974.

- "El pago de la deuda tributaria”, Revista Española de Derecho Financiero, núm. 6, 1975.

- "El privilegio general de los créditos tributarios (según la «interpretación auténtica» contenida en el Proyecto de Ley de Ejecución Singular)”, Quincena Fiscal, núm. 1, 2007.

PÉREZ ROYO, F y AGUAllo AVILÉS, A., Comentarios a la Reforma de la Ley General Tributaria, Aranzadi, Pamplona, 1996.

PÉREZ ROYO, I., "El tiempo en el pago de la prestación tributaria", en la obra Comentarios a la Ley General Tributaria y líneas para su reforma, libro-homenaje al profesor Dr. D. Fernando Sainz de Bujanda, Vol. II, Ministerio de Economía y Hacienda, Instituto de Estudios Fiscales, Madrid, 1991.

PÉREZ TORRES, E., “Título V. Revisión en vía administrativa”, en la obra Comentarios a la Nueva Ley General Tributaria, HUESCA BOADILLA, R. (coordinador), Thomson Aranzadi, Navarra, 2004.

PONT MeSTRES, M. y PONT CLEMENTE, J. F., Análisis de la Ley 25/1995 de modificación de la Ley General Tributaria (Estudio detallado de cada artículo), Civitas, Madrid, 1995.

PONT I CLEMENTE, J. F., El pago fraccionado de los tributos, Marcial Pons, Madrid, 1993.

- "Las garantías del crédito tributario ante los supuestos de aplazamiento y fraccionamiento de pago, así como ante la suspensión de la ejecutividad del acto de liquidación. En particular la suspensión en el recurso de reposición”, en la obra La suspensión de los actos de liquidación tributaria y el problema de las garantías, Marcial Pons, Madrid, 1994.

PUEBLA AGRAMUNT, N., "E1 recargo por declaración extemporánea sin requerimiento previo no puede cobrarse en todo caso", Quincena Fiscal, núm. 1-2, 2010.

- "Suspensión sin garantías en la vía judicial cuando el obligado tributario que recurre está en concurso", Revista de Contabilidad y Tributación, núm. 328, 2010.

PUGLIESE, M., Instituciones del Derecho financiero, Estudio preliminar de Alfonso Cortina Gutiérrez, 2ª ed., Porrúa, México, 1976. 
PULGAR EZQUERRA, J., "El proyecto de Ley Concursal de 2002. Una aproximación crítica", Actualidad Jurídica Aranzadi, núm. 550, octubre de 2002.

RAMALlO MASSANET, J., Prólogo a la obra de LÓPEZ MARTÍNEZ, J: Régimen jurídico de los llamados "intereses moratorios" en materia tributaria. Un análisis de su ubicación en el seno de la deuda tributaria, Civitas, Estudio de Derecho Financiero y Tributario, Madrid, 1994.

- "Los nuevos recargos en la Ley General Tributaria", Tribuna Fiscal, núm. 65, marzo de 1996.

REBOLLO PUIG, M., "Medidas provisionales en el procedimiento administrativo", en la obra $L a$ protección jurídica del ciudadano. Estudios de Homenaje al Profesor Jesús González Pérez, Tomo I, Civitas, Madrid, 1993.

REY PORTOLÉS, J. M., "La Hipoteca como derecho real divorciable del crédito garantizado", en la obra Jornadas sobre tipos especiales de garantía hipotecaria, Colegio de Registradores de la Propiedad y Mercantiles de España, Centro de Estudios Registrales, Madrid, 1993.

RIGAUD, L., El Derecho real, historia y teorías, su origen institucional, Reus, Madrid, 1928.

ROCA SASTRE, R y ROCA SASTRE, L., Derecho Hipotecario, Tomo IV-1 ${ }^{\circ}, 7^{\mathrm{a}}$ ed., Bosch, Barcelona, 1979.

RODRÍGUEZ-BEREIJO, A., "Las garantías del crédito tributario", Revista Española de Derecho Financiero, núm. 30, 1981.

- “Comentarios a los artículos 71 a 76 LGT", en la obra Comentarios a las Leyes tributarias y financieras, Tomo I, Edersa, Madrid, 1982.

RODRÍGUEZ-BEREIJO LEÓN, M., La Responsabilidad Tributaria en la Contratación y Subcontratación de Obras y Servicios, Aranzadi, Madrid, 2005.

RODRÍGUEZ MÁRQUEZ, J. S., El interés de demora en la Ley General Tributaria, Instituto de Estudios Fiscales-Marcial Pons, Barcelona, 1999.

- "El interés de demora exigible por la Administración en el Proyecto de Ley General Tributaria: luces y sombras", Quincena Fiscal, núm. 15, 2003.

- "La prescripción de la obligación del responsable en la nueva Ley General Tributaria", Nueva Fiscalidad, núm. 4, 2004.

- "Los sujetos que contratan o subcontratan una obra o servicio: un supuesto de responsabilidad poco meditado", Jurisprudencia Tributaria Aranzadi, núm. 12, 2004.

- "Un nuevo problema en el supuesto de responsabilidad de las personas o entidades que contraten o subcontraten la realización de obras y servicios: el caso particular de la Diputación Foral de Vizcaya", Jurisprudencia Tributaria Aranzadi, núm. 11, 2005.

- La Hacienda Pública y los procesos concursales, Aranzadi, Navarra, 2006.

RODRÍGUEZ MÁRQUEZ, J. y MARTÍN FERNÁNDEZ, F. J., "La responsabilidad tributaria de los sujetos que contraten o subcontraten ejecuciones de obras o prestaciones de servicios", Jurisprudencia Tributaria Aranzadi, núm. 5, 2005. 
RODRÍGUEZ MÁRQUEZ, J. y RUIZ HIDALGO, C., "La responsabilidad tributaria de los administradores de personas jurídicas", en la obra Patrimonio Familiar, empresarial y profesional, Tomo VII, Bosch, Barcelona, 2005.

ROMANÍ BIESCAS, A., Sujetos pasivos y responsables tributarios, Instituto de Estudios Fiscales, Ministerio de Hacienda, Madrid, 1975.

- "Efecto de las liquidaciones caucionales con nota registral de afección de bienes", Crónica Tributaria, núm. 12, 1975.

ROSSY, H., El tercero fiscal y las responsabilidades subsidiarias ante la Hacienda, Bosch, Barcelona, 1947.

ROZAS VALDÉS, J. A., "Sucesores y responsables en el proyecto de la Ley General Tributaria", Gaceta Fiscal, núm. 226, 2003.

RUBIO SOLER, C. L., "La recaudación en la nueva LGT", en la obra Estudios sobre la nueva Ley General Tributaria (Ley 58/2003, de 17 de diciembre). Homenaje a D. Pedro Luis Serrera Contreras, MARTÍNEZ LAFUENTE, A. (director), Instituto de Estudios Fiscales, Madrid, 2004.

RUFIÁN LIZANA, M. D., "La responsabilidad tributaria de los administradores de las sociedades en las infracciones cometidas por estás”, Impuestos, núm. 3, marzo, 1987.

RUIBAL PEREIRA, L., La sucesión en el derecho tributario. Especial referencia a la sucesión de empresa, Lex Nova, Valladolid, 1997.

RUIZ HIDALGO, C., La responsabilidad tributaria en el alzamiento de bienes en la nueva Ley General Tributaria, Marcial Pons, Madrid, 2009.

- "La responsabilidad por levantamiento del velo como una cláusula antielusiva", Quincena Fiscal, núm. 3, 2011.SABINIANO MEDRANO, I., "Las obligaciones tributarias accesorias: el interés del demora y los recargos", en la obra Estudios sobre la nueva Ley General Tributaria (Ley 58/2003, de 17 de diciembre) en homenaje a D. Pedro Luis Serrera Contreras, MARTÍNEZ LAFUENTE, A. (director), Instituto de Estudios Fiscales, Madrid, 2004.

SÁINZ DE BUJANDA, F., “Organización política y Derecho financiero”, en la obra Hacienda y Derecho, Tomo I, Instituto de Estudios Políticos, Madrid, 1962.

- "La responsabilidad tributaria en régimen de solidaridad", en la obra Hacienda y Derecho, Vol. VI, Instituto de Estudios Políticos, Madrid, 1973.

SÁNCHEZ CASAL, A., El "levantamiento del velo" y su plasmación en la Ley General Tributaria. Análisis del artículo $43.1 \mathrm{~g})$ y h) de la Ley 58/2003. Tesina, 2010.

SÁNCHEZ GALIANA, J. A., "El responsable", en la obra Comentarios a la Ley General tributaria y líneas para su reforma, homenaje a F. Sáinz de Bujanda, Vol. I, Instituto de Estudios Fiscales, Madrid, 1991. 
SÁNCHEZ HUETE, M. A., El levantamiento del velo en la nueva LGT. La responsabilidad de la sociedad pantalla y refugio, Jurídicas y Sociales, Marcial Pons, Madrid, 2008.

- "Aplazamiento y fraccionamiento de la deuda tributaria en momentos críticos de la actividad económica”, Revista Técnica Tributaria, núm. 91, 2010.

SÁNCHEZ PINO, A. J., Problemas fiscales de la suspensión de pagos, Aranzadi, Pamplona, 1997.

SÁNCHEZ ONDAL, J. J., "Presupuestos materiales y formales del procedimiento de apremio", en la obra Recaudación ejecutiva y Hacienda Local, SERRANO ANTÓN, F. (director), ThomsonCivitas, Navarra, 2008.

SANTOLAYA BLAY, M., "El procedimiento de derivación de responsabilidad tributaria en la Ley 58/2003”, Revista de Contabilidad y Tributación, núm. 271, 2006.

- "El levantamiento del velo en el ámbito tributario: algo más que dos letras finales en el primer apartado de un precepto de la Ley 58/2003", Revista de Contabilidad y Tributación, núm. 327, 2010.

- "La responsabilidad tributaria: un potente instrumento administrativo de lucha contra el fraude recaudatorio", Carta Tributaria, núm. 3, 2010.

- "El embargo de sueldos, salarios y pensiones: cuestiones legales, teóricas y jurisprudenciales (I) “, Tribuna Fiscal, núm. 263, 2012.

SANZ CLAVIJO, A., "La responsabilidad tributaria en la contratación y subcontratación: cuestiones problemáticas y aspectos prácticos”, Gaceta Fiscal, núm. 248, 2005.

SANZ LARRUGA, F. J., "Reforma de la recaudación ejecutiva de los derechos económicos de la Hacienda Pública", Impuestos, Vol. II, 1988.

- El procedimiento administrativo de apremio, La Ley, Madrid, 1991.

SÁNCHEZ LÓPEZ, M. E., "Los nuevos supuestos de responsabilidad tributaria incluidos en la Ley 7/2012, de 29 de octubre”, Gaceta Fiscal, núm. 239, 2013.

SANCHO REBULLIDA, F. A., Facultad de retención posesoria, Estudios de Derecho Civil, I, Universidad de Navarra, Pamplona, 1978.

SARTORIO ALBALAT, S., Ley General Tributaria e interés de demora, Marcial Pons, Madrid, 1999.

SEMPERE NAVARRO, A. V. y LUJÁN ALCARAZ, J., "El empresario aparente y la doctrina del "levantamiento del velo"', Aranzadi Social, Tomo II, parte Presentación, 1996.

SERRANO ANTÓN, F., La terminación convencional de procedimientos tributarios y otras técnicas transaccionales, Asociación Española de Asesores Fiscales, Madrid, 1996.

- "Algunas reflexiones sobre la oposición del deudor a la vía de apremio", Tribuna Fiscal, núm. 80, 1997. 
- "Capítulo 11. Recaudación tributaria", en la obra Comentario sistémico a la nueva Ley General Tributaria, PALAO TABOADA, C. (coordinador), Centro de Estudios Financieros, 2004.

SERRERA CONTRERAS, P. L., "La prelación general de créditos tributarios (artículo 71 de la Ley General Tributaria)", en la obra Estudios de Derecho Tributario, Vol. II, Instituto de Estudios Fiscales, Madrid, 1982.

- "La anualidad corriente en la hipoteca legal tácita por contribuciones", Revista Crítica de Derecho Inmobiliario, núm. 524, 1978.

SESMA SÁNCHEZ, B., "Responsabilidad subsidiaria de administradores: aplicación objetiva y automática”, Jurisprudencia Tributaria Aranzadi, núm. 21, 2002.

SIERRA BRAVO, R., "Comentarios a los artículos 36 y ss. RGR”, en la obra Comentarios a las Leyes Tributarias y Financieras, Tomo XVI, Edersa, Madrid, 1983.

SIMÓN ACOSTA, E., "Registro de Solares e Impuesto Municipal sobe Solares. Reflexiones sobre el Derecho Tributario material y formal", Impuestos, 1985-II.

- El Derecho Financiero y la Ciencia Jurídica, Publicaciones del Real Colegio de España, Bolonia, 1985.

- "Obligados tributarios”, en la obra Cuestiones Tributarias Prácticas, 2a ed., La ley, Madrid, 1990. "La hipoteca legal tácita en garantía de deudas tributarias", en la obra Comentarios a la Ley General Tributaria y líneas para su reforma, libro-homenaje al profesor Dr. D. Fernando Sainz de Bujanda, Vol. II, Ministerio de Economía y Hacienda, Instituto de Estudios Fiscales, Madrid, 1991.

- "Los intereses de demora en Derecho Tributario", Actualidad Jurídica Aranzadi, núm. 612, 2004.

SOLER ROCH, M. T., Los recargos de prórroga y apremio en los tributos de la Hacienda Pública, Estudios de Hacienda Pública, Institutos de Estudios Fiscales, Madrid, 1974.

- "Notas sobre la configuración de las obligaciones y deberes tributarios con especial referencia al Impuesto sobre la Renta de las Personas Físicas", Revista Española de Derecho Financiero, núm. 25, 1980.

- "Plazos (art. 23)", en la obra Comentarios a la Ley de Derechos y Garantías de los Contribuyentes, Centro de Estudios Financieros, Madrid, 1999.

- "La estructura jurídica del tributo y las distintas obligaciones tributarias: especial referencia a intereses de demora y recargos", en la obra La Reforma de la Ley General Tributaria, ZORNOZA PÉREZ, J. (director), Consejo General del Poder Judicial, Madrid, 2005.

SOPENA GIL, J., El embargo de dinero por deudas tributarias, Marcial Pons, Madrid, 1993.

TEJERIZO LÓPEZ, J. M., Ejecutividad y suspensión de los actos administrativos tributarios. Algunos aspectos relevantes”. Información Fiscal, Lex Nova, núm. 1, 1994. 
- "Los obligados tributarios en el ordenamiento español: aspectos generales de su configuración”, en la obra Sujetos Pasivos y Responsables Tributarios, Instituto de Estudios Fiscales-Marcial Pons, Madrid, 1997.

- "Las normas financieras y tributarias de la nueva Ley Concursal”, Nueva Fiscalidad, núm. 8, 2002.

- “Capítulo VII. Procedimientos de recaudación”, en la obra La nueva Ley General Tributaria, Thomson- Civitas, Madrid, 2004.

- "Capítulo III. Procedimiento de Apremio", en la obra Los nuevos Reglamentos Tributarios, CALVO ORTEGA, R. (director), Thomson-Civitas, Madrid, 2006.

THOMÀS PUIG, P. M., La posición de la administración tributaria y el crédito tributario en el proceso concursal, La Ley, Madrid, 2011.

TUR FAÚNDEZ, M. N., El derecho de reembolso: en el pago por tercero, regímenes económicomatrimoniales, solidaridad, fianza, responsabilidad civil y otros supuestos: régimen jurídico, jurisprudencia, Editorial General de Derecho, Valencia, 1996.

URBIARTE Y ZULUETA, M. M., "Los sujetos pasivos en el procedimiento recaudatorio", Hacienda Pública Española, núm. 2, 1970.

VALENTÍN-FERNÁNDEZ SANTACRUZ, M. J., "La Ley de Derechos y Garantías del Contribuyente en materia de recaudación”, Actualidad Jurídica Aranzadi, núm. 356, 1998.

VALERO LOZANO, N., "La Ley General Tributaria y la normativa concursal", en la obra $L a$ aplicación de los tributos en la nueva Ley General Tributaria. XLIX Semana de Estudios de Derecho Financiero, Instituto de Estudios Fiscales-Ministerio de Economía y Hacienda, Madrid, 2005.

VALLET DE GOYTISOLO, J., "Observaciones sobre la naturaleza jurídica de la hipoteca”, en la obra Estudios sobre garantías reales, Montecorvo, $2^{\text {a }}$ ed., Madrid, 1984.

VAQUERA GARCÍA, A., y RUIZ GARIJO, M., “Aspectos problemáticos de la responsabilidad de los contratistas y subcontratistas", Jurisprudencia Tributaria Aranzadi, núm. 15-22, 2005.

VARONA ALABERN, J. E., Extinción de la obligación tributaria: novación y confusión, Lex Nova, Valladolid, 1998.

- El crédito tributario en la quiebra, Lex Nova, Madrid, 2000.

VEGA BORREGO, F. A., "Los intereses de demora y la reiteración de actos tributarios previamente anulados”, Revista Técnica Tributaria, núm. Extra 1, 2011.

VEGA HERRERO, M., Las Contribuciones Especiales en España, Instituto de Estudios Fiscales, Madrid, 1975.

- La prescripción de la obligación tributaria, La Ley, Valladolid, 1990.

- "Capítulo I. Extinción y garantías de la deuda", en la obra Los Nuevos Reglamentos Tributarios, Thomson-Civitas, Navarra, 2006. 
VEGA HERRERO, M. y MUÑOZ DEL CASTILLO, J. L., "Capítulo II. Tributos y obligaciones tributarias", en la obra La Nueva Ley General Tributaria, CALVO ORTEGA, R. (director), Thomson- Civitas, Madrid, 2004.

VEGA TORRES, J., "El embargo de bienes (I, II, III)", en la obra Derecho Procesal Civil. Ejecución forzosa. Procesos Especiales. Conforme a la Ley 1/2000, de 7 de enero, de Enjuiciamiento Civil, Centro de Estudios Ramón Areces, Madrid, 2000.

VILLANUEVA, V. E., "La responsabilidad tributaria, solidaria y subsidiaria, en el procedimiento de recaudación”, Revista Española de Derecho Financiero, núm. 23, 1979.

VILlEGAS, H. B., Curso de Finanzas. Derecho financiero y tributario, Tomo I., $5^{\mathrm{a}}$ ed. Actualizada, Depalma, Buenos Aires, 1992.

ZABALA RODRÍGUEZ-FORNOS, A., "La intervención de la Hacienda Pública en los procesos concursales", Tribuna Fiscal, núm. 20, 1992.

- "La responsabilidad tributaria solidaria por conductas obstativas del embargo en el apremio administrativo", Tribuna Fiscal, núm. 109, 1999.

- "Comentario a los arts. 41, 42 y 43", en la obra Comentarios a la nueva Ley General Tributaria, HUESCA BOADILLA, R. (coordinador), Thomson-Aranzadi, Pamplona, 2004.

- "Artículo 78", en la obra Comentarios a la nueva Ley General Tributaria, ThomsonAranzadi, Pamplona, 2004.

ZABALA RODRÍGUEZ-FORNS, A., LLOPIS GINER, F. y DAGO ELORZA, I., Recaudación, aspectos sustantivos y procedimentales, $2^{\mathrm{a}}$ ed., CISS, Valencia, 1993.

ZORNOZA PÉREZ, J., El sistema de infracciones y sanciones tributarias (Los principios constitucionales del Derecho sancionador), Civitas, Madrid, 1992.

- "Levantamiento del velo y determinación de la cuota en el delito de defraudación tributaria", Derecho de los Negocios, enero de 2002.

- "Los obligados tributarios en la aplicación de los tributos", en la obra La aplicación de los tributos en la Nueva Ley General Tributaria, XLIX semana de estudios de Derecho Financiero, Instituto de Estudios Fiscales, Madrid, 2005. 